DIDIER DOMINIQUE CERQUEIRA DIAS DE MORAES

\title{
Uma trajetória do design do livro didático no Brasil: a Companhia Editora Nacional, 1926-1980
}

\author{
TESE APRESENTADA À FACULDADE DE ARQUITETURA E URBANISMO DA \\ UNIVERSIDADE DE SÃO PAULO PARA OBTENÇÃO DO TÍTULO DE DOUTOR \\ EM CIÊNCIAS, NO PROGRAMA DE PÓS-GRADUAÇÃO EM ARQUITETURA E URBANISMO, \\ ÁREA DE CONCENTRAÇÃO DESIGN E ARQUITETURA, \\ LINHA DE PESQUISA HISTÓRIA, TEORIA E ENSINO DE DESIGN, \\ SOB ORIENTAÇÃO DA PROF.A DR.A PRISCILA LENA FARIAS.
}


AUTORIZO A REPRODUÇÃO E DIVULGAÇÃO TOTAL OU PARCIAL DESTE TRABALHO, POR QUALQUER MEIO CONVENCIONAL OU ELETRÔNICO, PARA FINS DE ESTUDO E PESQUISA, DESDE QUE CITADA A FONTE.

Email do autor: didier.moraes@usp.br

Catalogação na Publicação

Serviço de Biblioteca e Documentação

Faculdade de Arquitetura e Urbanismo da Universidade de São Paulo

\footnotetext{
Moraes, Didier Dominque Cerqueira Dias de

M827t Uma trajetória do design do livro didático no Brasil: a Companhia Editora Nacional, 1926-1980 / Didier Dominique Cerqueira Dias de Moraes. - São Paulo, 2016.

385 p. : il.

Tese (Doutorado - Área de Concentração: Design e Arquitetura FAUUSP

Orientadora: Priscila Lena Farias.

1. Livro didático 2. Design gráfico (História) - Brasil 3. Editorial (História) 4. Cultura material I. Companhia Editora Nacional, 19261980 II. Título
}

CDU 7.05 


\section{AGRADECIMENTOS}

À bibliotecária Maria José Paiva Fagundes, da Biblioteca do Livro Didático da Faculdade de Educação da USP e às bibliotecárias Maria Luiza Lourenço, Nicolly Soares Leite e Rosemeire Amara da Silva, da Biblioteca da Faculdade de Educação da USP pelo fundamental apoio à pesquisa material da tese.

Ao Prof. Dr. Chico Homem de Melo, da Faculdade de Arquitetura e Urbanismo da USP, pelo incentivo e apoio desde o primeiro momento, bem como pela cessão de imagens de seu acervo.

À Prof. ${ }^{a}$ Dr. ${ }^{a}$ Maria Rita de Almeida Toledo, da Universidade Federal de São Paulo, pela contribuição com informações valiosas e cessão de imagens e arquivos.

À socióloga Ana Lia Leonel, por inestimável colaboração com a organização da pesquisa bibliográfica.

A Diógenes Nicolau Lawand e Felipe de Andrade Sanches, do Centro de Referência em Educação Mario Covas, e à Prof. a Dr. ${ }^{a}$ Azilde Andreotti, do Acervo Histórico do Livro Escolar da Biblioteca Monteiro Lobato de São Paulo, pelo apoio à pesquisa material.

Às bibliotecárias Maria Aparecida Pereira, do CAPH - Projeto Memória da Faculdade de Filosofia, Letras e Ciências Humanas da USP, e Daniela Piantola, do Instituto de Estudos Brasileiros da USP, pelo apoio à complementação da pesquisa.

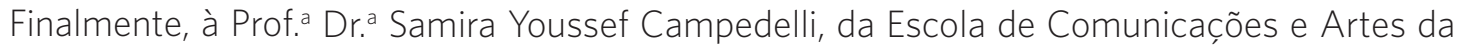
USP, pelo incentivo e motivação. 



\section{RESUMO}

Moraes, D. D. C. D. Uma trajetória do design do livro didático no Brasil: a Companhia Editora Nacional, 1926-1980. Tese de Doutorado. Faculdade de Arquitetura e Urbanismo da Universidade de São Paulo. São Paulo, 2016.

O presente trabalho tem como objeto a visualidade e a materialidade do livro didático produzido pela Companhia Editora Nacional desde o início de suas atividades, em 1926, após sua fundação por Monteiro Lobato e Octalles Marcondes Ferreira, até 1980, quando foi incorporada a um grupo editorial que possuía estrutura própria de produção dos livros. Durante três décadas, a Nacional foi a maior editora do país e seus livros estiveram presentes na formação intelectual e de gosto de diversas gerações de brasileiros, produzindo memória individual e coletiva e integrando a cultura material e visual do país em sua época. Assim, o amplo levantamento produzido por esta pesquisa de memória gráfica, de cunho panorâmico e exploratório, pretende contribuir para integrar o livro didático, pouco estudado por ter uso temporal restrito e não possuir valor literário e científico, ao rol dos artefatos gráficos merecedores de atenção dos estudos de cultura material e de história do design brasileiro. Utilizando como critério exclusivo as características materiais e visuais das obras, o trabalho identificou seis momentos diferenciados na produção de design da editora, abordando em cada um deles possíveis nexos entre sua materialidade e visualidade e os principais fatores ou contextos nelas atuantes: a educação (estrutura de ensino, abordagens pedagógicas e cultura escolar), a produção (tecnologia e práticas de trabalho) e as linguagens visuais e gráficas circulantes em cada época. A direção geral identificada nesse percurso foi de um momento inicial caracterizado por extrema sobriedade e formalidade de capas exclusivamente tipográficas e soluções padronizadas de composição e diagramação nos miolos até um momento final caracterizado por capas ilustradas ou fotográficas e soluções mais particularizadas e com forte presença de elementos pictóricos nos miolos. A par do desenvolvimento das tecnologias gráficas para a reprodução das imagens, o percurso mostra a própria trajetória das relações da cultura escolar com as demais esferas da vida social no aspecto da visualidade, indo de um momento inicial de maior isolamento e retração a influências externas à cultura escolar até um momento de maior flexibilidade e permeabilidade a elas, particularmente à influência dos meios de comunicação de massas, com a valorização da imagem que os caracteriza.

Palavras-chave: Livro didático, Design gráfico, História do design gráfico no Brasil, História editorial, Cultura material. 


\section{ABSTRACT}

Moraes, D. D. C. D. Uma trajetória do design do livro didático no Brasil: a Companhia Editora Nacional, 1926-1980 [A trajectory of school textbook design in Brazil: the Companhia Editora Nacional, 1926-1980]. Doctoral dissertation. Faculdade de Arquitetura e Urbanismo, Universidade de São Paulo. São Paulo, 2016.

The focus of this investigation was the visuality and materiality of school textbooks produced in Brazil by the Companhia Editora Nacional from its inception in 1926 by writer Monteiro Lobato and Octalles Marcondes Ferreira to 1980, when the enterprise was incorporated into a publishing group operating under a proprietary publishing approach. For three decades, Nacional was the country's largest publisher, and its titles became integral to the intellectual training of, as well as to the development of book appreciation among, a number of Brazilian generations, while helping to build both individual and collective memory and integrate Brazil's material and visual culture during the period. As part of this panoramic, exploratory investigation of editorial graphic memory, an extensive survey was conducted willing to push the inclusion of school textbooks - to date poorly studied, given their limited useful lifespan and lack of first-hand literary or scientific value-into a roster of graphic artifacts insufficiently addressed in investigations of Brazilian design history and material culture. Drawing exclusively on the material and visual characteristics of the books, six periods were identified in the design production at Nacional. For each period, the study addressed possible connections between, on the one hand, materiality and visuality and, on the other, the principal factors or contexts influencing the material and visual character of textbooks-namely, education (educational structure, pedagogical approaches, and school culture), production (technology and work practices), and the visual and typographic languages available at the time. A general trajectory was identified in this evolution, spanning from an initial point in time, characterized by the stark simplicity and formality of all-type covers and standardized textblock typography and layout, to a final period, characterized by handmade or photography-based artwork and more individualized solutions, with a strong presence of pictorial elements in the textblock. In addition to the growing refinement of graphic technologies for image reproduction, the trajectory reveals an evolution of the relationships established between school culture and other spheres of social life in terms of visuality, extending from an initial point in time, marked by a more pronounced isolation from and avoidance of influences foreign to the school culture, to a period of more evident flexibility and permeability to these influences, particularly those conveyed by mass media, with their intrinsic valuing of images.

Keywords: Textbooks, Graphic design, History of graphic design in Brazil, Publishing history, Material culture. 


\section{SUMÁRIO}

INTRODUÇÃO $\ldots 11$

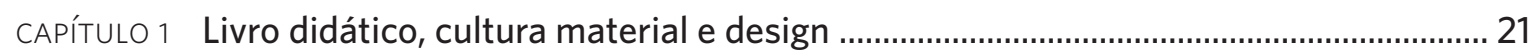

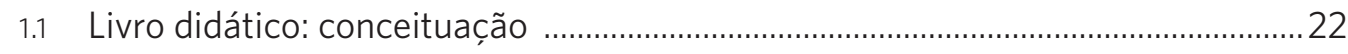

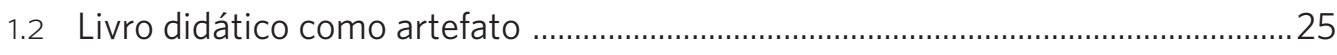

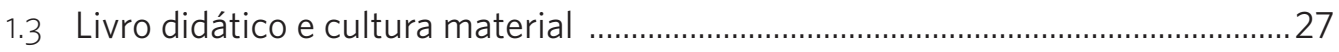

1.4 Cultura material: forma, produção e uso …………………………………….....30

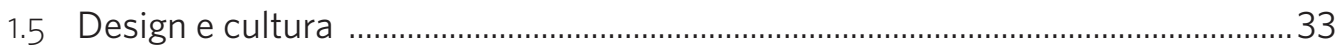

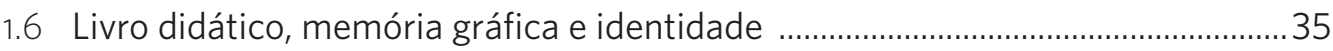

1.7 Livro didático e cultura visual .................................................................................... 40

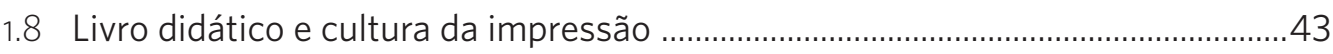

1.9 Design, história do design e conceito de projeto

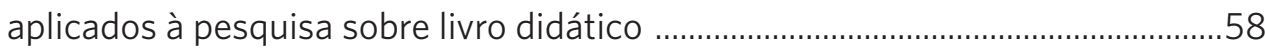

CAPÍTULO 2 Origens, formação e primeiros anos da Companhia Editora Nacional ........................65

2.1 Origens da Companhia Editora Nacional .............................................................66

2.1.1 As edições avulsas e a Revista do Brasil (1917-1920) ..........................................67

2.1.2 A Monteiro Lobato \& Cia. Editores (1919-1924) ................................................. 71

2.1.3 A Companhia Graphico-Editora Monteiro Lobato (1924-1925) .......................75

2.2 O início da Companhia Editora Nacional ...............................................................

CAPÍTULO 3 1926-1931: O design de livros didáticos dos

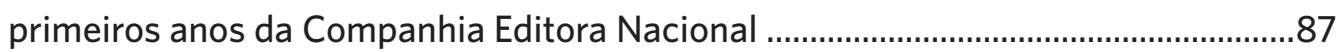

3.1 Os livros didáticos da Companhia Editora Nacional de 1926 a 1931 ...................89

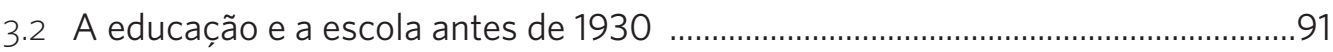

3.2.1 Organização e currículo do Ensino Primário ...........................................................94

3.2.2 Organização e currículo do Ensino Secundário ...................................................95

3.3 O mercado editorial didático na década de 1920 ...................................................97

3.4 O design e a materialidade dos livros didáticos da CEN de 1926 a 1931 ............101

3.4.1 O design de capas dos livros didáticos da CEN de 1926 a 1931 ......................102

3.4.2 O design de miolo dos livros didáticos para

o Ensino Secundário da CEN de 1926 a 1931 ........................................................111

3.4.3 O design de miolo dos livros didáticos para

o Ensino Primário da CEN de 1926 a 1931 .........................................................117

3.5 Considerações gerais sobre o design dos livros

didáticos da CEN do período 1926-1931 
CAPÍTULO 4 1932-1942: As coleções didáticas da Companhia Editora Nacional e seu design .. 127

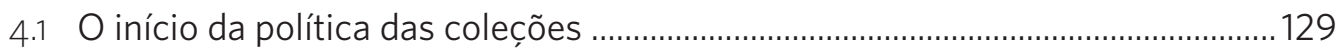

4.2 A educação e a escola após a Revolução de 1930 ...................................................136

4.3 A Biblioteca Pedagógica Brasileira e a missão de renovação da cultura ...............139

4.3.1 A Biblioteca Pedagógica Brasileira Série II - Livros Didáticos..................................143

4.4 Novas coleções de didáticos, livros avulsos e

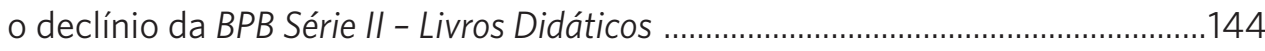

4.5 O design e a materialidade dos livros didáticos da CEN de 1932 a 1942 ..........144

4.5.1 O design de capas da Biblioteca Pedagógica Brasileira

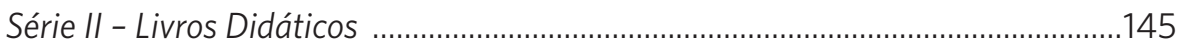

4.5.2 O design de capas de outras coleções e de livros avulsos ................................156

4.5.3 O design de miolos das coleções e livros avulsos ............................................ 160

4.6 Considerações gerais sobre o design dos livros

didáticos da CEN do período 1932-1942

CAPÍTULO 5 1943-1952: A renovação do design de didáticos da

Companhia Editora Nacional para uma nova expansão do ensino ............................. 175

5.1 A Companhia Editora Nacional, maior editora do país ........................................... 178

5.2 As Leis Orgânicas do Ensino e a nova estrutura da educação ............................. 182

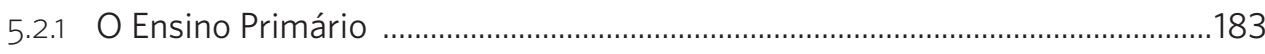

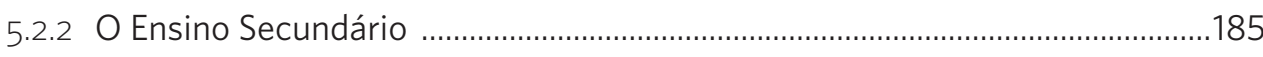

5.3 A Comissão Nacional do Livro Didático e

a primeira legislação nacional para o livro escolar .................................................186

5.4 O design e a materialidade dos livros didáticos da CEN de 1943 a 1952 .......... 187

5.4.1 O novo design de capas de livros didáticos a partir de 1943 ..........................188

5.4.2 Outros modelos de capas tipográficas …………………………………….....195

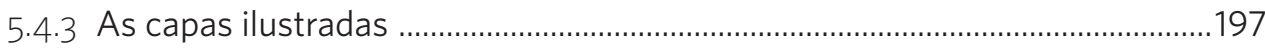

5.4.4 O design de miolo dos livros didáticos do período 1943-1952 …....................201

5.5 Considerações gerais sobre o design dos livros

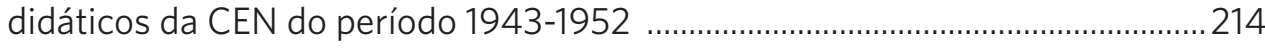

CAPÍTULO 6 1953-1960: A generalização das capas ilustradas coloridas nos livros didáticos da Companhia Editora Nacional ................................................ 217

6.1 Os livros não didáticos da CEN no período 1953-1960 .........................................220

6.2 A educação brasileira no período 1953-1960 …………………………………......223

6.3 O design e a materialidade dos livros didáticos da CEN de 1953 a 1960 ........ 225

6.3.1 O design de capas de livros didáticos no período 1953-1960 .........................225

6.3.2 O design de miolo dos livros didáticos do período 1953-1960 ........................242

6.4 Considerações gerais sobre o design dos livros

didáticos da CEN do período 1953-1960 
CAPÍTULO 7 1961-1969: A valorização do design de miolo nos livros didáticos da Companhia Editora Nacional ............................................... 253

7.1 A educação brasileira no período 1961-1969 ……………………………........ 256

7.2 A Companhia Editora Nacional no período 1961-1969 ……………………...... 259

7.3 O design e a materialidade dos livros didáticos da CEN de 1961 a 1969 ......... 262

7.3.1 Os livros de História e o trabalho de Eugênio Hirsch ........................................263

7.3.2 O design dos novos livros de Matemática, Ciências e Desenho ......................271

7.3.3 As mudanças no design dos livros de Geografia ...........................................28

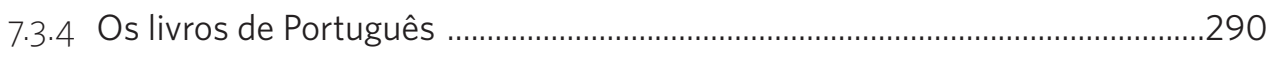

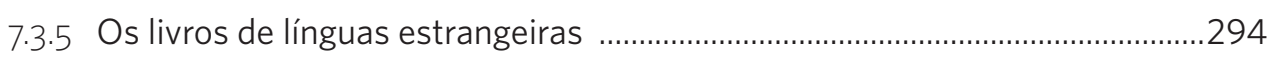

7.3.6 Os livros para o Primário: cartilhas e Programa de Admissão .........................296

7.4 Considerações gerais sobre o design dos livros didáticos da CEN do período 1961-1969 299

CAPÍTULO 8 1970-1980: O design dos últimos anos da Companhia Editora Nacional e as transformações do livro didático brasileiro ..........................................................303

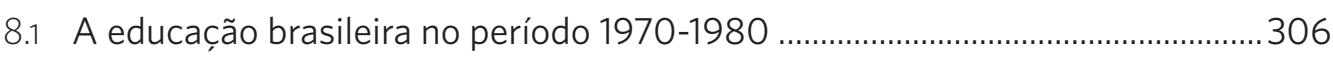

8.2 A Companhia Editora Nacional no período 1970-1980 ......................................309

8.3 A cultura de massas, a imagem fotográfica e o "poder jovem" ........................... 313

8.4 O design e a materialidade dos livros didáticos da CEN de 1970 a 1980 ..........314

8.4.1 O predomínio da ilustração nas capas e miolos dos livros de Pré-escola e 1a a 4⿳亠口冋 série do Primeiro Grau .........................................315

8.4.2 Das soluções tipográficas à ilustração e à fotografia

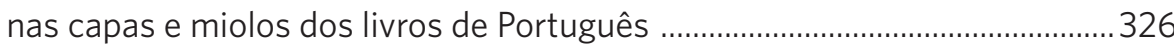

8.4.3 Fotografia e ilustração nas capas e miolos dos livros de História ...................334

8.4.4 Livros de Geografia: presença da ilustração mas predomínio da fotografia nas capas 343

8.4.5 Fotografia e soluções tipográficas nas capas de livros de Matemática 346

8.4.6 Da ilustração à fotografia nas capas e miolos dos livros de Ciências ............350

8.4.7 Fotografia e ilustração nas capas de livros de Inglês ............................................351

8.5 Considerações gerais sobre o design dos livros didáticos da CEN do período 1970-1980 352 

Introdução 

origem de meu interesse pela visualidade dos livros didáticos da Companhia Editora Nacional (CEN) remonta ao período de realização da pesquisa material para minha dissertação de mestrado sobre a renovação do design de capas de livros didáticos empreendida pela Editora Ática nas décadas de 1970 e 1980 [MORAES, 2010]. A documentação de amostras do que seria o contraponto à produção da Ática realizada na Biblioteca do Livro Didático da Faculdade de Educação da USP levou ao encontro, ou reencontro, com os livros da Nacional, pois vários já conhecia do tempo de escola. Mesmo não tendo objetivos imediatos de pesquisa, a possibilidade de acesso ao Acervo Histórico da CEN, então mantido pelo Ibep (Instituto Brasileiro de Edições Pedagógicas), ao qual a editora pertence, me levou a tomar conhecimento acerca de toda uma produção de cuja existência eu não suspeitava e que atestava a importância da editora para o país, deixando incubada a idéia de uma futura pesquisa em torno de algum tema que aqueles livros poderiam oferecer.

O que eu não imaginava é que este tema daria origem a uma tese que não se restringiria à visualidade dos livros de uma determinada disciplina, autor ou período, mas que se atreveria a abarcar a trajetória do design do livro didático da Nacional por um intervalo de quase seis décadas, do início de suas publicações didáticas, em 1926, até 1980, quando encerrou sua atividade como empresa independente.

Uma primeira razão para ter empreendido um recorte tão amplo dizia respeito à importância da Companhia Editora Nacional para a vida cultural e para a educação no Brasil. Fundada em 1925 por Monteiro Lobato e Octalles Marcondes Ferreira, a empresa publicou obras para todos os segmentos do mercado e notadamente para a escola, ressaltando-se que, entre 1940 e a primeira metade da década de 1970, ocupou o primeiro lugar em vendas e lançamentos de títulos entre todas as editoras do país.

Uma segunda razão dizia respeito ao principal produto da editora, o livro didático. De uso generalizado na escola - e lares - em todas as épocas, particularmente após a extensão do ensino a novas camadas da população ocorrida no século passado, este artefato gráfico tem estado presente nos anos decisivos para a formação intelectual e do gosto de sucessivas gerações de brasileiros. No entanto, como aponta Alain CHOPPIN [2004, p. 599], seu uso confinado no tempo e espaço da vida escolar, a ausência de valor literário e científico decorrente de seus objetivos pragmáticos de instrumento de ensino e aprendizagem e sua presença cotidiana tornando-o quase invisível resultaram numa desvalorização do livro didático como objeto cultural e, consequentemente como objeto de interesse para o campo da história do livro e das edições e mesmo da educação. Segundo o autor, esse esquecimento vem sendo revertido há pelo menos quarenta anos, em termos mundiais. Ainda assim, o livro didático vem sendo investigado quase que exclusivamente em seus aspectos de conteúdo textual e em suas relações com os currículos, disciplinas, vida escolar, ideologias e instituições, dando-se pouca ou 
nenhuma ênfase a suas dimensões material e visual, quando um dos aspectos mais evidentes desse artefato de ensinar, que vai ser reafirmado ao longo dessa tese, é o seu caráter multimodal, estabelecido pela forte relação existente entre texto e imagem.

Com relação ao campo da pesquisa sobre cultura material e design, o estudo dos artefatos materiais - produtos ou gráficos, da indústria ou do artesanato - , no Brasil e mesmo no mundo, é também bastante recente, o que faz com que o livro didático dispute com inúmeros outros objetos, de maior ou menor visibilidade e reconhecimento cultural, a atenção dos pesquisadores.

Assim, a existência de poucos estudos sobre a visualidade do livro didático no Brasil, e particularmente sobre os títulos didáticos de uma de suas mais importantes editoras, sugeriu a necessidade e oportunidade de uma abordagem de caráter mais largo e exploratório, do que uma abordagem extremamente verticalizada num período ou aspecto muito particular. Em outras palavras, a abordagem abrangente e panorâmica pareceu ser a mais adequada a uma pesquisa sobre memória gráfica e cultura material inscrita no campo da história do design no Brasil que lidava com um objeto ainda pouco estudado.

\section{Hipóteses, questões e objetivos}

Dado que a produção de didáticos a ser pesquisada se deu num intervalo de tempo extenso, em que certamente vigoraram mais de um sistema produtivo e tecnológico, em que as demandas da educação não permaneceram estáticas e em que diferentes contextos culturais e tendências de gosto se sucederam, estabeleceu-se a hipótese de que se encontrariam diversas manifestações de visualidade e materialidade, correspondentes à ação daqueles fatores.

Com base na identificação de características materiais e visuais dos livros pesquisados - aquilo que é específico e exclusivo de uma pesquisa no terreno do design e sua história - , considerou-se a possibilidade de identificar momentos ou períodos em que determinadas soluções de design predominaram, o que definiria a tendência ou a abordagem básica do design produzido em cada um desses períodos. Assim, estabeleceu-se como segunda hipótese que que seria possível construir a trajetória do design dos livros didáticos da Nacional por uma sucessão de momentos ou períodos claramente distinguíveis entre si.

Como o design de um artefato não existe por si, mas tem como condicionantes processos e contextos relativos à sua produção, comercialização e uso, estabeleceu-se como terceira hipótese que cada uma das configurações materiais e visuais que caracterizam cada um desses períodos seria resultado da ação e da interação de alguns desses fatores ou contextos, dos quais se elegeram dois como aqueles que concorreriam mais diretamente para a configuração do livro didático. O primeiro deles diz respeito à educação em geral, onde estaria incluídos aspectos como modelos de ensino, disciplinas escolares e abordagens pedagógicas. O outro 
diz respeito à produção, que incluiria processos tecnológicos, organização do trabalho, práticas profissionais e repertórios formais.

Assim, como decorrência das hipóteses levantadas, a primeira questão enfrentada foi a de reconhecer quais características materiais e visuais definiriam cada um dos períodos de design da Nacional. A segunda questão foi a de definir quais e com que participação atuaram cada um dos fatores relativos ao campo da educação e da produção na configuração material e visual dos livros produzidos em cada período.

Portanto, procurou-se em primeiro lugar produzir uma narrativa visual do design do livro didático da Companhia Editora Nacional a partir da sucessão de períodos claramente definidos por características materiais e visuais dominantes - pela linguagem e materialidade de seu design - , estabelecendo os nexos de constinuidade entre esses momentos, bem como possíveis viragens ou ruptura entre eles.

Em segundo lugar, procurou-se explicar o design que caracterizou cada período como resultado da ação e relação entre os dois contextos e fatores que se admitiu inicialmente como aqueles que mais diretamente agiriam sobre a configuração material - em termos sintéticos, os relativos à finalidade e à produção.

Por fim, como decorrência de se empreender uma pesquisa sobre um artefato ainda pouco estudado pela história do design e da cultura material, estabeleceu-se o objetivo de contribuir para inscrever o livro didático, por sua participação na construção da memória individual e coletiva de um determinado período, no rol dos artefatos investigados pelos estudos de memória gráfica e de história do design no Brasil.

\section{Constituição do corpus e procedimentos gerais da pesquisa}

O corpus da pesquisa é constituído de livros didáticos da Companhia Editora Nacional de 1926 a 1980 encontrados principalmente na Biblioteca do Livro Didático da Faculdade de Educação da USP, a partir de consulta prévia ao site Livres - Banco de Dados de Livros Escolares Brasileiros, que reúne dados do acervo de algumas bibliotecas do país dedicadas a este gênero. O corpus foi complementado com pesquisa na Biblioteca Monteiro Lobato, no Centro de Referência da Educação Mário Covas e com aquisições em sebos. O melhor acervo para pesquisa, em abrangência de títulos e edições, o arquivo histórico da Companhia Editora Nacional, doado para a Universidade Federal de São Paulo, encontra-se fechado sem previsão de data de abertura para pesquisadores.

Foram documentados 425 títulos ou edições (algumas para títulos já computados em função de transformações no design) pertencentes aos níveis de ensino correspondentes aos atuais Ensino Fundamental e Médio, ao que se circunscreve a pesquisa. Os livros, fotografados ou digitalizados, estão assim distribuídos, considerando-se a equivalência à nomenclatura 
que prevaleceu a maior parte do tempo: Pré-escola, 2 títulos; Ensino Primário, 46 títulos ou edições, Ginásio, 248 títulos ou edições; Colégio: 121 títulos ou edições; Magistério, 2 títulos; Comércio: 6 títulos.

Considerando-se que Ephraim BEDA [1987, p. 289-291] discrimina por disciplina 787 títulos diferentes entre 1926 e 1978 para esses níveis de ensino, acredita-se que, apesar das inevitáveis lacunas, a amostragem é suficientemente representativa para estabelecer a trajetória de design da editora como um todo.

Para cada período em que se dividiu a trajetória de design, nos capítulos correspondentes, será apresentado seu corpus específico, detalhado por nível e modalidade de ensino, com a nomenclatura adotada na época.

Além da documentação fotográfica ou digitalização de capas e páginas de miolo dos livros, foram feitos registros em fichas preparadas para cada obra, com anotações de características físicas de capa e miolo (dimensões, materiais, acabamento, cores), tecnologias empregadas na composição e impressão (identificadas pelo método proposto por Bamber GASCOIGNE, 2011, descrito no capítulo 4), créditos profissionais (projeto, ilustração, impressor), percepções e observações relativas à forma, remissões a casos semelhantes ou opostos, etc. - e parte das imagens coletadas foram aplicados a essas fichas. Depois de impressas, as fichas de obras constituíram material de fácil manipulação que permitiu agrupamentos e comparações para a extração de sentidos dos dados, bem como o retorno à fonte primária para a complementação de informações, imagens e resolução de dúvidas.

O trabalho de interpretação e análise dos dados consistiu basicamente na análise gráfico-visual de capas e miolos, tomados isoladamente ou em grupos formados por características formais comuns. Esta análise incluiu o estabelecimento de relações com as tecnologias de composição, impressão e produção de imagens e eventualmente com demandas de conteúdos e de representação de informações.

Devido às diferenças de função, estrutura e forma de produção de capas e miolos, a análise gráfico-visual desses dois componentes foi feita separadamente, seguindo alguns procedimentos comuns aos dois, mas também apresentando particularidades e métodos específicos.

No caso das capas, a análise gráfico-visual incluiu os seguintes procedimentos:

- reconhecimento das informações enquanto elementos visuais, hierarquia estabelecida entre elas e recursos para obtê-la, conforme modelo de variáveis gráficas de MIJKESENAAR [1997], descritos no capítulo 4.

- identificação de linguagem, técnica e estilo da ilustração.

- identificação da estratégia geral de linguagem para criação de significado e comunicação.

- registro das conclusões em pranchas, que integraram o trabalho Percurso da visualidade dos 
livros didáticos da Companhia Editora Nacional: as capas (1926-1980), apresentado no processo de qualificação.

A análise gráfico-visual de miolos incluiu os seguintes procedimentos:

- reconhecimento dos tipos e subtipos de material gráfico (texto, fotografia, ilustração, gráficos, mapas, esquemas) e suas relações formais e de significado conforme matriz de classificação de linguagem gráfica de Michael TWYMAN [1979], apresentada no capítulo 4;

- registro das conclusões em pranchas dos grupos ou peças isoladas, que integraram o trabaIho Percurso da visualidade dos livros didáticos da Companhia Editora Nacional: os miolos (19261980), apresentado no processo de qualificação.

Com base no material assim organizado, foi possível identificar o predomínio de determinadas características materiais e visuais em determinados intervalos de tempo e estabelecer a pretendida periodização da visualidade e materialidade dos livros didáticos coletados.

\section{Estruturação da tese e conteúdo dos capítulos}

A trajetória do design do livro didático da Companhia Editora Nacional foi dividida em seis períodos, tratados em capítulos próprios dedicados a cada um deles. Cada capítulo apresenta um boxe inicial reproduzindo capa e miolo de duas obras exemplificando as principais características de design do período, seguido de um texto introdutório justificando os motivos para o delineamento daquele período.

Em seguida, cada capítulo apresenta tópicos destinados a trazer análises e informações relativas ao momento da educação vivido pelo país e ao momento da editora, que se acredita importantes para compreender o design produzido no período. Ainda antecedendo a apresentação mais detalhada do design do período, são fornecidas informações sobre tecnologia, procedimentos produtivos e características materiais relativas ao conjunto do design abordado, além da delimitação do corpus específico da pesquisa no intervalo tratado.

A forma de apresentação do design dos livros varia de capítulo a capítulo: ora tratando separadamente seus componentes - capa e miolo - ora os reunindo; ora os agrupando por níveis de ensino, disciplinas ou cronologia, ora dando mais ênfase a volumes tomados isoladamente ou a coleções ou grupos de obras. Os critérios para essa diversidade de procedimentos são explicitados em cada capítulo, mas de forma geral a motivação é corresponder ao que o design de cada período impõe e evitar repetições de informações válidas para diversos períodos, por exemplo as relativas à visualidade determinada pelo conteúdo didático das disciplinas, componente de maior estabilidade.

Ao final dos capítulos são apresentadas considerações gerais ou conclusões a que se pode chegar acerca do conjunto do design do período, quando possível relacionando-o a contextos mais amplos como cultura escolar e cultura visual, por exemplo. 
Antecedendo esses seis capítulos, dois capítulos são dedicados à contextualização conceitual e teórica do trabalho e à história inicial da editora.

Assim, o Capítulo 1 - Livro didático, cultura material, e design - traz o exame de termos e conceitos como livro didático, artefato gráfico, cultura material, visualidade, projeto, design, memória gráfica, identidade, história do design, cultura da impressão e outros - produzidos e utilizados em campos disciplinares diversos como a história, a educação e o design -, que embasam não só a abordagem geral adotada no tratamento do objeto da tese, como explicitam o sentido com que são empregados em momentos pontuais ao longo do trabalho.

O Capítulo 2 - Origens, formação e primeiros anos da Companhia Editora Nacional - se dedica a construir o quadro histórico e institucional que estabeleceu as bases da atividade da editora ao longo da sua existência mas também de sua produção inicial e inserção no campo e mercado editorial que se constituía no Brasil naquele momento. Mostra suas origens e o legado dos empreendimentos anteriores de Monteiro Lobato e seu sócio Octalles Marcondes Ferreira, tanto em termos de fundo editorial como de visualidade das publicações, que estarão na base da produção geral da editora mas também da didática, abordada no capítulo 3.

O Capítulo 3 - 1926-1931: O design de livros didáticos dos primeiros anos da Companhia Editora Nacional - mostra uma produção ainda bastante desigual em termos editoriais e visuais, decorrente da incipiente especialização da editora no segmento e da dependência de fornecedores externos. Apresenta as insuficiências e elitismo da educação brasileira e um panorama da produção didática das principais editoras já estabelecidas, incluindo a sua visualidade, situando o quadro em que a produção didática da editora se inseria. Mostra como as soluções de capa, majoritariamente tipográficas, acabamento e composição do miolo correspondiam à tecnologia e à cultura gráfica do período e respondiam à demanda de originais em que predominavam a abordagem de compêndio, e não de manual escolar, com uma única exceção voltada à educação popular e com produção diferenciada.

O Capítulo 4 - 1932-1942: As coleções didáticas da Companhia Editora Nacional e seu design - aborda a visualidade decorrente da adoção de uma estratégia de organização do catálogo e da produção - a criação de coleções - quando a editora consolida um perfil editorial em que o livro didático torna-se um produto chave e ela se torna a segunda maior editora do país. Apresenta o contexto político e de discussão da educação que antecedeu a Revolução de 1930 e sua reforma da educação, que embasaram a constituição da Biblioteca Pedagógica Brasileira e o grande crescimento da editora com obras voltadas para o Ensino Secundário. Mostra a adoção de uma solução padronizada de capa tipográfica com letras desenhadas para a principal coleção como decorrente de necessidades de produção. Apresenta o design dos miolos como 
decorrência do estabelecimento de critérios e padrões gráficos correspondente à profissionalização da editora na produção didática.

O Capítulo 5 - 1943-1952: A renovação do design de didáticos da Companhia Editora Nacional para uma nova expansão do ensino - apresenta a visualidade do terceiro período do design de didáticos da Nacional, que a editora já inicia como a maior do país. São apresentados o novo contexto da educação com a divisão do Ensino Secundário em dois ciclos, Ginásio e Colégio (Reforma Capanema), e o contexto tecnológico de utilização de impressoras ofsete, que ensejam o surgimento de um novo formato e solução de capas, ainda tipográficas com letras desenhadas, diferenciando livros entre os dois segmentos, e as primeiras capas ilustradas para o Ensino Secundário, com o conjunto comunicando uma a idéia de modernização da editora. A apresentação do design de miolo ressalta o maior uso de fotografia e aprimoramento dos critérios gráficos de composição e diagramação, decorrentes de investimento tecnológico e humano.

O Capítulo 6 - 1953-1960: A generalização das capas ilustradas coloridas nos livros didáticos da Companhia Editora Nacional - mostra como um quarto período de design se configura com o abandono das soluções tipográficas padronizadas e a adoção de soluções ilustradas particularizadas para cada série autoral ou volume. O contexto da produção não didática da editora é apresentado como uma possível referência para essa transformação, enquanto que o contexto educacional é apresentado mostrando que a estrutura de ensino não sofre nenhuma transformação que incorra em novas demandas para o design dos livros. A apresentação do design de capas mostra o predomínio de soluções impressas em duas e três cores, seguida de algumas impressas em quadricromia, incluindo o uso de fotografia colorida, e os primeiros exemplos de capas com influência da arte e do design modernista construtivo. A apresentação do design de miolo mostra o maior incremento da impressão em duas cores e casos de impressão em quadricromia.

O Capítulo 7 - 1961-1969: A valorização do design de miolo nos livros didáticos da Companhia Editora Nacional - apresenta a configuração de um quinto período no design dos livros da CEN apoiada no estabelecimento de um novo procedimento, a particularização também do design dos miolos para cada obra, que a par da identidade própria passam a apresentar em alguns casos maior unidade gráfica entre seus componentes - capa, miolo, páginas pré-textuais e textuais -, modernização da linguagem de ilustrações e diagramação flexível, integrando texto e imagem. Ressalta-se o papel do designer austríaco Eugênio Hirsch como iniciador desse procedimento, que a editora adotou para diversas obras, particularmente de disciplinas que traziam inovações no ensino, como Matemática e Ciências, atestando-se uma maior sensibilidade da editora para estímulos vindo de outras mídias impressas. Apresenta-se a permanência da editora como a primeira em produção didática, apesar de a grande expansão de ensino que 
se seguiu à Lei de Diretrizes e Bases da Educação Nacional, de 1961, ter estimulado o surgimento de novas editoras na segunda metade da década.

O Capítulo 8 - 1970-1980: O design dos últimos anos da Companhia Editora Nacional e as transformações do livro didático brasileiro - traz a visualidade e materialidade dos livros didáticos dos últimos anos de vida independente da Nacional. É mostrado como inovações tecnológicas como a impressão ofsete rotativa, a fotocomposição, as letras transferíveis e uma ampliação sem precedentes do ensino e sua massificação começam a gerar um novo livro didático, em formato maior, acabamento brochura, impressão em quadricromia de capa e miolo, com espaços para preenchimento de respostas pelo aluno e criação do livro do professor. Com relação à visualidade, mostra-se como a disseminação dos meios de comunicação audiovisuais, particularmente a televisão em cores, estabelece novos parâmetros de realismo fotográfico e de linguagens de ilustração que fornecem modelos que o livro didático vai seguir, além do predomínio de temas ligados a uma cultura jovem diferenciada. Por fim, mostra-se que a editora perde seu lugar de maior empresa do ramo editorial e perde iniciativa e qualidade gráfica e de design a partir da metade da década, após a mudança de propriedade e saída das antigas direções editorial e de arte.

As Considerações Finais apresentam uma súmula dos períodos de design e promovem sua articulação numa interpretação geral da trajetória que eles compõem, relacionando os aspectos concernentes à produção e à educação que concorreram para o design produzido. Concluem apresentando perspectivas de aprofundamento em temas levantados pela pesquisa, com sugestões de possibilidades de prosseguimento da investigação sobre o design do livro didático brasileiro.

Por fim, uma observação sobre a reprodução de amostras de design ao longo do trabalho. Com a finalidade de permitir a percepção da variação das dimensões dos livros ao longo do tempo e em cada período, adotou-se o critério de reproduzir capa e miolo dos livros didáticos da Nacional com a redução única para 35\% do tamanho original, excetuando-se ampliações para mostrar detalhes, reproduções em tamanho natural para certas aferições e reduções para 25\% para reproduzir um número maior de páginas no quarto e no oitavo capítulos. Com relação às fontes das imagens reproduzidas, apenas se menciona aquelas que não pertencem ao acervo da Biblioteca do Livro Didático da FEUSP, pois estas constituem a maioria. 
CAPÍTULO 1

Livro didático, cultura material e design 
C omo explicitado na introdução desta tese, o objeto de que ela trata é o livro didático, ou mais propriamente, os livros didáticos produzidos pela Companhia Editora Nacional durante um intervalo de 54 anos e sob um determinado aspecto deles, o de sua conformação visual e material. E como também já foi dito, o extenso período abordado traz implícita a idéia não de uma conformação, mas de várias, e, portanto, de uma trajetória de conformações. Conformações estas que são produto da ação de diversos agentes, como autores, editores, planejadores gráficos e outros; em determinados contextos produtivos, como tecnologia disponível, cultura gráfica e práticas de trabalho vigentes; para atender demandas de uso relativas ao ensino e aprendizagem de determinados conteúdos curriculares decorrentes de programas educacionais definidos em nível de Estado; sob determinadas formas e práticas institucionalizadas em espaço próprio, a escola; etc.

Enfim, mesmo se tratando da abordagem de um objeto sob um enfoque bastante particularizado, o do design, só por esta disciplina dizer respeito à atividade de projeto de objetos que serão produzidos, vendidos e utilizados e que precisa considerar todas essas instâncias, grande número de conceitos pertencentes a campos disciplinares diversos, como a história, a educação e mesmo o design, precisam ser mobilizados e apropriados. Assim, termos e conceitos como livro didático, artefato gráfico, cultura escolar, visualidade, projeto, design, história do design e outros - que apareceram na formulação quase empírica do parágrafo acima precisam ser examinados em sua origem e na relação com o objeto da tese - a trajetória da visualidade do livro didático da Companhia Editora Nacional -, o que será feito neste capítulo.

\subsection{Livro didático: conceituação}

A primeira questão colocada é a da própria definição de livro didático, do que o caracteriza como um objeto gráfico diferente de outro tipo de livro.

Já em trabalho anterior, dissertação de mestrado também abordando a visualidade do livro didático no Brasil, mas referente a outro período e objeto [MORAES, 2010], esta questão se colocou e motivou uma investigação sobre o estado da arte pesquisa do livro didático no país, a definição de seu objeto e mesmo sua relação com o campo do design.

O tempo transcorrido é curto para se esperar o acréscimo de contribuições que pudessem modificar substancialmente os conceitos lá utilizados, mas a verdade é que as obras pesquisadas e citadas foram produzidas em um período bem maior, ao menos vinte anos, e se referem a um período bem mais longo, no caso dos livros didáticos brasileiros a mais de um século. Assim, as definições aplicadas ao objeto livro didático praticamente permanecem as mesmas, necessitando poucos reparos ou atualizações. Como um comentário antes de retomar essas definições, pode-se dizer que as transformações de conteúdo e forma que o 
livro didático possa ter sofrido não mudaram sua essência, e a estabilidade de sua definição decorre deste fato.

Embora naquele trabalho se mencione a diversidade de vocabulário para designá-lo (livro didático, livro escolar, manual escolar, compêndio), proveniente de diversas origens e usos, e a não correspondência precisa entre as diferentes línguas (schoolbook, textbook no inglês; mannuel no francês; manual, livro didático ou livro escolar, no português, etc.), o principal problema de definição do que é livro didático decorreria das diversas formas que ele assume, da indefinição de fronteiras entre, por exemplo, catecismos, cartilhas, livros de leitura, compêndios, paradidáticos [MORAES, 2010, p. 19-20].

Assim, é ainda válida a solução para o problema dada por Circe Bittencourt e não há porque não citá-la também aqui:

Para os pesquisadores de livros o livro didático é toda obra produzida com a intenção de ser material escolar, ou seja, a ser utilizado em sala de aula. O livro didático e os denominados paradidáticos acabam sendo, na verdade, livros didáticos. Um exemplo dessa dimensão do livro didático pode ser fornecida pelos clássicos ou religiosos como os Os Lusíadas, a Bíblia e outros. Ao serem editados especialmente para servir a fins pedagógicos, ou seja, quando sofrem adaptações de linguagem ou alterações no conteúdo, transformam-se em livros didáticos. [...] Um clássico da literatura quando adaptado, mesmo que apenas incluindo exercícios a serem feitos por alunos, torna-se igualmente um livro didático. [BITTENCOURT, 1993, p. 389]

Portanto, mais do que a origem do gênero, é o local e o uso que definem a natureza "didática" do livro didático, que por enquanto pode receber o epíteto de um gênero que reúne muitos gêneros.

Mas é da atenção dada ao aspecto uso que se pode chegar a uma precisão maior da caracterização do objeto livro didático. Sobre ele, diz Kazumi MunAKATA:

Pois, a rigor, livro didático não é para ser lido como se lê um tratado científico - postura adotada por muitos críticos do conteúdo dos livros didáticos. Livro didático é para usar: ser carregado; ser aberto; ser rabiscado (não, isso não pode, o livro não pode ser consumível!); ser dobrado; ser lido em voz alta em alguns trechos e, em outros, em silêncio; ser copiado (não se pode consumi-lo!); ser transportado de volta a casa; ser aberto de novo; ser "estudado". Raros livros didáticos [...] são efetivamente lidos de cabo a rabo, do mesmo modo que ninguém lê um dicionário ou uma enciclopédia de A a Z [...].

Objeto para ser usado, o livro didático implica não uma relação direta e imediata do aluno e do professor com o conteúdo, esse mundo platônico de formas inteligíveis, mas antes de atividades, práticas e fazeres, numa situação efetiva de ensino e aprendizagem. [MUNAKATA, 1997, p. 203-204]

Mas há ainda dois aspectos, ainda apenas indicado nessas considerações, que Circe BITTENCOURT [1993] explicita, o de conteúdo para o aluno e o de instrumento pedagógico para o professor: 
O livro didático é um depositário de conteúdos escolares [que] realiza uma transposição do saber acadêmico para o saber escolar no processo de explicitação curricular [...]

[é um] instrumento pedagógico com uma larga tradição, que elabora as estruturas e as condicões de ensino para o professor [e que] produz uma série de técnicas de aprendizagem. [BITTENCOURT, 1993, p. 172]

Esta concepção do livro didático portando uma transposição de um saber acadêmico para um saber escolar foi mais tarde questionada pela própria autora [BITTENCOURT, 2003], mas é aqui ainda referida porque parece manter sua validade ao menos no caso dos primeiros livros didáticos produzidos no período da "virada instrucional" ocorrida no Renascimento, como será visto na seção 1.8 (Livro didático e cultura da impressão), quando os conteúdos das disciplinas escolares - ou a própria constituição dessas - provavelmente estavam sendo produzidos numa relação muito mais próxima com as respectivas ciências a que se referiam.

Mas, de fato, para uma conceituação do livro didático a partir da natureza dos conteúdos que veicula, o exame da natureza de disciplina escolar é fundamental. Referindo-se à crítica de André Chervel à concepção de disciplina escolar como transposição didática, afirma a autora:

Os pontos centrais de sua proposição residem na concepção das disciplinas escolares como entidades epistemológicas relativamente autônomas e desloca o acento das decisões, das influências e de legitimações exteriores em direção à escola, inserindo o saber por ela produzido no interior de uma cultura escolar. As disciplinas escolares se formam no interior dessa cultura, tendo objetivos próprios e muitas vezes irredutíveis aos das ciências de referência, termo que Chervel emprega no lugar de conhecimento científico. [...] o autor concebe a escola como uma instituição que obedece a uma lógica particular e específica e na qual participam vários agentes, tanto internos, como externos, mas que deve ser entendida como lugar de produção de um saber próprio. [BITTENCOURT, 2003, p. 25]

Dessa concepção de escola como lugar de produção de conhecimento e de disciplina escolar como parte integrante da cultura escolar decorre que "os conteúdos escolares não são vulgarizações ou meras adaptações" do conhecimento científico e que a seleção desses conteúdos depende de outras finalidades que os objetivos das ciências de referência [BITTENCOURT, 2003, p. 26], o que deve necessariamente ser estendido ao conteúdo dos livros didáticos.

Há ainda outros aspectos, aqui rapidamente mencionados, mas que demonstrarão sua importância em alguns momentos adiante neste capítulo: o livro didático é uma "mercadoria", produzida e comercializada obedecendo a lógicas determinadas pelas técnicas disponíveis e por interesses de mercado, "um objeto da indústria cultural" e "um importante veículo portador de um sistema de valores, de uma ideologia, de uma cultura" [BITTENCOURT, 1993, p. 72].

Essas formulações aparecem incorporadas na relação de quatro funções do livro didático apresentadas por Alain CHOPPIN [2004], feitas a partir da observação histórica, funções essas 
que podem ocorrer simultaneamente ou não, e variar segundo o ambiente sociocultural, época, disciplinas, níveis, métodos e formas de utilização:

1. Função referencial, também chamada de curricular ou programática, desde que existam programas de ensino: o livro didático é então apenas a fiel tradução do programa ou, quando se exerce o livre jogo da concorrência, uma de suas possíveis interpretações. Mas, em todo o caso, ele constitui o suporte privilegiado dos conteúdos educativos, o depositário dos conhecimentos, técnicas ou habilidades que um grupo social acredita que seja necessário transmitir às novas gerações.

2. Função instrumental: o livro didático põe em prática métodos de aprendizagem, propõe exercícios ou atividades que, segundo o contexto, visam a facilitar a memorização dos conhecimentos, favorecer a aquisição de competências disciplinares ou transversais, a apropriação de habilidades, de métodos de análise ou de resolução de problemas, etc.

3. Função ideológica e cultural: é a função mais antiga. A partir do século XIX, com a constituição dos estados nacionais e com o desenvolvimento, nesse contexto, dos principais sistemas educativos, o livro didático se afirmou como um dos vetores essenciais da língua, da cultura e dos valores das classes dirigentes. [...]

4. Função documental: acredita-se que o livro didático pode fornecer, sem que sua leitura seja dirigida, um conjunto de documentos, textuais ou icônicos, cuja observação ou confrontação podem vir a desenvolver o espírito crítico do aluno. [...] [CHOPPIN, 2004, p. 553]

Desse conjunto de abordagens, pode-se extrair uma definição sucinta bastante operativa: o livro didático é um objeto definido por sua finalidade utilitária de portar conteúdos restritos do que deve ser ensinado ao aluno - não o "estado da arte" do conhecimento acadêmico estabelecido -, de oferecer ao professor meios e técnicas de ensino, e em espaço institucional e tempo definidos - a escola e o período letivo - , fora e além dos quais esgota sua função original.

Ou, em outras palavras, adequadas a um trabalho que enfoque o livro didático do ponto de vista de sua materialidade e visualidade: o livro didático é um artefato, conforme as definições que veremos a seguir.

\subsection{Livro didático como artefato}

Do Grande Dicionário Houaiss [2012], as acepções tomadas da palavra artefato confirmam não se aplicar a objetos da natureza, mas a produto da atividade humana:

[...] 1 produto de trabalho mecânico; objeto, dispositivo, artigo manufaturado.

2 aparelho, engenho, mecanismo construído para um fim determinado [...]

4 antrpol aral forma individual de cultura material ou produto deliberado da mão de obra humana. [...]

[Grande Dicionário Houaiss da Língua Portuguesa, versão eletrônica, 2012] 
David Jules Prown [1993] explicita, a partir da etimologia, os sentidos de conhecimento e utilidade trazido pela palavra:

Objetos feitos ou modificados por seres humanos são agrupados sob o termo artefato. Esta palavra conecta duas palavras - arte e fato - refletindo sua dupla raiz latina. A palavra art deriva de ars, artis (habilidade em juntar) e fato deriva de factum (ação ou ato) a partir de facere (fazer), enfatizando o sentido utilitário já implícito na palavra art; portanto habilidade ou conhecimento aplicado na feitura de algo. [Prown, 1993, p. 2] ${ }^{1}$

Já trabalhando com um conceito bastante ampliado da palavra, que inclui não só objetos naturais modificados pelo homem, mas até o que o homem pode ter deixado preservado, para a finalidade de estabelecer relações entre a estrutura de coisas feitas pelo homem e a estrutura das coisas naturais, não haveria portanto razões para Prown não incluir objetos produzidos como arte na categoria de artefatos. Apesar da diferença do sentido dessa palavra ao longo do tempo, ou mesmo de sua ausência para distinguir objetos em vários povos ou períodos passados, Prown adota uma abordagem inclusiva, em que não só os objetos feitos com finalidade utilitária mas os que hoje entendemos como arte devem ser vistos como artefatos, o que tem consequências para a definição de cultura material que será vista adiante.

Assim, resume Luiz Antonio Coelho, "trata-se de uma categoria muito ampla, abrangendo sem distinção objetos tecnológicos e artísticos, industriais e artesanais, independentemente de função, utilidade ou valor simbólico" [CoelHo, 2008, p.21].

E na generalização do conceito para obter a própria definição de cultura material, afirma Rafael Cardoso Denis:

Mais correta do que 'objeto', no contexto atual, seria a palavra 'artefato', a qual se refere especificamente aos objetos produzidos pelo trabalho humano, em contraposição aos objetos naturais ou acidentais. Generalizando a partir do artefato individual para o conjunto de artefatos produzidos e usados por um determinado grupo ou por uma determinada sociedade, chegamos ao conceito de 'cultura material', termo que tem sua origem na etnologia e no estudo de povos considerados 'primitivos' pelos seus colonizadores europeus. [DENIS, 1998, p. 19]

Assim, "a noção de artefato é o elemento básico para definir o conceito ainda mais abrangente de cultura material. Uma cultura material se constitui de um determinado conjunto de artefatos, relacionados por critérios de contiguidade temporal, geográfica, étnica, ou de uso" [COELho, 2008, p. 21].

Constatando portanto que, pela definição atual e por sua etimologia, o termo artefato

\footnotetext{
"Objects made or modified by human are clumped togheter under the term artifact. That words connects two words - art and fact reflecting its double Latin root. The word art derives from ars, artis (skill in joining), and fact derives through factum (deed or act) from facere (to make or to do), emphasizing the utilitarian meaning already implicit in the woer art; thus, skill or knowledge is applied to the making of a thing."
} 
reúne as noções básicas de algo ter sido feito pelo homem, de ter sido feito mediante emprego de alguma habilidade e, por fim, podendo cumprir uma finalidade utilitária, até com o risco de estar cometendo um truísmo, concluímos pela pertinência de sua aplicação plena ao livro didático, o que liga este ao conceito de cultura material, inseparável do de artefato, como acabou de ser visto, mas que merecerá maior atenção no tópico seguinte.

\subsection{Livro didático e cultura material}

Conforme a definição clara e direta de Jules Davis Prown, "Cultura material é exatamente o que ela diz que é - especificamente, as manifestações de cultura através das produções materiais". E o objeto de estudo da cultura material são os artefatos, conforme a concepção por ele definida e apresentada acima, com o objetivo de compreender a própria cultura, as "crenças - valores, ideias, atitudes, e pressupostos - de uma comunidade particular ou uma sociedade em uma determinada época" [PROWN, 1993, p. 1].2

Para Richard Bucallle e Jean-Marie Pesez [1989]:

A cultura material pode ser definida antes de mais nada como a cultura do grosso da população [...] a cultura material, cultura do colectivo, contrapõe-se sobretudo à individualidade. [BuCAILLE; PESEZ, 1989, p. 13]

Ao interessar-se pela investigação dos não-acontecimentos, o estudo da cultura material dedica-se, pelo contrário, a observar de preferência aquilo que na colectividade é estável e constante e que, como tal, a possa caracterizar: em vez da sucessão de factos diversos, procura os factos que se repetem suficientemente para serem interpretados como hábitos, tradições reveladoras da cultura que se observa. [BuCAILlE; PESEZ, 1989, p. 15]

Esta definição não menciona a possibilidade de os objetos artísticos serem tomados, pela sua materialidade e por terem sido produzidos em determinada época e cultura, como artefatos, como quer Prown, e assim também poderem ser estudados e trazerem indícios da cultura em que foram produzidos. Mas, feita essa ressalva, a definição não deixa de servir para se pensar a natureza do livro didático como artefato e a possibilidade de estudá-lo como um integrante da cultura material de uma época do país.

Antes disso, no entanto, como a origem do conceito de cultura material pode ser ainda fortemente associado ao estudo das chamadas sociedades arcaicas ou mesmo da pré-história quando do início das descobertas arqueológicas no final do século XVIII e início do XIX, um retrospecto da trajetória epistemológica do conceito deve ajudar a verificar o alcance e a va-

2 "Material Cultural is just what it says it is - namely, the manifestations of culture through material productions. [...] to discover the beliefs - the values, ideas, attitudes, and assumprions - of a particular community or society at a given time." 
lidade de sua aplicação para o estudo de um artefato produzido e consumido na forma de mercadoria em plena época contemporânea.

Aqui, recorremos novamente a BUCAILlE; PESEz [1989], que apresentam detalhadamente uma história do conceito na obra citada. Num primeiro momento a noção apareceu, não com os termos que a constituem, com a pesquisa arqueológica da pré-história na primeira metade do século XIX, passando pela paleontologia de Darwin, pela economia política de Marx e Engels, até o início da sociologia de Comte e Durkheim e a antropologia social e cultural aplicada às sociedades arcaicas. Nas novas e antigas ciências que se transformavam no século XIX, diversas correntes confluiram para a constituição de uma "ruptura epistemológica", em que uma nova metodologia de pesquisa se apoiava nas evidências materiais deixadas pelos organismos, pelos indivíduos e pelas sociedades, para a produção do conhecimento, num ambiente sociopolítico propício à contestação da velha ordem científica, em que as opções políticas gerais progressistas e socialistas concordavam na atenção dada à vida material [BuCAILlE; PESEz, 1989, p. 3-6].

Porém, até o início do século XX, ela não aparece ainda formulada e isolada, mas desenvolvem-se as condições sociológicas e científicas para seu surgimento. Seu "processo de maturação" se completará nos primeiros vinte anos do século, quando é formulada pelo materialismo histórico e aparece no decreto oficial de Lênin que cria, em 1919, a Academia de História da Cultura Material em Moscou. É quando a cultura material passa a ser objeto da história que, segundo os autores, se completa a noção de cultura material como "instrumento intelectual acabado" [BucAille; Pesez, 1989, p. 7].

A cultura material como objeto da história tem um desenvolvimento exemplar na escola dos Annales, na França, quando, procurando romper a parcialidade e incompletude da história tradicional focada na realeza e nos feitos individuais de seus membros como sendo a história de toda a nação, historiadores como Marc Bloch e Lucien Febvre procuraram reconstruir a vida cotidiana de grupos sociais mais amplos, como os camponeses por exemplo, recorrendo aos objetos e indícios materiais da vida ordinária dos indivíduos, ao que eles produziam e consumiam, e não a episódios excepcionais [BuCAILle; Pesez, 1989, p. 8].

Por fim, tirando as consequências do que está implícito na noção consolidada de cultura material, aqui apresentada por BUCAILlE; PESEZ [1989], pode-se citar a aplicação dela pela antropologia nos dias de hoje que faz Daniel MiLler [2007] ao investigar o fenômeno do consumo de massas, de refrigerantes a eletrodomésticos, automóveis e arquitetura. Segundo o autor, o consumo dos artefatos não é um fenômeno da sociedade atual e esteve sempre presente em relação estreita com a produção de artefatos, como sua motivação ou consequência necessárias, adquirindo conformações diferenciadas em cada época, incluindo a forma específica de mercadoria sob o capitalismo [MILLER, 2007, p. 33-66]. 
Agora, por fim, com os atributos que o livro didático apresenta - ser um objeto de uso em instituição criada pela sociedade, pertencer a um gênero específico decorrente desse uso, ter presença na vida e na formação intelectual de seu público, ter importância comercial como bem de consumo - o livro didático reúne algumas condições que inscrevem uma investigação sobre sua materialidade e visualidade em algum campo de estudos da cultura material, no nosso caso, a história do design.

De fato, a condição de artefato produzido em massa para amplos públicos, conforme práticas correntes, de longa permanência e geralmente não creditadas, e sua inserção na vida cotidiana de alunos, professores e familiares, fazem do livro didático um objeto percebido como quase banal, desprovido de excepcionalidade, e portanto capaz de, aplicando-se o raciocínio tanto de Prown como de BuCAILLE; PESEZ, informar sobre a cultura da sociedade que os produz e que os utiliza.

Ou, antecipando um desdobramento deste raciocínio e explicitando suas consequências, a pesquisa da materialidade e visualidade do livro didático deve ser capaz de trazer informações sobre as condições técnicas e econômicas de sua produção, valores e ideologias vigentes em sua época, linguagens, estilos e gosto estético circulantes na sociedade. Também antecipando o que vai ser tratado neste capítulo, a título de advertência, fala-se aqui em trazer informações, e não em pretender construir todo o contexto social e cultural mencionado a partir exclusivamente de deduções das características materiais e visuais dos livros escolares estudados.

Prosseguindo, como artefato, o livro didático tem algo em comum com instrumentos, ferramentas e dispositivos, que segundo Jules David Prown [1993] são evidências históricas porque não só existem ou acontecem, mas são o resultado de causas:

Artefatos, como outros eventos históricos, não acontecem simplesmente; eles são resultado de causas. Há razões porque um objeto ganhe existência com uma determinada configuração, é decorado com determinados motivos, é feito de um determinado material, e tem uma determinada cor e textura. [PROWN, 1993, p. 3] ${ }^{3}$

Ainda segundo o autor, essas causas são de três ordens: a do ofício, que se refere ao modo de fazer herdado da tradição; a da cultura, que se refere a atitudes, hábitos e crenças vigentes que condicionam o fazer e o utilizar; e a do domínio da privacidade, que se refere à psicologia individual da pessoa que produz o objeto [Prown, 1993, p. 3]. Assim, os estudos de artefatos sob o enfoque da cultura material seriam capazes de revelar as crenças - de superfície e profundas - dos indivíduos, grupos de indivíduos e sociedades inteiras, coincidindo com a noção de cultura material apresentada por BUCAILLE; PESEZ [1989].

3 "Artifacts, like other historical events, do not just happen; they are the result of causes. There are reasons why an object comes into existence in a particular configuration, is decorated with particular motifs, is made of particular materials, and has a particular color and texture." 
É importante, no entanto, cercar-se de cuidados para não entender o mundo material construído pelo homem como reflexo de crenças ou visão de mundo que se materializariam nos objetos, como se houvesse uma cultura como um mundo de ideias e concepç̃es mentais e uma cultura material que a refletisse, e não um único fenômeno que abarcasse diversas dimensões, incluída a material, e que esta dimensão também atua na construção e modificação das consciências, ou seja, da cultura como um todo. Para Marcelo REDE [1996, p. 267], a noção de cultura material como "reflexo de uma cultura concebida como patrimônio abstrato, alheia a toda materialidade", cria dois polos, um mental e um material, e introduz um divórcio entre eles e tem como consequência o "esvaziamento da historicidade da noção de cultura" [REDE, 1996, p. 268]. Para o autor:

O universo material não se situa fora do fenômeno social, emoldurando-o, sustentando-o. Ao contrário, faz parte dele, como uma de suas dimensões e compartilhando de sua natureza, tal como as idéias, as relações sociais, as instituições.

Eis aí a fortuna do termo cultura material, além das ambiguidades possíveis: ele denota que a matéria tem matriz cultural e, inversamente, que a cultura possui uma dimensão material.

Em suma, como a cultura não é um segmento do fenômeno social, mas uma dimensão extensiva sua, não se poderia isolar uma seção que não fosse cultural ou uma outra que o fosse exclusivamente. [REDE, 1996, p. 274]

Essas considerações são importantes para estabelecer as premissas da aplicação do conceito de cultura material a uma pesquisa em história do design, permitindo fixar objetivos diferentes daqueles visados por exemplo pela antropologia, que utiliza os indícios materiais para buscar reconstruir a dimensão simbólica da vida de um grupo social, ou da história, que os utiliza como documentos, ao lado dos escritos, para reconstruir a vida social e explicar seus processos e eventos. Essas premissas e objetivos serão vistos no tópico seguinte.

\subsection{Cultura material: forma, produção e uso}

Não se descarta que os objetos propiciem indícios da vida mental e das motivações de ordem espiritual de quem os produziu, uma vez que são evidências históricas e portanto resultado de causas de diversas ordens, e que por isso seu estudo contribua para a comprensão de uma totalidade social e cultural mais ampla. Mas o que uma pesquisa sobre a visualidade e a materialidade de artefatos impressos pelo recorte original e específico da história do design pode propor é exatamente a compreensão da forma em si mesma como resultado da interação entre produção (materiais, técnica, organização de trabalho) e finalidade (circulação, demandas, consumo/uso) e a inserção dessa forma num conjunto e num processo de produção de formas ao longo do tempo, como componente e manifestação da cultura, com relativa autonomia e dinâmica própria. 
No caso do livro didático, gênero que tem espaços e práticas de produção, circulação e uso bastante específicos e com relativa estabilidade - ao menos no período abarcado por esta pesquisa - a possibilidade de compreensão desse artefato não só como objeto isolado, mas principalmente como integrante de uma série material em que está inserido e que justifica sua existência, começa pelo reconhecimento e entendimento de sua configuração física e formal e do que ela pode conter de indícios de sua fabricação, circulação e apropriação. Mas se objetos intermediam relações pessoais e sociais, e sua forma de alguma maneira as possibilita e expressa, não é um reflexo automático dessas, o que pode ser verificado quando a forma de um artefato permanece estável durante um período longo de tempo que abarcou transformações sociais consideráveis ou quando um artefato é apropriado por novos grupos com mudança de seu sentido ou uso original.

Essa abordagem é corroborada por BUCAILLE; PESEz [1989], que aqui resumem e completam a noção de cultura material incorporando duas outras características a partir do segundo termo da expressão:

Em primeiro lugar, demasiadas vezes se ignora o facto de que a cultura material é, antes de mais, tal como o seu nome indica, uma cultura. Nessa qualidade, possui dois dos seus aspectos principais: a colectividade (oposta à individualidade) e a repetição por oposição ao acontecimento dos fenômenos que a compõem, o que, em qualquer ciência, define uma importante situação epistemológica e, por conseguinte, opções ideológicas e metodológicas. Além disso, esta aproximação cultural é determinada pela angularidade da materialidade, que foi a escolha para essa abordagem, tal como indica o adjectivo "material". Esta escolha da materialidade revela dois aspectos precisos: o apego aos fenómenos infraestruturais como causalidade heurística e a atenção aos objectos concretos que explicam estes fenómenos: mesmo estes aspectos - sobretudo o primeiro - pressupõem orientações ideológicas e metodológicas evidentes e bem precisas. [BuCAIlle; Pesez, 1989, p. 18, grifos meus]

Daí que, em outra passagem, os autores possam afirmar que, ao estudar a cultura material é preciso atribuir importância causal aos aspectos materiais da cultura, "entendidos como causas explicativas, e isso, em certa medida, em prejuízo dos seus aspectos menos materiais" [BuCAille; PeSEZ, 1989, p. 16, grifo meu].

A forma (com todos os seus atributos materiais), suas relações causais com as condições que a produziram (como o nível tecnológico, matérias-primas, divisão do trabalho) e suas relações com as expectativas e com o uso efetivo, no nível prático e simbólico (gosto, linguagem, estilos), é a esfera de atuação do design, como atividade que antecede a feitura dos artefatos que constituem uma cultura material.

Assim, deve-se considerar que uma abordagem do artefato gráfico livro didático circunscrita ao campo história do design implica, em primeiro lugar, dirigir o olhar para a materialidade 
desse objeto em seus aspectos formais. Ou seja, reconhecer os elementos de linguagem plástica e gráfica, como materiais utilizados, cores, dimensões, tipografia, as relações sintáticas entre eles (posição, proporções, contrastes) e estilos, relacionando-os aos que circulam socialmente. Em segundo lugar, procurar identificar na forma apresentada os processos industriais, técnicas, práticas profissionais e até organização do trabalho envolvidos na sua configuração. Em terceiro lugar, identificar na forma os aspectos de uso, ou seja, o tipo de conteúdo que veicula e as demandas que a geraram.

Resumindo, abordar a materialidade de um artefato é considerá-lo sob as seguintes dimensões conceituais:

- formal: características e sintaxe gráfico-visual presentes e relação com linguagens e estilos circulantes no campo gráfico e editorial no período;

- tecnológica: processos industriais, técnicas, práticas profissionais e organizacão do trabaIho envolvidos na produção;

- de uso: o tipo de conteúdo que veicula e as demandas a ele relacionadas.

O estabelecimento das relações entre forma, produção e uso precisa necessariamente começar pelo reconhecimento da existência concreta da forma e de suas relações internas como objeto material e visual, ou seja, sua sintaxe formal-visual:

O método chave para derivar história de "coisas gráficas" é a análise de linguagem gráfica e visual, que pode nos revelar algo sobre repertórios, tendências, gosto e sua circulação. Combinada com observações sistemáticas sobre os meios e técnicas de produção de artefatos gráficos e com uma compreensão dos significados atribuídos a eles por clientes, produtores e consumidores, tal análise pode permitir ricas interpretações históricas. [FARIAS, 2014, p. 204] ${ }^{4}$

Sobre a questão da relação entre tecnologia e forma, diz Adrian FoRTY [2007]:

a qualidade especial da palavra design é que ela transmite ambos os sentidos [aparência estética e preparação de instruções para a produção de bens manufaturados], e a conjunção deles em uma única palavra expressa o fato de que são inseparáveis: a aparência das coisas é, no sentido mais amplo, uma consequência das condições de sua produção. [FoRTY, 2007, p. 12]

Assim, antes do que procurar interpretações de alcance mais amplo ou ser condicionado por conhecimentos e definições prévias trazidas de outras áreas do conhecimento, por temor de deixar escapar a "dimensão social do design", o esforço por relacionar a forma às condições de produção e às necessidades de uso é o que em primeira instância pode

\footnotetext{
4 "The key method for deriving history from 'graphic things' is graphic and visual language analysis, which can tell us about repertoires, trends, tastes, and its circulation. Combined with systematic observations about the means and techniques of production of graphic artifacts, and with an understanding of the meanings attributed to them by clients, producers, and consumers, such analysis can aford rich historical interpretations."
} 
sintetizar a dimensão social desse objeto, tanto nos aspectos de sua inserção como forma na produção de formas da sociedade, como no de ser condicionada por exigências sociais externas a ela.

Isto não quer dizer que os métodos de leitura gráfico-visual específicos do campo do design, que vai se utilizar na análise das peças obtidas pela pesquisa material, expliquem isoladamente o objeto ou a série de que faz parte, sem o concurso de informações obtidas em outras disciplinas e campos de conhecimento:

Os atributos intrínsecos dos artefatos, é bom que se lembre, incluem apenas propriedades de natureza físico-química: forma geométrica, peso, cor, textura, dureza etc. etc. Nenhum atributo de sentido é imanente. O fetichismo consiste, precisamente, no deslocamento de sentidos das relações sociais - onde eles são efetivamente gerados - para os artefatos, criando-se a ilusão de sua autonomia e naturalidade. Por certo, tais atributos são historicamente selecionados e mobilizados pelas sociedades e grupos nas operações de produção, circulação e consumo de sentido. Por isso, seria vão buscar nos objetos o sentido dos objetos. [MENESES, 1998, p. 91]

Mas, prosseguindo, o autor ressalva que os traços materiais dos artefatos - como a matéria-prima, seu processamento, a morfologia do artefato, sinais de uso, etc. - permitem inferências diretas sobre muitas esferas de fenômenos, como a natureza e propriedade dos materiais, o saber-fazer envolvido, a divisão técnica do trabalho, aspectos funcionais e semânticos etc., que constituem a base empírica necessária para a inferência de dados sobre a organização econômica, social e simbólica da existência social e histórica do objeto. No entanto, por se tratar de uma inferência, "há necessidade, não apenas de uma lógica teórica, mas ainda do suporte de informação externa ao artefato" [MENESES, 1998, p. 91], mais ainda por ele não ser um objeto passivo e inerte, mas sim algo que interage no tempo e no espaço social. "Daí a importância da narrativa e dos discursos sobre o objeto para se inferir o discurso do objeto" [MENESES, 1998, p. 91].

\subsection{Design e cultura}

Se o design é uma atividade projetual envolvida na produção da cultura material e esta é uma dimensão da própria cultura, qual a relação do design com a cultura de uma sociedade?

O verbete cultura material, em Luiz Antonio CoelHo [2008] menciona uma ambiguidade, uma área de indefinição para o design:

pois enquanto atividade que tem como objetivo a configuração de objetos de uso e sistemas de informação, ora pertence à expressão cultural mais ampla de uma sociedade, enquanto atividade que se apropria de valores estabelecidos; ora à cultura material dessa mesma sociedade, enquanto 
resultado, ou seja, objetos e sistemas configurados, que representam materialmente e formalmente esses valores. Essa parece ser justamente uma das características do design: materializar ideais, valores e conceitos, configurando-os através de objetos utilitários, correspondentes às mais diversas necessidades, demandas e anseios sociais. [CoElHo, 2008, p. 63-64]

No entanto, apenas a título de alerta, não se está tomando essa acepção, ou o lado "mais cultural" do conceito design, como participante da cultura num sentido mais amplo, para apresentar o design como valor em si, ideologia autônoma "agregadora de valor" a bens de consumo na promoção de sua venda, desligado do que primariamente ele faz, que é, até subordinado a essa demanda específica, participar da produção de artefatos em sua etapa de projeto. Como afirma Rafael Cardoso DenIS:

Independentemente dessas questões, acho que quase todos concordariam que o design se encaixa em um fenômeno humano bem mais abrangente: o processo de projetar e fabricar objetos. Do ponto de vista antropológico, o design é uma entre diversas atividades projetuais, tais quais as artes, o artesanato, a arquitetura, a engenharia e outras que visam a objetivação no seu sentido estrito, ou seja, dar existência concreta e autônoma a ideias abstratas e subjetivas. [DENIS, 1998, p. 19]

Mas, aplicando o conceito para a sociedade atual, que pauta sua identidade cultural na abundância material, prossegue o autor:

Restringindo a análise ao universo dos bens móveis (em contraposição aos imóveis, que são produtos da arquitetura e da engenharia), o design se configura como o foro principal para o planejamento e o desenvolvimento da maioria quase absoluta dos objetos que constituem a paisagem artificial (no sentido de 'não natural') do mundo moderno. Se não bastasse esse largo predomínio quantitativo do universo dos artefatos, o design ainda exerce uma influência considerável sobre a paisagem semiótica moderna, principalmente no que diz respeito à transmissão de informação por meios outros que os discursos falados, cinemático e/ou musical, exceções importantes mas praticamente únicas (e até certo ponto parciais) à ubiquidade do design gráfico como processo de ordenação dos meios de comunicação. [DeNIS, 1998, p. 22]

Assim, é nesse contexto e com esse papel que o design integra a produção de cultura material da sociedade atual, incluindo o de atuar, em muitos casos primordialmente, como o promotor do consumo de determinados bens - aspecto bastante complexo e polêmico que foge ao objetivo da discussão deste capítulo. O que importa considerar é o alcance e a influência dessa atividade materializada em livros de uma editora com presença constante e massiva no ambiente escolar por mais de cinco décadas, seu possível papel na formação do gosto e da identidade de seu público e sua relação com a visualidade proveniente de outras fontes, em cada momento, assunto dos dois próximos tópicos deste capítulo. 


\subsection{Livro didático, memória gráfica e identidade}

A pesquisa proposta, por se apoiar na coleta e registro de artefatos gráficos de ampla circulação numa época e país determinados e procurar identificar suas características de linguagem e quem as produziu e as utilizou — em última instância seu significado coletivo pode ser inscrita numa linha de pesquisa que vem sendo identificada com a denominação de memória gráfica.

Relativamente ao contexto de seu emprego, afirma Priscila FARIAS:

Ele reflete uma tendência, que pode ser rastreada até o início do século XXI, de usar esta expressão para descrever os esforços em resgatar ou reavaliar artefatos visuais, em particular impressos efêmeros, visando a recuperação ou o estabelecimento de um sentido de identidade local. [FARIAS, 2014, p. 201] ${ }^{5}$

A mencionada reavaliação de artefatos visuais e os objetivos relativos ao estabelecimento de identidade local referem-se ao reconhecimento de que esses objetos desempenharam e desempenham algum papel como formadores da cultura visual de uma coletividade e se inscrevem na formação de sua própria identidade:

Artefatos gráficos desempenham um papel importante na vida cotidiana, através de nossas experiências de comunicação e de troca e em nossas interações com a paisagem urbana. Apesar da sua importância para a constituição de uma cultura visual que participa da formulação de identidades coletivas, estudos sobre a configuração de tais artefatos, em particular antes do estabelecimento do campo acadêmico e profissional de design, e especialmente nos países que importaram tradições de design do exterior, têm sido negligenciadas por muitas décadas. [FARIAS, 2014, p. 202] ${ }^{6}$

Há assim uma nova perspectiva, bastante diferente de tendências há pouco vigentes na história do design que tinham como foco apenas a produção autoral de designers de filiação modernista ou no máximo localizados dentro da corrente do design iniciada em fins do século XIX nos países europeus, que desembocou no modernismo e foi posteriormente exportada para países periféricos. Visão esta, segundo Rafael CARDoso [2004, p. 12-13], componente legitimadora do próprio processo de diferenciação e afirmação profissional da atividade.

O termo memória, como primeiro componente da expressão memória gráfica, nesse contexto histórico e com o sentido em que vem se estabelecendo, parece ter a forte conotação de constituição de acervo, coleção, para se contrapor ao esquecimento dos indícios materiais

\footnotetext{
5 "That reflects a trend, that can be traced back to the early $27^{\text {st }}$ century, of using this expression to describe efforts to rescue or to reevaluate visual artifacts, in particular printed ephemera, aiming at the recovery or the establishment of a sense of local identity."

6 "Graphic artifacts play an important role in everyday life, through our communication and exchange experiences and in our interactions with the urban landscape. Despite their importance for the constitution of a visual culture that contributes to the formulation of collective identities, studies on the configuration of such artifacts, in particular before the establishment of the academic and professional field of design, and especially in countries that imported design traditions from abroad, have been neglected for many decades."
} 
da identidade coletiva, tanto como resultado do processo autóctone natural de cada cultura como da influência ou dominação de culturas externas. ${ }^{7}$ E parece haver também uma extensão do sentido psicológico de memória individual para a dimensão do coletivo, em que da mesma forma que a lembrança dos objetos e fatos resgata o passado individual e afirma a particularidade de uma existência presente, a coleta e organização dos fatos e objetos da vida material de um povo ou comunidade são necessárias para enfrentar uma tendência ao enfraquecimento de sua identidade coletiva, particularmente num momento em que culturas economicamente mais poderosas tenderiam mais a se impor do que estabelecer trocas.

Nesse sentido, é importante estabelecer, mesmo que de maneira sumária, o "mecanismo" de formação da identidade coletiva a partir da memória e o papel dos objetos materiais nesse processo.

Com esse intento, Jan Assmann [2008] inicialmente parte de uma conceituação de memória estabelecida por Thomas Luckmann em sua obra Remarks on Personal Identity: Inner, Social and Historical Time:

Memória é a faculdade que nos permite formar uma consciência de individualidade (identidade), tanto no nível individual como no coletivo. A identidade, por sua vez, está relacionada com o tempo. O eu (humano) é uma "identidade diacrônica", construída "da matéria do tempo" (Luckmann). Esta síntese de tempo e identidade é produzida pela memória. [ASSMANN, 2008, p. 109] ${ }^{8}$

E em seguida, o autor identifica a existência de três formas de memória - individual, comunicativa e cultural —, relacionadas a três níveis fenomenológicos — interno (pessoal), social e cultural:

No nível interno, a memória é um assunto do nosso sistema neuromental. É a nossa memória pessoal, a única forma de memória reconhecida como tal até a década de 1920. No nível social, a memória é uma questão de comunicação e interação social. Foi a grande conquista do sociólogo francês Maurice Halbwachs, ao mostrar que a nossa memória depende, como a consciência em geral, da socialização e da comunicação, e que a memória pode ser analisada como uma função da nossa vida social. [AsSMANN, 2008, p. 109] ${ }^{9}$

7 A relação de acervos, sites, bancos de dados e pesquisas acadêmicas cobrindo diversos tipos de artefatos impressos - do vernacular ao comercial - na América Latina e no Brasil apresentada por Farias [2014, p. 201-204], chama atenção para o alcance e o sentido desse movimento de recuperação da memória gráfica em países não-hegemônicos e excluídos das "narrativas dominantes da história do design"( dominant narratives of design history) [FARIAS 2014, p. 205].

8 "Memory is the faculty that enables us to form an awareness of selfhood (identity), both on the personal and on the collective level. Identity, in its turn, is related to time. A human self is a 'diachronic identity', built 'of the stuff of time' (Luckmann). This synthesis of time and identity is effectuated by memory."

9 "On the inner level, memory is a matter of our neuromental system. This is our personal memory, the only form of memory that had been recognized as such until the 1920s. On the social level, memory is a matter of communication and social interaction. It was the great achievement of the French sociologist Maurice Halbwachs to show that our memory depends, like consciousness in general, on socialization and communication, and that memory can be analyzed as a function of our social life." 
Esta segunda forma de memória, chamada por Assmann [2008] de memória comunicativa, diz respeito à transmissão de comportamentos, hábitos e conhecimentos que ocorre na interação e comunicação do dia-a-dia, sem o quadro de instituições ou conhecimento especializado, e não cobrindo mais do que o tempo de oitenta anos, ou seja, o que é transmitido por três gerações em contato direto. Embora sem depender de instituições formais, evidentemente se dá por formas, gêneros de comunicação e tipos de relações socialmente estabelecidas.

Já a forma de memória a que AsSMANN [2008] chama de memória cultural diz respeito ao que é mediado por instituições e objetos materiais, e diferentemente do alcance e sentidos de palavras e gestos, apresenta grande estabilidade, seus conteúdos podem ser transferidos de uma situação a outra e transmitidos a gerações distantes.

A identidade dos indivíduos, no sentido da consciência de sua individualidade e pertencimento a um grupo ou sociedade, é portanto formada pela participação simultânea e articulada desses três níveis de memória, o imediatamente individual e os coletivos - o comunicativo e o cultural.

Ou, como afirma Kathrin WoOdWARD [2007], em relação ao componente social da individualidade:

"Subjetividade" sugere a compreensão que temos sobre o nosso eu. O termo envolve os pensamentos e as emoções conscientes e inconscientes que constituem nossas concepções sobre "quem nós somos". A subjetividade envolve nossos sentimentos e pensamentos mais pessoais. Entretanto, nós vivemos nossa subjetividade em um contexto social no qual a linguagem e a cultura dão significado à experiência que temos de nós mesmos e na qual nos dotamos de identidade. Quaisquer que sejam o conjunto de significados construídos pelos discursos, eles só podem ser eficazes se eles nos recrutam como sujeitos. Os sujeitos são, assim, sujeitados ao discurso e devem, eles proprios, assumi-lo como indivíduos que, dessa forma, se posicionam a si proprios. As posições que assumimos e com as quais nos identificamos constituem nossas identidades. [WOODWARD, 2007, p. 55]

O livro didático obviamente se inscreve nessa categoria de objeto relacionado à transmissão da memória cultural pela função de que é revestido - o ensino - , pelo conteúdo que veicula - conhecimentos estabelecidos - e pelos meios como o faz - o uso da escrita e de imagens.

Como artefato relacionado a uma cultura escolar determinada, participa da constituição dessa cultura em sua dimensão material. Ou seja, pode-se falar dele e estudá-lo como um artefato da cultura material escolar, relacionado às práticas que definem a cultura escolar tal, como expresso por Dominique JULIA [2001]:

Para ser breve, poder-se-ia descrever a cultura escolar como um conjunto de normas que definem conhecimentos a ensinar e condutas a inculcar, e um conjunto de práticas que permitem a 
transmissão desses conhecimentos e a incorporação desses comportamentos; normas e práticas coordenadas a finalidades que podem variar segundo as épocas (finalidades religiosas, sociopolíticas ou simplesmente de socialização). [JuLIA, 2001, p. 10]

E a pesquisa da cultura material escolar tem efetivamente sua razão de ser no âmbito da história da educação, como afirma Cláudia Alves [2010]:

Apesar das nuanças nos modos de operar com o conceito, a materialidade dos suportes da atividade escolar - portadores dos indícios das práticas educativas, mas também de sua normatização, das formas de controle, bem como dos conteúdos selecionados no conjunto de saberes eleitos pela escola - impôs-se como parte da problemática da pesquisa histórica em educação, acompanhando a incorporação dos estudos em torno da cultura escolar [...] Recortada na ampla rede de relações culturais que constrói a escola e suas práticas, a cultura material escolar não pode, portanto, ser pensada fora delas. Por isso, o recurso às contribuições do debate historiográfico mais amplo permite encontrar parâmetros de análise que articulem a materialidade da escola à produção cultural que envolve outros âmbitos da vida social. [ALVES, 2010, p. 104, grifos meus]

Com relação aos livros escolares, a autora mesmo identifica que "enquanto objeto material, são, em geral, produzidos por editoras", mas não deixa de salientar que "os historiadores da educação têm demonstrado a participação ativa dos professores como autores, o que implica uma concepção originária da atividade de ensino" [ALVES, 2010, p. 105].

Assim, mesmo reconhecendo essa ligação estreita com a escola, que faz do livro didático um produto da cultura escolar e um participante dela, ele é produzido fora da cultura escolar e mantém vínculos com "outros âmbitos da vida social", trazendo-os para o interior da própria cultura escolar e para a memória de suas vivências. Este é um primeiro aspecto que pode legitimar uma pesquisa no campo da história do design na linha definida como de memória gráfica a partir de sua condição de artefato gráfico integrante de um conjunto mais amplo de artefatos gráficos. Conjunto este que participaria não só de uma cultura escolar específica, mas de uma cultura visual mais ampla, em alguma medida identitária do país em alguns de seus momentos.

Nessa formulação há um outro aspecto implícito relativo à memória e identidade cultural que inscreve a pesquisa sobre o livro didático no campo da memória gráfica, mas que merece ser explicitado. Como integrante de uma cultura escolar vivenciada coletivamente - condição para se falar em cultura - o livro didático é um artefato que participa intensa e extensivamente da experiência de formação intelectual dos indivíduos em um momento de suas vidas, gerando memória individual e memória coletiva identitária daquela geração. Assim, a par de artefato portador de memória no nível cultural apontado por Assman, através dos conteúdos textuais e visuais que transmite, o livro didático é também portador de memória em outro nível 
coletivo, o comunicativo, através das práticas envolvidas no seu uso, e também no nível individual, o que, retomando o que diz o mesmo autor, são os três níveis que, articulados, participam da formação da identidade dos indivíduos.

Assim, embora o uso do livro didático tenha "prazo de uso e validade" para os indivíduos, ele não é exatamente um impresso efêmero, não só porque acompanha o trajeto escolar por pelo menos um ano letivo, como porque é continuamente reeditado, às vezes com pouquíssimas modificações formais, atingindo inúmeras gerações de estudantes e constituindo um artefato gráfico com grande estabilidade e potencial para constituir a memória e identidade de uma sociedade.

Mas se o livro didático, como outros objetos gráficos mais efêmeros, se ressente de não ter sido antes objeto de pesquisa em história do design, o mesmo ocorreu em outros campos, como a história do livro e das edições e mesmo no campo mais estabelecido da história da educação até ao menos a década de 1970, segundo Allain Choppin [2004]. Se no caso da história do design isso pode se dever pelo predomínio até pouco tempo de abordagens centradas na história de personalidades ou artefatos desenhados dentro linguagens identificadas com uma corrente principal do design modernista, como será visto no tópico 1.9 deste capítulo, no caso de outras disciplinas mencionadas pesou principalmente a desvalorização cultural do livro didático.

A principal causa do desprestígio do livro didático residiria na dupla condição de uso temporário e de não portador de informação científica atualizada, o que não motivava sequer sua presença em bibliotecas, fato que acabava por reforçar sua invisibilidade para a cultura e contribuir para seu esquecimento, a não-memória.

No entanto, num movimento paralelo ao que ocorre no campo da história do design, o esquecimento do livro didático vem sendo substituído pela constituição de acervos e bancos de dados especializados em todo o mundo, e no Brasil com a formação da Biblioteca do Livro Didático da FEUSP, dentre outras, e do Livres - Banco de Dados de Livros Escolares Brasileiros, o que vem incentivando estudos no campo da Educação e de sua história, particularmente os ligados à história das disciplinas e das práticas e cultura escolar.

Do ponto de vista da história do design, a recuperação da memória do livro didático como objeto gráfico, como já se disse, pode ter o objetivo de documentar e analisar a materialidade e visualidade de um artefato presente na vida da sociedade brasileira, que ao lado de outros integraria um conjunto de objetos participantes da formação de sua cultura visual e identidade. No entanto, o fato de esse objeto constituir um gênero bastante diferenciado, ter uma presença delimitada no tempo dos indivíduos e estar ligado a uma prática e cultura específica, a escolar, acrescenta uma dimensão particular a esse estudo: a identificação e descrição de uma cultura visual específica, com suas práticas e tradição de design próprios, ligados à produção 
realizada por um tipo específico de indústria e ao uso num tipo de espaço próprio, com práticas e necessidades particulares.

\subsection{Livro didático e cultura visual}

Dotados de materialidade e visualidade diferenciadas decorrentes de sua função específica, os livros didáticos utilizados por um estudante durante sua vida escolar fazem parte de um conjunto mais amplo de objetos e informações de caráter visual consumidos durante esse período. Da mesma forma, os livros utilizados ou vistos por um professor de uma disciplina se somam a objetos e informações visuais presentes na sociedade e que chegam até ele. Essa constatação empírica pressupõe a existência de algo a que se possa chamar de cultura visual de uma determinada sociedade em determinado tempo e admite a existência de um segmento ou subcultura visual específica ou especializada, com algumas particularidades em relação à essa cultura visual geral.

Como já foi visto, o que se chamou cultura material não é uma materialização ou expressão material de uma suposta cultura localizada no mundo das idéias, mas é a parte material da própria cultura, seus objetos ou, melhor dizendo, artefatos. Que por sua vez, como são percebidos pelos sentidos, no tocante à visão poderia levar a se pensar apenas em simples percepção visual, em visibilidade do material, como recepção de tudo que é visível, que se apresenta à visão. Mas tudo que é cultura material é antes de tudo, cultura, ou seja, é produzido pelo homem, conforme a noção operativa de cultura tomada aqui de Roque de Barros LARAIA [2001]:

Em 1871, Tylor definiu cultura como sendo todo o comportamento aprendido, tudo aquilo que independe de uma transmissão genética, como diríamos hoje. [LARAIA, 2001, p. 28]

[...] Culturas são sistemas (de padrões de comportamento socialmente transmitidos) que servem para adaptar as comunidades humanas aos seus embasamentos biológicos. Esse modo de vida das comunidades inclui tecnologias e modos de organização econômica, padrões de estabelecimento, de agrupamento social e organização política, crenças e práticas religiosas, e assim por diante. [LARAIA, 2001, p. 59]

As formas de que se reveste a cultura material, ou seja, que os objetos e artefatos apresentam, foram produzidas como resultado de atividade eminentemente cultural, a de produção de formas (que na citação acima estaria incluída no "e assim por diante"). Assim, a cultura visual seria parte da própria cultura material, mas não só. Constatando a generalização do uso da expressão cultura visual por diversas disciplinas que abordam o fenômeno da visualidade a partir da percepção de sua importância na contemporaneidade - particularmente 
as correntes reunidas sob o nome de Visual Culture Studies - Ulpiano Bezerra de MENESES [2003] afirma:

Neste variegado panorama de conceitos, recursos, propósitos e aspirações fica difícil definir unitariamente o que seja Cultura Visual. Não basta colocar "o visual" no centro das preocupações. Malcolm Barnard, ao menos tentou discernir duas vertentes fundamentais. A primeira tem a cultura como traço forte e se referiria a valores e identidades construídas e comunicadas pela cultura por mediação visual. Inclui a natureza conflitiva do visual, os mecanismos de exclusão que os processos identitários envolvem, a inclusão do visual no processo social, etc. A outra vertente enfatizaria o visual e com isto incluiria toda a gama de coisas que os homens produzem e consomem "as part of their cultural and social lives": de arte e design a expressões faciais, moda, tatuagem e assim por diante. [MENESES, 2003, p. 27]

No entanto, o autor considera a distinção ambígua e que as duas opções precisam ser conceitualmente articuladas, pois observa que a cultura não é um segmento à parte da vida social, mas uma sua qualificação, "de todos os segmentos dessa mesma vida" [MENESES, 2003, p. 25]. Assim, a cultura material, da qual a cultura visual seria uma subcategoria, "teria que ser estudada não como o conjunto de coisas e contextos materiais de que se serve o homem na sua vida social, mas como a dimensão física, empírica, sensorial, corporal, da produção/reprodução social (o uso do termo 'cultura' aqui também pressuporia mediação de significados e valores)" [MeNESES, 2003, p. 27].

Assim, mais do que estar presente como um acessório nos objetos materiais - como uma mera "visibilidade da cultura" - a visualidade se apresenta como a própria cultura, ou ao menos uma de suas dimensões.

Nicholas Mirzoeff vai ainda mais longe, ao identificar cultura e visualidade como fenômenos indissociáveis na contemporaneidade, a marca mesma da vida cotidiana na pós-modernidade - ressaltando-se apenas que o autor utiliza o termo "visual culture" a maior parte das vezes como o nome do novo campo de estudos do fenômeno visual integrante dos "cultural studies", como aponta MENESES, ou como uma estratégia multidiscilinar para abordar todas as manifestações da visualidade contemporânea.

A razão mais frequentemente colocada para esta intensificação da visibilidade é que a experiência humana é atualmente mais visual e visualizada do que nunca. Em diversos aspectos, as populações nas sociedades industrial e pós-industrial vivem em culturas visuais a um ponto que parecem marcar uma divisão entre presente e passado. A imprensa popular constantemente chama a atenção para o uso da imagem digital no cinema, o advento da pós-fotografia e o desenvolvimento do uso médico da imagem, para não mencionar o curso interminável de comentários dedicados à Internet. A globalização do visual, tomada coletivamente, exige novas formas de interpretação. Ao mesmo tempo, esta transformação do presente pós-moderno também requer 
uma reescrita das explicações históricas do modernismo e da modernidade a fim de esclarecer a 'virada para o visual'. [MiRzoEfF, 1998, p. 4] ${ }^{10}$

Mas, em uma acepção de cultura visual bastante abrangente, válida também para períodos anteriores à mencionada pós-modernidade, ou ao menos válida para a modernidade, diz MiRZOEFF:

Cultura visual diz respeito a eventos visuais nos quais informação, significado ou prazer são obtidos pelo consumidor em uma interface com tecnologia visual. Por tecnologia visual refiro-me a algum tipo de aparato concebido para ser olhado ou para melhorar a visão natural, indo da pintura a óleo à televisão e à Internet. Esta apreciação leva em conta a importância do ato de produção de imagem, os componentes formais de uma dada imagem e a conclusão desse processo através de sua recepção cultural. [MıRzoefF, 1998, p. 3] ${ }^{11}$

Para Martin JAY, no entanto, se se pode falar em uma "virada para o visual" ocorrida a partir da Renascença, da ciência moderna, da invenção do microscópio e do telescópio e do surgimento da imprensa, em relação ao mundo medieval basicamente "literário", não se deveria falar na vigência de um regime escópico único na cultura visual da modernidade, mas da convivência de vários ${ }^{12}$ e, o que principalmente nos interessa, da existência de várias subculturais visuais:

Mas o que precisamente constitui a cultura visual desta era não é tão facilmente perceptível. Na verdade poderíamos nos perguntar, emprestando o termo cunhado por Christian Metz, se há um único "regime escópico" na modernidade, ou se existem vários, talvez concorrentes. Pois, como Jacqeline Rose recentemente nos lembrou, "nossa história prévia não é o bloco petrificado de um único espaço visual, uma vez que, olhando-se obliquamente, sempre pode-se ver nele al-

10 "The reason most often advanced for this heightened visibility is that human experience is now more visual and visualized than ever before. In many ways, people in industrialized and post-industrial societies now live in visual cultures to an extent that seems to divide the present from the past. Popular journalism constantly remarks on digital imagery in cinema, the advent of post-photography and developments in medical imaging, not to mention the endless tide of comment devoted to the Internet. This globalization of the visual, taken collectively, demands new means of interpretation. At the same time, this transformation of the postmodern present also requires a rewriting of historical explanations of modernism and modernity in order to account for 'the visual turn'."

11 "Visual culture is concerned with visual events in which information, meaning or pleasure is sought by the consumer in an interface with visual technology. By visual technology, I mean any form of apparatus designed either to be looked at or to enhance natural vision, from oil painting to television and the Internet. Such criticism takes account of the importance of image making, the formal components of a given image, and the crucial completion of that work by its cultural reception."

12 O regime escópico, ou "modelo de visualização", ou "forma de olhar", considerado hegêmonico na cultura ocidental moderna seria aquele definido pela representação visual do espaço estabelecida pela perspectiva geométrica linear concebida no Renascimento, com o espaço tridimensional representado racionalmente no plano bidimensional como isotrópico, abstrato e uniforme, a partir de um ponto de vista monocular e com conotação fortemente narrativa. Mas a ele, Martin Jay acrescenta a existência de pelo menos outros dois regimes divergentes, também resumidamente apresentados aqui: 1) a representação plana da pintura holandesa do século XVII, em que objetos e seres, em todos os seus detalhes, cores e texturas sob o efeito da luz são o tema, ocupando toda a tela, com abordagem eminentemente descritiva e atemporal (e assim compartilhando algumas características da experiência visual proporcionada pela invenção da fotografia no século XIX); 2) a representação barroca caracterizada pela "distorção", "desfoque", preferência pelo peculiar e pelo bizarro, tatilidade e corporalidade, em tudo oposta à representação racional da perspectiva linear. [JAY, 1988, p. 3-20] 
gum momento de inquietação". Pode então, na verdade, haver vários desses momentos discerníveis, mesmo que frequentemente de forma reprimida, na era moderna? Se assim for, o regime escópico da modernidade será melhor compreendido mais como um terreno em disputa do que um complexo harmoniosamente integrado de teorias e práticas visuais. Ele pode, de fato, ser caracterizado por uma diferenciação de subculturas visuais, cuja separação tem nos possibilitado compreender as múltiplas implicações do olhar de maneiras que apenas agora começam a ser consideradas. Quero sugerir que isto pode ser resultado de uma inversão radical na hierarquia de subculturas visuais no regime escópico moderno. [JAY, 1988, p.3-4] ${ }^{13}$

A possibilidade de se falar em várias subculturas visuais convivendo, seja no sentido de produção e recepção simultânea de signos identitários por grupos sociais como nacionalidades, etnias, gêneros, movimentos políticos, seja no sentido de apropriação cotidiana de signos produzidos pelas mais variadas fontes por parte de populações na sociedade globalizada, parece ser mais adequada para a compreensão do que seja cultura visual hoje. No caso do livro escolar, como produto do cruzamento de uma atividade editorial com demandas de um cultura escolar constituída e da qual ele também ajudará a constituir, pode-se também falar em subcultura visual, integrante da cultura visual geral de uma determinada época, em relação de intercâmbio, aproximação e talvez até de conflito com os signos desta última, constituindo possíveis traços identitários da chamada cultura escolar.

\subsection{Livro didático e cultura da impressão}

Considerar o livro didático um artefato gráfico implica examinar como ele se relaciona com a cultura estabelecida pela impressão a partir de seu surgimento no Renascimento. Claro que esta é uma tarefa que transcende em muito os objetivos de um capítulo de fundamentação teórica de uma tese sobre o design do livro didático de um período estipulado. Mas como este livro não surgiu do nada, tem seus precedentes, modelos, e foi conformado pelo desenvolvimento da impressão e sua cultura - e talvez suas demandas tenham até influenciado esse desenvolvimento -, é necessário, mesmo que de forma sumária, procurar identificar algumas relações entre livro didático e cultura impressa.

\footnotetext{
13 "But what precisely constitutes the visual culture of this era is not so readily apparent. Indeed, we might well ask, borrowing Christian Metz's term, is there one unified 'scopic regime' of the modern or are there several, perhaps competing ones? For, as Jacqueline Rose has recently reminded us, 'our previous history is not the petrified block of a single visual space since, looked at obliquely, it can always be seen to contain its moment of unease'. In fact, may there possibly be several such moments, which can be discerned, if often in repressed form, in the modern era? If so, the scopic regime of modernity may best be understood as a contested terrain, rather than a harmoniously integrated complex of visual theories and practices. It may, in fact, be characterized by a differentiation of visual subcultures, whose separation has allowed us to understand the multiple implications of sight in ways that are now only beginning to be appreciated. That new understanding, I want to suggest, may well be the product of a radical reversal in the hierarchy of visual subcultures in the modern scopic regime."
} 
Segundo Marisa LAjolo e Regina Zilberman [1999], “o livro didático talvez seja uma das modalidades mais antigas de expressão escrita, já que é uma das condições para o funcionamento da escola", e a Poética, de Aristóteles, por ser o resultado de notas de aulas ministradas pelo filósofo no século $\vee$ a.C., seria um "ancestral ilustre" do gênero [LAJOLO; ZILBERMAN, 1999, p. 120]. Outro título é citado pelas autoras, o Instituto Oratoria, de Marcus Fabius Quintiliano, do século I d.C., que apresenta apreciação sumária dos principais autores gregos e latinos para alunos de retórica. Mas aqui estamos falando de reprodução manuscrita, e não ainda de impressão, a não ser quando eles passaram a ser impressos no final do século XV (FIG. 1.1 e 1.2).
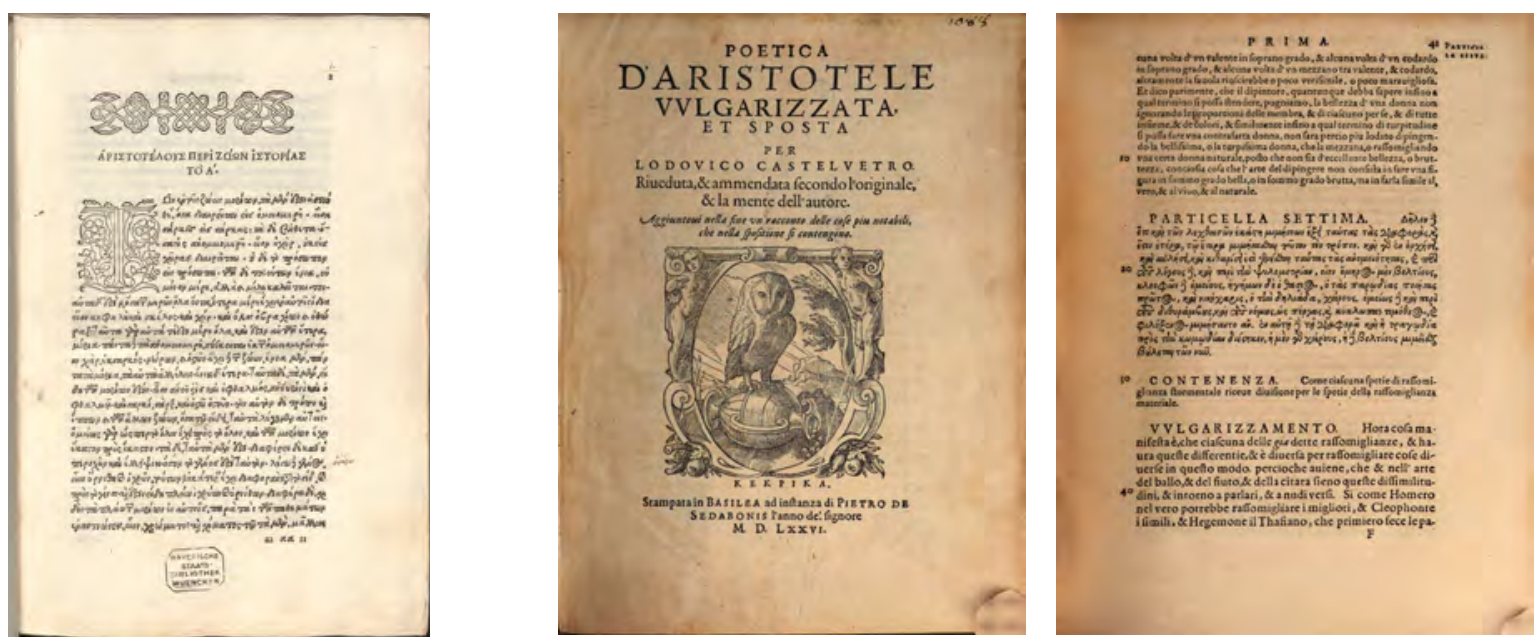

Fig. 1.1. À esquerda: Aristoteles. Praedicamenta, Veneza, 1497. Edição de Aldo Manuzio, que publicou todas as obras de Aristóteles, incluindo a Poética, no original grego, na íntegra e sem acréscimos. [Fonte: Bayerische Staatsbibliothek München, Ink A-698 - GW 2334, urn:nbn:de:bvb:12-bsb00045770-2]. À direita: Aristoteles; Lodovico Castelvetro. La Poetica d'Aristotile, Basilea, 1576. Edição em italiano, com interpretação e explicações do tradutor, para uso facilitado. [Fonte: Bayerische Staatsbibliothek ünchen, VD16 A 3573, urn:nbn:de:bvb:12-bsb10981043-3.]
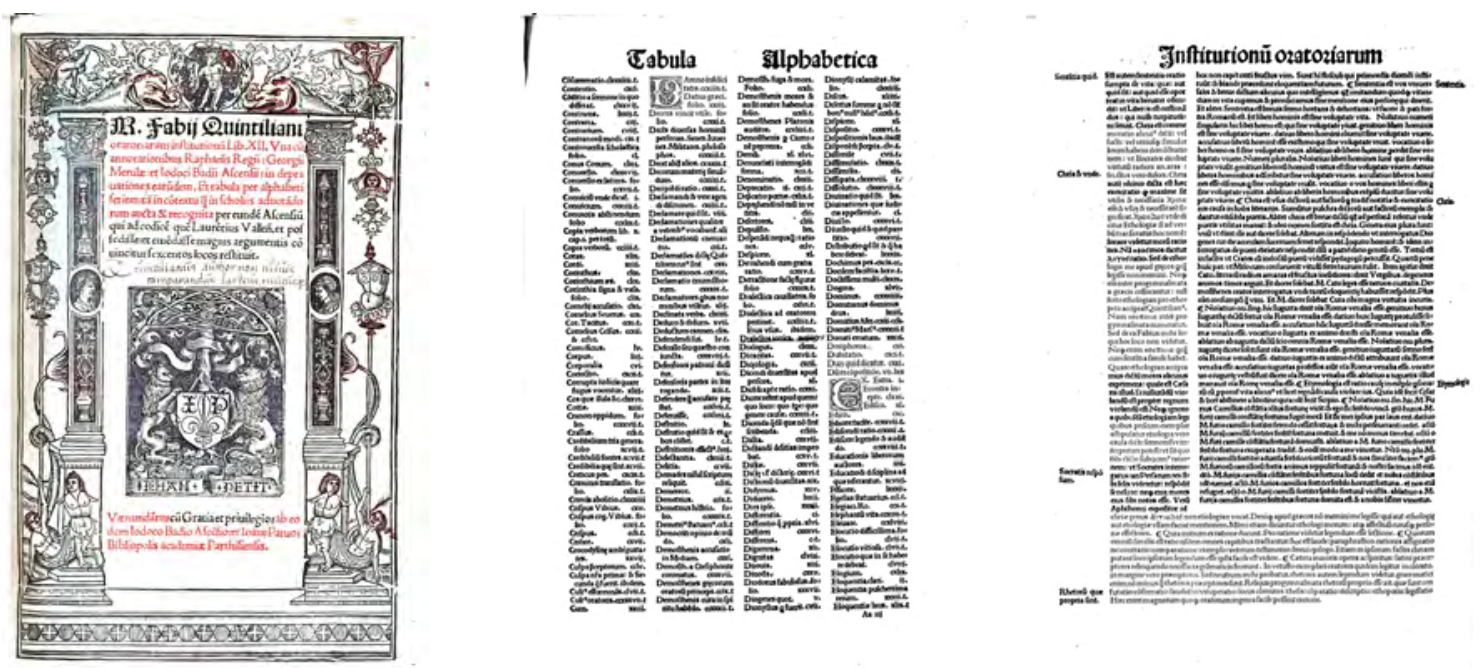

Fig. 1.2. Marcus Fabius Quintilianus (séc. I dC), Oratoriarum institutionum libri duodecim, S.I., 1516. Edição que inclui facilidades para consulta e utilização didática, como índice alfabético, comentários e referências laterais. [Fonte: Bayerische Staatsbibliothek München, urn:nbn:de:bvb:12-bsb10140826-7.] 
Como ancestral igualmente ilustre do livro didático, pode-se certamente incluir Os elementos, obra escrita pelo filosófo possivelmente grego que viveu em Alexandria entre o séc. IV e III a.C. Esta obra, constituída de treze livros, é um dos mais antigos tratados científicos conhecidos e, pelo método de sistematização, tem não só caráter de obra científica como de obra didática, e assim foi utilizada no ensino de matemática e geometria até o início do século XX. Por ser apoiar em sequências de imagens para efetivar as demonstrações e instruir, assume a feição multimodal típica do livro didático moderno, como será visto adiante (FIG.1.3 e 1.4).
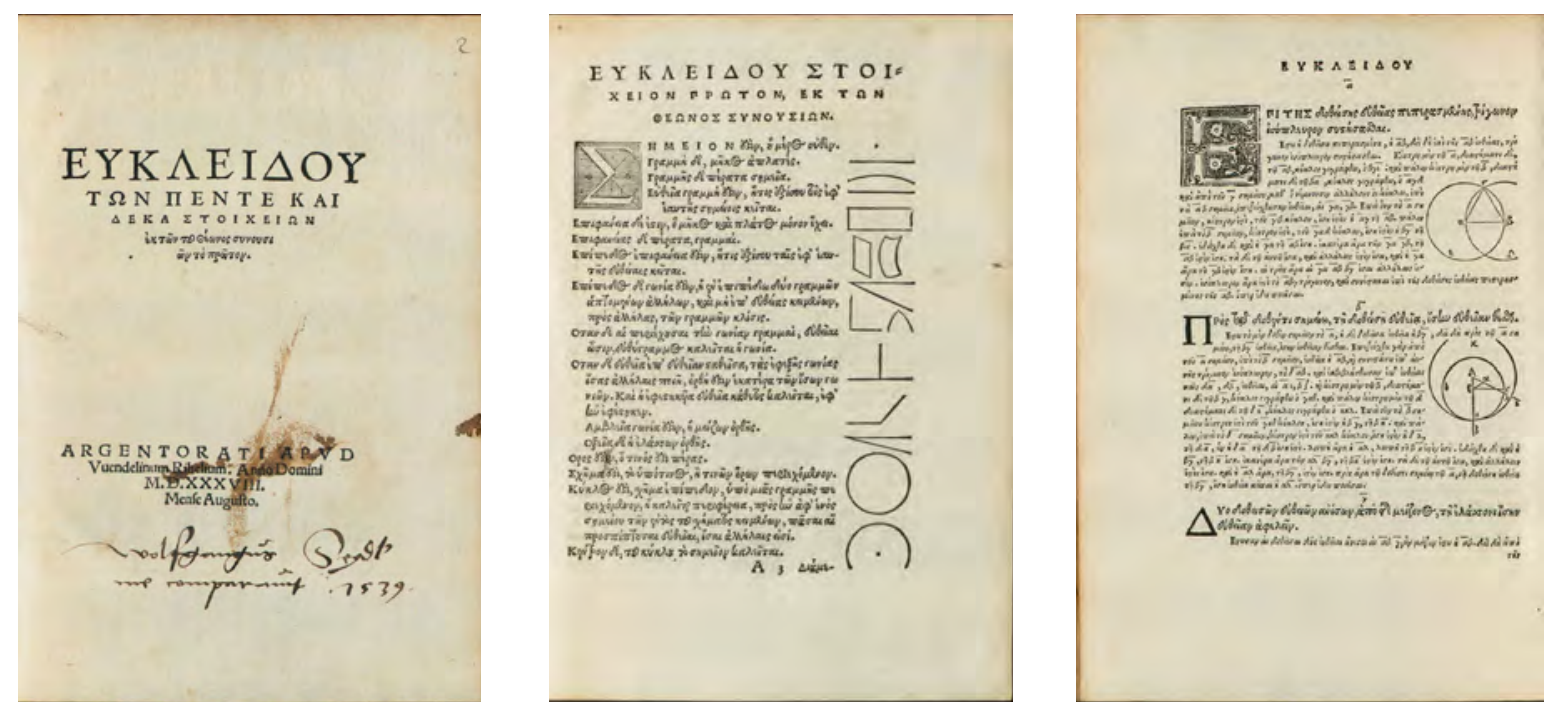

Fig. 1.3. Euclides, Elementa, liber 1, Edição em grego de Argentoratum, 1538. [Fonte: Bayerische Staatsbibliothek München, VD16 E 4143, urn:nbn:de:bvb:12-bsb00076066-2.]
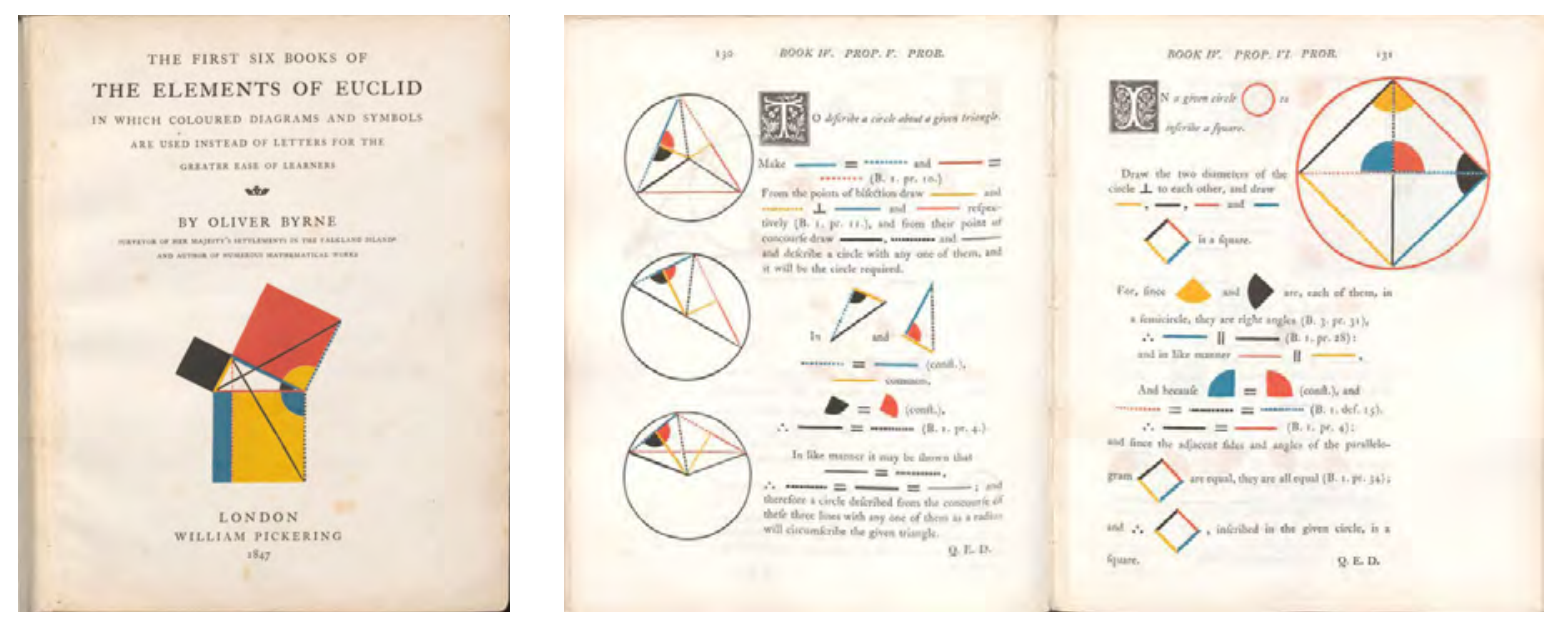

Fig. 1.4. The first six books of The Elements of Euclid, London, William Pickering, 1847. Edição de Oliver Byrne. [Fonte: The Public Domain Review, Open Knowledge Foundation.]

Ainda com produção manuscrita, circularam na Idade Média os chamados Donats, tratados de gramática latina elementar para uso escolar que teriam origem em obra mais ampla de Aelius Donatus (séc. IV DC), a Ars Grammatica. Esses Donats ganharam edições impressas em xilogravura, portanto anteriormente ao uso de tipos móveis, feitas provavelmente nos Países 
Baixos e em território da atual Alemanha, e tiveram uso tão generalizado que a palavra donatos foi estendida, por analogia, a outros livros escolares [MARTINS, 2002, p. 143]. Com a invenção dos tipos móveis, foram, junto com a Bíblia, os primeiros livros a serem impressos, "em número prodigioso de edições" [SILVA, 1922, p. 7] (FIG. 1.5 e 1.6).
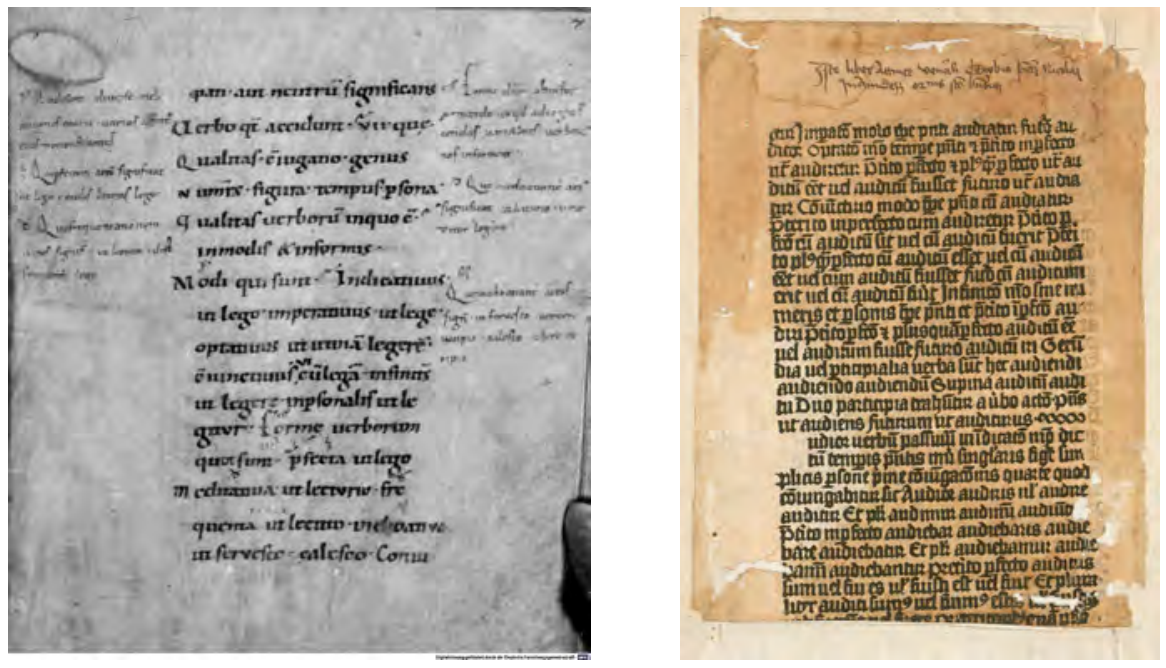

Fig. 1.5. Páginas de Donats (gramáticas latinas escolares): À esquerda: Aelius Donatus. Grammatische Sammelhandschrift. Manuscrito do século IX. [Fonte: Bayerische Staatsbibliothek München, CIm 14737, urn:nbn:de:bvb:12-bsb00012921-8]. À direita: Aelius Donatus. Ars minor, 1475? Edição xilográfica alemã. [Fonte: Bayerische Staatsbibliothek München, urn:nbn:de:bvb:12-bsb00038682-3.]
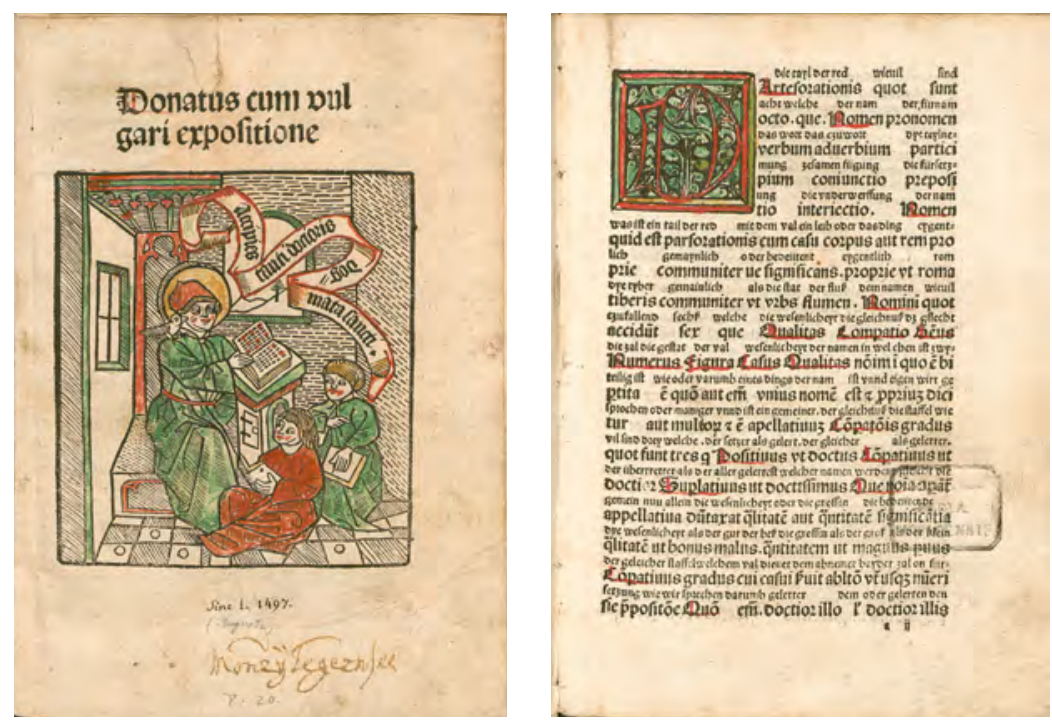

Fig. 1.6. Páginas de Donats (gramáticas latinas escolares). Aelius Donatus: Ars minor, Augsburg, 1497. A tradução para o alemão aparece em corpo menor sobre a linha em latim. [Fonte: Bayerische Staatsbibliothek München, Ink D-266 GW 8982, urn:nbn:de:bvb:12-bsb00026765-8.]

O livro didático impresso mais próximo do que conhecemos hoje surgirá exatamente no século XVI, com Petrus Ramus, conforme estabelece Walter ONg [2002], não exclusivamente pelo uso ligado à escola, mas também pela definição do tipo de conhecimento a ser tratado e pela forma mesma de fazê-lo: 
[...] manuais para virtualmente todas as disciplinas (dialética ou lógica, retórica, gramática, aritmética, etc.) que provinham de definições peremptórias e divisões principais conduzindo a outras definições e mais divisões, até que cada última partícula do assunto fosse dissecada e eliminada. Um livro ramista sobre um determinado assunto não estabelecia nenhum intercâmbio com qualquer coisa fora dele mesmo. Nem mesmo dificuldades ou "adversários" apareciam. Um assunto curricular ou "art" [disciplina] se apropriadamente apresentado conforme o método ramista não envolvia nenhuma dificuldade (segundo sustentavam os ramistas): se você definia e dividia de modo apropriado, tudo na disciplina seria auto-evidente e a disciplina ela mesma seria completa e autônoma. Ramus relegava as dificuldades e refutações a adversários a palestras separadas (scholae) sobre dialética, retórica, gramática, aritmética e todo o resto. [ONG, 2002, p. 131-132] ${ }^{14}$

Ramus (Pierre De La Ramée, 1515-1572) foi figura proeminente da chamada virada instrucional ocorrida no século XVI como reação ao ensino ministrado conforme os parâmetros estabelecidos pela escolástica medieval. Segundo David Hamilton [2003], Ramus lançou as bases da didática moderna, ao estabelecer currículos - um quadro fechado dos conhecimentos a serem ensinados, o que não existia na escolástica medieval - e um método de ensino, prosseguindo o trabalho de Lorenzo Valla (1407-1457) e Rudolphus Agricola (1444-1486), de transformação da dialética ("arte" da argumentação) em didática ("arte" do ensino) [HAMILTON, 2003, p. 8-10]. A consequência prática foi a própria organização dos assuntos das chamadas "artes" em configurações gráficas que relacionavam os conteúdos a serem ensinados, apresentadas nas obras que divulgavam seus escritos, como também a edição de obras didáticas dedicadas a várias dessas "artes", que também reproduziam esquemas de conhecimentos para facilitar sua consulta e memorização (FIG. 1.7 a 1.10).

ONG define o surgimento desse tipo de livro como uma consequência das transformações no pensamento e cultura ocidental decorrentes do surgimento da impressão, como o foram a transformação do Renascimento italiano num movimento europeu, o surgimento e difusão da Reforma protestante e o próprio surgimento da ciência moderna, relacionados por Elizabeth EISENSTEIN como as três mais importantes consequências do surgimento da imprensa [EISENSTEIN, 1980, p. 101]. Assim, em contraposição a características de escrita vigentes no período da cultura do manuscrito, ONG aponta que:

A impressão estimula um sentimento de conclusão, uma sensação de que o que foi encontrado em um texto foi finalizado, atingiu um estado de acabamento. Esta sensação afeta a criação literária e isto afeta a análise filosófica ou o trabalho científico.

\footnotetext{
14 "[...] textbooks for virtually all arts subjects (dialectic or logic, rhetoric, grammar, arithmetic, etc.) that proceeded by coldblooded definitions and divisions leading to still further definitions and more divisions, until every last particle of the subject had been dissected and disposed of. A Ramist textbook on a given subject had no acknowledged interchange with anything outside itself. Not even any difficulties or "adversaries" appeared. A curriculum subject or "art", if presented properly according to Ramist method, involved no difficulties at all (so Ramists maintained): if you defined and divided in the proper way, everything in the art was completely self-evident and the art itself was complete and selfcontained. Ramus relegated difficulties and refutations of adversaries to separate "lectures" (scholae) on dialectic, rhetoric, grammar, arithmetic, and all the rest."
} 
[...] A impressão do mesmo modo situa elocução e pensamento em uma superfície desimpedida de tudo o mais, mas também vai mais longe ao sugerir auto-contenção. A impressão encerra o pensamento em milhares de cópias de uma obra com exatamente a mesma consistência visual e física. [ONG, 2002, p. 129] ${ }^{15}$
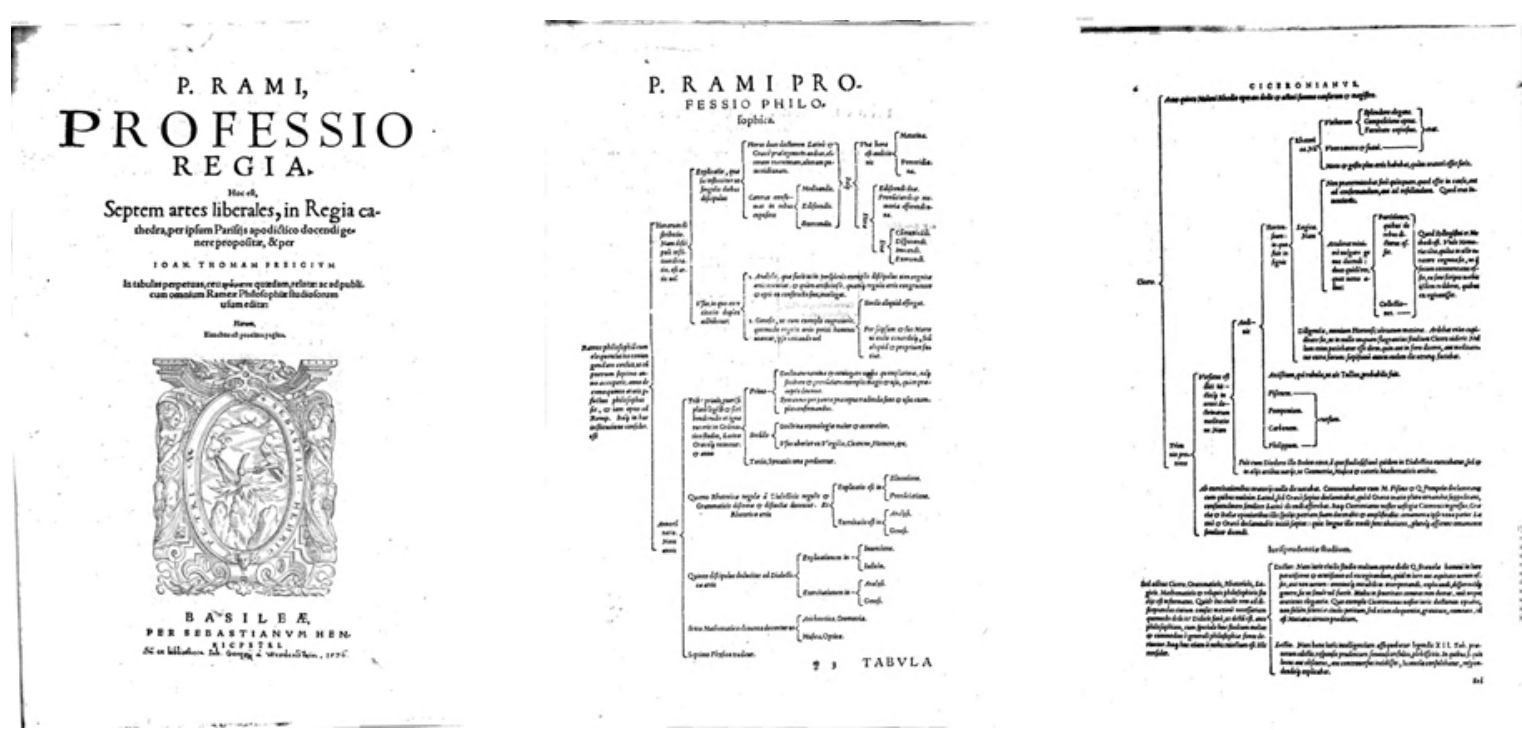

Fig. 1.7. Petrus Ramus: Professio Regia: Septem artes liberales..., Basilea, 1576. Rosto, página inicial com esquema do conteúdo geral do livro e páginas com esquemas dos assuntos específicos. [Fonte: Bayerische Staatsbibliothek München, VD16 L 529, urn:nbn:de:bvb:12-bsb10142572-7.]

$$
\text { Malk Q } 12 \text { wirs }
$$

\section{A R I T H M E- TI C A.}

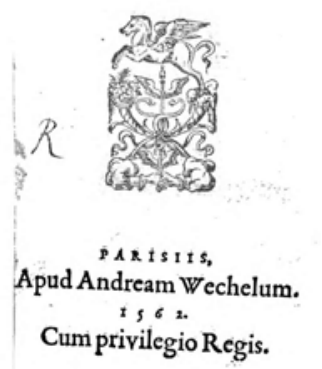

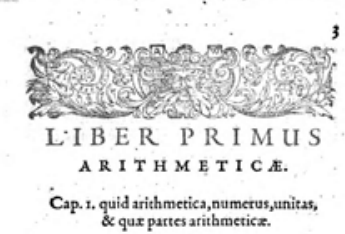

x. A RITHMetrica eff doctriA A nene numerandi. 2. Numerus eft ex anitatibus colles Ca multitudo. 2.d.7. Ut binarius numerus eft collectus ex uno \&

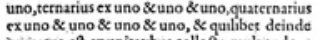
numerus ef ex unitartbus colleats multrtudo. 3. Unitas eft fecundum quam unumquodque unsum dicitur. 1.d.7. Ut unus Deus, unus mundus, unus Rex.
Unitas numerus non efta nec cnim eft ex unitatibus collecta multitudo: Attamen ut unitas de. finturt, fecundum quam unum quodque unum
dicitur; fie numerus definiri pocel, fecundum

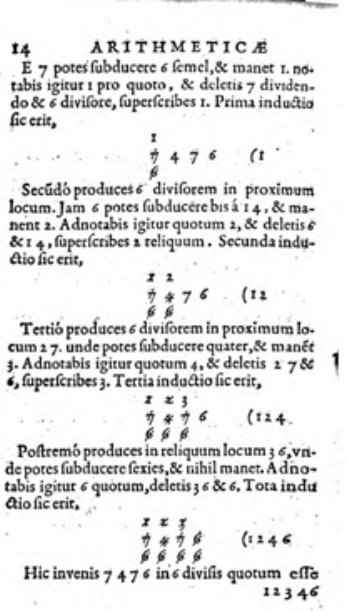

Fig. 1.8. Petrus Ramus. Arithmetica, Paris, 1562. Note-se a composição de formas matriciais, composição em blocos e uso de itálico como contraste tipográfico. [Fonte: Bayerische Staatsbibliothek, urn:nbn:de:bvb:12-bsb10186745-7.]

15 "Print encourages a sense of closure, a sense that what is found in a text has been finalized, has reached a state of completion. This sense affects literary creations and it affects analytic philosophical or scientific work. [...] Print in the same way situates utterance and thought on a surface disengaged from everything else, but it also goes farther in suggesting self-containment. Print encloses thought in thousands of copies of a work of exactly the same visual and physical consistency". 

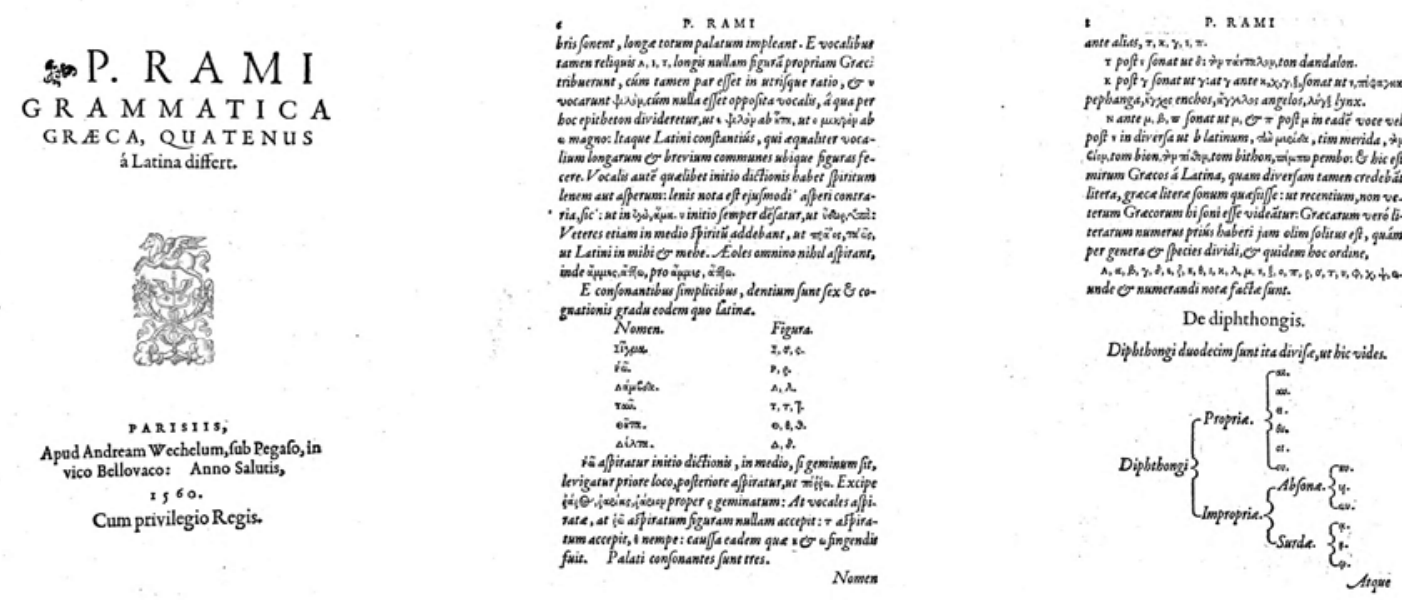

Fig. 1.9. Petrus Ramus. Grammatica graeca quatenus a lat. differt., Paris, 1560. Uso de itálico e variação de corpos como contraste tipográfico. [Fonte: Bayerische Staatsbibliothek, urn:nbn:de:bvb:12-bsb10162747-8.]

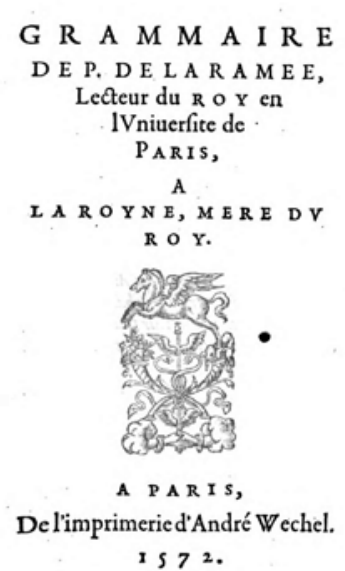

G R A M M A I R E

E P. DE L A R A MEE, Vniuerfite de.

PARIS,

E,

(4) 9 हEe?

\%

ecosis

I 52 .

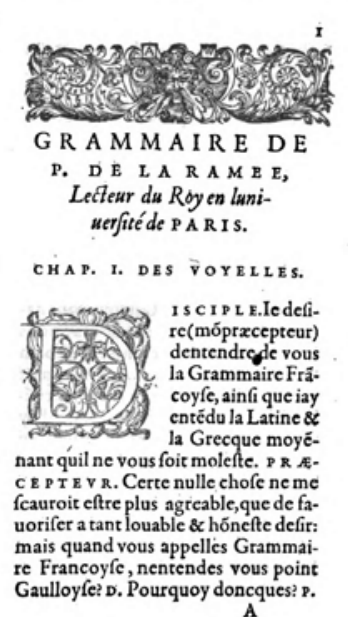

A

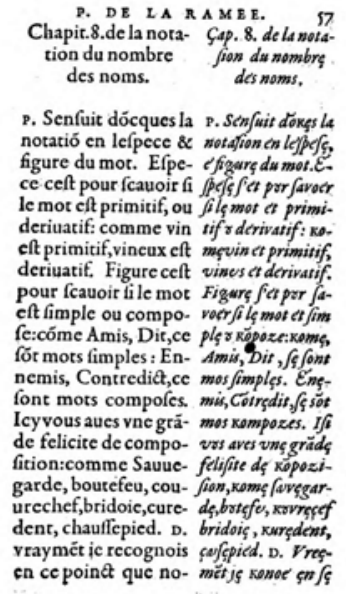

Fig. 1.10. P. De La Ramée. Grammaire, Paris, 1572. Páginas com leiautes e tipografia diferenciados em função do assunto tratado. [Fonte: Bayerische Staatsbibliothek, urn:nbn:de:bvb:12-bsb10185562-6.]

Essas características estão presentes nos livros que Ramus escreveu e que são basicamente o modelo geral dos manuais escolares produzidos pelo menos até o século XVII. Assim, não só por coincidência temporal, o surgimento do livro didático moderno está organicamente ligado ao surgimento da própria cultura da impressão, de suas características e das transformações de mentalidade relacionadas a uma modalidade de produção textual diferente da manuscrita.

Considerando que a escrita lança a palavra originalmente falada num espaço visual, e que a impressão o faz de maneira definitiva, criando um "espaço tipográfico abstrato", Ong examina a transformação de algumas formas já existentes no livro manuscrito e o surgimento de novas formas próprias da impressão tipográfica, como índices de assunto, índices alfabéticos, titulagens, reprodução de imagens em relação a palavras e atesta que "Cedo na era da impressão, gráficos 
extremamente complexos aparecerem no ensino de assuntos acadêmicos" [ONG, 2002, p. 126]. ${ }^{16}$

No caso dos esquemas didáticos de Ramus, Hamilton chega a citá-los explicitamente como tendo sido beneficiados pela nova tecnologia da impressão por tipos móveis e estabelece uma relação entre as novas idéias pedagógicas, o design e a proliferação dos livros escolares:

Para concluir, propus que o design e a organização de textos instrucionais devem muito a um pressuposto - originado de Aristóteles - que o conhecimento pode ser mapeado e ordenado de acordo com a "natureza". Além disso, também tenho sugerido que este pressuposto não apenas sustentou o design do livro didático, como foi fundamental para o surgimento do currículo e do pensamento pedagógico. Na verdade, eu mesmo iria tão longe a ponto de propor que, nesses termos, o século XVII foi a era de ouro dos livros didáticos, dos currículos e da didática. [HAMILTON, 1990, s/n de pág.] ${ }^{17}$

Apoiando-se mais numa reflexão histórica do que simplesmente formal, aqui talvez seja o momento em que se possa estabelecer uma diferença mais significativa entre os ancestrais dos livros didáticos e os livros didáticos propriamente ditos. Os primeiros, que como vimos existiriam pelo menos desde a Poética, de Aristóteles, seriam livros para estudo, realizado solitariamente ou mesmo em grupo ou até em aulas nas universidades medievais. Os últimos já seriam livros para instrução, os quais só teriam surgido com a virada instrucional do século $\mathrm{XVI}$, o ramismo e as primeiras formulações e estabelecimento da didática e dos currículos:

Talvez o problema conceitual fundamental seja encontrar um modo de distinguir manuais [livros didáticos] de livros escolares. Não surpreendemente, minha posição é que livros didáticos refletem visivelmente considerações pedagógicas. Isto é, um livro didático não é apenas um livro usado em escolas. Ao contrário, é um livro que foi conscientemente concebido e organizado para servir aos fins da educação escolar.

Nesta medida, então, livros didáticos estão organicamente ligados às novas circunstâncias da educação escolar. [...] Minha tese é que livros didáticos têm sua origem nos séculos XVI e XVII. [HAMilton, 1990, s/n de pág.] ${ }^{18}$

E estes livros para educação escolar foram desde o início conformados com a participação decisiva do surgimento da impressão com tipos móveis:

16 "Early in the age of print, extremely complex charts appear in the teaching of academic subjects."

17 "Further, Ramist specialization of knowledge was also greatly assisted by the new technology of moveable-type printing [...] To conclude, I have suggested that the design and organization of instructional texts owes much to an assumption -- derived from Aristotle -- that knowledge could be mapped and ordered according to 'nature'. Further I have also suggested that this assumption not only underpinned textbook design, it was also central to the emergence of curriculum and didactic thinking. Indeed, I would even go so far as to propose that, in these terms, the 17th century was the golden age of textbooks, curricula and didactics."

18 "Perhaps the fundamental conceptual problem is to find a way of distinguishing textbooks from schoolbooks. Not surprisingly, my own stance is that textbooks visibly reflect pedagogic considerations. That is, a textbook is not just a book used in schools. Rather, it is a book that has been consciously designed and organized to serve the ends of schooling. To this extent, then, textbooks are organically linked to the changing circumstances of schooling. [...] My thesis is that textbooks had their origins in the $16^{\text {th }}$ and $17^{\text {th }}$ centuries." 
No entanto, mesmo esses desenvolvimentos foram prenunciados pelas primeiras mudanças no leiaute de livros [...] e na posterior organização de dicionários, compêndios, bibliografias e enciclopédias dos séculos XV e XVI [...]. Na verdade, muitas dessas primeiras mudanças na organização dos livros não se destinavam a atender a objetivos pedagógicos. Em vez disso, pretendiam fazer com que os textos fossem mais acessíveis a seus possuidores/usuários habituais (por exemplo, pregadores). [HAMILTON, 1990, s/n de pág.] ${ }^{19}$

Assim, com essas transformações de leiaute, desde seu início, o livro didático apresenta outras configurações gráficas além da que Michael TwYMAN [1986] chama de "configuração linear interrompida" (linear-interrupted configuration), ou seja, o texto composto como prosa contínua. Este é o equivalente mais próximo em comunicação gráfica da linearidade temporal do discurso, em que as quebras nas extremidades de linhas são interrupções arbitrárias sem relação com a sintaxe ou a semântica. Já os livros didáticos desde cedo apresentavam listas, matrizes ou tabelas e ramificações, além de uso de imagens com finalidade não decorativa e uso de variações nos próprios caracteres e nas dimensões, além do eventual emprego de cores, como uma necessidade decorrente do seu propósito didático.

O autor apoia a sua análise da evolução da linguagem gráfica numa distinção entre dois tipos de características que ela apresenta, às quais denomina intrínsecas e extrínsecas:

Por intrínseca se entende aquelas características que residem nos caracteres ou sinais próprios e no sistema que é usada para produzi-los. Características intrínsecas incluem a gama de caracteres disponíveis (o que diferentes especialistas podem chamar alfabeto, fonte, ou conjunto de caracteres), as variantes desses caracteres (como letras maiúsculas, minúsculas, itálicos e negritos), o estilo dos caracteres (tipo e estilo de escrita ou letras), e tamanho. [TWYMAN, 1986, p. 190-191] 20

Características extrínsecas incluem as configurações de linguagem gráfica. Quatro delas têm sido convencionalmente usadas graficamente na organização de palavras e números: a interrupção linear (prosa contínua), lista, matriz e as configurações de ramificação. Outras características extrínsecas são espaciais em um sentido mais limitado e se relacionam com a organização de unidades linguísticas dentro de uma determinada configuração. No nível micro o uso do espaço inclui ajuste fino tais como o espaçamento das letras e o posicionamento no eixo vertical de caracteres superiores e inferiores. Trabalhando no nível macro inclui espaçamento entre palavras, espaça-

\footnotetext{
19 "Yet, even these developments were foreshadowed by earlier changes in the layout of books [...], and in the later organization of dictionaries, compendia, bibliographies and encyclopedias of the $15^{\text {th }}$ and $16^{\text {th }}$ centuries $[. .$.$] In fact, however, many of these early changes$ in the organization of books were not intended to serve pedagogic purposes. Rather, they were intended to make texts more accessible to their regular users/owners (e.g., preachers)."

20 "By intrinsic is meant those features that reside in the characters or signs themselves and in the system that is used to produce them. Intrinsic features include the range of available characters (what different specialists might call alphabet, font, or character set), the variants of these characters (such as capitals, small letters, italics, and bolds), the style of the characters (typeface and style of writing or (ettering), and size."
} 
mento entre linhas, e o espaçamento de unidades maiores de informações do tipo discutido por muitos escritores sobre tipografia. [TWYMAN, 1986, p. 191] ${ }^{21}$

Assim, o autor apresenta a evolução e o acréscimo de recursos oferecidos pelas duas características da linguagem gráfica a partir das necessidades de comunicação impressa dos diversos tipos de conteúdos produzidos ao longo dos séculos. Começa mencionando a unificação dos alfabetos romano e uncial na criação de um único com maiúsculas e minúsculas, passa pela incorporação do itálico, do negrito - que existiam como fontes independentes com desenho próprio -, do versalete etc. como variações tipográficas de uma mesma fonte, e mostra as transformações no uso e organização do espaço da página, cor etc., destacando particularmente as necessidades dos textos científicos e de uso escolar, mostrando a íntima relação destes com a cultura da impressão.

O uso de imagens com finalidade didática é outra característica dos livros escolares que surge bastante precocemente, impondo exigências técnicas à atividade impressora num tempo em que a combinação de texto e imagem inicialmente obrigava à impressão separada de tipografia e xilografia ou gravura em metal. A obra de Jan Amos Comenius (1592-1970), Orbis Sensualium Pictus (O mundo sensível em imagens), de 1658, para o ensino de diversos conteúdos simultaneamente ao ensino do latim e do vernáculo (alemão), traz composição tipográfica com combinação de tipos góticos e latinos, em romano e itálico e ilustração gravada em metal com números sobre ela (FIG. 1.11 e 1.12).

A concepção deste livro expressa a relação direta e explícita entre a nova arte da didática, a transformação da escola e do ensino e a cultura gráfica. Jan Amos Comenius completa o processo iniciado com a virada instrucional ao instituir a didática moderna com sua ação pedagógica e sua obra Didática Magna: tratado universal de ensinar tudo a todos, publicada em 1679. Nesta obra, a partir de uma crítica radical à escola e aos métodos vigentes, Comenius propõe uma reforma profunda do ensino e uma nova organização escolar por graus etários, com princípios pedagógicos, currículos correspondentes, métodos específicos para cada disciplina (línguas, ciências, artes) e qualidades (moral, piedade), normas de funcionamento escolar, universalização da educação sem distinção de classe e sexo, constituindo um edifício teórico da educação não superado até hoje em seus aspectos essenciais. E, no que nos interessa mais de perto, define como um dos principais meios, incontornável na verdade, o uso de um único livro exclusivo para o nível elementar e o mesmo para cada disciplina nos níveis subsequentes, com as seguintes características gerais:

21 "Extrinsic features include the configurations of graphic language [...]. Four of these have conventionally been used when organizing words and numbers graphically: the linear interrupted (continuous prose), list, matrix, and branching configurations. Other extrinsic features are spatial in a more limited sense and relate to the organization of language units within a given configuration. At the micro level the use of space includes such fine tuning as the spacing of letters and the positioning on the vertical axis of superior and inferior characters. Working toward the macro level it includes word spacing, interlinear spacing, and the spacing of larger units of information of the kind discussed by many writers on typography[... $]^{\prime \prime}$ 
III. Sejam feitos com primor e escritos em linguagem acessível.

33. Estes livros, portanto, deverão ser conformes às nossas leis da facilidade, da solidez e da brevidade, e contar, para todas as escolas, tudo o que é necessário, de modo completo, sólido e aprimorado, para que sejam uma imagem verdadeira de todo o universo (o qual deve ser impresso nas mentes juvenis). E (o que vivamente desejo e inculco) que esses livros exponham todas as coisas de modo familiar e popular, para que tornem tudo acessível aos alunos, de modo que o entendam por si, mesmo sem qualquer professor. [...]

34. Gostaria que esses livros fossem compostos em forma de diálogo [...] porque, dessa maneira, mais facilmente se pode adaptar a matéria e o estilo aos espíritos juvenis, para que não imaginem que as coisas são, para eles, ou impossíveis ou árduas ou demasiado difíceis [...] [CoMENIUS, 2001, cap. XIX]
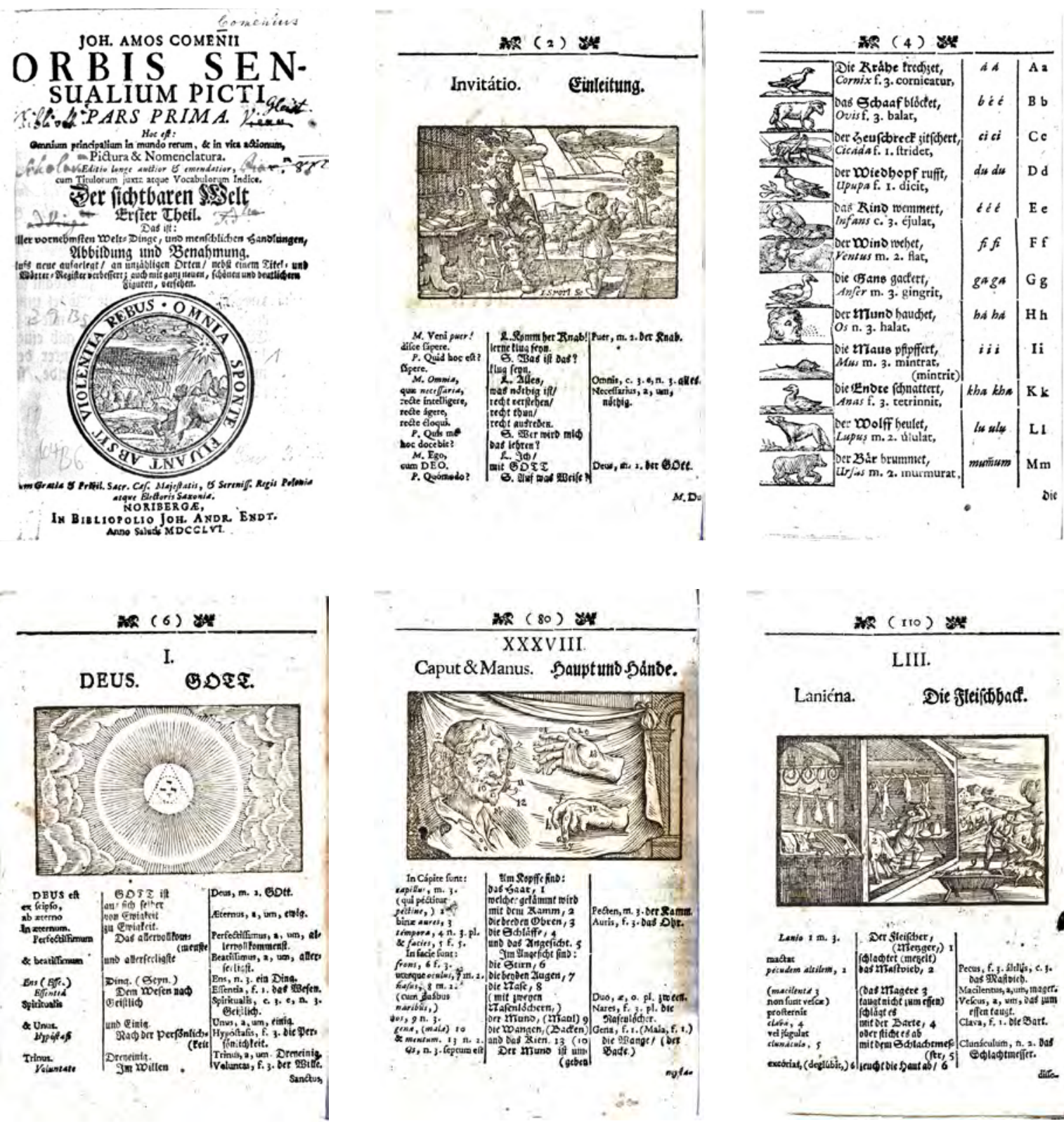

Fig. 1.11. Johann Amos Comenius. Orbis Sensualium Picti (O mundo visível em imagens, 1658), Nuremberg, 1756. Uso de tipos romanos e góticos como principal contraste tipográfico com finalidade didática. [Fonte: Bayerische Staatsbibliothek, urn:nbn:de:bvb:12-bsb10912059-6.] 

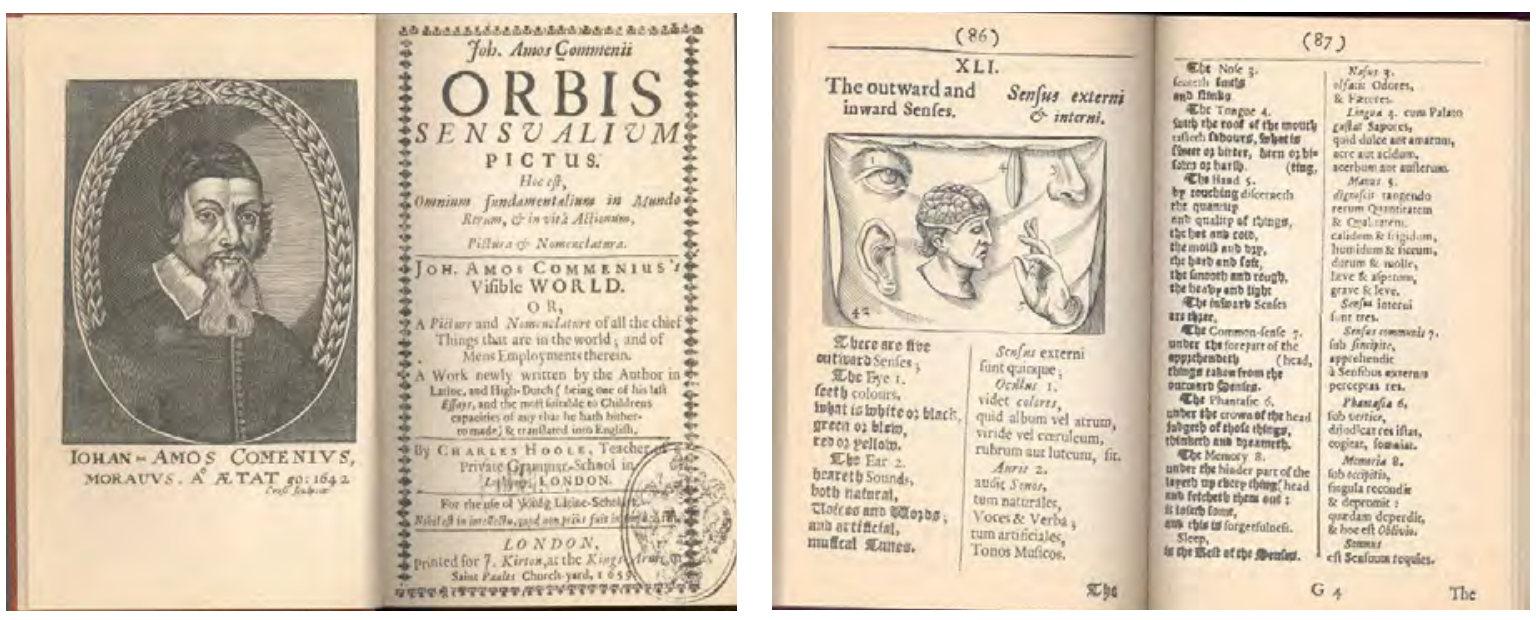

Fig. 1.12. Johann Amos Comenius. Orbis Sensualium Pictus. London, 1659. Primeira edição em língua inglesa. [Fonte: Centro de Investigación MANES-Manuales Escolares: http://www.uned.es/manesvirtual/ Historia/Comenius/OPictus/OPictusAA.htm.]

No caso do primeiro grau, a escola materna, ele mesmo se ocupou da escrita do livro, seguindo esses princípios e recomendações:

II. O exercitador dos sentidos.

25. Outra coisa que poderá ser útil aos exercícios da escola materna será um Livrinho de Imagens, a colocar nas mãos das próprias crianças. Com efeito, como nesta escola se deve sobretudo exercitar os sentidos a receber as impressões das coisas mais fáceis, e a vista ocupa um lugar importante entre os sentidos, conseguiremos o nosso objetivo se colocarmos sob os olhos das criancinhas todas as primeiras noções de história natural, de ótica, de astronomia, de geometria, etc., mesmo segundo a ordem do programa didático, há pouco delineado. Neste livro, com efeito, pode pintar-se montes, vales, plantas, aves, peixes, cavalos, bois, ovelhas, homens de várias idades e de várias estaturas, e principalmente a luz e as trevas, o céu com o sol, a lua, as estrelas, as nuvens, as cores fundamentais, e também os utensílios domésticos e os dos artesãos: panelas, frigideiras, talhas, martelos, tesouras, etc. De igual modo, podem pintar-se pessoas com os seus distintivos, como um rei com o cetro e a coroa, um soldado com as armas, um cocheiro com o coche, um lavrador com a charrua, um carteiro a distribuir cartas, e, em cima de cada figura, uma inscrição a indicar o seu significado: cavalo, boi, cão, árvore etc.

Utilidade deste livro.

26. A utilidade deste livro é tríplice: 1. ajuda a imprimir as coisas na mente das crianças, como dissemos já; 2. atrai os espíritos tenros a procurar em qualquer outro livro coisas para se divertir; 3. faz aprender a ler mais facilmente, pois, como as figuras das coisas têm o seu nome escrito por cima, poderá começar-se a ensinar a ler, ensinando a ler as letras desses nomes. [COMENIUs, 2001, cap. XXVIII]

A extensão dessas citações se justifica porque elas exprimem precisamente o papel atribuído ao livro didático dentro da didática moderna inaugurada por Comenius e como ele deve se constituir graficamente. Assim, o Orbis Sensualium Pictus não só receberá uma edição em 
Inglês e Latim no ano seguinte (FIG. 1.8) à sua edição em alemão, seguida de edições trilíngues e quadrilíngues menos de uma década depois, como será o modelo para outros livros e precursor das cartilhas e livros com imagens adotados em todo o mundo ocidental.

Mas um aspecto ainda a ressaltar é que, dadas as características de integração entre texto e imagem dessa obra, Comenius certamente se envolveu diretamente com sua concepção gráfica e impressão. Seu conhecimento da matéria é tão evidente que ele a utiliza para estabelecer um paralelo entre a organização da escola e do ensino e a impressão de livros em múltiplos e detalhados aspectos, a partir da nomeação de seu método pedagógico como um derivação da palavra tipografia. Omitindo muitas passagens, seguem alguns exemplos dessa relação entre didática e impressão, que corrobora a afirmação de David HAMILTON quanto à interrelação entre didática, cultura da impressão e livro didático, e o século XVII como a sua "idade de ouro":

5. Mas retomemos a comparação que fomos buscar à tipografia e utilizemo-la para explicar melhor ainda em que consiste o mecanismo regular do nosso método e para mostrar claramente que é possível imprimir as ciências no espírito da mesma maneira que, externamente, é possível imprimi-las no papel, com tinta. E que razão haverá para que se não possa forjar um nome susceptível de convir à nossa nova Didática, como o termo didacografia, modelado sobre a palavra tipografia? [...]

6. A arte tipográfica tem os seus materiais e os seus trabalhos. Os materiais principais são: o papel, os tipos, as tintas e o prelo; os trabalhos são: a preparação do papel, a composição, a paginação, colocar tinta nos tipos, a tiragem das folhas, a secagem, a correção das provas, etc., e cada uma destas coisas faz-se de uma maneira especial, e se se faz da maneira prescrita, tudo corre normalmente.

E igualmente da arte didática.

7. Na Didacografia (agrada-me usar esta palavra), as coisas passam-se precisamente da mesma maneira. O papel são os alunos, em cujos espíritos devem ser impressos os caracteres das ciências. Os tipos são os livros didáticos e todos os outros instrumentos propositadamente preparados para que, com a sua ajuda, as coisas a aprender se imprimam nas mentes com pouca fadiga. A tinta é a viva voz do professor que transfere o significado das coisas, dos livros para as mentes dos alunos. O prelo é a disciplina escolar que a todos dispõe e impele para se embeberem dos ensinamentos. [...]

Relação entre os tipos e os livros didáticos.

9. A analogia entre os tipos metálicos e os nossos livros didáticos (tais como nós queremos) é muito grande. Efetivamente, em primeiro lugar, assim como é necessário fundir, polir e adaptar os tipos, antes de se começar a impressão dos livros, assim também é necessário preparar os instrumentos do novo método, antes de começar a pôr em prática esse novo método. [...]

12. Os tipos, para que possam estar sempre à mão para qualquer uso, não se devem deixar espalhados aqui e além, mas devem ser colocados ordenadamente em caixas e em caixotins. Do mesmo modo, os nossos livros, tudo o que nos oferecem para aprendermos, não o devem oferecer 
de modo confuso, mas repartido do modo mais distinto possível, em tarefas de um ano, de um mês, de um dia e de uma hora. [...]

13. Retiram-se das caixas apenas os tipos de que temos necessidade para executar determinada obra, deixando-se os outros sem se lhes tocar. Também se devem colocar nas mãos das crianças somente os livros didáticos de que têm necessidade na sua classe, para que os outros não sejam ocasião de distração e de confusão.

14. Finalmente, o tipógrafo serve-se de um componedor para dispor linearmente os caracteres em palavras, as palavras em linhas, as linhas em colunas, para que nada fique fora de proporção. Do mesmo modo, aos educadores da juventude, é necessário dar normas, em conformidade com as quais executem as suas obras, isto é, devem escrever-se para uso deles Livros-roteiros que os aconselhem quanto ao que hão-de fazer, em que lugar e de que modo, para que se não caia em erro. [...]

20. Os livros mais elegantemente impressos têm os capítulos, as colunas e os parágrafos claramente distintos, com certos espaços vazios (requeridos, quer pela necessidade, quer por uma melhor visão), tanto marginais como interlineares. Também o método didático deve necessariamente prescrever períodos de trabalho e períodos de repouso, de determinada duração, para recreações honestas. Efetivamente, esse método prescreve programas para serem desenvolvidos em um ano, em um mês, em um dia e em uma hora [...]

26. Por último, terminada a tiragem do livro, recolhem-se todas as folhas impressas e põem-se em ordem, para que possa ver-se claramente se os exemplares estão completos e íntegros, sem defeitos e em estado de serem expedidos e postos à venda, de serem lidos e utilizados. Isto mesmo farão os exames públicos, no fim do ano, quando os inspetores das escolas verificarem o aproveitamento dos alunos, para constatarem a sua solidez e a sua coesão, que são a prova de que tudo o que devia ser aprendido foi, de fato, completamente aprendido.

[ComenIus, 2001, cap. XXXII]

Este tipo de obra didática inaugurada por Comenius compartilha com as obras científicas um avanço propiciado pelo surgimento da impressão relativo à reprodução de imagens, apontado por E. EISENSTEIN:

Em domínios como anatomia, geografia e astronomia a influência da impressão indicou sentidos além da ambiguidade de palavras, mediante declarações pictóricas e matemáticas precisas. Ao tornar possível duplicar mapas, quadros, tabelas e gráficos, a impressão revolucionou a comunicação científica. Imagens repetíveis e equações repetíveis tornaram possível contornar a confusão gerada pela tradução de uma língua para outra. [EISENSTEIN, 1980, p. 100] 22

No aspecto específico das imagens, David OLSON, citando o historiador das ciências George Sarton, para quem "o principal evento separando o período que conhecemos como Renascença da Idade Média foi a dupla invenção da tipografia, para o texto, e da gravura, para as

22 "In such fields as anatomy, geography, and astronomy the influence of printing pointed communications away from ambiguous words, and toward precise pictorial and mathematical statements. By making it possible to duplicate maps, graphs, tables, and charts, print revolutionized scientific communications. Repeatable pictures and repeatable equations made it possible to bypass confusion engendered by translation from one language to another." 
imagens", relaciona o esforço de representar o mundo em função dos novos meios e públicos a alguns aspectos centrais do desenvolvimento da estrutura do conhecimento e da maneira de pensar [OLson, 1997, p. 222]. No caso dos mapas, aponta que antes da impressão não se conseguiu reunir informações encontradas em mapas parciais num único grande mapa abrangente devido à falta de meios confiáveis de reprodução - e à ausência de um quadro matemático/geométrico comum, saliente-se, mas este também só possível a partir da transformação da matemática em uma nova linguagem universal para representação do mundo, o que só foi ocorrer num novo quadro mental possibilitado pela cultura impressa.

O exemplo mais claro dado por OLson é o da nova iconografia botânica, em que a possibilidade de reprodução fiel de um mesmo original detalhado e preciso, em que se sobressai a função técnica de representação da função meramente estética ou simbólica, associada com a descrição científica, levou à constituição da Botânica como ciência no século XVIII. Em ambos os casos, o do mapa e o do diagrama:

a informação é substituída pela verossimilhança. Uma figura de livro didático das partes de uma flor não se parece em nada com nenhuma flor real. Contudo, essa flor pintada, uma representação, se torna a entidade conceitual em termos da qual nós percebemos e classificamos as flores reais. [OLSON, 1997, p. 242]

Um aspecto da configuração do livro didático ainda timidamente indicado nas obras ramistas mas concretizado pela incorporação de imagens no Orbis Sensualium Pictus e seus sucessores, é o caráter multimodal, a partir da presença de duas linguagens, verbal e visual, e sua interação para a produção de informação e sentido, preconizado conscientemente pelo próprio Comenius embora não utilizasse esse léxico. Assim, se no tópico dedicado à conceituação do livro didático não salientamos essa característica, a multimodalidade, como definidora do livro didático, pode-se dizer que ela estará presente na praticamente totalidade da produção dos livros dedicados aos níveis iniciais e médios da educação moderna e contemporânea e uma visualidade específica pode caracterizá-lo em relação a outros impressos.

Por fim, um último aspecto que relaciona livro didático e cultura da impressão a ser destacado é apontado também por Michael TWYMAN, ao referir-se ao fato de que

Alfabetização em todos os níveis, quer ao nível acadêmico, administrativo, industrial, ou empresarial, em uma extremidade do espectro, ou da criança ou adulto marginalmente alfabetizados, no outro, certamente deve ser interpretada como mais do que a compreensão de como ler e escrever prosa contínua [...] [TWYMAN, 1986, p. 190] ${ }^{23}$

\footnotetext{
23 "Literacy at all levels, whether at the level of the academic, administrator, industrialist, or businessperson, at one end of the spectrum, or of the young child or marginally literate adult at the other, should surely be construed as more than on understanding of how to read and write continuous prose $[\ldots]^{\prime \prime}$
} 
Para TWYMAN, a visão convencional de alfabetização é falha por não levar em conta

os métodos gráficos muito mais sutis de articulação de linguagem de que comumente fazemos uso quando criamos linguagem (pela escrita, impressão e digitação) e quando lemos. Refiro-me ao uso de alfabetos variantes, tais como versais para complementar letras minúsculas, e itálicos e negritos que acompanham as letras de peso normal. [TWYMAN, 1986, p. 190] 24

Ou, seja, mais do que a alfabetização propriamente dita, a leitura da forma impressa, particularmente nos livros didáticos, envolve também uma alfabetização gráfica, uma iniciação nos códigos estabelecidos pela tipografia e pelo desenho da página impressa, o que definitivamente liga o livro didático à cultura da impressão.

\subsection{Design, história do design e conceito de projeto aplicados à pesquisa sobre livro didático}

Dois aspectos se apresentam a uma pesquisa sobre memória gráfica como estratégia para a construção da história do design. O primeiro é o do artefato em si, sua linguagem e a relação dele com as condições que o produziram. Este aspecto, que já teve suas premissas teóricas abordadas neste capítulo, está diretamente relacionado ao objetivo primeiro da pesquisa, o da constituição de uma trajetória do design do livro didático da CEN.

O outro aspecto, estreitamente ligado ao primeiro, até porque é uma das condições para a produção do design do artefato analisado, é o da atividade projetual envolvida na configuração desse artefato. Embora não seja objetivo dessa tese investigar a natureza da atividade projetual nas manifestações de design em período tão extenso, o papel determinante que pode ter na configuração dos artefatos gráficos produzidos praticamente exige que suas premissas teóricas sejam também abordadas.

No caso de uma produção ocorrida em períodos muito diversos, deve-se encontrar desde uma atividade com características basicamente vernaculares provavelmente exercida dentro das oficinas gráficas por oficiais tipógrafos qualificados, até o projeto feito por designers com formação acadêmica modernista em sua vertente construtiva, passando por situações intermediárias quanto ao tipo de profissionais envolvidos e sua formação. E, evidentemente, linguagens gráficas diversas.

No entanto, embora se possa estabelecer relações entre as linguagens e a prática projetual em cada um desses períodos, é preciso se dizer que, em todos os casos em que produza

24 " [...] the much more subtle graphic methods of articulating language we commonly make use of when originating language (by writing, printing, and typing) and when reading it. I am referring here to the use of variant alphabets, such as capitals to complement small letters, and italics and bolds to go along with upright letters of normal weight." 
um desenho novo para a produção de livros trata-se sempre de atividade projetual em sentido completo e de resultados que caracterizam a presença de design. Ou, seja, trata-se de concepção oposta à que prevaleceu durante o período de afirmação e legitimação do profissional designer, no século passado, que considerava design apenas o que trazia linguagens identificadas como modernistas construtivas ou no máximo suas precursoras. Segundo Rafael CARDoso:

Como em toda profissão nova, a primeira geração de historiadores do design teve como prioridades a delimitação da abrangência do campo e a consagração das práticas e dos praticantes preferidos da época. Sempre que um grupo toma consciência da sua identidade profissional, passa a se diferenciar pela inclusão de uns e pela exclusão de outros, e uma maneira muito eficaz de justificar essa separação é através da construção de genealogias históricas que determinem os herdeiros legítimos de uma tradição, relegando quem fica de fora à ilegitimidade. As primeiras histórias do design, escritas durante o período modernista, tendem a impor uma série de normas e restrições ao leitor, do tipo 'isto é design e aquilo não', 'este é designer e aquele não' [...]. [CARDOSO, 2004, p. 12-13]

Ao contrário, pretende-se recorrer ao conceito de design decorrente da noção de projeto para a produção, ao de toda produção de artefatos do período industrial, qual seja, aquele que estipula o design como um processo definido por etapa clara de preparação de modelos, matrizes e instruções, separada da etapa de fabricação, para viabilizá-la e responder necessidades do público para que se realize como mercadoria, como define Adrian FoRTY [2007, p. 11-16]. Ou, em formulação feita por Renato DE Fusco [1993, p. 144-161], quando os fatores projeto, produção, venda e consumo integram um só processo unitário, como eventos sequenciais relacionados e interdependentes. Essas duas visões superam as visões concentradas exclusivamente no repertório formal oferecidas por uma história fortemente vinculada à vertente construtivista do design modernista como condição para o reconhecimento da presença do design.

Hoje, um número crescente de pesquisas e obras consolidam esse reconhecimento, algumas tornando-se referência para o prosseguimento de pesquisas no campo das mais diversas realizações gráficas no país, como por exemplo a recente Linha do tempo do design gráfico no Brasil [Melo; RAmos, 2011] ou as obras de Rafael CARDoso, em que se destaca Uma introdução à história do design [2004], O design brasileiro antes do design [2005] e Impresso no Brasil [2009].

Mas em que medida ocorre exatamente a atividade de projeto quando é o tipográfo o responsável pela composição, que estabelece o desenho da página e faz as escolhas de fontes tipográficas e suas variações seguindo cânones e tradições estabelecidas por outros e antes dele?

Brian LAWSON [2011] faz uma distinção entre processo vernacular, ou artesanal, e processo profissionalizado e autoconsciente de projetar. No primeiro caso, ligado à produção artesa- 
nal e à manufatura, "o projetar é intimamente associado ao fazer" [LAWSON, 2011, p. 32], em que grande número de objetos podem ser sistematicamente produzidos com soluções muito sofisticadas, complexas e totalmente eficazes sem a compreensão de princípios teóricos, mas a partir de padrões antigos experimentados e passados de geração a geração [LAWSON, 2011, p.30-32]. No segundo caso, como resultado da industrialização e da introdução de tecnologias avançadas e situações e problemas cada vez mais complexos, o processo de projeto precisa se separar do fazer, utilizando quantidade maior de informação científica e ferramentas como o desenho, geração de protótipos e simulações, para produzir instruções de execução e fabricação.

Assim, o autor não faz uma valoração do processo de projeto profissionalizado correspondente ao momento em que o design se institui como disciplina e prática profissional em relação a um saber de projeto vernacular que, no caso das páginas "mais simples" de livros didáticos produzidas dentro da tradição da tipografia, seria de domínio de oficiais tipógrafos e atenderia às necessidades colocadas por um determinado tipo de original de texto e pelo público. Mas mesmo nessas páginas, em que há uma diferenciação do simples texto corrido, e mais ainda em páginas em que entram imagens - uma cartilha por exemplo, em que a relação texto e imagem é estabelecida por uma abordagem pedagógica particular - , há um empenho projetual determinado pela finalidade "ensinar", diferenciada por sua vez da finalidade das obras literárias, de entretenimento etc., com soluções gráficas conscientemente buscadas para cada caso, mesmo que recorrendo ao estabelecido pela tradição. E este empenho projetual ocorre independentemente da atividade de design ser ou não ensinada sob esse nome ou haver profissionais com o nome designer ou mesmo com o nome planejador ou projetista gráfico.

Nigel Cross [1982], por sua vez, identifica que a produção de todos os artefatos que vem caracterizando a construção do mundo "artificial" do homem é necessariamente resultado de uma forma de pensar e agir pertencente a uma área ou cultura diferenciada tanto da ciência como da arte, exercida portanto muito antes da atual configuração da atividade sob a denominação design. Como disciplina diferenciada, o design trabalha com o "modo" próprio de conhecimento necessário para a visualização e reconhecimento dos problemas e proposição de soluções que está na base da atividade de projeto de nosso mundo material. Modo esse diferenciado do empregado na compreensão "do que já existe no mundo" pela ciência, mas também do empregado pela arte na observação da experiência humana.

Esta diferenciação de modos tem como consequência diferenciação de métodos - experiência controlada, classificação e análise nas ciências; analogia, metáfora, crítica e avaliação na arte; modelação, formação de padrões, síntese, no design. Por fim, cada um desses modos trabalha com valores próprios - objetividade, racionalidade, neutralidade, preocupação com a "verdade" nas ciências; subjetividade, imaginação, comprometimento, preocupação com 
a "justiça" na arte; praticidade, engenhosidade, empatia, adequação e pertinência no design [CROSS, 1982, p. 221-222].

Assim, a atividade do designer - e, no nosso caso, daqueles que projetaram as capas e miolos dos livros didáticos da Companhia Editora Nacional - estaria inscrita numa chamada "terceira cultura" - "das artes do planejamento, invenção, construção" - , onde se localizaria a tecnologia não como ciência aplicada, mas como aplicação de conhecimentos não só científicos mas também intuitivos e tácitos na resolução de tarefas práticas. O tipo de pensamento envolvido assentaria principalmente na manipulação de códigos não verbais, em modos concretos-icônicos de cognição, diferentes dos formais-simbólicos das ciências. Teria também como principal instrumento de raciocínio o desenho. E, diferentemente das práticas de projeto na engenharia, baseadas no pensamento voltado para o problema, a prática de projeto em design basear-se-ia num pensamento voltado para a solução [CROSS, 1982, p. 222].

LAWSON [2011] vai mais longe nessa direção, abordando em vários capítulos o componente criativo dessa forma de pensamento focada na solução, o que explicaria a diversidade de soluções possíveis para um mesmo problema ou mesmo a identificação de problemas somente a partir da antecipação de soluções.

Dentre outros autores que também delimitam o campo da atividade design, é bastante útil a definição de Ken Friedman: "Design é um campo abrangente de disciplinas do fazer e planejar" as quais envolvem três exigências relativas ao quesito desempenho ou performance: "1. Atuar no mundo físico; 2. Dirigir-se a necessidades humanas; 3. Gerar o ambiente construído" [FRIEDMAN, 2000, p. 6].25

Se isto não constitui uma novidade em relação ao que foi visto até aqui, é de nosso interesse a consequência que o autor tira ao detalhar cada uma dessas exigências quando identifica um momento histórico da atividade projetual em que o ambiente e as demandas eram "mais simples" e "a experiência e o desenvolvimento individual eram suficientes para a essência e profundidade da prática profissional" [FrIEDMAN, 2000, p.7]. Conhecimento e experiência que hoje já não seriam suficientes, pois "a maioria das exigências atuais para o design requerem habilidades analíticas e sintéticas de planejamento que não podem ser obtidas da prática por si só" e envolvem conhecimento avançado qualitativamente diferente da prática profissional e construído como "resposta às demandas da sociedade de informação e da economia de conhecimento" [FrIEDMAN, 2000, p. 7].26

\footnotetext{
25 "Design is a broad field of making and planning disciplines. [...] The three performance challenges of making disciplines are they: 1. Act on the physical world. 2. Address human needs. 3. Generate the built environment."

26 "Past environment were simpler. They made simpler demands. Experience and development were sufficient for depth and substance in professional practice. Experience and development are still necessary. They are no longer sufficient. Most of todays design challenges require analytic and sinthetic planning skills that can't be developed through practice alone."
} 
Os livros didáticos da Nacional e a prática profissional envolvida no seu design, ao menos em seu início, estão assim localizados num período para o qual as exigências na caracterização da atividade projetual podem não ser as mesmas a serem empregadas no estudo de um objeto e prática de design atuais, mas nem por isso essas exigências são inexistentes.

No entanto, dada a extensíssima produção de títulos de uma editora do porte da Nacional, em que ao longo de sua existência se identifica inúmeros casos de design comum e repetido, ao lado de um número bem menor de soluções particulares e originais, cabe perguntar se se pode falar da presença de design em sua acepção plena em todos esses casos. Uma resposta para esta questão que não se apoie no gosto ou preferência por linguagens passa necessariamente pela verificação das condições formuladas por FoRTY e DE Fusco para a verificação de existência de design.

A primeira delas é, sem dúvida, a necessária existência de matrizes que obedecerão a especificações e serão acompanhadas de instruções em acordo com o processo industrial utilizado para sua reprodução na forma de volumes impressos e com acabamento pré-definido, condição que de fato pode ser verificada. Mas o conteúdo dessa matriz deve responder a necessidades não só de produção mas também de venda e de uso, ou seja, o projeto deve articular essas três instâncias.

A demanda principal de uso, relacionada à finalidade do livro didático, está em princípio contida na concepção autoral e editorial materializada pelo original de texto e imagem, que prevê uma determinada utilização definida pela interação entre o programa curricular e um usuário médio imaginado - ou usuários, uma vez que o livro didático é utilizado por professor e aluno - original este que será transposto para a matriz como resultado de atividade de projeto. $O$ atendimento à instância venda depende do reconhecimento, por parte do professor - que é quem decide a escolha - , do atendimento das necessidades da instância uso.

Mas a instância venda também deve depender de fatores como preço e acabamento principalmente no que este sugere de sua durabilidade e resistência, uma demanda de uso - , que serão definidos na instância produção, como resultado da ação de projeto articulando as três instâncias.

Assim, pode-se dizer de forma geral que as condições para verificação da existência de design estão em tese preenchidas, restando apenas verificar em cada caso particular a qualidade e a eficiência com que o projeto se articula com as instâncias de produção, venda e uso no atendimento de suas demandas, resultando num design mais ou menos adequado a elas, ou inclusive totalmente inadequado.

Há no entanto outro aspecto da instância uso que não se identifica com a simples funcionalidade, mas diz respeito a expectativas do usuário no campo simbólico, relacionadas ao gosto, atração visual, identificação, empatia, a partir dos signos veiculados pelo design em 
questão. É o terreno da cultura, ou das culturas visuais em que o usuário está imerso, seu repertório e capacidade de decodificação e construção de significados. E, por consequência, adesão e motivação, em diversos ou nenhum grau, resultando, agora sim, em maior ou menor eficiência no uso ou funcionalidade primária pretendida.

O peso das expectativas dos usuários com relação à visualidade no processo de comunicação e de resposta ao uso programado certamente é diferente para cada tipo de livro, faixa etária, experiência e repertório individual etc. e é provavelmente em cada momento condicionada pela cultura escolar e permeabilidade dessa à circulação de visualidades produzidas em outras esferas, condições enfim que variam no tempo e no espaço. Mas essa demanda menos "objetiva" que a prática de projeto também vai em maior ou menor grau responder é que justamente faz do design uma atividade de produção de signos da cultura.

Portanto, não há nenhuma impropriedade em se falar genericamente em "design dos livros didáticos da Companhia Editora Nacional", com este abarcando desde uma produção com pouco empenho projetual, como no caso da aplicação de soluções da tradição vernacular da tipografia - que pode ou não mostrar-se adequada - , até soluções desenvolvidas particularmente para livros únicos específicos, com uma série de situações intermediárias, como a de projetos para coleções ou a reaplicação em novas situações de soluções anteriormente desenvolvidas para casos específicos.

Mas se de forma geral pode-se falar em design, sua qualidade vai justamente depender do investimento projetual envolvido, ou seja, da capacidade deste em articular as demandas da produção, da venda e do consumo (uso):

No entanto, se se pode dizer que sempre existe design no caso da produção de livros e outros produtos, nem sempre existe projeto em sua acepção plena. No caso de uma capa de livro, mas também do seu interior, as instruções para reprodução estão consubstanciadas na própria matriz, que será reproduzida tecnicamente sem mais interferência de trabalhadores, a não ser no controle da reprodução com base em uma prova-referência da matriz. Assim, toda a concepção do projeto está concentrada nessa matriz, que pode ou não ter sido desenvolvida de forma a responder aos principais aspectos de produção, circulação e significado cultural com a consciência, a intencionalidade e o domínio dos meios que caracterizam o exercício do projeto. Se a reprodutibilidade exige algum grau de planejamento e projetação, outros aspectos decisivos no campo da circulação e do consumo, envolvendo, portanto, o imaginário e o simbólico, podem estar sendo ignorados. [MORAES, 2010, p. 28]

Assim, podemos ter algumas situações de enfraquecimento do sentido de projeto, como: a) aplicação de procedimentos estandardizados em função única e exclusivamente de necessidades da produção, ignorando especificidades do original e contextos diferenciados de uso; b) hábitos produtivos cristalizados aplicados em novos contextos tecnológicos que resultarão 
em inconsistências de linguagem do próprio artefato; c) apropriação superficial de linguagens sem referência a necessidades reais de uso, gerando soluções gratuitas e destituídas de sentido; d) resultado do exercício da função por profissionais sem a necessária qualificação para estabelecer as relações entre projeto, produção, venda e consumo.

Com base nesses parâmetros é que a trajetória do design dos livros didáticos da Companhia Editora Nacional pode ser apresentada e avaliada. 
CAPÍTULO 2

Origens, formação e primeiros anos da Companhia Editora Nacional 


\section{A}

história da formação da Companhia Editora Nacional já está razoavelmente estabelecida por diversos trabalhos de envergadura e, em princípio, esta tese, focada no design de seus livros didáticos, pretendia recorrer e fazer referência àqueles somente a partir dos problemas colocados pela visualidade de capas e miolos à medida em que se apresentassem.

Seria perfeitamente possível reproduzir capas e miolos de livros e estabelecer nexos entre sua materialidade/visualidade e fenômenos e eventos da história da própria editora, do mercado, da tecnologia, das demandas da educação e das linguagens circulantes. Afinal, a materialidade e a visualidade não são fruto do acaso e sim da ação de um conjunto de fenômenos de diversas esferas e, se não é possível depreender tudo do testemunho material sem se recorrer a informações provenientes de outros campos, é bem possível partir desse testemunho e construir as narrativas e nexos que o explicam a partir de pesquisas, por ele provocadas, nas demais esferas. Esta forma de abordagem, aliás, é a que melhor reproduziria o movimento e dinâmica da pesquisa material realizada e da bibliográfica que a sucedeu, em que a materialidade e visualidade não comparecem como ilustração de uma história editorial ou de fenômenos e processos estabelecidos previamente.

No entanto, a produção inicial didática da editora careceria de uma contextualização básica das origens da editora e suas condições e objetivos iniciais, capaz de fornecer o quadro histórico e institucional em que se deu não só essa primeira produção, mas que estabeleceu as bases da atividade da editora ao longo de sua existência. Do contrário, as referências a esses aspectos teriam de ser feitas a cada momento, de forma truncada, e não evitaria que o procedimento parecesse artificial, uma vez que de fato já se dispunha de algum conhecimento para situar e explicar o fenômeno material e visual tratado.

\subsection{Origens da Companhia Editora Nacional}

De uma história já bastante conhecida, estabelecida principalmente por HALLEWELL [2005] e BEDA [1987], com informações relevantes obtidas também em biografias e obras sobre a atividade editorial de Monteiro Lobato (CAvalheiro, 1962. Azevedo; Camargos; SAChetta, 2001. Bignotto, 2007. Koshiyama, 2006. Simionato, 2010), a correspondência de seu protagonista (LOBATO, 1951) e sua obra editada (LAJOLO; CECCANTINI, 2008. LAJOLO, 2014), a estratégia de publicações da Nacional em seus primeiros anos (Toledo, 2010) e o contexto da atividade editorial do período (SORÁ, 2010), vai-se aqui apresentar apenas um resumo que permita estabelecer o quadro institucional, objetivos e espaço no mercado da CEN como empresa editora.

A Companhia Editora Nacional foi constituída oficialmente em novembro de 1925, apenas porque a empresa anterior de Monteiro Lobato e Octalles Marcondes Ferreira, a Companhia 
Graphico-Editora Monteiro Lobato faliu. Com isto, não se quer dizer que ela não tenha vindo a se constituir como uma nova realidade e traduzido novos desejos de seus proprietários, que se agregaram ao projeto original como resposta a novas demandas do mercado e da realidade social. Mas de fato, o projeto original de uma editora com características que a Nacional iria apresentar em seus primeiros tempos estava definido para ser cumprido pela empresa anterior. Ou melhor, se concretizou nas obras editadas e comercializadas por aquela editora e continuou a se concretizar de forma aproximada nas obras editadas e comercializadas pela nova empresa nos primeiros anos de sua existência. Assim, um processo de falência iniciado em agosto de 1925, com a liquidação ocorrida em setembro, e a constituição de uma nova empresa apenas dois meses depois indica muito mais uma possibilidade de continuidade do que de ruptura, não apenas dada pela vontade de seus agentes mas também pela realidade concreta objetiva: o tempo transcorrido era muito pequeno para que novos meios e procedimentos fosse forjados ou colocados à disposição, um novo fundo editorial fosse constituído, ou idéias completamente novas substituissem as antigas.

Essa interpretação de fatos sobejamente narrados pelas histórias da Nacional e particularmente sobre o momento da falência da Cia. Graphico-Editora Monteiro Lobato contraria em parte o tom dos discursos de seus participantes, que obviamente no calor da luta vêem os esforços de correção dos erros e superação das dificuldades a partir da experiência vivida como a própria criação de uma nova realidade, diferente da anterior. Mas antecipando uma conclusão que a pesquisa material vai mostrar adiante, o catálogo das obras e sua visualidade revelam mais uma atividade que procura preservar o capital físico e simbólico construído que uma falência obviamente indesejada veio ameaçar —, do que a de construir uma nova empresa em tudo diferenciada da antiga. Outra coisa é que novos eventos e a dinâmica própria da editora construirá um empreendimento que irá muito além do que foram as empresas que a gestaram.

Assim, as raízes do que foi a Companhia Editora Nacional, seu fundo editorial e o papel nele ocupado pelos livros didáticos - e a visualidade desses - precisam ser principalmente buscados nas editoras que Monteiro Lobato, inicialmente sozinho e depois associado a Octales Marcondes Ferreira, constitui antes de fundar a Nacional.

\subsubsection{As edições avulsas e a Revista do Brasil (1917-1920)}

A atividade de Monteiro Lobato como editor teve início em 1917, quando com recursos próprios fez imprimir, sob o pseudônimo de Demonólogo Amador, O Sacy-Perêrê: resultado de um inquérito, a partir de grande número de depoimentos obtidos em pesquisa que coordenou no chamado Estadinho, edição vespertina do jornal O Estado de S. Paulo, sobre a personagem das lendas contadas no interior do país. O livro, com 300 páginas e muitas ilustrações, teve 
duas edições esgotadas em dois meses. No ano seguinte, também com recursos próprios, publicou seu livro de contos Urupês, que foi um sucesso editorial imediato, com 11.500 livros vendidos em um ano, chegando a 30 mil nos 5 primeiros anos [HALLEWELL, 2005, p. 315-316 e BIGNOTTO, 2007, p. 197-198].

Embora ainda não se possa caracterizar essa atividade de Lobato como a de um editor plenamente profissionalizado, também não era a de um simples autor com meios financeiros para encomendar a impressão de seus livros, como ocorria, e até hoje ocorre. No caso d'O Sacy, em carta dirigida a seu amigo Godofredo Rangel, fala de seus esforços para produzir "prefácio, prólogo, proêmio, dedicatória, notas, epílogo" [LoBATo, 1951, p. 160], além da opção por um formato grande e da reprodução de muitas ilustrações [BIGNOTTO, 2007, p. 196]. No caso de Urupês, o autor Lobato curva-se ao editor Lobato ao descartar o título original Dez mortes trágicas, a conselho de Artur Neiva, em troca do utilizado no artigo de ampla repercussão em que criara o personagem Jeca Tatu, Urupês, que de nome de um dos contos passa ao próprio livro, com a intenção de usufruir comercialmente daquela repercussão na divulgação da obra [BıGNOTTO, 2007, p. 204]. As duas obras expressam também um momento da construção de uma visão da literatura e dos problemas brasileiros de cunho nacionalista, que vai presidir a militância cultural, empresarial e política de Lobato a partir de então, que no caso da edição de literatura SoRÁ [2010, p. 55-56] aponta como sendo a de realização e legitimação de uma literatura nacional autêntica mediante o lançamento de autores novos e de obras inéditas de autores já conhecidos [Hallewell, 2005, p. 320-322. Azevedo; Camargos; Sachetta, 2001, p. 120-122].

Mas o aspecto que mais diretamente nos interessa desse primeiro Lobato editor é o cuidado dado aos aspectos materiais das duas obras, tanto o interior do livro como suas capas. Se os dois volumes são ilustrados, e Urupês pelo próprio autor, para as capas o editor chama um artista já razoavelmente conhecido, J. Wasth Rodrigues, que até se baseia em ilustração de Lobato para a coletânea de contos (FIG. 2.1). A capa d'O Sacy vai um pouco mais longe, ao ser dotada de cores, e ambas fogem ao padrão usual de capas tipográficas no chamado modelo francês para obras literárias consideradas sérias, já expressando a visão que Lobato tinha do papel desse componente para valorização do objeto livro como produto comercial popularizado.

Não que Lobato tenha inaugurado no Brasil a estratégia de adoção de capas ilustradas e coloridas como instrumento de persuasão para venda das obras, mas foi um defensor explícito e consciente dela. Rafael CARDOSO [2005] considera decisiva sua atuação para a generalização dessa prática, mas cuida em desfazer alguns equívocos da história editorial até então produzida, que atribuía a Lobato um papel precursor e único no uso de capas ilustradas. Assim, menciona os predecessores dessa prática já no final do século XIX e os exemplos nas duas primeiras décadas do século XX e, principalmente, contextualiza o uso das capas ilustradas num momento de crescimento dos centros urbanos e ampliação do cenário literário profissional, em que o gosto 
do público já havia sido impactado pela generalização das revistas ilustradas, possibilitada pela modernização da indústria gráfica brasileira, com a importação de impressoras litográficas e implantação de fábricas de papel. Assim, revistas ilustradas como Revista da Semana, O Malho, Kosmos, Fon-Fon!, A Maçã, Careta, a infantil Tico-Tico, dentre muitas outras existentes desde a primeira década do século, contavam com a atuação de artistas gráficos e ilustradores como J. Carlos, K.lixto, Alvarus, Voltolino, Belmonte, Guevara, e constituiram referências de gosto e expectativas do público favoráveis à adoção das capas ilustradas [CARDOSO, 2005, p. 165-171].
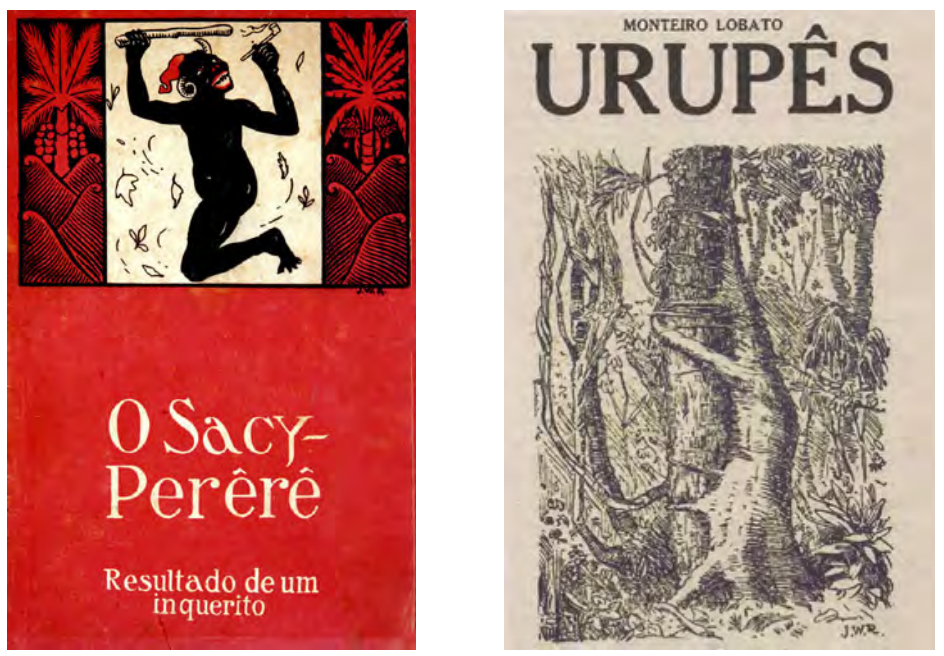

Fig. 2.1. Capas das primeiras edições de O sacy-pererê: resultado de um inquérito (1917) e Urupês (1918), ambas de J. Wasth Rodrigues. [Fontes: Azevedo; Camargos; SAchetta, 2001 e Cardoso, 2005.]

A atuação profissional de Monteiro Lobato como editor tem início em 1918 com a aquisição da Revista do Brasil, da qual era colaborador, de propriedade da família Mesquita, do jornal O Estado de S. Paulo. Nela empreendeu uma reforma gráfica modernizadora mas seu objetivo principal era utilizar o selo da revista para iniciar a publicação de livros não só seus, como também de outros autores, chegando a editar até 1920 pelo menos dezessete títulos [BIGNOTTO, 2007, p. 218]. E paralelamente ao esforço pela expansão das assinaturas da revista, procurou experimentar novos métodos para a divulgação e distribuição em caráter nacional dos títulos que publicava, incluindo a publicidade e a venda por reembolso postal, o que contribuiu para a construção de uma imagem de editor ousado e revolucionário [AzEVEdo; CAMARGOS; SACHETTA, 2001, p. 120 e 130].

Data também desse período o contato que Lobato trava com as idéias e com alguns intelectuais que se engajavam no movimento por transformações da educação, como Afrânio Peixoto, Sampaio Dória, Carneiro Leão e Lourenço Filho. A Revista acolhe o debate "cívico-patriótico" da educação como solução para os problemas do país, cedendo espaço para artigos em prol de reformas na educação [Toledo, 2001, p. 45].

Também é importante ressaltar que, diferentemente dos primeiros editores no país, como Garnier, Laemmert, Paula Brito ou Francisco Alves, a atividade editorial de Lobato não decorre 
de atividade impressora nem livreira, nem são as gráficas e as livrarias (como a Garraux, em São Paulo) os pontos de reunião com autores, mas a sede da Revista, o que é uma novidade em termos de diferenciação da atividade editorial em relação à de produção e de comércio do livro no país [SORÁ, 2010, p. 30, 39 e 46-52]. ${ }^{1}$
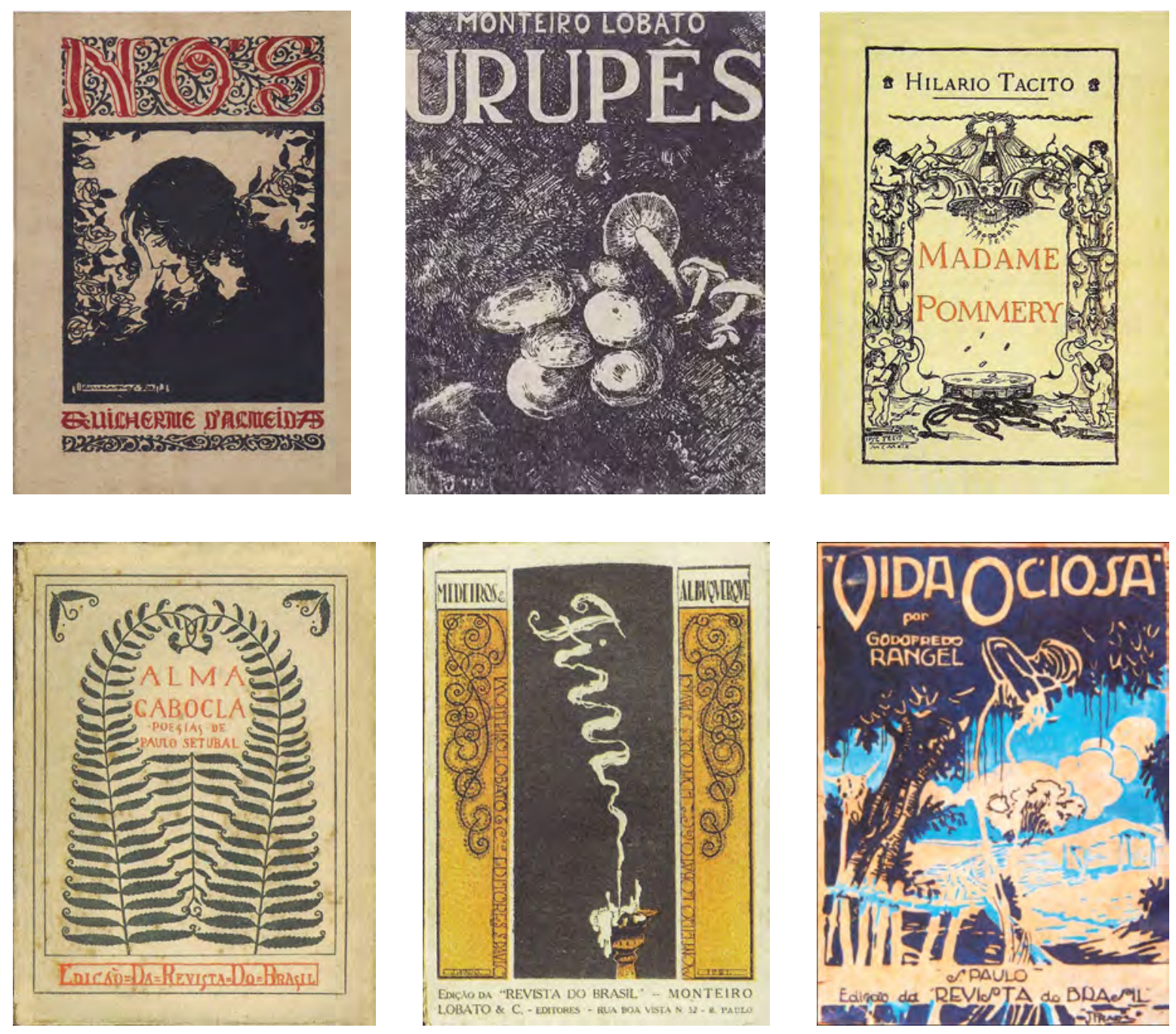

Fig. 2.2. Capas ilustradas de edições da Revista do Brasil: Nós, de Guilherme de Almeida, por Correia Dias (1917); segunda edição de Urupês (1918), ainda por J. Wasth Rodrigues; Madame Pommery, de Hilário Tácito (pseudónimo de José Maria de Toledo Malta) (1919), artista desconhecido; Alma cabocla, de Paulo Setúbal, por Paim (1919); Fim, de Medeiros e Albuquerque e Vida ociosa, de Godofredo Rangel, por J. Prado (1919). [Fontes: Azevedo; Camargos; Sachetta, 2001. Cardoso, 2005 e Simionato, 2010.]

Gustavo Sorá afirma que o caso de Lobato exemplifica a reconversão de capitais da produção agrícola em declínio para a industrial em expansão - Lobato vendera a fazenda de café da qual era herdeiro - com o emprego desses recursos na nascente indústria do livro motivada pela própria experiência do autor com as dificuldades de produção e difusão de suas obras e pela percepção de uma demanda existente por esse produto. Mas ao contrário de obras hagiográficas que atribuem a Lobato uma atuação absolutamente pioneira e revolucionária em todos os campos e procedimentos da edição, o autor situa o surgimento de suas inovações no contexto do movimento editorial em expansão na décadas de 1910 e 1920, seu alcance e suas limitações [SORÁ, 2010, p. 51-56]. O mesmo faz Cilza Carla Bignotto, de forma bastante detalhada ao localizar a atuação de Lobato dentro de uma "tradição editorial e tipográfica" e de um "sistema literário" já consolidados e pela investigação e ampla documentação das relações contratuais de suas editoras com seus autores, fornecedores, movimento editorial geral e "psicologia" do público [BıGnOtTo, 2007, diversas páginas]. 
De maior interesse nosso, dentro do escopo deste trabalho, está a generalização do uso de capas ilustradas, por artistas como Paim, J. Prado e J. Wasth Rodrigues (FIG. 2.2), bem como o esforço por superar as dificuldades com a qualidade de composição e impressão da revista e dos livros, que ocorria em tipografias de jornais e outros impressos. Para isso, Lobato estabelece um nova sociedade para a aquisição de uma empresa gráfica especializada em livros, a Olegário Ribeiro, Lobato \& Cia., e mesmo depois de dela sair, continua utilizando seus serviços [Azevedo; Camargos; Sachetta, 2001, p. 124].

\subsubsection{A Monteiro Lobato \& Cia. Editores (1919-1924)}

A nova empresa de Lobato, nascida em 1919 dentro e a partir da expansão da Revista do Brasil, na verdade uma mudança de razão social e de composição societária daquela, traz o nome de um autor já consagrado, que assim transfere seu prestígio para as obras que edita. Para esse empreendimento constitui também uma oficina gráfica e estoques de papel, que importa diretamente. Aqui se estabelece uma divisão de trabalho decisiva, com Lobato ocupando a "direção literária" e Octalles Marcondes Ferreira, jovem funcionário do setor de contabilidade da Revista, sendo alçado à direção comercial da nova sociedade, constituindo "uma das primeiras relações econômico-culturais propriamente editoriais" [SORÁ, 2010, p. 53].

Esse novo passo da profissionalização do trabalho editorial, com o editor podendo se dedicar à "caça de talentos" (com viés nacionalista, dentro de novos padrões de legitimidade cultural perseguido por Lobato, cf. SoRÁ, 2010, p. 53), se traduziu na construção de um catálogo que ultrapassou o número de 365 títulos, segundo levantamento feito por Juliana Siani SimionATO [2010, p.137-156].

Mas para além do número de lançamentos, uma marca importante da nova editora é a constituição de segmentos e coleções, particularmente de livros infantis, escolares e técnicos, o que será fundamental para o sucesso comercial da empresa. No segmento de livros para crianças figuram títulos do próprio Lobato, como A menina do narizinho arrebitado e sua versão escolar, Narizinho arrebitado, que teve tiragem de 50.500 exemplares porque foi adotado nas escolas do Estado de São Paulo (fig. 2.5).. Dentre as coleções, a Bibliotheca da Rainha Mab, destinada a moças, em formato pequeno $(8,00 \times 11,0 \mathrm{~cm})$ para ser levada "no cestinho de costura" e a Coleção Brasília, de literatura brasileira com preço reduzido, indicam a utilização da estratégia de fidelizar leitores oferecendo livros com perfil definido (FIG. 2.6).

Além do aprofundamento do emprego de capas coloridas ilustradas para as obras de literatura e de projeto gráfico e composição tipográfica mais sofisticada principalmente para títulos de poesia, é adotado um formato menor para parte das obras (11,0 a 12,5 cm por 15,0 a $16,0 \mathrm{~cm}$ ) e o acabamento brochura, mais prático e de custo de produção mais baixo, favorável à popularização do produto livro. 

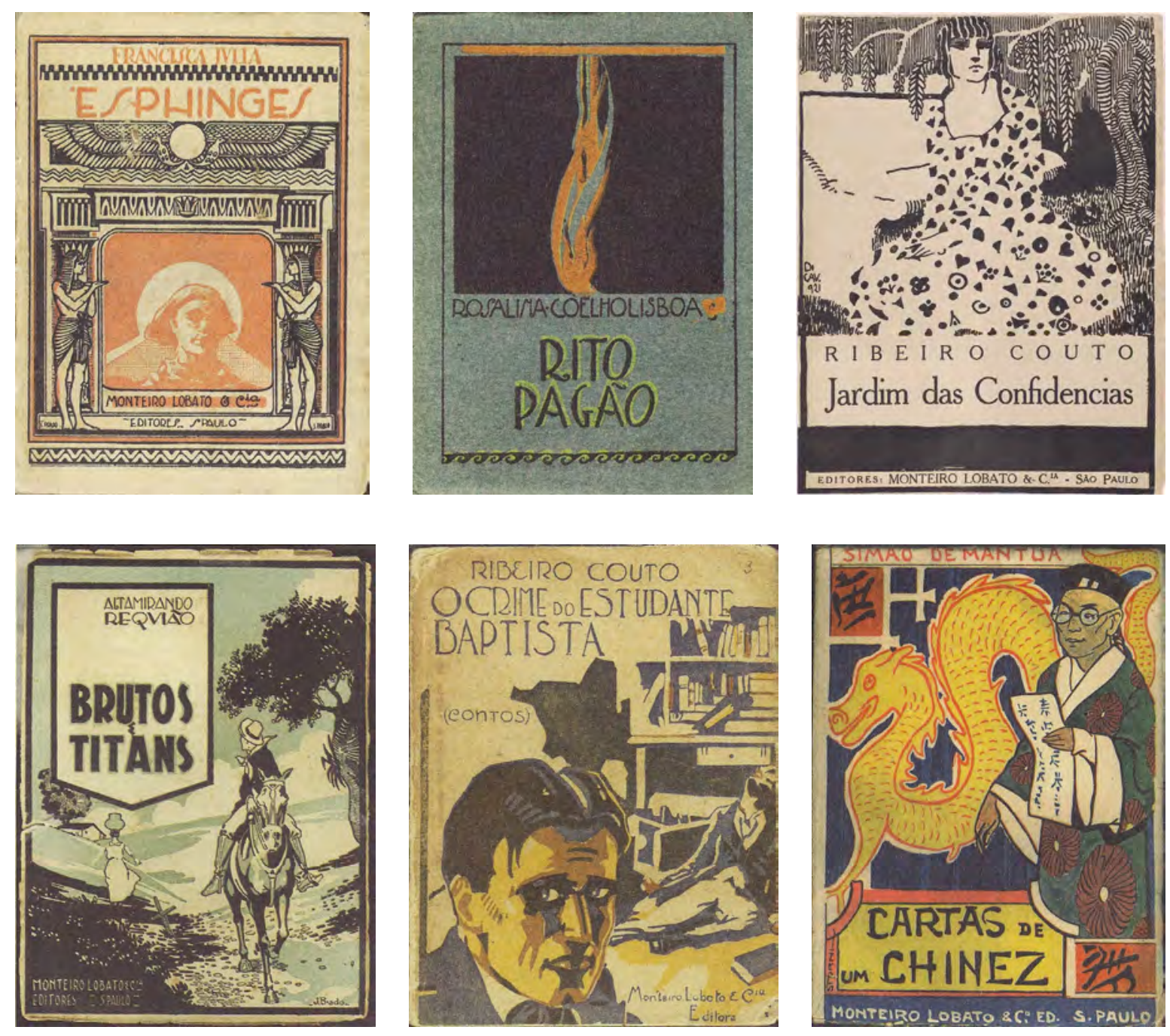

Fig. 2.3. Capas ilustradas da Monteiro Lobato \& Cia.: Esfinges, por J. Prado (1921); Rito Pagão e Jardim das confidências, por Di Cavalcanti (1921); Cartas de um chinês, por Alfredo Storni (1923). [Fontes: Melo; RAMOS, 2011 e Simionato, 2010.]
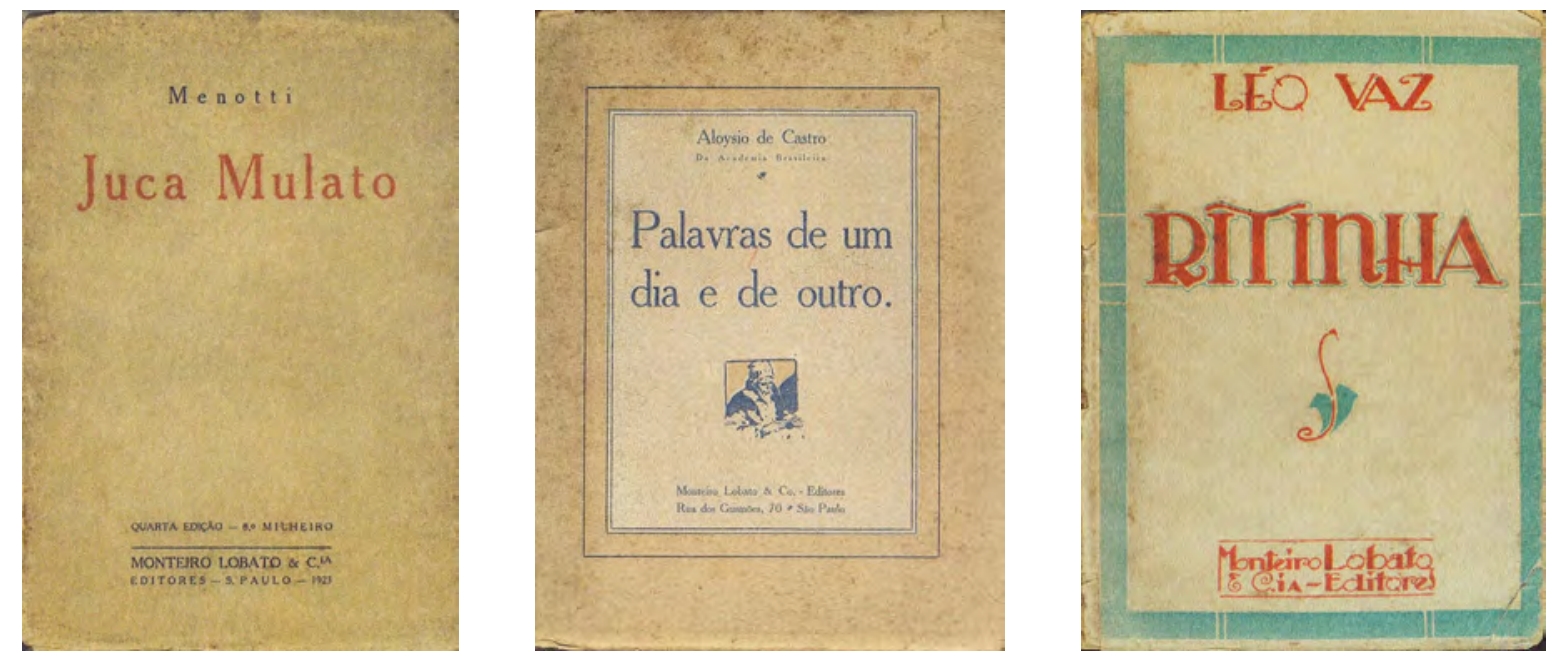

Fig. 2.4. Capas tipográficas da Monteiro Lobato \& Cia., as duas primeiras com composição mecânica e a última com desenho manual das letras, com qualidades de ilustração. [Fonte: SIMIONATO, 2010.] 

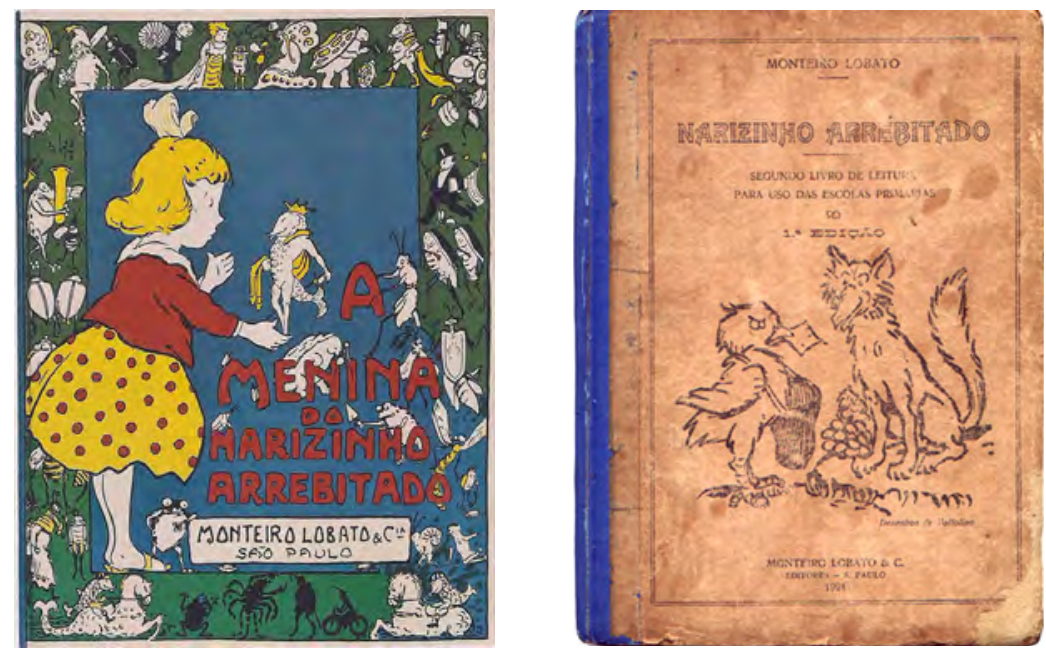

Fig. 2.5. Capas da edição "comercial" (A menina do narizinho arrebitado), de 1920, e da edição escolar (Narizinho Arrebitado), de 1921, ambas com ilustração de Voltolino. [Fontes: MELO; RAMOS, 2011 e AHECC/CRE Mario Covas/EFAP/SEE-SP.]
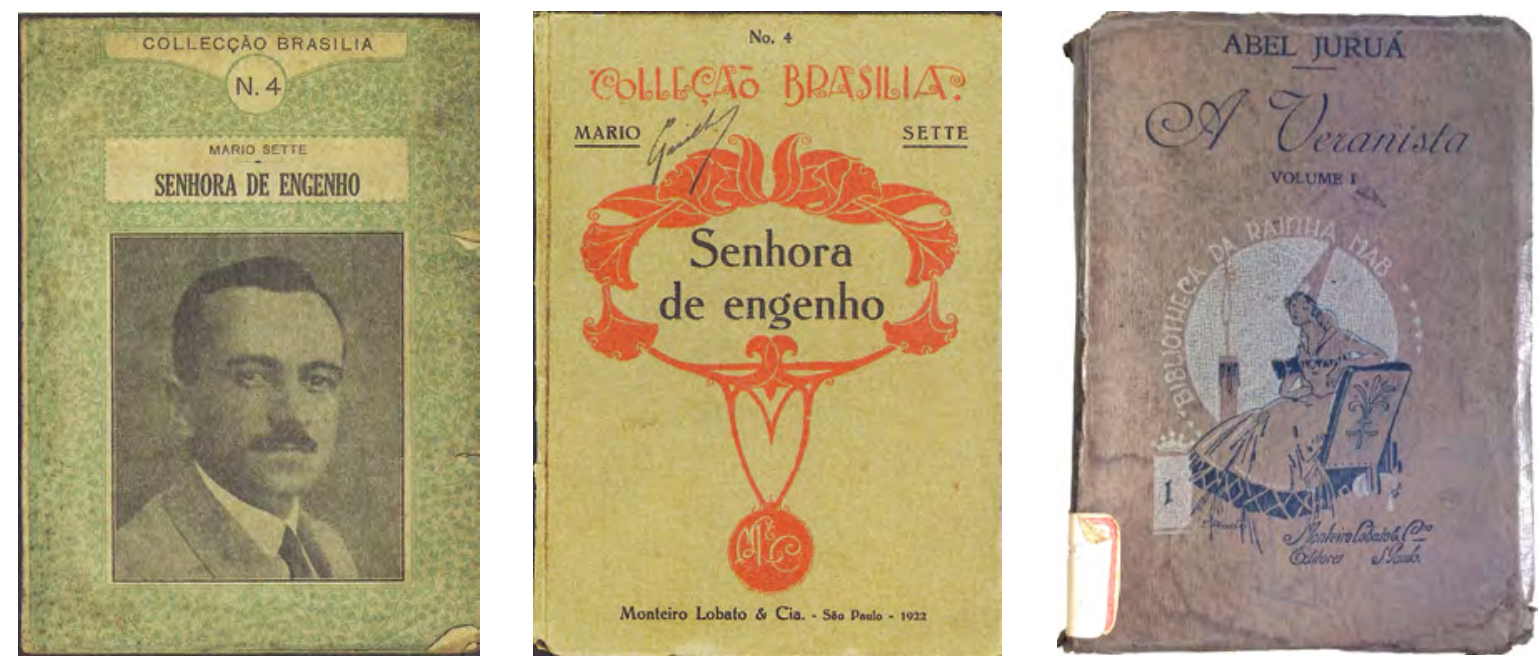

Fig. 2.6. Capas de volumes da Coleção Brasília, de literatura brasileira, em edições brochura e encadernada. Capa de volume da Biblioteca da Rainha Mab, com desenho de J. Prado. [Fontes: SIMIONATO, 2010 e IEB-USP.]

Essas iniciativas traduzem "uma nova concepção do livro como objeto gráfico industrial", em que a ilustração das capas

está inserida em um amplo esforço para tornar atraentes as novas edições mais baratas em brochura. Distanciando-se do tradicional culto ao livro como objeto de luxo, bem encadernado, com bom papel e acabamento artesanal, as edições populares das décadas de 1910 e 1920 empreendem uma nítida tentativa de compensar com um projeto gráfico vistoso a má qualidade de seus materiais e o seu péssimo acabamento. [CARDoso, 2005, p. 176-177]

A menção à falta de qualidade de materiais e acabamento diz respeito ao não aparelhamento da indústria gráfica brasileira para a produção de livros, que motivou as iniciativas de Lobato de montar oficinas próprias, além da insuficiência, do custo e da baixa qualidade do papel produzido no Brasil. Aqui também é importante mencionar que, por essas razões, era 
significativa a importação de livros de Portugal e a impressão de livros de autores brasileiros naquele país e até mesmo na França, situação que perdurará até começos da década de 1930 [SORÁ, 2010, p. 41].

\section{Os livros didáticos da Monteiro Lobato \& Cia.}

Fruto de posicionamentos assumidos e relações estabelecidas na experiência da Revista do Brasil e o interesse em se engajar no mercado de livros didáticos, Lobato começa a publicar obras identificadas com o movimento de renovação do Ensino Primário, em São Paulo, como cartilhas com novos métodos de alfabetização e literatura infantil, mas também livros para o Ensino Secundário, técnico-comercial e Normal [Toledo, 2001, p. 42].

As obras escolares da Monteiro Lobato \& Cia. totalizam ao menos 22 títulos, incluindo uma cartilha de alfabetização, livros de leitura e obras ginasiais e de preparação para ingresso nos cursos superiores, em que já aparecem alguns títulos que farão parte do catálogo da Companhia Editora Nacional que encontramos em nossa pesquisa:

- Cartilha de Alfabetização, de Benedito Tolosa.

- Cartilha de Hygiene, de Antonio de Almeida Júnior.

- Como se aprende a língua, de Sampaio Dória.

- Como se ensina, de Sampaio Dória.

- Corografia do Brasil, de Olavo Freire da Silva.

- Gramática Expositiva - Curso Elementar, de Eduardo Cunha Pereira.

- Gramática Expositiva - Curso Superior, de Eduardo Cunha Pereira.

- Gramática Histórica, de Eduardo Cunha Pereira.

- Lições de Português, de Othoniel Motta.

- Saudade, de Thales de Andrade.

O que chama a atenção é que para a maioria dos livros destinados à escola, as capas adotam o criticado padrão tipográfico francês e a impressão somente em preto, além de o acabamento ser a encadernação com capa dura e o formato ser menor (aprox. 11,5 × 16,0 cm) (FIG. 2.7). A razão provável é os livros didáticos não estarem submetidos à necessidade de chamarem atenção do leitor em pontos de venda ou publicidade, pois são escolhidos pelos professores e pelas escolas, e o uso cotidiano exigir maior resistência. Assim, a editora de Monteiro Lobato se alinharia a uma tradição editorial já estabelecida, em que a sobriedade das capas reveste o livro didático da seriedade de sua missão e uso. A exceção são os livros destinados à faixa etária correspondente ao Ensino Primário, em que cartilhas e livros de leitura têm normalmente capas ilustradas, ainda que não necessariamente infantis, e os formatos usuais (aprox. 13,0 x 18,5 cm). 

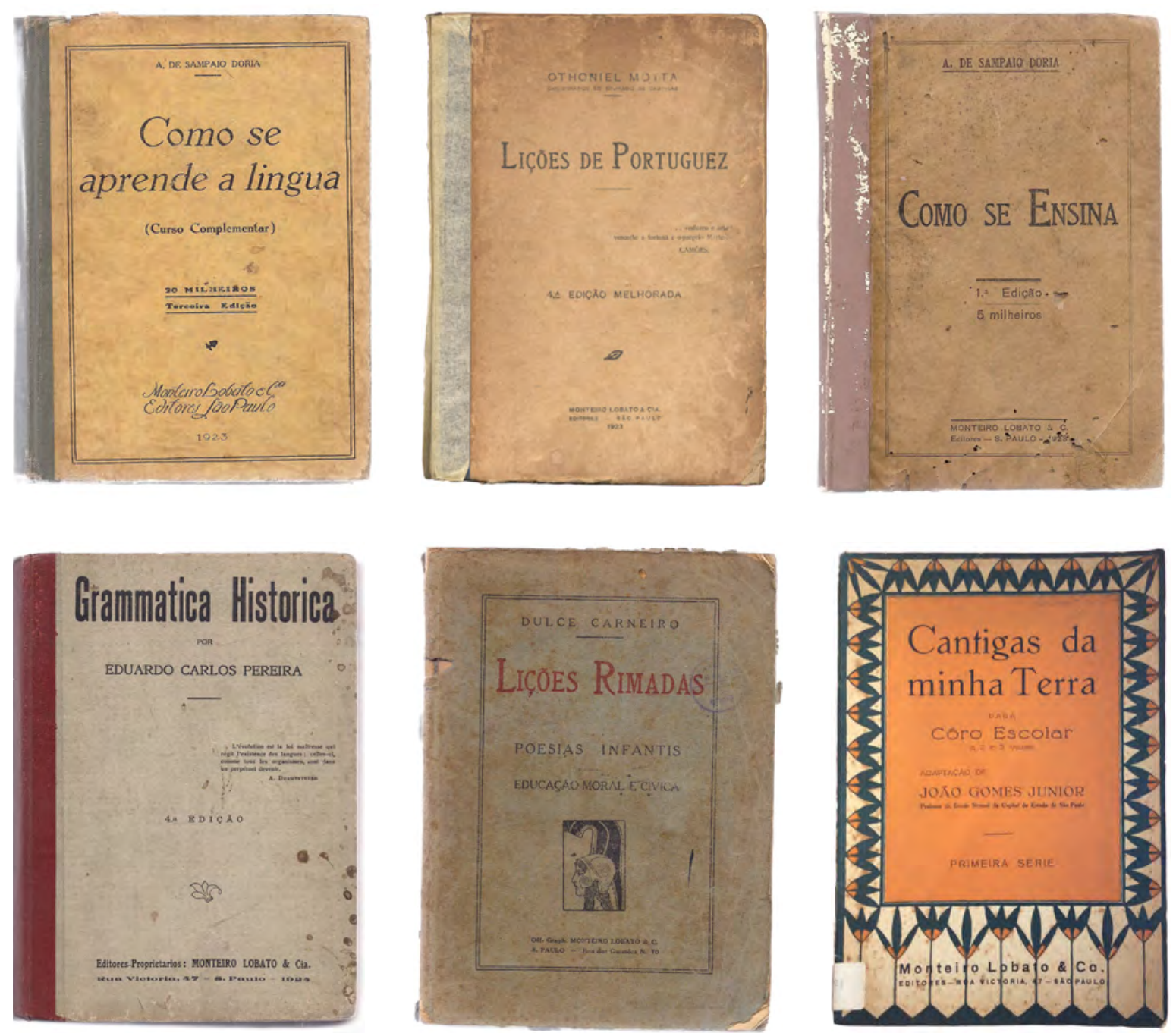

Fig. 2.7. Capas de livros didáticos da Monteiro Lobato \& Cia. Editores, de 1922 a 1924. Apenas os dois últimos títulos são em acabamento brochura. [Fontes: BBLD FEUSP; IEB-USP e acervo pessoal.]

\subsubsection{A Companhia Graphico-Editora Monteiro Lobato (1924-1925)}

A Companhia Graphico-Editora Monteiro Lobato é formada como uma continuidade da empresa anterior, motivada pela sua expansão e pela necessidade de constituir um parque gráfico capaz de produzir as tiragens e a qualidade desejadas por Lobato, além das possibilidades de lucro pela atuação nesse ramo. A capitalização para o empreendimento decorre do sucesso da Monteiro Lobato \& Cia., que foi capaz de atrair novos investidores para o empreendimento. Ephraim BEDA [1987, p. 150-152] relaciona os equipamentos importados, que inclui 17 impressoras planas e rotativas tipográficas e impressoras litográficas (segundo DonATO, 1990, seriam as primeiras ofsetes do país), conjunto para a produção dos cilindros estereotípicos (para impressão nas rotativas tipográficas), compositoras linotipos e monotipos (segundo Beda as primeiras do país), fontes tipográficas e máquinas de encadernação e outros acabamentos. 
As instalações e o pessoal técnico constituiram despesas que, acrescidos às dívidas para a compra dos equipamento, serviram para formar a maior e mais moderna empresa editora e gráfica do país, que no entanto não conseguiu entrar em produção plena em tempo de evitar sua liquidação. As causas relatadas vão desde o tamanho da dívida assumida, passando pela mudança brusca da política econômica, com a implantação de uma medida emergencial anti-inflacionária do governo de suspender o desconto de duplicatas e títulos, que privou a empresa de crédito de curto prazo, até a paralisação total da produção por vários meses e depois sua redução a dois dias por semana, devido a cortes de energia provocados pela seca no Estado de São Paulo e à revolta tenentista de julho de 1924, o que resultou no não atendimento de encomendas e do fluxo para o mercado [Hallewell, 2005, p. 339-340; Azevedo; Camargos; SACHETTA, 2001, p. 142-146].
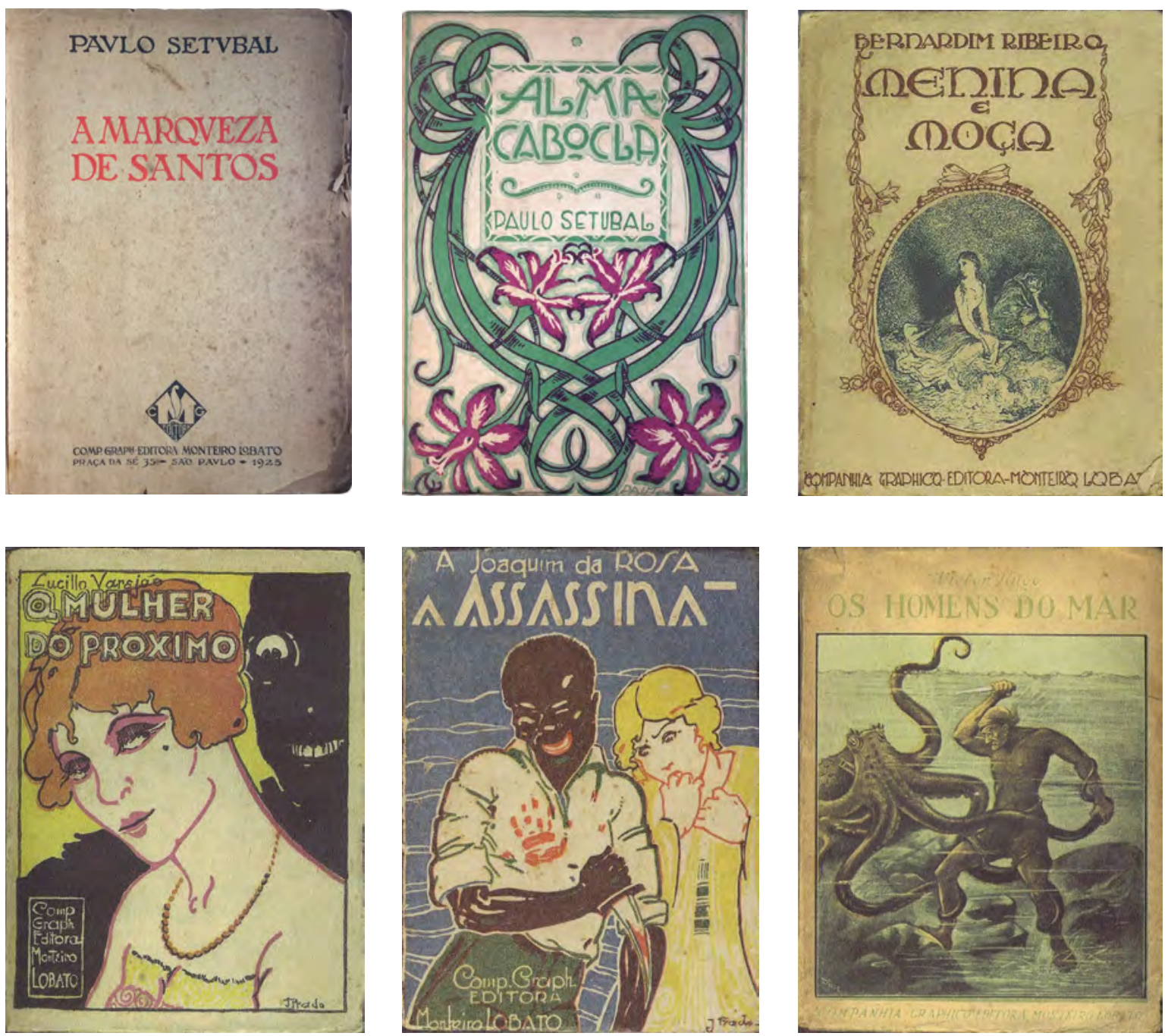

Fig. 2.8. Capas tipográficas e ilustradas da Cia. Graphico-Editora Monteiro Lobato: A Marquesa de Santos; Alma Cabocla, por Paim; Menina e moça, por artista não identificado; A mulher do próximo e A Assassina, por J. Prado; Os homens do mar, por artista não identificado, impressa em quadricromia, com meios-tons, indicando atualizacão tecnológica da empresa. [Fontes: IEB-USP e SIMIONATO, 2010.] 
No entanto, a falência, uma vez encarada como inevitável, gerou ações planejadas para a constituição de uma nova empresa no próprio bojo do processo de falência, uma vez que os bens da Cia. Graphico-Editora Monteiro Lobato poderiam ser liquidados para o pagamento do principal das dívidas e havia recursos preservados fora da sociedade suficientes para o reinício da atividade exclusivamente editorial, de forma modesta, mas sem os demais sócios [BEDA, 1987, p. 168-176; HALLEWELL, 2005, p. 345-346].

\section{Os livros didáticos da Cia. Graphico-Editora Monteiro Lobato}

Sobre os livros didáticos editados pela Cia. Graphico-Editora Monteiro Lobato, Marcia RAZZıNı [2010, p. 119] identifica no catálogo de 1925 um acréscimo de 18 títulos em relação ao da editora anterior, dos quais destacamos os que aparecerão em nossa pesquisa com o selo da Nacional:

- O meu idioma, de Othoniel Motta.

- O trabalho, de Thales de Andrade.

- Selecta nacional, de Othoniel Motta (provavelmente o título original do Selecta moderna).
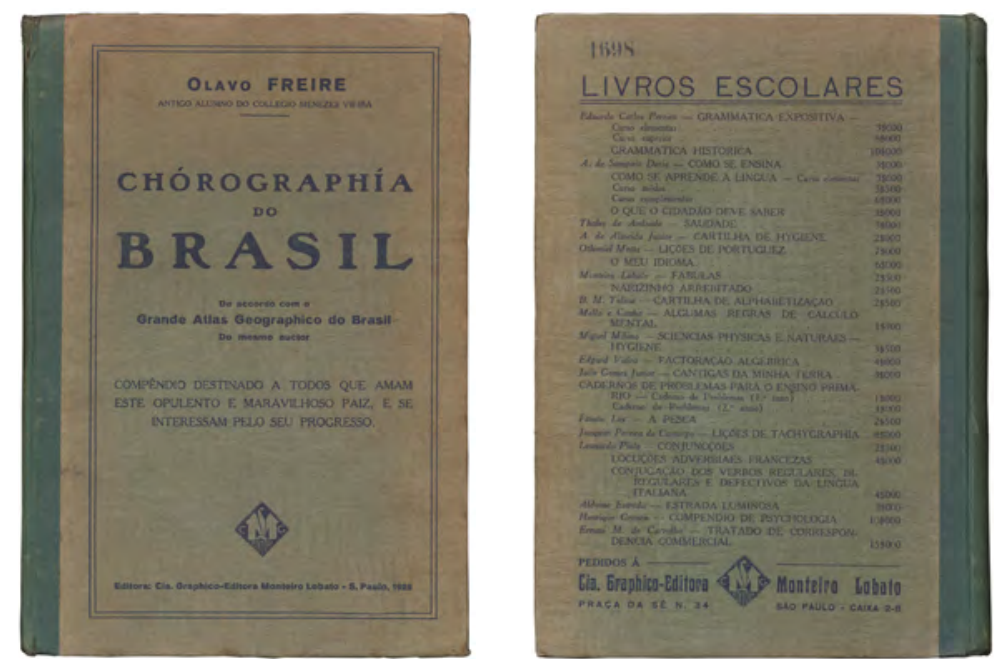

Fig. 2.9. Capa e quarta capa de Corografia do Brasil, editada pela Cia. Graphico-Editora Monteiro Lobato em 1925 , mas que já viera do catálogo da Monteiro Lobato \& Cia. [Fonte: BLD-FEUSP.]

\subsection{O início da Companhia Editora Nacional}

Dentre as medidas tomadas para garantir um renascimento da atividade editorial preservando o fundo editorial construído - catálogo e direitos de edição - e as condições para impressão dos títulos com saída certa, particularmente os didáticos, a primeira foi providenciar compradores para parte do maquinário integrante da massa falida - o que coincidia com os 
interesse dos credores - com o compromisso de trabalharem para a nova editora. Isto foi conseguido com os próprios gerentes técnicos de impressão da empresa, Natal Daiuto e Savério D’Agostino, que constituíram a São Paulo Editora, na verdade uma gráfica, que trabalhará para a Nacional até os anos 1970. Outra parte do equipamento foi adquirida pela Revista dos Tribunais, dirigida por Nelson Palma Travassos, que também fornecerá serviços para a Nacional [HALLEWELL, 2005, p. 348-349].

A outra providência foi a definição de um programa editorial para início das atividades que incluísse obras de domínio público, que dispensariam despesas com o pagamento de direitos autorais, autores e obras já conhecidas ou de baixíssimo risco, como novelas estrangeiras policiais e de aventura, e livros didáticos, de venda garantida [SoRÁ, 2010, p. 158-159]. Assim, o título de lançamento foi justamente uma primeira edição supervisionada por Lobato do famoso relato de Hans Staden, Meu cativeiro entre os selvagens do Brasil (FIG. 2.10), que de uma primeira edição de 5 mil exemplares vendeu 3 mil no primeiro ano [PAIXÃo, 1995, p. 67]. E como didático foi reeditada na nova casa a já consagrada Gramática expositiva, cujos volumes Curso Primário e Curso Superior venderam 25 mil exemplares até maio de 1926.

Assim, no primeiro ano, a CEN publicou 20 títulos, alguns com várias reimpressões, com uma tiragem total de 174 mil exemplares, dos quais destacam-se, segundo BEDA [1987, p. 220221]: livros didáticos, com 60 mil exemplares (quase 35\%); romances, com 51 mil exemplares (29\%); crônica histórica, romances históricos e biografias, com 45 mil exemplares (26\%).
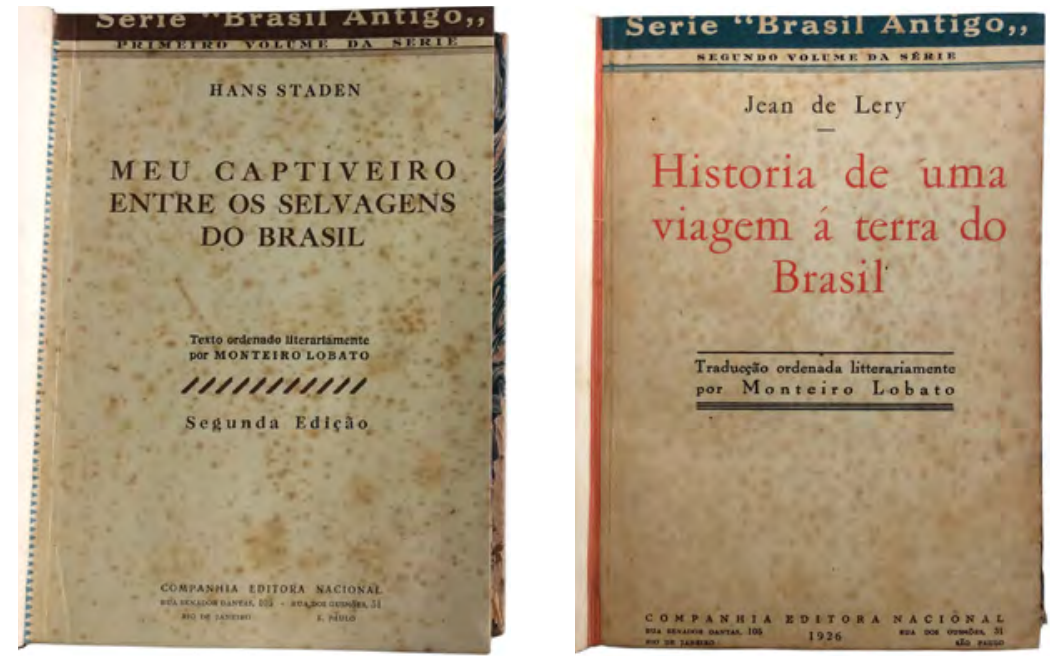

Fig. 2.10. Meu cativeiro entre os selvagens do Brasil, segunda edição, e História de uma viagem à terra do Brasil, ambos de 1926, com capas tipográficas. [Fonte: IEB-USP.]

O sucesso do primeiro ano propiciará o lançamento de 22 títulos novos em 1927, além de 26 reedições dos títulos do ano anterior, com uma tiragem total de 264 mil exemplares, com um aumento substancial dos outros gêneros em relação aos didáticos, que teriam sido reduzidos para 33 mil exemplares (12,4\% do total) [BEDA, 1987, p. 228]. Esse aumento de títulos e 
tiragem para obras voltadas para o público em geral pode ter significado uma maior segurança da empresa em não depender dos didáticos a partir de um presença maior no mercado editorial geral, mas como a relação do ano anterior não incluía infantis, que poderiam estar contidos na rubrica didáticos, e a de 1927 inclui 6,8\% de gêneros não especificados, talvez a desproporção não seja tão acentuada.

Os resultados dos dois primeiros anos permitirá à nova empresa arrematar o estoque de obras e os direitos de edição da antiga, em hasta pública que encerrou o processo de falência, em 1927, por um valor bem inferior ao da cotação, e com pagamento parcelado [BEDA, 1987, p. 228], concluindo a recuperação do fundo editorial e permitindo a obtenção de novos lucros com a venda do estoque.
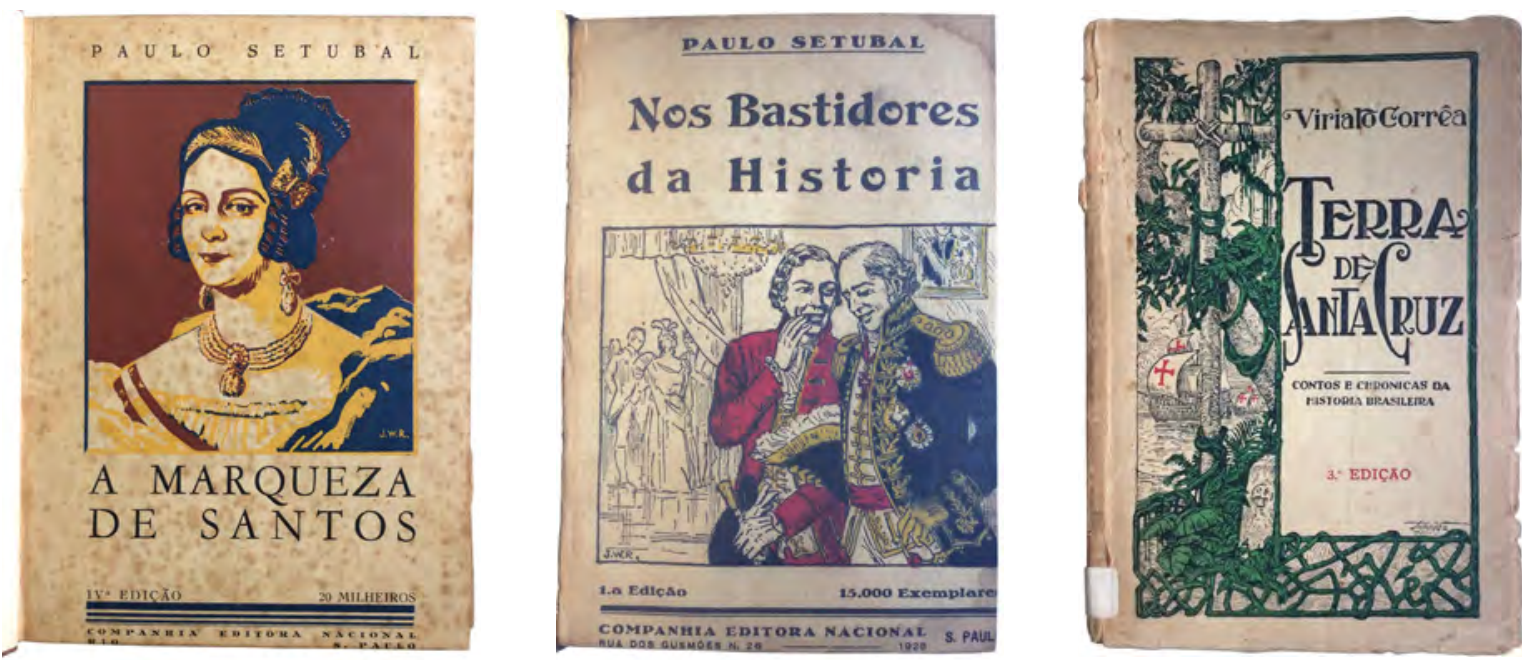

Fig. 2.11. Romances e crônicas históricas, gêneros que impulsionaram o crescimento da editora, tinham capas ilustradas: J. Wasth Rodrigues (1926 e 1928) e Paim (1930). [Fonte: acervo pessoal e IEB-USP.]
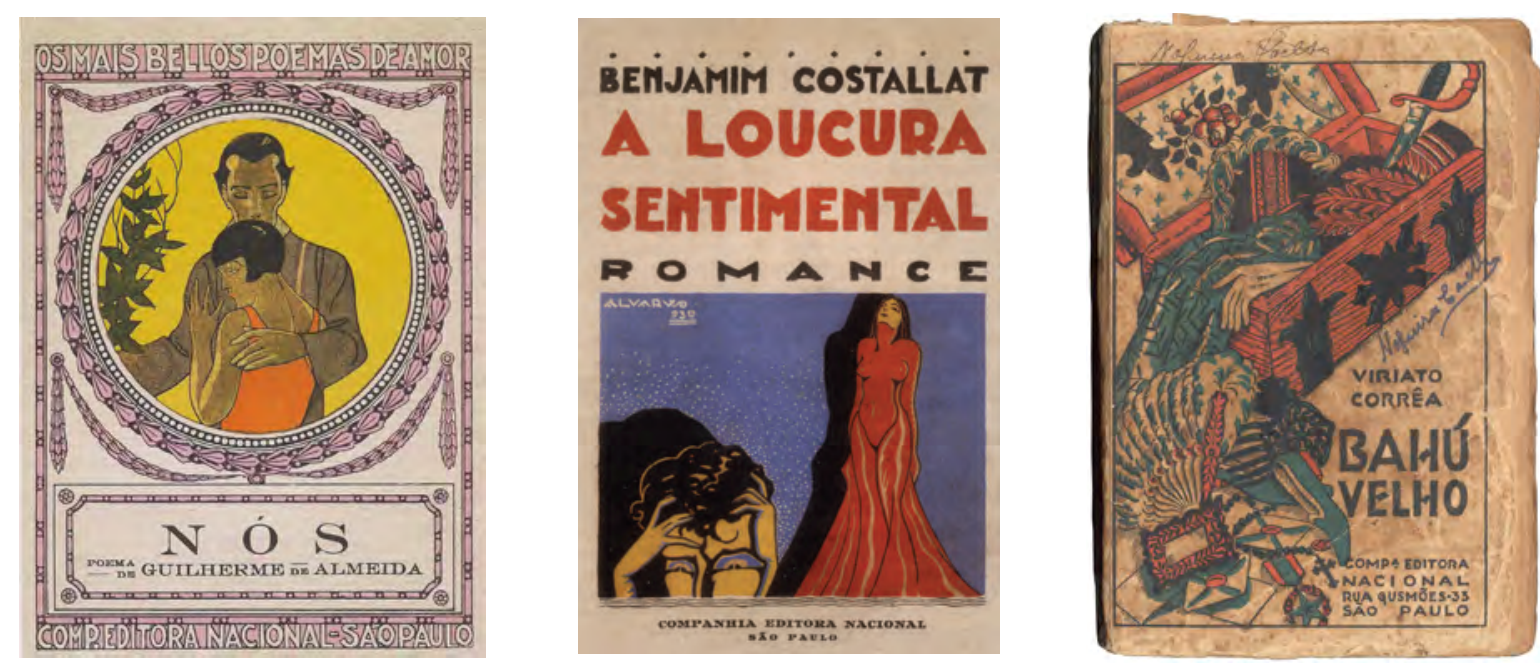

Fig. 2.12. Capas ilustradas por J. Prado (1927), Alvarus (1930) e ilustrador não identificado (1927). [Fontes: Cardoso, 2005; BLD-FEUSP.] 

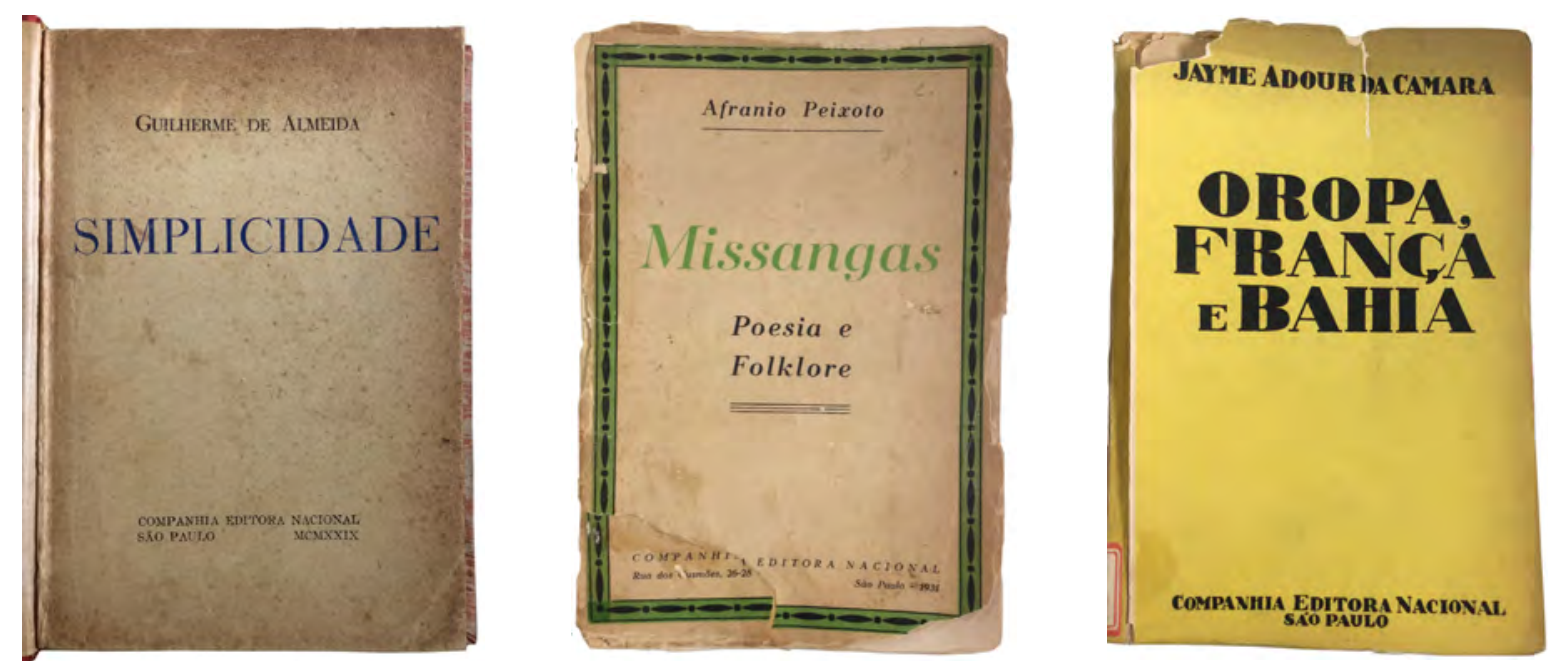

Fig. 2.13. Capas tipográficas, de 1929 a 1931, geralmente presentes em obras de poesia e ensaios, mas em linguagens diferentes para os dois gêneros. [Fonte: IEB-USP.]
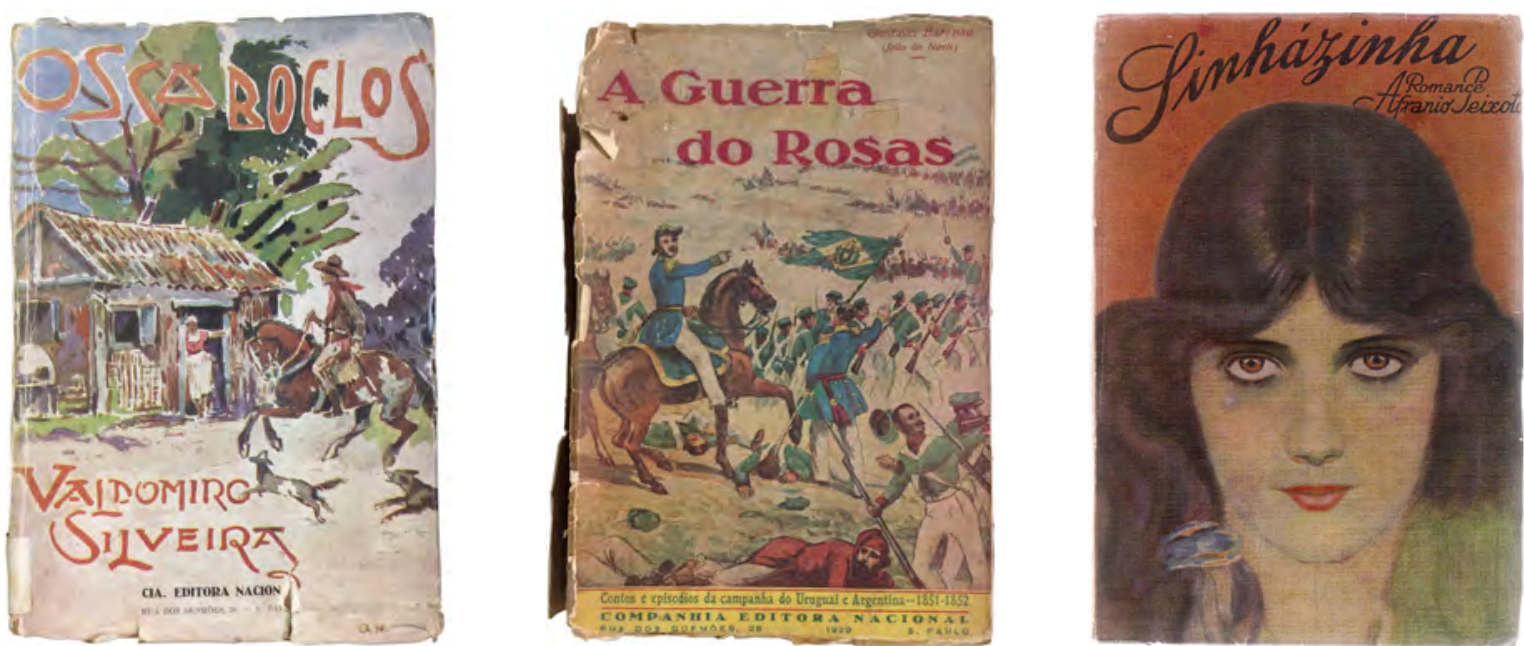

Fig. 2.14. Capas ilustradas impressas em tricromia e quadricromia, de 1926 a 1929, atestam a presença do equipamento mais atualizado disponível no país. Não há créditos dos ilustradores. [Fontes: IEB-USP e acervo pessoal.]
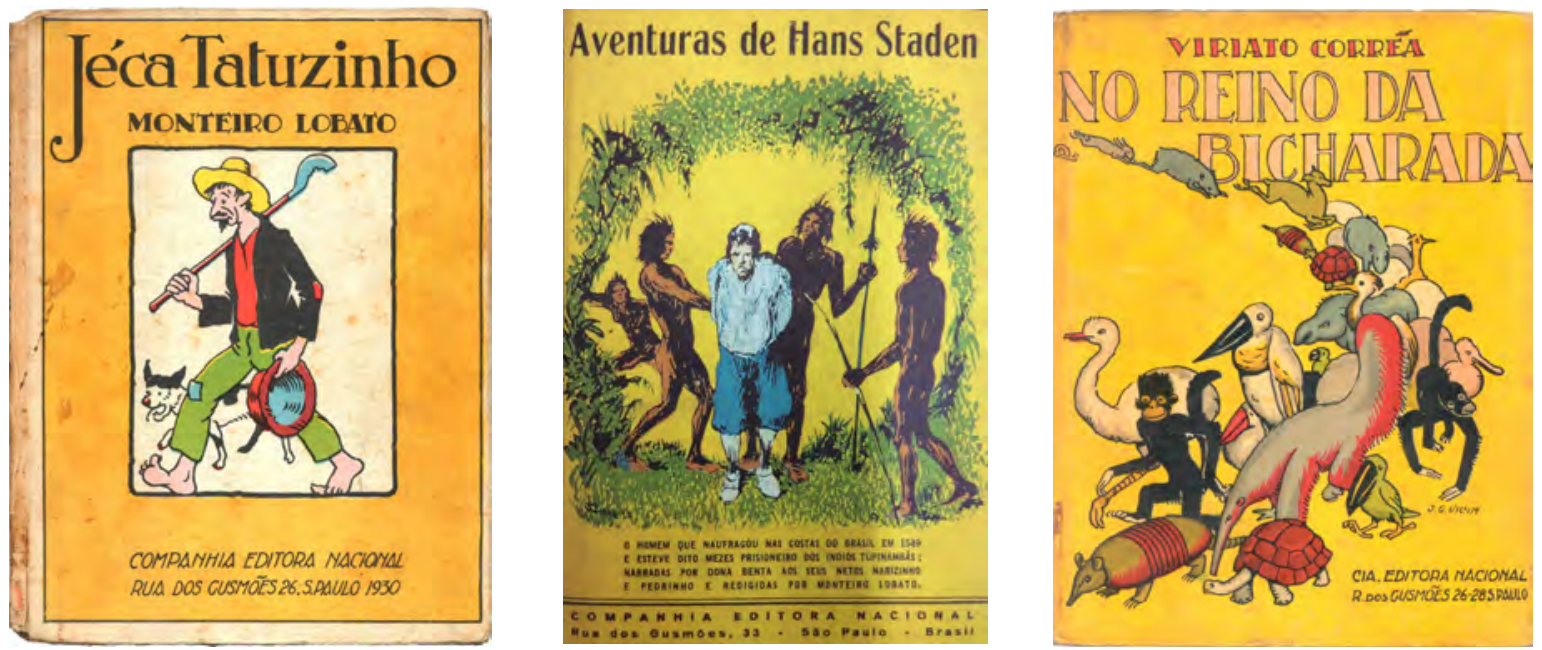

Fig. 2.15. Capas ilustradas para livros infantis: Aventuras de Hans Staden, 1927 e Jeca Tatuzinho, 1930, por Kurt Wiese; Reino da bicharada, de 1931, por Jean Gabriel Villin. [Fontes: AHECC/CRE Mario Covas/EFAP/ SEE-SP e LAJOLO; CECCANTINI, 2008.] 
O ano de 1928 marca um crescimento extraordinário, superior a 70\%, com 456.200 exemplares impressos, assim distribuídos: 55 títulos novos mais 29 reimpressões, com os didáticos tendo 48 mil exemplares (10,52\%) e a menção a uma nova categoria, os paradidáticos, também dirigidos para a escola, com 33 mil exemplares (7,23\%) [BEDA, 1987, p. 229-230]. E 1929 terá 43 títulos novos e ampliação dos gêneros e 36 reimpressões, mas com uma tiragem levemente menor que a do ano anterior (412.500 exemplares), com os didáticos somando 53 mil exemplares (12,85\%), sem menção a paradidáticos, mas com infantis somando 33.500 exemplares (8,12\%) e a informação de que a Cartilha de Hygiene (A. Almeida Júnior), teve uma reimpressão de 15 mil exemplares (3,3\% para uma única obra).

As tABelas 2.1 a 2.3, construídas com base nas pesquisas de BeDA [1987, p. 221-238], resumem e estendem estas informações até o ano de 1932. No caso da tabela 2.3 (Tiragem anual por gênero), como o autor se baseou em fontes diversas como catálogos e registros de produção das obras, constatou-se uma oscilação na nomenclatura e na divisão em subgêneros (crônica histórica e popular, ensaios políticos, econômicos, históricos etc.) e uma provável oscilação na própria distribuição dos títulos por gênero ano a ano (os romances históricos de grande sucesso dos primeiros anos aparecem no catálogo em 1931 sob a rubrica geral romance). Como nosso objetivo não é uma análise detalhada da evolução do catálogo e da performance de cada gênero editorial, e sim reconhecer o crescimento geral e identificar o lugar dos didáticos nesse processo, optou-se por omitir as subdivisões por gênero, mais acentuadas nos dois últimos anos do período, não deixando porém de ressaltar que ela indica a expansão do catálogo e a criação e ocupação de nichos do mercado, da mesma forma que a introdução de novos gêneros não existentes anteriormente.

Tabela 2.1. Títulos editados (1926-1932)

\begin{tabular}{|l|c|c|c|c|c|c|c|}
\hline \multicolumn{1}{l|}{} & 1926 & 1927 & 1928 & 1929 & 1930 & 1931 & 1932 \\
\hline Títulos novos & 20 & 22 & 55 & 43 & 61 & $\begin{array}{c}\text { não discrimi- } \\
\text { nado }\end{array}$ & $\begin{array}{c}\text { não discrimi- } \\
\text { nado }\end{array}$ \\
\hline Reimpressões & 7 & 26 & 29 & 36 & 33 & $\begin{array}{c}\text { não discrimi- } \\
\text { nado }\end{array}$ & $\begin{array}{c}\text { não discrimi- } \\
\text { nado }\end{array}$ \\
\hline Total & 27 & 48 & 84 & 79 & 94 & 98 & 133 \\
\hline
\end{tabular}

Fonte: BEDA, 1987. p. 221-238.

Tabela 2.2. Tiragem anual (1926-1932)

\begin{tabular}{|l|c|c|c|c|c|c|c|}
\hline \multicolumn{1}{|c|}{1926} & 1927 & 1928 & 1929 & 1930 & 1931 & 1932 \\
\hline Núm. exemplares & 174.000 & 267.000 & 456.200 & 412.500 & 378.900 & 345.800 & 675.600 \\
\hline
\end{tabular}

Fonte: BEDA, 1987. p. 221-238. 
Tabela 2.3. Tiragem anual por gênero, em número de exemplares e porcentagem da tiragem total (1926-1932)

\begin{tabular}{|c|c|c|c|c|c|c|c|}
\hline & 1926 & 1927 & 1928 & 1929 & 1930 & 1931 & 1932 \\
\hline Romance histórico & $\begin{array}{l}11.000 \\
6,32 \%\end{array}$ & $\begin{array}{l}59.000 \\
22,00 \%\end{array}$ & $\begin{array}{l}58.000 \\
12,72 \%\end{array}$ & $\begin{array}{l}15.500 \\
3,75 \%\end{array}$ & $\begin{array}{c}22.000 \\
5,80 \%\end{array}$ & & \\
\hline Poesia & $\begin{array}{l}3.500 \\
2,01 \%\end{array}$ & $\begin{array}{l}50.000 \\
19,00 \% \\
\end{array}$ & $\begin{array}{c}62.000 \\
13,6 \% \\
\end{array}$ & $\begin{array}{c}28.000 \\
6,78 \%\end{array}$ & $\begin{array}{c}23.000 \\
6,07 \%\end{array}$ & $\begin{array}{l}14.100 \\
4,07 \%\end{array}$ & $\begin{array}{c}10.000 \\
1,48 \%\end{array}$ \\
\hline Crônica & $\begin{array}{l}24.000 \\
13,80 \% \\
\end{array}$ & $\begin{array}{l}14.000 \\
5,00 \% \\
\end{array}$ & $\begin{array}{l}26.100 \\
5,72 \% \\
\end{array}$ & $\begin{array}{c}46.000 \\
11,14 \% \\
\end{array}$ & $\begin{array}{l}16.200 \\
4,30 \% \\
\end{array}$ & $\begin{array}{l}11.000 \\
3,18 \%\end{array}$ & $\begin{array}{l}16.000 \\
2,37 \%\end{array}$ \\
\hline Conto policial & $\begin{array}{c}10.000 \\
5,75 \% \\
\end{array}$ & & & & & & \\
\hline Biografia & $\begin{array}{c}10.000 \\
5,75 \%\end{array}$ & & & & & & \\
\hline Infantil & & $\begin{array}{l}16.000 \\
6,00 \%\end{array}$ & $\begin{array}{l}52.000 \\
11,40 \% \\
\end{array}$ & $\begin{array}{c}33.500 \\
8,12 \% \\
\end{array}$ & $\begin{array}{l}90.000 \\
23,75 \% \\
\end{array}$ & $\begin{array}{l}27.500 \\
7,95 \%\end{array}$ & $\begin{array}{l}33.000 \\
4,88 \%\end{array}$ \\
\hline Ensaio & & $\begin{array}{l}13.000 \\
4,80 \% \\
\end{array}$ & $\begin{array}{l}8.000 \\
1,75 \% \\
\end{array}$ & $\begin{array}{l}26.300 \\
6,37 \% \\
\end{array}$ & $\begin{array}{l}19.200 \\
5,08 \% \\
\end{array}$ & $\begin{array}{c}30.200 \\
8,73 \%\end{array}$ & $\begin{array}{r}74.100 \\
10,97 \% \\
\end{array}$ \\
\hline Direito & $\begin{array}{l}1.000 \\
0,86 \%\end{array}$ & & $\begin{array}{l}5.000 \\
1,10 \% \\
\end{array}$ & & $\begin{array}{l}2.500 \\
0,66 \%\end{array}$ & $\begin{array}{l}2.500 \\
0,73 \%\end{array}$ & \\
\hline Sociologia Política & $\begin{array}{l}3.000 \\
1,70 \%\end{array}$ & & & & & & \\
\hline Didático & $\begin{array}{l}60.000 \\
34,48 \% \\
\end{array}$ & $\begin{array}{l}33.000 \\
12,40 \% \\
\end{array}$ & $\begin{array}{l}48.000 \\
10,52 \% \\
\end{array}$ & $\begin{array}{l}53.000 \\
12,85 \% \\
\end{array}$ & $\begin{array}{l}69.000 \\
18,20 \% \\
\end{array}$ & $\begin{array}{l}44.000 \\
12,72 \%\end{array}$ & $\begin{array}{c}144.500 \\
21,39 \%\end{array}$ \\
\hline Paradidático & & & $\begin{array}{c}33.000 \\
7,23 \%\end{array}$ & & $\begin{array}{r}9.500 \\
2,50 \%\end{array}$ & $\begin{array}{c}14.000 \\
4,05 \%\end{array}$ & $\begin{array}{c}30.000 \\
4,44 \%\end{array}$ \\
\hline História & & & $\begin{array}{l}24.000 \\
5,26 \%\end{array}$ & & & $\begin{array}{l}3.000 \\
0,87 \%\end{array}$ & \\
\hline Higiene e saúde & & & $\begin{array}{l}16.100 \\
3,52 \%\end{array}$ & $\begin{array}{l}84.000 \\
20,40 \% \\
\end{array}$ & $\begin{array}{c}29.000 \\
7,65 \% \\
\end{array}$ & $\begin{array}{l}5.000 \\
1,45 \%\end{array}$ & \\
\hline Casa e família & & & $\begin{array}{l}5.000 \\
1,10 \%\end{array}$ & & $\begin{array}{l}5.000 \\
1,32 \%\end{array}$ & & \\
\hline Técnico-científico & & & & $\begin{array}{c}13.200 \\
3,19 \%\end{array}$ & $\begin{array}{l}5.000 \\
1,32 \%\end{array}$ & $\begin{array}{l}5.500 \\
1,60 \%\end{array}$ & \\
\hline Medicina & & & & & & $\begin{array}{l}11.600 \\
3,35 \% \\
\end{array}$ & $\begin{array}{l}1.900 \\
0,28 \%\end{array}$ \\
\hline Aventura & & & & & $\begin{array}{l}4.000 \\
1,05 \% \\
\end{array}$ & & \\
\hline Viagens & & & & & & & $\begin{array}{l}9.000 \\
1,33 \% \\
\end{array}$ \\
\hline Não especificados & & $\begin{array}{c}18.000 \\
6,8 \% \\
\end{array}$ & & & & & \\
\hline
\end{tabular}

Fonte: BEDA, 1987. p. 221-238.

Assim, prosseguindo a análise para os anos de 1930 e 1931, constata-se um crescimento geral de lançamentos mas uma redução de tiragem em relação a 1929, atribuídas por Beda a eventos da economia e à instabilidade política, com a Revolução de 30 como fato maior [BEDA, 1987, p. 233-235]. Mas justamente 1930 vai marcar um grande crescimento dos infantis (tiragem de 90.000 exemplares, 23,75\% do total) e dos escolares (didáticos 69.000, 18,2\%; paradidáticos 9.500, 2,50\%), com uma participação maior desses gêneros num momento de retração geral de tiragem em relação a 1929. Estes fatos revelam um grande crescimento de atividade editorial interna que não teria se refletido na tiragem total em função mesmo da situação política e econômica, cujos desdobramentos nas decisões de impressão é apresentado mês a mês pelo autor citado. 
O ano de 1931 será ainda de retração na tiragem e participação dos didáticos (44.000, $12,72 \%$ ) e dos infantis $(27.500,7,95 \%)$ mas de aumento substancial de romances (177.400, 51,30\%) e paradidáticos (14.000, 4,05\%).

De qualquer forma, mesmo com as dificuldades constatadas entre 1929 e 1931, o cômputo geral é de um crescimento da ordem de quase 100\% entre a fundação da empresa em 1926 e o final de 1931. E o ano de 1932, apresentado por Beda como o último "'ano crítico' desse difícil início da Companhia Editora Nacional", constituirá na verdade um salto em relação ao ano anterior e um marco inquestionável da consolidação da empresa, com multiplicação de tiragem de quase quatro vezes em relação a 1926, crescimento em todos os gêneros e elevação da participação dos escolares para quase $26 \%$ da tiragem total da editora, com um crescimento de exemplares impressos de quase três vezes desde a fundação da editora.

Estes dados revelam que 1930 e 1931 foram anos de intensa atividade editorial, preparatória ao salto de 1932, que marcará um novo período de existência da Nacional, com uma nova organização de seu catálogo e uma participação consolidada dos livros escolares.

Com relação a todo o processo vivido pela Companhia Editora Nacional no início de suas atividades, o que também se pode verificar é que, se ela nasce como uma continuidade "natural" das experiências editoriais e comerciais anteriores de Monteiro Lobato e Octalles Marcondes Ferreira, procurando preservar seu catálogo e um plano editorial modesto como base de apoio para uma esperada expansão, transformações importantes começaram a se delinear já nos primeiros anos da editora.

A principal modificação em si não teria consequências relativas à linha editorial, pois diria respeito a um retorno aos objetivos e ao espaço de atuação originais de uma empresa editorial como era Monteiro Lobato \& Cia Editores. Se para a expansão da atividade editorial Lobato e Ferreira viram a necessidade de investimento na atividade gráfica especializada em livros, este acabou sendo um passo arrojado que causou a falência de um empreendimento editorial que crescia no espaço aberto pela demanda geral de livros, particularmente de uma literatura de caráter nacionalista e de assuntos sensíveis ao momento do país, que Lobato se propôs veicular. A nova editora nasce então com um retorno ao perfil claramente delineado de editora de livros, sem envolvimento com o trabalho industrial, até contando que este pode ser perfeitamente cumprido pelas empresas gráficas "aliadas" que a experiência anterior, apesar de traumática, ajudou a formar [SORÁ, 2010, p. 158].

Outra modificação, relativa à gestão da empresa, já parece ter peso maior quanto ao desenvolvimento futuro da Nacional. Tanto na Monteiro Lobato \& Cia. Editores como na Cia. Gráfico-Editora Monteiro Lobato havia sido estabelecida uma divisão entre o trabalho editorial e o comercial e administrativo, que se mostrava necessário não só para o funcionamento da empresa, mas para a consecução do projeto editorial de Lobato de lançamento de autores e de 
legitimação de uma corrente literária nacionalista. Na fundação da Nacional, Lobato muda-se para o Rio de Janeiro, na verdade a "praça" onde foi constituída a empresa por impossibilidade de sê-lo em São Paulo até a finalização do processo de liquidação da editora anterior, para provavelmente cuidar de relações e negócios que a presença na capital federal permitiria, enquanto que Octalles acaba fazendo mais do que apenas cuidar da gestão administrativa e comercial, ocupando-se também de decisões editoriais exatamente por estar na sede real da empresa em São Paulo. Essa mudança acaba resultando que Lobato passa a se dedicar mais a sua atividade de tradutor e de escritor, principalmente de infantis, e ao seu interesse por uma política industrial para o país, inspirada no modelo norteamericano, que o leva a aceitar uma indicação para o cargo de adido cultural em Washigton, em maio de 1927 [HALLEWELL, 2005, p. 346].

A decorrência de seu afastamento da direção da empresa é, na prática, o fim da atividade de Lobato como editor engajando sua empresa como ponto de apoio para o lançamento de novos autores participantes da afirmação de uma literatura brasileira nacionalista. Este processo se conclui em 1929, com o afastamento de Lobato da própria empresa quando, para cobrir os prejuízos que teve com investimentos em ações na bolsa de Nova York, foi obrigado a vender sua metade de participação da Nacional para a família de Octalles, que assim assumiu a direção plena da editora e de sua política de publicações [HALLEWELL, 2005, p. 346].2

Assim, se o projeto inicial de constituição da CEN é a continuação de uma atividade editorial anteriormente construída, e isto de certa forma se dá com a recuperação do catálogo da editora anterior e com os resultados de vendas, novos acontecimentos relativos aos seus participantes e uma dinâmica nova do mercado editorial e da educação vão conduzir à formação de uma editora em que começam a se acentuar as diferenças com as anteriores mesmo nos primeiros anos de vida.

O papel atribuído aos didáticos dentro da estratégia de recuperação do capital perdido com a falência e de construção da nova editora parece não ter se limitado à constituição de um segmento de vendas com a finalidade de manter a saúde financeira da empresa para a consecução de objetivos editoriais relacionados à divulgação de uma literatura nacionalista ou de discussão dos problemas nacionais correspondentes aos planos originais de Lobato. A demanda por livros escolares, mas também por outros gêneros a que o mercado em formação se mostrava sensível, constituirá possibilidades de retorno financeiro que se somarão à natural preservação do patrimônio editorial original, gerando iniciativas da direção exercida agora exclusivamente por Octalles Marcondes Ferreira que podem estar configurando uma nova editora com características diversas das inicialmente previstas.

\footnotetext{
2 Isto no entanto não significa que Lobato não continuasse com participação privilegiada na política editorial da Nacional, a partir dos laços estabelecidos com o antigo sócio e com a intelectualidade do período, que o credenciava a indicar nomes e títulos para publicação e articular contatos e projetos, como demonstra Maria Rita ToLEdo [2008, p. 144-145].
} 
No entanto, como aponta Maria Rita Toledo, ao lado do aspecto comercial que motivaria uma editora como a Nacional se engajar no segmento de livros didáticos, havia o aspecto político e ideológico, o de publicar obras identificadas com as demandas de transformação na educação, uma vez que fazia parte do legado da editora a comunhão, ao menos de seu principal criador, com esses ideais e relações com seus defensores, desde os tempos da Revista do Brasil e as obras herdadas do catálogo da Monteiro Lobato \& Cia. [Toledo, 2001, p. 50].

Mas o momento vivido nos anos iniciais da editora está inevitavelmente marcado pelo esforço em se apoiar basicamente no catálogo herdado, ao qual vai-se acrescentando títulos novos, incluindo alguns didáticos. No entanto, apesar do sucesso de vendas assim obtido, ainda não é possível caracterizar a Nacional, ao menos até 1931, como uma editora de livros didáticos, mais ainda com a pretensão de oferecer algum risco significativo ao espaço ocupado pela Francisco Alves, do Rio de Janeiro, então a maior editora de livros escolares do país.

O que se pode afirmar é que as transformações de linha editorial, o catálogo que se vai configurando e os resultados obtidos com uma atividade exclusivamente editorial já indicam uma maturação das condições no país para o crescimento de empreendimentos claramente editoriais, que vão se estabelecendo uns em relação aos outros a partir de demandas estabelecidas por um mercado que se constituía em nível nacional e que vai definindo para cada um desses empreendimentos o espaço que ele ocupará 

CAPÍTULO 3

1926-1931:

O design de livros didáticos dos primeiros anos da Companhia Editora Nacional 

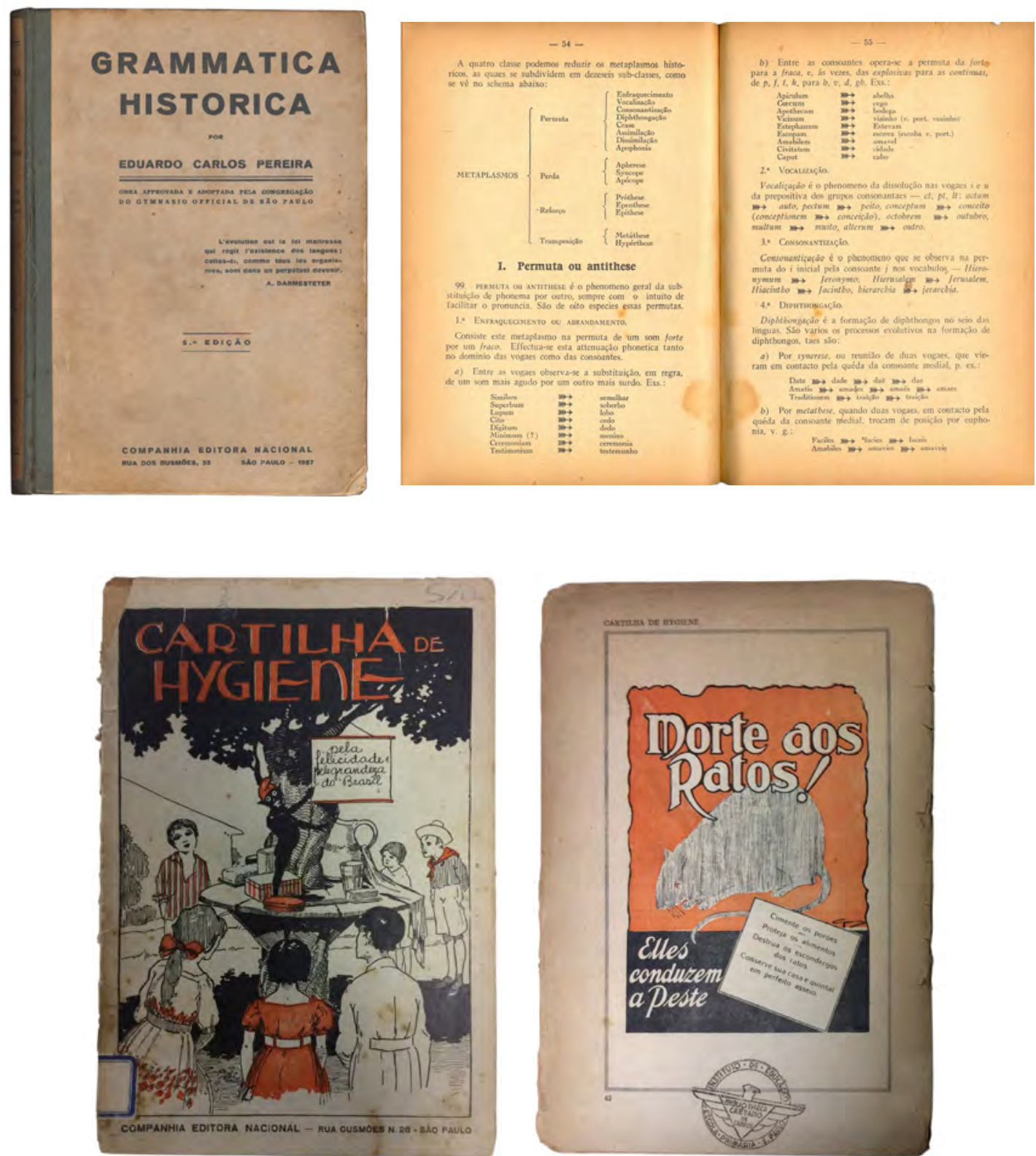

Estas duas obras aqui reproduzidas sintetizam as principais características do design de capa e miolo encontradas nos livros produzidos entre 1926 e 1931:

- a herança do catálogo e dos procedimentos e linguagens gráficas das editoras anteriores de Monteiro Lobato e Octalles Marcondes Ferreira - a Monteiro Lobato \& Cia e a Companhia Graphico-Editora Monteiro Lobato;

- as linguagens correspondentes às tecnologias de impressão disponíveis e utilizadas - a tipografia e a litografia industrial;

- encadernação em capa dura para os livros do Ensino Secundário e em brochura para obra destinada ao ensino popular. 
$\bigwedge_{\text {Editora Nacional permitiu a identificação de algumas características materiais e visuais }}$ que circunscrevem as obras produzidas entre 1926 e 1931 a um primeiro período de design dos livros didáticos da editora. Mas além de dados como materialidade, linguagem gráfica e tecnologia empregada, outras evidências corroboram a periodização proposta.

A primeira delas foi obtida pela contextualização histórica que se fez da produção editorial inicial da editora, apresentada no capítulo anterior, em que um primeiro momento é marcado pelo apoio no catálogo herdado das editoras anteriores, pela cautela com os riscos e pelas limitações de investimento nos primeiros anos, seguido de um segundo momento marcado por transformações na gestão da empresa, reconfiguração do catálogo e incremento notável em número de títulos e tiragem.

Uma segunda evidência favorável à periodização proposta diz respeito à configuração dos dois períodos na educação do país que têm como fronteira a chamada Revolução de 30. Ao primeiro corresponde um catálogo basicamente herdado da Cia. Graphico-Editora Monteiro Lobato e voltado para uma estrutura e necessidades de ensino que serão modificadas por esse evento histórico de importância maior e a reforma da educação que ele promoveu, em 1931. Ao segundo período corresponde uma ampliação substancial na produção de didáticos, com a oferta de obras para todos os níveis e disciplinas decorrente de uma ampliação do oferecimento de ensino pelo Estado brasileiro, que a editora soube explorar para sua expansão.

Assim, a definição de um período inicial do design de didáticos da Nacional não se dá apenas por reconhecimento de características intrínsecas nele encontradas, mas também pela força das características encontradas no momento seguinte, que têm marcos muito evidentes separando-o do primeiro.

\subsection{Os livros didáticos da Companhia Editora Nacional de 1926 a 1931}

O catálogo da CEN de 1931 apresenta, na seção "Livros escolares", 32 títulos, organizados pelo nome dos autores, não por disciplinas ou níveis. Os títulos novos, não provenientes das editoras anteriores de Lobato e Ferreira, estão indicados:

- Eduardo Carlos Pereira: Gramática expositiva, curso elementar; Gramática Expositiva, curso superior; Gramática Histórica.

- Saverio Christofaro: Como se aprende matemática, 1a parte; Como se aprende matemática, 2a parte (novos).

- L. Liard: Lógica (novo).

- Diversos professores: Exame de admissão, aos ginásios oficiais; Exame de Admissão, às escolas normais (novos). 
- Thales de Andrade: Saudade; Trabalho; Espelho (novo).

- Monteiro Lobato: Contos escolhidos; Fábulas; Aventuras de Hans Staden (novo).

- Theodoro de Moraes: Sei ler, Livro de leitura intermediária; Sei ler, 1ํ livro de leitura; Sei ler, 2oㅡ livro de leitura (livros da série Cesário Motta, todos novos)

- A. de Almeida Júnior: Anatomia e fisiologia humana (novo); Cartilha de Higiene.

- A. Sampaio Dória: Como se aprende a língua; Como se ensina; Psicologia (novo).

- Agenor Silveira: Colocação dos pronomes (novo).

- Casemir Lieutaud: Tratado completo de conjugação dos livros franceses (novo).

- Olavo Freire: Corografia do Brasil.

- João Gomes Júnior: Cantigas da minha terra.

- Othoniel Motta: Lições de Português; O meu idioma; Selecta moderna; Chave da língua (novo), As geórgicas de Virgílio (novo).

- Veríssimo \& Lourenço de Souza: Pontos de nossa história (novo).

A relação inclui títulos de leitura infantil de Monteiro Lobato, que se não foram inicialmente criados para serem destinados à escola foram adaptados para esse fim, sugeridos como livros de leitura para anos específicos e, nessa condição, adotados na rede escolar pública de alguns estados. Situação semelhante é a do livro Saudade, de Thales de Andrade, uma ficção para a juventude defendendo os valores da vida rural mas que já havia tido edições oferecidas para as escolas antes mesmo de integrar o catálogo da Monteiro Lobato \& Cia., e que na Nacional constituirá, junto com Trabalho e Espelho, uma série de leitura escolar. A coleção de leitura criada explicitamente para a escola é constituída pelos três volumes da série Sei Ler, de Theodoro de Moraes. Para o Primário há ainda um livro de música, Cantigas da minha terra, também proveniente das editoras anteriores de Lobato e Ferreira. Os demais títulos são destinados ao Ensino Secundário e mesmo superior, na forma de compêndios, não de cursos seriados, e de obras de consulta. Também novos são as duas obras de preparação à admissão ao Ginásio e ao curso Normal.

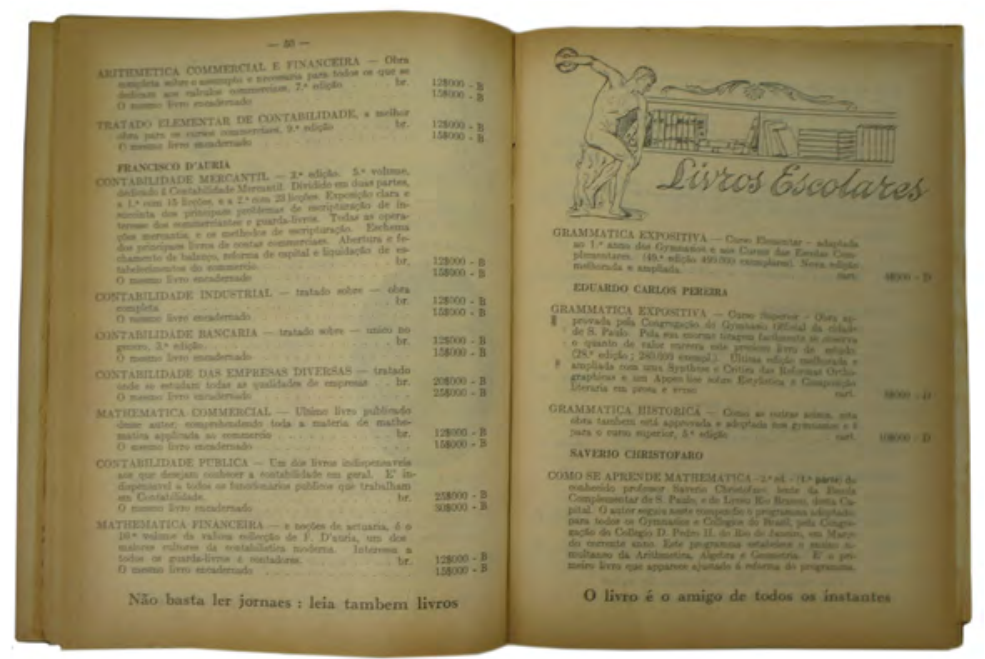

Fig. 3.1. Páginas do catálogo da CEN de 1931. [Fonte: acervo de Maria Rita de Almeida Toledo.] 
Essas informações indicam que a base do catálogo herdado das editoras anteriores de Lobato e Ferreira ampliou-se com a inserção de obras de consulta, compêndios e manuaia destinados ao Ensino Secundário mas principalmente com obras destinadas ao Ensino Primário, particularmente de leitura graduada. A comparação com as relações de obras das editoras anteriores, apresentadas no capítulo 2 (páginas 90 e 91), mostra a supressão de algumas obras, incluindo uma cartilha de alfabetização, com o novo catálogo acabando por não ter nenhuma (a Cartilha de alfabetização, de Benedito Tolosa, só fará parte do catálogo após 1932). Mas de qualquer forma, em relação às editoras anteriores, há um reforço do segmento didático, com características que deviam corresponder a pelo menos algumas demandas da educação como elas se configuravam no período, do contrário a Nacional não teria obtido os resultados que obteve nesse segmento.

Sendo assim, antes de entrarmos no exame da materialidade e visualidade dos livros do período encontrados, ainda é necessário investigar as características desse catálogo à luz das exigências da educação tal como se configurava no final da década de 1920.

Também se poderia analisar esse catálogo do ponto de vista do espaço que ocupava num contexto de produção de livros didáticos já existente e em evolução, em que a atuação de cada participante de alguma forma estabelece seu lugar e o lugar dos demais no mercado. Assim, o catálogo da Nacional se constrói não apenas em relação a demandas provenientes diretamente do mercado consumidor de livros escolares, mas também em relação às ações das editoras já instaladas para atender essas demandas. No entanto, estabelecer a produção de Nacional em relação aos catálogos e à política editorial de outras empresas é tarefa de grande amplitude e que foge aos objetivos de uma tese que procura reconstruir o trajeto da visualidade e do design de uma única editora.

\subsection{A educação e a escola antes de 1930}

Chama a atenção, no catálogo de escolares da Nacional, a existência para o ensino básico (Primário) de apenas livros de leitura, sem outras disciplinas. Para os demais níveis, a maioria dos livros de todas as disciplinas não são manuais seriados, isto é, livros destinados a anos específicos, com progressão didática de conteúdo, e sim compêndios com o conteúdo disciplinar correspondente a todo o nível de ensino, cabendo ao professor selecionar o conteúdo a ser estudado por sua classe. À parte o fato de tratar-se ainda de um catálogo de uma editora em construção, que não cobria todas as disciplinas em todos os níveis, ele não deixava de corresponder à organização do ensino então oferecido.

Embora quando a CEN foi constituída já se tinham passado quase quatro décadas da proclamação da República e ocorrido cinco reformas educacionais, sobrevivia, mesmo que solapado por profunda crise, um sistema educacional moldado no Império, com forte herança 
do próprio período colonial. Na verdade não é nem mesmo possível se falar em um sistema educacional, porque tanto nos aspectos de organicidade e complementaridade entre os níveis de escolaridade, como nos aspectos de organização e competência de atribuições, a educação propiciada ou regulamentada pelo Estado brasileiro não se articulava como um sistema único.

Como ocorria durante o Império, cursar o Ensino Primário não era condição obrigatória para o ingresso no Ensino Secundário. O primeiro era entendido como educação exclusiva das classes populares, mas mesmo assim tinha pequena abrangência, uma vez que na divisão de responsabilidades entre União e estados da federação, competia aos últimos prover o Ensino Primário e a educação profissional, sendo que a diferença de capacidade financeira entre os estados e a diferença de interesse pela educação por parte das elites governantes estaduais resultavam numa desigualdade extrema no oferecimento de vagas à população e mesmo na inexistência de rede articulada de escolas e da própria formação dos professores. Além disso, a legislação sobre conteúdos, duração e estrutura era de competência dos estados, inexistindo uma base curricular nacional [RomAnELLI, 2007, p.40]. Mesmo assim, estados exportadores, que pela legislação tributária vigente ficavam com os impostos correspondentes, e com urbanização mais acentuada, São Paulo principalmente, haviam superado parcialmente a situação herdada do Império e ainda bastante generalizada pelo interior do país, de escolas primárias dispersas, com professores sem formação lecionando para classes únicas reunindo alunos de diversos anos. No caso de São Paulo, o Ensino Primário gratuito já chega ao século XX com uma estrutura e um currículo comum, ministrado em uma ampla rede de grupos escolares (o nome grupo deriva do agrupamento das classes isoladas antes existentes) e da existência de escolas normais para a formação de professores (a primeira já existia desde 1846). Esse sistema serve de modelo para iniciativas em outros estados [RAZZINI, 2010, p. 102-106], mas a implantação é bastante desigual e o alcance limitado pela capacidade financeira de cada um deles, incluindo o próprio estado de São Paulo, que não consegue prover o Primário para toda sua população em idade de cursá-lo.

Já o Ensino Secundário não se constituía como um ensino para a formação geral ou mesmo profissional de adolescentes, pois tinha por objetivo único a preparação para o ingresso no Ensino Superior, ou seja, era destinado às classes com maiores recursos e com pretensão de ocupar os postos de direção pública do país e as funções de maior remuneração e prestígio na sociedade. Mas mesmo com esse caráter exclusivamente propedêutico ao Ensino Superior, a legislação do Ensino Secundário era obrigatoriamente aplicada apenas na única escola mantida pelo governo central, o Colégio Pedro II, no Distrito Federal. No entanto, durante boa parte da República Velha, as escolas estaduais que seguissem essas normas se equiparavam ao colégio modelo no sentido de obter a isenção de necessidade de novos exames para ingresso de seus alunos nas escolas superiores, as únicas legisladas, mantidas e com ingresso controlado pela União [NAGLE, 2001, p. 190]. 
Em várias escolas secundárias mantidas pelos governos estaduais e principalmente nas escolas particulares - que constituiam a grande maioria dos estabelecimentos, atestando o caráter elitista e seletivo do Ensino Secundário -, sobrevivia o chamado regime de exames parcelados herdados do Império (e, em última instância, das chamadas aulas régias instituídas no governo do Marques de Pombal durante o período colonial). Ou seja, não havia cursos regulares e seriados com todas as disciplinas, bastando ao candidato prestar ao longo do tempo, e não em períodos concentrados estabelecidos, exames que atestassem seu conhecimento do conteúdo exigido.

Assim, o sistema dual da educação no Brasil, marcado tanto pela separação total entre Ensino Primário voltado aos setores despossuídos da sociedade e o Ensino Secundário e superior destinado às classes intermediárias e proprietárias, como pela desarticulação entre a legislação e os agentes estatais na provisão do ensino, correspondia à instrumentalização da educação segundo os interesses das classes possuidoras, que dirigiam o país.

No entanto, o próprio processo econômico e social, iniciado com o fim da escravidão e a derrocada da monarquia e continuado com a industrialização, a ampliação do proletariado urbano e das camadas médias da população - processo esse na base do próprio ideário republicano que não se concretizou com a proclamação da República - , aprofundou contradições que em última instância levarão à crise política do regime e à Revolução de 1930. Um dos componentes dessa crise é a própria inadequação do sistema educativo vigente, a insuficiência de educação oferecida em todos os níveis, tanto em número como em qualidade, e a inexistência de um sistema e de uma política centralizada de ensino [ROMANELLI, 2007, p. 45-46].

Essa crise se aprofunda na década de 1920 e resulta em intensa movimentação de setores intelectuais e dos primeiros educadores profissionalizados em torno principalmente da generalização da educação popular, que deve ser obrigatória e gratuita, do combate ao analfabetismo e da criação de um sistema articulado de ensino, do Primário ao Superior, sob responsabilidade da União. É quando se funda a Associação Brasileira de Educação, em 1924, se promovem Conferências de Educação e se realizam reformas da educação em diversos estados do Brasil. Estas constituem as primeiras respostas concretas à demanda por educação de camadas mais amplas da população, de necessidades da indústria e dos serviços urbanos e dos próprios ideais republicanos de setores intelectuais e políticos, que vêem na educação a principal condição para o desenvolvimento do país e de seu povo. A década de 1920 vive assim o que se chamou de "entusiasmo pela educação" e "otimismo pedagógico" [NAGLE, 2001, p. 131-149], que resulta em medidas concretas de ampliação do Ensino Primário, o enriquecimento de seu currículo e a articulação com o nível subsequente, o secundário, visando romper o caráter dual e elitista do ensino vigente, a partir das reformas educacionais em estados como São Paulo, Ceará, Minas Gerais, Bahia, Pernambuco e no Distrito Federal [NAGLE, 2001, p. 265-281]. 


\subsubsection{Organização e currículo do Ensino Primário}

Como os estados tinham autonomia para legislar sobre o Ensino Primário, as reformas que eles promoveram previam duração, estrutura, currículo e distribuição dos conteúdos bastante variáveis. Aqui vamos ver apenas algumas dessas situações, mas exemplificar apenas com o currículo da reforma paulista, suficiente para estabelecer o quadro de conteúdos disciplinares que em tese a produção de livros didáticos deveria suprir.

A reforma paulista de 1920, concebida por Sampaio Dória, institui um Curso Primário de 7 anos, iniciado aos 9 anos de idade, formado por três etapas: a primeira, básica, de 2 anos, centrada no objetivo quase que exclusivo de alfabetizar, é a única de fato provida por recursos públicos para ser gratuita e universal; uma segunda, média, também de 2 anos; e finalmente a terceira, complementar, preparatória ao prosseguimento da escolarização nos ginásios e escolar normais, sendo que as duas últimas previam pagamento de taxas pelos alunos capazes. Essa reforma, movida pelo objetivo pragmático de extinguir o analfabetismo, foi acusada de quebrar a integralidade do Ensino Primário [NAGLE, 2001, p. 267-269]. No entanto seu currículo era o mais amplo e complexo do país, apresentando inclusive uma sobreposição com disciplinas do Ensino Secundário. As disciplinas do Ensino Primário Básico eram: Linguagem Oral, Linguagem Analítica, Linguagem Escrita, Aritmética, Geometria, Geografia E História, Ciência Físicas e Naturais e Higiene, Instrução Moral e Cívica, Desenho, Música, Trabalhos Manuais e Exercícios Ginásticos. O Ensino Primário Médio continha Leitura, Linguagem, Caligrafia, Aritmética, Geometria, História do Brasil, Instrução Moral e Cívica, Economia Doméstica, Ciências Físicas e Naturais, Higiene, Música, Desenho, Trabalhos Manuais e Ginástica. Finalmente, o Ensino Primário Complementar continha Língua Vernácula e Califasia (arte de falar com boa dicção e elegância), Latim, Francês, Aritmética, Álgebra e Logicidade, Geografia do Brasil, Geografia Geral, Ciências Físicas e Naturais, História do Brasil e Geral, Música, Desenho, Trabalhos Manuais e Ginástica [NAGLE, 2001, p. 277-278].

A reforma cearense do ensino, conduzida por Lourenço Filho em 1923, embora previsse uma divisão em etapas, afirmava o caráter integral e universal do nível primário, que iria bem além da finalidade alfabetizadora, apresentando no entanto um currículo bem mais simplificado que o da reforma paulista, mas com grande ênfase nas ciências físico-naturais. Era formado por um curso preliminar de 3 anos, com ingresso das crianças aos 7 anos de idade, ministrado nas escolas isoladas e reunidas, seguido de um curso médio de quatro anos, nos grupos escolares, e finalizado por um curso complementar de dois anos, em escolas complementares, perfazendo 9 anos, todos gratuitos [NAGLE, 2001, p. 272-273].

A reforma bahiana, dirigida por Anísio Teixeira em 1925, também previa uma escola primária integral, gratuita, obrigatória e "educativa", isto é, não apenas alfabetizadora, e era igualmente dividida em etapas. A primeira, chamada elementar, era de 4 anos em escolas urbanas 
e de 3 anos em escolas rurais. A segunda etapa, superior, de 3 anos, era ministrada em escolas primárias superiores, divididas em masculinas e femininas. Ao Ensino Primário Superior se seguia o Ensino Primário Complementar, de 2 anos, voltado para instruir para o exercícicio de futuras ocupações [NAGLE, 2001, p. 274].

O Regulamento do Ensino do Distrito Federal, de 1928, estabelecido sob a direção de Fernando de Azevedo, vai apresentar de forma mais elaborada os princípios da finalidade social da escolarização como "reação contra os defeitos dominantes do meios social", como "verdadeira escola do trabalho para fim educativo", como instrumento para "quebrar o sentimento isolador de diferenças sociais, criadas pelas diferenças de situação econômica", a partir do acolhimento de crianças de todas as proveniências, e pelo respeito e amoldamento às singularidades locais [NAGLE, 2001, p. 275].

Essas reformas, tendo por base teórica o liberalismo educacional de John Dewey e experiências internacionais e de escolas particulares brasileiras identificadas com a formulação da Escola Nova, significam uma ampliação e enriquecimento do currículo primário que vai estruturar a posterior modernização da escola primária brasileira em um sistema integrado de educação, que não encontra possibilidade de ocorrer no contexto político da Primeira República. Ao mesmo tempo, essas reformas mantém duas possibilidades ou orientações: uma nova, que procura romper com a herança da educação elitista, com a escola primária como etapa da escolarização que prosseguirá com o Ensino Secundário e superior, e uma da escola primária como finalidade profissionalizante e encerrada nela mesma, mas de melhor qualidade. Outra consequência dessas reformas, é a própria transformação e reforço do curriculo da escola Normal, de formação dos professores.

\subsubsection{Organização e currículo do Ensino Secundário}

O Ensino Secundário, legislado pelo governo federal, a despeito dos inúmeros decretos e reformas que sofreu, manteve no essencial o caráter preparatório ao Ensino Superior e, ministrado principalmente por escolas privadas pagas, dada a escassez de escolas mantidas pelo Estado, com taxas menores mas também pagas, manteve também um viés excludente e elitista. Apesar das tentativas de diversas reformas de implantar o sistema ginasial seriado, baseado na sequência e no currículo do Colégio Pedro II, sobrevivia o regime de exames parcelados, de grande interesse das escolas privadas. ${ }^{1}$

Com relação ao currículo, mesmo no do Ginásio Nacional (Colégio Pedro II), predominavam as disciplinas tradicionais - línguas, matemáticas, ciências, conhecimentos de geografia e história - com um conteúdo genérico, fechado em si mesmo, pouco especializado e não

1 Para um exame detalhado da sequência de reformas educacionais e seus conteúdos relativos aos Ensino Secundário durante a Primeira República, ver Jorge NAGLE, 2001, p. 187-204. 
voltado para aplicações - estas características só ocorriam no Ensino Superior. Não havia disciplinas mais técnicas, predominando os estudos literários aos científicos. Os programas das disciplinas eram no entanto "extensos e sobrecarregados de assuntos, conhecimentos e informações, nomenclaturas e bibliografias" e o ensino de caráter essencialmente aquisitivo, "verbalista, teórico e livresco", desenvolvido "por meio da exposição e recitação, do ditado de pontos e do uso sistemático de compêndios, sendo avaliado por meio de exames que exigem, de memória, a reprodução de lições" [NAGLE, 2001, p. 192-193].

Esta ênfase numa educação humanística "literária" seria proveniente do tipo de educação que na colônia e no Império era propiciada a uma classe social que não se envolvia de maneira alguma com o que era considerado trabalho, visto como extensão de sentido do trabalho manual exercido pelos escravos. Daí seu conteúdo desinteressado e bacharelesco, voltado para a literatura e o mundo das idéias, no máximo para a habilitação superior para o exercício de funções liberais e de administração do Estado, mas nunca da produção, como uma marca de distinção de classe herdada da vigência da escravidão. Essa ideologia, que foi abraçada também pelas camadas médias da população como uma forma de ascender socialmente e se distanciar das massas proletárias, sustenta coerentemente o dualismo educacional então vigente, com o ensino básico para as camadas populares exercerem o trabalho manual e o Ensino Superior - tendo o Ensino Secundário como simples passagem -, para o exercício pelas elites das funções ligadas ao mando ou ao predomíno do uso do intelecto [RoMANELLI, 2007, p. 39 e 44-45; NAGLE, 2001, p. 192 e 203-204].

Mesmo a reforma de João Luís Alves, de 1925, que, ao propugnar um Ensino Secundário como prolongamento do Ensino Primário e "preparo fundamental e geral para a vida, qualquer que seja a profissão a que se dedicar o indivíduo" [texto da lei, apud NAGLE, 2001, p. 194], e instituir a seriação obrigatória para todo o país, conseguiu apenas ampliá-la, atingindo os ginásios estaduais mas não totalmente o ensino privado, não eliminando os exames parcelados e principalmente o caráter propedêutico do Ensino Secundário. No entanto, como produto do mesmo movimento social e de idéias que sustentavam as reformas estaduais, explicita o sentido do Ensino Secundário como educação da juventude e a organização seriada do currículo e do progresso escolar que estarão nas bases da estruturação do ensino que ocorrerá após a Revolução de 1930.

O modelo curricular da Reforma Luís Alves, que foi ao menos adotado nos ginásios estaduais, distribuía nos seis anos as seguintes disciplinas: Português, Aritmética, Geografia Geral, Geografia do Brasil (Corografia), Inglês, Francês, Alemão, Instrução Moral e Cívica, Desenho, História Universal, Latim, Álgebra, Português (Gramática Histórica), Geometria e Trigonometria, História do Brasil, Física, Química, História Natural, Português (Noções de Literatura), Cosmografia, Filosofia, Literatura Brasileira, Literatura das Línguas Latinas, História da Filosofia e Sociologia [NAGLE, 2001, p. 196]. 


\subsection{O mercado editorial didático na década de 1920}

Evidentemente a estrutura e organização curricular do sistema educacional vigente, sua dimensão em relação ao tamanho da população, a ideologia e as demandas que o sustentam, e até mesmo o contexto de debate e transformações então vivido, serão os principais elementos que definirão as características do mercado editorial e seus produtos. Mesmo que nosso objetivo seja identificar nesse conjunto o que se reflete no catálogo da Companhia Editora Nacional - e mais do que isso fugiria ao escopo desse trabalho -, o surgimento da Nacional num terreno ocupado por outras editoras obriga a apresentar um quadro mínimo da produção dessas editoras como o contexto de mercado em que a produção da Nacional vai se inserir.

Particularmente no caso do Ensino Primário, a ampliação do número de estudantes, que já era, mesmo antes da proclamação da República, maior em estados econômicamente mais fortes, como São Paulo, e no Distrito Federal, vai resultar em demanda de materiais escolares, cartilhas e livros de leitura. Assim, uma editora como a Francisco Alves, fundada em 1854 no Rio de Janeiro e que cresceu incorporando outras editoras, chegará à década de 1910 como a maior editora de didáticos do país, com seu poderio construído a partir da expansão do Ensino Primário ocorrido já na última década do Império e ampliado com a proclamação da República, mesmo considerada a desigualdade de oferta da educação no país como um todo². Só entre 1894 e 1917 a editora chegou a lançar 264 títulos didáticos, dos quais 72 de autores atuantes no ensino público paulista, com 44 livros de leitura [RAZZINI, 2010, p.111-113] (FIG. 3.2).

Outra editora, localizada em São Paulo, a Typografia Siqueira, apresentará um catálogo preponderantemente constituído de cartilhas e livros de leitura, com 23 títulos publicados entre 1900 e 1927 (FIG. 3.3). Assim como a Francisco Alves, publicou também obras destinadas ao Ensino Secundário produzidas pela Congregacão Marista Brasileira para sua rede de escolas, a coleção FTD (de Frère Theophane Durand), mas também adotadas em outras escolas confessionais [RAZZINI, 2010, p.114-115]. Também editou obras sob o nome Coleção Caetano de Campos, ligadas à principal escola Normal do estado.

O Estabelecimento Graphico Weisflog Irmãos \& Comp., mais tarde Editora Melhoramentos, também localizado em São Paulo, iniciou suas atividades com a edição de livros escolares, começando em 1907 com um título que mais tarde integrará o catálogo da Monteiro Lobato e da CEN, a Gramática expositiva, de Eduardo Carlos Pereira. Em 1920 seu catálogo já possui 12 títulos para o Ensino Primário e 15 para o secundário [RAZZINI, 2010, p.115-116] (FIG. 3.4). ${ }^{3}$

\footnotetext{
2 A Francisco Alves teve diversas denominações, dentre elas Paulo de Azevedo e Cia., e é a mais antiga editora em atividade no país. O início de sua história pode ser vista em Aníbal BRAGANÇA, A Francisco Alves no contexto da formação de uma indústria brasileira do livro. Rio de Janeiro: I Seminário Brasileiro sobre Livro e História Editorial. FCRB/UFF. Nov. 2004.

3 Para a relação dos livros publicados pelas editoras citadas e números de edições e tiragens dos mais adotados, ver o amplo levantamento realizado por Marcia RazzINı [2010, p. 109-119].
} 

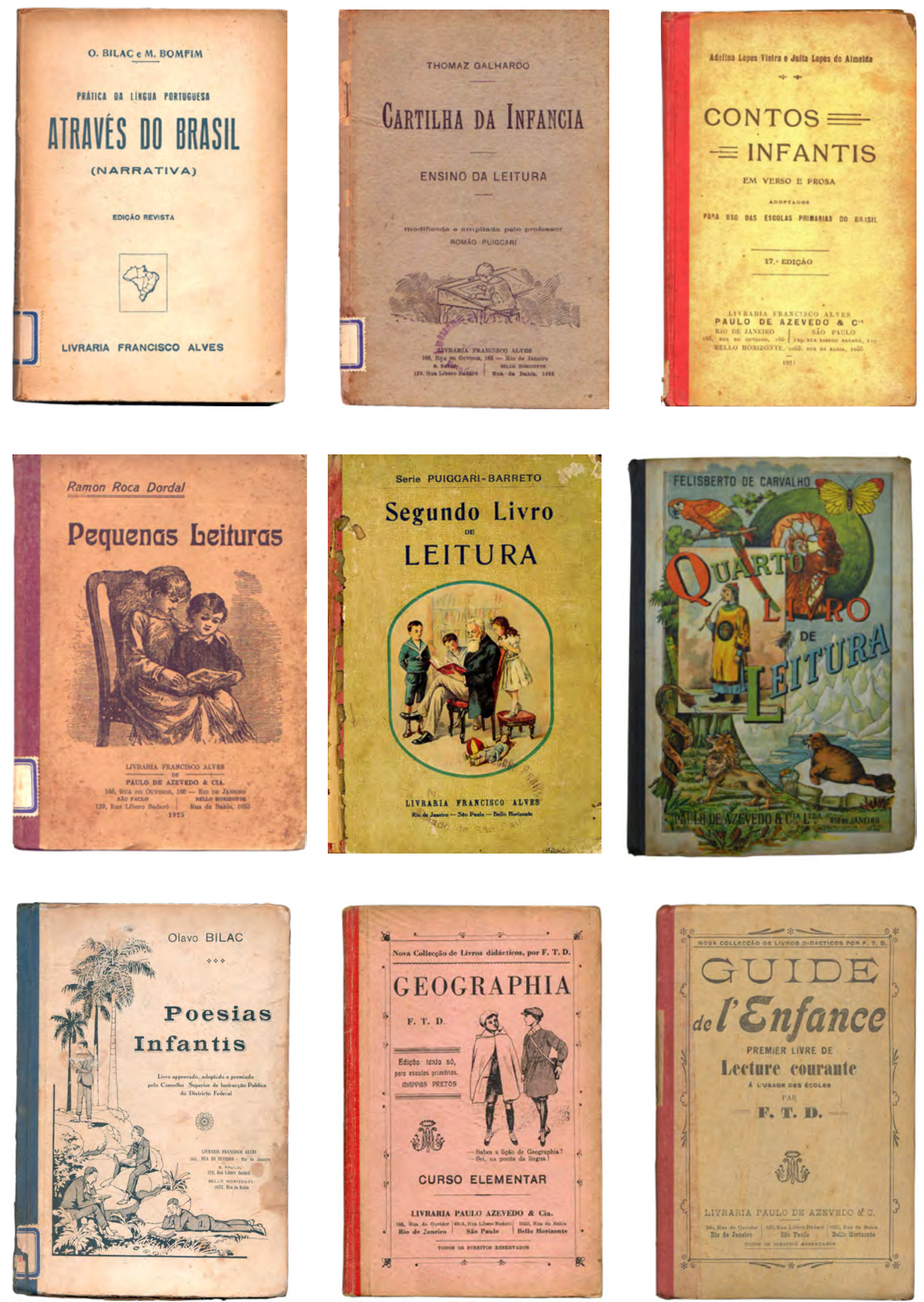

Fig. 3.2. Livros didáticos da Francisco Alves em edições da década de 1920, incluindo dois títulos para a coleção FTD. [Fontes: AHECC/CRE Mario Covas/EFAP/SEE-SP e BLD-FEUSP.] 

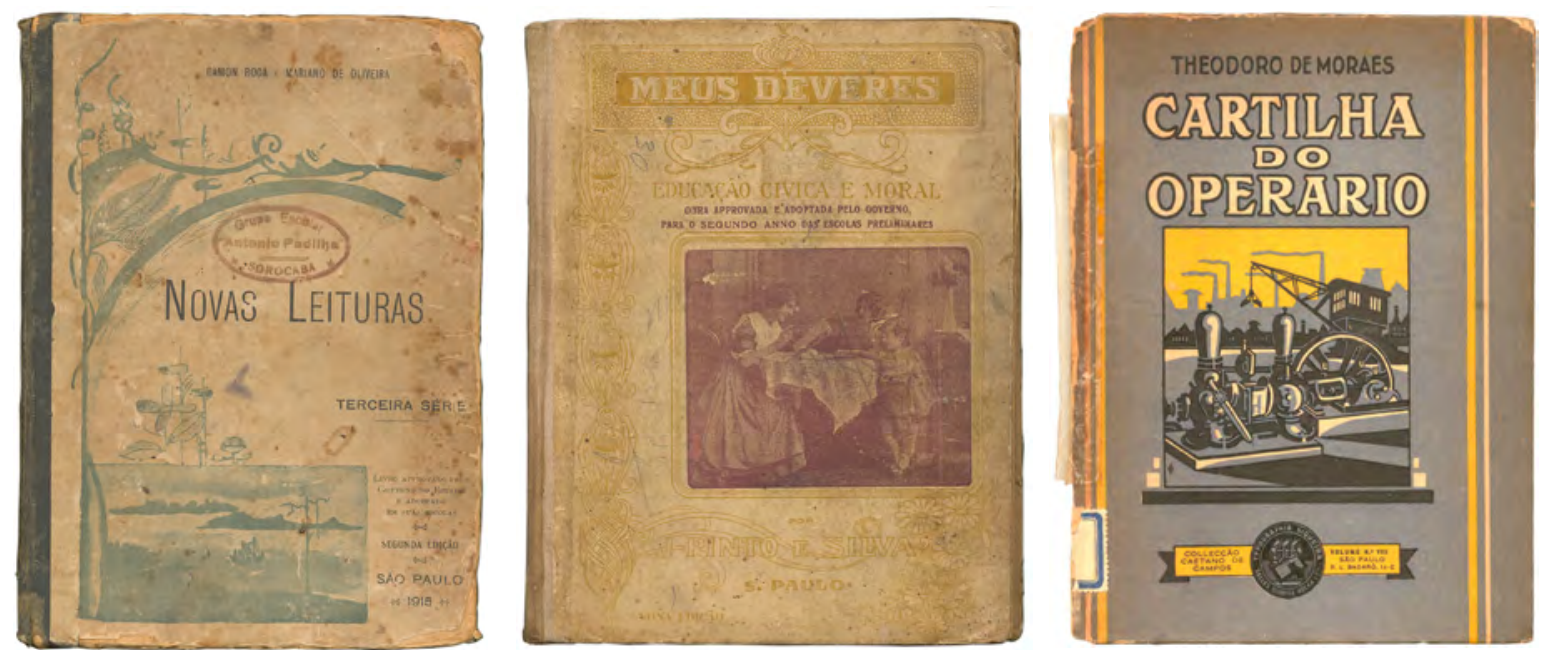

Fig. 3.3 Livros da Typografia Siqueira em edições da década de 1920. [Fontes: AHECC/CRE Mario Covas/ EFAP/SEE-SP e BLDFEUSP]
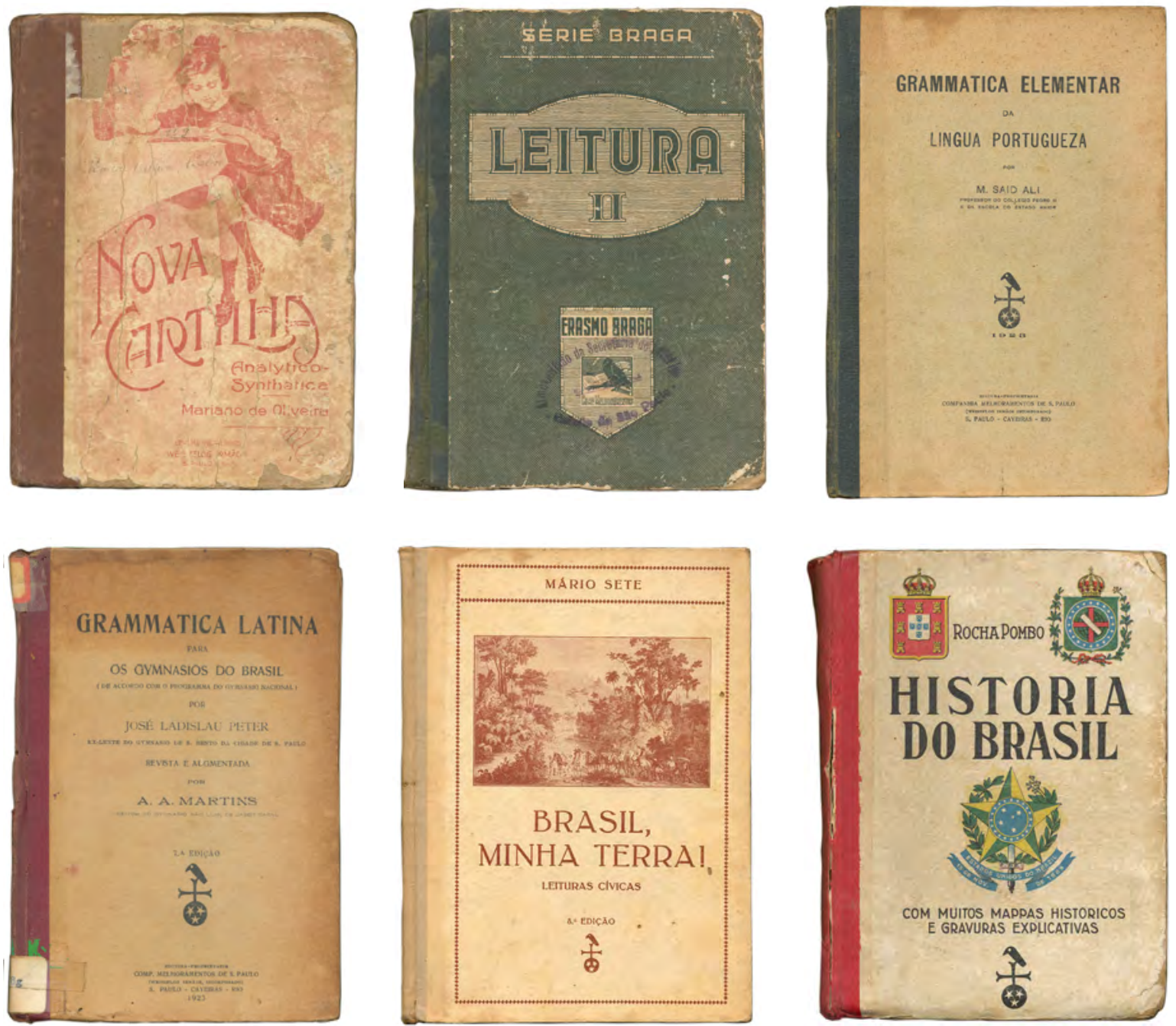

Fig. 3.4. Livros didáticos da Editora Melhoramentos em edições da década de 1920. [Fonte: BLD-FEUSP.] 
A concentração das editoras de livros escolares na cidade de São Paulo - a exceção seria a Francisco Alves, mas que no entanto estava presente no estado através de uma filial e com o já mencionado número expressivo de autores atuantes no ensino público no estado - explica-se exatamente pela dimensão da rede de escolas e de alunos cursando o nível primário e da compra governamental de cartilhas e livros de leitura [RAZZINI, 2010, p. 112]. O estado adquiria as obras para distribuição nas escolas públicas primárias após sua aprovação pela Diretoria Geral de Instrução Pública. A explicação para a quase inexistência de títulos de outras disciplinas que não Língua Portuguesa, não apenas no catálogo da Companhia Editora Nacional, mas também no de todas as demais editoras, é justamente porque apenas esses eram adquiridos pelo Estado, sendo que as demais matérias eram ensinadas pelos professores na forma de lições anotadas em caderno pelo alunos [RAZZINI, 2010, p. 107]. O catálogo da Nacional apresenta alguns títulos dirigidos às escolas normais e professores (Como se aprende Matemática, Como se ensina), utilizados tanta para a formação docente como para a referência de conteúdos a serem ensinados.

Embora os títulos das editoras apresentadas visassem majoritariamente o segmento que propiciava maiores vendas, o Ensino Primário, particularmente devido às aquisições estatais, evidentemente o mercado do Ensino Secundário era também disputado pelas editoras. Foge aos objetivos desse trabalho confrontar o currículo secundário da reforma de 1925, apresentado acima, com o catálogo das editoras em geral, mas no que concerne ao da Companhia Editora Nacional, alguns aspectos podem ser observados. Por exemplo, a seriação proposta parece não ter se refletido numa graduação na grande maioria dos livros, talvez porque a mudança fosse bastante recente e não suficientemente generalizada. Ou porque os livros, da forma como haviam sido escritos, poderiam ser utilizados indiferentemente em escolas seriadas ou nas que ministrassem cursos avulsos. Certamente a característica de compêndio da maioria deles, definido principalmente pelo caráter propedêutico do Ensino Secundário, seria ainda adequado às duas situações. Assim, títulos de Língua Portuguesa, por exemplo, têm conteúdo abrangente (Lições de Português, Chave da língua, dentre outros), bem como temáticos ou de apoio e consulta (Gramática histórica, Colocação dos pronomes), em função do conteúdo extenso dos exames de admissão ao curso superior. Exceção é O meu idioma, para o 4o ano do ginásio conforme adoção pelo Colégio Pedro II. A obra Pontos de Nossa História, com primeira edição em 1914, é apresentada como sendo de Educação Cívica, e também tem caráter de compêndio, reunindo episódios e biografias. Já a existência de processos de seleção para os cursos Secundário e Normal, que legalmente não pressupunha a frequência ao Curso Primário, gerou a necessidade de obras didáticas para cursos preparatórios, como os títulos da Nacional Exame de admissão aos ginásios oficiais e Exame de admissão às escolas normais. 


\subsection{O design e a materialidade dos livros didáticos da CEN de 1926 a 1931}

Dentre 32 títulos didáticos informados no catálogo de 1931, o que corresponde ao fundo de edições que a editora acumulou nesse período, a pesquisa material conseguiu documentar 10 títulos, 6 para o Ensino Secundário e 4 para o Ensino Primário. Pela diversidade de soluções encontradas acredita-se que esta seja uma amostragem suficiente para caracterizar o que foi o design de livros didáticos da CEN neste período.

Antes de se proceder a uma classificação das soluções de design e uma apresentação das obras, uma questão que se colocou foi se as obras seriam apresentadas em sua unidade de componentes, isto é, capa e miolo, ou se se trataria de design de capas e design de miolos separadamente, uma vez que se encontrou tanto exemplos de obras com total independência formal entre os dois componentes, resultado da tradicional independência de projeto do miolo do livro e de sua respectiva capa, como exemplos em que existe uma relação formal mais estreita entre os dois componentes, resultado de algum grau de concepção unitária de projeto. Como esta última situação é mais rara, particularmente no período de vigência da tipografia, em que a composição do texto segue padrões estabelecidos mais ou menos invariáveis encontrados em grande número de livros, principalmente os do Ensino Secundário, e a capa é que é o elemento de fato particularizador, sendo desenhada conforme a importância que se dava a ela, em função do público que se queria atingir, custos etc., pareceu mais coerente para este período abordar design de capa e design de miolo como dois fenômenos independentes, tratando-se à parte ou mencionando os casos em que uma concepção unitária de projeto tenha ocorrido.

Porém, antes de se abordar o design das capas, é preciso se tratar de um aspecto relativo à materialidade mesma dos livros. Excetuando uma obra que tem um programa e um destino muito particulares, e por isso é uma brochura, todos os demais livros do período são volumes encadernados. Este é um padrão de acabamento vigente para o livro didático no período, encontrado não só nos livro da Nacional, mas nos demais editoras também. Apenas no período subsequente, tratado no próximo capítulo, foi encontrada uma menção a este fato, em que se atribui à necessidade de durabilidade para um livro que será usado intensivamente por ao menos um ano letivo (ver p. 145). Como a brochura é na verdade o padrão novo, introduzido com a popularização do livro na segunda metade do século XIX e generalizado no início do século XX, o livro didático segue o padrão mais tradicional do livro, certamente por razões de durabilidade e de finalidade superior ligada à instrução. No caso da Nacional, a grande maioria dos livros didáticos produzidos até o final da década de 1960 serão de volumes encadernados.

Aqui, como nos capítulos seguintes, as reproduções das capas e páginas internas das obras mantém a mesma escala de redução, 35\% do tamanho original, para oferecer um termo 
de comparação mais sensível entre os formatos das diferentes obras. Um detalhe em tamanho natural permite avaliacão mais precisa do aspecto real dos tipos e corpos utilizados.

Como a maioria dos exemplares foram encontrados na Biblioteca do Livro Didático da Faculdade de Educação da USP, é identificada a origem apenas daqueles pertencentes a outros acervos.

\subsubsection{O design de capas dos livros didáticos da CEN de 1926 a 1931}

Embora trate-se de um único período - já definido como sendo de continuidade das características básicas de design herdadas das editoras anteriores de Lobato e Ferreira mas também em relação ao que será produzido no período posterior, a partir de 1932 —, pode-se identificar capas que têm seu design determinado pela impressão tipográfica e capas que têm seu design determinado pela impressão litográfica ${ }^{4}$. Essa constatação não leva por exemplo a uma identificação unívoca entre impressão tipográfica/capas tipográficas e impressão litográfica/capas ilustradas: as duas soluções são encontradas tanto para a impressão tipográfica como para a impressão litográfica. Nem impõe também uma subperiodização, o da impressão tipográfica, seguido da impressão litográfica, embora em 1931 só se tenha encontrado capas impressas litograficamente, mas também porque encontramos capas com impressão mista, litográfica e tipográfica.

Assim, dentre os volumes com acabamento cartonado, identificamos basicamente cinco soluções de design:

- Capas tipográficas com composição com tipos móveis (impressão tipográfica);

- Capas tipográficas com letras desenhadas (impressão tipográfica);

- Capas com título incorporado a grafismo ornamentado (impressão litográfica);

- Capas com título desenhado e ilustração (impressão litográfica e litográfica/tipográfica);

- Capas com título desenhado e grafismo geométrico (impressão litográfica/tipográfica).

\footnotetext{
4 Impressão tipográfica é aqui empregada no sentido estrito do método de impressão de textos e imagem a partir de uma matriz de impressão em alto-relevo, entintada nas áreas elevadas e pressionada diretamente contra o papel. É por isso classificada como um processo de impressão relevográfico [ver Rossı FILHO, 2001, p. 311]. Já o termo impressão litográfica é utilizado se referindo ao método de impressão que utiliza uma matriz que leva a imagem ou texto é tratada quimicamente para que as áreas de contragrafismo se tornem receptivas à água e rejeitem a tinta, enquanto as áreas de grafismo aceitam a tinta e rejeitam a água, e assim sejam transferidas ao papel. É por isso classificada como um processo de impressão planográfico [ver Rossi FILHo, 2001, p. 370].
} 
Solução 1. Capas tipográficas com composição com tipos móveis
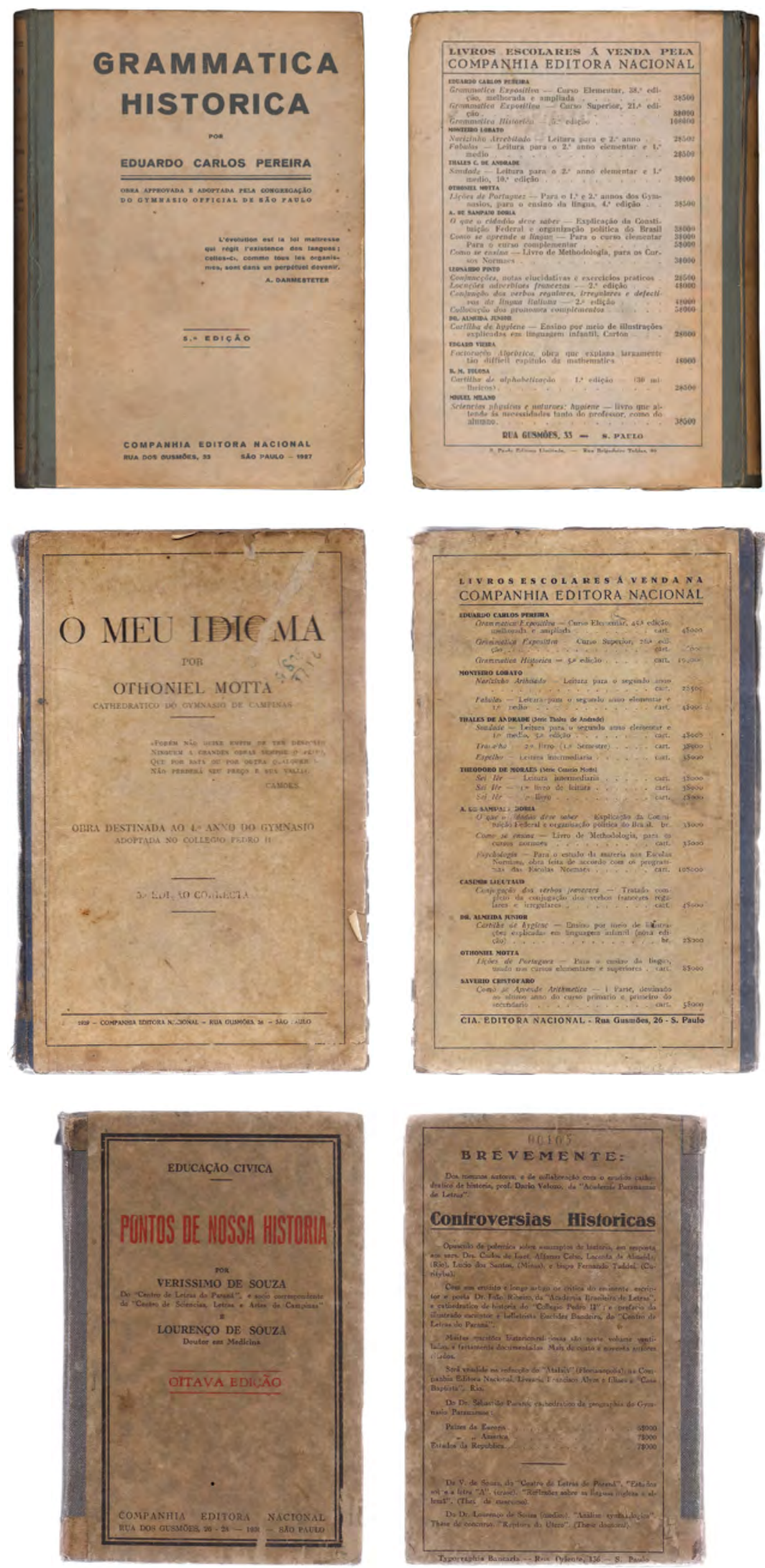

Fig. 3.5. Grammatica histórica, 1927, 5a edição $(13,5 \times 19,0 \mathrm{~cm})$.

O meu idioma, 1929, 5a edição $(13,9 \times 21,5 \mathrm{~cm})$. [Fonte: acervo pessoal.]

Pontos de nossa história, 1939, 8a edição (11,6 x 17,7 cm). [Fonte: acervo pessoal.]

Primeiras e quartas capas. 
Esta solução, de capas exclusivamente tipográficas, com composição de texto feita com tipos móveis, constituiu a solução com maior número de exemplares encontrados na pesquisa material e tem antecedentes em todas as obras didáticas encontradas da Monteiro Lobato \& Cia. e da Companhia Graphico-Editora Monteiro Lobato (FIG. 2.7 e FIG. 2.9), sendo também encontrada em livros destinados ao Ensino Secundário de outras editoras do período (FIG. 3.3 e 3.4).

Elas seguem o então chamado modelo francês, em que a primeira capa reproduz a página de rosto, de diagrama simétrico, sendo que em O meu idioma e Pontos de nossa história o diagrama e a tipografia são bastante fiéis às respectivas páginas de rosto (FIG. 3.16 e 3.17), mas a introdução de fios de contorno nas duas capas e a introdução de cor no título e informação de edição em Pontos de nossa história, indicam maior apuro e valorização desse componentes, sem deixar de significar que a capa é decorrência do miolo, resultado de um projeto unitário. Já na Grammatica historica, a fidelidade tipográfica é rompida, com a adoção de fontes grotescas (sem serifa) para o título e a maioria das informações, não seguindo a tipografia serifada adotada na página de rosto (FIG. 3.11) e em todo o miolo, obtendo-se mais peso principalmente para o título. Este é um primeiro exemplo da independência de projeto entre os dois elementos que será encontrada em grande parte das obras didáticas da editora neste e nos períodos seguintes, decorrente provavelmente de os dois componentes, capa e miolo, serem produzidos separadamente e unidos posteriormente, pois os trabalhos de impressão e de acabamento nem sempre ocorriam na mesma oficina gráfica.

As três capas também seguem um padrão mais antigo do livro tipográfico, que remonta ao manuscrito e ao incunábulo, que é a de o título encabeçar as informações, sendo seguido pelo nome do autor, quando o padrão autor no topo seguido de título já era bastante encontrado nos livros então produzidos no Brasil desde o século XIX.

Nas três capas, a hierarquia de informações é obtida por contraste tipográfico (desenho de tipo, corpo, peso, caixa) e posição (distribuição dos grupos de informação no campo, eventual quebra do alinhamento centralizado dominante, para algumas informações), com maior acentuação para o título.

Com relação às quartas capas, as três obras apresentam relação de títulos com finalidade publicitária ou divulgação de alguma obra específica. Assim, há a introdução de novas variações tipográficas e do necessário recurso do suporte gráfico do quadro de fios envolvendo a composição, em O meu idioma tendo a mesma espessura e dimensão que o quadro da primeira capa, indicando a preocupação em relacionar formalmente os dois itens, enquanto nas duas outras obras isto não ocorre.

Quanto ao acabamento da encadernação, as três obras utilizam o mesmo encontrado em todos os livros cartonados das editoras anteriores de Lobato e Ferreira (FIG. 2.7 e FIG. 2.9), que 
também aparece nas obras didáticas das editoras Franciso Alves, Melhoramentos e Typografia Siqueira (FIG. 3.2 a 3.4). Trata-se da encadernação quarter binding, em que o material de revestimento da capa é diferente do utilizado na lombada, tem a primeira e a quarta capas impressas em lâminas independentes e coladas nos planos, deixando a lombada, geralmente em tecido, à vista. Este parece ter sido o processo mais adotado, se não o único, na encadernação industrial até a década de $1920^{5}$.

\section{Solução 2. Capas tipográficas com letras desenhadas}
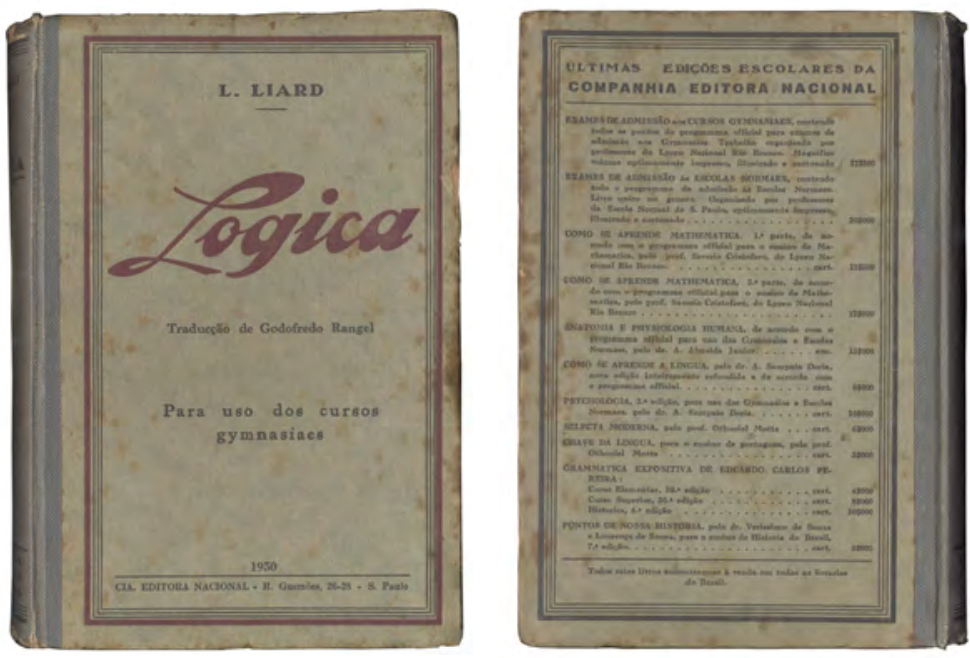

Fig. 3.6. Lógica, $1930(12,0$ × 17,5 cm). Primeira e quarta capas.

A solução de capas tipográficas com letras desenhadas teve como antecedente nas editoras anteriores à Nacional apenas obras literárias (FIG. 2.4), indicando a introdução de um procedimento não encontrado em livros didáticos, sempre com soluções mais formais e sóbrias, que mesmo a capa da obra apresentada não chega a contradizer, embora o desenho caligráfico do título, com contraste de espessuras acentuado, amenize um pouco a rigidez do diagrama simétrico e o uso de cor introduza maior interesse.

Mas aqui se dá uma inversão no padrão francês de a capa seguir a página de rosto: é evidente que o desenho do título, feito para valorizar a capa, é reproduzido no rosto (FIG. 3.12), dando coesão gráfica entre capa e miolo. A relação cromática entre o título e o quadro de fios, e entre este e a cor do tecido da lombada, bem como a reprodução do mesmo desenho dos fios na quarta capa atestam também um apuro maior de projeto.

Mesmo o título sendo desenhado, procedimento então comum nos impressos litográficos, a impressão é tipográfica, mediante a geração de clichês para a capa e a página de rosto. A tipografia na primeira capa e página de rosto, excluindo o título, é inteiramente serifada,

\footnotetext{
5 Sobre este e outros processos industriais de encadernação, ver Rossı FILHO, 2001, p. 219 e outras.
} 
com introdução de tipo grotesco apenas em uma linha da quarta capa.

O acabamento da encadernação é o mesmo da solução 1 (exclusivamente tipográfica), indicando aqui também a continuidade dos procedimentos das editoras anteriores de Lobato e Ferreira.

\section{Solução 3. Capas com título incorporado a grafismo ornamentado}
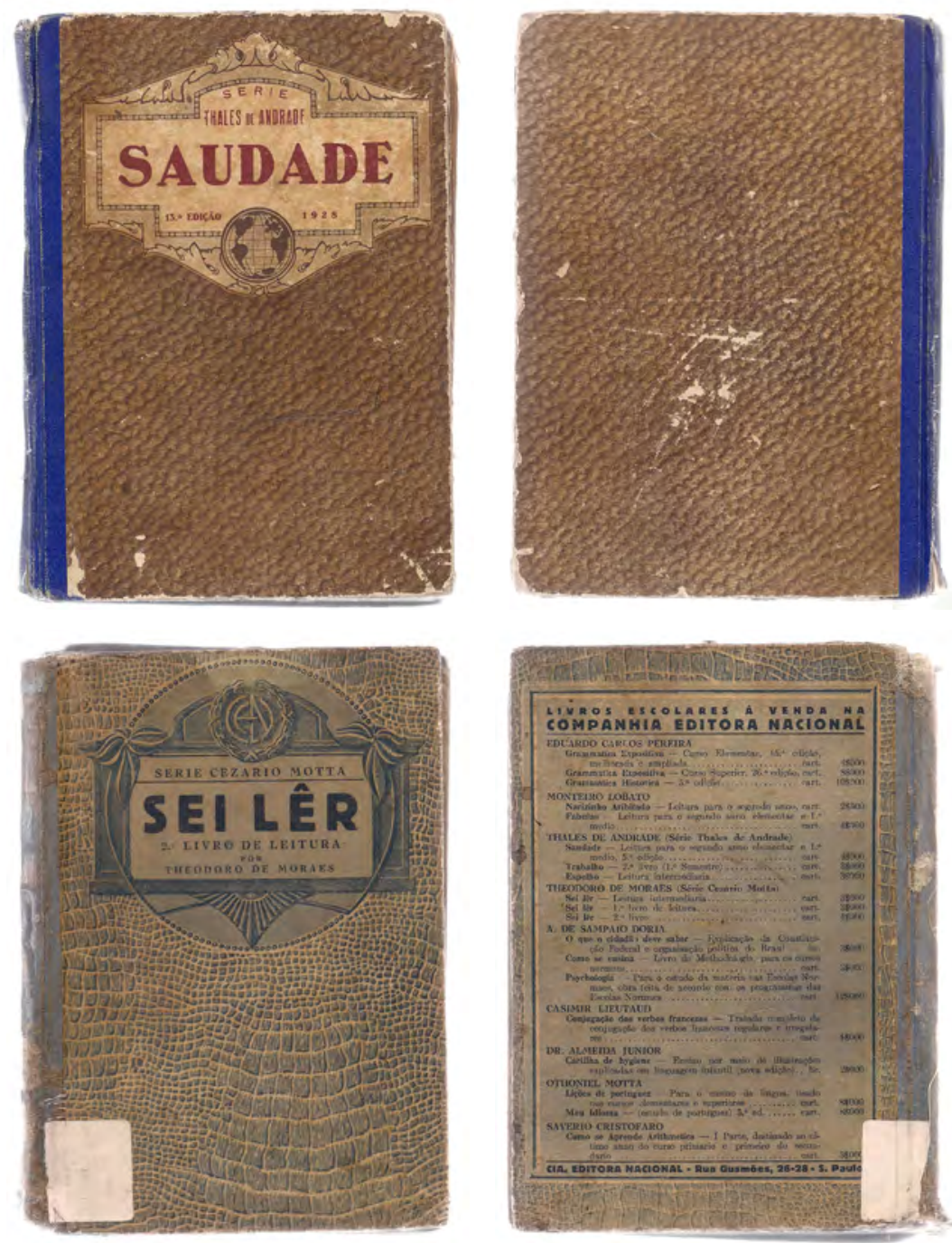

Fig. 3.7. Saudade, 1928, 13a edição $(13,2 \times 18,3 \mathrm{~cm})$. [Fonte: acervo pessoal.]

Sei Ler: Segundo livro de leitura, $1931(13,0 \times 17,8 \mathrm{~cm})$. [Fonte: acervo pessoal.]

Primeira e quarta capas.

Esta terceira solução apresenta um design determinado pelo processo de impressão litográfica, em que o fundo das capas reproduz texturas de couro a partir de imagem reticulada impressa em uma cor no caso de Saudade e duas cores em Sei Ler. Na primeira obra as informações textuais estão organizadas em ilustração com ornamento "neoclássico" simulando etiqueta colada sobre um caderno, em diagrama simétrico de design criado para os outros volumes da série, que não obtivemos, diferenciados pela cor de fundo e tipografia. Em Sei Ler, 
a "caixa" ornamentada que recebe as informações textuais tem desenho mais volumétrico, escultórico mesmo, que em Saudade, e está cromaticamente mais integrada ao desenho de fundo, sendo um trabalho mais elaborado mas de concepção derivada do primeiro título.

Esta semelhança formal parece servir justamente para caracterizar as duas únicas coleções didáticas propriamente ditas do período, a Série Thales de Andrade e a série de leitura graduada Sei Ler, de Theodoro de Moraes, de obras destinadas ao Ensino Primário. A despeito de serem destinadas ao público infantil, a área de título em desenho neoclássico e a textura de couro sugerida conferem certa "nobreza" às obras e são bastante sóbrias para o segmento se comparados com a maior parte dos títulos das principais editoras atuantes no período (FIG. 3.2 a 3.4 ).

A sobriedade dessas soluções parece ser trazida das capas de Ensino Secundário e passou ser uma marca da Nacional ao menos a partir de 1930, como veremos no próximo capítulo, uma vez que a 1ำ edição da Sei Ler, de 1928, traz capa ilustrada colorida, impressa em tricromia, e as edições de Saudade da Monteiro Lobato \& Cia. tinham capa igualmente ilustrada (FIG. 3.5).
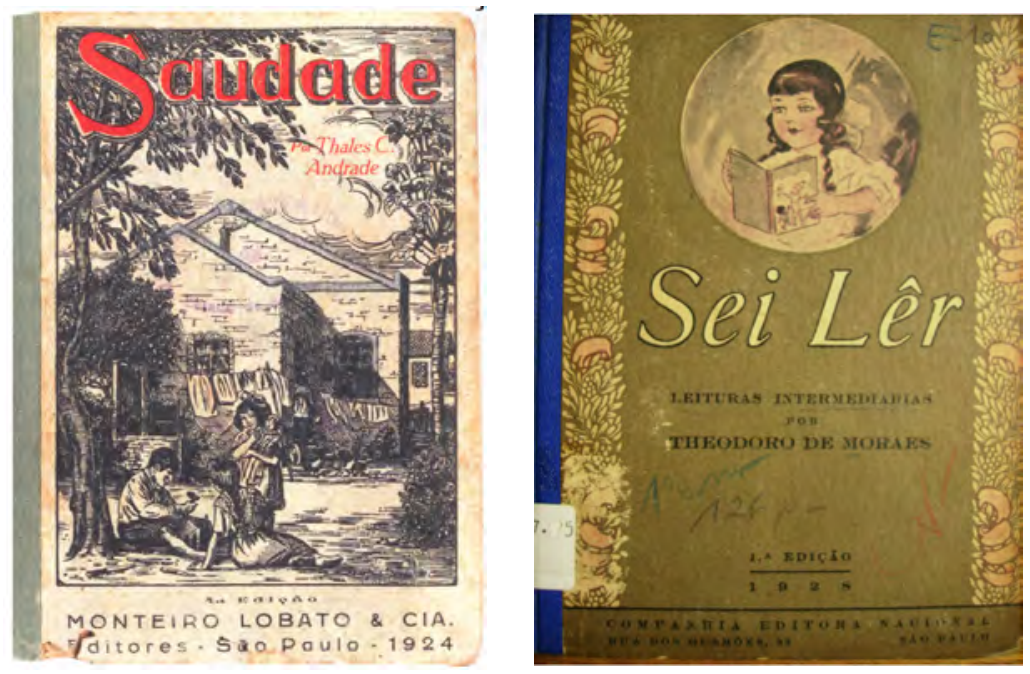

Fig. 3.8. Saudade, 4a edição, 1924, pela Monteiro Lobato \& Cia., com capa de J. Wasth Rodrigues (trazida da primeira edição produzida por Elvino Pocai em 1919).

Sei Ler: leituras intermediárias, 1a edição, 1928, pela Companhia Editora Nacional. [Fonte: PereIRA, 2009, p. 126-128.]

Nessas obras o acabamento da cartonagem também é o mesmo das duas soluções de capa anteriores, indicando a manutenção dos procedimentos industriais da Cia. Graphico-Editora Monteiro Lobato.

Apesar da sobriedade da capa de Saudade, evidenciada pelo contraste com a página de rosto ilustrada (FIG.3.18), trata-se de uma solução com afinidade semântica com o conteúdo da obra, em que um caderno (até sem a costumeira publicidade de livros na quarta capa) pode estar perfeitamente associado às lembranças de infância e juventude da personagem, como 
veremos quando tratarmos do miolo desta obra. Já no caso de Sei Ler, trata-se mesmo de independência de projeto entre os dois componentes do livro, ou então de um planejamento que comporta dois processos de desenho distintos, determinado pela produção independente de capa e miolo, que não gerava necessariamente falta de harmonia entre eles, uma vez que a utilização sistemática de fontes serifadas resultava em pecepção de neutralidade da composição dos miolos.

\section{Solução 4. Capas com título desenhado e ilustração}
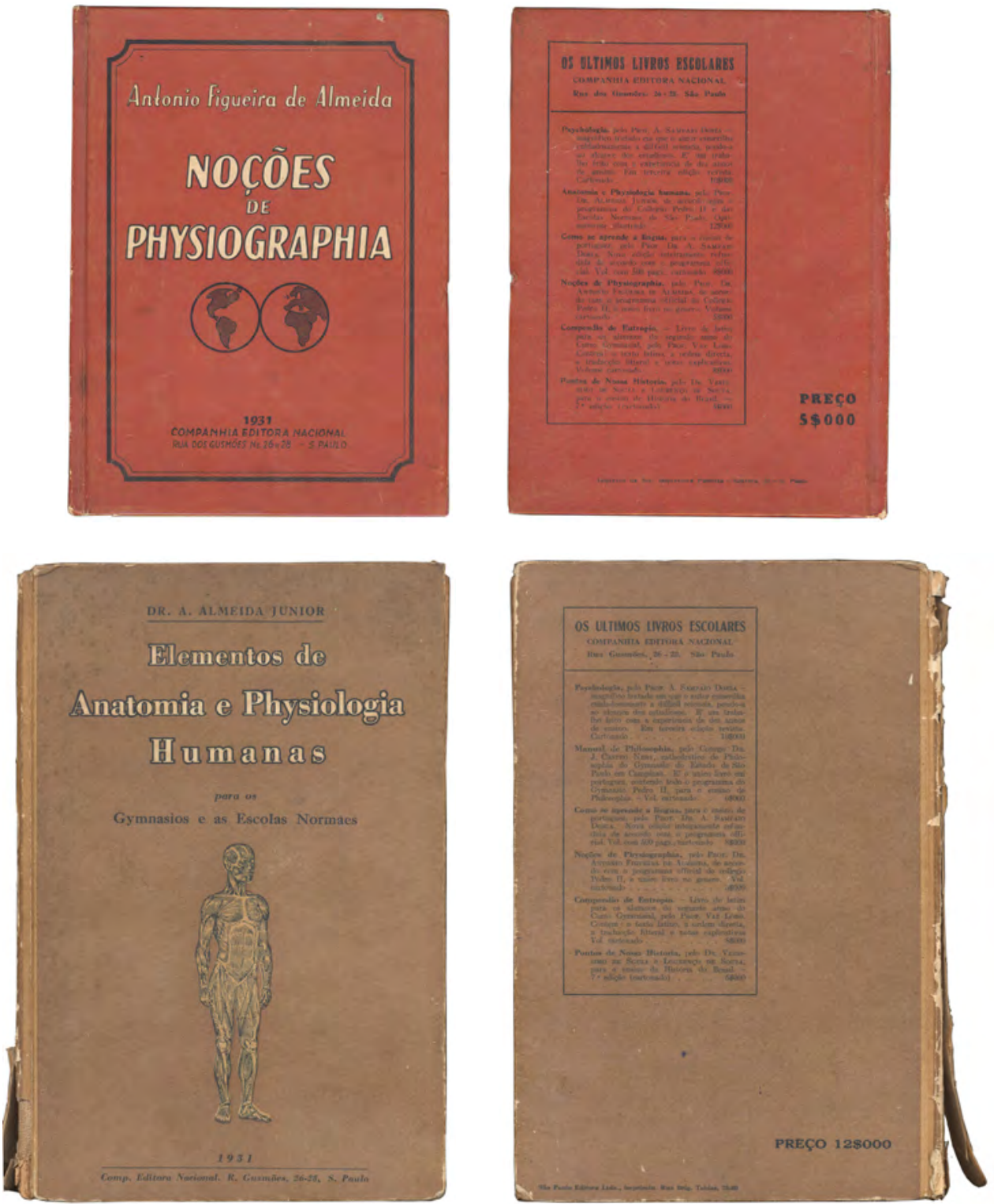

Fig. 3.9. Noções de Phisiographia, $1931(15,7 \times 23,0 \mathrm{~cm})$.

Elementos de anatomia e phisiologia humanas, 1931 (14,0 x 18,5 cm).

Primeira e quarta capa.

Esta solução, encontrada em títulos a partir de 1931, apresenta também layout simétrico, mas além da tipografia incorpora vinheta ou ilustração extraída do interior do livro e tem 
como condição a impressão litográfica, para permitir área de cor geral e área branca vazada no interior dos textos e imagens, recurso usado para dar destaque aos títulos, nome de autor e ilustração e para relacionar título e imagem, no caso de Elementos de Anatomia. Esta parece ter o título composto, mas algumas irregularidades indicam apurado desenho com instrumentos a partir de modelo tipográfico, e não tipo móvel com contorno (outline). As diferenças de corpo e de espacejamento entre as letras nas três linhas do título fornecem sensação de inconsistência talvez superior à da tipografia de Noções de Physiographia, esta assumidamente desenhada à mão e com maior irregularidade de desenho.

O desenho à mão de títulos e outras informações textuais são característicos da impressão litográfica, que permite integração entre texto e imagem, com os dois elementos sendo produzidos pelo próprio ilustrador, como pode ser visto nas capas ilustradas da Cia. Graphico-Editora Monteiro Lobato (FIG. 2.8) e mesmo da Nacional (FIG. 2.12).

Mas independentemente da presença do processo de impressão litográfico, que é um processo planográfico, a linguagem ainda corresponde à da impressão por relevo da tipografia, pois a referência de layout é ainda o modelo francês e as ilustrações são de traço, sem meios tons que a litografia permite. E uma peculiaridade encontrada nessas duas capas, a combinação de impressão litográfica para a cor e tipográfica para o preto, e não a impressão litográfica pura, faz supor que esta participe apenas para garantir fundo chapado uniforme e reserva de área branca para o interior dos títulos, como já foi mencionado. A questão é por que se ter o trabalho de imprimir por dois processos uma mesma peça gráfica6 ${ }^{6}$

A quarta capa tem desenho independente da primeira capa, com publicidade de obras padronizada aparentemente sendo aplicadas sem relação com a solução formal da primeira capa.

Com relação ao acabamento do volume, elas apresentam uma inovação em relação às três soluções anteriores, a encadernação inteira, em que a capa é uma única peça impressa que reveste os planos da frente e de trás do livro (ou pastas, como tecnicamente se utiliza) e a lombada7. A generalização deste acabamento nos livros da Nacional a partir de 1930, e que pressupõe a impressão litográfica, indica a aquisição de equipamento de encadernação industrial avançado pela sua principal fornecedora, a São Paulo Editora, creditada na quase totalidade das obras didáticas até a década de 1960.

\footnotetext{
6 Não se encontrou nenhum registro ou menção na pesquisa bibliográfica realizada à combinação de impressão de uma mesma peça em dois equipamentos diferentes, um relevográfico (tipografia) e outro planográfico (litografia) para o período em questão, mas o exame físico dessas capas, utilizando o método de Bamber GASCOIGNE [2011], permite reconhecer a presença simultânea de evidências dos dois sistemas, deixando poucas dúvidas a respeito. Este tema será retomado no capítulo 4.

7 Sobre este acabamento, conhecido como full binding, ver RossI FILHO, 2001, p. 220.
} 


\section{Solução 5. Capas com título desenhado e grafismo geométrico}

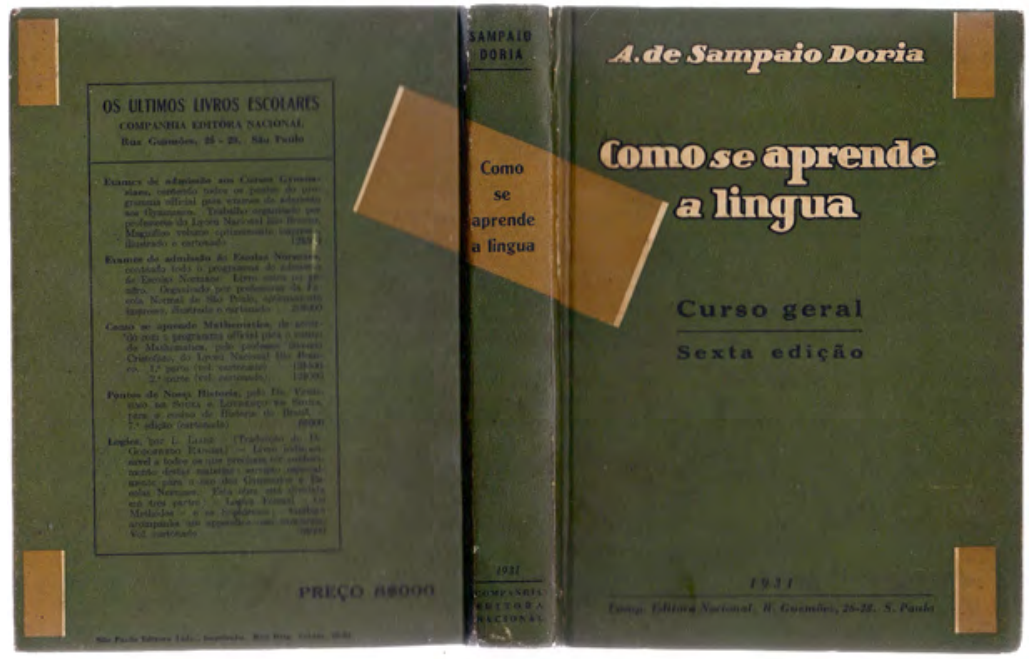

Fig. 3.10. Como se aprende a língua, 1931, 6a edição $(13,2$ × 18,2 cm). [Fonte: acervo pessoal.] Primeira e quarta capa.

Esta solução de capa, também produzida a partir de 1931, apresenta algumas características comuns com a solução anterior, como os textos de autoria e título desenhados à mão e vazados sobre o fundo de cor, a impressão combinada litografia para a cor e tipografia para o preto, o quadro promocional padrão na quarta capa e o acabamento de encadernação inteira (full binding).

Como novidade, apresenta uma terceira cor e simetria quebrada pela introdução de elementos gráficos retangulares dispostos a partir de um pensamento "volumétrico" inédito, que une quarta capa, lombada e primeira capa num desenho único, com um retângulo em posição oblíqua atravessando os três planos, embora o resultado não seja sintaticamente consistente no plano da primeira capa, marcada por ambiguidade entre simetria e assimetria e certo desequilíbrio entre os elementos.

O título e autoria são desenhados à mão e apresentam inconsistências de proporção e de desenho dos caracteres. A irregularidade decorrente, mais a quebra da simetria pela introdução dos retângulos, em particular o inclinado, resultam em design menos sóbrio e mais informal que o encontrado nas soluções tipográficas anteriores, mas com inconsistência sintática maior, o que não impediu a aplicação deste modelo em diversas obras avulsas até a década de 1940. 


\subsubsection{O design de miolo dos livros didáticos para o Ensino Secundário da CEN de 1926 a 1931}

Como vimos no início do capítulo, com um mercado de livros destinados ao Ensino Primário já ocupado por editoras como a Francisco Alves, a Melhoramentos e a Typografia Siqueira, o pequeno catálogo didático dos anos iniciais da Nacional é constituído majoritariamente por títulos destinados ao Ensino Secundário. Este é o motivo porque começamos por abordá-los, ao invés de seguir a ordem das etapas do ensino por faixa etária, pois se a visualidade dos livros do Ensino Primário é uma das componentes do design dos didáticos da CEN em seus primeiros anos, a visualidade mais característica é a encontrada na produção de maior volume, a dos títulos para o secundário.

A visualidade destes livros tem como importante elemento definidor as características de conteúdo que estes livros portavam, a partir dos programas curriculares, das abordagens autorais e do uso determinado pelo público final. Com um Ensino Secundário não plenamente regulamentado, sem classes seriadas e percurso curricular definido e com caráter preparatório aos exames de acesso aos cursos superiores, alguns livros da Nacional traziam características mais próximas às de compêndios, isto é, obras que apresentam um recorte do conhecimento de uma determinada área, sem atividades didáticas e proposição de percurso, em que cabia ao professor selecionar os "pontos" e a sequência para o seu curso. É o caso, por exemplo, de Grammatica historica, de Eduardo Carlos Pereira, título proveniente da Monteiro Lobato \& Cia. adotado pelo ginásio Oficial de São Paulo mas sem indicação de ano, e de Elementos de Anatomia e Physiologia Humanas, de Antônio Almeida Júnior, que no entanto se definia como manual secundário para o ginásio e a escola Normal (FIG. 3.11 e 3.14).

Outros livros, em maior número, mesmo se autointitulando manuais, já que ofereciam um percurso e atividades voltadas para a aprendizagem conforme um plano didático estabelecido, acabavam também por apresentar grande volume de conteúdos, grau elevado de profundidade de abordagem e não determinação de série para seu uso, constituindo também índices do caráter elitista do ensino da época, no sentido já apontado de que não guardavam uma continuidade com o que era oferecido na escola primária destinada às classes populares. É o caso de O meu idioma (FIG. 3.16), também originário do catálogo da Monteiro Lobato \& Cia., que, destinado ao 4ํano do ginásio conforme currículo do Colégio Pedro II, tem como plano estudar "em traços largos, a evolução do latim para o portuguez archaico e a deste para o moderno"(prefácio).

Já a obra Como se aprende a lingua, de Antonio de Sampaio Doria, proveniente do catálogo da Monteiro Lobato \& Cia., correspondia a um manual mais típico, pois se apresentava como "curso geral", filiado ao então chamado ensino intuitivo analítico, não seguindo a ordem lógica 
dos compêndios gramaticais, mas uma "ordem pedagógica" de dificuldade crescente, relativa à maturidade do estudante ${ }^{8}$.

Em um contexto de composição e paginação determinado pela tecnologia da composição tipográfica manual, ou recém automatizada com a introdução de compositoras linotipo e monotipo nos anos 1920 no Brasil, mas que prossegue os procedimentos convencionados pela larga tradição da composição manual em seus aspectos essenciais, esses compêndios e manuais tiveram como referência geral para seu desenho e produção exatamente essas convenções e mais precisamente a prática tipográfica e os recursos oferecidos pelas oficinas que forneciam os serviços de que a editora se utilizou?

As características de cada original e as exigências específicas do programa pedagógico de cada obra encontrou em cada um desses diferentes fornecedores diferentes soluções de composição e paginação. Mesmo que a definição geral de características gráficas e materiais partisse de profissionais da editora, as obras encontradas na pesquisa material não apresentam uniformidade de procedimentos e recursos para estabelecimento dos pesos e contrastes tipográficos exigidos pelos originais, para citar só um dos aspectos, o que indica a participação decisiva das oficinas tipográficas na visualidade final dos livros. Assim, imposições econômicas e programáticas da editora podiam determinar formato, tamanho da mancha de texto, corpo do texto principal, mas a tipografia e os recursos de destaque ficavam mesmo na dependência do que as oficinas tinham a oferecer, dentro da herança e das práticas vigentes da produção do livro tipográfico.

Assim, algumas das principais características dessa tradição são o uso exclusivo das fontes serifadas e o traçado da mancha impressa com área não superior a 50\% da área da página e deslocada para cima, determinando margens generosas para o texto ${ }^{10}$. Esse procedimento decorre da larga tradição de composição de livros literários e do uso de fontes serifadas desde a invenção da tipografia no século XV, uma vez que o desenho de fontes sem serifa foi introdu-

8 O método intuitivo analítico é exposto por Sampaio Doria no livro Como se ensina, dirigido ao ensino Normal e ao magistério, também editado pela Companhia Editora Nacional. Sobre este método e sobre Como se aprende a língua, ver CARVALHO, 2010, p. 39-44.

9 Linotipos são máquinas de composição desenvolvidas pelo alemão Ottmar Mergenthaler a partir de 1886, que fundem em chumbo linhas inteiras de tipos por meio de matrizes selecionadas comandadas por um teclado [Rossı FILHO, 2001, p. 369; mas para uma descrição detalhado do processo de funcionamento e trabalho, ver PORTA, 1958, p. 237-238]. Já as monotipos, inventadas em 1887 pelo norteamericano Tolbert Lanston e fabricadas pela Monotype Corp Ltd, fundiam letras individuais a partir de um fita perfurada produzida também pela utilização de um teclado [Rossı FILHO, 2001, p. 369]. Embora a composição dos tipos isolados pelas monotipos já previsse a justificação das linhas, o processo de montagem das páginas era mais trabalhoso que com as linhas completas produzidas pela linotipo, mas obras complexas com tabelas e equações, caso dos livros didáticos, exigiam o uso das monotipos [PORTA, 1958, p. 279-280].

10 Uma referência utilizada para conhecimento dos padrões estabelecidos para a composição, diagramação e paginação dentro do período da tipografia aqui mencionados foi a obra Manual do Typographo, de Libanio Silva, editada em Portugal e distribuída no Brasil pela Francisco Alves a partir de 1922. Outra foi o Manual do Tipógrafo, de Ralph W. Polk, não por ter sido usada para a formação ou como guia de trabalho antes de sua publicação no Brasil em 1948, mas por informar sobre práticas há muito estabelecidas nessa tradição, desde sua primeira edição americana em 1926. 
zido na composição de impressos apenas no século XIX, com finalidade em princípio comercial não destinada à composição de livros ${ }^{11}$.

Nos livros didáticos da produção inicial da Nacional encontramos portanto a tendência a que as variações tipográficas para atender às diferentes funções do texto - como texto de leitura, definições, exemplos, exercícios, comentários, destaques para palavras etc. - se dêem exclusivamente dentro da mesma família serifada adotada. É o caso de Grammatica historica (FIG. 3.11), Logica (FIG. 3.12), Como se aprende a língua (FIG. 3.13), Elementos de anatomia e physiologia humanas (FIG. 3.14) e Noções de physiografia (FIG. 3.15), em que as variações itálico, negrito, negrito itálico, versal, versalete e tamanhos de corpo de uma mesma fonte serifada são utilizadas funcionalmente para as diversas situações de texto.

Em O meu idioma (FIG. 3.16), temos a única exceção em que se recorre ao uso de fontes sem serifa, para titulagens em diversos níveis e para destaque funcional didático de termos e verbetes, mas de diversas famílias e com contraste exagerado, revelando provável imperícia e falta de recursos tipográficos mais apropriados.

Com relação ao diagrama de página, há uma tendência de a relação entre áreas de mancha de texto e de formato de página não seguirem a recomendação vigente para o livro literário, de resto já abandonada para as edições populares. Assim, temos desde obras que apresentam ainda margens razoavelmente generosas (Logica, FIG. 3.12; Como se aprende a lingua, FIG. 3.13) até margens bastante reduzidas (Noções de physiographia, FIG. 3.15; O meu idioma, FIG. 3.16), de qualquer forma inferiores às do livro literário, indicando uma característica do livro didático determinada pela economia de recursos.

A impressão de todos estes títulos é tipográfica, identificada pelo método proposto por Bamber GASCOIGNE ${ }^{12}$, mas devido às tiragens elevadas é provável que os produzidos pelas oficinas da São Paulo Editora utilizasse as impressoras cilíndricas adquiridas pela Cia. Graphico-Editora Monteiro Lobato (ver capítulo 2). Os gráficos, esquemas e ilustrações presentes em Como se aprende a lingua, Elementos de anatomia e physiologia humanas e Noções de physiographia (FIG. 3.13 a 3.15) utilizam apenas a linguagem de traço, mais facilmente reproduzida por clichês em relevo.

1 Diferentemente dos tipos serifados "romanos", criados no século XV a partir de referências na escrita epigráfica da Roma antiga para as maiúsculas e na escrita caligráfica humanística para as minúsculas, os tipos sem serifa referenciam-se no desenho das letras epigráficas gregas do período clássico, que não possuiam arremates, do qual um tipo só com maiúsculas, conhecido como egípcio, desenhado por William Caslon em 1816, foi o primeiro exemplo conhecido, seguido de outro que incorporava as minúsculas, chamado de "grotesque", desenhado por William Thorowgood em 1835 [BAINES \& HASLAM, 2002, p. 63].

12 Classificando a impressão em basicamente dois processos, o relevográfico e o planográfico, o autor ensina o leitor a inicialmente identificar um e outro a partir de indícios deixados na superfície impressa, permitindo chegar ao reconhecimento mais preciso de alguns dos equipamentos usados através de sucessivas aproximações de identificação das características encontradas [GASCOIGNE, 2011]. 

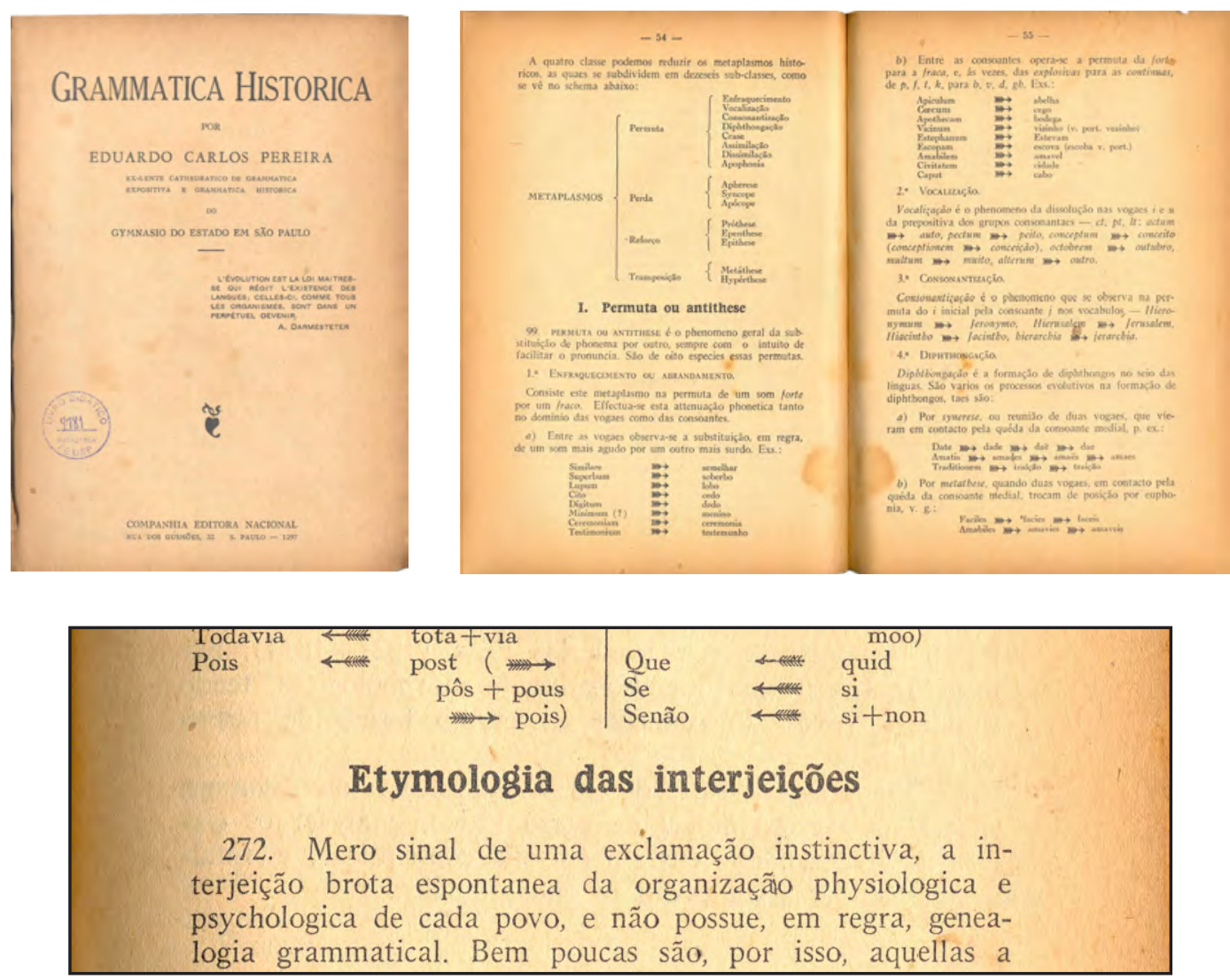

Fig. 3.11. Grammatica histórica, $1927(13,5 \times 19,0 \mathrm{~cm})$. Rosto, páginas de miolo e detalhe em tamanho natural. Tipografia serifada, com variações itálico, negrito e versalete, com uso de setas ornamentadas.
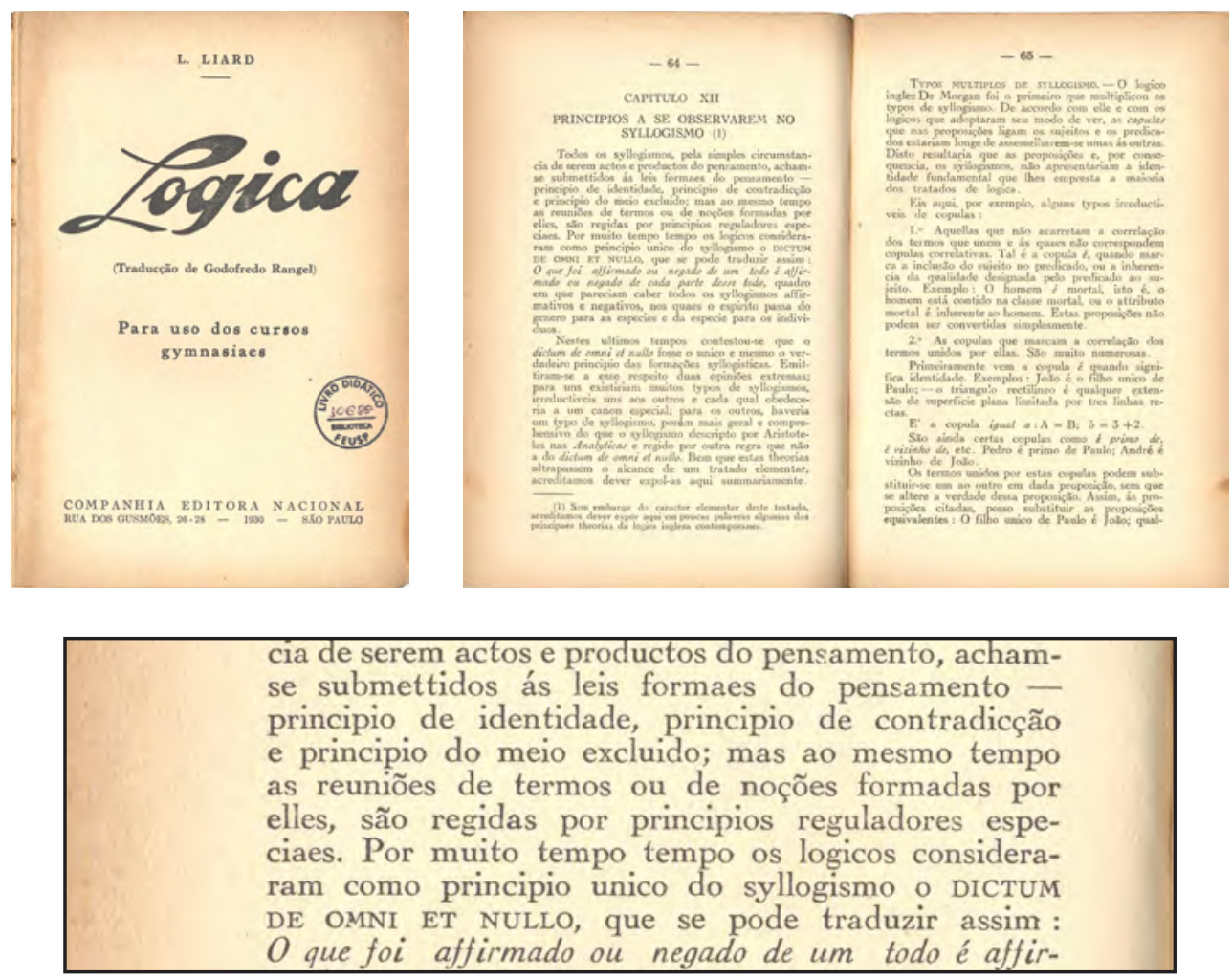

Fig. 3.12. Lógica, $1930(12,0 \times 17,5 \mathrm{~cm})$. Rosto, páginas de miolo e detalhe em tamanho natural. Tipografia exclusivamente serifada, com variações itálico e versalete. 

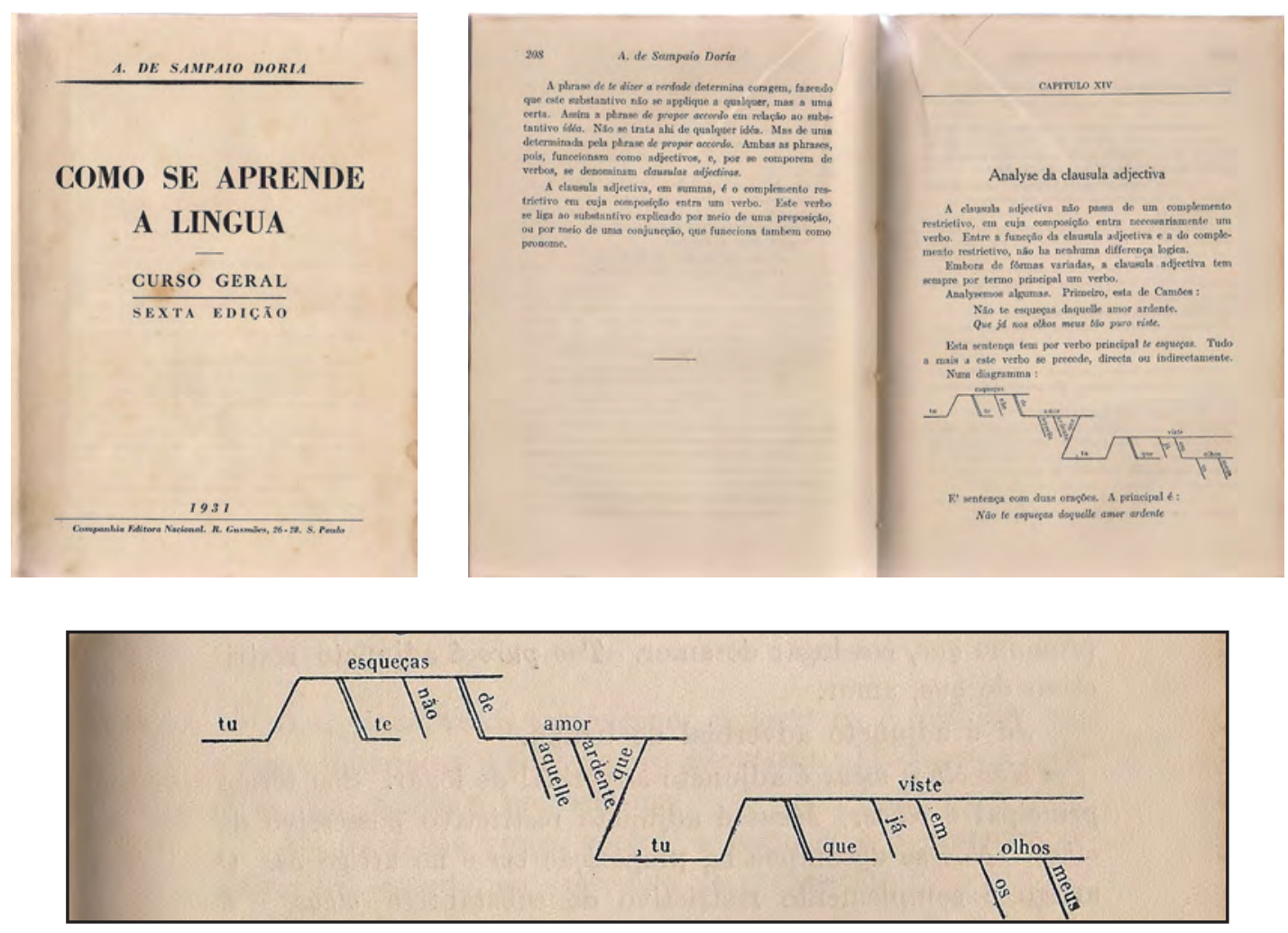

Fig. 3.13. Como se aprende a lingua, 1931 (13,2 × 18,2 cm). Rosto, páginas de miolo e detalhe em tamanho natural. Tipografia exclusivamente serifada, tendo como única variação o itálico.
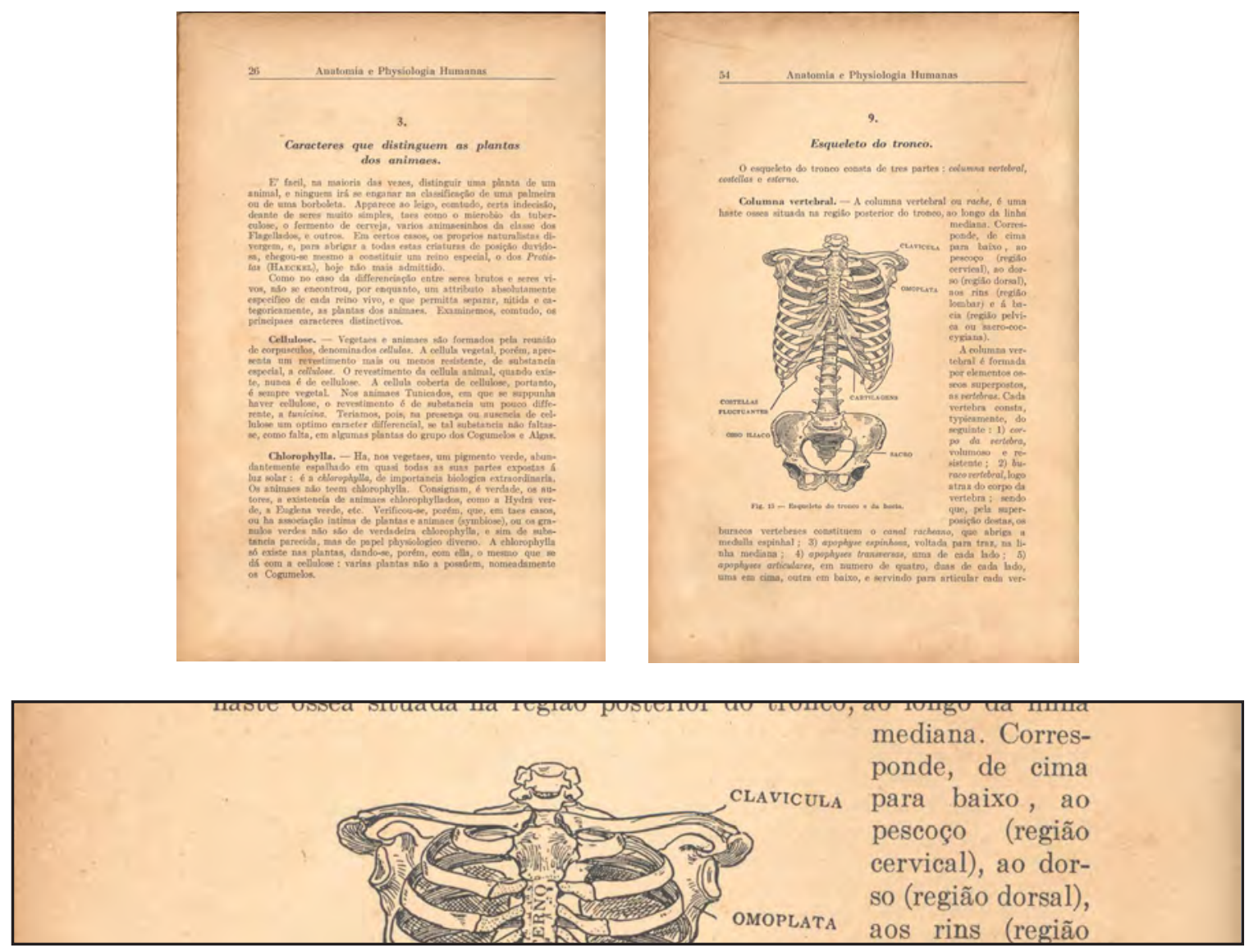

Fig. 3.14. Elementos de anatomia e physiologia humanas, 1931 (14,0 × 18,5 cm). Páginas de miolo.

Tipografia exclusivamente serifada, com variações itálico, negrito, negrito itálico e versalete. 

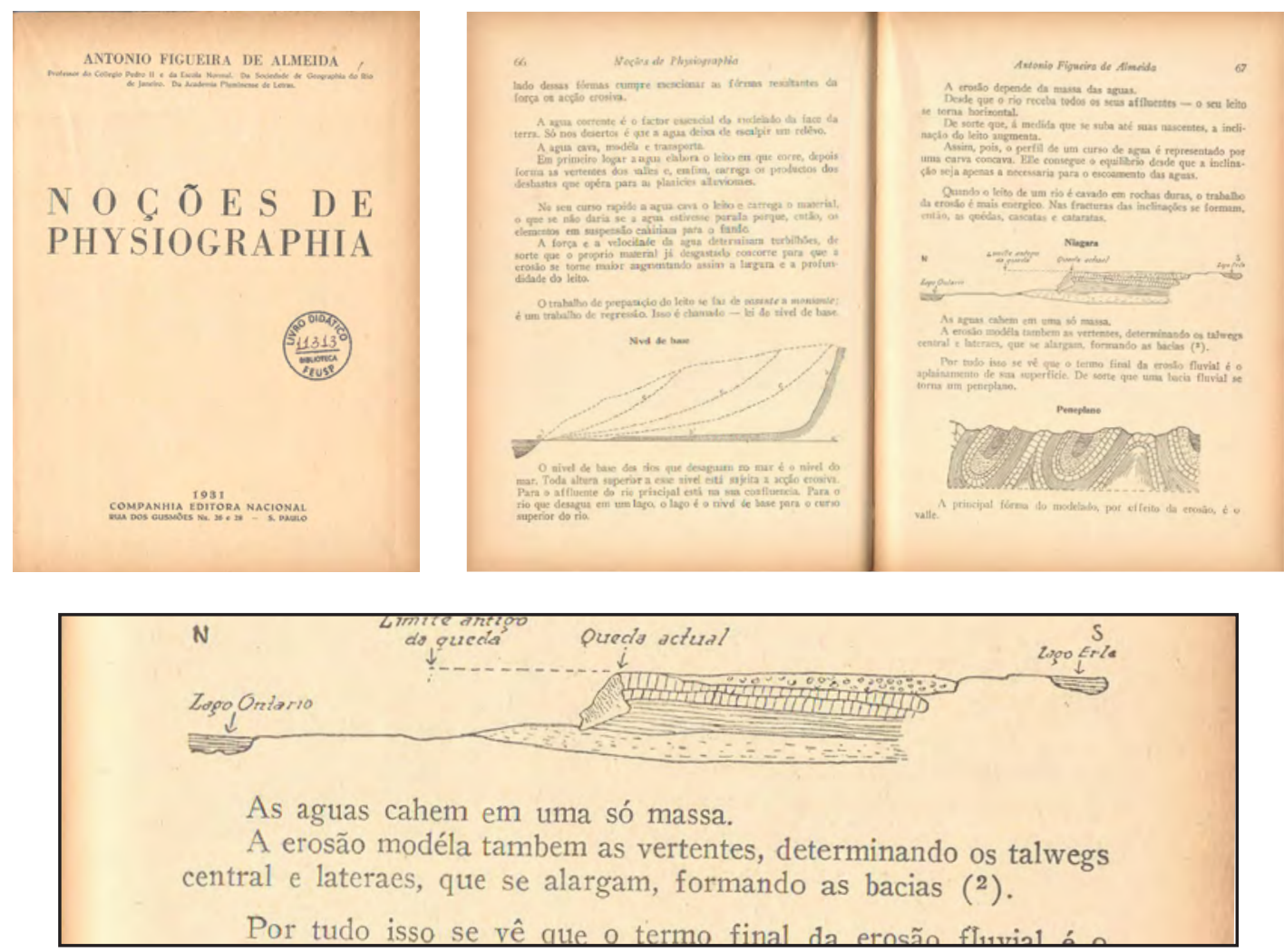

Fig. 3.15. Elementos de anatomia e physiologia humanas, 1931 (15,7 x 23,0 cm). Rosto e páginas de miolo. Tipografia exclusivamente serifada, com variações itálico, negrito, negrito itálico e versalete.
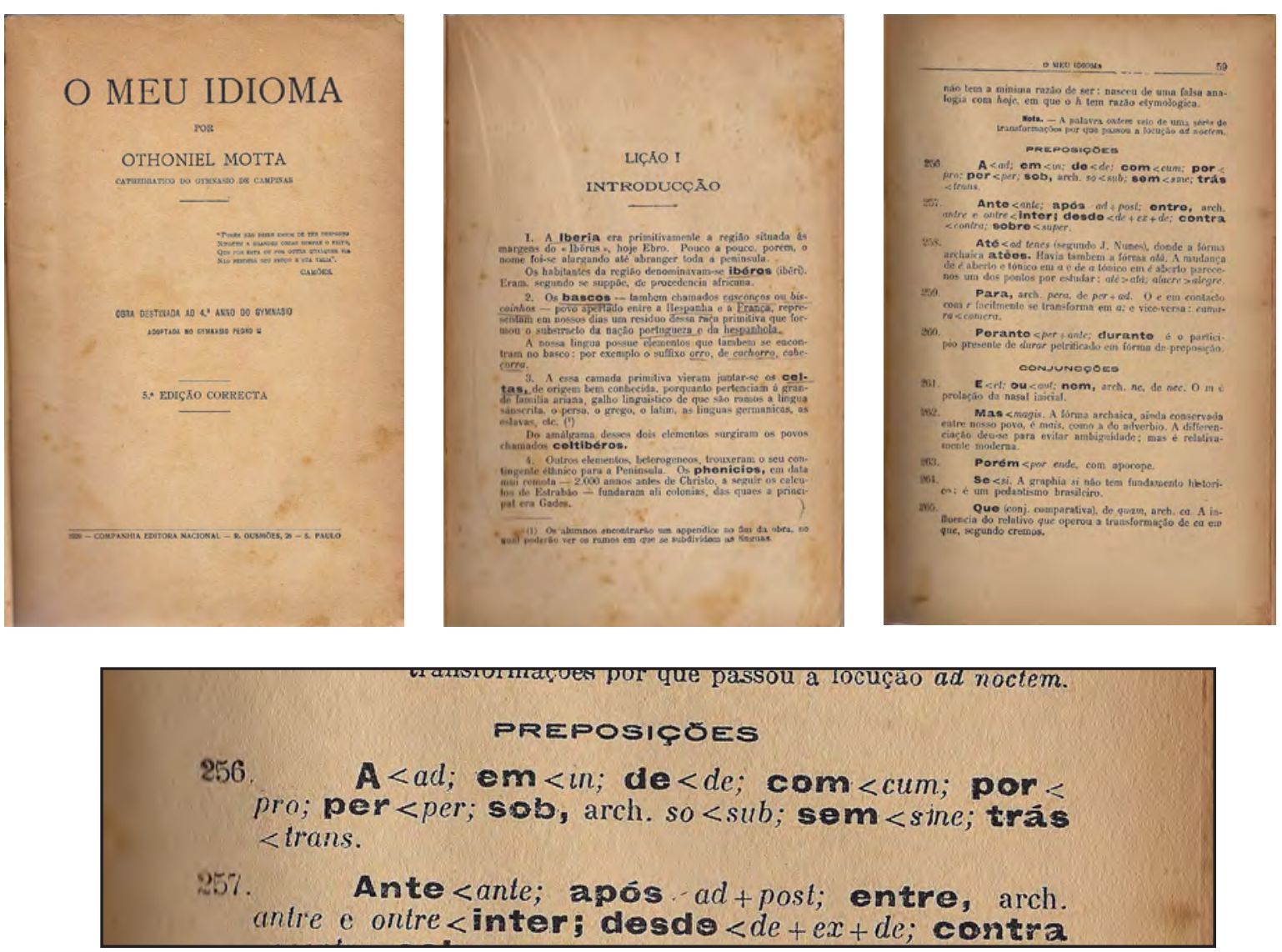

Fig. 3.16. O meu idioma, $1929(13,9 \times 21,5 \mathrm{~cm})$. Rosto, páginas de miolo e detalhe em tamanho natural. [Fonte: acervo pessoal.] Variação tipográfica incluindo negrito, versalete e fonte sem serifa. 


\subsubsection{O design de miolo dos livros didáticos para o Ensino Primário da CEN de 1926 a 1931}

Como vimos no início deste capítulo, apenas cartilhas e livros de leitura eram adquiridos pelo governo de São Paulo e de alguns outros estados para distribuição nas escolas públicas, constituindo o segmento de maior interesse comercial para as editoras. Neste grupo de livros a Nacional possuía apenas duas coleções, a Série Cezario Motta, com os livros Sei Ler, de Theodoro de Moraes, e a Série Thales de Andrade, com os livros Saudade, Trabalho e Espelho, alguns livros avulsos oferecidos para leitura de Monteiro Lobato (Contos escolhidos, Fábulas, Aventuras de Hans Staden) e nenhuma cartilha de alfabetização. Mas uma Cartilha de Hygiene pode ser acrescentada às obras dirigidas ao público escolar mais amplo, por também ser adquirida por governos estaduais para distribuição nas escolas.

Os demais títulos primários tinham venda mais restrita aos professores, para ministrarem suas aulas, no máximo atingindo alunos de escolas privadas que pudessem adquiri-los, como é o caso do Pontos de nossa história, de Veríssimo de Souza e Lourenço de Souza, obra apresentada como de educação cívica e que já traz no nome a idéia de pontos a serem selecionados e passados pelo professor (FIG. 3.17).
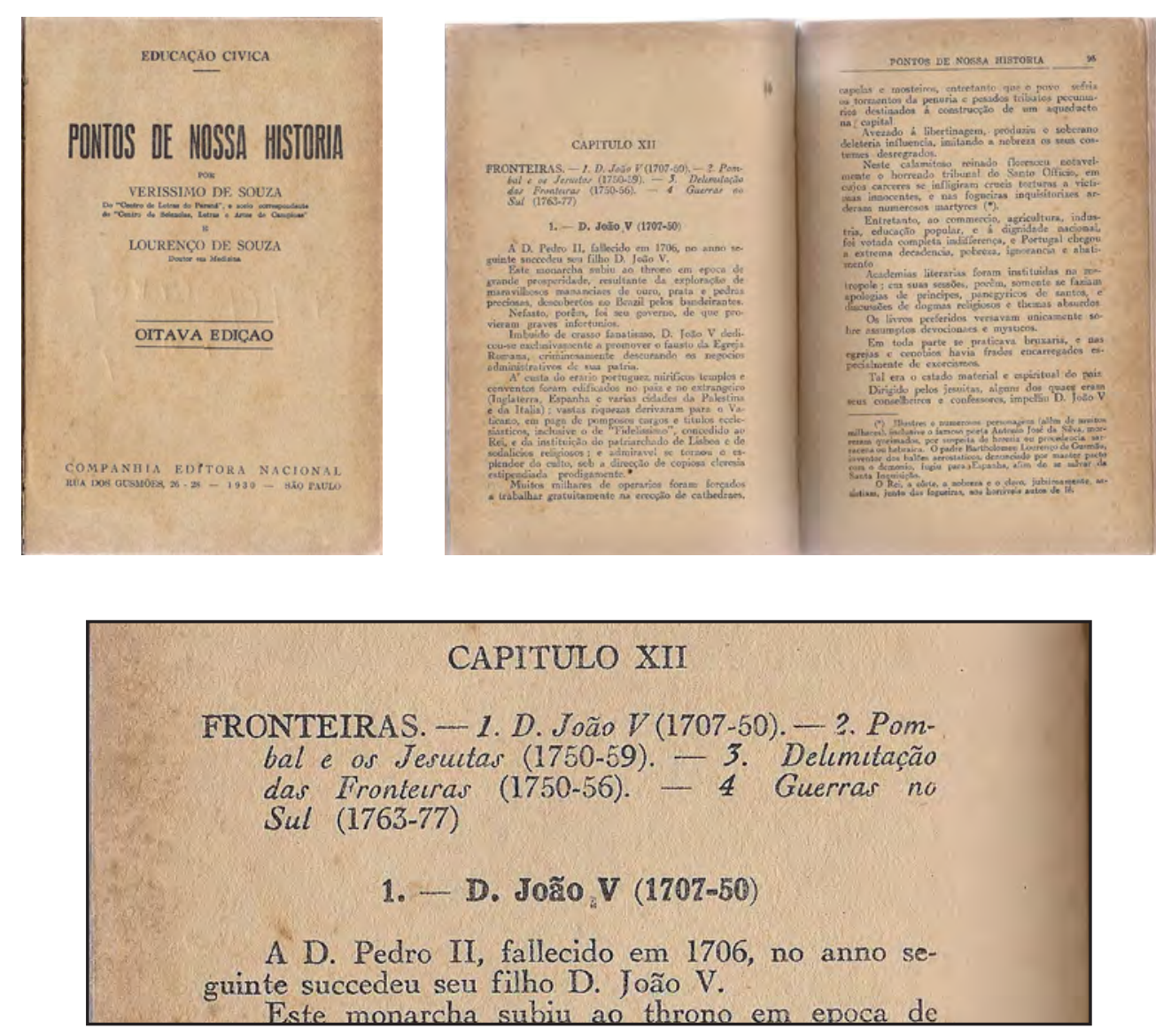

Fig. 3.17. Pontos da nossa história, $1930(11,6 \times 17,7 \mathrm{~cm})$. [Fonte: acervo pessoal.]

Rosto, páginas de miolo e detalhe em tamanho natural. 
Esta obra, bem como às destinadas às escolas normais, de formação de professores, mas que também traziam os conteúdos do Ensino Primário, como por exemplo Como se aprende matemática, de Saverio Christofaro, traziam a mesma visualidade mais sóbria e adulta encontrada nos livros do Ensino Secundário. Obras com Exame de admissão aos ginásios oficiais, que não obtivemos, de vários autores e abrangendo diversas disciplinas, provavelmente teriam mais afinidade gráfica com este tipo de obra, e não com cartilhas e livros de leitura.

Já os livros de leitura, se não chegam a ter uma visualidade tão diferenciada e particular como teria uma cartilha de alfabetização em função de suas características programáticas específicas, já apresentam soluções gráficas que as aproximam mais de seu público do que as obras mencionadas acima. As duas obras do gênero encontradas na pesquisa material, Saudade e Sei Ler, 2o livro de leitura, e a Cartilha de Hygiene, em tudo diferentes entre si, merecerão ser vistas separadamente, e não agrupadas como fizemos com os livros do Ensino Secundário.

Saudade. Thales de Andrade.
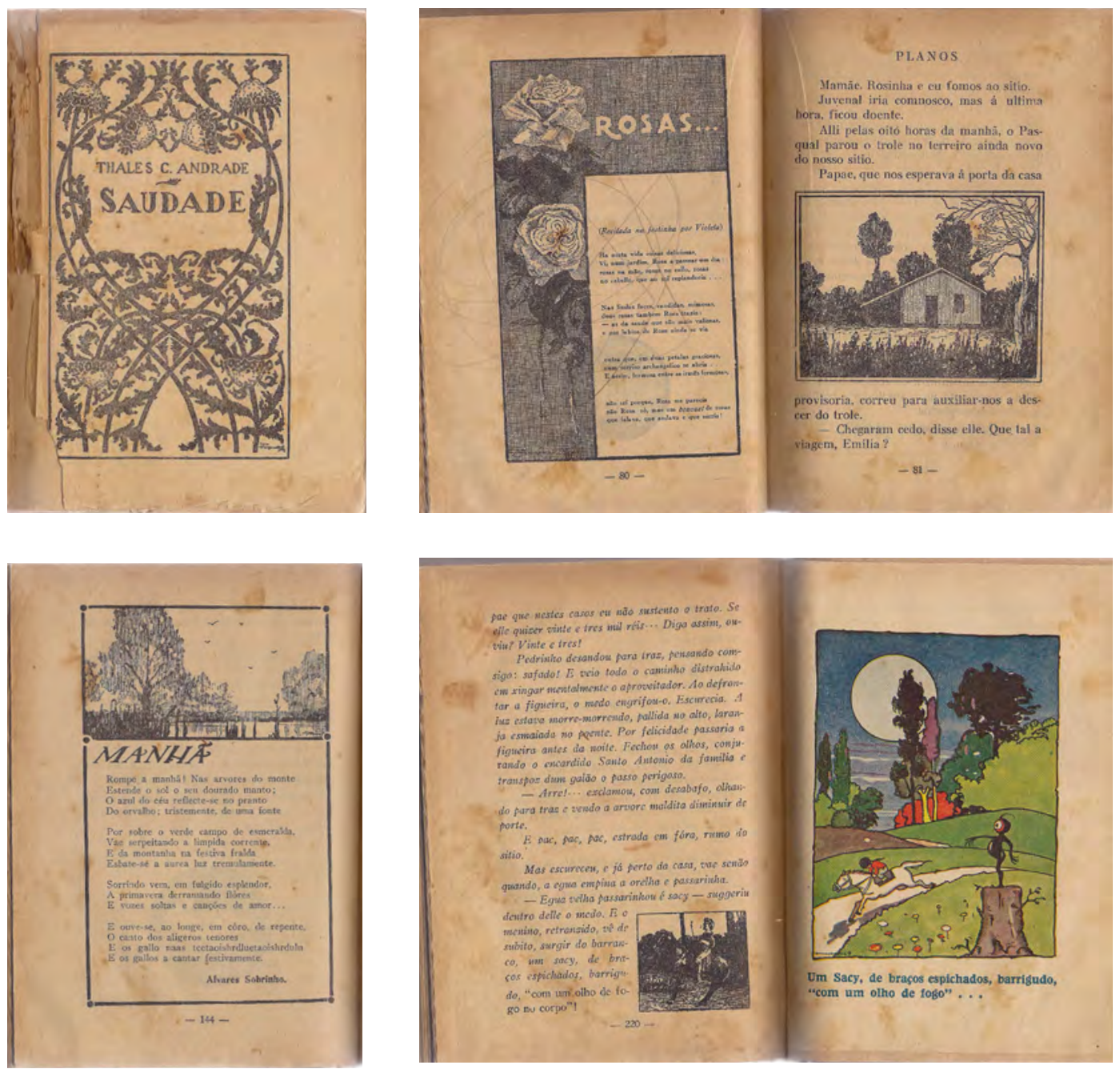

Fig. 3.18. Saudade, 1928,13 a edição $(13,2 \times 18,3 \mathrm{~cm})$. [Fonte: acervo pessoal.] Rosto e páginas de miolo. 
Oferecido para a leitura escolar, Saudade não foi originalmente escrito como livro didático ou dirigido apenas ao público infantil, embora este fosse seu alvo principal, dentro de uma "pedagogia ruralista" de valorização da vida simples do campo e da agricultura em relação às dificuldades da vida urbana, mas também de renovação da vida rural através da educação [BRAGION, 2007, p. 89]. Depois de uma primeira edição de 1500 exemplares financiada pela Secretaria de Agricultura, Comércio e Obras Públicas do Estado de São Paulo e produzida pelo editor e impressor Elvino Pocai, em 1919, para distribuição em escolas rurais, e de uma segunda edição de 20.000 exemplares financiada pelo Jornal de Piracicaba, em 1920, Saudade passou a integrar o catálogo da Monteiro Lobato \& Cia. Até 1931, junto com Trabalho e Espelho compôs a Série Thales de Andrade da Companhia Editora Nacional, que nos anos anos seguintes foi ampliada com a inclusão de dois outros títulos, Vida na roça e Alegria13.

A particularidade desta obra em relação aos demais títulos da Nacional deste primeiro período, principalmente os de Ensino Secundário, é apresentar grande variedade de diagramas, combinando composição de texto e ilustrações com grande liberdade em quase todas as páginas da obra, oferecendo grande atrativo ao público infantil e juvenil, mantendo características encontradas na primeira edição de Pocai, que incluía até fotografias reproduzidas por clichês reticulados (FIG.3.19). As ilustrações de traço de J. U. Campos, Rasmussen e Paim (autor da bela página de rosto), teriam vindo não só da edição da Monteiro Lobato \& Cia. mas da segunda edição do Jornal de Piracicaba, conforme informações de AleXANDRE [2007, p. 219] e imagens obtidas, mas apresentam a inserção de lâminas impressas em cromolitografia (tricromia) com ilustrações de Nino e possivelmente rediagramação em parte da obra.
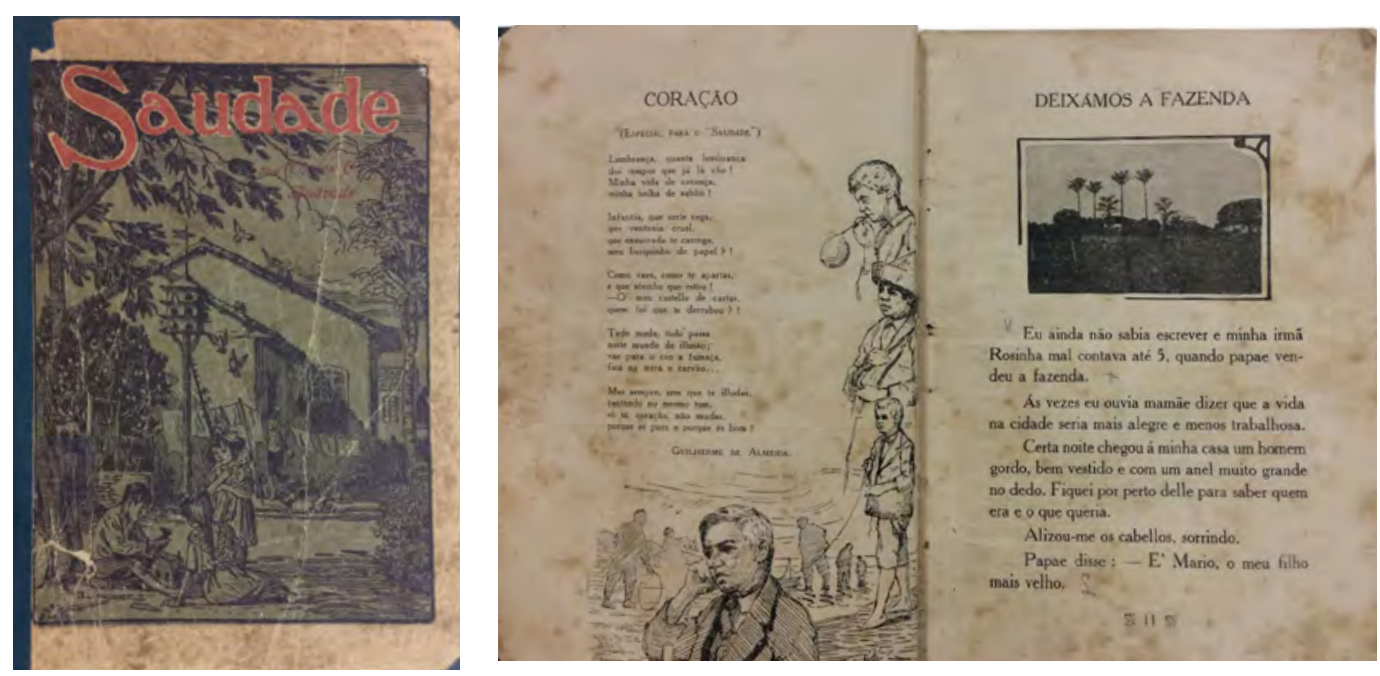

Fig. 3.19. Capa e páginas de miolo da primeira edição, de 1919, de Elvino Pocai, com capa de J. Wasth Rodrigues, fotografias e ilustrações de Alipio Dutra, João Dutra e João Pfuhl (não creditadas na edição, mas informações obtidas em AleXANDRE, 2007, p. 103). [Fonte: Biblioteca Infantil Municipal Monteiro Lobato, São Paulo.]

13 Sobre o autor, sua obra e a história das primeiras edições de Saudade, além de BRAGION, 2007, ver também ALEXANDRE, 2007. Sobre a Série Thales de Andrade da Companhia Editora Nacional, ver StANISLAVSKI, 2011. 
Sei Lêr: Segundo livro de leitura. Theodoro de Moraes.
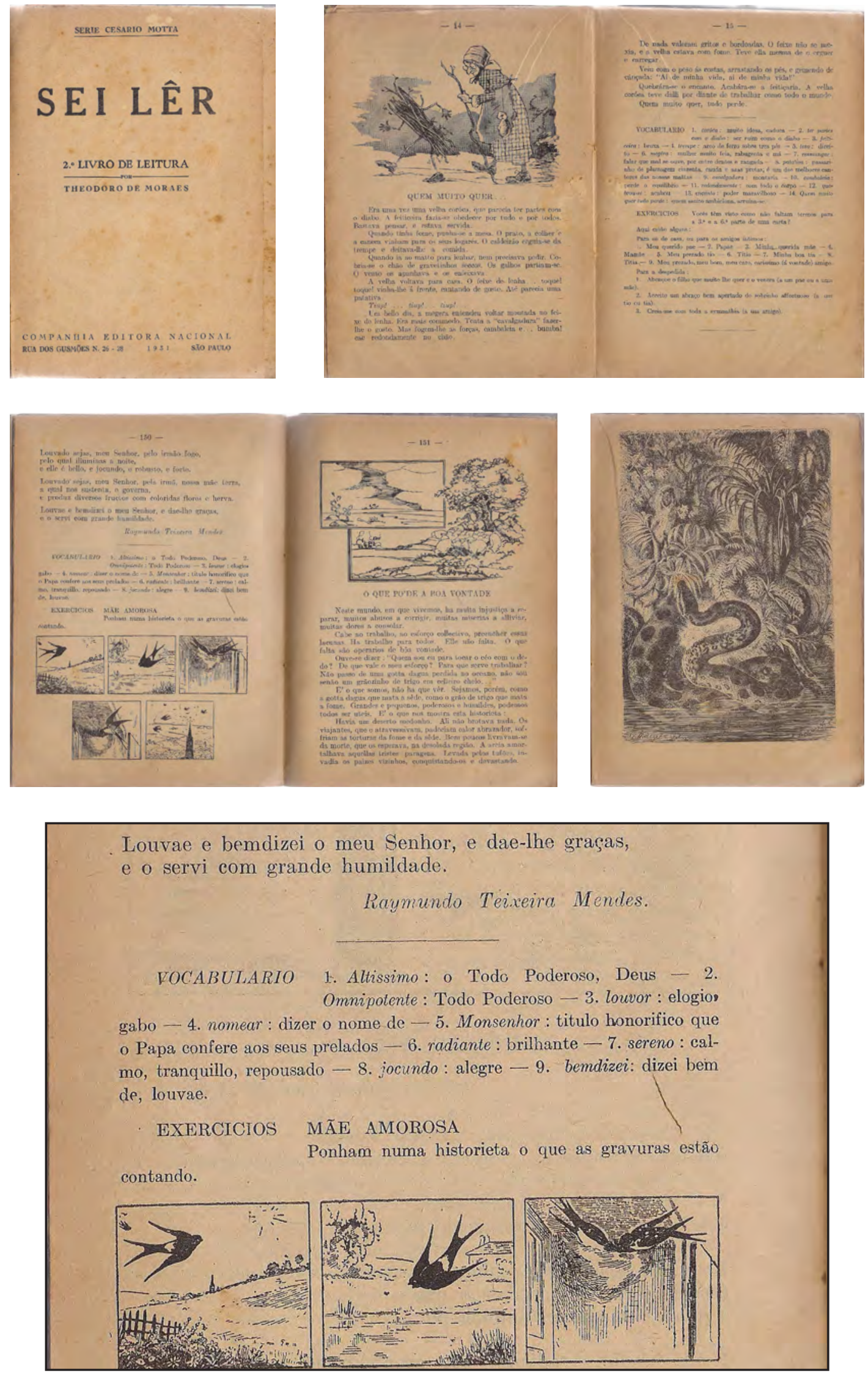

Fig. 3.20. Sei lêr: Segundo livro de leitura, $1931(13,0$ × 17,8 cm). [Fonte: acervo pessoal.] Rosto, páginas de miolo e detalhe em tamanho natural. 
Este é o terceiro volume da coleção de leitura graduada assinada por Theodoro de Moraes, iniciada em 1928, com Sei ler: Leituras intermediárias e Sei ler: Primeiro livro de leitura (sem o nome da série Cezario Motta, adotado em 1930 com o lançamento do Segundo livro de leitura). Indicado para o 3o e 4ำ anos do Ensino Primário, foi adotado nos Estados de São Paulo, Rio de Janeiro, Pernambuco e Rio Grande do Sul. O exemplar obtido traz data de 1931 mas provavelmente corresponde a reimpressão da edição de 1930.

A estrutura que se repete ao longo do livro é sempre de uma pequena história ou poema, de temática ligada ao universo infantil ou de fundo moral, religioso, patriótico ou instrucional, sempre antecedida por uma ilustração e seguida por um vocabulário e por exercícios, alguns também apoiados por ilustrações, estrutura esta que, segundo Bárbara Cortella PEREIRA, [2009, p. 126-143], corresponde a unidades de ensino de leitura conforme à então chamada abordagem analítica de alfabetização e ensino de leitura, que foi adotada como método oficial das escolas paulistas a partir de 1909. Os temas também estariam de acordo com os princípios deste método, visto que partiriam do concreto conhecido pela criança para o abstrato, incluindo os preceitos morais relativos à vida sadia e produtiva do cidadão ${ }^{14}$.

As imagens não constituiam simples ilustrações das histórias mas forneciam para o professor material para estimular os alunos a formularem sentenças completas do que observavam antes da leitura, estabelecendo uma associação direta entre forma gráfica e pensamento, o que fica mais claro nos exercícios de memória e organização de narrativas ou descrições. Assim, Theodoro de Moraes, não teria sido apenas um dos principais defensores do método analítico de alfabetização mas também, segundo a autora, pioneiro na adoção dessa estrutura didática que aparecerá em praticamente todos os livros de ensino de leitura e escrita dos períodos seguintes da Nacional e de outras editoras durante o século XX, a partir de sua influência.

A composição e diagramação do miolo utiliza uma única família serifada, com as diferentes funções definidas por contraste bastante discreto de corpo e variações itálico e caixa alta, sem utilização de negrito. O resultado é uma certa uniformidade visual, quebrada apenas pelas ilustrações, e uma diferenciação entre as diversas situações/funções à primeira vista bem pouco acentuada, mas no entanto suficientemente clara a partir de reiteração pela repetição da mesma sequência ao longo das lições/unidades. Além das ilustrações produzidas para as aberturas de texto e exercícios, sempre em linguagem de traço correspondente à impressão tipográfica, ocorre também reproduções de gravuras encontradas em obras literárias, como de Gustavo Doré e outros artistas, que contribuem para um enriquecimento da experiência gráfica dos leitores.

\footnotetext{
14 Sobre a concepção de método analítico defendida por Theodoro de Moraes e sua adoção pelas escolas paulistas, ver MoRTATTTI, 2000, p. 99-100
} 
Cartilha de Hygiene. Almeida Júnior.
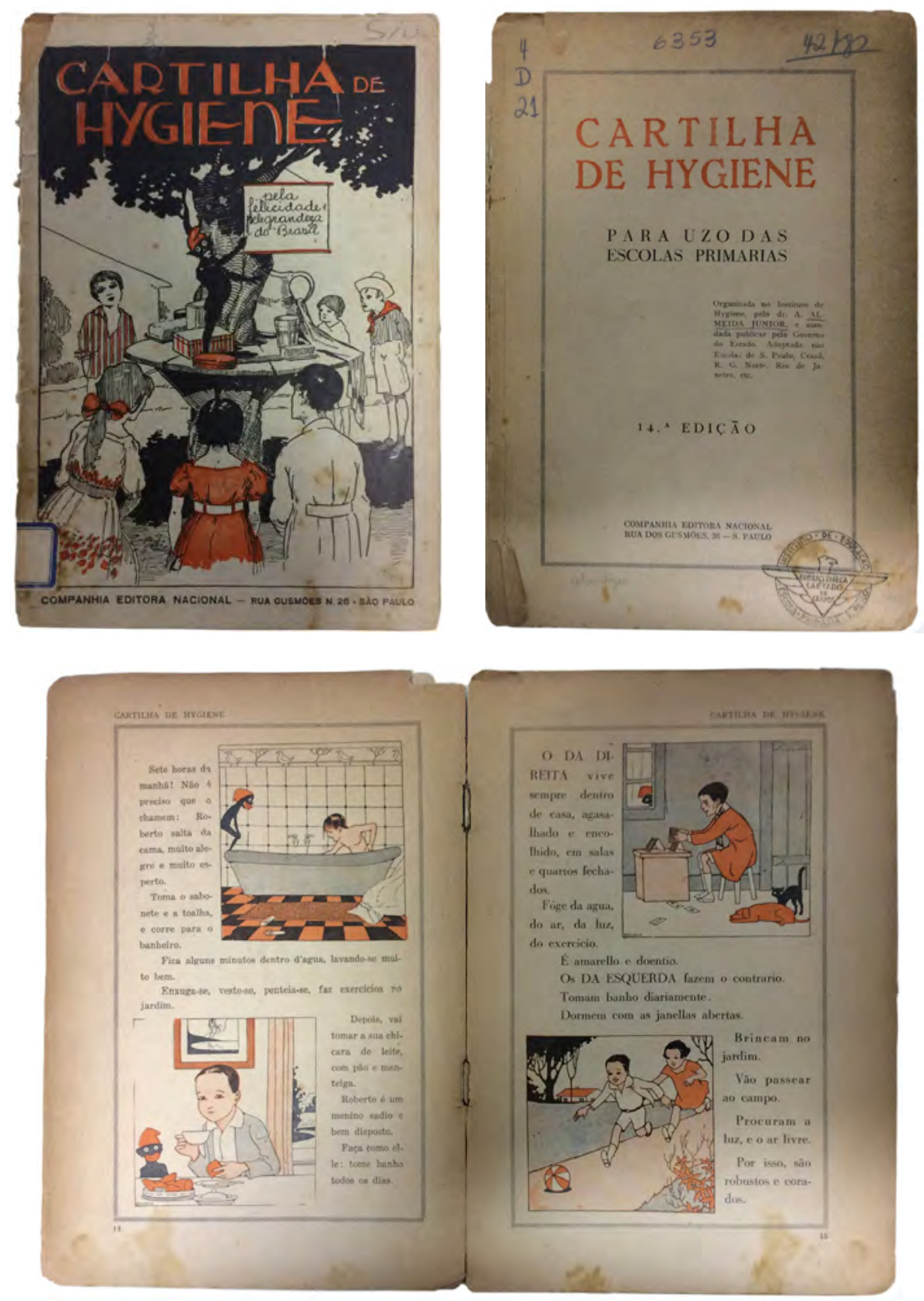

Fig. 3.21. Cartilha de hygiene, 1928, 14a edição $(16,0$ × 23,0 cm). [Fonte: AHECC/CRE Mario Covas/EFAP/SEE-SP.] Primeira capa, páginas de rosto e do miolo.

A introdução da disciplina Ciências Físicas e Naturais e Higiene no ciclo elementar alfabetizante da Reforma Sampaio Dória de 1920 (ver p. 94) teve como instrumento pedagógico esta e outras cartilhas, que materializavam as idéias então vigentes que atribuiam ao analfabetismo e aos hábitos insalubres, mais do que às condições de pobreza que os embasariam, as razões para o atraso do país, propugnando a redenção do Brasil pela educação e saúde, a partir de um efeito irradiador para a sociedade a partir da escola [RocHA, 2011, p. 152-153] $]^{15}$.

15 Além de analisar o contexto de surgimento desta e de várias cartilhas do gênero, a autora também faz uma análise da forma como alguns temas são tratados nesta cartilha em particular, que teve sua primeira edição em 1922 pela Monteiro Lobato \& Cia., mas da qual não se obteve nenhum exemplar para confrontar com a edição de 1928. 

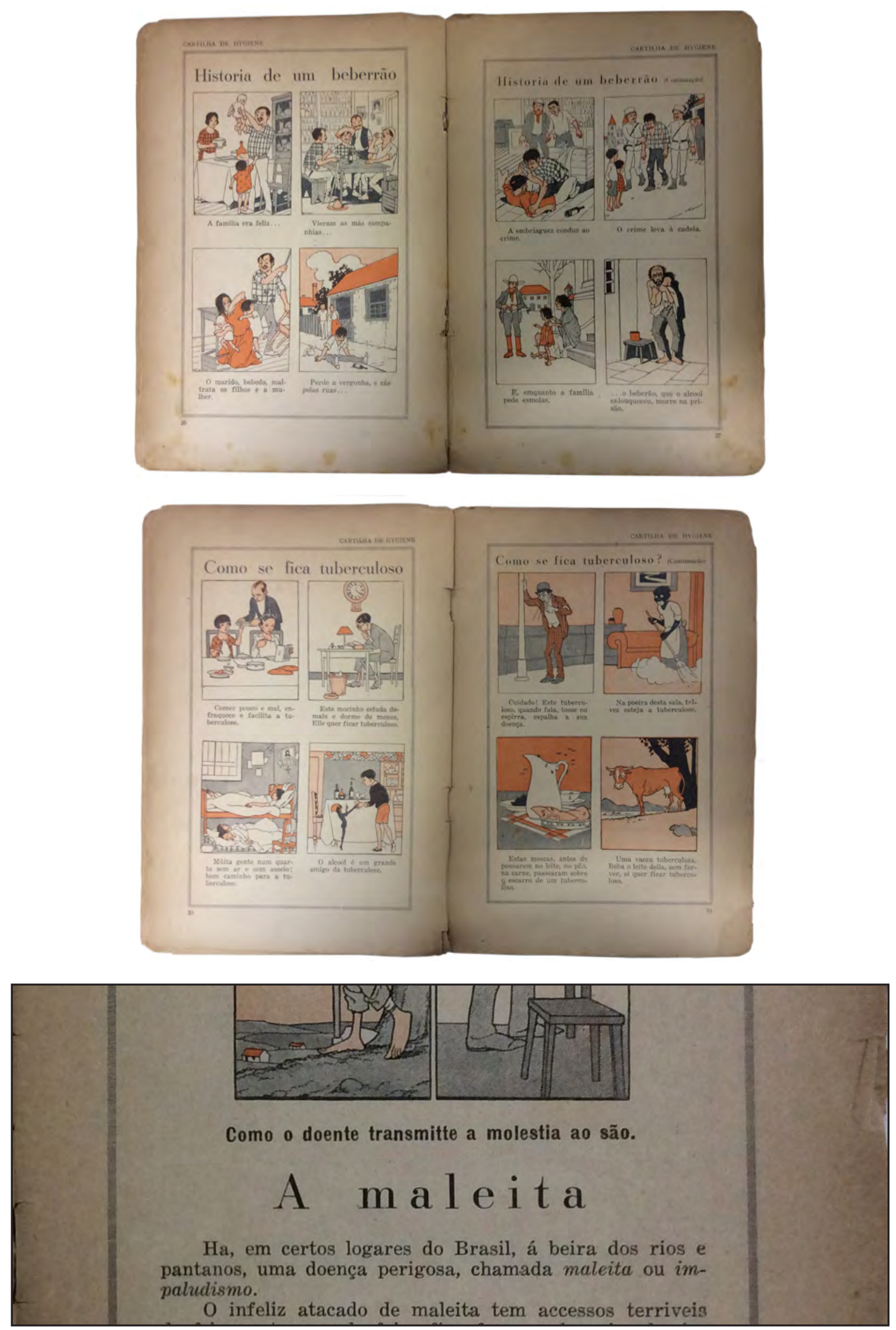

Fig. 3.21. Cartilha de hygiene, 1928. [Fonte: AHECC/CRE Mario Covas/EFAP/SEE-SP.]

Páginas do miolo e detalhe em tamanho natural. 
Com este programa pedagógico muito particular - objetivando atingir não só alunos mas também seus lares e inclusive os próprios professores, principalmente nas zonas rurais e lugares mais distantes do país -, a Cartilha de Hygiene vai apresentar uma abordagem editorial e uma solução gráfica e material que a distingue de todas as demais obras escolares da Nacional no período: é a única brochura encontrada para este segmento, possuindo apenas 42 páginas, formato maior que os livros encadernados e características de revista infantil de caráter popular (FIG.3.21 e 3.22).

Totalmente ilustrada por Belmonte e tendo como personagem apresentador o Saci-Pererê, recém popularizado por Monteiro Lobato, trata vários tópicos de seu conteúdo como história em quadrinho nos moldes da revista infantil Tico-Tico, isto é, com narração ao pé do quadro, sem balões de fala. A estreita relação entre imagem e texto e a técnica narrativa empregada indicam um trabalho de colaboração entre autor e ilustrador em função de propósitos pedagógicos que fazem de Belmonte verdadeiro coautor da obra. ${ }^{16}$

A impressão litográfica em duas cores e as altas tiragens mencionadsa por BEDA [1987, p. 232] indicam o uso de equipamento avançado para a época, embora o uso de retículas limite-se à definição de áreas de cores rebaixadas sem a composição de tons a partir da mistura óptica do preto e do laranja, que a cromolitografia industrial permitia. De qualquer forma, a Cartilha de Hygiene é um produto editorial diferenciado que recebeu grande investimento - e obteve igual retorno - em função das compras governamentais e do alcance de seu programa.

\subsection{Considerações gerais sobre o design dos livros didáticos da CEN do período 1926-1931}

As soluções tipográficas das capas e o design de miolo das obras destinadas ao Ensino Secundário produzidas entre 1926 e 1930 pela Companhia Editora Nacional indicam que, junto com a preservação dos títulos de maior aceitação do fundo editorial herdado das editoras anteriores de Monteiro Lobato e Octalles Marcondes Ferreira, deu-se também a manutenção de procedimentos de produção e das características visuais e materiais básicas das obras, definidas por recursos tecnológicos e humanos que pouco se modificam nesse intervalo, mas também por práticas e procedimentos que provavelmente não se quis mexer.

Pode-se considerar como motivos relevantes para este fato não apenas as dificuldades inerentes a um início de atividade marcado por limitação de recursos e cautela nos investi-

\footnotetext{
16 Belmonte (Benedito de Barros Barreto, 1897-1947), ilustrador, caricaturista e escritor paulista, atuou nos principais jornais da época, criou o personagem Juca Pato em charges relativas à II Guerra Mundial e ilustrou diversos livros infantis de Monteiro Lobato. A Tico Tico, que circulou semanalmente de 1905 a 1957, e depois com periodicidade variada, foi a primeira revista em quadrinhos brasileira.
} 
mentos, mas talvez também a não definição plena do perfil da CEN como uma empresa editora em que os livros escolares teriam o papel central que só veio a adquirir depois, a despeito da receita que desde o início propiciavam. O que caracteriza esses anos iniciais é um crescimento vertiginoso da editora em aparentemente todos os segmentos ou nichos experimentados, como participante de um processo de construção do campo editorial e de um mercado que se constituía naquele momento no país, em que talvez os planos iniciais e uma "vocação" pretendida não estivessem garantidos, o que de certa forma dava um caráter ainda indefinido e provisório para o perfil da editora.

Este fato, somado aos prováveis limites do próprio mercado de didáticos devidos ao contexto educacional e à atuação de outros concorrentes já estabelecidos, parecem estar na base de um catálogo ainda bastante modesto e que não exigiu da editora uma transformação das formas de produção e o estabelecimento de uma nova visualidade para seus livros escolares.

O confronto com títulos para o Ensino Secundário produzidos pelas principais editoras na década de 1920, como a Francisco Alves, a Typografia Siqueira e a Melhoramentos (FIG.3.2 a 3.4), indica que a solução exclusivamente tipográfica para as capas não era monopólio da Nacional - embora nas outras editoras seja mais frequente encontrar ilustrações a traço e até o uso de cores -, o que permite chegar à generalização de que esta é uma abordagem própria do livro didático brasileiro no período, que reproduz o modelo francês de diagrama simétrico, de eixo central, herdado das obras de literatura "séria" produzidas no Brasil durante o século XIX.

Como a escolha de didáticos se apoiaria mais na autoridade de seus autores e na capacidade das editoras em chegar diretamente às escolas do que na disputa por atenção a partir do apelo visual das edições populares ou destinadas às livrarias, a solução exclusivamente tipográfica - também a mais econômica - se justificava, ainda mais no caso da nascente Nacional. As características predominantes de compêndio das obras para o Ensino Secundário e o caráter elitista do ensino propiciado provavelmente também reforçavam a expectativa de seriedade para as obras do segmento.

Já as capas com título desenhado e ilustrações (soluções 4 e 5, FIG. 3.9 e 3.10), todas de 1931 e com impressão litográfica pura ou em combinação com tipografia, apresentam uma diferença marcante em relação às soluções tipográficas, não identificando tão cabalmente uma continuidade de design e procedimentos das editoras anteriores de Lobato e Ferreira que elas representam. Em certo sentido estas novas capas antecipam o emprego de uma solução que se generalizará mais tarde e caracterizará o segundo período de design de didáticos da editoras. Mas sua existência em 1931 não bastou para anteciparmos o início do segundo período, pois como se verá, mais do que a tecnologia conta a finalidade com que ela é empregada, no caso para configurar uma nova estratégia editorial que só virá a público em 1932, e que aqui ainda aparece em títulos sob uma organização editorial que ainda não se modificou. 

CAPÍTULO 4

\section{2-1942:}

As coleções didáticas da Companhia Editora Nacional e seu design 

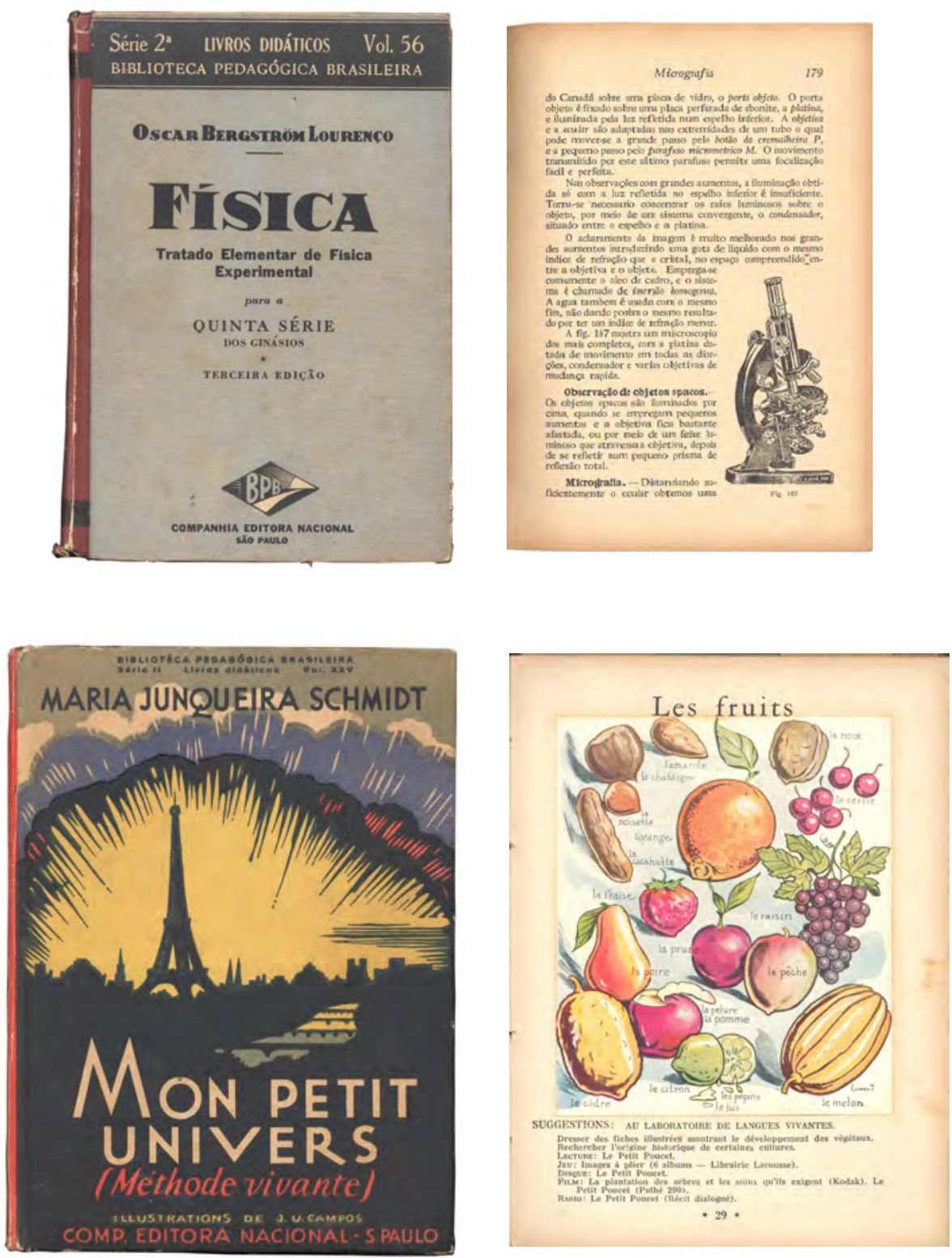

As duas obras aqui reproduzidas sintetizam as características do design dos livros didáticos da Nacional entre 1932 e 1943 :

- a criação de coleções e sua identidade pela capa;

- o estabelecimento de critérios e padrões gráficos de composição de texto e diagramação para os miolos e o incremento de sua qualidade;

- a produção de obras didáticas diferenciadas com design integrado de capa e miolo e produção gráfica sofisticada;

- encadernação em capa dura no acabamento dos volumes. 
C omo já se adiantou no capítulo anterior, este segundo período é definido pela visualidade resultante do salto que a CEN dá, em 1932, não apenas em termos quantitativos, com o aumento significativo de lançamentos em diversos segmentos editoriais, mas sobretudo em termos qualitativos, com a organização de todo o seu fundo editorial sob a forma de coleções e a consequente planificação editorial e gráfica envolvida. Trata-se de um novo momento na existência da empresa, com a consolidação de um perfil editorial e uma inserção diferenciada e significativa no mercado e na cultura do país. Como componente desse perfil editorial e de posicionamento da editora no mercado, o livro didático torna-se um produto chave, essencial, com uma estrutura de produção sendo criada para isso e padrões gráfico-visuais, para não falar em um sistema, sendo definidos para este produto.

Mas uma mudança desse porte não ocorre simplesmente por medidas administrativas, investimentos ou política comercial. Há uma nova situação política no país, um novo contexto cultural e um novo momento da educação, nos quais o capital cultural ou patrimônio intelectual que a editora trazia desde suas origens encontraram um terreno favorável para se articular na criação de um projeto político-editorial-comercial definido, em que as concepções políticas e ideológicas que o embasavam afinavam-se com o momento e suas demandas. Nesse projeto há um lugar específico para os livros escolares, perfeitamente delineado e fruto de ações planejadas como resposta a uma nova situação da educação no país, resposta essa que resultou em ampliação radical do catálogo de livros escolares e transformação da editora na segunda maior do segmento durante a década de 1930.

Como se verá, sem ser uma resposta automática e unívoca, a visualidade dos livros didáticos será bastante determinada por esse crescimento e pela nova forma de organização do catálogo, resguardados os papéis da cultura gráfica vigente e dos profissionais diretamente envolvidos, recursos tecnológicos disponíveis, exigências curriculares e conteudísticas de cada original, etc., todos eles participando em graus diversos da configuração final.

O encerramento desse período, pelos critérios aqui utilizados, seria novamente dado pela substituição das soluções de design vigentes por novas soluções para um volume significativo de obras. No entanto, como também essa mudança é associada a uma nova transformação da organização escolar, ocorrida em 1942, a periodização proposta, mesmo tendo como componente principal a visualidade, pode ser sustentada por um conjunto maior de fatores articulados.

\subsection{O início da política das coleções}

Retomando os quadros comparativos da atividade editorial da Nacional em seus anos iniciais (ver Tabelas 2.1 a 2.3 no capítulo 2), nota-se que de 1931 a 1932, o número total de exemplares impressos salta de 345.800 para 675.600 (95\%), o número de títulos editados de 98 
para 133 (35\%), a tiragem de romances de 177.400 para 357.100 (101\%), a tiragem de ensaios de 30.200 para 74.100 (145\%), a tiragem de paradidáticos de 14.000 para 30.000 (114\%) e, finalmente, a tiragem de livros didáticos de 44.000 para 144.500 (228\%), com a participação deste segmento sobre a tiragem total saltando de 12,72\% em 1931 para 21,39\% em 1932.

Evidentemente, um salto dessa magnitude supera em muito qualquer crescimento simplesmente vegetativo repentinamente favorecido por uma "colheita" inesperada decorrente de fatores circunstanciais. Aqui trata-se de resultados obtidos para esforços empreendidos, dos quais já se vêem indícios nas tiragens de romances e de ensaios de 1931, embora este ano tenha sido de uma queda geral das tiragens em relação a 1930 motivada pela crise política e econômica então vividas, como descreve BEDA [1987, p. 232-233] e vimos no capítulo 2 (p. 82-83).

O lançamento de títulos novos em tantos segmentos, mais do que a tiragem em si, envolve uma mobilização de recursos financeiros e humanos, com o crescimento numérico significativo de corpo editorial - revisores, planejadores gráficos, diagramadores e ilustradores -, mas também de editores especializados nas várias áreas de conhecimento que façam a prospecção de títulos e autores e dirijam os processos de edição, além de responsáveis pelo controle da produção e dos fluxos e prazos. Ao lado desses meios, estratégias de produção também precisam ser criadas, para dar conta do grande número de títulos a serem produzidos simultaneamente.

Mas todos esses meios e recursos foram, na verdade, mobilizados como decorrência de decisões estratégicas de base relativas ao crescimento e ao lugar que a editora pretendia ocupar na ampliação do mercado do livro no país, que ocorre a partir do crescimento das classes médias e da metropolização de capitais de estados como São Paulo e Rio de Janeiro principalmente, e da expansão da educação no início dos anos 1930. Essas decisões dizem respeito não só ao número de títulos ou assuntos tratados, mas à forma mesma como deveria ser oferecidos ao público. Algumas diferenças entre um catálogo do início de 1932 e o catálogo de setembro 1933 explicitam a nova configuração da CEN e de seus produtos.

O catálogo de 1932 reproduz a forma dos catálogos dos anos anteriores consultados, trazendo as obras organizadas sob as seguintes rubricas principais: Poesias; Biblioteca das Moças; Romances; Contos e crônicas; Literatura, ensaios, críticas e etc.; Medicina; Livros educativos (Educação sexual, Psicanálise, Saúde e otimismo); Direito; Obras de contabilidade; Livros escolares; Literatura infantil; Os romances do povo. Cada uma delas é dividida por autores, sendo que em Romance aparece a Coleção Para Todos, também subdividida por autores. Assim, excetuando a Biblioteca das Moças, que é apresentada enquanto coleção, e a Coleção Para Todos, que aparece discretamente sob a rubrica Romance, mas tem uma publicidade na segunda capa do catálogo, todos os demais livros não pertencem a coleções. Mesmo os escolares de Thales de Andrade e de Theodoro de Moraes, que têm na capa ou em publicidade a denominação 
de "série", aparecem apenas sob o nome dos autores, e a rubrica Os romances do povo não constitui uma coleção (FIG. 4.1 e 4.3).

Já o catálogo de 1933 (Catálogo Geral no 10 - Setembro), refletindo o trabalho e o investimento realizados nos dois anos imediatamente anteriores, traz os títulos assim organizados: Coleção Para Todos; Biblioteca das Moças; Nova Biblioteca das Moças; Coleção Terramarear; Literatura infantil; Biblioteca Pedagógica Brasileira - subdividida em 1̄a série/Literatura Infantil, 2a série/ Livros didáticos, 3ạ série/Atualidades Pedagógicas, 4a série/Iniciação Científica e 5ạ série - Brasiliana -; Coleção Os Mais Belos Poemas de Amor; Romances e contos brasileiros; Livros de viagens; Biblioteca de Estudos Econômicos e Comerciais; Contos e crônicas da nossa história; Regionalismo e humorismo; Literatura, biografia, crônicas, ensaios de história e de crítica; Livros educativos em geral; Livros escolares (divididos em Ensino da leitura, Português, Francês, Inglês, Latim, Geografia, História, Matemática, Pedagogia, Psicologia e Lógica, Desenho, Ciências Físicas e Naturais, História Natural, Puericultura, Higiene, Filosofia, Exames de admissão); Contabilidade e comércio; Medicina e farmácia; Direito em geral; Os romances do povo; Obras diversas; etc. (FIG. 4.2 e 4.4 ).

Dessa forma, embora ainda existam as antigas rubricas, elas são na maioria antecedidas pelas coleções, que agora existem em número bem maior e abrigam os títulos novos lançados, que aparecem repetidos também sob as rubricas. Uma parte dos títulos didáticos anteriormente existentes juntam-se aos novos que integram a Biblioteca Pedagógica Brasileira 2a Série - Livros Didáticos, e todos aparecem também sob a rubrica Livros escolares, agora subdividida por disciplinas.

Assim, a marca principal de todo o trabalho desenvolvido a partir de 1930 e mais acentuadamente em 1931 e 1932, que o Catálogo Geral no 10 de 1933 vai mostrar de forma inequívoca, mais do que a atividade editorial intensiva que resultou em novos lançamentos e inúmeras reedições, será mesmo a estratégia de organizar o fundo editorial da CEN em coleções.

BEDA justamente menciona não só o esforço de trabalho dispendido no decorrer de 1931 como base dos resultados colhidos em 1932, mas também o início das "Bibliotecas", "Coleções" e "Séries" e o convite feito a Fernando de Azevedo para assessorar a formação da Biblioteca Pedagógica Brasileira, de que falaremos adiante [BEDA, 1987, p. 235-236].

Esta estratégia de formar coleções foi o principal ponto de apoio para o salto apontado em 1932 e estará na base de todo o crescimento e expansão da CEN a partir de então. Os antecedentes dessa estratégia podem ser encontrados na Monteiro Lobato \& Cia, que como vimos no capítulo 2 constituiu a Biblioteca da Rainha Mab e a Coleção Brasília, e na própria Nacional com os dois títulos da Série Brasil Antigo, que não prosseguiu, e na Biblioteca das Moças, que existiria ao menos desde 1929, embora BEDA afirme que seu primeiro título foi publicado de forma avulsa em 1926 [BEDA, 1987, p. 316]. 

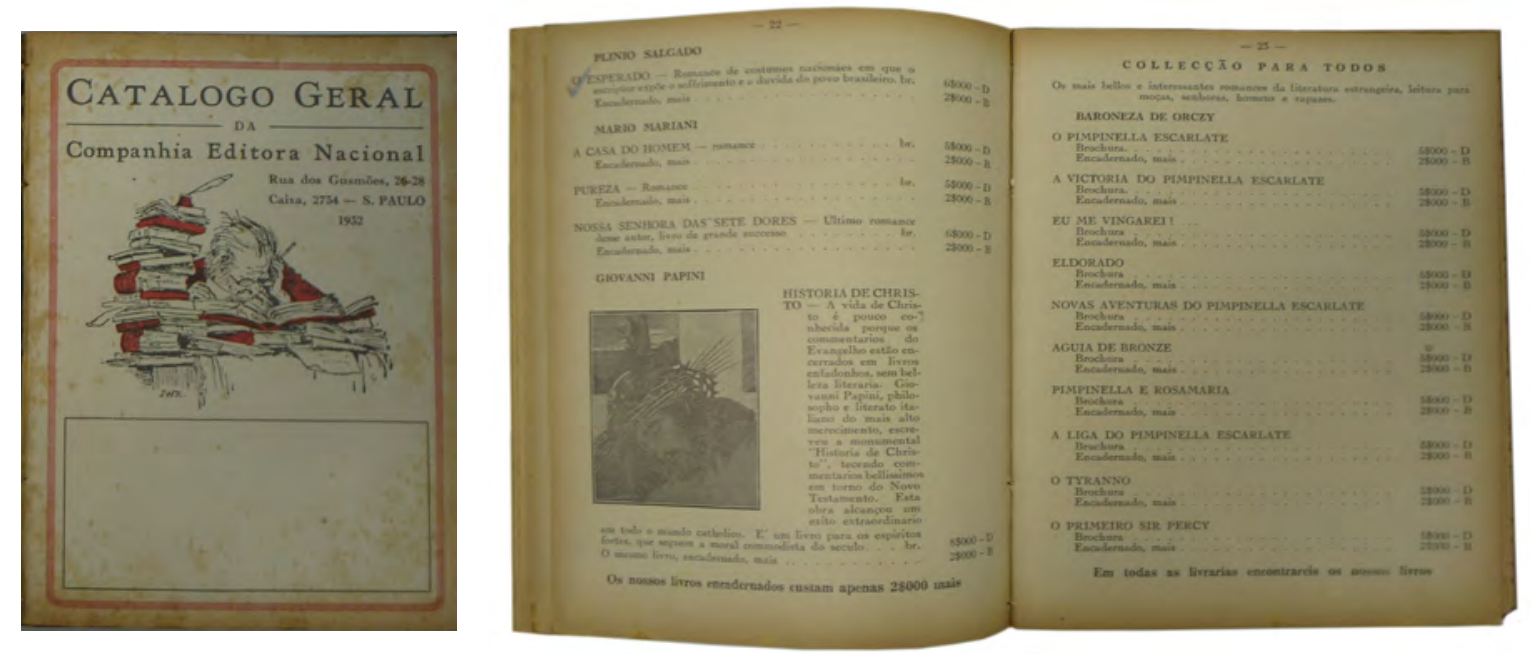

Fig. 4.1. Capa e páginas do catálogo de 1932, em que a Coleção Para Todos está incluída na rubrica Romance. [Fonte: acervo de Maria Rita de Almeida Toledo.]
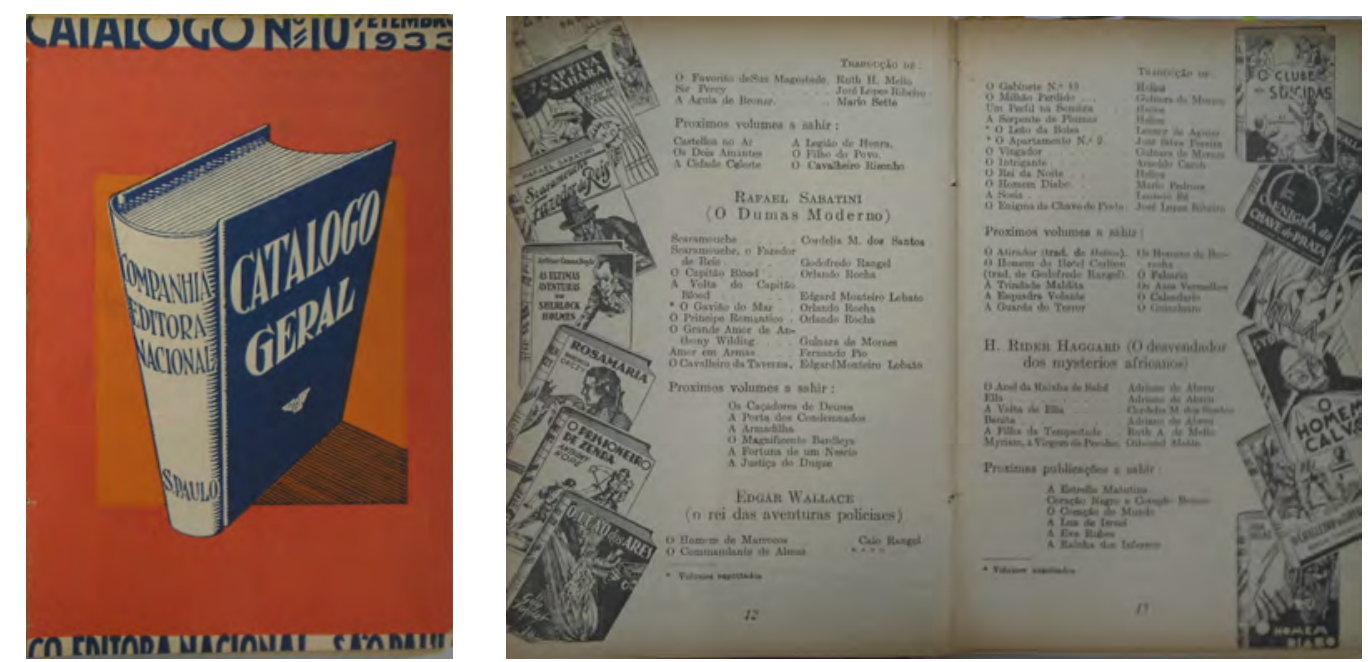

Fig. 4.2. Capa e páginas de catálogo de 1933, em que a Coleção Para Todos aparece independente, com desenho em traço reproduzindo as capas. [Fonte: acervo de Maria Rita de Almeida Toledo.]
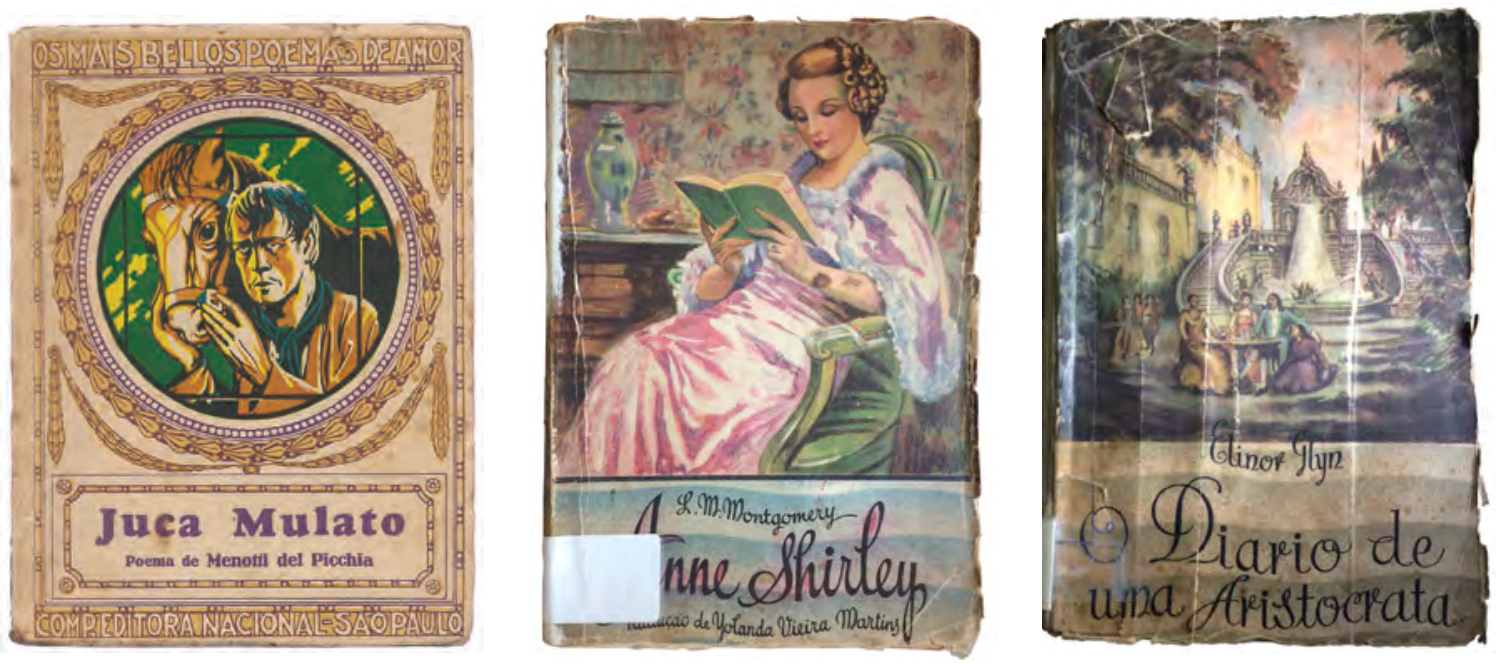

Fig. 4.3. Capas de volumes de coleções da CEN: Os Mais Belos Poemas de Amor (1927, ilustrações de Paim), Biblioteca das Moças (1934 e 1938). [Fontes: acervo pessoal e CAPH - Projeto Memória da FFCL/ FFLCH-USP.] 

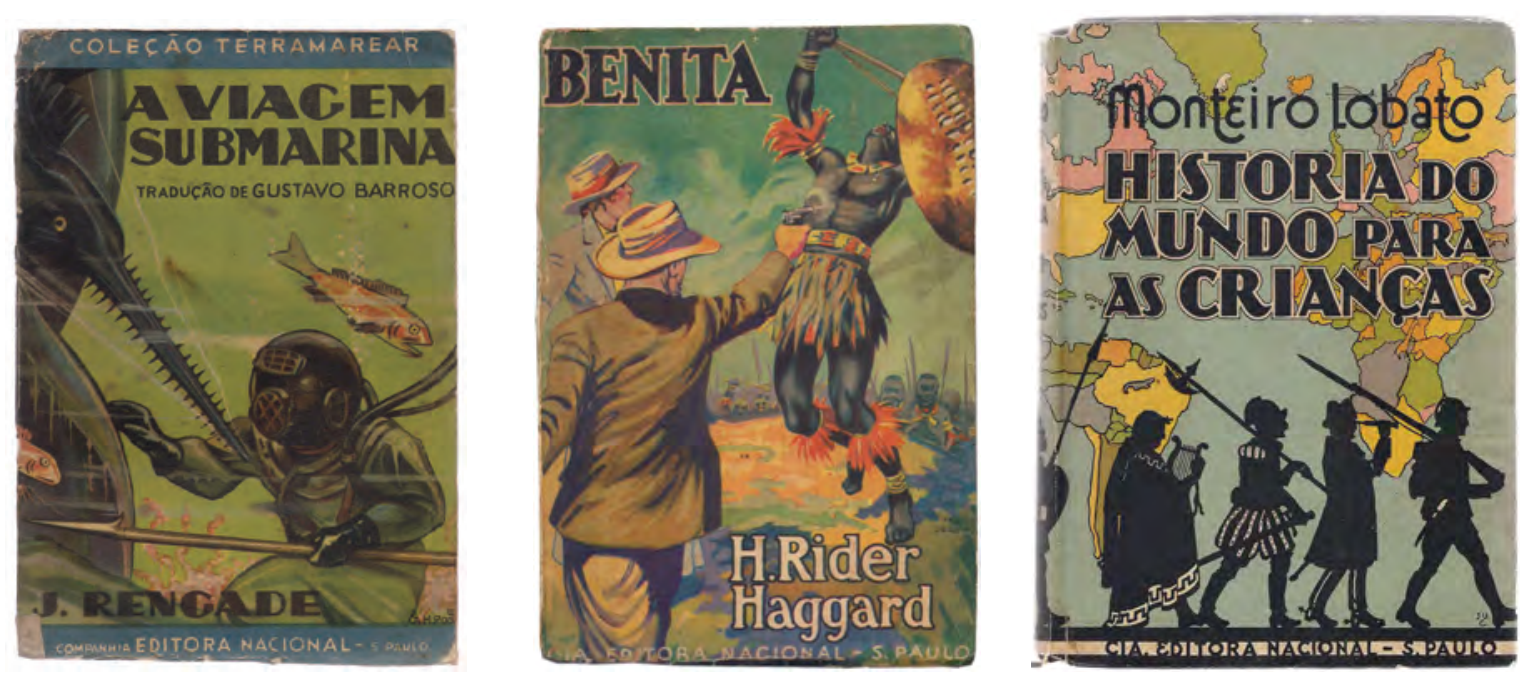

Fig. 4.4. Capas de volumes de coleções da CEN - Coleção Terramarear, Coleção Para Todos - e livros infantis, constantes no Catálogo de 1933, todas com ilustrações de J. U. Campos. [Fonte: acervo pessoal]
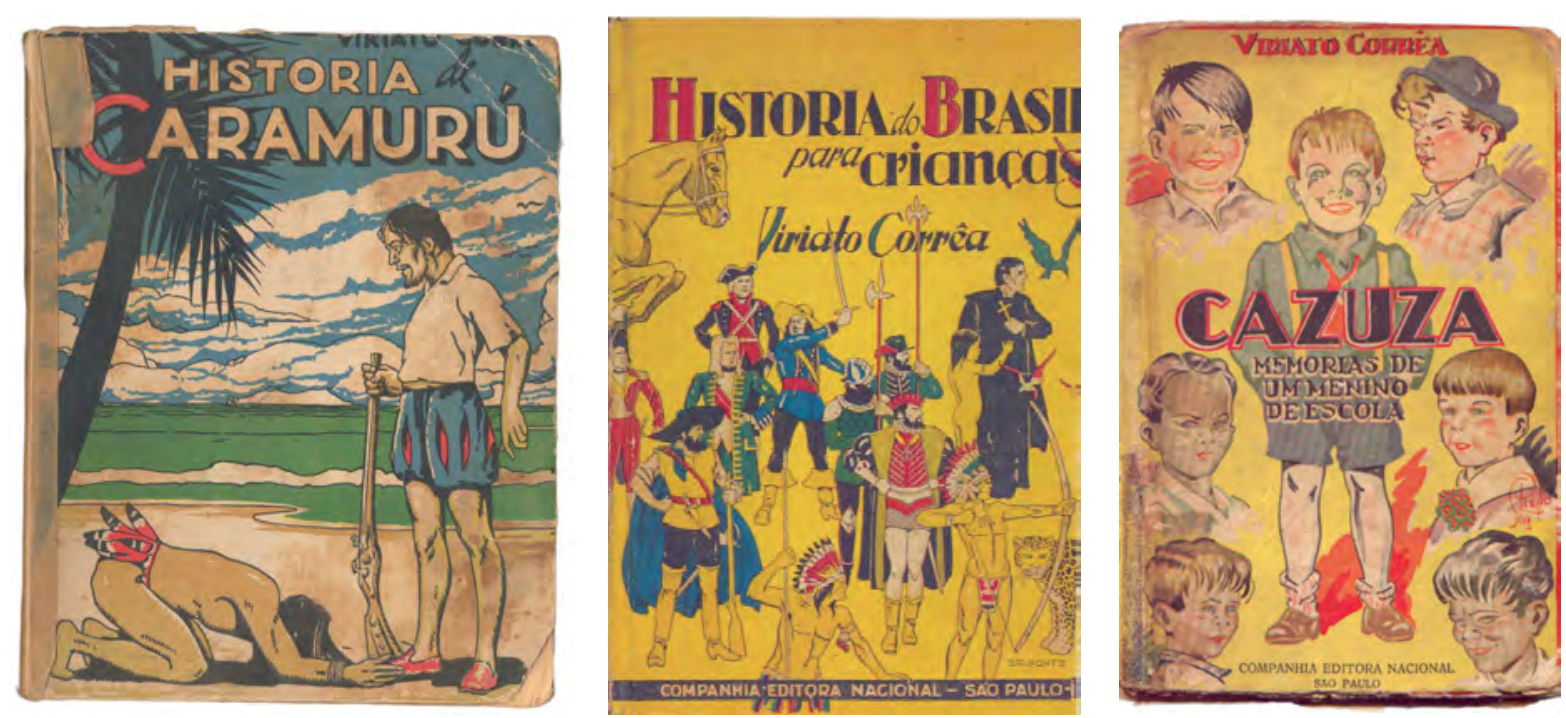

Fig. 4.5. Capas de obras infantis de Viriato Corrêa: História de Caramuru e História do Brasil para Crianças (1934, com ilustração de Belmonte) e Cazuza (1938, com ilustração de Renato Silva). [Fonte: BLDFEUSP e AHECC/CRE Mario Covas/EFAP/SEE-SP.]

De qualquer maneira, desde o início de suas atividades, a editora já havia identificado segmentos de público, produzia títulos para eles e divulgava esse títulos como se fossem de fato integrantes de uma série, como por exemplo os romances apresentados sob a rubrica Romances do Povo. Mais do que isso, para além do formato e tipo de papel, chegava-se a utilizar leiaute e linguagem de llustração semelhantes nas capas de determinados títulos, e às vezes um mesmo ilustrador, procurando-se criar uma identidade física favorável ao reconhecimento pelo público que se pretendia fidelizar, como por exemplo nos romances e crônicas históricas de Paulo Setúbal (FIG. 2.11). Isto não acontece com outro autor de romances e crônicas históricas para adultos, Viriato Correa, mas seus títulos infantis lançados na década de 1930 e que obtém sucesso imediato, recebem tratamento gráfico diferenciado e são fartamente ilustrados (FIG. 4.5). 
Portanto, a preocupação em organizar e classificar um fundo editorial que se diversificava conforme os segmentos de mercado que se pretendia atingir aparece mesmo antes da constituição das séries e coleções, como atestam as informações de catálogos e fichas de controle e produção a que BEDA teve acesso, que nos permitiu montar a tabela 2.3, (p. 82), e os catálogos de 1931 e 1932 citados (p. 89-90 e 130). Mas conforme vimos na apresentação do conteúdo do Catálogo Geral no 10, de 1933, trata-se agora de um novo estágio, mais avançado, de organização do fundo editorial, como parte de uma verdadeira "política de editar coleções", conforme conceitua Maria Rita de Almeida Toledo [2010, p. 139 a 147].

Segundo a autora:

As coleções de livros são compreendidas como modalidade específica de impresso, que carrega em sua materialidade dupla estratégia de intervenção cultural: a intervenção editorial, que, por meio da reorganização dos textos, objetiva a ampliação do mercado do livro; a intervenção no campo da cultura, que é fruto da seleção e adaptação do conjunto de textos e autores, assim como da prescrição de seus usos em um programa para formação do leitor destinatário da coleção. [...] Essa prática permitiu à editora articular, permanentemente, os materiais editados e o mercado leitor, constituindo uma geografia da cultura em seus catálogos. Também Ihe permitiu associar projetos político-culturais de diferentes intelectuais, em diferentes períodos, que se apresentavam na forma de coleções. [Toledo, 2010, p. 139-140]

Assim, as coleções permitiam estabelecer o marco dos diferentes públicos em função das competências leitoras e interesses, sendo um instrumento comercial importante para atingi-los e fidelizá-los. No caso de algumas coleções voltadas para segmentos especializados ou culturalmente valorizados, a fidelização dos leitores passava também pelo prestígio profissional e intelectual de seus organizadores/editores, que funcionavam como garantia de qualidade das obras:

Além disso, o organizador da coleção funcionava como autoridade legitimadora da seleção empreendida, indicando os títulos e autores necessários para a formação dos leitores. Na constituição das coleções, como já foi indicado, havia regras determinadas de acordo com os objetivos que eram definidos por seus organizadores e que se mostravam, sobretudo, no nome dado a elas. Além disso, a escolha do nome do organizador, do ponto de vista da estratégia comercial, muitas vezes garantia o convencimento do público que a seleção era confiável e servia aos fins que se propunha - funcionava, assim, como propaganda para o público, constituindo-se uma das chaves da difusão dos títulos selecionados. [TOLEDo, 2010, p.143]

Esta estratégia, que foi aplicada ao se trazer nomes de prestígio em áreas de conhecimento como direito e jurisprudência, medicina e pedagogia para as respectivas coleções, será também aplicada na constituição das coleções de didáticos, como veremos adiante neste capítulo. As coleções também desempenhavam importante papel na economia interna da editora, 
propiciando uma especialização em sua produção, com responsáveis pelo acompanhamento dos nichos de mercado específicos, prospecção de manuscritos e padronização de linguagem, procedimentos produtivos, acabamento e visualidade:

O editor geral - no caso Octalles Marcondes Ferreira -, ao delegar a administração das coleções aos organizadores especializados, garantia a pesquisa de manuscritos adequados ao público-alvo, atualizando permanentemente a imagem da coleção para este; isso também permitia a homogeneização dos textos pelo editor responsável, assegurando que as formas materiais da coleção fossem condizentes com os usos aos quais ela estava destinada, e controlava os lugares de difusão do livro e seus impactos. Com essa política, as coleções tinham, na economia interna da empresa, função fundamental para a produção do livro: permitiam a homogeneização dos textos, a especialização no segmento de leitores e a constante reordenação dos títulos de acordo com os espaços de expansão no mercado. [Toledo, 2010, p.143]

No caso dos livros didáticos em geral, cujo lançamento no mercado, seja de primeiras edições, seja de reedições, tem data limite definida pelo calendário letivo, a padronização de procedimentos e de linguagem, incluindo a visual, tem papel decisivo para o andamento da produção e o cumprimento dos prazos, ainda mais se considerando que o livro didático tem produção bem mais complexa que outros gêneros, por envolver trabalho de ilustração, projeto gráfico e diagramação diferenciada. No caso da CEN em particular, que, conforme os catálogos mencionados, oferecia 32 títulos em 1931, 41 títulos em 1932 e 48 títulos em 1933, um volume de produção dessa amplitude encontraria na estratégia de coleções o principal meio para se viabilizar.

Fechando o ciclo de motivações referentes à estratégia de editar coleções:

O investimento nas coleções, por parte dos editores, tem como objetivo ampliar o público leitor pelo barateamento dos custos de cada livro produzido. À medida em que a característica fundamental da produção de uma coleção é justamente a sua padronização em termos de cobertura (capa, lombada, contra-capa), de estrutura interna (estabelece-se um modelo ao qual os textos publicados são submetidos) e das estratégias de divulgação, há um barateamento da produção dos livros nela incluídos. [Toledo, 2001, p. 6]

Segundo a autora, em 1939 o fundo editorial "já se encontrava praticamente todo organizado em coleções", com 21 coleções e séries e 8 classificações fora delas constantes no Catálogo Geral no 14, de 1939-40 (que não obtivemos), abrangendo romance e poesia brasileira e mundial, literatura policial, infantil, juvenil, feminina, filosofia, psicologia, medicina, história e realidade brasileira, filologia, didáticos para todos os níveis, etc. [Toledo, 2010, p. 139-143, onde pode ser vista a relação completa das coleções, séries e classificações].

Assim, mesmo considerando ações precedentes de Lobato e Ferreira, no decorrer da década de 1920, na constituição de coleções ou na simples organização dos títulos do catálogo em função do público, a estratégia de editar coleções foi adotada de forma mais extensa na dé- 
cada de 1930, ao que tudo indica primeiramente pela Nacional. A difusão imediata para outras editoras teria sido decorrência do próprio crescimento do mercado editorial iniciado na década de 1920, com a difusão do livro como mercadoria de massa e a ampliação da publicação de títulos no Brasil, substituindo parte do que era importado. Mas diferentemente do surgimento das coleções na França na segunda metade do século XIX, fenômeno estudado por Isabelle Olivero', no Brasil:

Ela [a coleção] não aparece como estratégia comercial de intervenção em um mercado editorial em crise pelo excesso de concorrência entre os editores, mas pelo contrário, se estabelece com o florescimento do mercado editorial, nas décadas de 20 e 30, tanto em termos do crescimento do número de títulos, autores e das tiragens, quanto pelo número de editoras que nascem no período. É a partir da descoberta de que o livro é um "bom negócio", que as coleções se multiplicam, tendo em vista chegar àqueles que não liam os livros brasileiros e que agora podem passar a lê-los. [TOLEDO, 2001, p. 22]

Mas ao lado das coleções claramente estabelecidas por gêneros como romance e conto policial e de mistério, romance de aventura, romance feminino, prosa e poesia brasileira e livros especializados (médicos, jurídicos etc.), que certamente correspondem a seleções que envolvem linhas editoriais definidas mas uma maior independência em relação a fatores políticos e ideológicos, a Nacional constituirá uma grande coleção, que abrigará também seus livros didáticos, em total consonância com o contexto político e o debate ideológico então desenvolvido no país e seus desdobramentos no campo da educação. Sem abordar este tema não se consegue compreender a opção da Nacional pelo livro didático e a forma que encontrou para oferecê-lo ao mercado.

\subsection{A educação e a escola após a Revolução de 1930}

Como foi visto no capítulo 3, a década de 1920 assistiu a um amplo movimento por transformações de fundo da educação no país, vistas como condição para o desenvolvimento da nação e de seu povo e o cumprimento do ideário republicano. Justamente os mais representativos participantes do debate educacional, que extrapolava entidades como a Associação Brasileira de Educação e as Conferências de Educação e envolvia uma parcela maior da intelectualidade do país, foram chamados para promover reformas em diversos estados da federação. Com a Revolução de 1930, as idéias e reivindicações geradas pelo chamado "entusiasmo pela educação" e "otimismo pedagógico" conforme cunhou NAGLE [2001], e que foram parcialmente materializadas em algumas daquelas reformas, pareciam ser possíveis de serem assumidas

1 Olivero, Isabelle. 1999. L'invention de la colection. Paris :IMEC/Maison des Sciences de L'Homme. Esta obra forneceu o modelo para Maria Rita Almeida Toledo estudar o surgimento das coleções na Companhia Editora Nacional. 
pelo Estado brasileiro, particularmente o direito de todos à educação, gratuita e laica, e a criação de um sistema articulado de ensino, do Primário ao Superior, de abrangência nacional.

De fato, o ano de 1930 foi marcado pela criação do Ministério da Educação e Saúde Pública e o ano de 1931 por um conjunto de medidas promovidas por seu titular, Francisco Campos - ele mesmo um dos reformadores do ensino em Minas Gerais em 1927 -, conhecidas como Reforma Francisco Campos, das quais apresentamos resumidamente as seguintes:

- Criação do Conselho Nacional de Educação, com a finalidade de organizar e gerir um sistema nacional de ensino.

- Organização do Ensino Superior, com a instituição do regime universitário através da implantação do Estatuto das Universidades Brasileiras, que foi a base para a reorganização da Universidade do Rio de Janeiro (1932) e a fundacão da Universidade de São Paulo (1934) e de outras que se seguiram.

- Reforma do Ensino Secundário, com o estabelecimento do currículo seriado, a obrigatoriedade de frequência, a exigência do curso Secundário para o acesso ao Ensino Superior, a divisão em dois ciclos - o Fundamental, de formação geral, com duração de 5 anos, e o Complementar, de preparação a vários cursos superiores, com duração de 2 anos - a equiparação de todos os colégios secundários oficiais ao Colégio Pedro II e a possibilidade de que os colégios particulares a fizessem mediante a inspeção federal.

- Organização do ensino comercial em médio e superior, com a regulamentação da profissão de contador. [RomANELLI, 2007, p. 131-140]

A Reforma Francisco Campos avançou, portanto, na organização de um sistema nacional de ensino, particularmente com respeito ao Ensino Secundário, que foi realmente recriado, com a instituição do currículo seriado, que aboliu de vez os exames parcelados, e a exigência de sua frequência completa para o acesso ao Ensino Superior. Com isso, o Ensino Secundário pode de fato se expandir nos anos seguintes, com o aumento do número de vagas na rede oficial mas também na particular, agora submetidas à uma inspeção unificada.

No entanto, o currículo instituído para o Secundário conservou um caráter enciclopédico e extenso ${ }^{2}$ - mantendo a antiga concepção da educação voltada para as carreiras liberais - e que não se articulava com o Ensino Primário, que não foi objeto da reforma. Assim, o ingresso ao Secundário era feito por exames de admissão que exigiam o que grande parte das escolas primárias oferecidas às classes despossuídas não propiciavam. E durante o curso, um sistema de avaliação rígido e exigente, instituído pela reforma, dificultava o prosseguimento dos menos preparados, sendo responsável por elevados índices de abandono, reforçando o caráter elitista

2 As disciplinas do ciclo fundamental, de formação básica geral, eram: Português, Francês, Inglês, Latim, Alemão (facultativo), História, Geografia, Matemática, Ciências Físicas e Naturais, Física, Química, História Natural, Desenho, Música (Canto Orfeônico). As disciplinas do ciclo complementar, propedêutico, variavam conforme o curso superior a que o aluno se candidataria [ROMANELLI, 2007, p. 135-136]. 
e seletivo do Ensino Secundário, mantendo o dualismo classista na educação brasileira, com o Ensino Primário sendo na prática o grau máximo de educação propiciada à população pobre [ROMANELLI, 2007, p. 136-138].

Também o ensino Normal e o ensino profissional, excetuando o comercial, não foram objetos da reforma, que também não estabeleceu nenhum trânsito entre os cursos profissionais e o Secundário, impossibilitando que os alunos dos primeiros pudessem ter acesso ao Ensino Superior. Assim, a Reforma Francisco Campos, embora tenha sido produto das pressões do movimento reformador da educação e das populações urbanas reivindicando a ampliação do Ensino Primário e do Ensino Médio, não respondeu integralmente a esses anseios e às exigências de uma educação que acompanhasse as necessidades da industrialização e da urbanização que se processavam no país [ROMANELLI, 2007, p. 141-142].

Assim, o movimento renovador da educação, mesmo reconhecendo os avanços da Reforma Francisco Campos, prosseguiu insistindo principalmente em duas questões: a educação como direito de todos a ser propiciado pelo Estado, e que por isso precisaria ser gratuita e laica; e a necessidade da escola única, articulada do Primário ao Superior, rompendo o dualismo da escola para os pobres e a escola para a elite e gerando oportunidades iguais para todos a partir da educação. Essas bandeiras acabaram por traçar uma linha divisória em relação a outro grupo de educadores, ligados à igreja católica, que viam nesse programa a ameaça de monopólio da educação pelo Estado e de ingerência no que era ensinado nas escolas confessionais, que praticamente dominavam o ensino privado no país, e um risco concreto de a escola pública e gratuita esvaziar as escolas privadas. Um forte confronto ideológico entre os grupos de renovadores e católicos se estabeleceu, visando influir nos rumos das decisões do novo governo e na Constituição de 1934, com o primeiro grupo se organizando em torno do Manifesto dos Pioneiros da Educação Nova, lançado em 1932, e o segundo a partir do Centro D. Vital.

O Manifesto, elaborado por Fernando de Azevedo, reformador da educação do Distrito Federal, e assinado por 26 educadores, aprofundava a defesa da escola pública laica, situando o papel a educação no processo de desenvolvimento econômico e cultural do país, e propugnava a aplicação de novos métodos científicos aos problemas educacionais a partir dos conhecimentos produzidos por disciplinas novas como a psicologia e a sociologia da educação. Assim, o Manifesto combinava aspectos específicos da luta política pela educação no Brasil às formulações de John Dewey e do movimento da Escola Nova, responsáveis pela implantação de uma nova pedagogia nos Estados Unidos da América e em países da Europa. A reação católica, além da exigência do ensino religioso obrigatório, manteve-se alinhada com a defesa do ensino e da escola tradicional das elites existente na velha ordem social antes da Revolução de 1930³.

3 Para uma visão mais aprofundada do conteúdo do Manifesto, da luta ideológica entre os dois grupos e de seus sucessos e reveses ver ROMANELLI, 2007, p.142-153. 
A Constituição de 1934 praticamente incorpora as teses do Manifesto, mas concilia com os católicos ao instituir o ensino religioso facultativo. E apesar de a nova Carta definir a educação como dever do Estado, não faz referência aos meios para diagnosticar as necessidades educacionais do país e aos recursos a serem dispendidos. Ao contrário, limita a matrícula à capacidade dos estabelecimentos e reafirma a seleção por meio de provas de inteligência e aproveitamento, o que resulta na limitação da expansão do ensino público [ROMANELLI, 2007, p. 153].

No entanto, mesmo limitada, a expansão do Ensino Secundário decorrente de sua reformulação pela Reforma Francisco Campos, reafirmada pela Constituição de 1934, resultou numa ampliação sem precedentes do mercado de livros didáticos para este segmento.

\subsection{A Biblioteca Pedagógica Brasileira e a missão de renovação da cultura}

Vimos que desde os tempos da Revista do Brasil, Monteiro Lobato integrava um grupo de intelectuais identificados com a idéia de construção de uma cultura nacional e procurava lançar novos autores brasileiros para não só construir um público leitor de livros que sustentasse seu empreendimento, mas também constituir uma opinião pública em torno dessas idéias. Como elas abrangiam a educação e o papel da escola na formação do que deveria ser o homem brasileiro, faziam parte da rede de Lobato vários dos educadores envolvidos com as reformas da educação, e sua Revista foi um dos canais desse debate. Suas editoras também publicaram obras didáticas identificadas com novas propostas pedagógicas, como os livros de Sampaio Doria.

Mesmo não sendo mais proprietário da Nacional, Lobato manteve não só laços de amizade com seu ex-sócio, como contribuía com indicações de autores e mesmo integrava um conselho editorial não formalmente constituído, mas em que sua palavra era ouvida. Assim, é uma consequência quase natural que a identificação com as posições que mesclavam nacionalismo cultural e educação fizesse parte do legado transmitido à nova editora.

É em meio à efervescência cívico-patriótica e educacional que os editores, Lobato e Marcondes Ferreira buscavam identificar seu negócio como uma contribuição à cultura do brasileiro e não apenas como empreendimento comercial vantajoso e lucrativo. Publicam, então, autores empenhados nos debates de transformação do Brasil pela reforma da cultura, sejam autores modernistas de literatura e poesia, sejam autores do mundo escolar e educacional. A célebre frase de Lobato - "Um país se faz com homens e livros" - transforma-se em uma espécie de slogan da editora cuja função educacional é a de fornecer os livros necessários para fazer os homens do Brasil. [TOLEDo, 2001, p. 53] 
Assim, em 1931, a Companhia Editora Nacional anuncia o lançamento de uma coleção de caráter nacionalista e renovador, comprometida com as idéias da reforma da cultura pela reforma da escola e da educação, a Biblioteca Pedagógica Brasileira, a cargo de Fernando de Azevedo, educador responsável pela reforma do ensino do Distrito Federal em 1928 e integrante de maior projeção do movimento renovador, além de participante do círculo de Lobato desde início da década de 1920. Sua escolha como editor e organizador da coleção projetaria a editora e avalizaria a coleção frente outras que se constituíam em busca do público de literatura educacional e sobre a realidade brasileira em pauta naquele momento ${ }^{4}$.

A missão destinada à Biblioteca Pedagógica Brasileira é pedagógica porque deve renovar a cultura, oferecendo para o leitor os elementos necessários para sua formação. Mas também é cívica por estimular o desenvolvimento da cultura nacional e, ao mesmo tempo, de um público capaz de compreender e apreciar essa cultura. Tal projeto também reforça a auto-representação da editora como agência educadora da nação, à medida que é obra editorial de renovação do livro didático, para todos os graus de ensino, e difusão de cultura, em todos os setores de conhecimento.

O ambicioso programa da B.P.B. - de larga ofensiva de renovação cultural - é uma espécie de síntese das propostas preconizadas pelo grupo de educadores, do qual Azevedo fazia parte, que pretendia reformar a cultura realizando ampla reforma educacional que atacasse dois pontos fundamentais: a modificação da mentalidade das novas gerações das classes média e alta, por meio de uma educação mais realista cujos fins seriam o de formar a consciência nacional, preparando melhor as elites do país; educar as classes populares para que encontrassem meios mais racionais de viver, elevando seu nível econômico, moral e intelectual, dando-Ihes a possibilidade de participar da circulação das elites dirigentes do país. A solução educacional seria o modo mais racional de gerar as transformações necessárias para o Brasil. [TOLEDo, 2001, p. 72, grifos da autora referentes a trechos de material de divulgação da editora.]

Esse ideário de "educação para a nacionalidade" ou "pedagogia da nacionalidade" [DuTRA, 2004, p. 14] é então traduzido por um projeto editorial constituído de uma única grande coleção voltada para a renovação cultural que atacaria em quatro frentes - as crianças, os estudantes de todos os níveis, os professores e a população "extra e pós-escolar" - , com subcoleções, as séries, aglutinadas sob a denominação comum "Pedagógica" e seguindo um plano editorial de seleção de títulos e autores voltado para a formação intelectual do leitor.

Assim, a própria ordem das séries segue a ordem etária e de aquisição dos conhecimentos considerados necessários às transformações das mentalidades, embora essa ordem obviamente não exclua o trânsito de leitores entre elas:

- Série I - Literatura Infantil, para despertar e estimular o hábito da leitura nas crianças;

\footnotetext{
4 Em 1927, a Editora Melhoramentos já havia feito o mesmo com outro expoente do movimento renovador, Lourenço Filho, chamando-o para organizar a Biblioteca de Educação, com títulos voltados exclusivamente para o magistério [TOLEDo, 2001, p. 63-64 e MIORIM, 2009, p. 161].
} 
- Série II - Livros Didáticos, de todas as disciplinas, para atingir os estudantes das escolas primárias, secundárias, profissionais e superiores;

- Série III - Atualidades Pedagógicas, para a formação do magistério de todos os graus, com base em novas concepções do ensino de raiz científica;

- Série IV - Iniciação Científica, para o público escolar e pós-escolar, de ampliação e vulgarização do conhecimento em várias áreas da ciência, que depois foi subdividida para também abrigar a Iniciação Técnico-Profissional;

- Série V - Brasiliana, de sistematização do conhecimento histórico e sociológico produzido sobre o país, ponto culminante do trajeto de formação da consciência nacional. [ToLEdo, 2001, p. 66, citando texto de divulgação constante em volumes da coleção.]
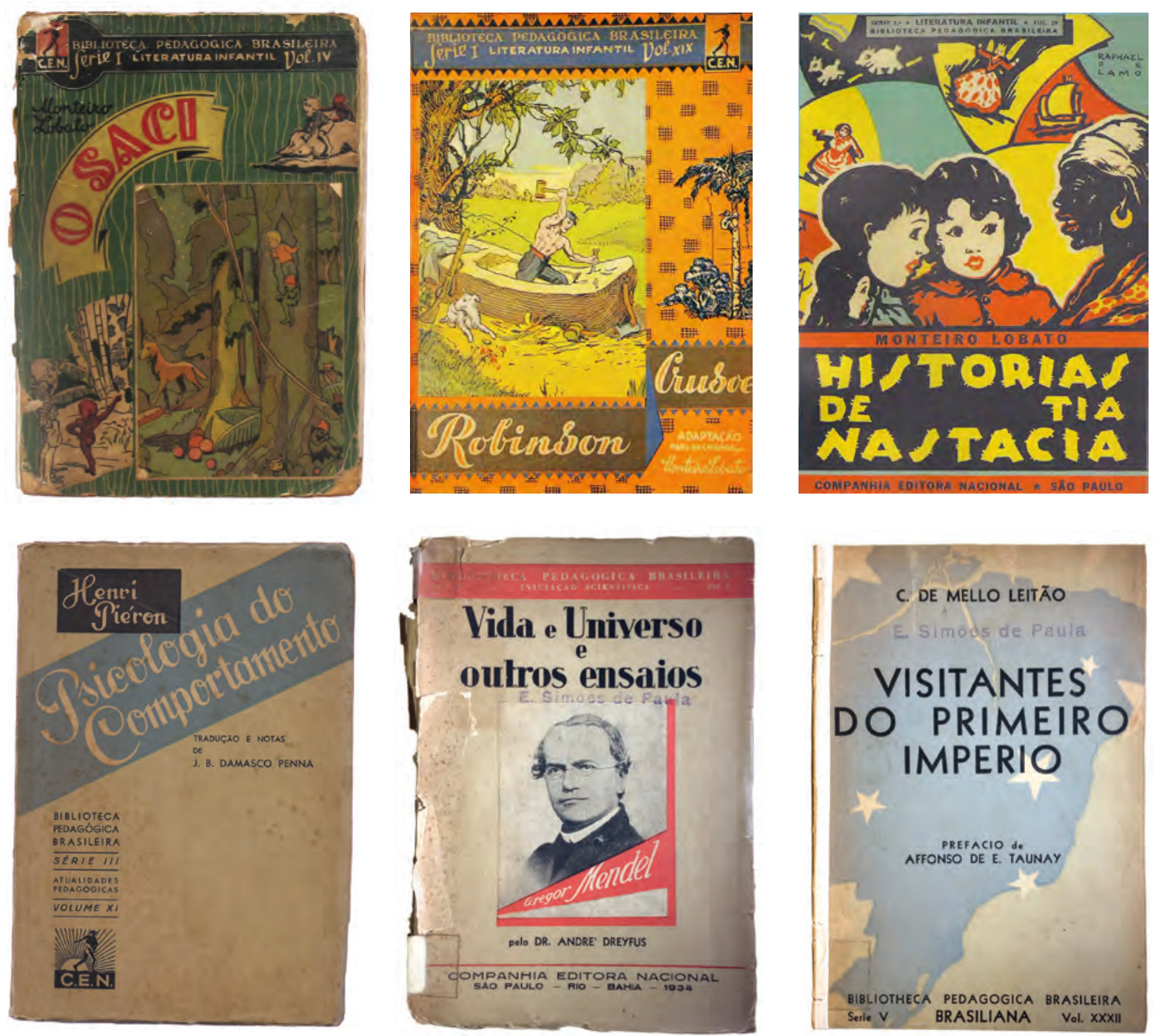

Fig. 4.6. Capas das séries I, II, III, IV e V da Biblioteca Pedagógica Brasileira, em edições da década de 1930. [Fontes: acervo Chico Homem de Melo, IBEP, 2005, acervo pessoal e CAPH - Projeto Memória da FFCL/FFLCH-USP.] 
Consagrando e reforçando a articulação entre as séries estava a chancela do educador Fernando de Azevedo, cujo nome aparece na página de rosto dos livros de todas as séries como organizador geral da BPB, mesmo no caso dos títulos infantis e didáticos já publicados pela editora. Mesmo que as séries I e II da BPB correspondam a segmentos editoriais já cobertos pela produção anterior da editora e que as três última séries é que constituam segmentos novos, destinados a públicos específicos ainda não atingidos pela atuação da editora, a articulação de todas em uma só coleção combina a já mencionada estratégia comercial e produtiva de editar coleções com o projeto político-cultural de reforma da nação pela reforma da educação e marca um novo momento na trajetória da Companhia Editora Nacional.

Não se encontrou a data exata da adoção do conhecido sinal gráfico da CEN (FIG. 4.7), mas suas primeiras ocorrências em peças publicitárias parecem se dar justamente nesse período de expansão da editora. Traduzindo a idéia de semeadura de livros para a construção da nação em direção ao futuro - "Um país se faz com homens e livros", Monteiro Lobato - , a marca evidencia o sentido de projeto nacionalista contido no nome da editora. O símbolo da Biblioteca Pedagógica Brasileira, que aparece nas capas da Série II - Livros Didáticos, retoma o mesmo sentido, pondo em relevo a coleção como meio para se chegar a esse futuro (FIG. 4.7).
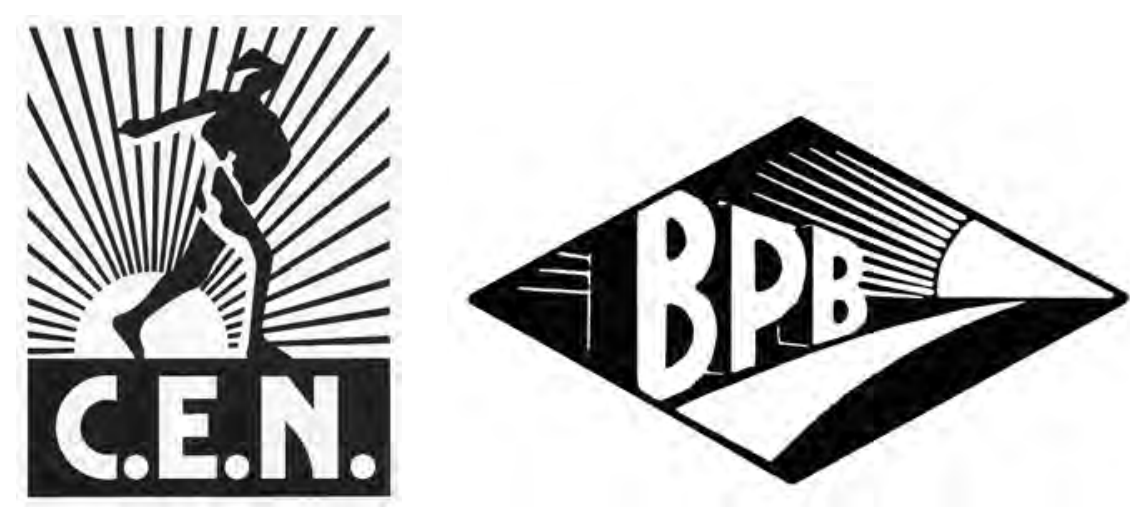

Fig. 4.7. Logotipos da Companhia Editora Nacional e da Biblioteca Pedagógica Brasileira.

Por fim, é preciso dizer que, ao colocar Fernando de Azevedo como titular desta grande coleção, que se pretende de caráter nacionalista e renovador, a CEN acaba por abarcar o projeto político desse educador e vinculá-lo ao seus objetivos comerciais, de certa forma tornando-se seu porta-voz num contexto de forte disputa com o grupo dos católicos, chegando a imprimir e distribuir o Manifesto dos Pioneiros da Educação Nova, em 1932, instrumento do grupo no combate pela hegemonia em relação aos educadores católicos 5 .

\footnotetext{
Como o grupo católico também tinha forte expressão e constituía um mercado considerável, Octalles Ferreira faz de sua editora carioca recém adquirida, a Civilização Brasileira, porta-voz das idéias desse grupo, através do lançamento, em 1932, da coleção Biblioteca Brasileira de Cultura, de livros católicos, atuando comercialmente nas duas frentes [ToLEDo, 2001, p. 65].
} 


\subsubsection{A Biblioteca Pedagógica Brasileira Série II - Livros Didáticos}

Se a Série III - Atualidades Pedagógicas da BPB era o canal para a divulgação dos novos métodos pedagógicos de base científica e o instrumento para formação dos novos professores segundo as novas concepções defendidas pelos signatários do Manifesto, a oportunidade de selecionar autores e encomendar obras para a Série II - Livros Didáticos se inscrevia nos objetivos de realizar uma "ofensiva contra a literatura escolar tradicional, viciada, antiquada e mal apresentada, que é um dos últimos redutos de resistência da escola tradicional" [Fernando Azevedo em carta a Venâncio Filho, citada por Toledo, 2001, p. 175] e instituir novas práticas a partir do livro e da própria sala de aula. Assim, era trabalho de Azevedo - em total consonância com os interesses comerciais da editora em aproveitar a expansão do ensino, Secundário principalmente - constituir uma rede de novos autores, recrutados entre os "melhores professores do país" que se alinhassem com as novas práticas em cada um dos seus campos, para produzir "livros de qualidade e muito baratos" [Toledo, 2001, 175].

A BPB Série II - Livros Didáticos, se apresentava como "a mais ampla e variada coleção que já se tentou no Brasil, de obras escolares destinadas a todos os graus de ensino, isto é, de manuais, livros de texto e livros-fonte, para alunos das escolas primárias, secundárias (gerais e profissionais), normais e superiores". Tal afirmação, impressa na quarta capa de muitos títulos do período, exprimia claramente a consolidação da estratégia editorial da CEN de organização de um catálogo baseado em coleções.

O lançamento da nova coleção no mercado, em 1932, se deu com um número significativo de títulos - a publicidade de quarta capa de uma obra de 1933 apresenta uma relação de 18 títulos -, alguns trazidos do catálogo anterior a 1931 e outros novos, chegando em 1939 a "mais de cem volumes", conforme publicidade de quarta capa de obras editadas naquele ano.

Nem todos os títulos dessa série foram selecionados por Fernando de Azevedo a partir de seu propósito de privilegiar novas epistemologias didáticas. Várias das obras já editadas entre 1926 e 1931 são trazidas para a coleção, como também novos títulos de professores destacados que optam por metodologias já questionadas naquele momento, como é o caso das obras de Matemática de Jácomo Stávale [Mıorım, 2006, p. 12]. De outro lado, títulos de grande aceitação, que já constituíam séries oferecidas ao público, permaneceram fora da coleção, como os já mencionados livros de leitura de Thales de Andrade e de Theodoro de Moraes, enquanto que obras novas não chegaram a integrar a coleção, como os livros de História de Joaquim Silva. Mas num cômputo geral, com poucas exceções, a quase totalidade das obras didáticas editadas na primeira metade da década de 1930 fazia parte da BPB Série II, como pode ser verificado nos catálogos obtidos e nas relações de obras constantes nos volumes, que permitem acompanhar a evolução da coleção. 


\subsection{Novas coleções de didáticos, livros avulsos e o declínio da BPB Série II - Livros Didáticos}

Embora a BPB Série // tivesse sido planejada para ser a coleção de livros didáticos da CEN, com a marca da inovação pedagógica, na segunda metade da década de 1930 surgirão duas novas coleções de didáticos, a Biblioteca Escolar Brasileira, sob a direção de Aníbal Bruno, e a Coleção Dom Bosco, dirigida pelo padre Edgar de Aquino Rocha, além dos novos títulos que surgirão avulsos. Estes fatos parecem ser um reflexo interno na editora das derrotas sofridas por Fernando Azevedo e o grupo de renovadores no campo institucional, com os católicos assumindo o controle da política educacional no país, com a escolha de Gustavo Capanema como novo ministro da Educação e os recuos da constituição outorgada de 1937, num contexto do estabelecimento da ditadura do Estado Novo [Toledo, 2010, pp. 155-6].

Assim, numa adequação da editora à nova conjuntura política e condições de mercado, a corrente católica era acolhida e alguns autores da BPB, desejosos de não serem mais identificados com seu projeto, eram liberados contratualmente. Por fim, Fernando de Azevedo, bastante desgastado e atacado, se afasta em 1939 da direção geral da BPB, que deixa de existir com as mesmas características, com suas séries transformando-se em coleções autônomas, ao lado de outras que foram criadas. A Série II - Livros Didáticos perderá diversos títulos mas ainda terá alguns acréscimos nos anos 1940, com seu 147ㅇe e último volume sendo lançado em 1953. Mas segundo BARBOSA [2009, anexos: planilha], alguns títulos remanescentes terão edições sob o selo BPB Série Il até 1957, embora exemplares encontrados traziam essas indicações apenas na página de rosto, não nas capas.

\subsection{O design e a materialidade dos livros didáticos da Companhia Editora Nacional de 1932 a 1942}

A pesquisa material, também realizada majoritariamente na Biblioteca do Livro Didático da FEUSP, concluiu pela documentação de 68 títulos para o período, assim distribuídos:

- Biblioteca Pedagógica Brasileira Série II - Livros Didáticos, 40 títulos (Secundário);

- Coleção Bom Bosco, 5 títulos (3 Secundário, 2 comercial);

- Biblioteca Escolar Brasileira, 4 títulos (Secundário);

- Biblioteca de Estudos Comerciais, 2 títulos;

- Série Cezario Motta, 1 título (Primário);

- Série Thales de Andrade, 1 título (Primário);

- Livros para o Departamento de Educação do Distrito Federal, 2 títulos (magistério);

- Livros avulsos, 13 títulos (2 Primário, 9 Secundário). 
O protagonismo das coleções, particularmente da BPB Série II, fica assim confirmado.

Quanto à forma de apresentar o design do período, também se optou por manter a separação entre capa e miolo, pois da mesma forma que no período anterior ainda vige uma produção separada dos dois componentes, além de que a produção de cada um deles se especializou ainda mais, tanto pelo estabelecimento da política de coleções, que padronizou a solução de capas, como pelo engajamento definitivo da editora na publicação de didáticos e o consequente aumento do número de títulos e diversificação de disciplinas cobertas.

Como característica material comum a todos os títulos didáticos da Nacional nesse período está a encadernação industrial conhecida com encadernação inteira, em que três planos de cartão espesso, correspondentes à primeira capa, quarta capa e lombada são recobertos por uma única lâmina de papel liso impresso com as informações do volume, acabamento este que já aparece em títulos de 1931, como vimos no capítulo anterior.

Assim, os títulos da Biblioteca Pedagógica Brasileira Série II - Livros Didáticos tem todos capa dura obtida por encadernação inteira, acabamento encontrado ainda na Série I - Infantis e na Série III - Atualidades Pedagógicas, enquanto as séries IV - Iniciação Científica e V - Brasiliana) eram constituídas de brochuras, além da apresentação visual diferente de cada uma, como pode ser visto nas capas reproduzidas na FIGURA 4.6.

O padrão de acabamento encontrado nos livros didáticos das demais editoras atuantes no segmento também era a encadernação em capa dura, mas a CEN alardeava a qualidade superior de sua cartonagem como argumento de vendas:

"Da boa cartonagem depende a duração dos livros didáticos que se destinam ao manuseio continuado ao menos por um ano inteiro, precisam ser fortes. Acontece, entretanto que se fizerem excepcionalmente sólidos, tornar-se-ão demasiadamente caros. O justo será um termo médio que permita serem duráveis e ao mesmo tempo acessíveis às bolsas do estudante [...] As capas devem ser cobertas de papel forte e acetinado e nunca em papel áspero porquanto este, ao atrito das mãos, se esfarela." [Catálogo da CEN de 1936, apud DUTRA, 2004, p.11-12]

\subsubsection{O design de capas da Biblioteca Pedagógica Brasileira Série II - Livros Didáticos}

Diferentemente dos didáticos das outras editoras, que apresentavam maior diversidade de soluções de design, os títulos da BPB Série /l apresentam uma visualidade padronizada, com um leiaute básico e formato com poucas variações, como pode ser visto na fIGURA 4.8. Aqui fica particularmente evidente uma das motivações que leva a editora à já mencionada decisão de de organizar seu fundo editorial em coleções: a padronização dos processos de produção dos livros, que inclui o desenho e finalização de um de seus componentes, a capa, procedimento necessário para a produção intensiva que então se realizou, com quase vinte títulos lançado no primeiro ano. 

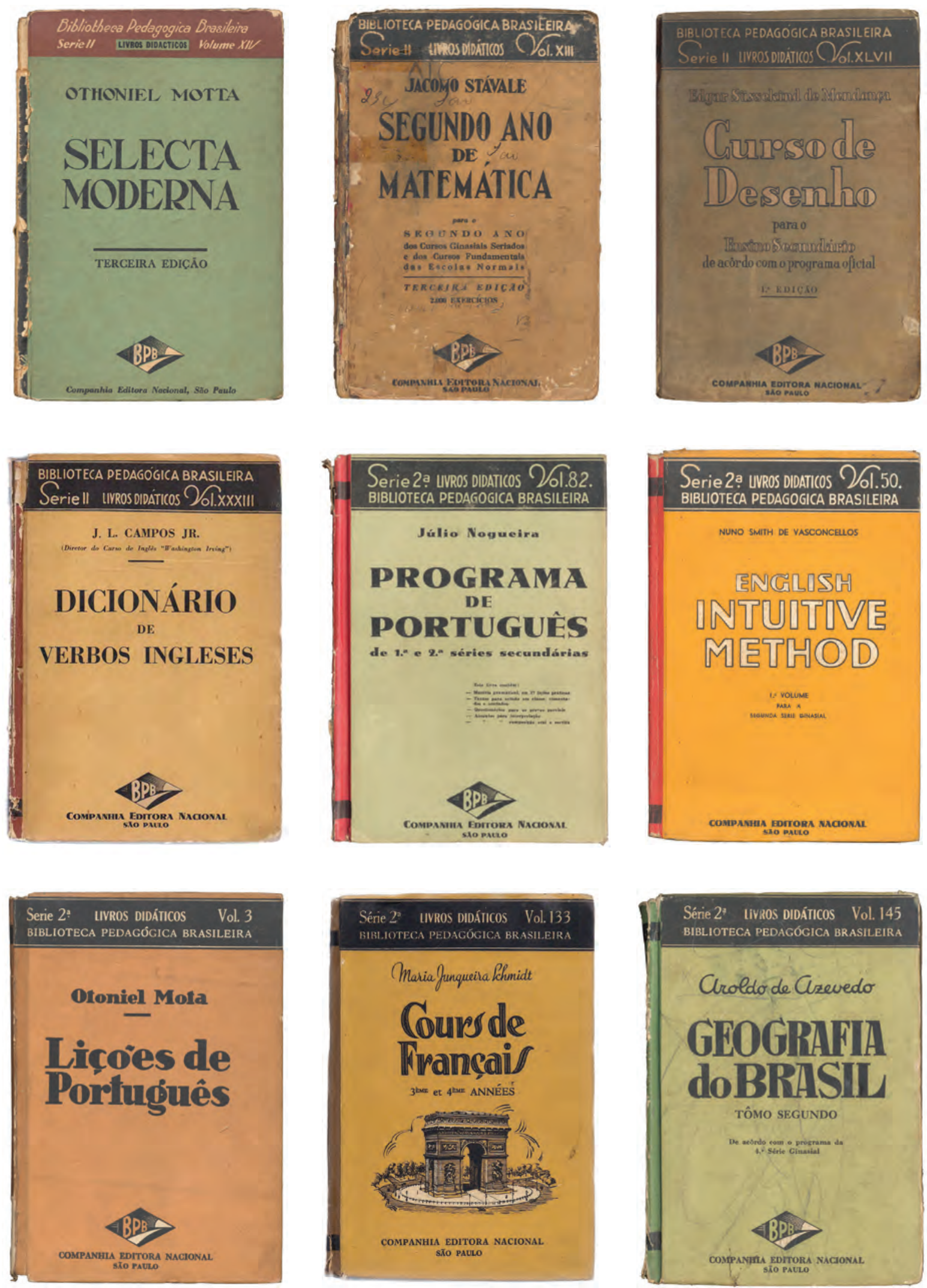

Fig. 4.8. Capas da BPB Série /l da década de 1930 e 1940. 
A solução é fundamentalmente tipográfica, sendo o desenho das letras e a composição dos títulos e demais informações, ao lado das cores de fundo e lombada, os principais recursos para se criar uma particularização visual para cada volume. Raramente havia ilustrações - dos títulos da BPB Série /l encontrados na pesquisa material, apenas o Cours de Français apresentava pequena ilustração dentro do mesmo leiaute de capa da coleção (FIG.4.8) e outros dois tinham ilustrações em leiaute de capa e formato diversos do padrão da coleção: Mon Petit Univers e Desenho ao alcance de todos (FIG.4.9).

O resultado era uma sobriedade visual talvez condizente com a séria missão de remodelar o ensino no país e que fornecia uma identidade inequívoca para a coleção, mas que acabava por igualar livros destinados a faixas etárias muito diversas, aparentemente servindo apenas ao propósito de viabilizar uma extensa produção anual de títulos em prazos determinados pelo calendário escolar.
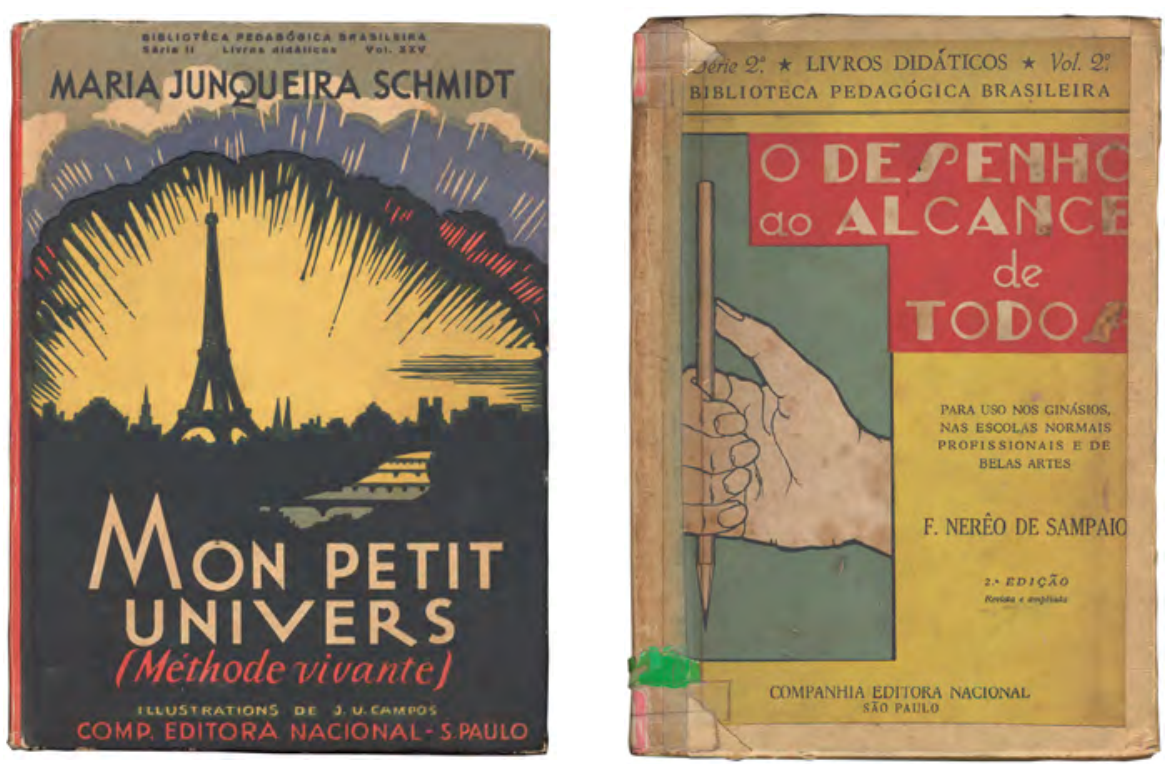

Fig. 4.9. Capas de Mon Petit Univers, 1a edição, $1934(15,7 \times 21,3 \mathrm{~cm})$ e Desenho ao alcance de todos, 2ª ed, 1938 $(15,0 \times 21,0 \mathrm{~cm})$.

Ao longo da existência da BPB Série II - Livros Didáticos, foi possível identificar a sucessão de quatro modelos, que as capas dos livros lançados em cada período de vigência do modelo seguiam. Na verdade, o diagrama básico da coleção parece ter sido definido no primeiro modelo e a maior alteração apareceu com a adoção do segundo modelo, com variações menores ocorrendo a partir daí. Também pelas datas das edições foi possível constatar que as reimpressões de alguns livros ainda mantiveram o desenho do modelo da época de seu lançamento, com a adaptação ao novo modelo só ocorrendo posteriormente. 
Primeiro modelo (1932-1933)
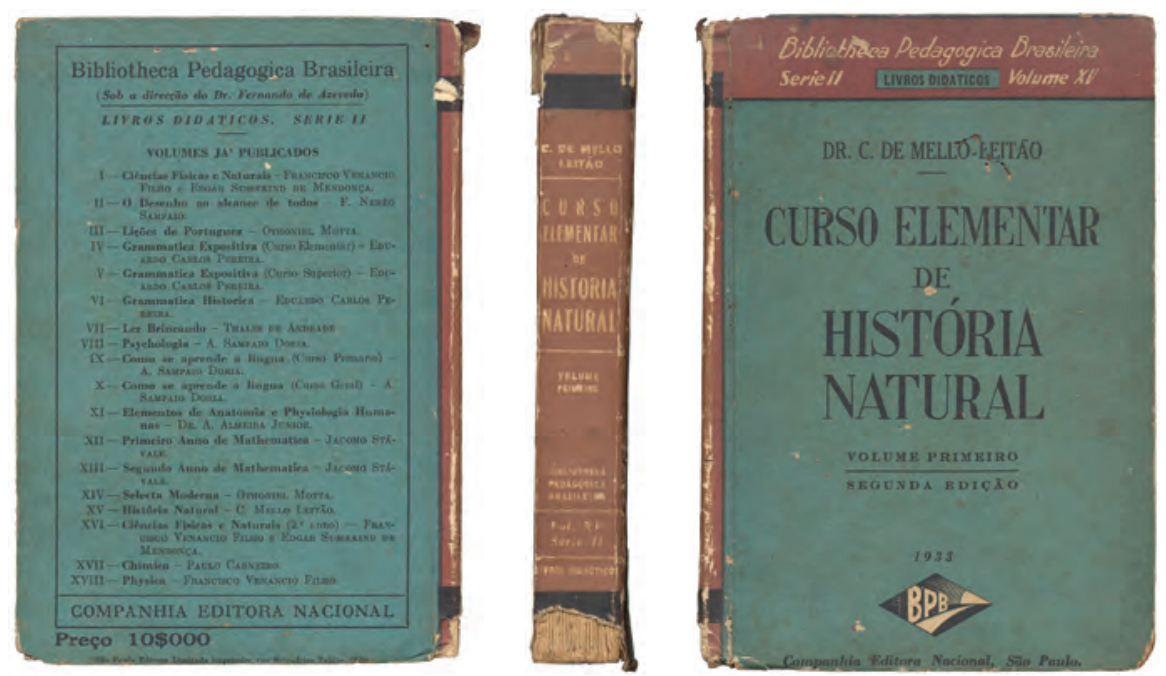

Fig. 4.10. Capa de 1933, correspondente ao primeiro modelo, em que a faixa superior tem a mesma cor da lombada. Quarta capa com quadro de fios envolvendo lista de obras da coleção.

Como dissemos, formato e organização das informações foram definidos por esse primeiro modelo, que nossa pesquisa indica ter vigorado apenas nos dois primeiros anos do lançamento da coleção, isto é, em 1932 e 1933.

Dentro de um formato padrão médio de 13,7 x 19,7 cm, incluída a capa dura $(13,2 \times 19,2$ internos), o diagrama básico da primeira capa comporta uma organização das informações centralizadas na seguinte sequência vertical, de cima para baixo, conforme a FIGURA 4.10:

- faixa ou caixa superior estreita em impressão de cor chapada com a identificação da coleção, série e volume em duas linhas de texto vazado;

- área restante chapada colorida com impressão em preto de:

- autoria, composta tipograficamente ou na maioria das vezes com letras desenhadas;

- título da obra ou disciplina em letras maiores, composta tipograficamente ou na maioria das vezes com letras desenhadas;

- subtítulos e/ou qualificações e/ou número de edição;

- símbolo/logotipo da coleção BPB seguida de assinatura da editora.

A lombada tem a mesma cor da faixa superior, também com os dizeres vazados. A quarta capa geralmente apresenta texto promocional sobre a BPB ou relação de volumes publicados6.

\footnotetext{
6 As quartas capas eram reservadas para publicidade da coleção, geralmente com lista de obras, ou mesmo publicidade de títulos de disciplinas afins, mesmo que não pertencentes à coleção. Como não apresentam diferenças em relação ao que foi visto no capítulo anterior, não serão reproduzidas neste capítulo.
} 


\section{Segundo modelo (1934)}
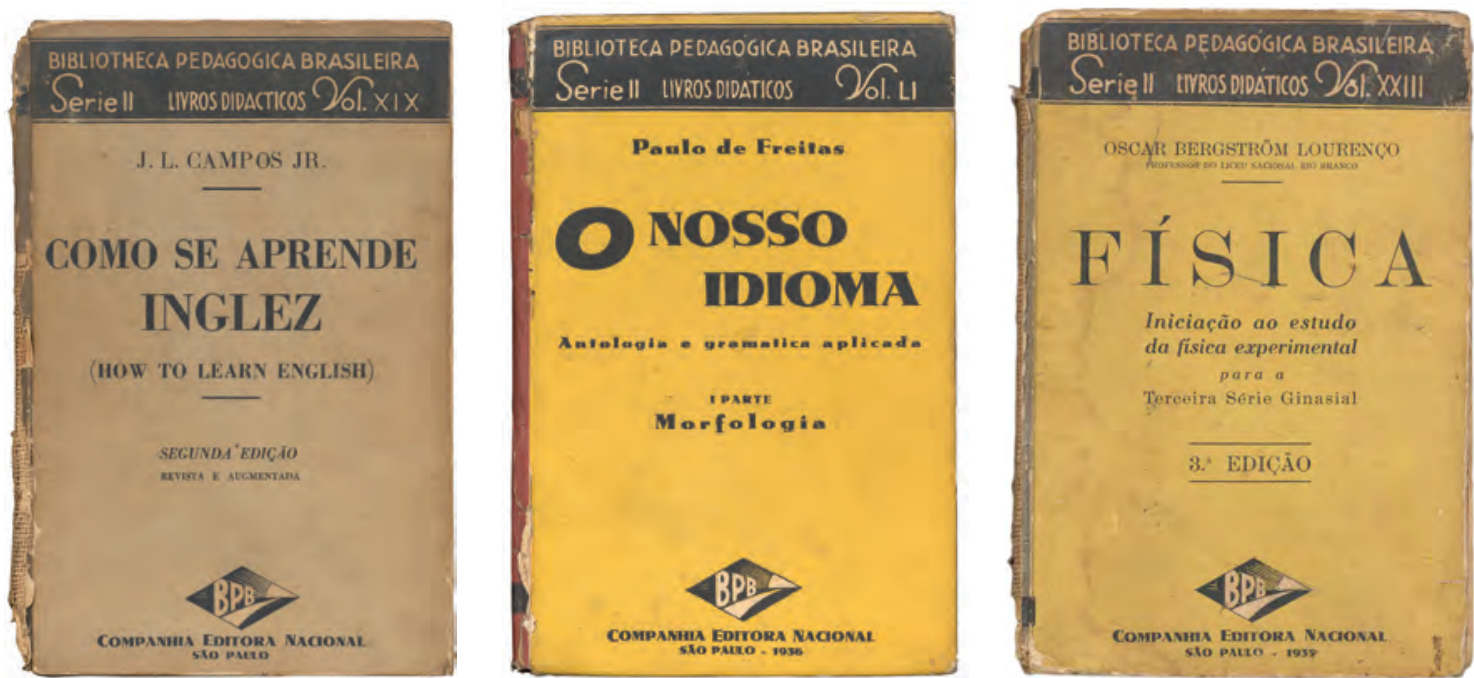

Fig. 4.11. Capas de 1935 e 1936, correspondentes ao segundo modelo, com faixa superior em preto e nova organização tipográfica das informações textuais.

A sequência dos grupos de informações da primeira capa do primeiro modelo permaneceu a mesma neste segundo modelo, que na pesquisa material aparece pela primeira vez em 1934, com as seguintes modificações de desenho e composição sendo introduzidas:

- a faixa superior com as informações da coleção passa a ser preta, contornada por frisos;

- Informações textuais na faixa superior ocupando maior largura, com estabelecimento de contraste tipográfico entre subgrupos textuais - caixa alta para o nome da coleção, capitulares para série e volume, caixa alta estreita para nome da série (Livros Didáticos) em letras ainda feitas à mão, bastante irregulares, e vazadas na faixa (FIG. 4.11).

\section{Terceiro modelo (1936)}
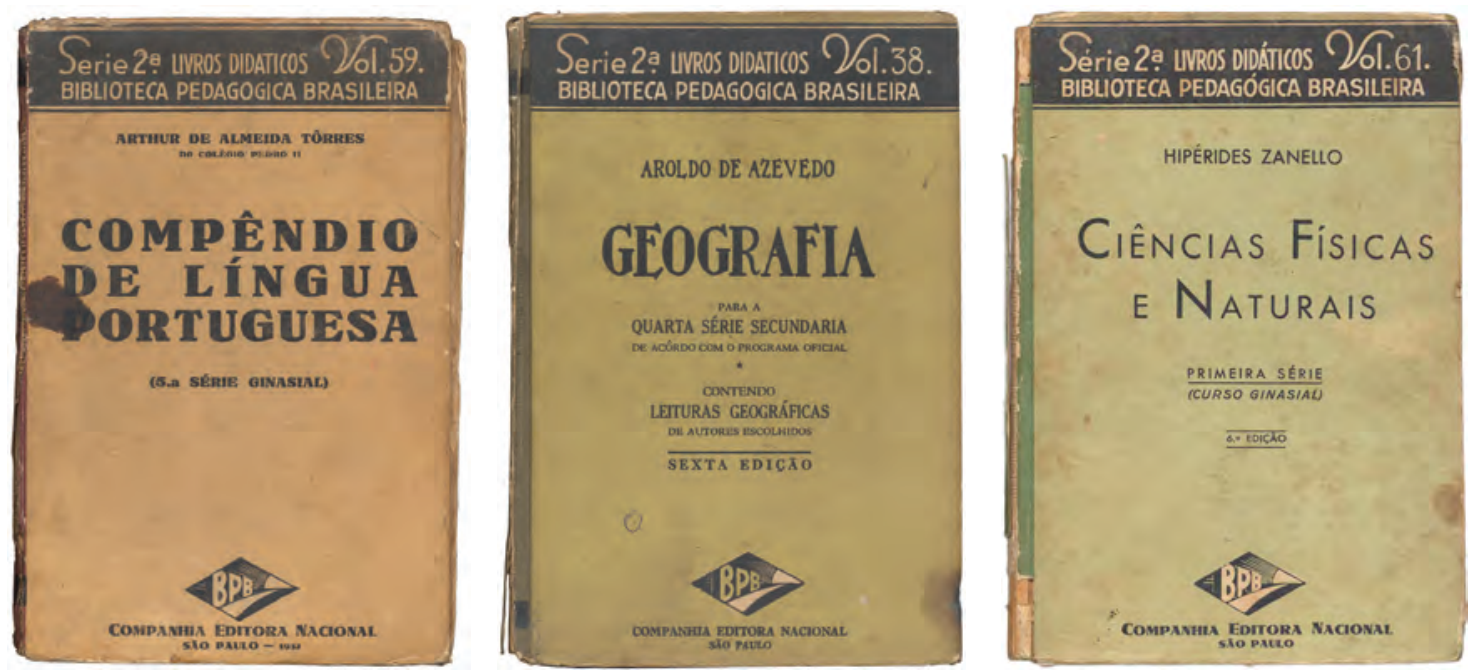

Fig. 4.12. Capas de 1937 e 1938, correspondentes ao terceiro modelo, com nova organização interna das informações na faixa superior. 
Diferenciado em relação ao segundo modelo apenas pela inversão entre as linhas referentes à coleção maior e à série e volume, permite supor a intenção de reforçar a informação específica da série e do volume em detrimento da coleção, ou então de obter maior coesão formal, que é um resultado perceptível (FIG. 4.12).

Essa solução aparece em um título com data de 1936, em maior número em títulos de 1937 e 1938, mas também em muitos títulos de 1939 e dos anos 1940, o que indica ausência de preocupação com atualização e padronização talvez decorrente da apontada perda de importância da coleção naquela última década.

\section{Quarto modelo (1938)}
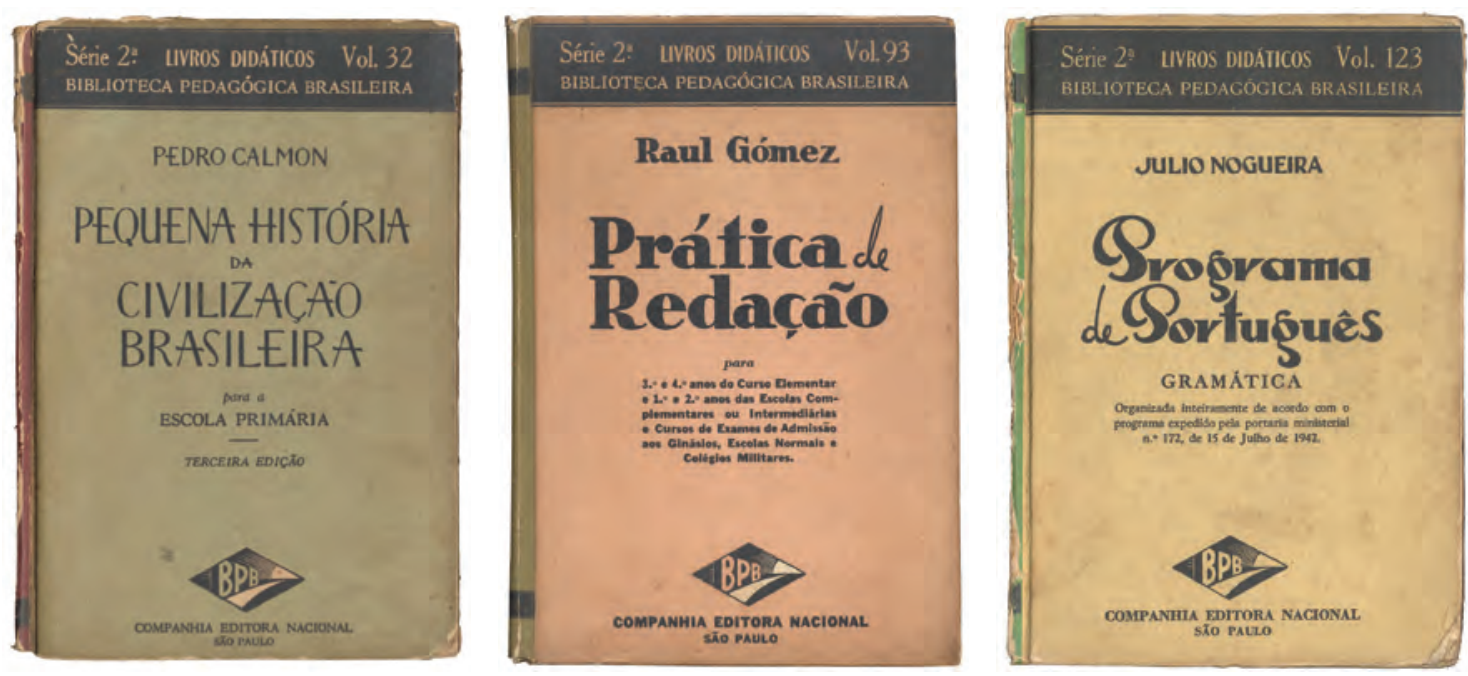

Fig. 4.13. Capas de 1938, 1943 e 1948, correspondentes ao quarto modelo, com composição tipográfica nas informações da faixa superior e maior regularidade na composição ou desenho de letras dos títulos.

Neste modelo, introduzido em 1938, as informações da faixa superior passam a ser compostas tipograficamente, marcando uma regularidade formal maior, que também será vista na composição ou desenho de letras dos títulos, que mesmo variando parecem indicar uma preocupação com uma configuração mais estável e duradoura do projeto (FIG. 4.13).

\section{A linguagem gráfica e a organização das informações nas capas da BPB Série II - Livros didáticos}

Por se tratar de um grande grupo de capas com uma solução basicamente comum, ensaiou-se aqui a conveniência de aplicar alguns métodos de análise gráfica que, embora não tenhamos utilizado explicitamente no primeiro período e só voltemos a utilizá-lo no terceiro período, parece ser perfeitamente aplicável às situações similares que venham a ser encontradas. O primeiro método é, na verdade, um "esquema" bastante geral de classificação das manifestações da linguagem gráfica, conforme denomina seu autor, Michael TwYMAN [1979, p. 117-150]. 
O esquema de classificação das manifestações da linguagem gráfica de Twyman é constituído por uma matriz formada por dois eixos de análise, um referente ao método de configuração, que pode ser de sete tipos (linear, linear interrompido, lista, ramificação linear, matriz, visualização dirigida não linear, visualização aberta), e outro referente ao modo de simbolização, que pode ser de quatro tipos (verbo-numérico, verbo-numérico e pictórico, pictórico e esquemático). A combinação de ambos os eixos resulta em 28 possibilidades de caracterização de manifestações de linguagem gráfica.

A aplicação desse modelo à análise do leiaute básico das capas da BPB Série /l permite nele reconhecer um método de configuração de visualização dirigida não linear e um modo de simbolização verbo-numérico pictórico.

O primeiro termo quer dizer que a leitura das informações não segue a disposição sequencial linear das unidades linguísticas, mas "salta" por elementos distribuídos no espaço gráfico a partir da utilização de recursos gráficos que orientam o movimento do olhar. Assim, no caso de qualquer volume da BPB Série II, a informação primeiramente percebida é o conjunto título-área da coleção, com o título sendo lido em primeiro lugar, seguida pelo reconhecimento do logotipo e nome da editora no pé da capa. Em alguns casos, as informações da editora são percebidas quase simultaneamente com o nome do autor, mas este em geral é lido depois, para só então as demais informações serem decodificadas.

O segundo termo faz referência à natureza sígnica das informações, que inclui palavras e imagens, com o logotipo da BPB estando presente em quase todas as capas. No caso da capa do Cours de Français (FIG. 4.8), é ainda mais evidente a combinação método de configuração não linearmente dirigida $X$ modo de simbolização verbo-numérico pictórico, com uma ilustração efetivamente participando da composição e informação do volume [TWYMAN, 1979, p. 119-122 e 129].

Já para se proceder ao entendimento da organização interna do leiaute das capas da BPB Série Il - Livros Didáticos e seu papel na construção da informação veiculada, isto é, chegar-se a uma aproximação maior da análise das capas como peças gráficas de comunicação, empregou-se o método proposto por Paul MiJKSENAAR [1997, p. 38-42]. Este método, elaborado como ferramenta de projeto em design de informação para situações de grande complexidade de comunicação, tem sido utilizado também na análise da informação veiculada por peças gráficas prontas, inclusive em pesquisas em história do design?

Como as capas não correspondem a situações de informação tão complexas como as enfrentadas pelo design de informação tratadas por Mijksenaar, que exigem a elaboração de gráficos com eixos e atribuição de pesos, positivos e negativos, para cada tipo de informação, adotamos aqui uma versão simplificada do método do autor, mas em que estão presentes as

7 Um exemplo da utilização do método de Mijksenaar em pesquisa de história de design no Brasil é o trabalho de Solange Coutinho, O Sistema informacional nos rótulos comerciais de cachaça em Pernambuco (1940-1970) [CoUTINHO, 2011]. . 
três variáveis gráficas que ele utiliza, quais sejam, variáveis de hierarquia, variáveis de categorização e variações de suporte. O emprego dessas variáveis, articuladas entre si, resulta na organização e hierarquia da informação.

Combinando a definição de cada variável gráfica com sua ocorrência nas capas da BPB Série II, identificamos:

1) Como variáveis de hierarquia, isto é, que indicam a diferença pela importância, temos:

- posição no espaço gráfico: informações de coleção/série no topo; título no centro; logotipo no pé;

- diferenças de tamanho e intensidade: dimensão das áreas; corpo das letras para as várias unidades de informação;

- espaçamento entre as informações.

2) Como variáveis de categorização, isto é, que indicam a diferença pelo tipo de elemento gráfico-visual utilizado para a informação, temos:

- uso de cor: informações de coleção/série no preto (ou vermelho nas capas do primeiro modelo); fundo geral da capa em cores chapadas variáveis conforme o volume;

- desenho de letra: diferentes para a informação da série/coleção e para o título/autor;

- uso de ilustração: para o nome da coleção (sinal gráfico/logotipo);

3) Como variáveis de suporte, temos linhas, fios e cores de fundo, que contribuem para acentuação e ênfase das informações organizadas pelas outras variáveis, mas que, excetuando a caixa superior e seu friso, raramente são utilizados nas capas da coleção.

Assim, o leiaute geral da coleção estabelece a posição e diferenças de tamanho (variáveis de hierarquia), o desenho de letra, uso de cor e ilustração (variáveis de categorização) e o elemento gráfico de nome da coleção/série (variável de suporte) dos itens informacionais fixos, com esse conjunto sendo responsável pela identidade da coleção. Os itens informacionais não fixos - título, autoria e informações específicas de cada volume - têm também seu lugar no espaço gráfico (variável de hierarquia) definido pelo leiaute geral, mas será a combinação de uma variável de categorização, o desenho de letra, e de uma variável de hierarquia, corpo da letra, na configuração desses itens, que estabelecerá sua participação na informação geral e sua maior ou menor eficácia comunicativa.

Ou seja, o uso do termo variável gráfica indica que a informação é resultado de combinação e de relações, e nunca de valores fixos absolutos que se possa atribuir aos componentes gráficos participantes da informação, mesmo num diagrama pré-definido como é o caso do estabelecido para a BPB Série II. Observando-se um conjunto de capas, como as da FIGURA 4.8, mesmo com a grande variedade de desenho de letras dos títulos pode-se de forma geral reconhecer a equivalência de pesos dos itens informacionais e a manutenção da hieraquia básica estabelecida pelo leiaute da coleção, além da identidade visual que ele propicia. 

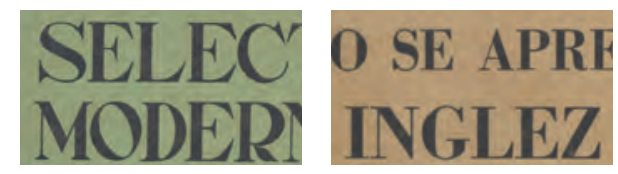

इNGLIS
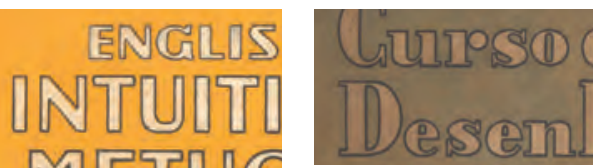
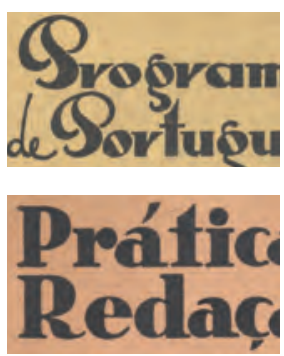
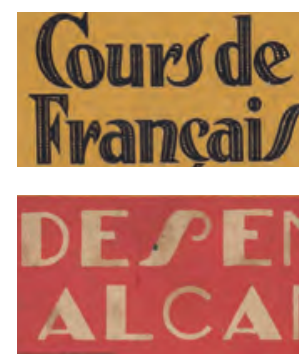
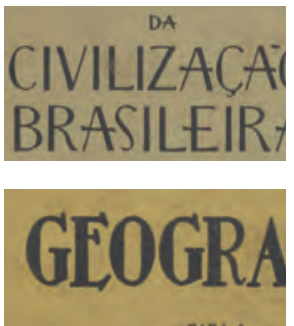

Fig. 4.14 Amostragem de desenhos de letras encontrados nas capas da BPB Serie II - Livros didáticos.

Dado que a opção tipográfica, nas capas da coleção BPB Série II, excluiu a ilustração como elemento particularizador de cada volume, esse papel foi atribuído principalmente ao desenho das letras e seu arranjo, em combinação com a cor de fundo. Ou seja, a opção por uma visualidade econômica e que privilegia a idéia de coleção não excluiu a necessidade de diferenciar cada obra e até mesmo valorizá-la. Assim, é grande a variedade de desenhos de letras utilizadas, bem como evidente o trabalho cuidadoso de composição dos títulos em dimensões e relação apropriadas com o campo e seus elementos, particularmente a tarja superior e o logotipo/símbolo da BPB, mas também nome do autor e demais informações, que resultam em soluções equilibradas e consistentes.

Nota-se também que apenas poucas capas utilizam tipos móveis na composição dos títulos, geralmente compostos com letras serifadas (Como se aprende Inglez, FIG. 4.11). A maioria dos títulos apresenta letras desenhadas à mão livre ou com instrumentos, fato que pode ser observado pela presença de irregularidades e ajustes intencionais de largura para blocar as linhas (como em Selecta Moderna, FIG. 4.8). Algumas têm ainda letras com desenho de contorno (outline), como em Curso de Desenho e English Intuitive Method (FIG. 4.8), igualmente desenhadas à mão.

Na maioria das capas encontradas, o mesmo desenho de letra é utilizado no título e no nome do autor, sendo frequente sua extensão para as informações complementares e a assinatura da editora, evidenciando a intenção de construir consistentemente a identidade visual da obra apoiada na tipografia. Em número menor de capas ocorre a combinação de tipos diferentes, mas havendo cuidado com o desenho geral e identidade da obra, como no Geografia do Brasil e no Cours de Français (FIG. 4.8), que utiliza letra de desenho caligráfico para o autor, como em Geografia do Brasil (FIG. 4.8), ou ainda para iniciais e conetivos, como em Prática de Redação e Programa de Português (FIG. 4.13).

Um trabalho à parte seria identificar as referências e modelos dessas letras, que podem provir de catálogos, mas também de amostras de publicidade ou titulagens de revistas estrangeiras recolhidas pelos letristas, que completariam os caracteres inexistentes, além de realizar desenhos originais ou mais livremente inspirados. Este fato não surpreende, pois a prática de dese- 
nhar os títulos em capas vigorou desde o surgimento da litografia no século XIX, acompanhando o que se fazia nos rótulos e anúncios, até a década de 1960, como pode ser visto em incontáveis exemplos em Cardoso (2005, p. 164-247) e Homem de Melo \& Ramos (2011, p. 357, 360, 372, e 382), prática que só foi superada com a generalização da fotocomposição e letras transferíveis na década de $1970^{8}$. O que pode surpreender é que o desenho dessas titulagens não foi produzido para a impressão litográfica, plana, como ocorria com revistas, rótulos e anúncios e mesmo o miolo dos livros de maior tiragem da editora. Estes títulos desenhados foram reproduzidos pela tradicional impressão tipográfica, mediante a confecção de clichês em relevo fundido.

\section{A BPB Série II: design e tecnologia gráfica}

Todas as capas da década de 1930 e muitas das capas do início da década de 1940, tanto nos livros impressos pela São Paulo Editora como pela Revista dos Tribunais, e quaisquer que fossem os modelos, mesmo com letras desenhadas à mão, tiveram impressão mista, com as áreas de cor impressas em litografia e as áreas pretas impressas em tipografia, mediante o uso de clichês, como parece indicar o exame físico das capas utilizando o método de identificação de impressos proposto por Bamber GASCOIGNE [2011].

Segundo esse método, ampliações de detalhes como as mostradas na FIGURA 4.14 revelam impressão tipográfica do preto, com utilização de clichês, pois se vê claramente a marca da pressão do relevo, causando um halo mais claro e um contorno mais escuro e irregular pelo espalhamento da tinta "esmagada" além dos limites do relevo. Já as cores da capa e da lombada são impressas por litografia, como revela a reserva nas letras do topo e no símbolo mostrando a cor do papel.

A título de comparação, as ampliações dos mesmos detalhes mostradas na fIGURA 4.15 revelam o uso de impressão litográfica, pois o que se vê é uma impressão menos densa e nenhuma descontinuidade nos limites da área impressa, característica da impressão plana segundo Gascoigne.

Não se encontrou, na bibliografia consultada que aborda tecnologias de imºpressão9 ${ }^{9}$, nenhum registro ou menção a respeito da combinação de impressão de uma mesma peça em equipamento relevográfico (tipografia) e outro planográfico (litografia), apenas referência à conhecida combinação entre xilografia e tipografia e água-forte e tipografia encontrada em livros produzidos até o século XIX.

\footnotetext{
8 Um trabalho também a ser feito seria identificar não só a autoria do projeto geral da coleção mas do trabalho de desenho das letras de cada capa, se executado por desenhistas "letristas" do meio editorial ou publicitário contratados para trabalhos pontuais ou profissionais internos da editora. Isto pode vir a ser possível assim que o acervo de obras e documentos da Companhia Editora Nacional, em mãos da Universidade Federal de São Paulo, venha a ser reaberto para pesquisadores.

9 Sobre tecnologias gráficas, foram utilizadas as seguintes obras, constantes nas Referências bibliográficas da tese: SiLVA, 1922; Pollock, 1948; Porta, 1958; Craig, 1980; Rossi, 2005 e GASCOIGnE, 2011.
} 
Uma hipótese plausível para o emprego dessa impressão feita em dois momentos, em máquinas diferentes, com todo o trabalho que acarretava, é a qualidade superior que se poderia obter com a impressão tipográfica, particularmente a densidade do preto, aliada a uma possível permanência de alguma prática vigente na produção de capas encadernadas, que tinham suas informações gravadas por processos relevográficos.

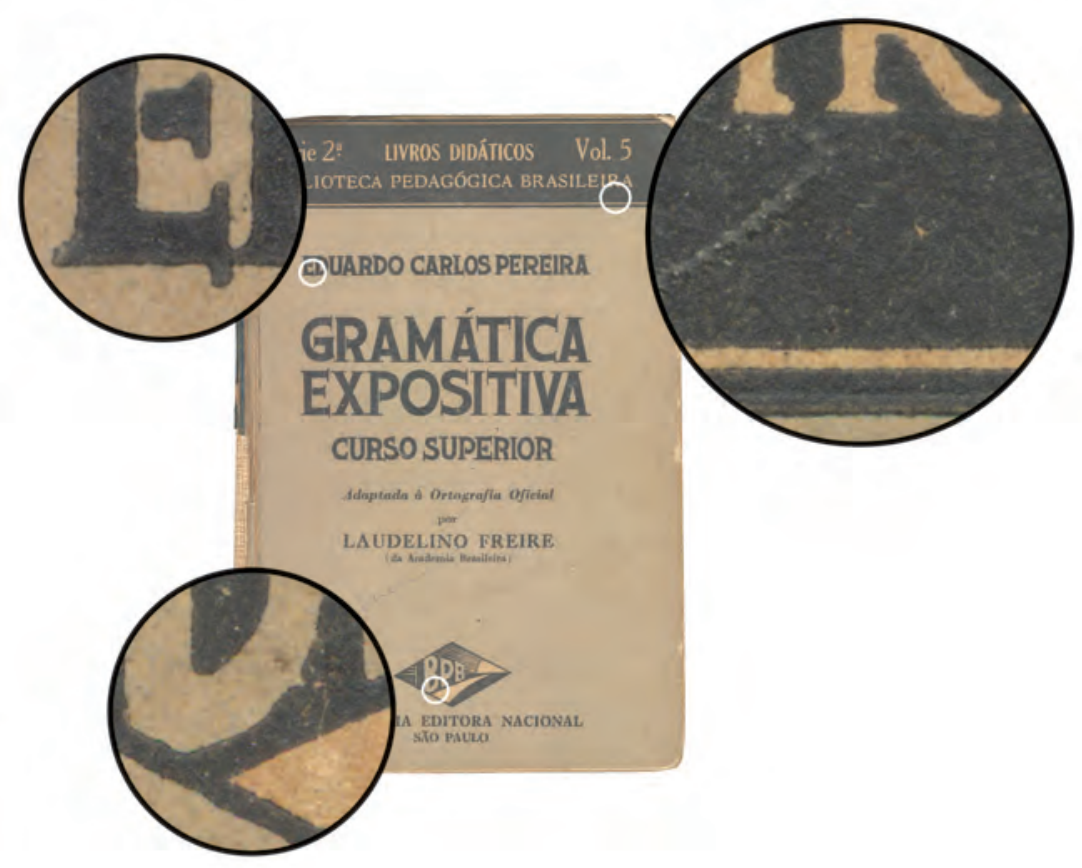

Fig. 4.14. Capa da edição de 1943 da Gramática expositiva, de Eduardo Carlos Pereira, impressa na São Paulo Editora, com ampliação de detalhes.

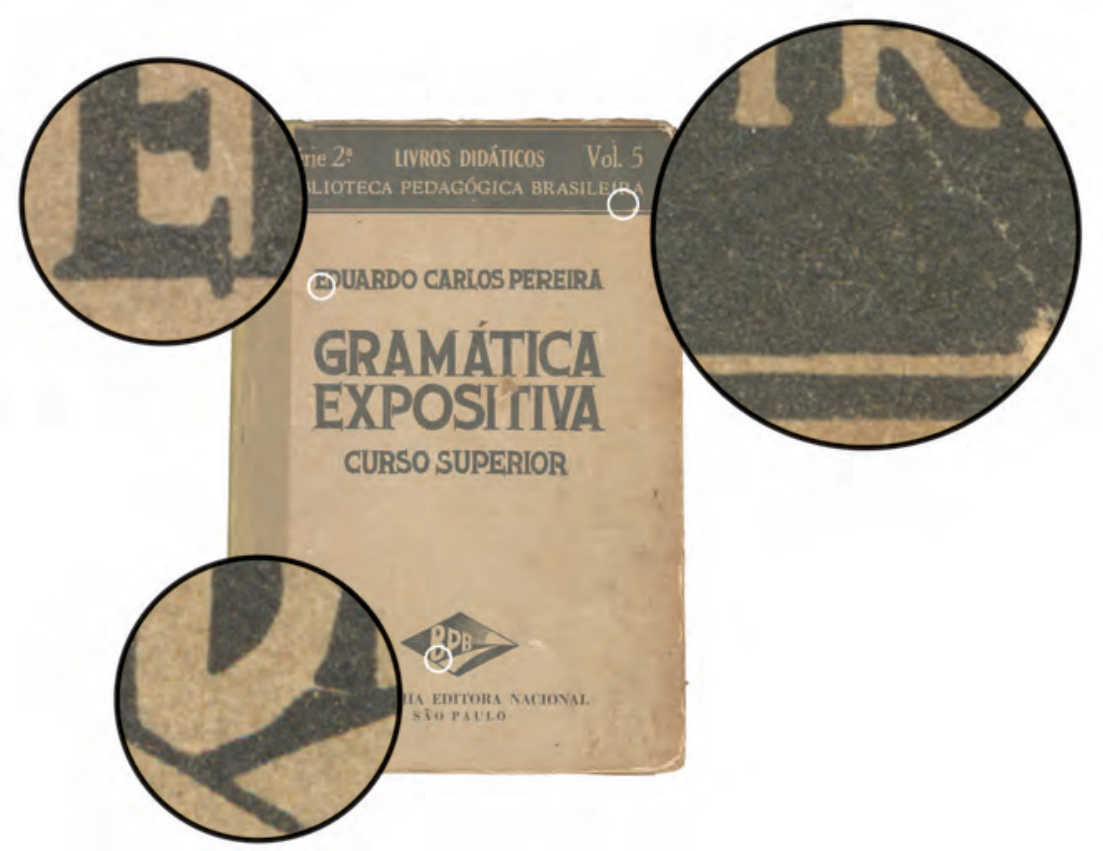

Fig. 4.15. Capa da edição de 1952 da Gramática expositiva, de Eduardo Carlos Pereira, também impressa na São Paulo Editora, com ampliação dos mesmos detalhes. 
Em crônicas sobre o mundo dos livros e autores, Nelson Palma TRAVASSOS, proprietário da gráfica Revista dos Tribunais, afirma: "com a facilidade de reprodução de clichês, enorme é a interferência do desenhista que executa, podemos dizer, tudo quanto há de arte na tipografia, pois o desenho gráfico tornou-se uma especialidade artística" [1944, p. 155-156]. De fato, obras de História, Geografia e Ciências eram impressas tipograficamente, apesar de apresentarem grande número de ilustrações e fotografias, porém provavelmente utilizando rotativas dotadas de chapas cilíndricas com relevo gravado pelo processo conhecido como estereotipia curva [RossI FILHO, 2001, p. 246]. Estas obras tinham grande tiragem e as gráficas utilizadas pela Nacional dispunham desse equipamento [BEDA, 1987, pp. 151-152] ${ }^{10}$.

\subsubsection{O design de capas de outras coleções e de livros avulsos}

Embora a intenção inicial da editora parece ter sido reunir todos os livros didáticos em uma única coleção, alguns autores não se afinavam com as proposições que sustentavam a BPB Série // e duas outras coleções foram criadas, além de uma voltada para o ensino comercial e o surgimento de títulos avulsos que não vieram a integrar nenhuma delas.

\section{Biblioteca Escolar Brasileira}
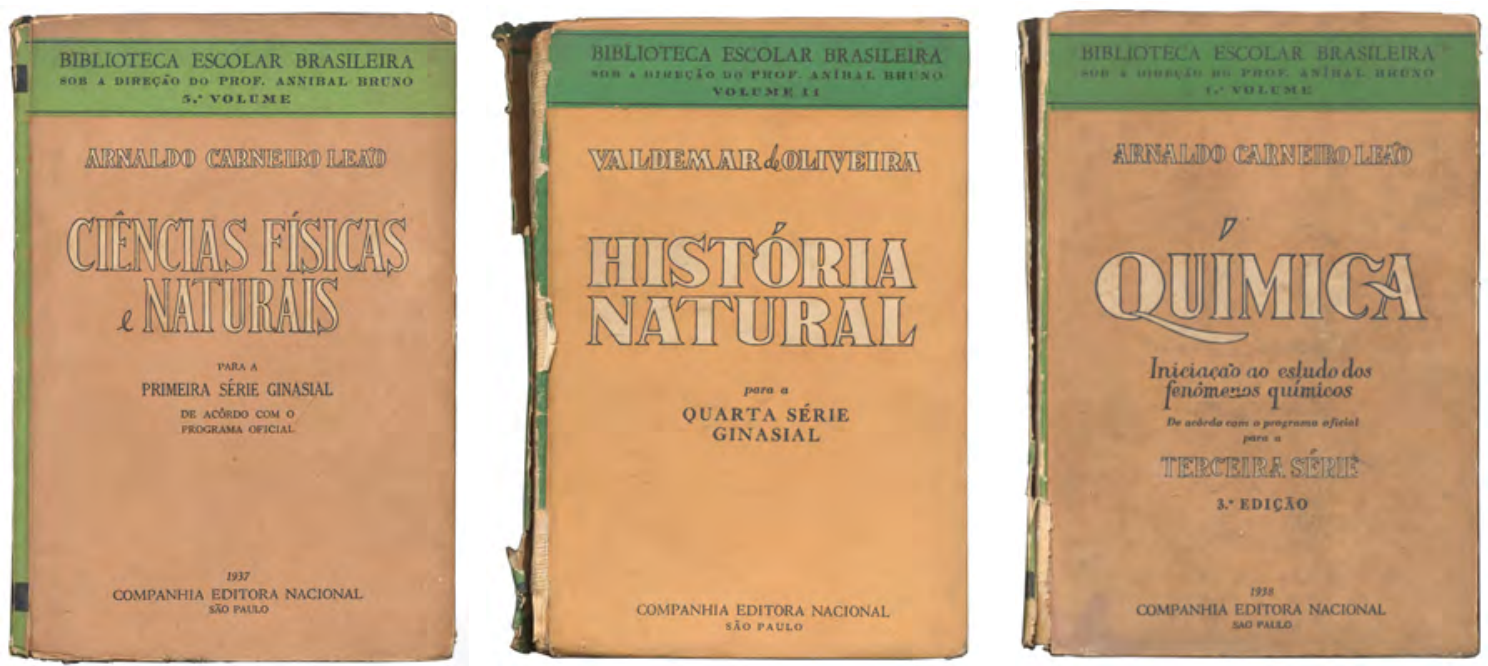

Fig. 4.16. Capas de livros da Biblioteca Escolar Brasileira, em edições de 1937 e 1938 (13,2 x 19,2cm).

O diagrama das capas da Biblioteca Escolar Brasileira segue o padrão da BPB Série II, mas com um desenho diferente para os itens informacionais e de identidade da coleção, como a caixa superior com o nome da coleção e número do volume. Há também uma definição de projeto mais abrangente para os itens, como cor fixa para o fundo e a caixa superior/lombada e a tipografia serifada e com contorno do título e autor, resultando em maior padronização entre

10 Processo de produção de matrizes de metal fundido de dimensões variadas que combinavam texto e imagens também é bem explicado por PORTA (1958, pp. 33-4, 79-80 e 145-6, verbetes autotipia, clichê e estereotipia), embora este autor, mesmo mais próximo ao período estudado, não mencione o procedimento de impressão mista identificado nas capas da BPB Série /l. 
os volumes e reforço da identidade da coleção. No entanto, alguma variação é introduzida no desenho das letras em função das dimensões do título e das especificidades das informações de cada volume, pela intervenção mais livre do artista letrista (FIG. 4.16).

\section{Coleção Dom Bosco}
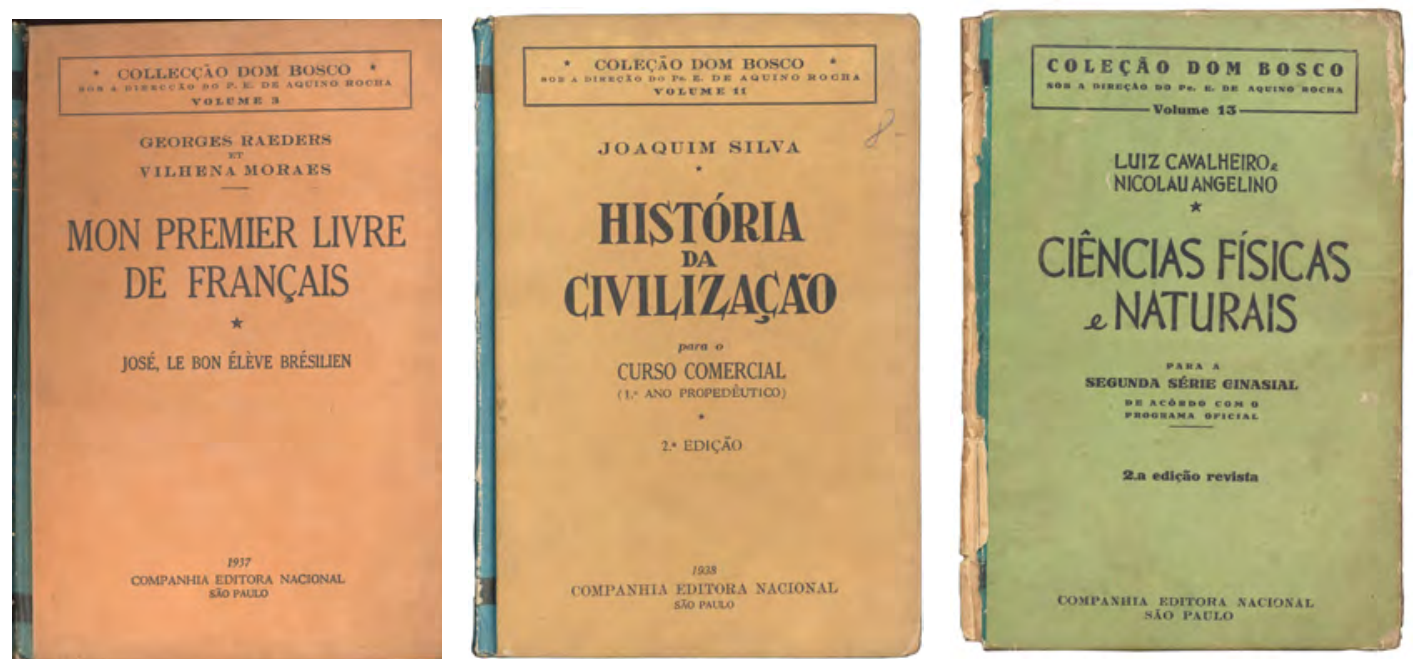

Fig. 4.17. Capas de livros da Coleção Dom Bosco, de edições de 1937, 1938 e 1940 (13,2 × 19,2cm).

A solução tipográfica das capas da Coleção Dom Bosco é mais contida que a da BPB Série II, com uma simples caixa com fios e composição tipográfica para as informações da coleção e composição tipográfica ou desenho manual de letras para o título mais discreta, mesmo assim, ocorrendo uma variação de desenho entre os volumes, o que contribui para uma particularização maior dos volumes. A partir de 1940 a capa ganha um fundo colorido e uma alteração na tipografia das informações da coleção (FIG. 4.17).

\section{Biblioteca de Estudos Comerciais e Econômicos}
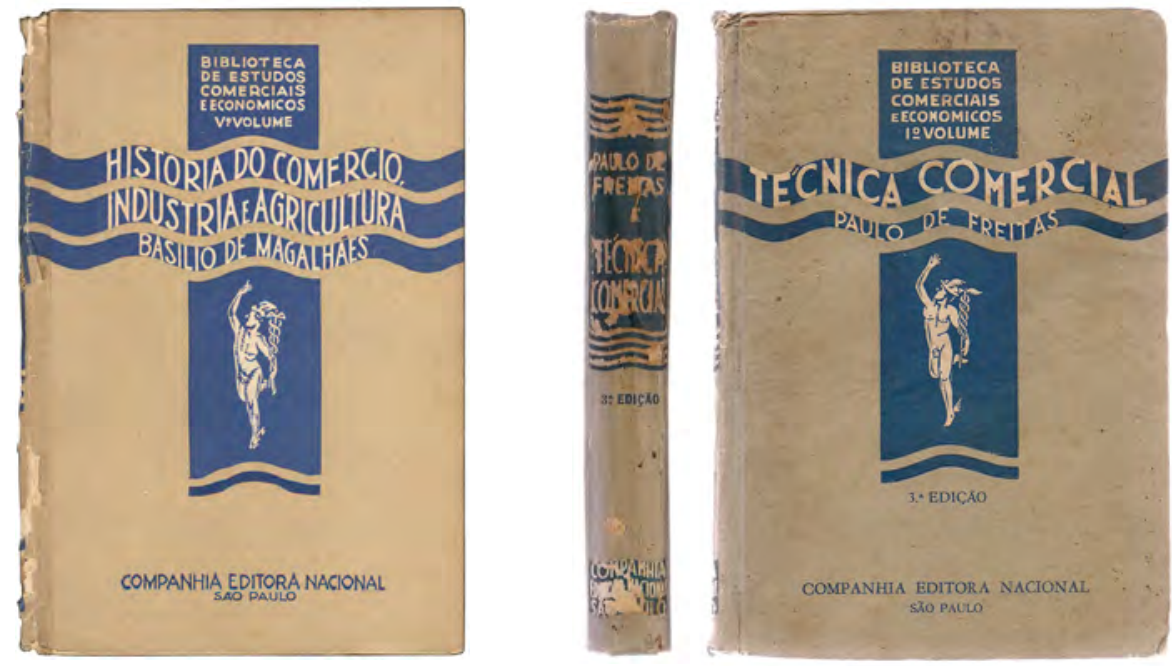

Fig. 4.18. Capas de livros da Biblioteca de Estudos Comerciais e Econômicos, edições de 1934 e 1938 (13,2 × 19,2cm). 
Coleção destinada ao ensino técnico comercial, a Biblioteca de Estudos Comerciais e Econômicos possui um design de capa diferenciado e sofisticado, com um trabalho bastante apurado de desenho dos títulos e da lombada em consonância com os recursos oferecidos pela impressão litográfica, apesar de limitado a uma só cor. A identidade da coleção é inequívoca, mas a variação de dimensão dos títulos introduz diferenciações entre os volumes com efeito particularizador deles (FIG. 4.18).

\section{História da Civilização e outros livros avulsos}
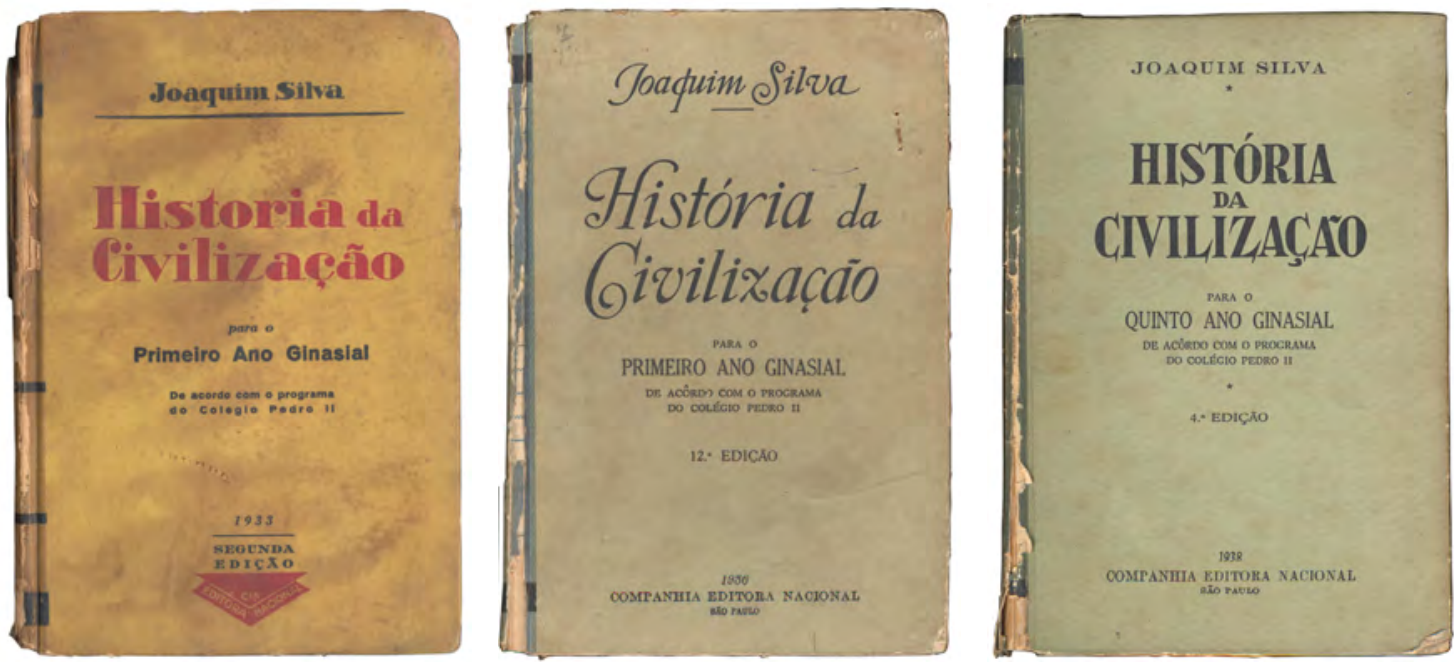

Fig. 4.19. Capas de livros de História de Joaquim Silva, de 1933, 1936 e 1938 (13,2 × 19,2cm).
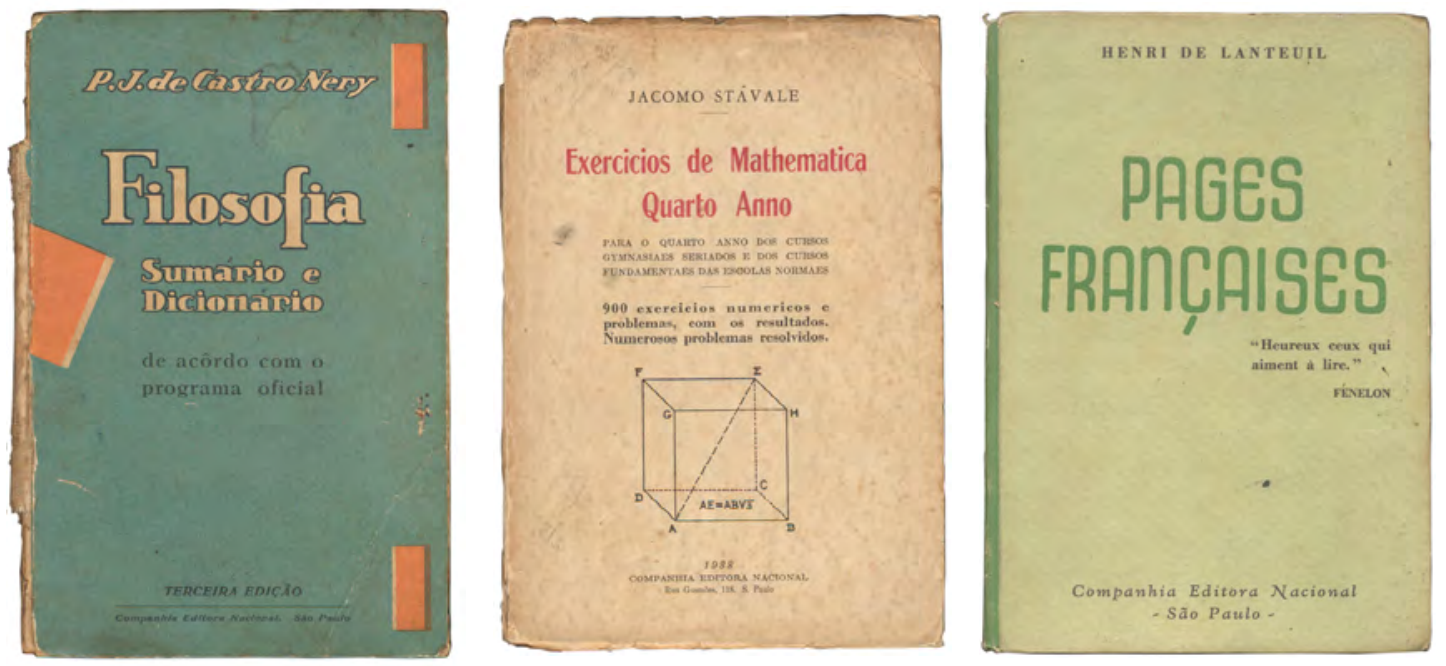

Fig. 4.20. Capas para o Ensino Secundário, de 1934, 1938 e 1940 (13,2 × 19,2cm).

Com o título de História da Civilização, nome da disciplina História adotado pela Reforma Francisco Campos, os livros de Joaquim Silva não integraram a BPB Série II, provavelmente devido à filiação católica do autor e seu perfil de professor conhecido mas não historiador comprometido com a pesquisa e renovação do ensino da disciplina, como os outros autores 
da BPB Série II, Pedro Calmon e Pandiá Calógeras [PINTO JR., 2010, p. 150-152]. Mas devido à sua ampla aceitação, não só nas escolas confessionais, praticamente constituiu uma coleção à parte, com identidade definida para seus volumes em cada edição, pelo diagrama, desenho de letras dos títulos e uso de cor, em títulos e fundo, em solução totalmente tipográfica mantida até além desse período, como veremos adiante (FIG. 4.19).

As obras para o Ensino Secundário, ginasial ou complementar, não pertencentes à coleções continuaram adotando soluções principalmente tipográficas, mas com maior uso de cor propiciado pela impressão litográfica, como em Filosofia: Sumário e Dicionário e Pages Françaises, enquanto que Exercícios de Matemática apresenta cor no título e uma ilustração mas é impressa em tipografia (FIG. 4.20). Note-se que Filosofia apresenta o mesmo design de livro de 1931 (FIG. 3.10), indicando o aproveitamento de soluções padronizadas mesmo para títulos avulsos, não pertencentes a coleções, procedimento que será encontrado ao menos no período subsequente, tratado no próximo capítulo.

\section{Livros de leitura: Sei Ler e Alegria}
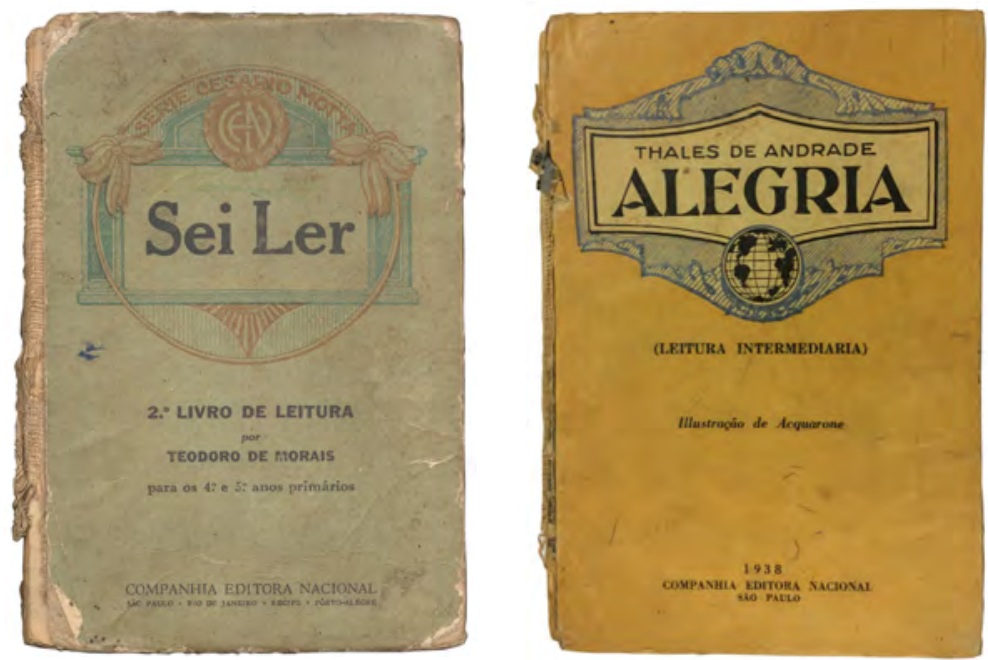

Fig. 4.21. Capas de livros de leitura Sei Ler: 2o livro de leitura, de 1933, e Alegria, de 1938 (13,2 × 19,2cm).

As séries Cezario Motta, com o livro de leitura Sei Ler, de Theodoro de Moraes, e Thales de Andrade, com Alegria, apresentam um redesenho das respectivas soluções encontradas nas edições entre 1928 e 1930 (FIG. 3.7). Há uma simplificação no traçado da caixa ornamentada e a introdução de mais uma cor, além da ocupação de todo o espaço gráfico com informações da obra e da edição, numa modernização evidente do design mais sóbrio das edições anteriores (FIG. 4.21). Em Alegria, há uma maior integração do título com o ornamento, a partir de um desenho de letras com traço e peso adequados, enquanto que em Sei Ler a relação é mais de justaposição, resultando em maior solenidade. De qualquer forma, ambos os livros se diferenciam das soluções puramente tipográficas dos livros para o Secundário. 

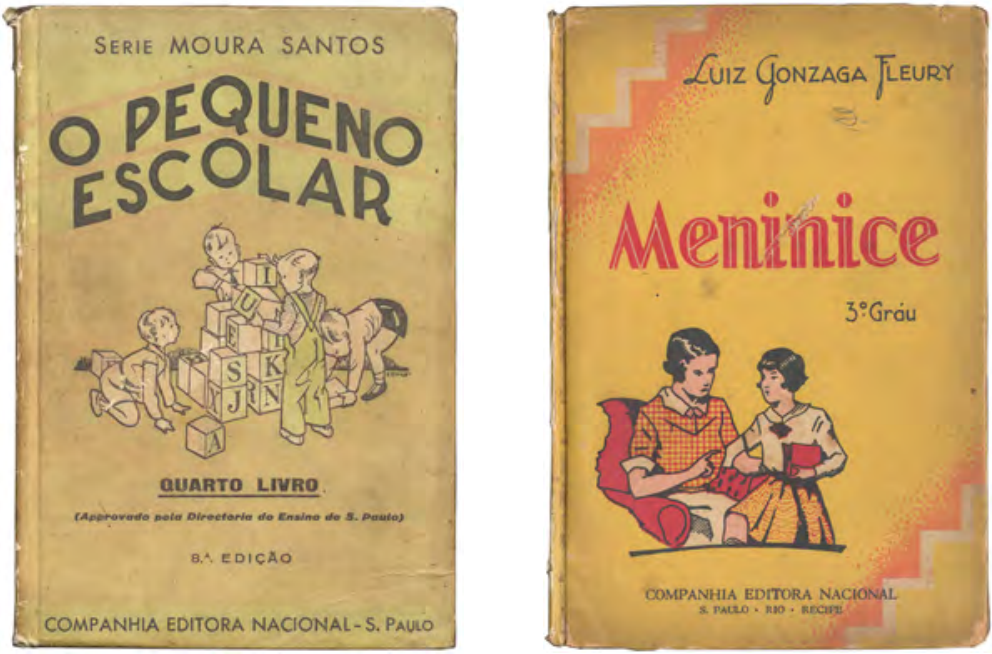

Fig. 4.22. Capas de novos livros de Primário, O pequeno escolar, de 1936 e Meninice, de 1940 (13,2 × 19,2 cm).

As únicas capas com ilustrações coloridas do período são dessas novas cartilhas e livros de leitura, para o Ensino Primário, numa maior aproximação com as soluções menos sóbrias praticadas por outras editoras. O estado deste exemplar de $O$ pequeno escolar: quarto livro (FIG. 4.22) exige algum esforço para distinguir as áreas de cor chapada que apóiam o nome da série, o título e a editora e que preenchem a ilustração em traço, mas que são mais vivas e contrastantes em outros volumes da coleção, não obtidos para reprodução. Em um diagrama simétrico, o desenho das letras de título é duro e irregular, não apresentando a qualidade encontrada em outros títulos da própria BPB Série II, de solução geral mais sóbria, e não tira partido dos recursos oferecidos pela impressão litográfica utilizada, transpondo para ela uma linguagem mais afim à tipografia.

Já na capa de Meninice (FIG. 4.22), o uso de cor e o desenho de letras correspondem à tecnologia de impressão litográfica, mesmo considerando o uso limitado de retícula e a presença do traço definindo áreas de preenchimento de cor chapada na ilustração. Mas a definição de uma área diagonal delimitada pelo ziguezague ortogonal não é utilizada consistentemente para posicionar os elementos gráficos de primeiro plano, resultando numa organização ambígua e desequilibrada, nem simétrica nem assimétrica, e apresentando uma ilustração sem qualidades plásticas e maior interesse para o público.

\subsubsection{O design de miolos das coleções e livros avulsos}

A seriação no Ensino Secundário, estabelecida pela Reforma Francisco Campos, não só estabeleceu o terreno para a expansão da Nacional no setor didático a partir de 1931, como determinou as características gerais de seus novos títulos. Assim, não só um número bem maior de disciplinas passou a ser oferecido, como o foi na forma de volumes para todos os anos do 
programa curricular. Não que os antigos compêndios ou manuais com características de compêndios tenham deixado de ser publicados ou mudado completamente de forma, mas agora quase todos os livros passaram a ter as características de manuais com conteúdo definido por série, além de particularidades gráficas determinadas pelas especificidades de cada disciplina.

Mas ao mesmo tempo que aumenta a diversidade de visualidade resultante das diferentes formas de organização e da iconografia das diferentes disciplinas, essa maior diversidade é produzida dentro de padrões gráficos anteriormente inexistentes, que inclui:

- formato: $13,2 \times 19,2 \mathrm{~cm}$;

- mancha de texto: 10,0 x 15,5 cm, com pequenas variações;

- tipografia: fonte exclusivamante romana (serifada), com variações itálico, negrito, negrito itálico, versal, versalete, empregadas segundo critérios funcionais estabelecidos para todas as obras;

- diagrama e tipografia de páginas pretextuais (guarda, falsa folha de rosto, folha de rosto, sumário, etc.), com variações ao longo do tempo;

- diagrama de página-tipo (posição e tipografia de cabeço e folio), com variações ao longo do tempo.

O resultando é uma uniformização gráfica inexistente antes de 1931, até em obras de uma mesma disciplina, como pudemos ver nos títulos abordados no capítulo 3, em que as características da composição tipográfica eram determinadas pelos recursos dos fornecedores dos serviços. Agora, ao contrário, temos certamente um modelo gráfico básico, com alguns critérios e procedimentos gerais para aplicação nas obras que entrassem em produção - que não hesitaríamos em chamar de projeto gráfico geral, como entendemos hoje, se tivéssemos a certeza da existência de um documento físico com instruções e especificações detalhadas. E temos também uma equipe de profissionais que segue este modelo na necessária adaptação em função das ocorrências específicas de texto e imagem de cada obra e disciplina, o que explica a variação encontrada.

Para esta uniformização parece também contar o fato de o principal fornecedor de composição e impressão ter se tornado a São Paulo Editora, responsável pela quase totalidade desses serviços, conforme crédito encontrado na quarta capa dos livros. Se esta gráfica e componedora não participou diretamente da própria elaboração do projeto gráfico, ao menos os seus recursos foram considerados.

Por fim, é possível constatar que este não foi um modelo desenvolvido exclusivamente para a BPB Série II, mas sim para todos os livros didáticos produzidos pela editora. Excluindo as obras muito particulares, algumas até pertencentes à BPB Série II, as obras didáticas avulsas e de outras coleções seguiram os mesmos padrões elencados acima. Não havia portanto um projeto gráfico de capa e miolo particularizador de cada coleção. A identidade de cada uma 
era definida exclusivamente pelo design da capa, atestando a produção independente dos dois componentes. Isto pode ser facilmente constatado pelo confronto entre uma amostragem das páginas de rosto da BPB Série II (FIG. 4.23) e capas daquela coleção (FIG. 4.7 e 4.9 a 4.12). No primeiro caso, elas apresentam soluções definidas por um projeto próprio com diagrama e tipografia composta acompanhando o miolo, em total contraste com a tipografia variável quase sempre desenhada à mão das capas.
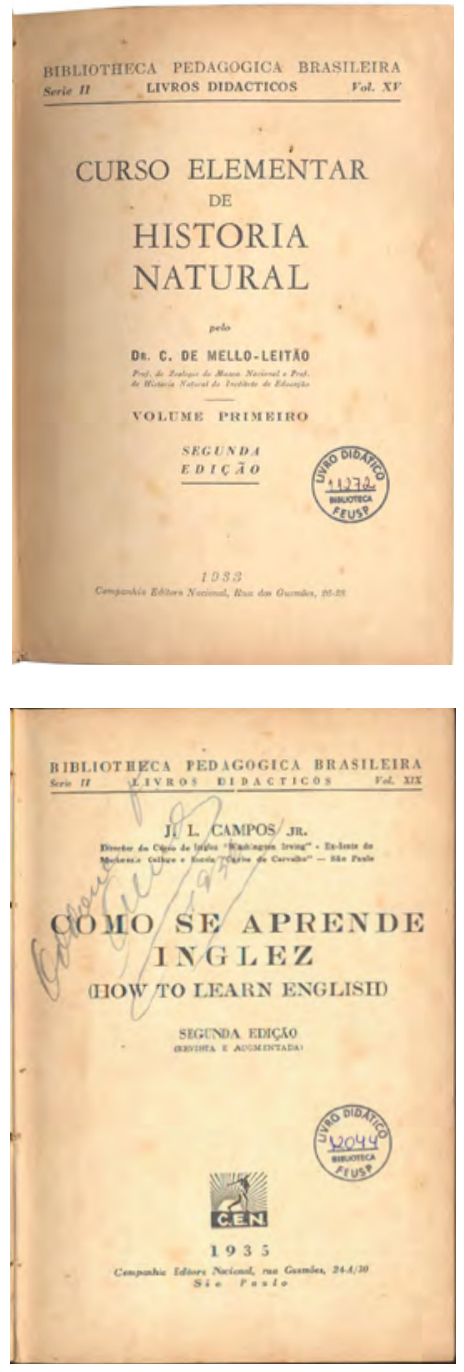
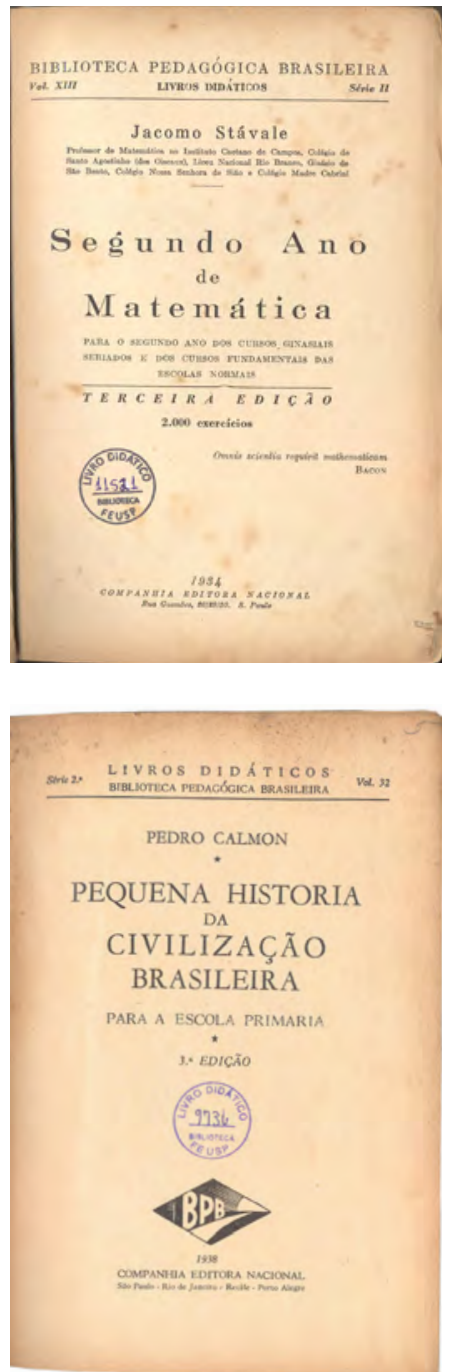
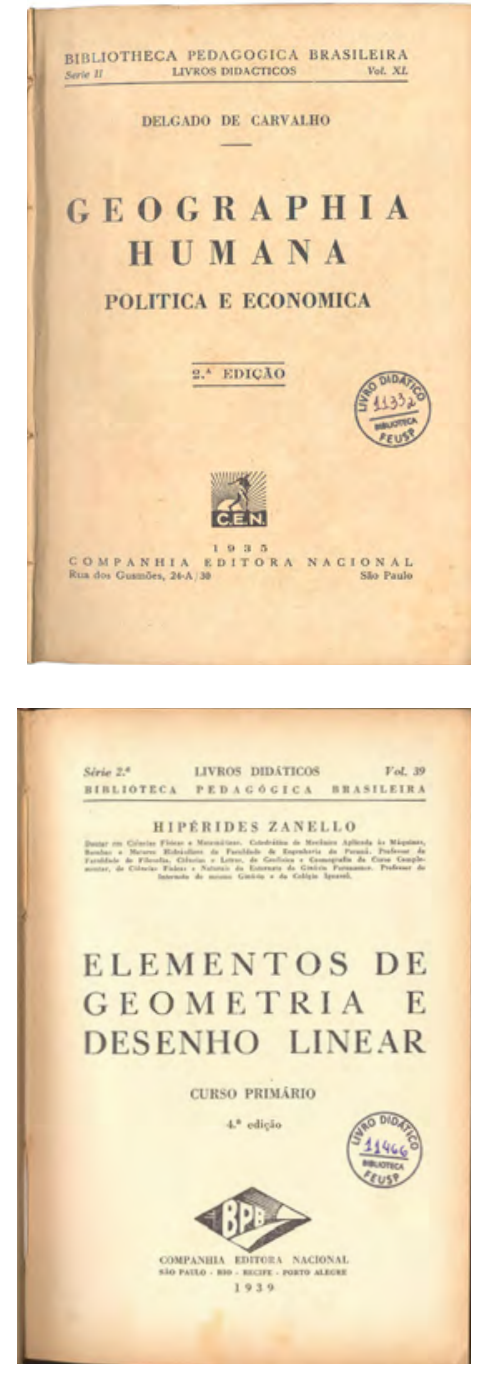

Fig. 4.23. Páginas de rosto da BPB Série /l de edições de 1933 a 1939.

Com o design de miolo tendo sido definido à parte e sem relação com o design de capas, ele será apresentado por meio de uma amostragem de ocorrências em diversas disciplinas e níveis do Secundário, independentemente da coleção a que pertença ou de ser um livro avulso. Os livros de Português para o Primário, particularmente os de leitura, não integram as coleções e apresentam particularidades próprias do segmento, sendo apresentados na sequência desse conjunto voltado para o Secundário. Por fim, será apresentada uma obra que constitui uma exceção, por ter um projeto mais particularizado e ser uma realização de design mais completa, que integra capa e miolo, prática não comum no período. 


\section{Português para o Ensino Secundário}
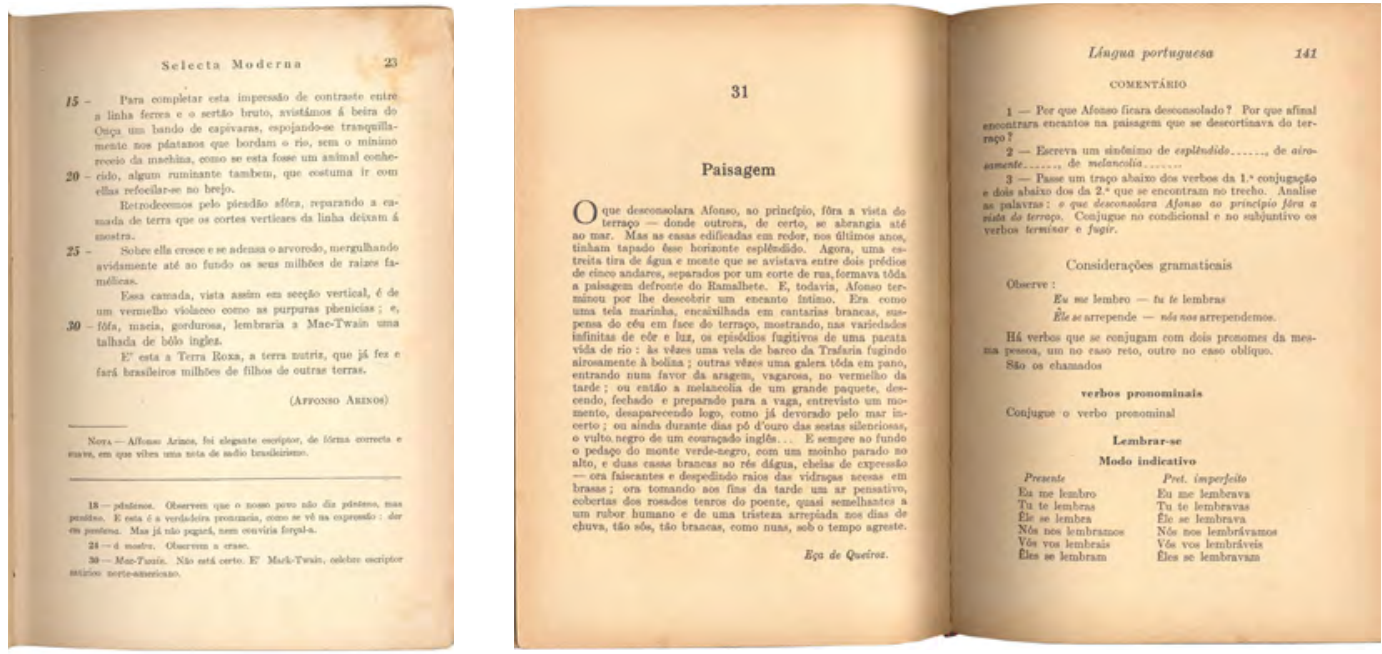

Fig. 4.24. Othoniel Motta, Selecta Moderna. BPB Série II, vol. 14, 1933 (13,5 x 19,7 cm).

Anibal Bruno, Língua Portuguesa, 1a série ginasial. Biblioteca Escolar Brasileira, vol. 8, 1938 (13,3 x 19,0 cm).
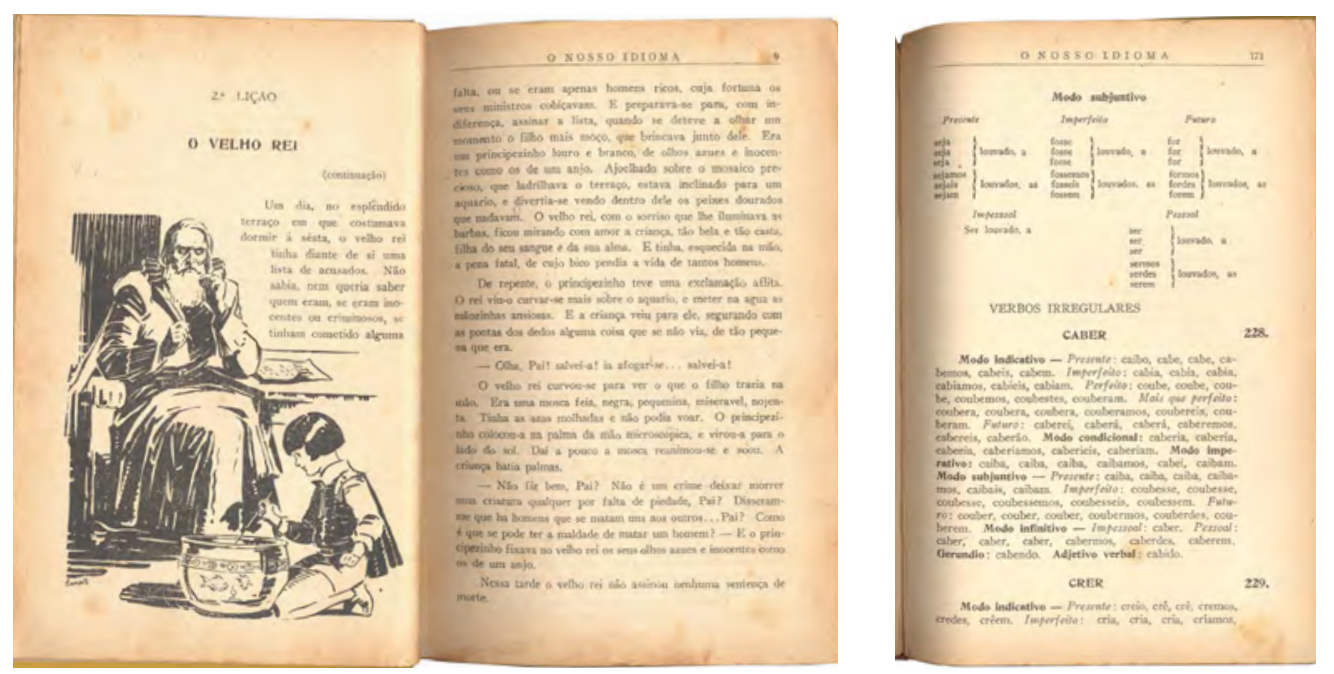

Fig. 4.25. Paulo de Freitas, O Nosso idioma, BPB Série II, vol. 51, $1936(13,2$ × 19,2cm).

A obra Selecta Moderna é uma antologia com trechos de textos literários, em que a numeração de linhas serve de referência para comentários semânticos e gramaticais em corpo menor na própria página, enquanto que Língua Portuguesa constitui um livro para ensino seriado do programa de língua, com a sequência texto/questões de compreensão/pontos gramaticais (FIG. 4.24). Nesta obra, e também em O nosso idioma (FIG. 4.25), as diversas situações funcionais são bem resolvidas apenas com variações itálico, negrito, versal e versalete, com espaçamento adequado, em composição tipográfica equilibrada. Na última obra, o texto literário é valorizado com ilustração (J. U. Campos), um acréscimo de qualidade aos livros secundários de português feitos nesse período. A impressão é tipográfica para as três obras, e a linguagem da ilustração corresponde a essa tecnologia. 
História para o Ensino Secundário: os livros de Joaquim Silva.
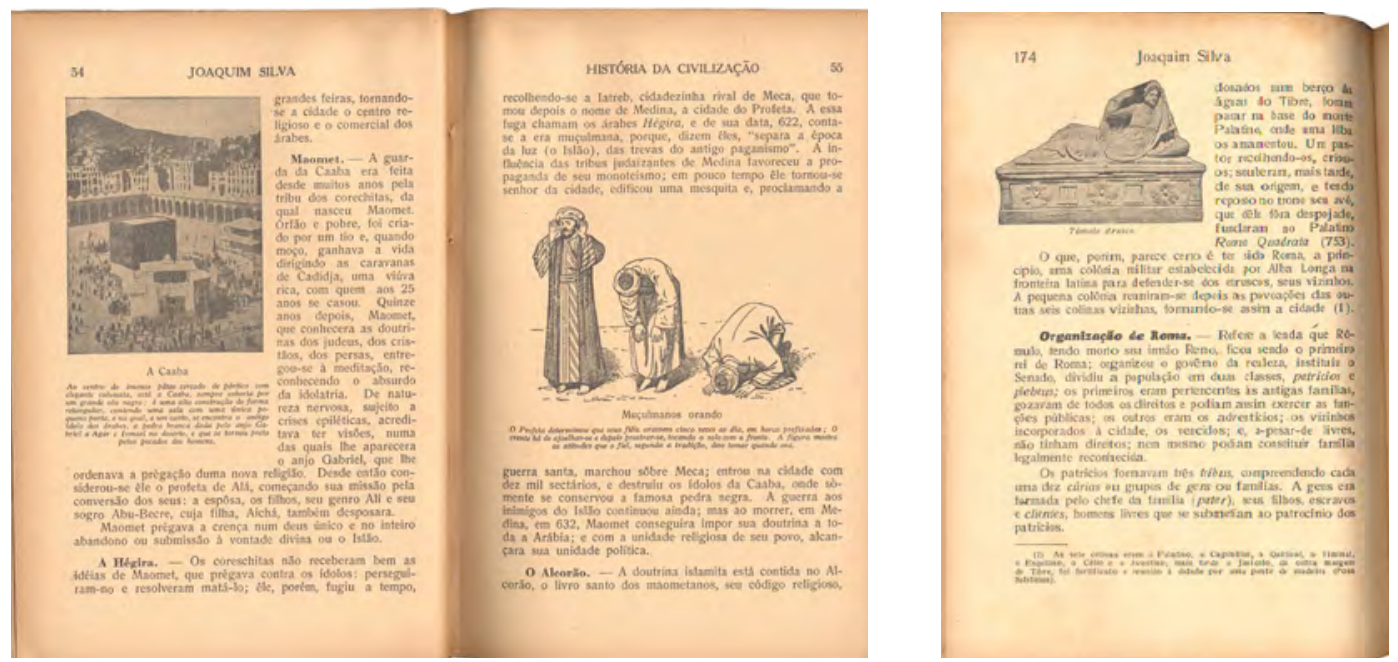

Fig. 4.26. Joaquim Silva, História da Civilização para o terceiro ano ginasial, 1937 (13,0 x 19,0 cm). Joaquim Silva, História da Civilização para o segundo ano ginasial, 1940 (13,0 x 19, 0 cm).
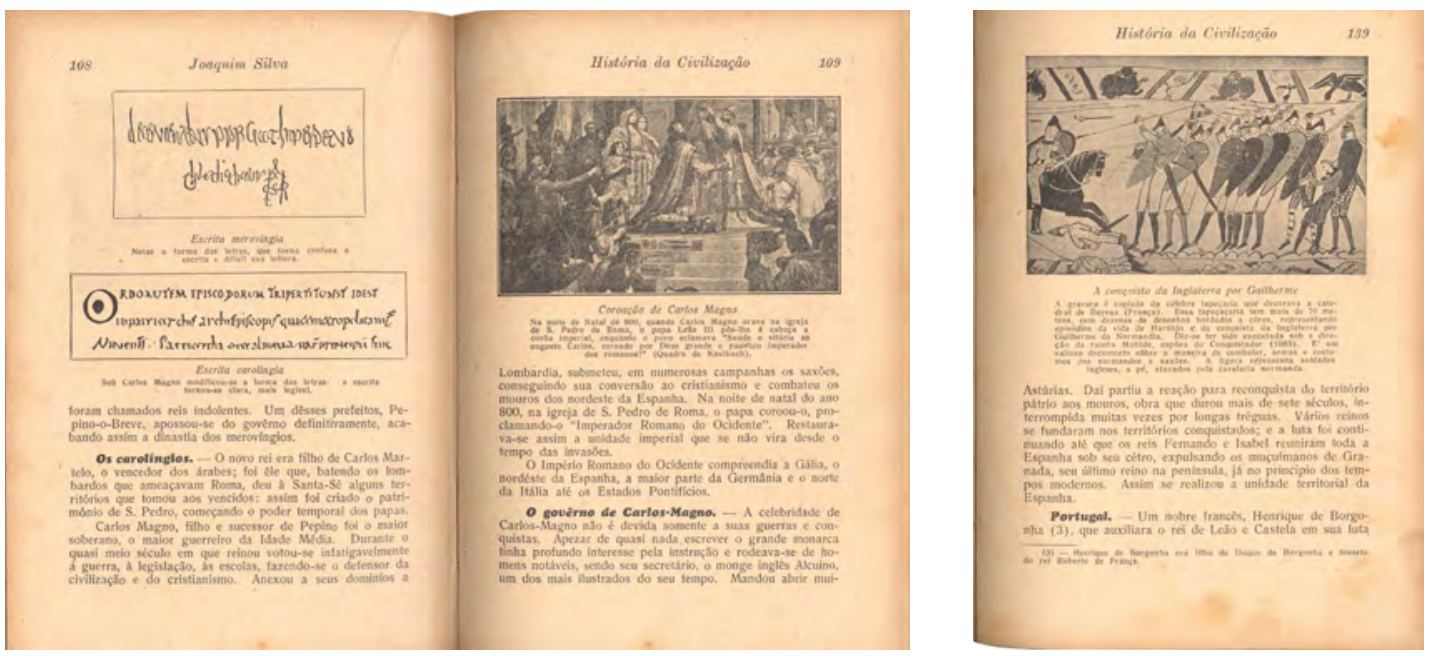

Fig. 4.27. Joaquim Silva, História da Civilização para o Curso Comercial (1ํo ano propedêutico), Coleção Dom Bosco, $1938(13,2 \times 19,5 \mathrm{~cm})$.

As obras de História apresentam grande complexidade editorial, com situações funcionais que exigem emprego de maior variedade tipográfica, como o uso de negrito itálico, que não apareceu nas obras de Português, e corpos menores para legendas de ilustrações e notas, mas tudo é resolvido com variações de mesma família serifada em cada obra (FIG. 4.26 e 4.27). A iconografia também é mais diversa que nas obras de Português, com mapas, ilustrações a traço, reprodução fotográfica de obras de arte e fotografias, indicando planejamento e produção gráfica apurados. A impressão dessas obras é tipográfica, ou seja, os meios tons de fotografia e reproduções de obras são obtidos por clichês reticulados, com lineatura de 40 linhas por cm, que obtém bons resultados no papel acetinado usado. 
Geografia para o Ensino Secundário.
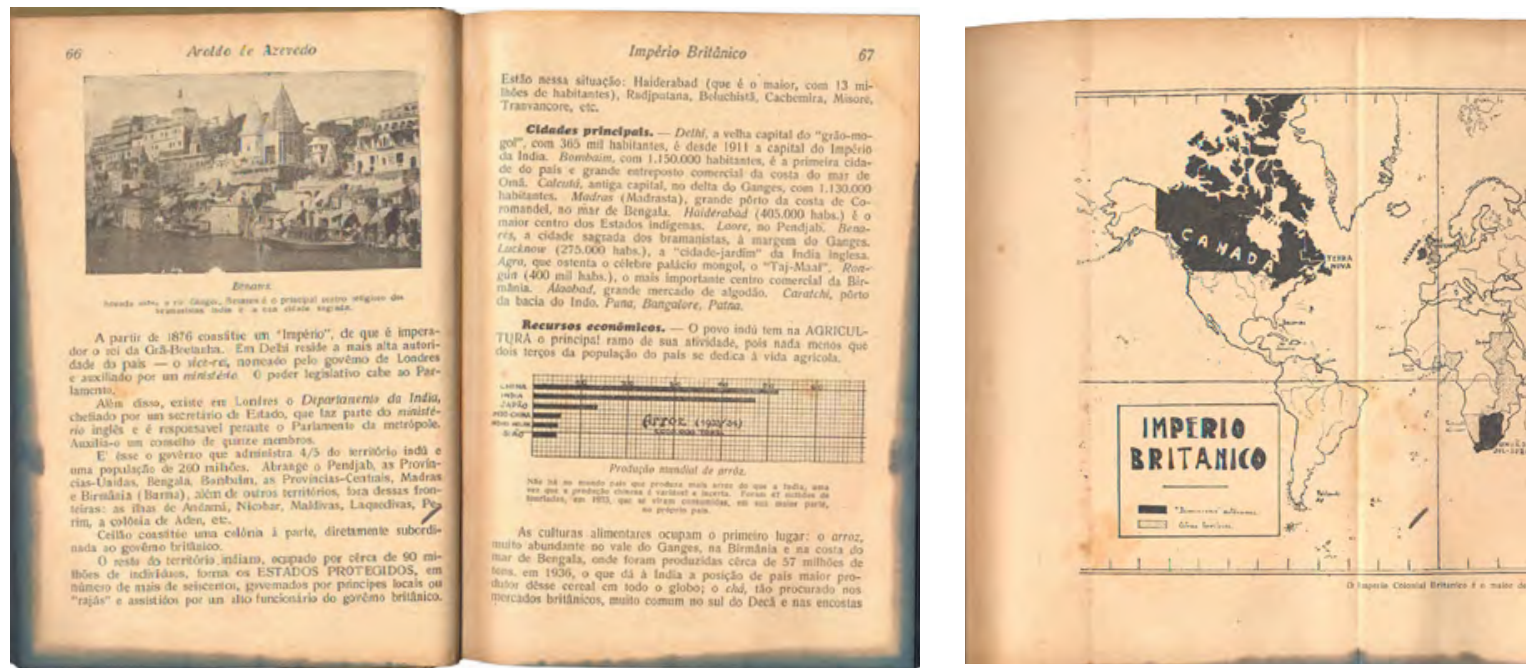

Fig. 4.28. Aroldo de Azevedo, Geografia para a quarta série secundária, BPB Série II, vol. 38, 1938 (13,2 × 19,2cm). Páginas e parte de encarte dobrado.

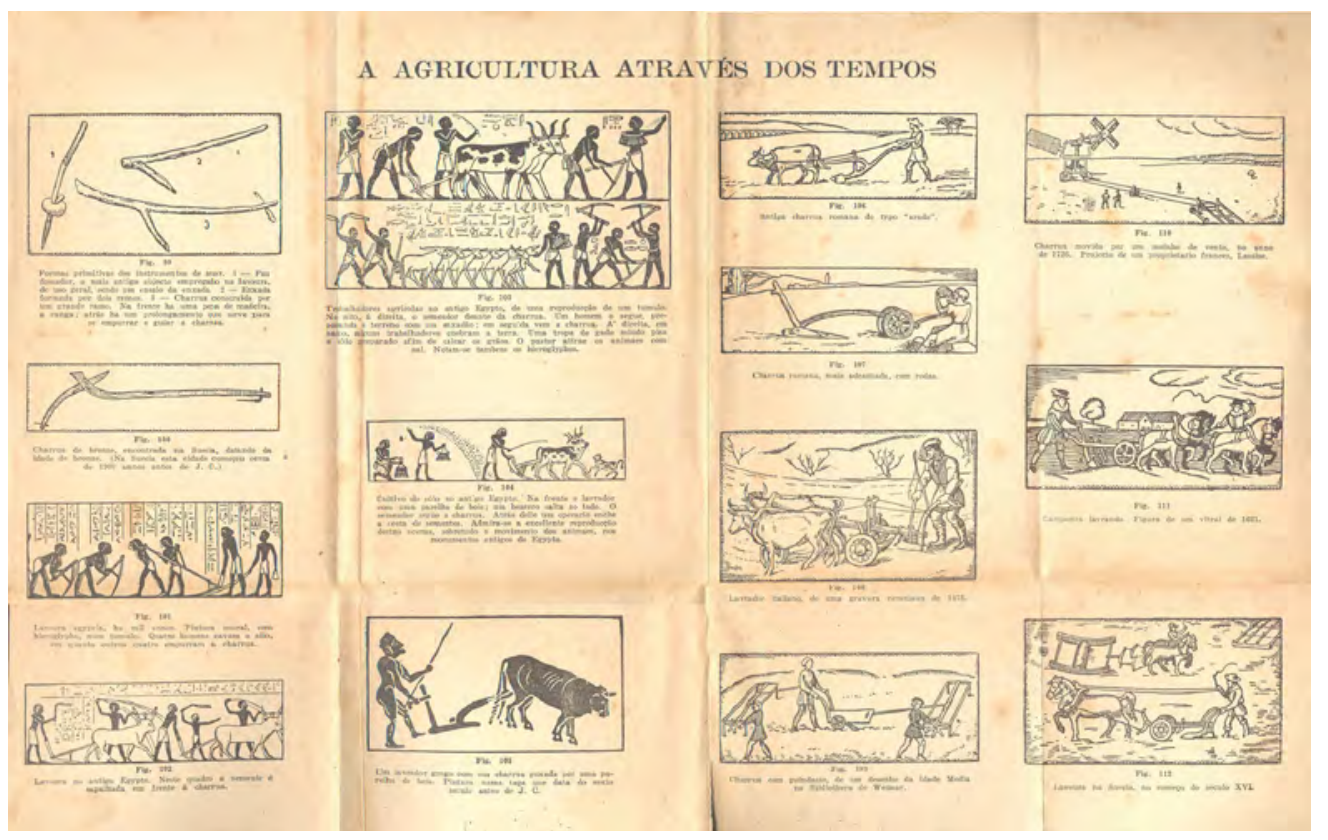

Fig. 4.29. Delgado de Carvalho, Geografia humana, BPB Série II, vol. 40, 1935 (13,2 x 19,2 cm). Encarte dobrado.

As obras de Geografia também apresentam grande complexidade editorial, com situações funcionais que exigem o uso de todas as variações tipográficas possíveis dentro de uma família serifada. A dupla reproduzida na FIGURA 4.29 apresenta margens estreitas e entrelinha fechada, para acomodar o conteúdo em número menor de páginas, resultando em páginas mais densas que as dos demais livros do período. Mas planejamento e produção gráfica apurada podem ser constatados pela presença de mapas, gráficos, esquemas e fotografias, chegando nesses livros a incorporar encartes dobrados e colados, trabalho feito manualmente. $O$ encarte reproduzido na FIGURA 4.29 apresenta ilustrações a traço referenciadas em iconografia de diversas epocas, mostrando trabalho de pesquisa também apurado. 


\section{Ciências Naturais e Biologia}
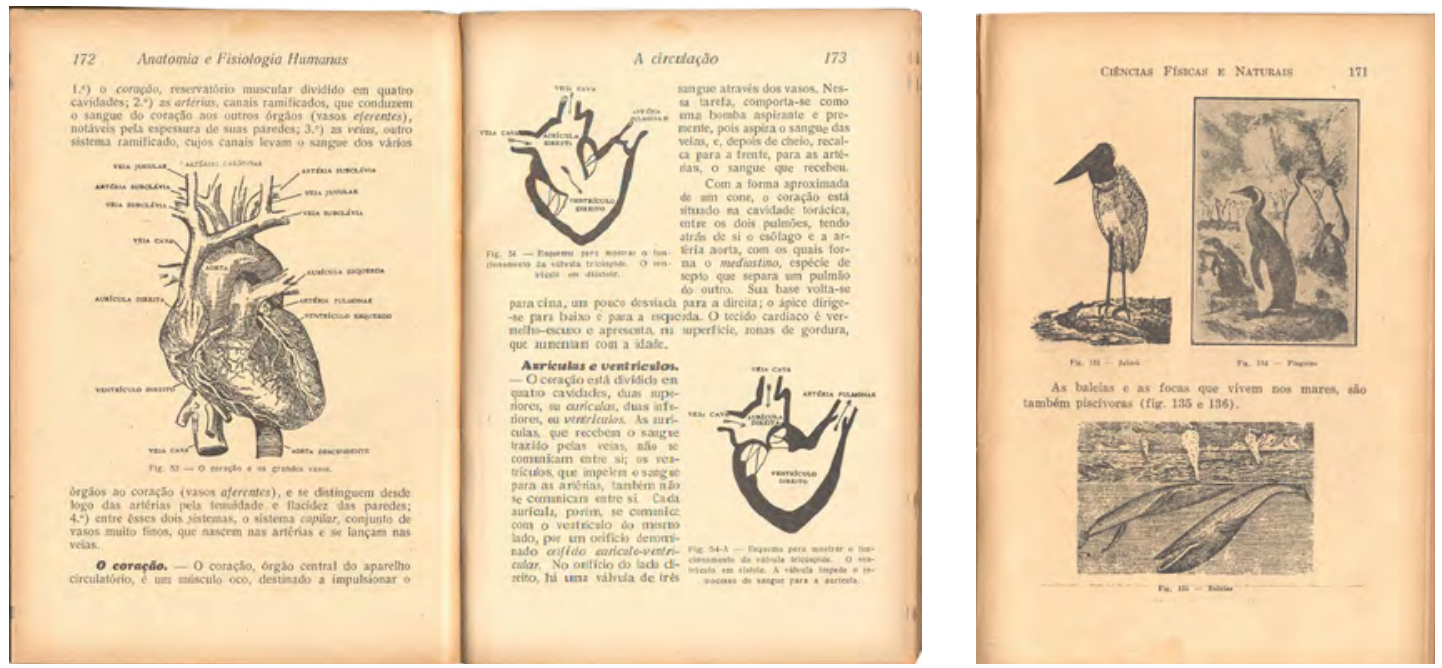

Fig. 4.30. A. Almeida Junior, Elementos de anatomia e fisiologia humanas, BPB Série II, vol. 11, 1941 (13,0 x 19,2cm). Luiz Cavalheiro e Nicolau Angelino, Ciências físicas e naturais: para a segunda série ginasial, Coleção Dom Bosco, vol. 13, $1940(13,2 \times 19,2 \mathrm{~cm})$.
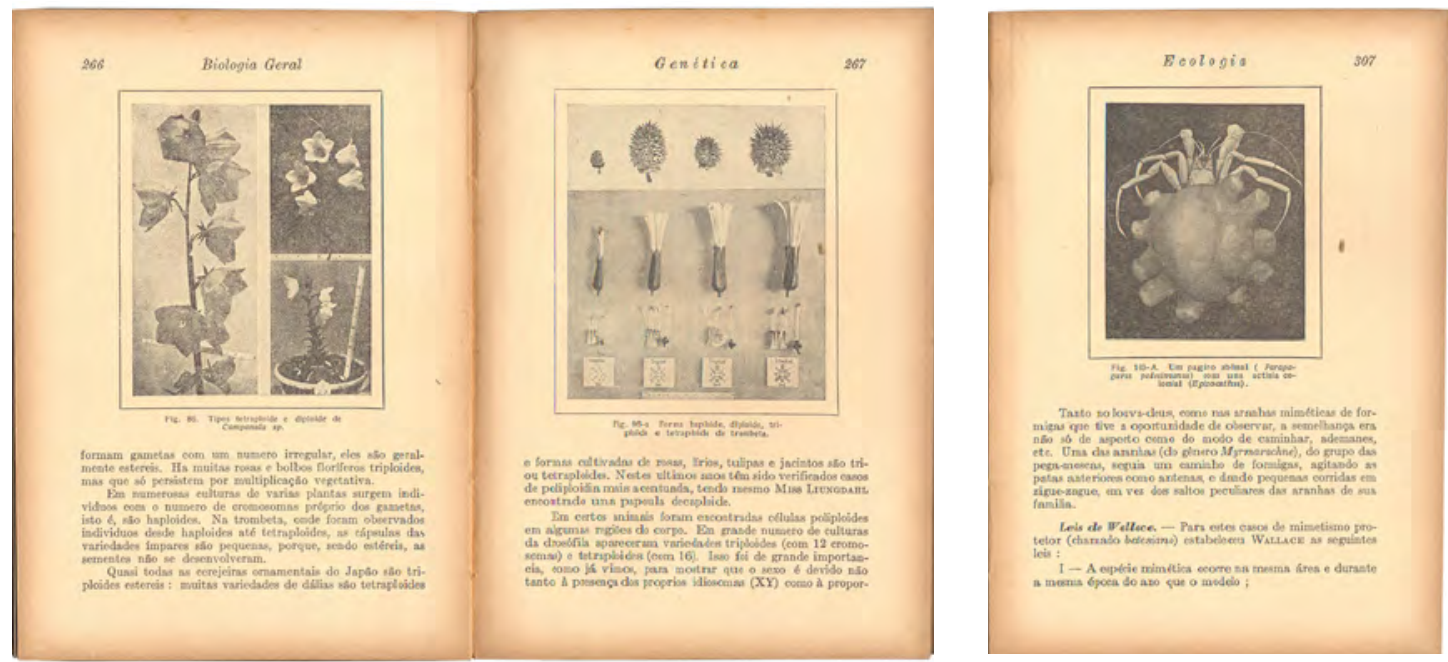

Fig. 4.31. Candido de Melo-Leitão, Biologia geral, BPB Série II, vol. 42, 1940 (13,2 x 19,0cm).

As obras de Ciências Naturais apresentam também as soluções tipográficas adotadas nos livros das demais disciplinas. O que as particulariza visualmente é principalmente a linguagem das ilustrações a traço do desenho de anatomia e do desenho naturalista de plantas e animais herdado da grande tradição da zoologia e botânica para impressão relevográfica (FIG. 4.30). Mas além das cuidadosas ilustrações trazidas da edição anterior de Elementos de anatomia (FIG. 3.14) para o novo formato da BPB Série II, as novas obras chegam a incluir produção fotográfica especial (FIG. 4.31), em apresentação também diferenciada, com fios de contorno organizando as montagens das fotografias, num padrão gráfico elaborado e didaticamente eficiente. A qualidade das imagens, com percepção de detalhes, deve-se à impressão litográfica, que permite retículas com lineatura mais elevada. 


\section{Física}
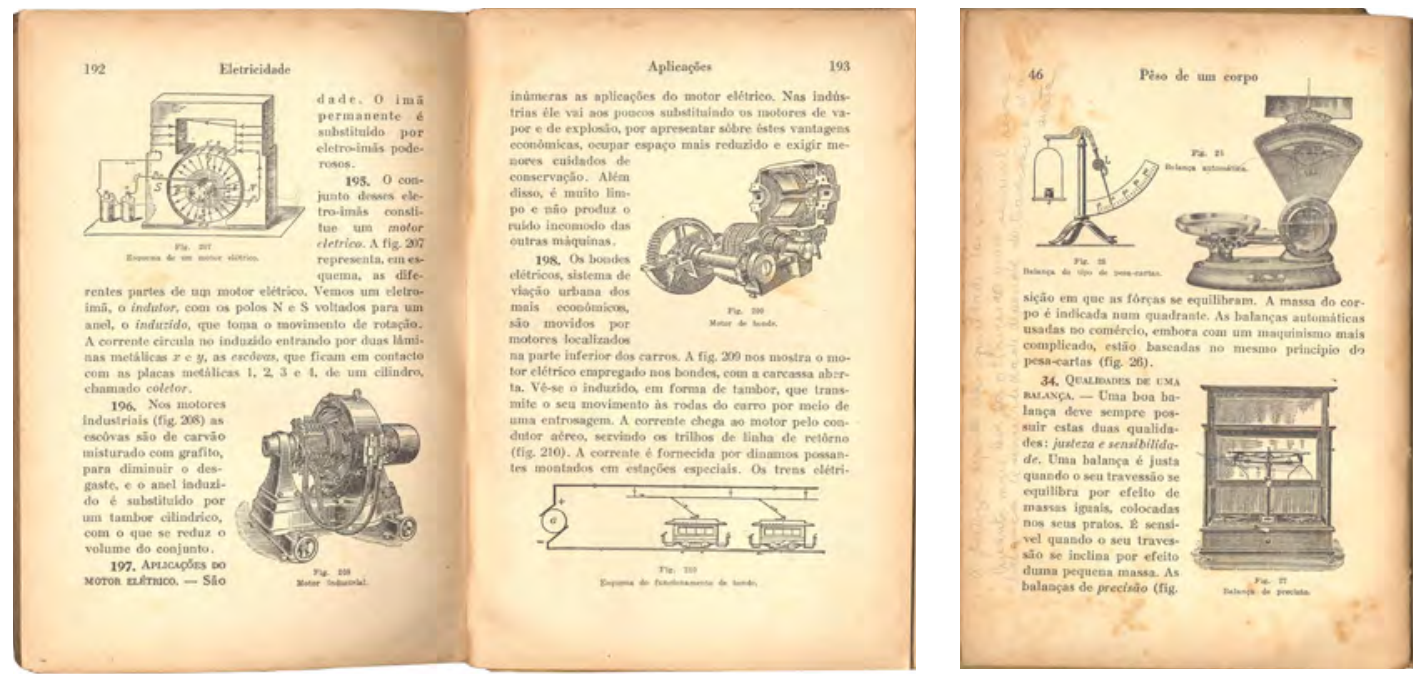

Fig. 4.32. Oscar Bergstrôm Lourenço, Iniciação ao estudo da fisica experimental: terceira série ginasial, BPB Série II, vol. 23, $1935(13,0 \times 19,0 \mathrm{~cm})$.

No livro reproduzido (p. 4.32), a composição tipográfica segue os padrões adotados para todos os didáticos, sendo que o cabeço de página é usado para uma necessidade específica, a indicação do conteúdo dos capítulos. As ilustrações são de dois tipos, esquemáticas e realistas com perspectiva, com meios tons obtidos por linhas e hachuras trazidos da linguagem da xilogravura e da água forte e ponta seca, mas agora reproduzidos mediante clichês tipográficos. Há ainda a inclusão de fotografias reticuladas (40 linhas/cm) recortadas, que faz dos livros de Física obras de razoável complexidade e investimento.

\section{Matemática e Geometria}
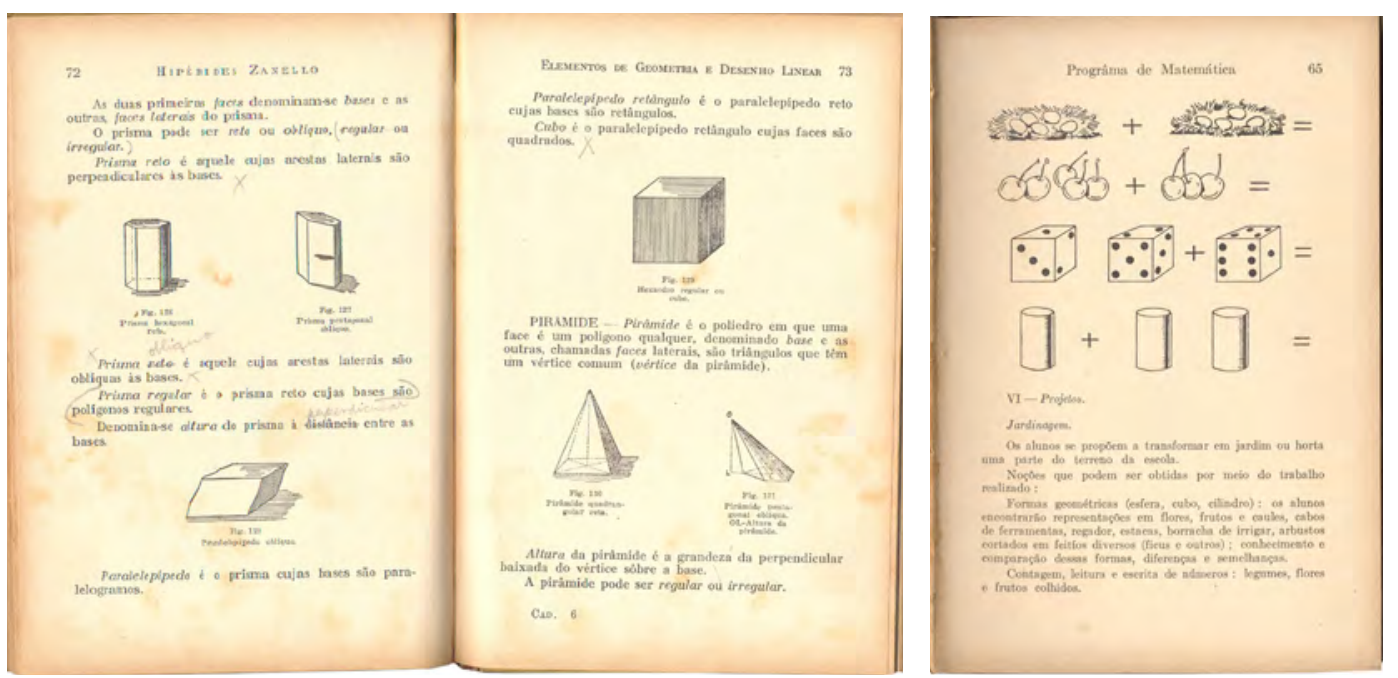

Fig. 4.33. Hipérides Zanello, Elementos de geometria e desenho linear, BPB Série II, vol. 39, 1939 (13,2 × 19,0cm). Programa de matemática, Dep. de Educação do Distrito Federal, Programas e Guias de Ensino, Série C, no $2,1934(13,2 \times 19,0 \mathrm{~cm})$. 
Os acervos consultados não propiciaram exemplos de composição de equações algébricas, raízes e matrizes, mas estas são situações já perfeitamente resolvidas por composição em monotipo, como vimos no capítulo 3 (p. 112). As páginas reproduzidas na fIGURA 4.33 mostram o emprego de ilustrações a traço para representação de volumes, incluindo sombras, mas muito claras e precisas, indicando abordagem gráfica perfeitamente adequada ao assunto.

\section{Desenho}
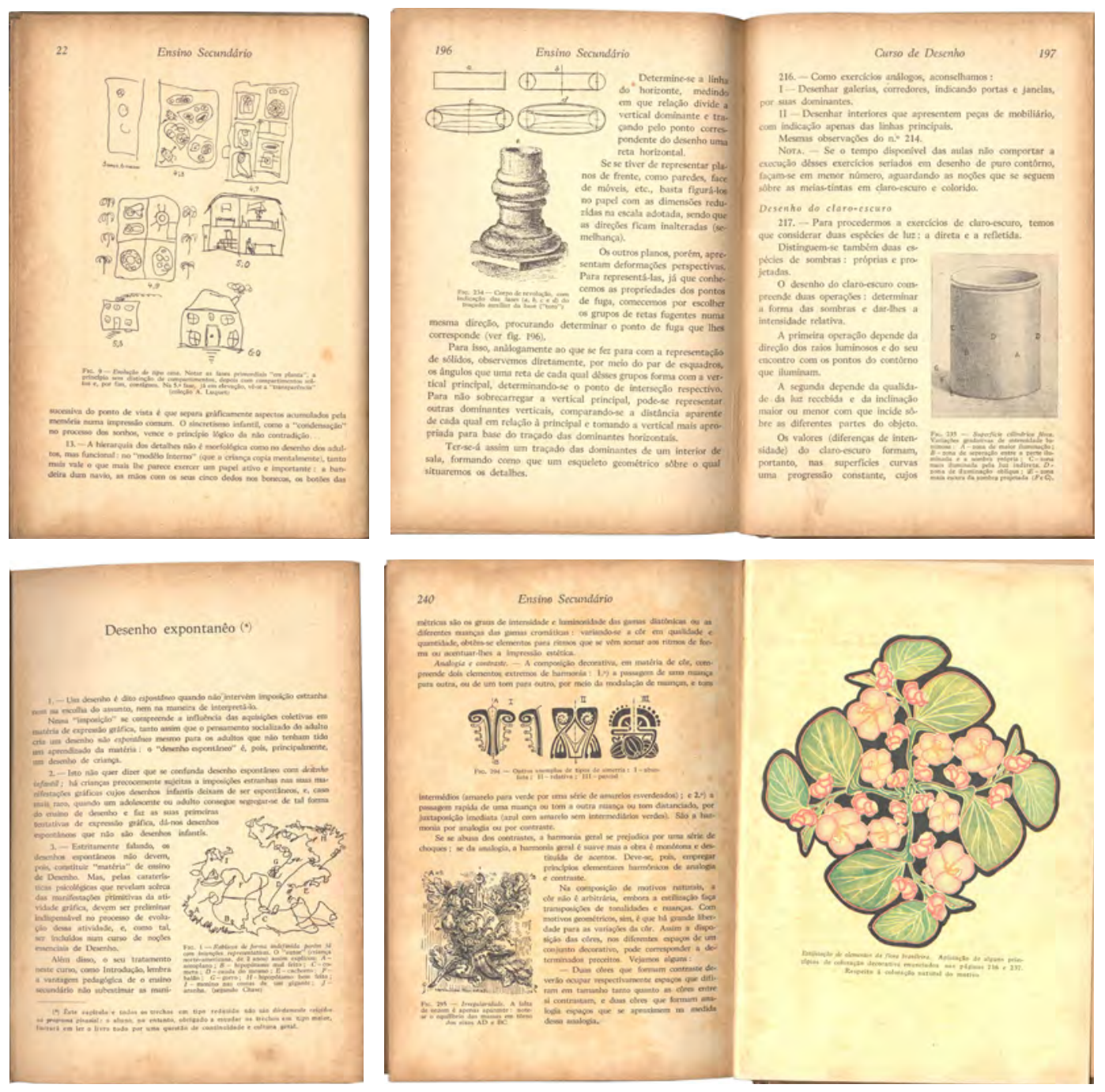

Fig. 4.34. Edgar Süssekind de Mendonça, Curso de desenho, BPB Série II, vol. 47, 1936 (13,2 × 19,2cm).

As páginas reproduzidas (FIG. 4.34) mostram a variação tipográfica empregada em acordo com os critérios adotados para os didáticos, a complexidade de diagramação das páginas com alternância de blocos de texto em diversas medidas para abrir janelas para a inserção das imagens - e a diversidade de iconografia. Esta vai da reprodução de desenho a traço ou pontos, a reticulação fotográfica de desenho de grafite e até a reprodução de trabalho com cor por reticulação e impressão em tricromia, em folhas especiais encartadas e coladas manualmente, revelando a complexidade de produção envolvida em algumas obras. 


\section{Línguas estrangeiras}
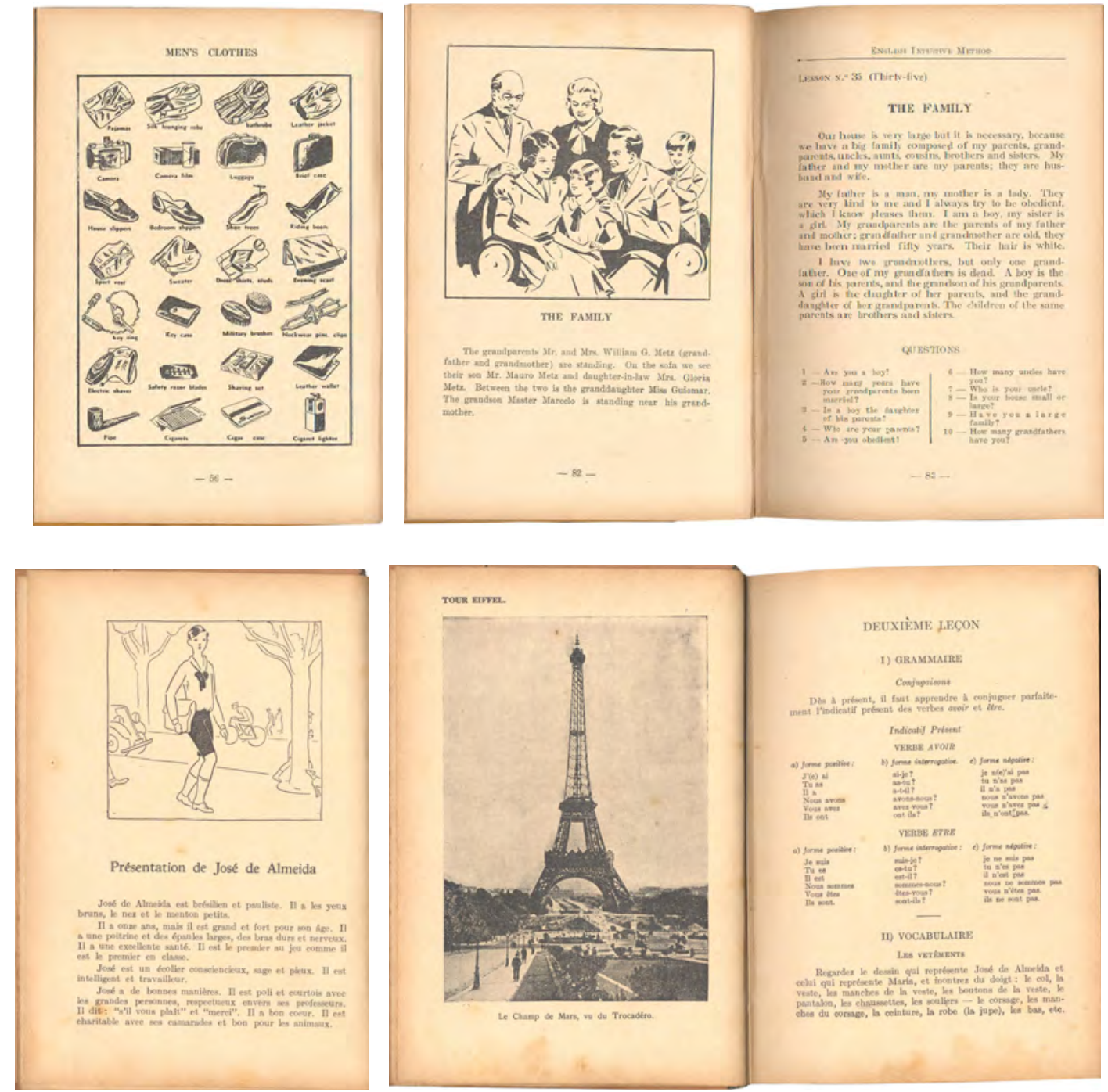

Fig. 4.35. Nuno Smith de Vasconcellos, English intuitive method: segunda série ginasial, BPB Série II, vol. 50, 1941 $(13,0 \times 19,2 \mathrm{~cm})$.

Georges Raeders e Vilhena de Moraes, Mon premier livre de français, Coleção Dom Bosco, vol. 3, 1937 $(13,0 \times 19,2 \mathrm{~cm})$.

As obras de línguas estrangeiras do período se caracterizam por uma diagramação mais leve e aberta, mantendo os recursos e critérios da composição tipográfica encontrados nas obras de cursos seriados de Português. A iconografia abrange da ilustração literária menos referencial àquelas icônicas legendadas (FIG. 4.35). O primeiro exemplo traz este tipo de ilustração, em linguagem de traço para impressão tipográfica, feita com grande maestria embora não creditada, com os objetos reproduzidos com perspectiva e volume sem uso de meios tons. 0 segundo exemplo incorpora fotografia de página inteira e ilustrações leves e singelas de Gastão Worms, atestando uma modernização do livro didático promovida pela Nacional ainda na década de 1930. 


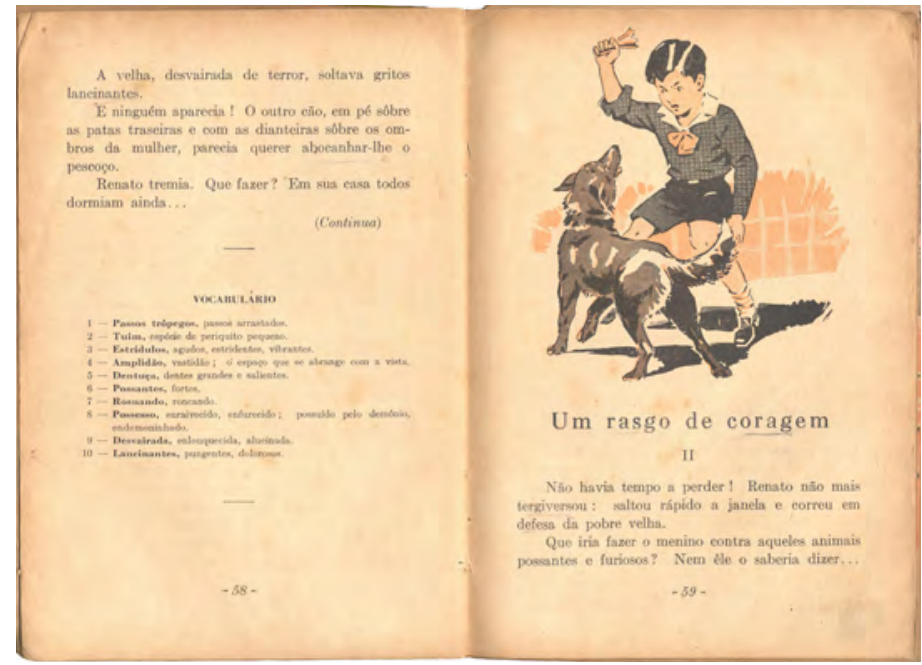

Fig. 4.36. Luiz Gonzaga Fleury, Meninice: 3o grau, 1937 (13,0 x 19,0 cm).
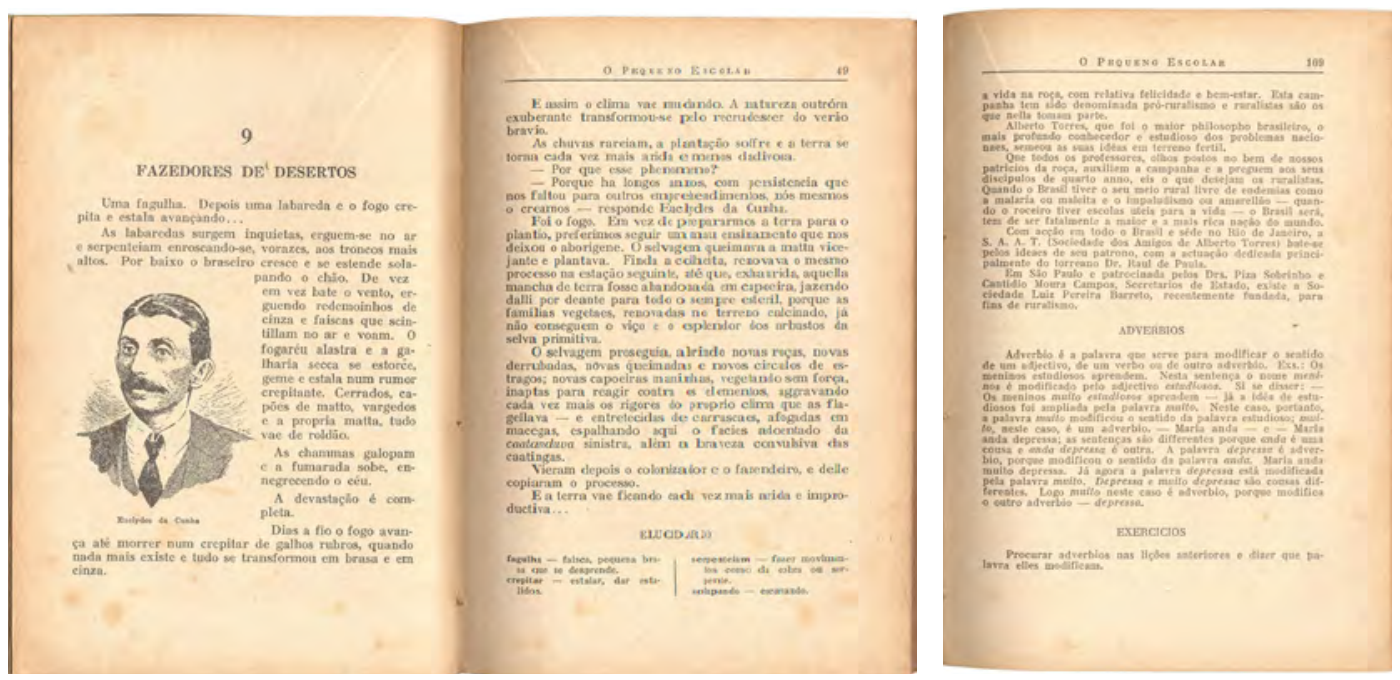

Fig. 4.37. O pequeno escolar: quarto livro, Série Moura Santos, $1936(13,3 \times 19,2$ cm).

O livro de leitura Meninice (FIG. 4.36) traz a mesma abordagem pedagógica utilizada por Theodoro de Moraes na década de 1910 e presente na obra Sei Ler editada pela Nacional (ver p. 120-121) - texto/vocabulário/exercícios -, mas apresenta uma modernização gráfica e visual marcante, com diagramação aberta e valorização da ilustração por suas dimensões e pelo uso de cor por combinação de retícula em impressão litográfica.

Já O Pequeno escolar (FIG. 4.37) é um livro com características de curso seriado - últimos anos do Primário, preparatório à admissão ao ginásio ou primeiros anos do ginásio, segundo o prefácio -, e além de texto literário ou informativo, vocabulário e exercícios traz pontos gramaticais e biografia do autor do texto. Assim, os textos e a iconografia são sérios e formais, o que se reflete na diagramação e recursos tipográficos. Embora a linguagem das ilustrações seja de traço, a impressão é litográfica. 

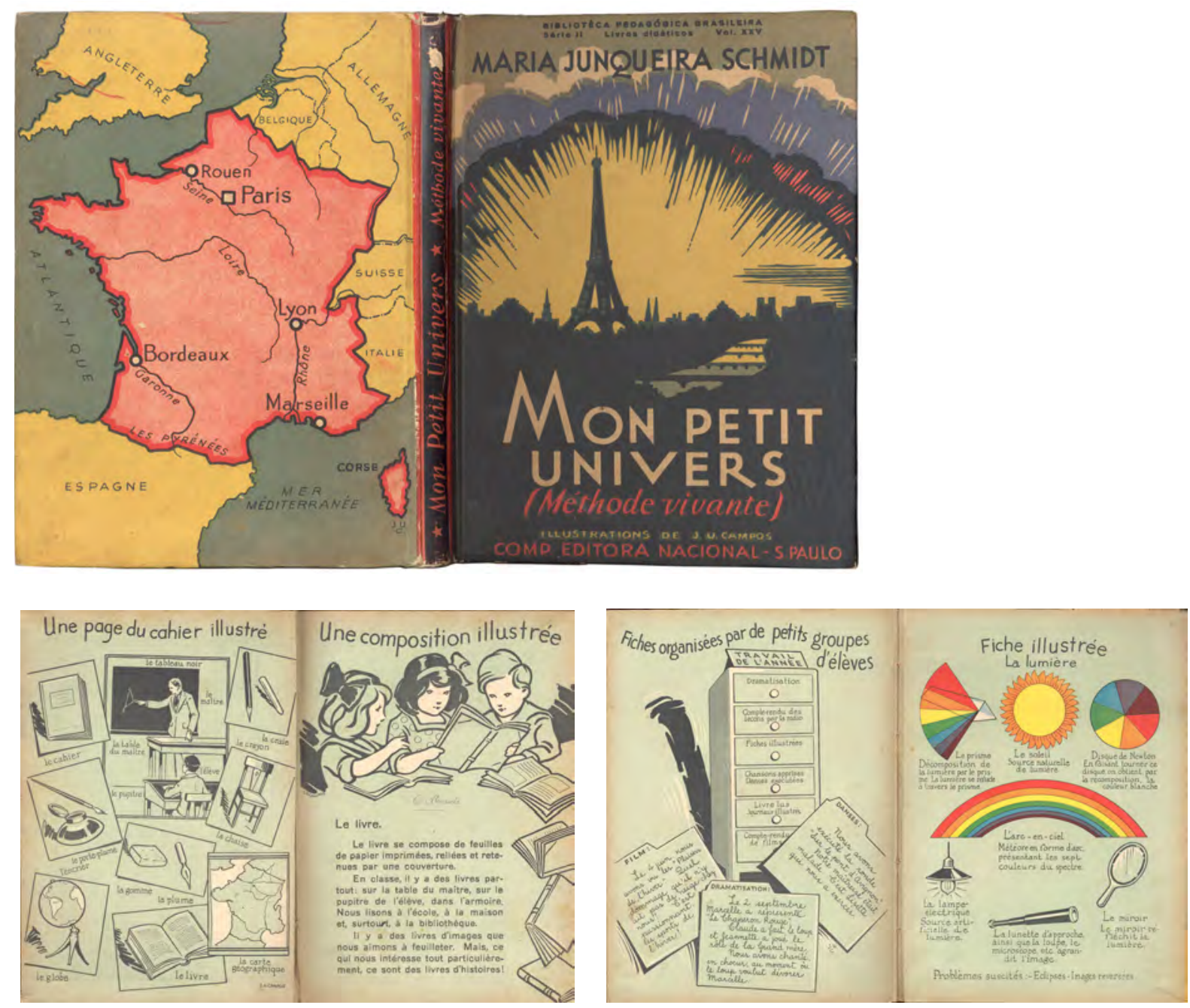

Fig. 4.38. Maria Junqueira Schmidt, Mon petit univers, BPB Série II, vol. 25 (15,7 x 21,3cm). Capa e guardas.

Embora outros livros do período apresentem planejamento e produção gráfica cuidadosos e complexos, este é dos raros que trazem design e ilustração de capa e miolo concebidos conjuntamente, dada a integração entre texto e imagem variável em todas as páginas. Assim, o trabalho de J. U. Campos, embora creditado só como ilustração, é na verdade um trabalho de design e edição de arte completo. Além da capa, J. U. Campos desenhou as guardas, que trazem conteúdo didático até impresso em tricromia (FIG.4.38). A sofisticação da produção é completada com o formato maior e a inserção de lâminas impressas em tricromia. As ilustrações trazem quantidade e complexidade de informação obtidas com pesquisa em referências até na pintura naturalista de Jean François Millet, como pode ser visto na página 35 da obra e são resolvidas com a criação de diversos planos mesmo só utilizando a linguagem de traço, como na página 81 ou o uso preciso da retícula aplicada, na página 69, com legendas escritas à mão na própria ilustração. As duplas reproduzidas e a página 49 em particular (FIG. 4.39) mostram a concepção de desenho unitária texto/imagem e as ilustrações em aquarela mostram a versatilidade do artista. 

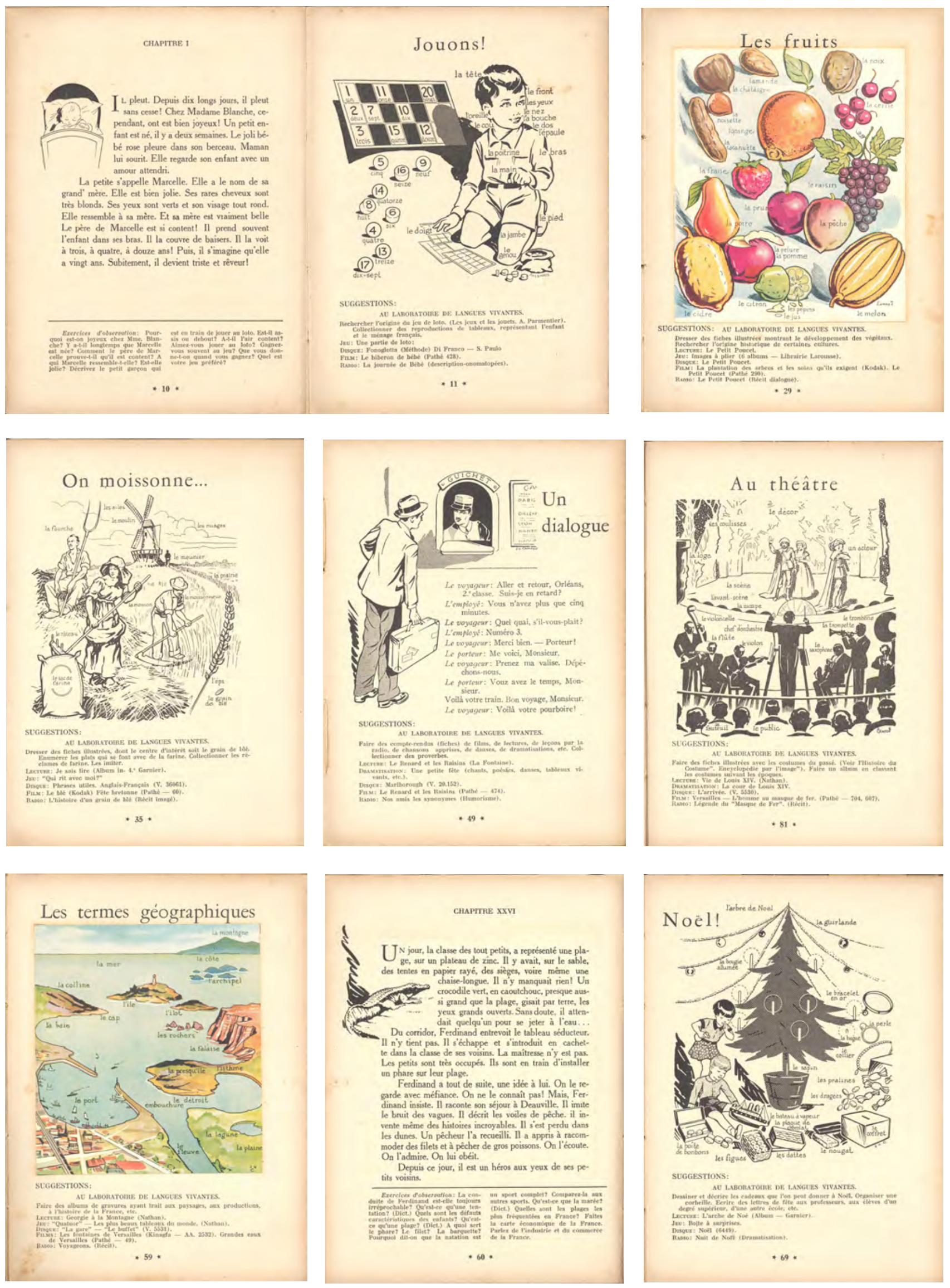

Fig. 4.39. Maria Junqueira Schmidt, Mon petit univers, BPB Série II, vol. 25 (15,7 x 21,3 cm). Páginas de miolo. 


\subsection{Considerações gerais sobre o design dos livros didáticos da CEN do período 1932-1942}

Se a introdução da política de coleções serviu para criar padrões de identidade visual para reconhecimento do público e padrões e critérios necessários a uma produção que envolvia grande número de obras, de todas as disciplinas e em prazos determinados pelo calendário escolar, é preciso dizer que essa produção foi realizada com grande qualidade editorial e gráfica. A produção anual de títulos não é só muitas vezes maior que a do período inicial de atividade da editora, como apresenta um considerável incremento de qualidade.

Isto quer dizer que, no momento em que a CEN se lançou a uma expansão de seu catálogo didático para ocupar o espaço aberto com a expansão do Ensino Secundário, o fez com extrema profissionalização de seus meios e quadros. Por um lado, criou os instrumentos necessários ao planejamento e produção, com o estabelecimento de modelos e padrões de configuração gráfica. Por outro, constituiu equipes capacitadas a aplicá-los. Isto é demonstrado pelas realizações documentadas, particularmente os miolos das inúmeras disciplinas, que apresentam complexidade e visualidade próprias, determinadas pelas especificidades de conteúdo textual e iconográfico, mas recebem todas elas soluções adequadas ao seu programa.

A produção gráfica envolvida em algumas disciplinas, com o desenho de pranchas especiais e sua inserção e dobragem manual, faz com que se possa mudar a visão que se tem do livro didático como produto inferior em relação ao livro literário, assim considerado por sua produção e distribuição massiva e uso datado e descartado. E o trabalho de design de algumas realizações, se não corresponde ao das linguagens de vanguarda encontradas em obras literárias ou periódicos sofisticados da época, não deixa de ser muito elaborado e desenvolvido, como exemplifica a atuação precisa e mesmo virtuosa de J. U. Campos em Mon Univers. Mesmo considerando que este seja um caso excepcional de livro didático com investimento em design e produção superior à média, a produção didática geral da Nacional na década de 1930 é caracterizada por um salto de qualidade evidente e estabelece um novo padrão de realização para o livro didático brasileiro.

O que se pode questionar é que o design de capas não acompanha a qualidade da realização dos miolos, sendo mais caracterizado por soluções padronizadas determinadas por necessidades de produção com pouco investimento em particularização e considerações ao público. Para isto contou a tradição do livro didático mesma, sua finalidade educativa "séria" que o separava do livro de apelo popular, que já tinha seus precedentes na Companhia Editora Nacional mas foi levada a extremos de sobriedade pela finalidade superior de refundação da nação pela educação atribuída à Biblioteca Pedagógica Brasileira. No entanto, a particularização das obras através do desenho de letras, se nem sempre apresentou o mesmo nível de qualidade, é em muitos casos bem realizada e eficiente. 

CAPÍTULO 5

1943-1952:

A renovação do design de didáticos da Companhia Editora Nacional para uma nova expansão do ensino 


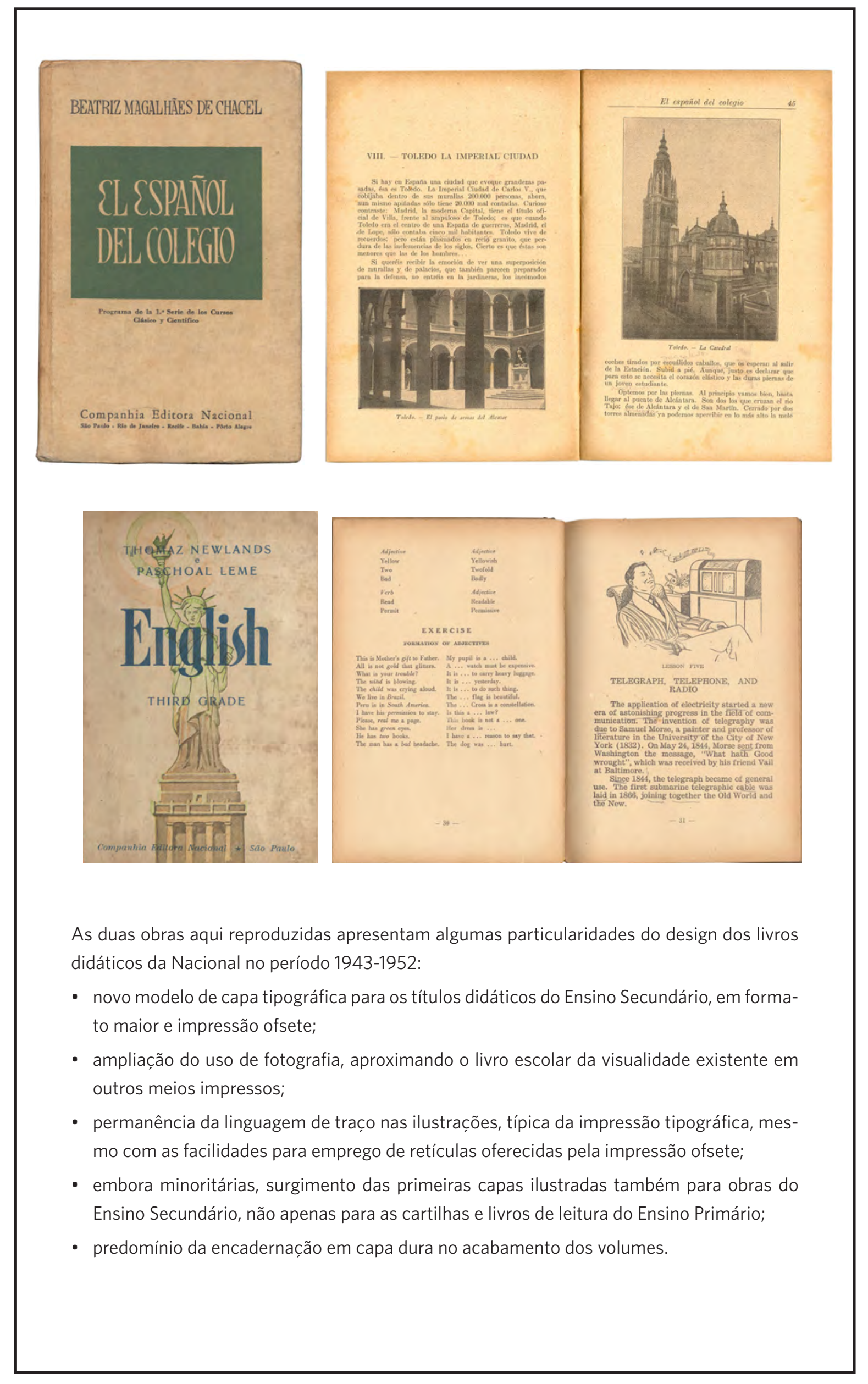



que mais visivelmente marca o terceiro período de design dos livros didáticos da Companhia Editora Nacional é o surgimento de nova e marcante solução gráfica para as capas, adotada em um número expressivo de títulos, mais precisamente aqueles destinados ao segundo ciclo do Ensino Secundário, o Colegial, então criado pela Lei Orgânica do Ensino Secundário, de 1942, também conhecida como Reforma Capanema. Ainda tipográficas, mas com cores mais fortes e vibrantes, e em novo formato, ligeiramente maior, as novas capas marcam a adequação da produção didática da editora à nova organização do ensino, pela diferenciação material e visual entre os volumes destinados aos dois ciclos do Secundário - Ginasial e Colegial -, ao mesmo tempo que modernizam o aspecto de parcela importante dos livros didáticos da Nacional, contribuindo para uma atualização da imagem da editora junto ao público.

Mesmo com o progressivo esvaziamento das antigas coleções já mencionado no capítulo anterior, uma parte dos títulos mesmo para o Colegial ainda permanece sendo publicada sob o abrigo da BPB Série II, da Coleção Dom Bosco e da Biblioteca Escolar Brasileira, com o design e formato definidos originalmente para elas e as necessárias mudanças de informação nas capas e páginas de rosto. E para os títulos de Ginasial, antigos e novos modelos de capas são utilizados, também no formato anteriormente vigente.

Um outro aspecto, um pouco menos visível, a definir esse terceiro período do design da CEN, diz respeito ao miolo dos livros. Menos visível porque não é criado um novo projeto de miolo, mas sim porque são efetivadas mudanças mais sutis, como o aperfeiçoamento dos critérios gráficos, um reforço da padronização do diagrama das páginas das obras e - este mais perceptível - um incremento do uso de fotografia.

Nos dois casos, design de capa e design de miolo, as mudanças vieram associadas a uma questão tecnológica: a generalização do uso de impressão litográfica em máquinas ofsete ${ }^{1}$ para os livros da editora. A preparação para esse salto antecedeu a marcante reforma da estrutura de ensino no país e mesmo não tendo sido diretamente motivada por ela e sim pela necessidade de expansão da produção, serviu para configurar visualmente os novos livros em acordo com a nova estrutura de ensino, identificando-os com ela. Assim, o início do terceiro período de design de didáticos da Nacional também coincide com os efeitos da primeira das Leis Orgânicas do Ensino, a referente ao Ensino Secundário, que junto com as que se seguiram, impulsionou um novo crescimento da oferta de educação no país e a demanda por mais livros escolares. A capacidade da editora em responder às demandas decorrentes dessas transformações no ensino do país será o principal fator para uma nova expansão da CEN, que já inicia a década de 1940 como a maior editora do Brasil, em número de títulos e tiragem.

\footnotetext{
1 O sistema de impressão ofsete é um sistema planográfico, mas diferentemente da litografia industrial, em que a transferência das áreas de grafismo dava-se diretamente da matriz cilindrica (chapa metálica) para o papel, é um sistema indireto, com a transferência se dando para um cilindro emborrachado e só então para o papel (ver nota 4 do capítulo 3, p. 102 e Rossı, 2001, p. 422)
} 


\subsection{A Companhia Editora Nacional, maior editora do país}

Como vimos no capítulo anterior, a constituição da BPB Série // no começo dos anos 1930 significou o engajamento definitivo da Nacional na produção de livros didáticos, o que a levou à condição de maior editora paulista e líder do mercado no estado. De uma produção de 117 títulos e 418.800 exemplares de tiragem em 1931, a editora salta para 158 títulos e tiragem de 1.192.000 exemplares em 1933, chegando em 1937 a uma tiragem de 2 milhões de exemplares e a partir de 1938 a uma média anual de 3,5 milhões de exemplares até o ano de 1948. Isto significa que já em 1938, o número de exemplares impressos pela Nacional correspondia a mais de um terço da produção nacional, que para aquele ano foi de 10 milhões de exemplares [Hallewell, 2005, p. 371]. Assim, Hallewell pode afirmar que já nos primeiros seis meses de 1940, a Companhia Editora Nacional é líder no país em número de títulos novos, tamanho de catálogo e tiragem.

A empresa chega também aos anos 1940 com um perfil editorial diferente de seus primeiros tempos. As intenções e a prática de Lobato de lançar autores brasileiros inéditos que marcaram sua atuação como editor nos anos 1910 e 1920, se já no início da Nacional foram limitadas, deixaram mesmo de ser prioridade. Na verdade, Octalles Marcondes Ferreira passou a trabalhar com um catálogo bastante amplo, voltado para os mais diversos segmentos de público e com obras que propiciassem grandes tiragens e vendas. Coleções de livros infantis, romances juvenis, históricos e para moças, coleções de direito, medicina, pedagogia e realidade brasileira foram completadas com títulos avulsos sobre temas de grande atualidade no momento, como doutrinas políticas e vida sexual, contando com grande número de traduções em todos esses segmentos. E, ao lado dessa diversidade de assuntos, cresceu o número de lançamentos didáticos, principalmente para os níveis primário e secundário e alguns títulos para o ensino superior, para a formação de docentes (ensino normal) e para o ensino comercial.

Essa "especialização" da editora em obras para públicos maiores definiu um perfil da editora que de fato excluiu o trabalho editorial especializado voltado para o mercado da literatura brasileira que se produzia naquele momento. Este trabalho dependia de outras redes e relações que a editora deixou de manter, seja porque Lobato efetivamente não tinha mais papel de editor para continuar articulando-as, seja porque que novos atores ocuparam esse espaço no mercado, particularmente a José Olympio e a Martins, que se tornaram os polos do lançamento dos novos títulos de literatura brasileira na década de 1940. A ação da editora no campo da literatura nacional restringe-se ao lançamento de uma coleção de obras completas de poetas já consagrados, em 1938, tendo Castro Alves como autor do primeiro volume [HALLEWELL, 2005, p. 355].

Assim, no campo dos livros não didáticos, coleções criadas na década de 1930, como a Biblioteca das Moças e Coleção Terramarear, entram na década de 1940 com muitos lançamentos 
e com grande aceitação de mercado, intensidade confirmada pela manutenção das mesmas características materiais e visuais de seus primeiros volumes, como o leiaute de capa e a linguagem de ilustração (FIG. 4.3 e 4.4, no capítulo anterior). E se a política de coleccões foi interrompida ou ao menos bastante reduzida no segmento dos didáticos, manteve todo o seu potencial de atingir novos segmentos de público e oferecer programas de leitura que os fidelizavam à editora. Esse é o caso de uma coleção criada em 1938, com grande número de lançamentos até 1943 e inúmeras reimpressões ao longo dessa década.

Trata-se da Biblioteca do Espírito Moderno, organizada pelo educador Anísio Teixeira e oferecida como uma coleção de cultura geral voltada para a formação intelectual de um "leitor médio" abrangendo quatro campos temáticos - Filosofia, Ciência, História/Biografias e Literatura:

A Biblioteca do Espírito Moderno visa coordenar para o leitor brasileiro, dentre as obras consagradas pela aceitação pública, aquelas que mais diretamente buscam condensar, esclarecer e popularizar a herança cultural da espécie, tornando-a realmente, sem perda de nenhum dos finos e raros valores que sempre a caracterizaram quando não passava de legado atribuído a privilegiados eruditos, a herança comum e por todos partilhada. [...] Biblioteca de civilização e cultura, os leitores terão em seus volumes o mais rico documentário com que se poderá tentar compreender e acompanhar o longo esforço do pensamento humano para embelezar, enriquecer e dirigir a vida. [Texto do catálogo da coleção, reproduzido em orelhas e quartas capas de alguns volumes, apud FONSECA, 2010, p. 40.]

Embora o espectro de assuntos e o propósito da coleção seja mais amplo que o da Biblioteca Pedagógica Brasileira, a citação permite identificar uma abordagem semelhante à adotada quando do lançamento da $B P B$, particularmente a idéia de se reunir campos de conhecimentos os mais diversos sob um mesmo crivo editorial, apresentados como séries. No caso da BPB, o fio condutor para a reunião em uma mesma coleção desde obras de literatura infantil até ensaios sobra a realidade nacional era a idéia de construção da nação e da nacionalidade. Agora, com a BEM trata-se da idéia mais universal de herança cultural de toda a humanidade e de conhecimentos atualizados, oferecidos para um mesmo leitor, o homem moderno brasileiro, de formação secundária ou mesmo superior, que queira ampliar seus conhecimentos para além da sua especialização ou atividade profissional. Assim, ao invés de obras segmentadas em coleções especializadas, para o ensino universitário, o apelo da coleção está em oferecer obras de divulgação mais acessíveis, de vários campos da cultura, para um único leitor num mesmo momento de sua vida, ao contrário do programa da BPB, cujas séries eram mais estanques e para públicos diversos.

O sucesso imediato da Biblioteca do Espírito Moderno foi possibilitado pela ampliação de um público de extração social média, parte dele com formação secundária nos moldes do 
ensino ainda elitizado vigente mas que cresceu numericamente, e outra parte com formação superior nas profissões liberais e quadros nas empresas, administração pública e magistério².

A materialidade e visualidade da coleção indicam também o sentido do projeto da coleção e o público a que se destinava. Foram lançadas duas versões, em capa dura com gravação dourada e sobrecapa, e em brochura, ambas com projeto de Otto Bendix [FonsECA, 2010, p. 161]. O diagrama simétrico e o desenho ornamentado não procuravam trazer nenhuma idéia de modernidade ou atualidade, mas de valores clássicos e estáveis, da cultura consolidada e permanente que a coleção dizia representar, e que provavelmente constituía uma visualidade eficaz para ao menos parte do público a que se dirigia, daí seu aparente anacronismo formal e conservadorismo (FIG. 5.1).
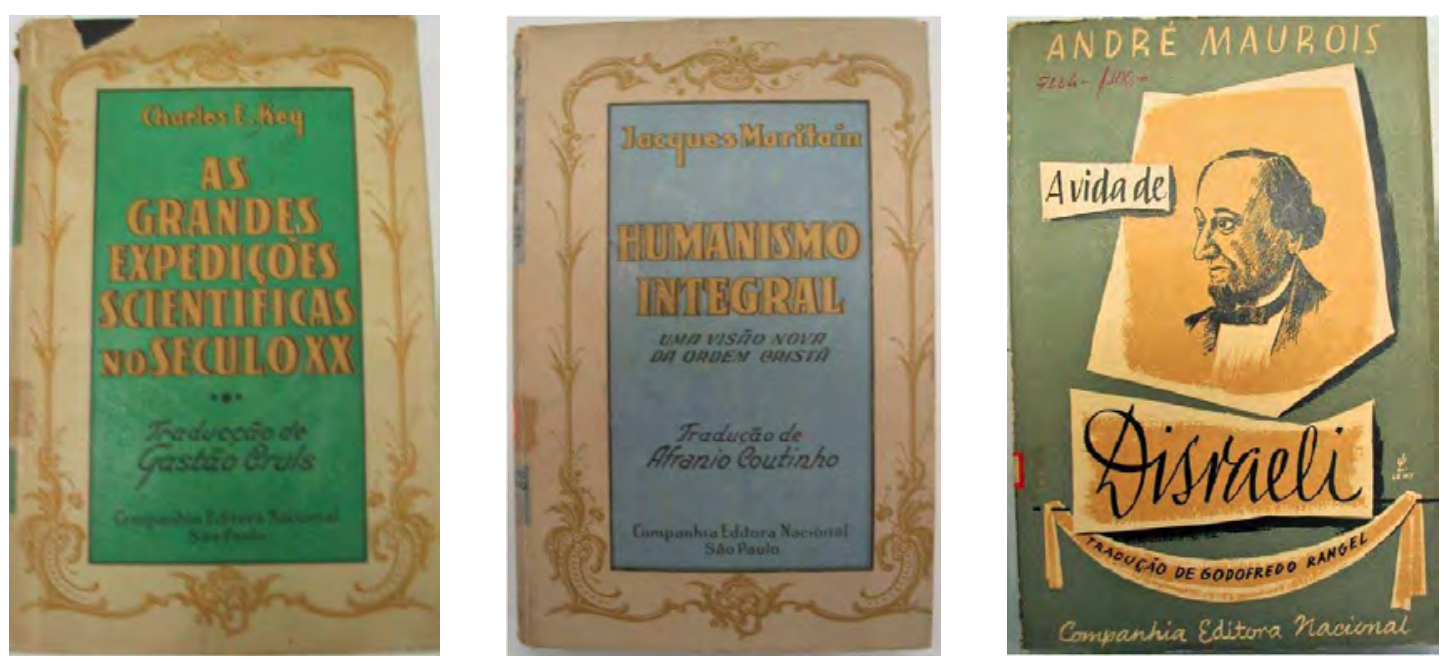

Fig. 5.1. Biblioteca do Espírito Moderno: capas de dois volumes em brochura da entre 1938 e 1943, em que as diferentes cores de fundo indicam as séries temáticas da coleção; capa de volume em brochura assinada por Walter Lewy, posterior a 1944. [Fonte: FonSECA, 2010.]

A partir de 1943, o número de lançamentos é menor, mas a coleção cresce em tiragens, com reimpressões na forma de brochura que recebem novas capas, agora diferentes para cada volume, mas dentro de um estilo gráfico definido pelo autor do novo design e das várias capas, Walter Lewy, pintor surrealista e artista gráfico alemão que havia chegado ao Brasil em 1938. Esta mudança provavelmente acompanha transformações na sensibilidade do público, também sob influência da visualidade veiculada por outras editoras e outros meios impressos e corresponde também à idéia de renovação dos conhecimentos propiciada por obras de divulgação produzidas por autores então atuais que integravam a coleção (FIG. 5.1).

\footnotetext{
2 Segundo BEDA [1987, p. 316], a coleção atingiu durante sua existência (1938-1984) 161 títulos e tiragem total de 2.306.324 exemplares, assim distribuídos: Filosofia, com 33 títulos e 425.637 exemplares; Ciências, com 30 títulos e 158.527 exemplares; História e Biografia, com 72 títulos e 890.152 exemplares; Literatura, com 26 títulos e 832.008 exemplares. Mas FonSECA [2010], que propõe uma periodização para a coleção, apresenta mais detalhadamente a distribuição de lançamentos e reimpressões, apontando o escasseamento de títulos novos ao longo do tempo e 1977 como o ano do último lançamento, com a coleção prosseguindo apenas com reimpressões e redução drástica de vendagem, por motivos que analisa em profundidade.
} 
A modernização do design da Biblioteca do Espírito Moderno, com as capas de Walter Lewy, não é a única mudança de abordagem gráfica identificada nos livros da Nacional nesse período. A coleção Atualidades Pedagógicas, que pertencia à série III da Biblioteca Pedagógica Brasileira, a partir de 1951 passa a ser dirigida por J. B. Damasco Pena, em substituição a Fernando de Azevedo, e é desvinculada da BPB, recebendo novas capas. A solução tipográfica (FIG. 5.2) é equilibrada, limpa e traz a regularidade dos títulos compostos, não desenhados, o que traduziria a visão mais moderna e profissionalizada de Rubens de Barros Lima, que assumiu a função de encarregado da Produção em 1943 e a exerceu até 1973.

Segundo Ephraim Beda, este profissional introduziu um controle maior na marcação dos originais, estabelecendo a prática de execução de "boneco" para a diagramação completa de cada livro, "do falso rosto e frontispício, até o colofão", e no acompanhamento da composição, impressão e acabamento das obras [BEDA, 1987, p. 267]. De formação autodidata, Rubens de Barros Lima iniciou sua trajetória na Nacional no depósito e expedição, passando para o balcão e depois para a Contabilidade pela qualidade de sua letra, e chegou à seção de Propaganda, onde reproduzia em traço as capas dos catálogos e controlava as encomendas de impressão.

Como encarregado da Produção, viajava para a Europa para providenciar a compra de papéis, chegando a participar, junto com um técnico finlandês, do desenvolvimento de um papel ofsete exclusivo para os livros escolares da Nacional, com características intermediárias entre papéis de primeira e segunda qualidades mas de custo reduzido, que foi batizado de Eastlander [BEDA, 1987, p. 267]. Suas viagens tinham também a finalidade de aperfeiçoar e atualizar seus conhecimentos de editoração, com visitas e estágios em editoras, como a italiana Mondadori. O resultado foi um acréscimo na qualidade visual e material dos livros, com a observação de regras e critérios de composição, diagramação e paginação adotadas internacionalmente, e o cuidado com a interação papel e tinta, os acabamentos e a viabilidade de custos, aspectos que eram em geral improvisados na produção livreira do país [BEDA, 1987, p. 268-269].
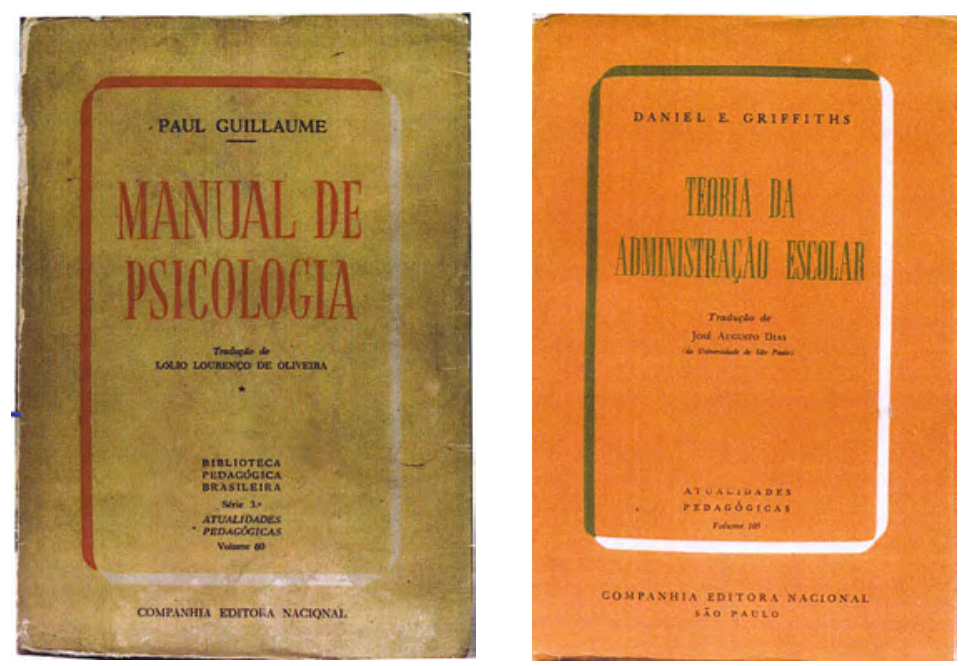

Fig. 5.2. Capas da coleção Atualidades Pedagógicas a partir de 1951. [Fonte: Toledo, 2001.] 
A expansão da editora, particularmente no segmento didático, contou com o comprometimento maior da São Paulo Editora como principal fornecedora dos serviços de impressão e acabamento dos livros escolares, como atesta o crédito encontrada na quase totalidade dos exemplares encontrados durante a pesquisa material. Este maior compromisso certamente foi obtido pela entrada de Octalles Ferreira como sócio da empresa, em 1938, e do aporte de capital efetuado, resultando em participação de 40\% das ações preferenciais e 60\% das ações ordinárias, o que permitiu a aquisição de novos equipamentos pela São Paulo com vistas a atender a demanda crescente da Nacional. Assim, sem ser proprietária direta das máquinas e mantendo o perfil de editora de livros, a CEN obteve a garantia dos serviços gráficos necessários à sua expansão [BEDA, 1987. p.248].

Concluindo, a abrangência de público atingido pelo catálogo da Nacional, mais o crescimento dos títulos e tiragens de livros escolares, foram responsáveis pela consolidação da CEN como a maior editora do país, posição que não chegou a ser afetada pela saída de "seis professores responsáveis pela execução do programa de livros didáticos", que vão formar a concorrente Editora do Brasil, em 1943 [HALLEWELL, 2005, p. 367]. A editora estava suficientemente consolidada para também absorver a devolução ao autor dos direitos das obras de Monteiro Lobato, que passaram a ser publicadas pela Editora Brasiliense, que se formou com a saída de Arthur Neves, um dos principais editores da Nacional, no mesmo ano de 1943 [HALLEWELL, 2005, p. 367-368].

\subsection{As Leis Orgânicas do Ensino e a nova estrutura da educação}

Como vimos no capítulo anterior, a Constituição de 1937, expressão jurídica da ditadura do Estado Novo, significou um retrocesso em relação ao papel do Estado em prover educação gratuita em todos os níveis de ensino, favorecendo as instituições de ensino católicas dirigidas para a elite econômica do país. Assim, persistia também o caráter dualista do ensino, com forte conotação de classe, como também vimos no capítulo anterior. No entanto, a necessidade de uma reforma profunda e global da educação no país, até então nunca enfrentada, tornava-se ainda mais premente, num contexto de guerra mundial que impunha a necessidade de industrialização do país para suprir a importação de bens, mas que não encontrava mão-de-obra qualificada para provê-la.

De um lado, prosseguia a existência de um Ensino Primário oficial que não oferecia condições de continuidade da formação e profissionalização especializada das camadas populares. De outro, um Ensino Secundário de caráter propedêutico para os cursos superiores, de conteúdo humanístico, propiciava às classes econômicamente favorecidas condições para ocupar postos superiores nos diversos níveis da adminstração estatal e privada, além do exercício 
das profissões liberais, mas pouca inserção em atividades produtivas. Assim, o dualismo na educação brasileira se apresentava como um entrave bastante concreto ao desenvolvimento industrial do país [RomANELLI, 2007, p. 166].

A pressão crescente de setores populares por educação primária e profissional e de setores médios pela educação secundária foi outro fator a exigir por parte do governo da época não só uma ampliação da rede escolar existente mas, em combinação com as demandas de desenvolvimento que esse ensino deveria suprir, uma reforma integral de todo o sistema de ensino no país. No entanto, mais uma vez a resposta aos problemas educacionais brasileiros não veio como como uma reforma global, mas sim com reformas parciais por ramos de ensino tomados separadamente, através de decretos-leis específicos [RomANELLI, 2007, p. 153-154.].

Cada um desses decretos-leis, seguidos de sua regulamentação específica, constituiram o que se chamou Leis Orgânicas do Ensino, e foram iniciadas em 1942 e 1943 pelo então ministro da Educação Gustavo Capanema:

- Lei Orgânica do Ensino Industrial;

- Criação do Serviço Nacional de Aprendizagem Industrial (Senai);

- Lei Orgânica do Ensino Secundário;

- Lei Orgânica do Ensino Comercial.

Esse primeiro conjunto é conhecido como Reforma Capanema, mas o termo é particularmente aplicado à Lei Orgânica do Ensino Secundário. Com a queda de Vargas, a reorganização geral do Ensino Primário e Médio é completada pelo Governo Provisório, em 1946:

- Lei Orgânica do Ensino Primário;

- Lei Orgânica do Ensino Normal;

- Criação do Serviço Nacional de Aprendizagem Comercial (Senac);

- Lei Orgânica do Ensino Agrícola. [RomanelLi, 2007, p. 153-154.]

A Constituição de 1946, de caráter democrático e liberal, consagrará essa legislação, estabelecendo que à União caberia legislar sobre todos os ramos do ensino, o direito de todos à educação, a obrigatoriedade do Ensino Primário e sua gratuidade nas escolas oficiais. Embora a reforma do Ensino Secundário tenha ocorrido primeiro, seguiremos aqui a ordem crescente dos níveis de ensino na identificação de suas características.

\subsubsection{O Ensino Primário}

Com o Ensino Primário historicamente a cargo das administrações estaduais, com várias delas tendo efetivado as suas reformas desde a década de 1920, este nível de ensino não havia tido até então diretrizes de fato nacionais, apresentando grandes diferenças entre os estados, oferta desigual e desorganização como sistema educativo. Assim, a Lei Orgânica do Ensino Primário, promulgada após o fim da ditadura varguista, apresentou pela primeira vez princípios 
e diretrizes para todo o país, estrutura e currículo nacional e os meios para implementá-los - planejamento administrativo, dotação orçamentária estipulada para cada nível de governo, aparelhamento escolar e política de formação de professores. No entanto, mais uma vez se verificou uma distância entre as intenções da lei e os fatos, particularmente em decorrência das dificuldades com a formação do número de docentes necessários através da estrutura de Ensino Normal existente. Mas a inclusão do Ensino Primário como parte de um sistema de ensino de caráter nacional correspondeu à realização de uma tarefa histórica até então postergada e uma vitória do movimento renovador da educação, só possível após a redemocratização do país [ROMANELLI, 2007, p. 159-163].

A estrutura de Ensino Primário previa duas categorias de curso, com os seguintes currículos:

- Ensino Primário Fundamental. Ensino regular, para crianças de 7 a 12 anos, dividido em:

- Primário Elementar, de 4 anos

Disciplinas: Leitura e linguagem oral e escrita; Iniciação à Matemática; Geografia e História do Brasil; Conhecimentos Gerais aplicados à vida social, à educação para a saúde e ao trabalho; Desenho e Trabalhos Manuais; Canto Orfeônico; Educação Física.

- Primário Complementar, de 1 ano.

Disciplinas: as mesmas do Elementar acrescidas de Noções de Geografia Geral e História das Américas e Ciências Naturais e Higiene.

- Ensino Primário Supletivo. Com duração de 2 anos, destinado a adolescentes e adultos que não conseguiram a formação primária na idade adequada e visando a redução dos elevados índices de analfabetismo.

Disciplinas: Leitura e linguagem oral e escrita; Aritmética e Geometria; Geografia e História do Brasil; Ciências Naturais e Higiene; Noções de Direito usual (legislação do trabalho, obrigações da vida civil e militar); Desenho; Economia Doméstica e Puericultura (apenas para o sexo feminino).

O Ensino Primário teve uma nova expansão e, junto com o ensino profissional, em particular os cursos de nível Ginasial e os de treinamento oferecidos pela indústria e comércio - Senai e Senac -, continuará destinado às camadas populares, que encerraria neles sua educação. Com o afluxo de camadas médias, o Ensino Secundário também terá uma nova expansão, incorporando alguns extratos populares ao seu ciclo inicial, o Ginásio, que continuava exigindo o exame de admissão e não era gratuito em todos os estabelecimentos oficiais. Mas a educação secundária completa - e mesmo o ensino técnico de nível colegial - continuará destinada apenas a quem tem recursos para não se engajar cedo no mercado de trabalho, mantendo seu caráter propedêutico ao ensino superior e significando a permanência da educação dualista no país [ROMANELLI, 2007, p. 167-169]. 


\subsubsection{O Ensino Secundário}

Em termos de estrutura, a reforma do Ensino Secundário estabeleceu dois ciclos: o Ginasial, com duração de quatro anos, e o Colegial, com duração de três anos. Este oferecia duas opções de curso, o Clássico e o Científico. Sem detalhar a distribuição das disciplinas em cada série, este era o currículo de cada ciclo e curso:

\section{- 1ำ ciclo - Ginasial}

Português, Latim, Francês, Inglês, Matemática, Ciências Naturais, História Geral, História do Brasil, Geografia Geral, Geografia do Brasil, Trabalhos Manuais, Desenho, Canto Orfeônico.

\section{- 2ำ ciclo-Colegial}

- Curso Clássico: Português, Latim, Grego (optativo), Francês, Inglês, Espanhol, Matemática, História Geral, História do Brasil, Geografia Geral, Geografia do Brasil, Física, Química, Biologia, Filosofia.

- Curso Científico: Português, Francês, Inglês, Espanhol, Matemática, História Geral, História do Brasil, Geografia Geral, Geografia do Brasil, Física, Química, Biologia, Filosofia, Desenho.

Além do currículo enciclopédico, sem grande distinção entre as disciplinas dos cursos Científico e Clássico, a Lei Orgânica do Ensino Secundário manteve também o sistema de provas e exames da Reforma Campos de 1931, com sua rigidez e seletividade que serviram para "acentuar a velha tradição do Ensino Secundário acadêmico, propedêutico e aristocrático" [RomAnelli, 2007, p. 157-158]. A finalidade de proporcionar cultura geral e humanística e condições para ingresso no curso superior era completada com o caráter patriótico e cívico dado às disciplinas de História do Brasil e Geografia do Brasil, com a "finalidade do Ensino Secundário formar as individualidades condutoras", conforme o texto da lei, enquanto o Ensino Primário era dirigido aos que deveriam ser conduzidos.

Ainda segundo a lei, esse caráter patriótico se manifestaria nas "festividades cívico-patrióticas", no culto aos heróis nacionais e na educação militar na própria escola, culminando com a formação de uma Juventude Brasileira, que Vargas não conseguiu implementar, mas que claramente seguia os modelos das juventudes fascistas da Alemanha e de Itália. A legislação ainda estabelecia o ensino religioso facultativo e limitava a frequência mista, recomendando a educação secundária das mulheres em estabelecimentos exclusivamente femininos. Assim, a reforma não só reforçava a educação classista voltada para a preparação de lideranças e impunha retrocessos a princípios da Educação Nova que haviam sido reconhecidos na Constituição de 1934, como apresentava um caráter autoritário e fascista. No entanto, a demanda social por educação, com a classe média emergente e parcelas das camadas populares pressionando pelo acesso ao secundário, obrigou o sistema a flexibilizá-lo e acentuou as contradições entre 
as finalidades previstas para esse nível de ensino e as necessidades de desenvolvimento do país [ROMANELLI, 2007, p. 159].

\subsection{A Comissão Nacional do Livro Didático e a primeira legislação nacional para o livro escolar}

Em dezembro de 1938, o governo Vargas promulgou a primeira legislação de âmbito nacional voltada para o livro didático, através da criação da Comissão Nacional do Livro Didático, com a finalidade de examinar os manuais produzidos para as escolas pré-primárias, primárias, normais, profissionais e secundárias do país, com poder de rejeitar e proibir sua adoção pelas escolas [FILGUeIRAS, 2013, p. 166]. Vinculada ao Ministério da Educação e formada por especialistas nas várias áreas científicas e do ensino, a CNLD tinha por tarefa avaliar os livros de cada especialidade em dois aspectos:

- Ideológicos, relativos à defesa do Estado e do governo constituído, em que seriam vetadas obras que contestassem as idéias vigentes de nação, identidade nacional, tradições brasileiras, família e religião;

- Pedagógicos, relativos à correção de conceitos, metodologia de ensino, linguagem e questões gráficas.

Os critérios ideológicos tinham função claramente de controle da circulação de idéias, enquanto os pedagógicos visavam padronizar os conteúdos e métodos conforme normas didáticas oficialmente adotadas pela legislação e uniformizar a linguagem segundo a nova ortografia oficial e abolir regionalismos [FILGUEIRAS, 2013, p. 168].

A CNLD só foi efetivamente constituída em janeiro de 1941 e, dos quase 2 mil títulos encaminhados para avaliação, em junho apenas 144 haviam sido avaliados. Dos 150 pareceres encontrados pela pesquisadora Juliana Miranda Filgueiras, a Companhia Editora Nacional foi a que mais submeteu livros para avaliação, com 30 títulos apresentados, dos quais 25 foram aprovados ou autorizados mediante correções, 4 não avaliados por não serem considerados didáticos e apenas 1 reprovado, por incorreções e linguagem inadequada. A Melhoramentos submeteu 27 títulos, com 3 aprovados ou autorizados mediante correções e 24 reprovados ou não avaliados por não atenderem algum requisito, seguida pela Francisco Alves, com 22 títulos apresentados, 4 aprovados ou autorizados mediante correções e 18 reprovados ou não avaliados por não atenderem algum requisito [FILGUEIRAS, 2013, p. 175].

Esse número de pareceres certamente está aquém do efetivamente produzido pela comissão, mas permite identificar quais eram de fato as maiores editoras didáticas do país e a capacidade da Nacional em se antecipar às demais na submissão de seus títulos à avaliação e 
atender aos seus critérios, talvez porque vários de seus autores eram membros da comissão ou tinham acesso privilegiado a ela [FILGUEIRAS, 2013, p. 174].

Do ponto de vista da materialidade e visualidade, Filgueiras não menciona informações dos pareceres quanto aos critérios constantes na ficha de avaliação - resistência, qualidade de impressão e "gosto" da capa; adequação de formato; qualidade de papel e impressão do miolo; adequação de tipo, corpo e entrelinha; adequação e distribuição das gravuras; etc. Mas deve-se supor que no caso da Nacional eles teriam sido atendidos, pelo índice de aprovação verificado.

Com o fim do governo Vargas, uma nova legislação sobre livros didáticos foi criada, com a Comissão Nacional do Livro Didático continuando a existir mas passando "a ser questionada por grupos oriundos das Faculdades de Filosofia, Ciências e Letras, que se opunham à uniformização e padronização dos conteúdos dos livros didáticos, propondo novos projetos para a educação brasileira, com crítica à centralização das decisões em âmbito federal e defesa da autonomia dos estados em organizar seus sistemas de ensino" [FILGUEIRAS, 2013, p. 188].

\subsection{O design e a materialidade dos livros didáticos da Companhia Editora Naciona de 1943 a 1952}

O corpus da pesquisa material para este período, obtido majoritariamente no acervo da Biblioteca do Livro Didático da FEUSP, mas também na Biblioteca Infantil Municipal Monteiro Lobato (São Paulo) e no Acervo Histórico da Escola Caetano de Campos/Centro de Referência em Educação Mário Covas, é constituído de 68 títulos/edições de obras didáticas, assim distribuídos:

- Livros avulsos para o Ensino Secundário: 46 títulos/edições, sendo 23 para o Ginasial e 23 para o Colegial;

- Cartilhas e livros de leitura: 4 títulos/edições;

- Livros da BPB Série II, para o Ensino Secundário: 14 títulos/edições, sendo 11 para o Ginasial e 3 para o Colegial;

- Livros da Biblioteca Escolar Brasileira e da Coleção Dom Bosco: 4 títulos, sendo 2 para o Ginasial e 2 para o curso técnico comercial.

Essa distribuição acompanha proporcionalmente a representação de coleções e de livros avulsos do acervo da BLD-FEUSP, indicando a maior incidência dos títulos avulsos e a diminuição de importância das coleções no catálogo da Nacional.

A quase totalidade dos livros é constituída por volumes de capa dura, tanto os das antigas coleções, como os novos, mas dentre esses já aparecem algumas edições em brochura, destinadas ao segundo ciclo do secundário, o Colegial, e uma cartilha. 
A adoção de uma solução comum para a os títulos novos, ou oriundos das antigas coleções, destinados ao Colegial, que será apresentada no próximo tópico, indica que a produção de capas prossegue majoritariamente sendo feita independentemente dos miolos, continuando a justificar a apresentação separada dos dois componentes de design dos livros também para este período.

Os novos títulos ou os reeditados com a nova solução de capa, que será vista a seguir, apresentam formato de página ligeiramente maior - 13,7 a 14,0 cm x 20,7 a 21,0 cm - em relação ao formato dos livros do período anterior. A identificação do processo de impressão, tanto de capa como de miolo, indica a utilização de litografia industrial, com máquinas ofsete da São Paulo Editora, conforme crédito em todos os volumes de novo formato e com a nova solução de capa ${ }^{3}$.

Esse fato indica que uma mudança de design de miolo, ao menos nas medidas de página e de mancha de texto, já havia sido definida para a produção de livros que seria efetivada no decorrer do ano de 1942, como resultado da aquisição de novas impressoras pela São Paulo Editora a partir da entrada de Octalles Ferreira como sócio da empresa. Ephraim Beda menciona viagem conjunta de Ferreira e Savério D'Agostino, o sócio majoritário da São Paulo Editora, para compra de máquinas e pesquisas editoriais [BEDA, 1987, p. 248].

Com relação às capas, a definição de um novo formato para os livros do Colegial impôs a necessidade de criação de uma novo modelo, usado intensivamente conforme prática já definida pela editora a partir da adoção da estratégia de coleções, para cumprimento do extenso programa de edições.

\subsubsection{O novo design de capas de livros didáticos a partir de 1943}

A decisão pela criação de um novo modelo de capas para livros didáticos provavelmente antecedeu o anúncio da nova estrutura de Ensino Secundário, feito pelo governo em abril de 1942, uma vez que os prazos industriais não permitiriam que um volume tão significativo de títulos saísse no novo formato para o próximo ano letivo. Assim, não se pode descartar que os aspectos gerais da nova divisão do Ensino Secundário em dois ciclos já fosse de conhecimento das editoras e que a própria Nacional possa ter pretendido fazer coincidir suas mudanças gráficas com o oferecimento de livros para uma reforma que se sabia que viria, independentemente do conhecimento em detalhe de todo o seu conteúdo.

Assim, teria sido pelos detalhes da reforma que Hallewell [2005, p. 367] menciona o

\footnotetext{
3 A variação de medidas corresponde à tolerância industrial do formato $14,0 \times 21,0 \mathrm{~cm}$, obtido por dobra e corte de folhas do chamado formato americano, de $87,0 \times 114,0 \mathrm{~cm}$, padrão usual de máquinas impressoras planas ofsete para produção de livros. As folhas nessa medida são impressas em frente e verso e, conforme a imposição das matrizes e após dobras cruzadas sucessivas, geram cadernos de 4, 8, 16 ou 32 páginas, os quais serão ordenados, costurados, colados e refilados formando volumes de medida próxima a 14,0 x 21,0 cm [RossI, 2001, p. 281 e CRAIG, 1980, p. 145].
} 
prazo de apenas quatro meses para as editoras providenciarem as mudanças nos livros para atender à nova divisão do secundário nos ciclos Ginasial e Colegial, e este com duas opções de curso, Clássico e Científico. Estas modificações diziam respeito à redistribuição dos conteúdos conforme a distribuição das disciplinas nas séries de cada ciclo, e em particular à nova organização da disciplina História, que de História da Civilização passa a se chamar História Geral,

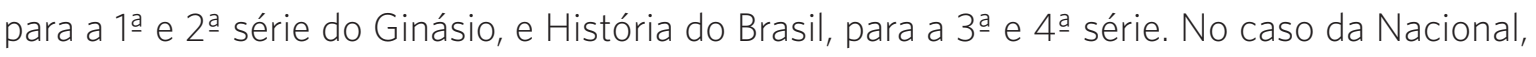
segundo HALLEWELL [2005, p. 367], nada menos do que quarenta títulos foram afetados e precisariam estar impressos com as modificações no início de 1943, mas é provável que o número de volumes, correspondentes à divisão das obras em séries, tenha sido bem maior.

Muito trabalho editorial deve ter sido dispendido, em prazo exíguo, para adaptação dos conteúdos à nova grade curricular, mas por menor que fossem as alterações ou rearranjos de conteúdo em livros já existentes, estes livros já não eram mais os mesmos e sua atualização precisava ser evidenciada e comunicada. Alguns livros que permaneceram dentro das antigas coleções mantiveram as capas antigas, trazendo as informações referentes à nova nomenclatura e série a que se destinava através da simples recomposição do texto. Mas a solução ideal seria que os livros correspondentes à nova estrutura do Ensino Secundário fossem material e visualmente reconhecíveis.

Assim, independentemente de quando tenha sido desenvolvida a nova solução de capa que figuraria nos lançamentos ou reedições didáticas a partir de 1943, ela deveria atender simultaneamente a duas demandas importantes. A primeira, de caráter mais permanente, seria dotar os livros didáticos da Nacional, e a ela por extensão, de uma nova identidade gráfica, o que vinha sendo diluído ou perdido com a pulverização dos livros em edições avulsas com capas tipográficas sem um princípio ou partido gráfico reconhecível ou marcante. A segunda, de caráter mais imediato, seria marcar a nova produção didática da editora como plenamente identificada com a recente reforma de ensino em vigor no país.

Mesmo considerando que a motivação principal para adoção de um projeto gráfico básico de capas para todos os livros de um segmento com uma produção tão extensa como a didática eram as necessidades de cumprimento de cronograma, não se deve descartar que aspectos relacionados à identidade e comunicação tenham sido considerados pelos dirigentes da empresa, a partir de sua recente experiência com própria BPB Série II. Não deve ter sido difícil para eles perceberem que o design de capa desta coleção serviu não só para identificá-la como uma coleção comprometida com a renovação da escola e da cultura como, pela aplicação na grande maioria de livros didáticos da editora, tenha se tornado uma marca de identidade de própria editora. Daí não seria também difícil para eles concluirem que a visualidade da nova produção deveria cumprir um papel análogo, demandando uma solução radicalmente diferenciada da anterior, talvez já reconhecida como defasada enquanto linguagem e correspondendo a uma tecnologia já superada. 

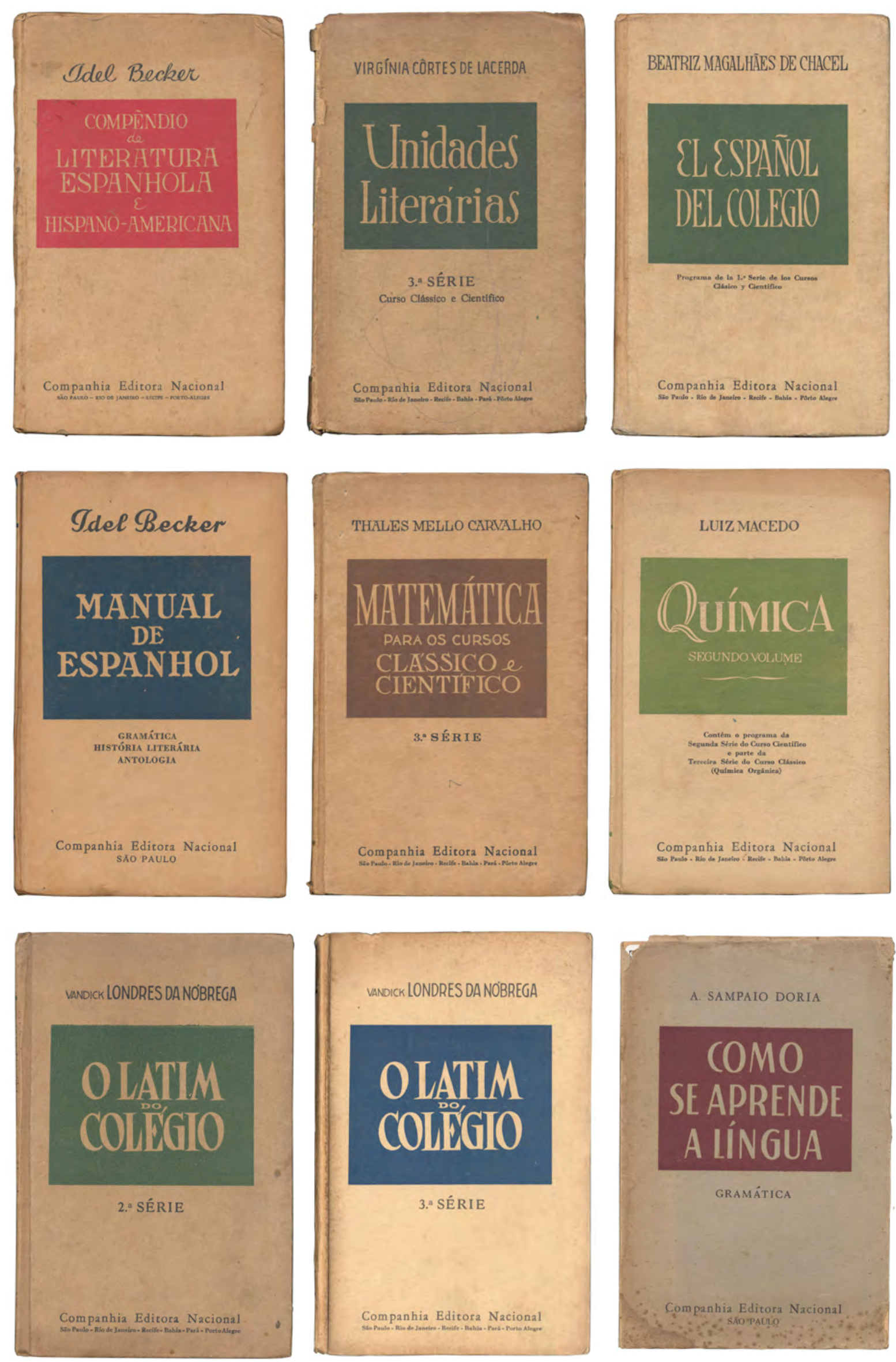

Fig. 5.3. Capas de livros didáticos para o Colegial no novo formato $(14,0 \times 21,0 \mathrm{~cm})$ e design, impressas em ofsete, de 1943 a 1946. 
A fIGURA 5.3 apresenta um primeiro conjunto de livros que traz a nova solução. Sua eficácia quanto aos aspectos comunicativos apontados deve-se ao grande contraste formal em relação às soluções anteriores. Tanto antes como agora, as capas são tipográficas, mas a inserção do título em letras vazadas (brancas) em um retângulo colorido faz toda a diferença em termos de atualização de linguagem e comunicação de modernidade naquele momento, principalmente em comparação com as capas anteriores de quaisquer das coleções. Note-se que os desenhos das letras são bem mais contidos e menos particularizados que o encontrado em muitas das capas da BPB Série II, mas sua associação com o retângulo e a variação de cor são num primeiro momento bastante impactantes e suficientes para marcar uma nova produção didática para efeito prático imediato e, de forma mais permanente, uma imagem mais moderna e atualizada para a editora.

A economia formal da solução traduz também o atendimento ao quesito produção, que já estava na base da adoção da estratégia das coleções no período anterior. Se, diferentemente dos livros da BPB Série II, os novos livros não constituem uma coleção, mantém-se o mesmo princípio de adoção de um modelo gráfico para facilitar a produção de um grande número de obras. A solução não implica particularização que dependa de qualquer relação com o miolo de cada obra e não envolve mais do que a grafia dos títulos específicos, em desenho de fonte e arranjo adequados ao comprimento e número de palavras envolvidas, e escolha de cor para cada volume. Claro que esse é um trabalho que exige critério e habilidade para resultar em soluções equilibradas e que, no final, levam a uma particularização mais ou menos eficaz para cada volume. Mas a opção por uma solução tipográfica, que dispensa o uso de imagens, encurta radicalmente o processo de concepção, finalização e aprovação de cada capa.

A aplicação desse modelo foi estendida também para capas de didáticos em outros formatos, principalmente para o antigo formato padrão anterior $(13,2 \times 19,2 \mathrm{~cm})$, como pode ser visto nas FIGURAS 5.4 a 5.6. Mas em todos essas aplicações, ao contrário dos demais modelos e capas antigas, a quarta capa é branca, não possui propaganda de outros títulos da editora.

\section{Estrutura gráfica e linguagem do novo modelo de capas}

Aplicando a classificação para as manifestações de linguagem gráfica elaborada por Michael Twyman apresentada no capítulo 4, vemos que há aqui uma pequena mudança de categoria em relação ao grupo de capas da BPB Série II, submetidas a essa classificação naquele capítulo. Sem a presença de qualquer logotipo ou ilustração, temos aqui ainda um método de configuração visual não linearmente dirigida mas um modo de simbolização verbo-numérico (ver p. 150-151)

A referência àquele modelo de capa se justifica porque indica a permanência da mesma abordagem, a tipográfica, em diagrama simétrico de eixo vertical, no novo modelo. Embora aqui o resultado seja menos sóbrio, dada a inserção da cor e a utilização de um procedimento 
encontrado em manifestações gráficas mais tipicamente modernistas (uma forma geométrica colorida, de grande dimensão, incorporando o título vazado), pode-se dizer que prossegue, de forma mais atualizada, a abordagem "séria" e "sóbria" imputada ao livro didático.

Com relação ao entendimento da organização interna das capas e seu papel na construção da informação veiculada, utiliza-se novamente o método de Paul MIJKSENAAR [1997] (ver p. 151-152):

1) Como variáveis de hierarquia, isto é, que indicam a diferença pela importância, temos, em ordem decrescente:

- posição no espaço gráfico: informações do título imediatamente acima do centro geométrico; informação de autor no topo, assinatura da editora no pé;

- diferenças de tamanho e intensidade: dimensão da área e corpo das letras do título; dimensão/peso das letras para autor; dimensão/peso variáveis das informações do volume e da assinatura da editora, conforme a capa;

- espaçamento entre as informações: enquanto os três blocos - título, autoria, assinatura editora - são distantes, as informações complementares ao título estão logo abaixo dele.

2) Como variáveis de categorização, isto é, que indicam a diferença pelo tipo de elemento gráfico-visual utilizado para a informação, temos:

- uso de forma geométrica: para o retângulo que contém informação do título;

- uso de cor: para o retângulo que contém informação do título;

- desenho de letra: diferentes para a informação de título, para autoria e para as demais informações;

3) Como variáveis de suporte, teríamos linhas, fios, caixas, cores de fundo, utilizados como elementos que contribuem para acentuação e ênfase das informações organizadas pelas outras variáveis. Assim, aqui em princípio teríamos o retângulo colorido que recebe o título vazado, mas nessa situação ele não é um elemento coadjuvante, de simples apoio à informação do título, senão que é um elemento principal do qual o título faz parte, uma vez que ambos são percebidos simultaneamente, daí a opção por considerá-lo uma variável de categorização.

Assim, a percepção e leitura desse modelo geral de capa é muito clara e direta: primeiro o título, com grande força e evidência, seguido do nome do autor, de informação complementar do volume quando existe e, por fim, da assinatura da editora. Essa solução, de grande simplicidade e sem buscar originalidade, acabou constituindo uma marca visual de identidade da editora, a partir de seu uso reiterado em livros didáticos ao longo da década de 1940 e mesmo na década de 1950.

Com relação ao uso da cor, nota-se que não foi pensado nenhum sistema a priori. A escolha é livre para cumprir a função de diferenciar as obras entre si e os volumes de cada obra. 
Assim, duas obras de uma mesma disciplina para o mesmo ano não terão as mesmas cores e os volumes de uma mesma obra, destinados a anos diferentes, também serão cromaticamente diferenciados.

\section{Tipografia e desenho das letras}

Como nas capas do período anterior, os títulos têm também letras desenhadas à mão, mas o conjunto de capas apresentado na fIGURA 5.4 mostra a predominância de desenho de letras mais simples que os encontrados em muitas capas da BPB Série II. Normalmente usam-se letras serifadas, altas e com grande contraste de espessura dos traços e preferência pelo uso de caixa alta. Excetuando os títulos longos, em que ocorre mistura de estilo - serifada e grotesca -, tamanhos e caixa, a tendência é uma composição mais coesa, sem variação de corpo, resultando em informação mais direta e imediata. Alguns títulos apresentam uma liberdade maior, com desenho de letras diferente para iniciais e até um único caso de uso de ornamento.

O conjunto apresentado na fIGURA 5.4 mostra capas com duas soluções tipográficas mais concisas e regulares e um caso em que o título é formado por duas fontes diferentes, com o nome do autor também utilizando a segunda fonte e obtendo maior destaque do que as soluções que utilizam fontes de composição mecânica. Note-se que este grupo e todas as da FIGURA 5.4 têm no retângulo colorido apenas informações do título, com as informações específicas de volume e série sendo compostas em linhas de texto logo abaixo do retângulo do título, solução prática em que um único desenho de letras serve para todos os volumes, diferenciados pela cor do retângulo e pela complementacão textual.
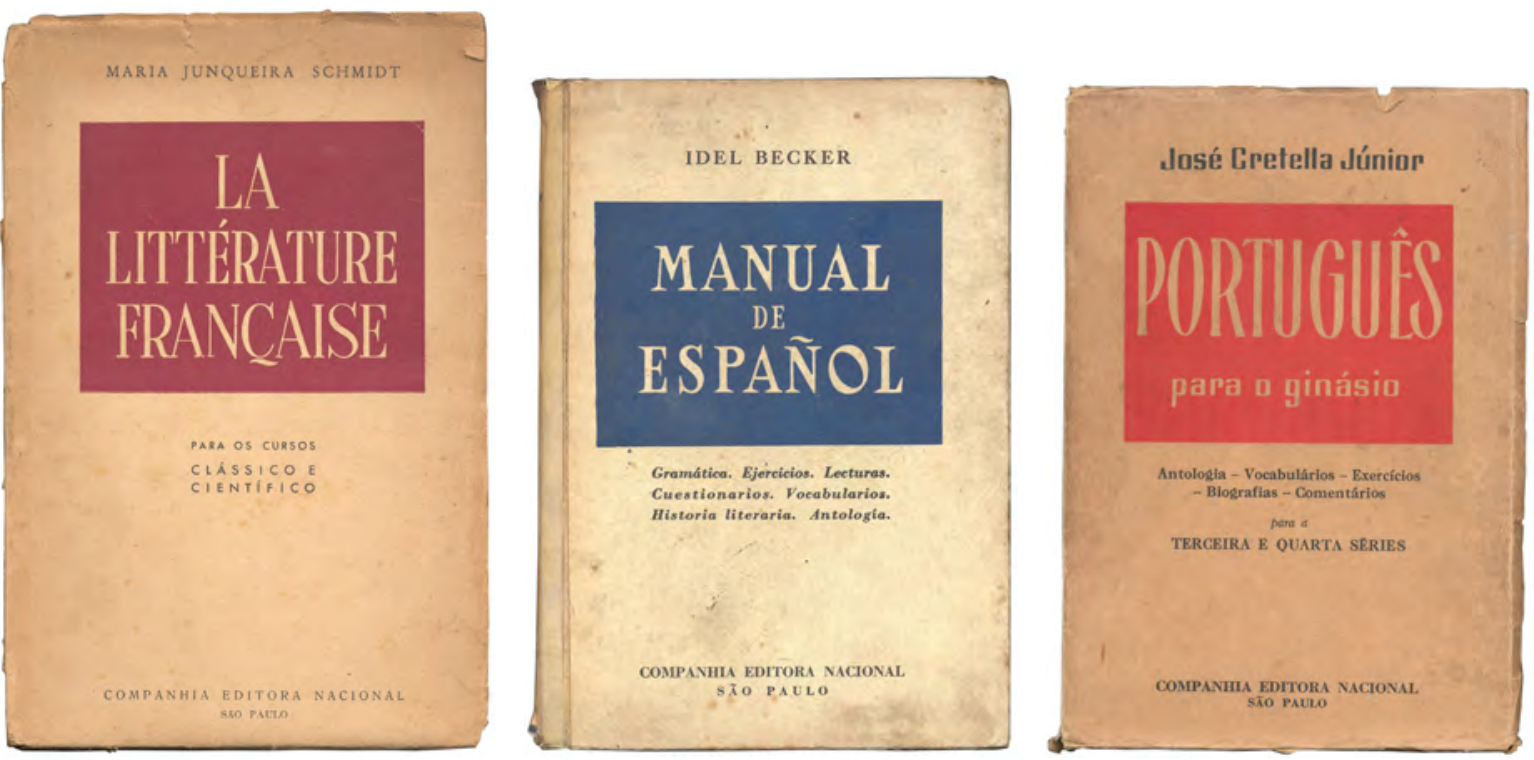

Fig. 5.4. Capas de livros com o novo design, de 1948, 1950 e 1948, apresentando duas soluções concisas com desenho de letra única para o título e uma solução com dois desenhos de letra. A solução criada para o novo formato $(14,0 \times 21,0 \mathrm{~cm})$ é estendida também ao formato padrão anterior de 13,0 x 19,0 cm. 
A FIGURA 5.5 mostra outra solução, minoritária, em que as informações de volume/série estão inseridas na área do título. Se com isso se conseguem uma valorização dessas informações, o resultado geral é uma evidente perda de coesão formal, devido à extensão das informações e variação de desenho e dimensão das letras.

O grupo de capas da figURA 5.6, mostra um trabalho de desenho de letras diferenciado, com vistas a uma particularização mais qualificada das obras. São obras que têm títulos próprios, não simplesmente o das disciplinas, e foram encontrados em obras da década de 1950.
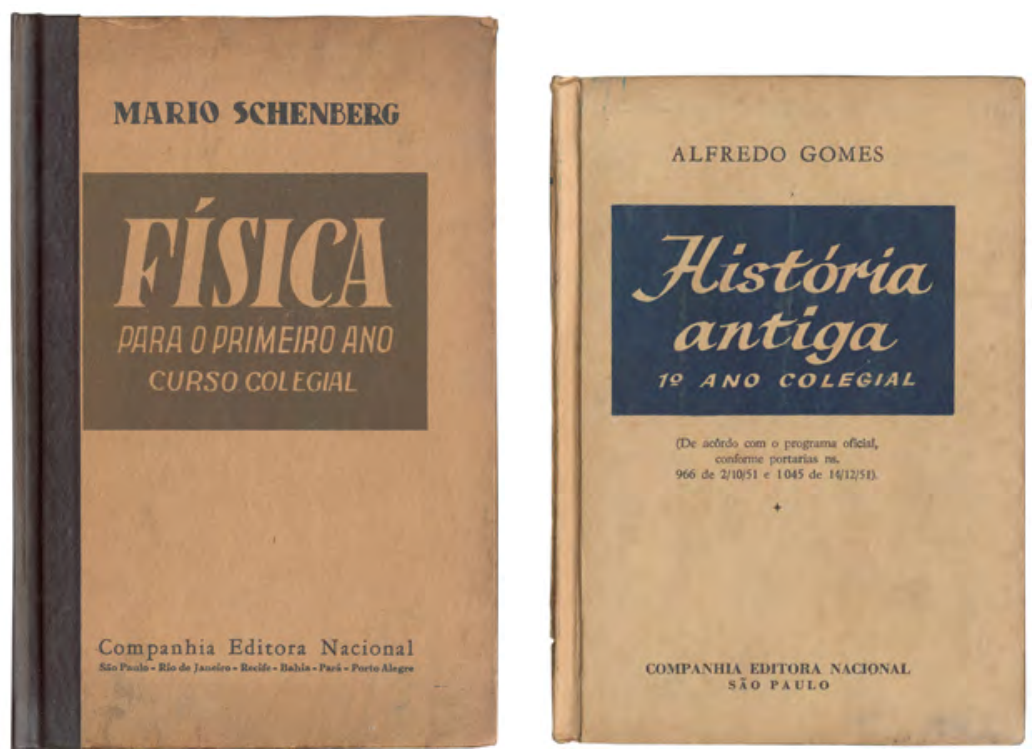

Fig. 5.5. Capas de livros com o novo design, de 1945 e 1952, com informações de ano e ciclo junto ao título, em formatos diferentes $(14,0 \times 21,0 \mathrm{~cm}$ e $13,0 \times 19,0 \mathrm{~cm})$.
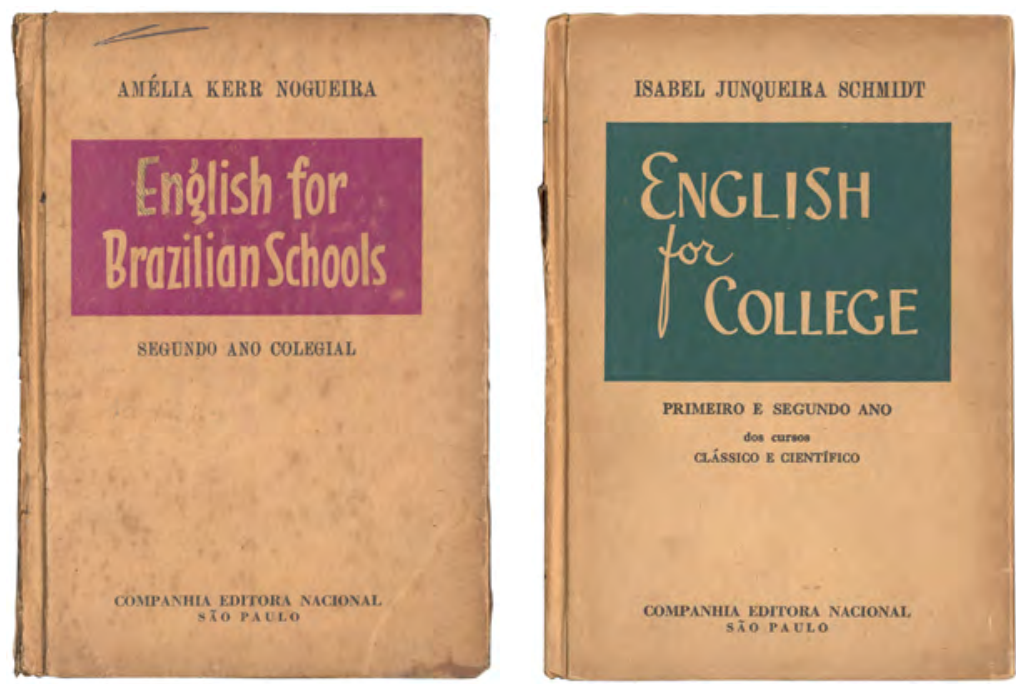

Fig. 5.6. Capas de livros com o novo design, aplicado em formato menor $(13,0 \times 19,0 \mathrm{~cm})$, de 1951, com desenho de letras particularizando as obras.

A liberdade de desenho das letras do título e sua aplicação vazada sobre área impressa em cor correspondem à tecnologia de impressão litográfica, confirmada pelo exame efetuado conforme o método de Amber Gascoigne (ver p. 154). 
Sobre o desenho de letras das capas, Ephraim Beda obteve de entrevistas com Rubens de Barros Lima, encarregado de produção gráfica de 1943 a 1973, e Thomaz de Aquino Queiroz, "desenhista e letrista" autônomo e mais tarde contratado para a área de produção gráfica, a informação de que as capas eram executadas por profissionais contratados por tarefa, não funcionários da editora [BEDA, 1978, p.269]. Provavelmente isso também ocorria no período anterior, com as capas da BPB Série 2 e todas as demais tipográficas, da mesma forma que as capas ilustradas eram feitas por capistas ilustradores.

\subsubsection{Outros modelos de capas tipográficas}

As obras impressas em tipografia e mesmo reimpressões em ofsete de obras antigas, em alguns casos mediante aproveitamento de composição tipográfica anterior, portanto no antigo formato de 13,2 × 19,2 cm, mantiveram as capas anteriores ou utilizaram novos modelos, diferentes do modelo criado para a maioria dos novos títulos. Embora fossem modelos fixos, como no período anterior, aplicavam-se a títulos avulsos, não coleções de vários autores, e provavelmente serviam para particularizar certas obras que se desejasse, com variação de cor para cada ano. As coleções BPB Série II, Biblioteca Escolar Brasileira e Coleção Dom Bosco não tiveram design renovado, embora suas capas passassem a ser impressas litograficamente.

A FIGURA 5.7 apresenta exemplares de um modelo caracterizado por uma lombada com textura gráfica que passa para a primeira e quarta capa criando uma faixa na mesma cor do título, que recebe desenho de letra particularizador para cada obra. O resultado, embora sóbrio, é visualmente mais atualizado em relação às capas tipográficas avulsas do período anterior. Este modelo será largamente usado na década de 1950.
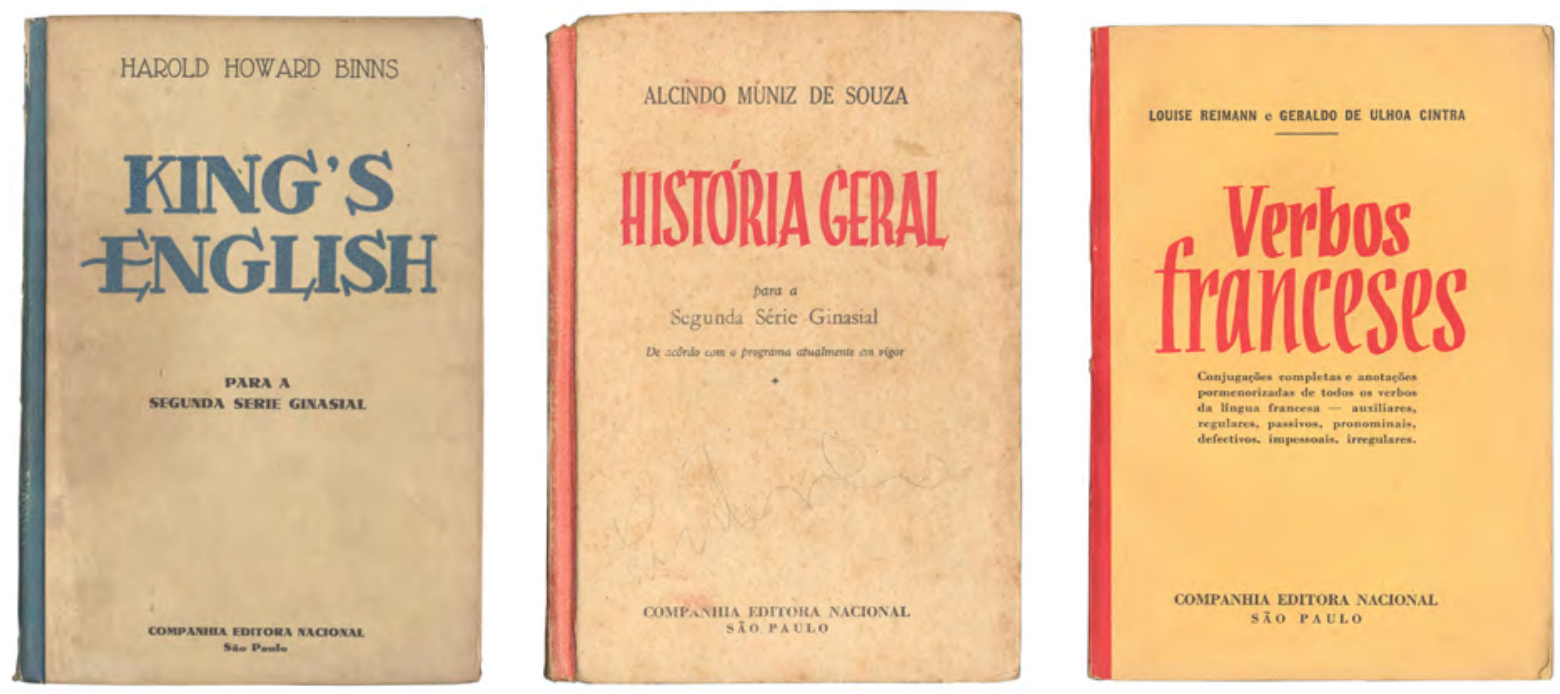

Fig. 5.7. Capas tipográficas para novas obras didáticas, em edições de 1942, 1950 e 1950, para formato 13,0 x $19,0 \mathrm{~cm}$. 
A FIGURA 5.8 traz capas tipográficas que não se associam a nenhum modelo especialmente desenhado, mas trazem título desenhado e impresso em cor, em solução também sóbria mas diferenciada das capas tipográficas avulsas do período anterior. A quarta capa trazia publicidade de obras geralmente impressa em preto, com a cor sendo reservada apenas para o título.
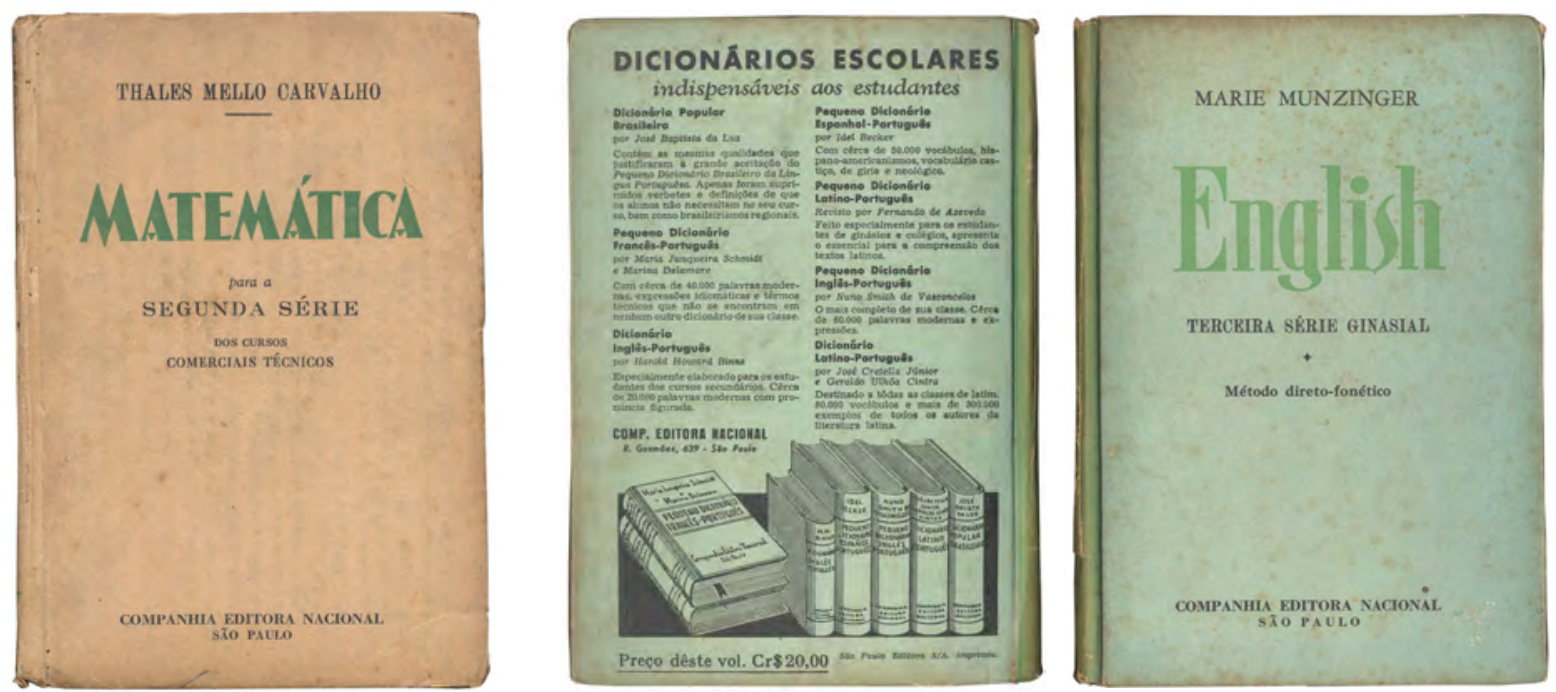

Fig. 5.8. Capas tipográficas para obras em edições de 1947 e 1950 (formato 13,0 × 19,0 cm). Quarta capa com publicidade.

As capas dos livros de história de Joaquim Silva, que já no período anterior não integravam nenhuma coleção (exceto a versão para Curso Comercial, na Coleção Dom Bosco), prosseguiram com um modelo sóbrio - tipográfico e sem uso de cor -, com as edições sendo diferenciadas por mudança de tipografia, até a introdução de cores de fundo e no título. A solução mais sóbria foi adotado para os livros de um novo autor da editora, Ary da Matta (FIG. 5.9).
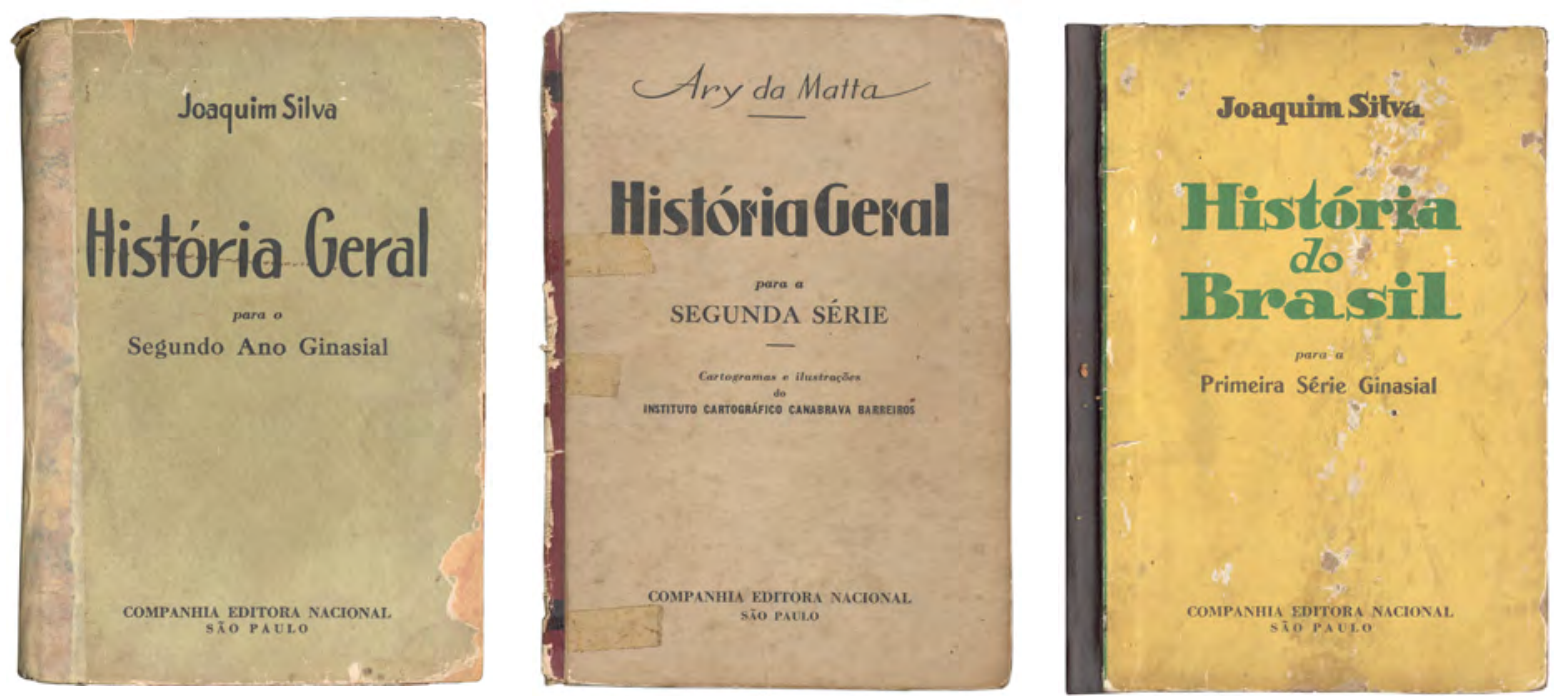

Fig. 5.9. Capas tipográficas de livros de História, de Joaquim Silva e Ary da Matta, de 1946 a 1952 (formato 13,0 $\mathrm{x} 19,0 \mathrm{~cm})$. 


\subsubsection{As capas ilustradas}

Como vimos, os livros didáticos para o Ensino Secundário continuam neste período a receber majoritariamente capas tipográficas, com alguns poucos títulos apresentando vinhetas e apenas algumas obras de geografia e de língua inglesa recebendo ilustrações propriamente ditas, antecipando o que será a norma na década seguinte.

A fIGURA 5.10 mostra duas capas com imagens correspondendo à primeira situação. A primeira delas, História do Brasil, se apropria da nova solução geral para capas de Ensino Secundário, o retângulo colorido, mas utiliza cor mais clara e tem o título aplicado em preto. Este utiliza o desenho de letras do História do Brasil de Joaquim Silva (FIG. 5.9) como base para uma variação "outline". Por fim é aplicada uma vinheta em linguagem de clichê tipográfico alusiva ao Descobrimento do Brasil. O resultado é equilibrado e bastante modernizado em relação às capas exclusivamente tipográficas impressas em uma cor. A segunda amostra é basicamente uma capa tipográfica, com composição mecânica dos textos, acrescida de vinheta (orquídea associada a símbolo geométrico) e efetivamente impressa em tipografia, mostrando como esse processo continuou sendo usado, com soluções adequadas mas sempre bastante sóbrias.
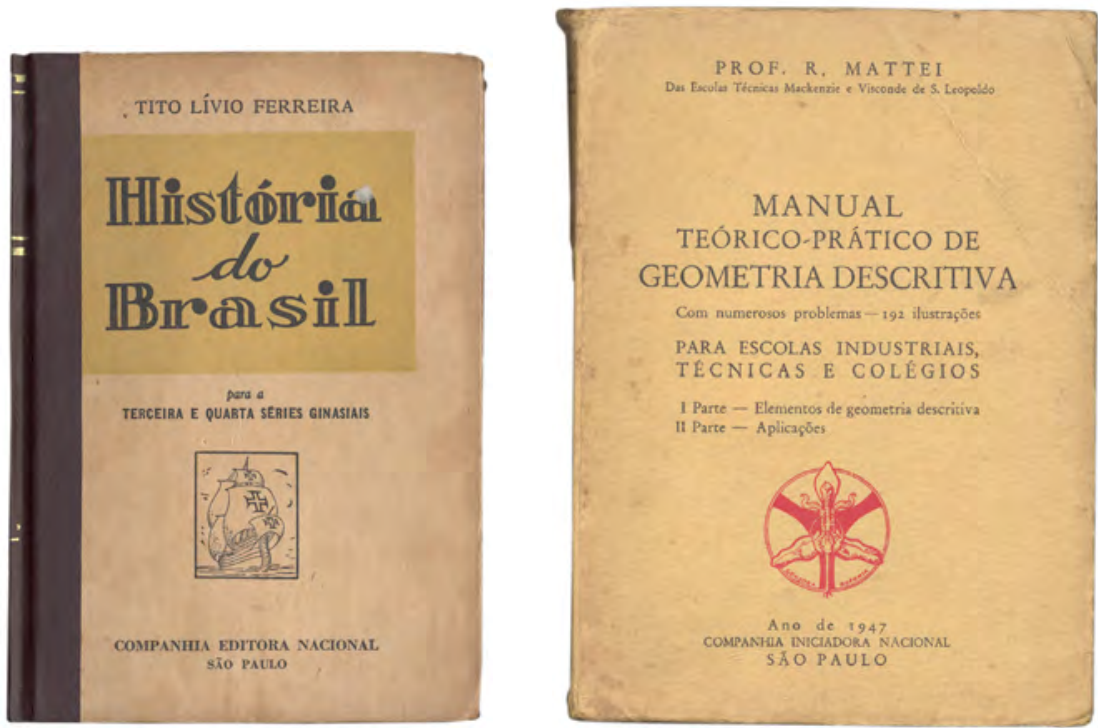

Fig. 5.10. Capas com vinheta de 1947 e 1950 (formatos 13,0 × 19,0 cm e 14,0 × 21,0 cm respectivamente).

As obras de geografia de Aroldo de Azevedo para o Colegial receberam capas ilustradas (FIG. 5.11). A de primeiro ano é mais diretamente originada do novo modelo de capa tipográfica, em que uma imagem é acrescida ao título vazado, num resultado bastante conciso de integração de texto e imagem. As dos outros anos são visualmente referenciadas na prmeira, mas se diferenciam pelos títulos aplicados em preto sobre ilustração em uma cor e variação no desenho de letras. As ilustrações são baseadas em desenhos de mapas do miolo assinados pelo próprio autor. 

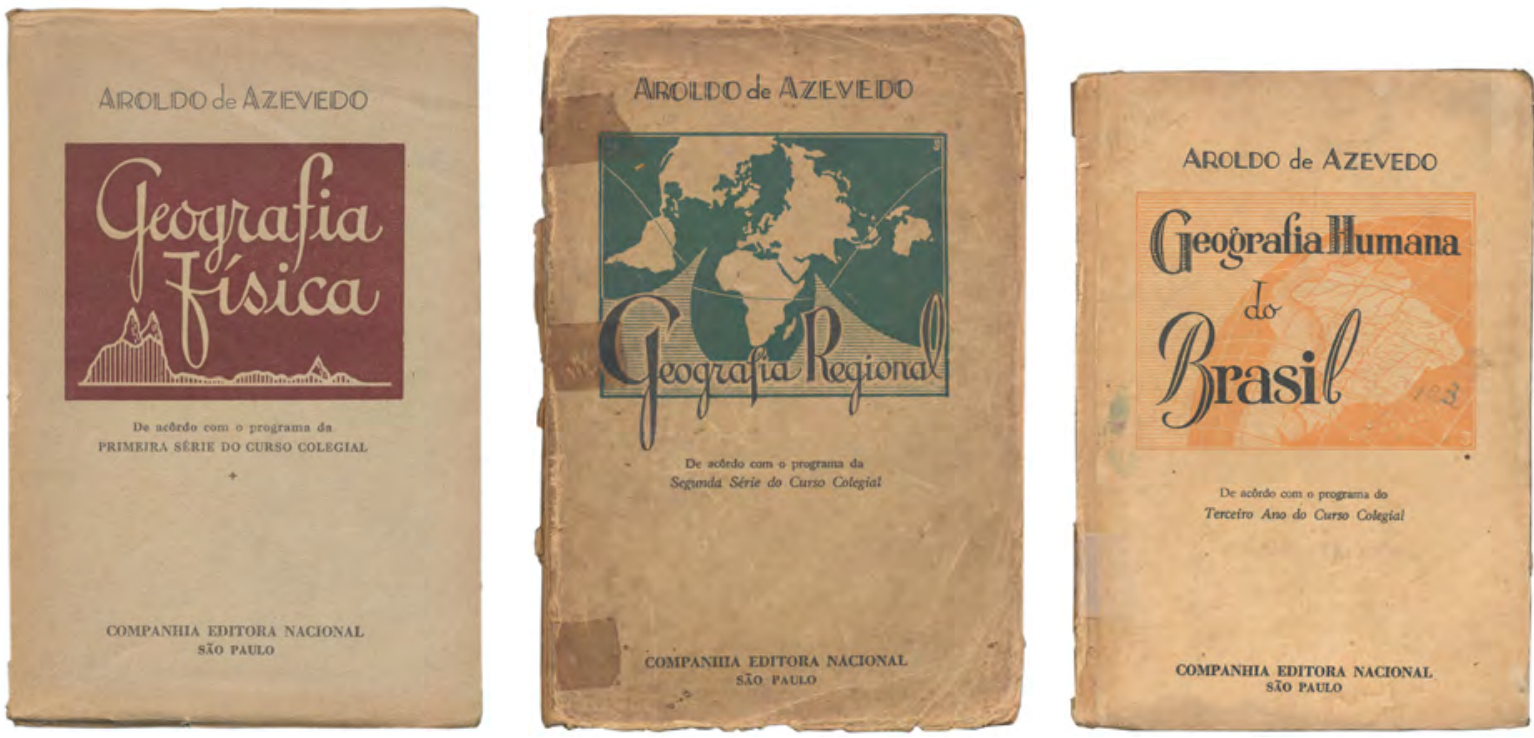

Fig. 5.11. Capas das obras de Geografia, de Aroldo de Azevedo, em edições de 1949 (1ª e 2ª séries, brochura, 14,0 × 21,0 cm) e 1950 (capa dura, $13,0 \times 19,0 \mathrm{~cm}$ ).

Obras de inglês para o secundário receberam também capas ilustradas (FIG. 5.12), mas enquanto o primeiro exemplo corresponde à linguagem de impressão litográfica de cor chapada, sem uso de retícula, encontrada no período anterior, o segundo exemplo já apresenta aplicação de cor por retícula sobre fotografia PB, não fotografia colorida. A lombada segue um modelo padrão encontrado em capas com diferentes soluções e a quarta capa traz publicidade, ausente nos modelos tipográficos criados a partir de 1943.
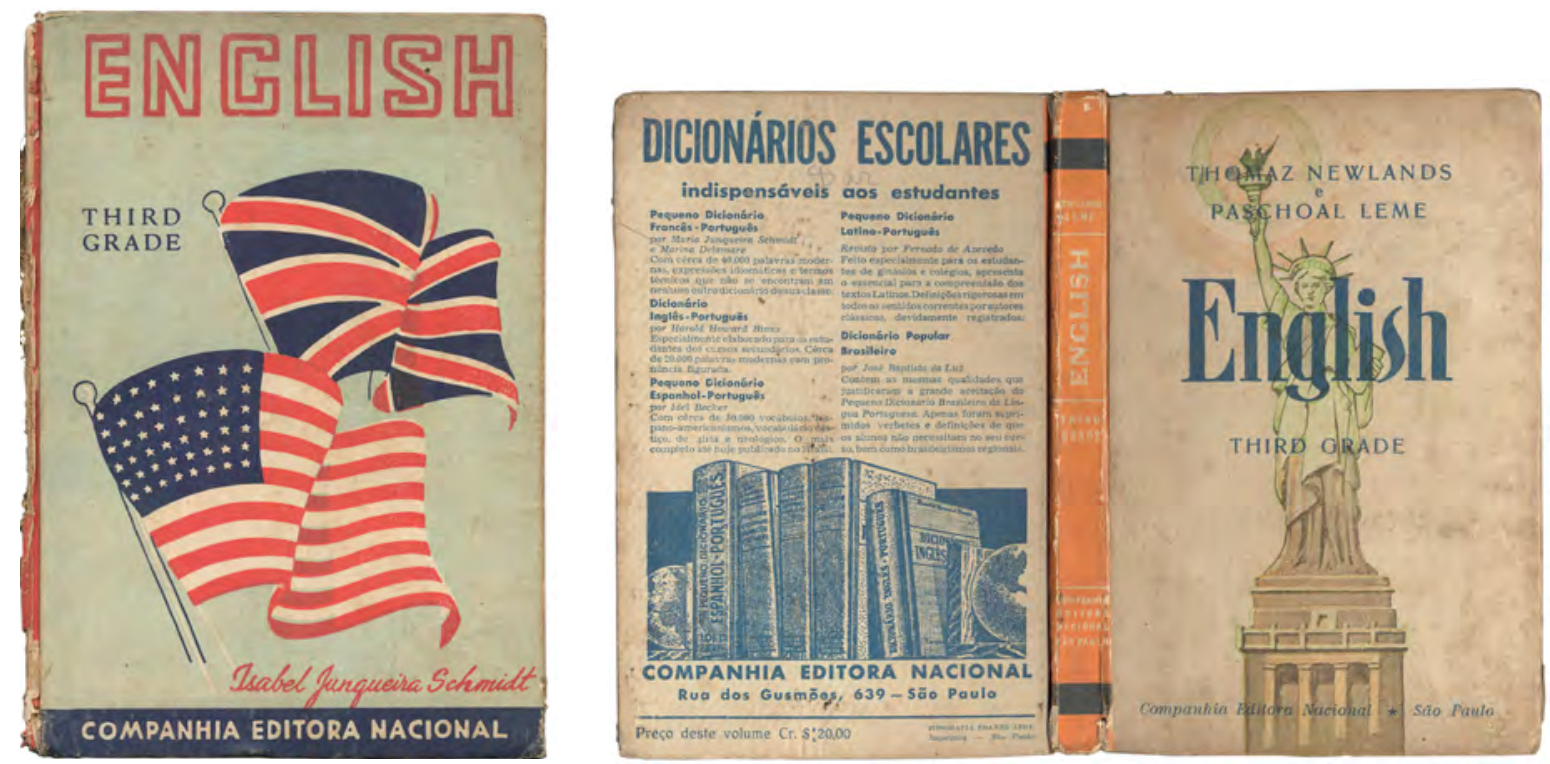

Fig. 5.12. Capas de Inglês em edições de 1949 (formatos 15,0 × 21,0 cm e 13,0 × 19,0 cm respectivamente).

Como vimos, as obras para o Ensino Primário nos períodos anteriores eram as únicas que tinham capas ilustradas, mesmo que nem sempre tivessem apelo exatamente infantil. A CartiIha Fácil, de Claudina Barros (fIG. 5.13), tem como capa o mesmo modelo adotado para as obras 
de Thales de Andrade na década de 1930 (FIG. 4.21), com um desenho simplificado em relação ao original de 1928 (FIG.3.7), que apresenta um design sóbrio e formal. Temos aqui também um exemplo da prática de se apropriar de solução de design adotada para outra coleção ou série, e não a realização de um projeto específico.

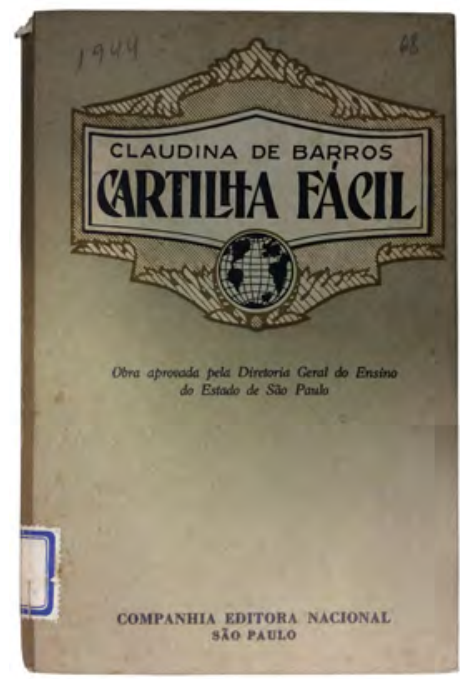

Fig, 5.13. Capa da Cartilha Fácil, 17ª edição, de 1944 (13,0 x 19,0cm). [Fonte: AHECC/CRE Mario Covas/EFAP/ SEE-SP.]

Já o livro de leitura Vamos Ler, de Renato Sêneca Fleury, apresenta uma capa com grande afinidade com o universo imagético das crianças, encontrado em livros não escolares (FIG. 5.14). Realizada por Belmonte, ilustrador das capas e livros infantis de Monteiro Lobato nas décadas de 1920 e 1930, apresenta um trabalho de exceção, em que o livro didático recebe um tratamento visual que o aproxima dos livros de literatura para crianças (ver FIG. 2.5, 2.15 e 4.5).
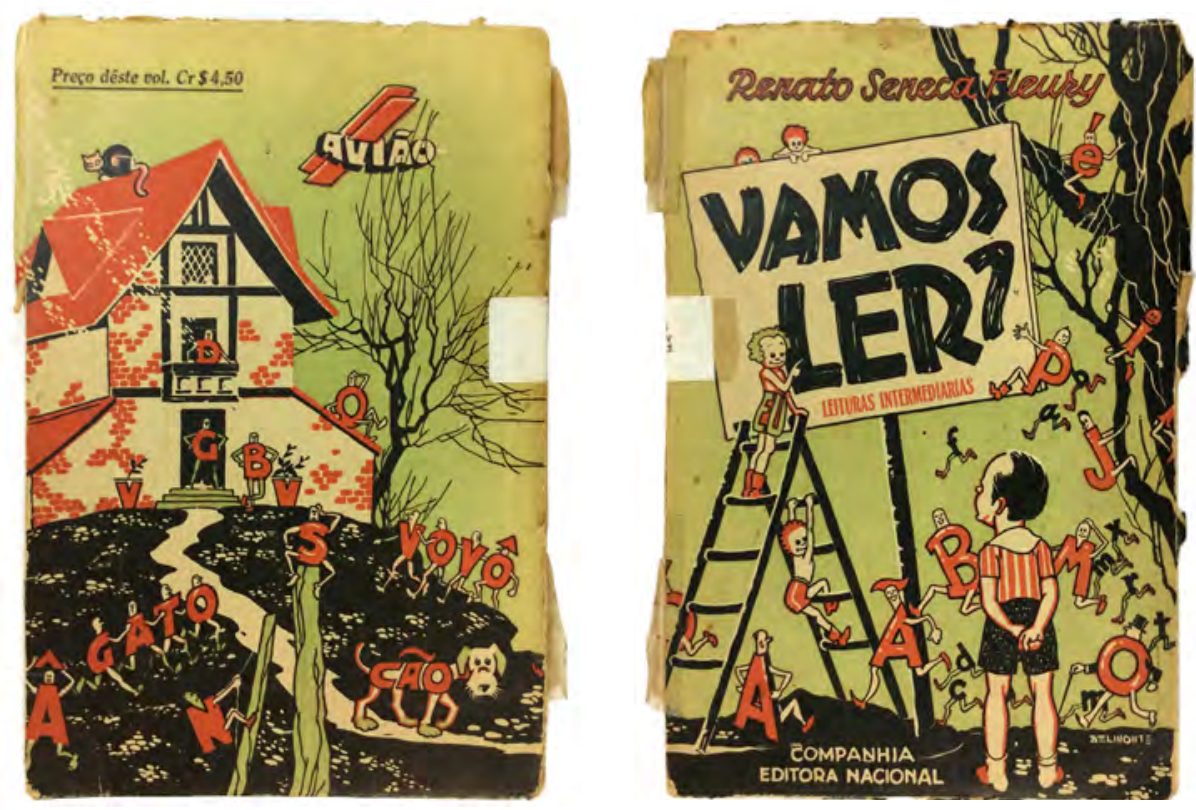

Fig. 5.14. Capa do livro de leitura Vamos Ler, por Belmonte, em edição de 1944 (15,0 × 23,0 cm). [Fonte: Biblioteca Infantil Municipal Monteiro Lobato, São Paulo.] 
A Cartilha de Vivi e Vavá, com capa e ilustrações de Buthy (FIG. 5.15), apresenta um trabalho de ilustração menos elaborado, o que era comum no universo dos didáticos. Apesar de impressa nas quatro cores da impressão quadricrômica (magenta, ciano,amarelo e preto), trabalha com aplicação das cores separadas e o uso de retícula serve apenas para obter tonalidades mais claras, sem combiná-las para a obtenção de matizes diferentes. Vamos encontrar esse uso das cores da impressão quadricrômica, puras ou rebaixadas por retícula, em miolos de livros na década de 1950, como veremos no capítulo seguinte.
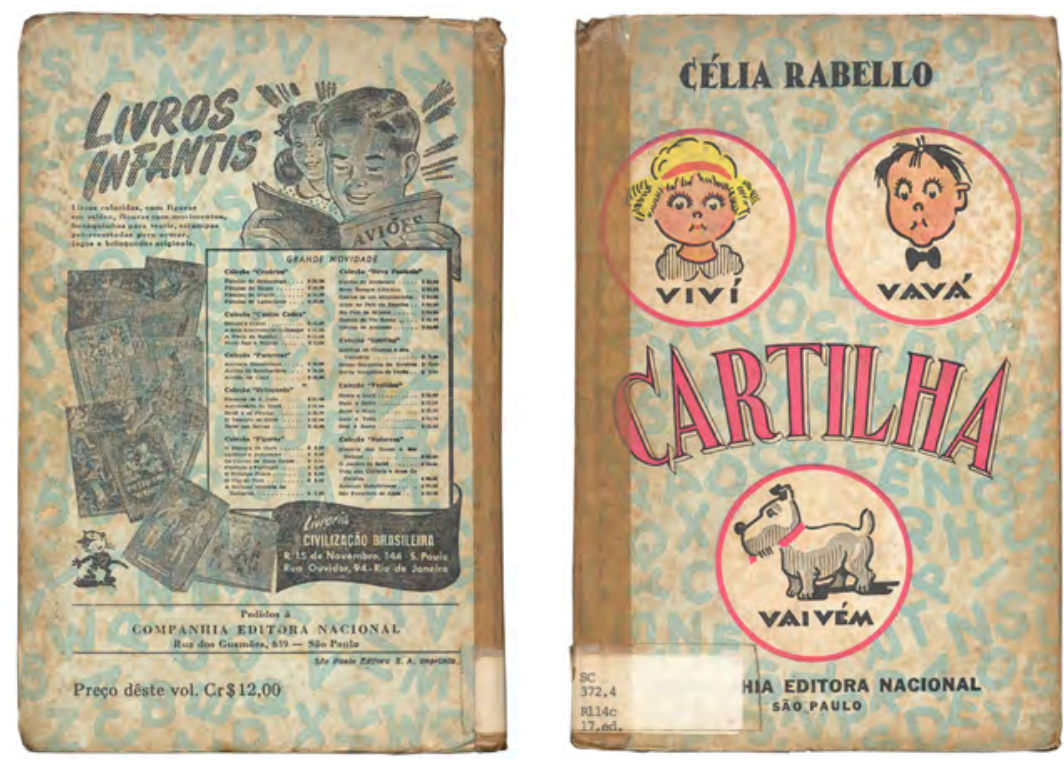

Fig. 5.15. Capa da Cartilha de Vivi e Vavá, 17ạ edição, $1949(14,0$ × 21,0cm).

A capa da Cartilha Sodré reproduzida na FIGURA 5.16 é de edição posterior ao período enfocado nesse capítulo, mas é idêntica à da primeira edição, de 1948. Criada por Augustus, ilustrador e capista de todos os volumes da obra infantil de Monteiro Lobato lançados pela Editora Brasiliense desde meados da década de 1940, foi aplicada em todas as brochuras que vieram a compor a Coleção Sodré. Impressas em três cores, com forte contraste de áreas chapadas, luzes e contornos marcados, tem desenho habilmente executado em linguagem referenciada na ilustração publicitária e nas revistas populares da época, em que a personagem dirige o olhar para o leitor, buscando empatia e identificação. A solução econômica corresponde à destinação popular da obra, com o acabamento em brochura grampeada e custo reduzido em relação aos livros encadernados 4 .

\footnotetext{
4 Augusto Mendes da Silva (1917-2008), que assinava Augustus, era pintor com formação acadêmica e atuava principalmente como retratista e artista publicitário. Seu domínio do desenho naturalista é a base tanto da ilustração de publicidade e das capas que fez para a Nacional como das imaginativas capas da obra infantil de Lobato, que podem ser vistas em HOMEM DE Melo; Ramos, 2011, p. 218-219. Uma análise mais detalhada das capas da Coleção Sodré pode ser vista em MoRAES, 2010, p. 62-63.
} 

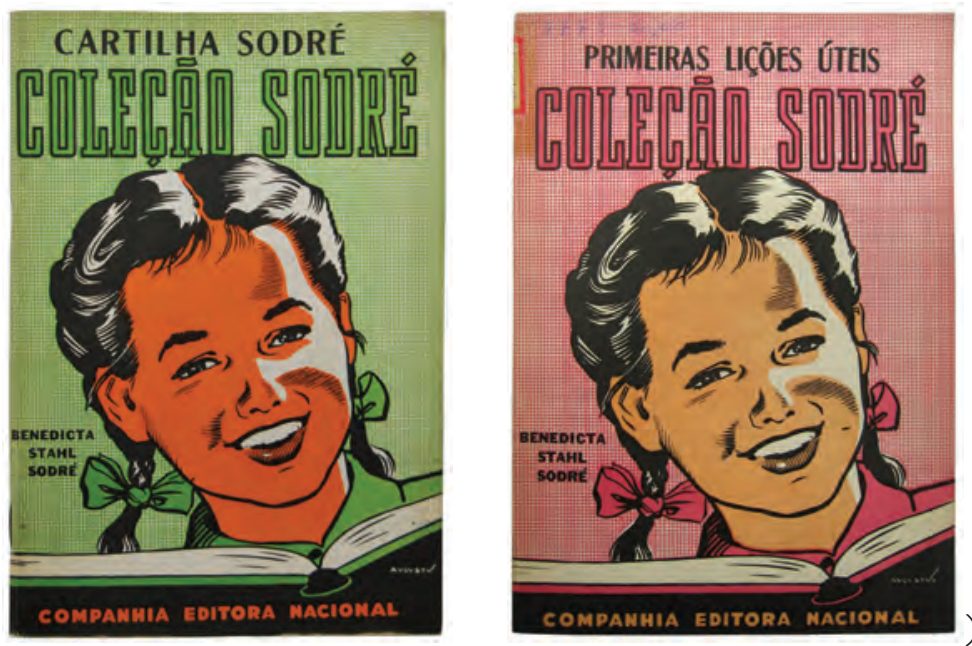

Fig. 5.16. Capas da Coleção Sodré, com a Cartilha tendo sido lançada em 1948 (13,3 x 18,0 cm).

\subsubsection{O design de miolo dos livros didáticos do período 1943-1952}

\section{Os livros do Ensino Secundário: Ginásio e Colégio}

A introdução da impressão ofsete, responsável pela criação de um novo modelo de capa para os livros de Ensino Secundário impressos no novo formato $14,0 \times 21,0 \mathrm{~cm}$, pode também ser identificada em alguns aspectos da visualidade dos miolos produzidos nesse formato. $O$ primeiro deles diz respeito ao próprio formato, que talvez comunicasse ou complementasse a idéia de modernização trazida pelo novo design das capas e pela materialidade do volume. 0 segundo, consequência do primeiro, diz respeito à mancha de texto e às margens, que aumentam proporcionalmente, o que em si não resulta em nenhuma visualidade diferenciada, uma vez que o pequeno acréscimo, maior na altura, não alterou o diagrama de composição em uma coluna nem possibilitou novas opções de inserção das imagens.

O terceiro aspecto - não resultado automático da adoção do novo formato, mas uma medida de projeto deliberada - é a supressão do fio de apoio das informações de cabeço (título corrente, autor e fólio), que estava presente na maioria do livros no formato anterior. Embora a composição tipográfica tradicional admitisse cabeços com ou sem fio de apoio, era mais frequente o seu uso, fazendo com que sua supressão, com acréscimo de espaço e contraste tipográfico, resultasse em páginas mais limpas e uma visualidade modernizada. Isto não ocorreu apenas nos livros de novo formato, mas em livros do formato antigo e em alguns de formato diferenciado.

Com relação à composição de texto, os livros no novo formato não trazem novidade em relação aos critérios introduzidos no período anterior. A composição em fonte exclusivamente serifada e suas variações dentro da mesma família continua sendo a norma absoluta, não 
se encontrando nenhum exemplo que a contrariasse. O que se pode constatar é uma maior regularidade de uso dos critérios de aplicação das variações conforme as situações funcionais no conjunto das obras pesquisadas. Ou seja, há um maior rigor na aplicação das variações da família adotada, com a correspondência entre cada uma delas e a ocorrência funcional sendo a mesma em originais com características semelhantes, independentemente do formato adotado. E em obras com estrutura textual mais diferenciada, encontram-se também soluções particulares precisas na escolha das variações e corpos, que estabelecem clareza de contrastes que propiciam o entendimento das diferentes situações textuais por parte do leitor (FIG. 5.17 e 5.18).

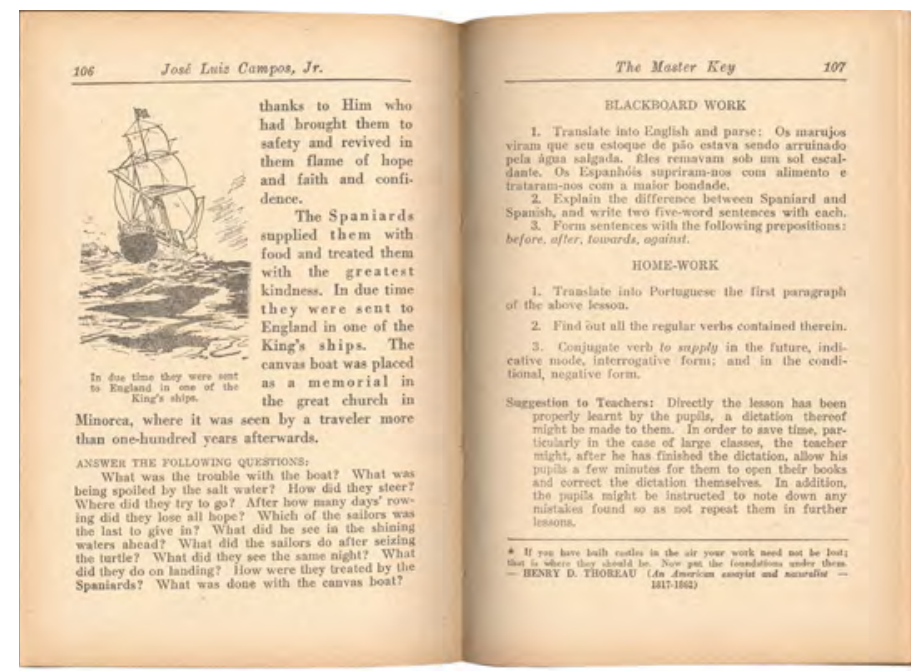

Fig. 5.17. José Luiz Campos Jr., The Master Key, 1945 (13,0 × 19,0cm). Contraste tipográfico acentuado entre as várias situações textuais.

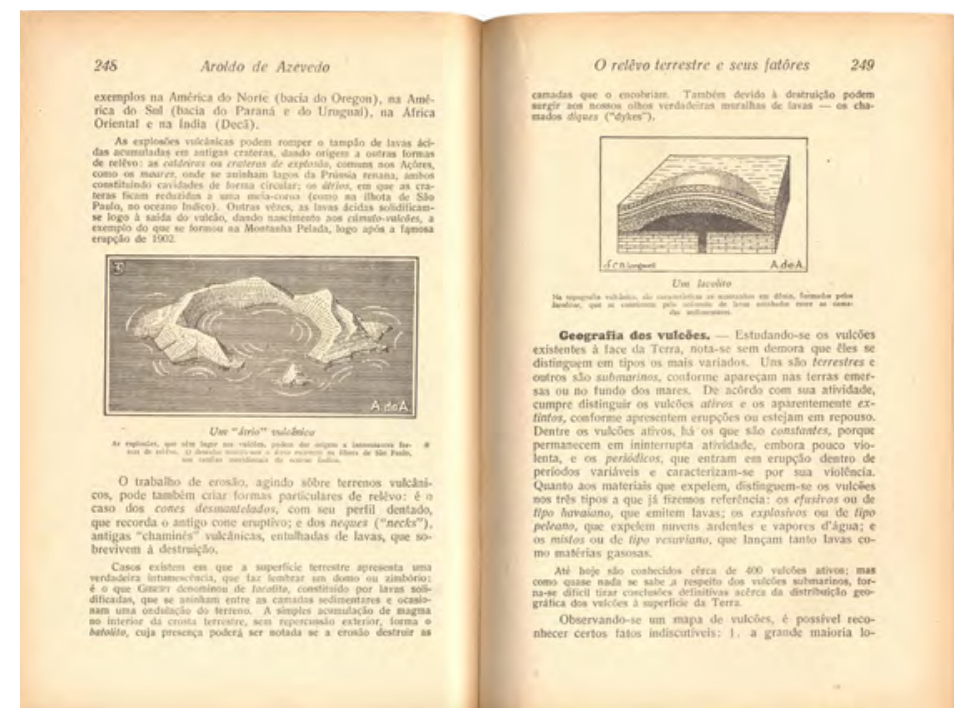

Fig. 5.18. Aroldo de Azevedo, Geografia física, $1949(14,0 \times 21,0 \mathrm{~cm})$. Economia na variação tipográfica, mas contraste suficiente para marcar as diversas situações textuais. 
O que a generalização da impressão ofsete trouxe foi o aumento do uso de imagens fotográficas nos livros, ainda em uma cor e com retícula mais fechada (46 linhas por cm) do que a da impressão tipográfica, propiciando maior qualidade da reprodução. Obras de História e Geografia, independentemente do formato, são as mais favorecidas pela adoção da tecnologia (FIG. 5.19 a 5.21), o que resulta numa modernização de sua visualidade e aproximação com a que aparecia em outros meios impressos, principalmente jornais e revistas, em que a fotografia foi introduzida ainda no final do século XIX, mas generalizou-se mesmo nas décadas de 1930 e 1940 [Editora ABRIL, 2000, p. 43, 90-95].
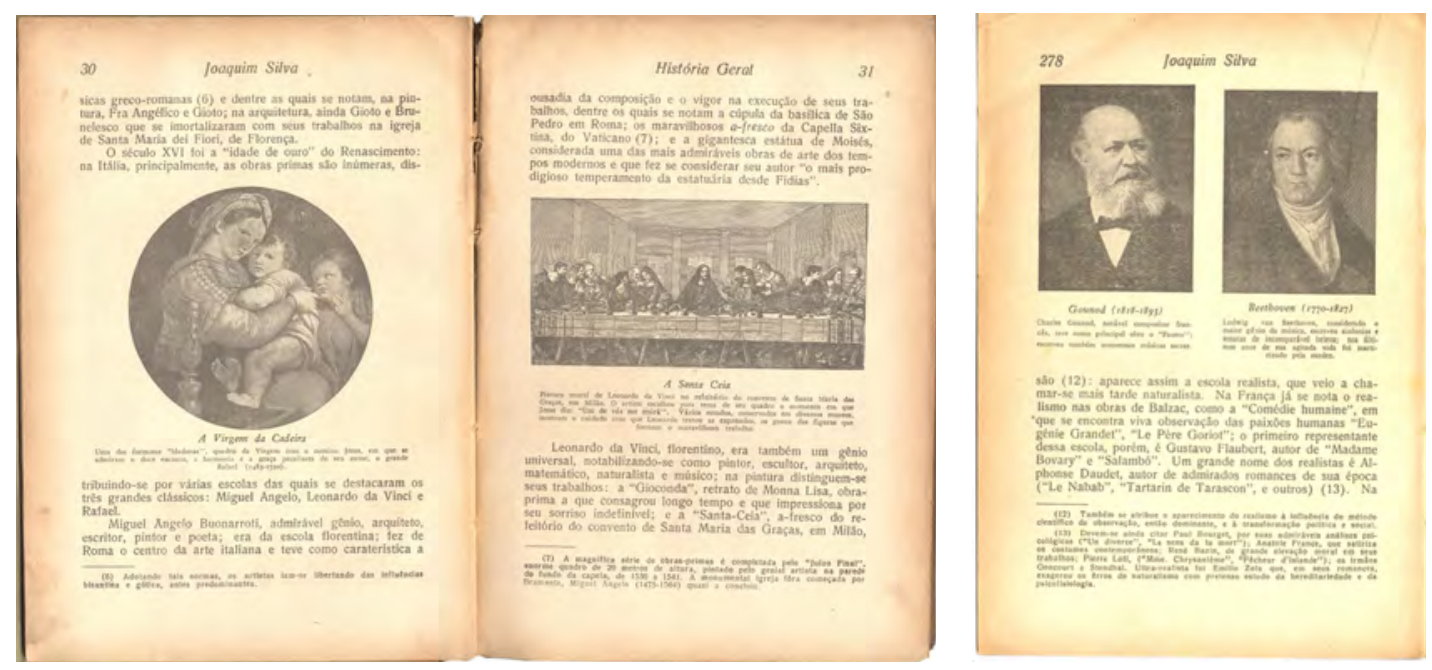

Fig. 5.19. Joaquim Silva, História Geral: para o segundo ano ginasial, $1950(13,2 \times 18,8 \mathrm{~cm})$. Fotografia para reprodução de obras de arte e retratos.
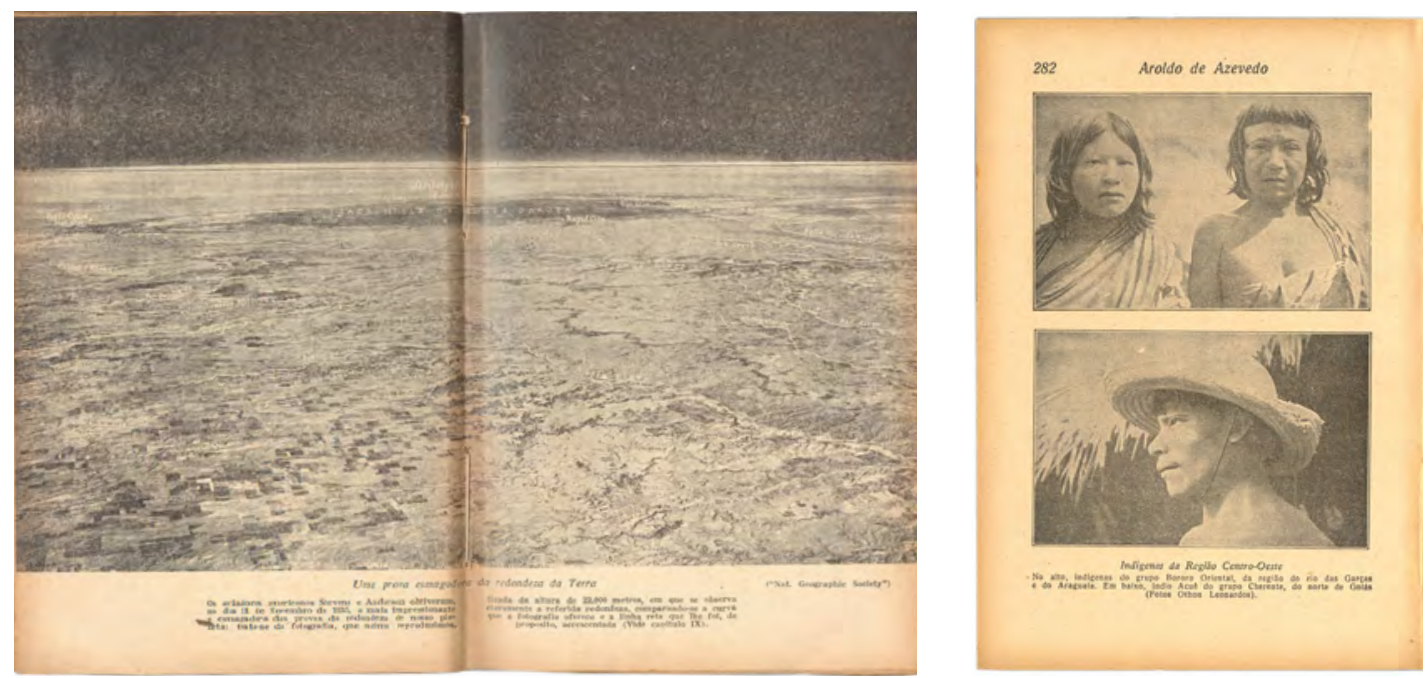

Fig. 5.20. Aroldo de Azevedo, Geografia do Brasil: as regiões geográficas, BPB Série II, v. 145, 1947 (13,2 × 19,2 cm). Uso mais raro de fotografia sangrada em dupla de páginas. 

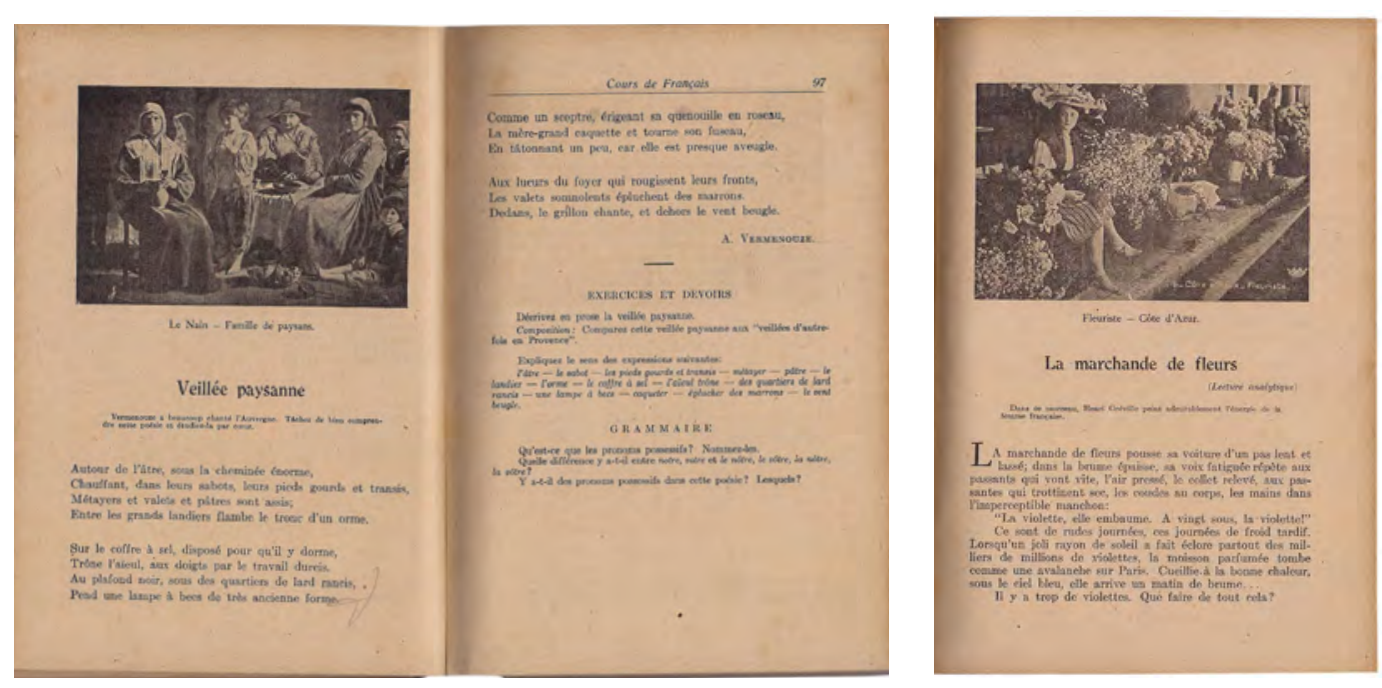

Fig. 5.21. Maria Junqueira Schmidt, Cours de Français: $3^{3 e ̀ m e}$ et 4ème années, BPB Série II, v. 133, 1943, (13,2 x 19,2cm). Reprodução de fotografia, mediante uso de retícula de alta lineatura em papel acetinado, com grande definição de tons.

Com relação à linguagem das ilustrações dos livros escolares, a impressão ofsete não trouxe imediatamente transformações, embora essa tecnologia de impressão planográfica propiciasse a reprodução de trabalhos em meio tom, como aquarela, lápis ou crayon, por meio da captura fotográfica e reticulação. O que continuou predominando em todo o período analisado foi mesmo a linguagem do traço, correspondente à impressão relevográfica.

A primeira razão seria o fato de que várias obras do catálogo didático, que até então eram impressas tipograficamente, simplesmente passaram a ser impressas em ofsete, mediante o reaproveitamento da composição e de impressões dos clichês de ilustrações a traço. Mesmo a rediagramação no novo formato, com recomposição de texto, se deu com frequente reaproveitamento de antigas ilustrações em linguagem de traço.

Uma segunda razão seria que, se a tecnologia de produção de matrizes reticuladas não era nova na indústria gráfica em geral, particularmente a dedicada às revistas de grande e média tiragem, no segmento do livro didático não contava ainda com ilustradores que produzissem originais de arte em linguagens e técnicas em meio tom que demandassem o trabalho de reticulação.

Assim, uma terceira razão, relacionada à anterior, seria a continuidade de práticas estabelecidas pela tradição, em que a linguagem de ilustração em traço, desenvolvida para a impressão tipográfica, já configurava a visualidade dos livros escolares, cumprindo perfeitamente as demandas didáticas e estéticas a eles associadas e contando com profissionais que dominavam essa linguagem aplicada a esse fim específico (FIG. 5.22). 

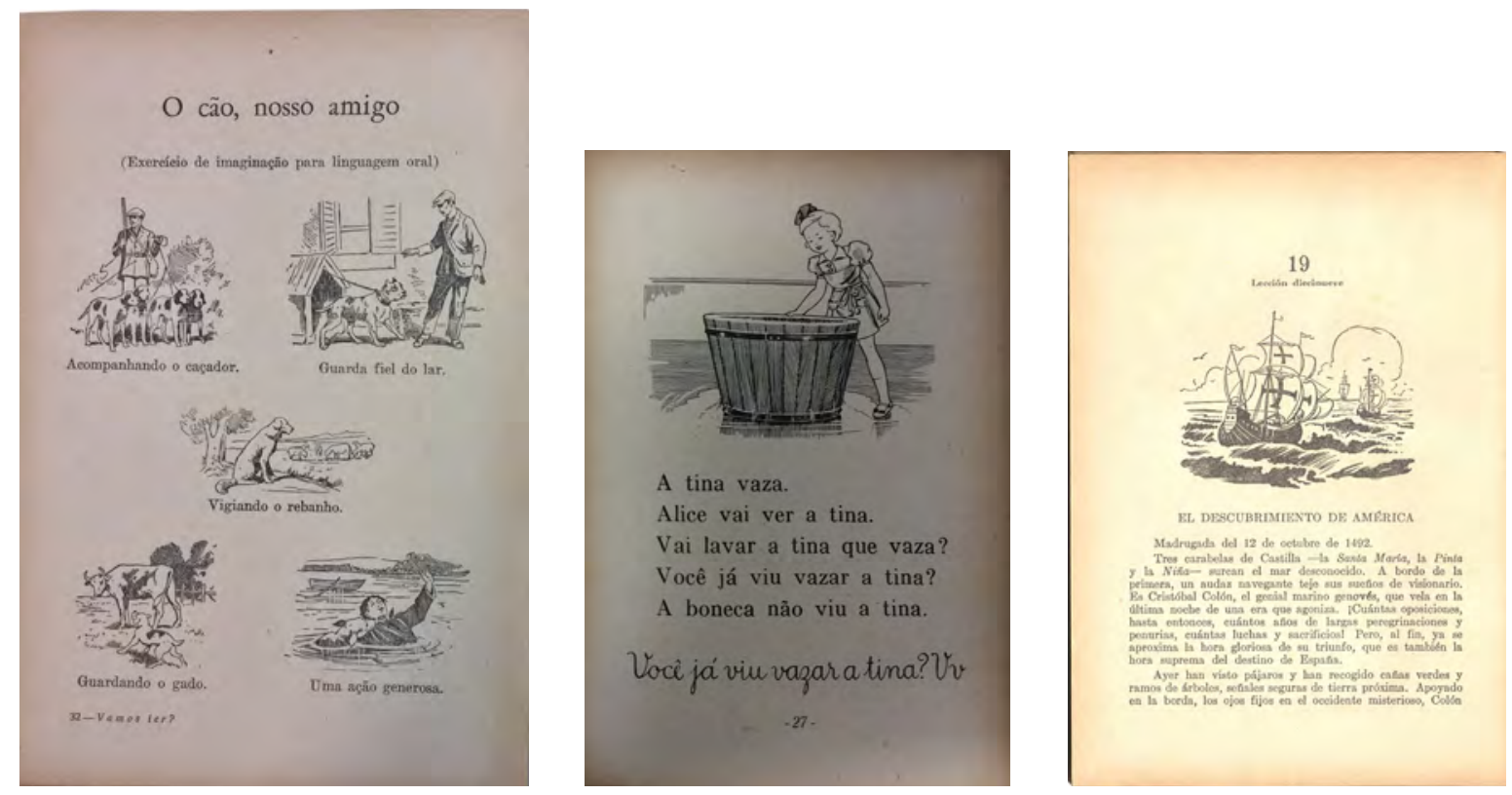

Fig. 5.22. Renato Sêneca Fleury, Vamos ler: leituras intermediárias, 1944; Claudina de Barros, Cartilha Fácil, 1944; Idel Becker, Manual de Español, 1950. Exemplos de ilustração em traço.

Assim, encontramos apenas um exemplo em todo o período, de ilustração produzida em meio tom e reproduzida por reticulação (FIG. 5.23). A outra possibilidade de linguagem de ilustração oferecida pela impressão ofsete - o traço de contorno com preenchimento tonal mediante aplicação de retícula feita pelo estúdio de fotolito a partir de instruções do ilustrador - não apareceu em nenhuma das obras pesquisadas.
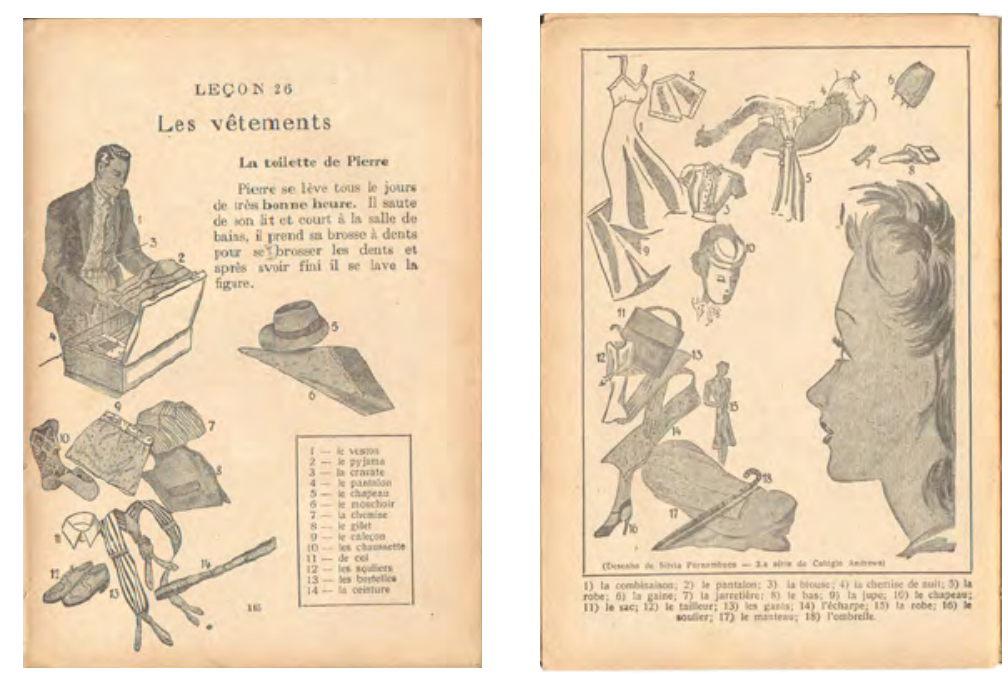

Fig. 5.23. Raul Penido Filho, Le Français: 7ere année, BPB Série II, v. 132, 1944 (13,2 x 19,2cm). Ilustração em traço com aplicação de retícula.

Na totalidade das disciplinas do Ensino Secundário abordadas pelos livros documentados deste período não se identificou uma visualidade de miolo essencialmente diferente da apresentada no capítulo anterior. Eventuais mudanças nos meios de representação de fenômenos 
e eventos das ciências de referência das disciplinas ou novas metodologias de ensino não se fizeram perceber na visualidade dos livros, não exigindo portanto uma apresentação detalhada e sistemática por disciplina como fizemos no capítulo anterior.

No entanto, obras de História e de Geografia merecem uma observação mais detida de sua visualidade, bem como o registro do ocorrido com uma obra de Inglês.

\section{Livros de História para o Ensino Secundário}

A iconografia presente nos livros de História, particularmente de História do Brasil, foi marcada desde o final do século XIX até o final do século XX, apesar das mudanças de enfoque ocorridas no ensino da disciplina, por grande repetição das mesmas imagens - reprodução de gravuras, pinturas e retratos de personagens da vida política - , que a tornaram "imagens canônicas", incorporadas ao imaginário coletivo, e frequentemente aplicadas sem identificação de autoria e momento em que foram produzidas [PINTO JR., 2010, p. 181-182]. Esvaziadas assim do sentido de documento histórico, correm paralelas ao texto, que não fazem referência a elas, cumprindo na maior parte das vezes o papel de simples decoração da página.

No período tratado, esse tipo de iconografia é também complementado com ilustrações em traço, oriundas de clichês de obras do período anterior ou mesmo novas, produzidas nessa linguagem, mas identificadas como sendo uma reprodução do fato ou objeto e não uma interpretação gráfica, às vezes fantasiosa, produzida posteriormente (FIG. 5.25).

Esse é o contexto gráfico-disciplinar em que é introduzido um maior número de fotografias a partir do emprego da impressão ofsete. No entanto, mesmo como meras ilustrações do texto e não testemunhos ou documentos com valor em si, ampliam, mesmo que limitadamente, a veiculação de uma iconografia mais autêntica. Nos capítulos de história contemporânea, fotografias também parecem entrar como meras ilustrações dos eventos relatados no texto, mas emprestam autenticidade a eles, como ocorre com jornais e revistas. O resultado são livros com iconografia mais rica e uma visualidade mais contemporânea e mais próxima da encontrada em outros meios impressos, introduzindo mudanças na cultura visual escolar, até então bastante defasada em relação à cultura visual mais ampla.

No entanto, a continuidade da presença, nesses mesmos livros, de ilustrações interpretativas de fatos ou objetos, reaproveitadas de edições anteriores, misturadas às novas imagens fotográficas e reproduções, permite supor que essas últimas entram mais como consequência da disponibilização de novos recursos tecnológicos do que como resultado de novas posturas metodológicas dos autores. 

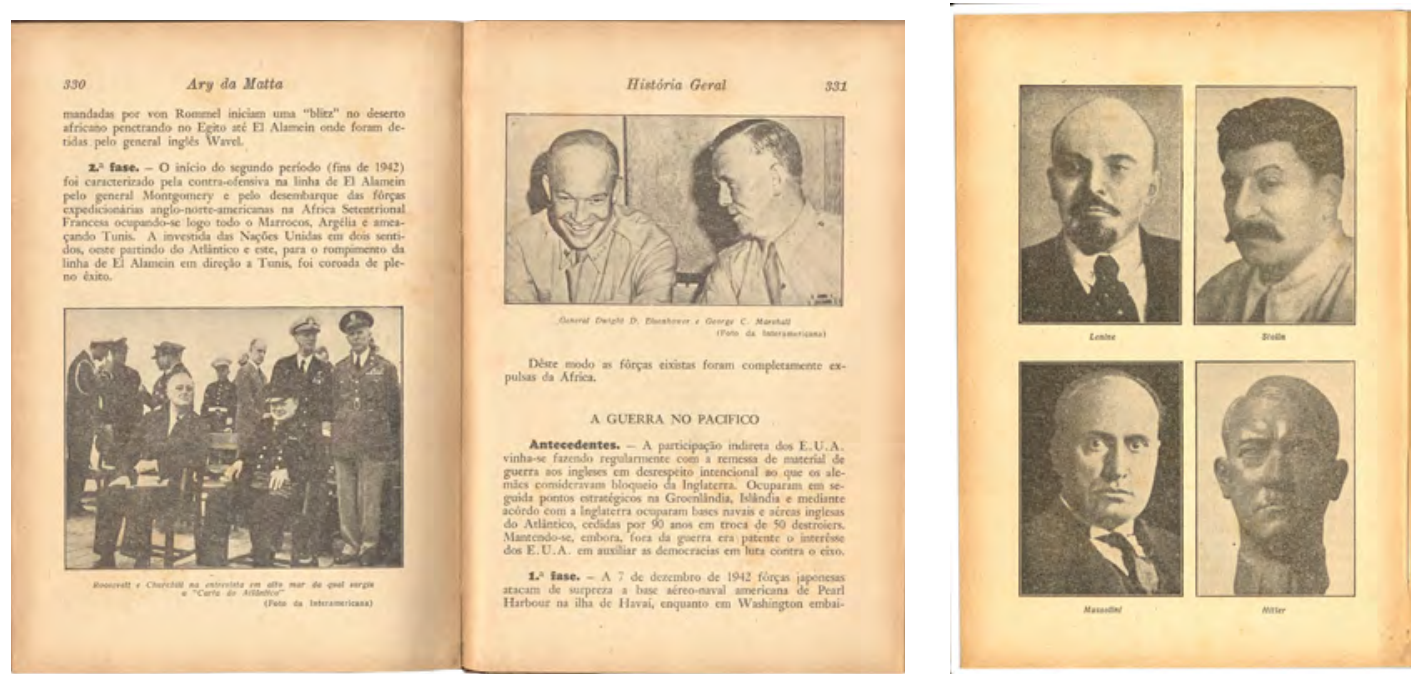

Fig. 5.24. Ary da Matta, História Geral, 1946 (13,0 x 19,0cm). Documentação fotográfica e reproduções de retratos e bustos.
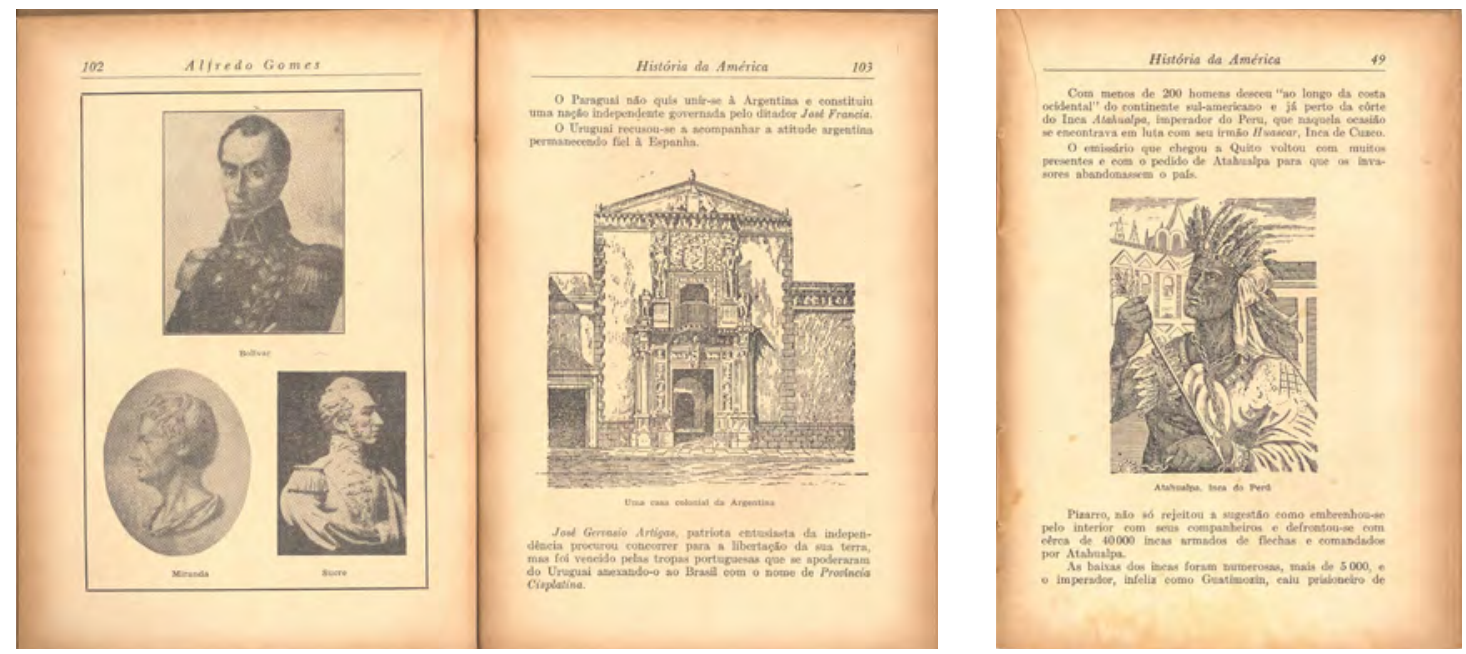

Fig. 5.25. Alfredo Gomes, História da América: para a segunda série ginasial, 1952 (13,3 × 18,8cm). Reproduções de retratos, bustos e interpretações fantasiosas de vultos históricos.

\section{Os livros de Geografia de Aroldo de Azevedo}

Discípulo de Carlos Delgado de Carvalho, como este, Aroldo de Azevedo teve seus livros escolares editados inicialmente dentro da BPB Série II, ainda na década de 1930 (FIG. 4.28). A disciplina de Geografia, junto com História e Língua Portuguesa, constituía o que veio a ser designado como "tripé da nacionalidade", por propiciarem a produção de livros didáticos com conteúdo nacional, incentivada pelo poder público desde finais do século XIX.

Os livros de Delgado de Carvalho e mais ainda os de Aroldo de Azevedo, sob influência da corrente francesa da Geografia, vão trazer um modelo de ensino descritivo da ciência, para as regiões do Brasil ou os continentes, baseado no paradigma "a terra e o homem", ou na "tricotomia natureza-homem-economia", em que a descrição do ambiente físico (geologia, relevo, 
clima, vegetação, etc.) é seguida da descrição da ocupação humana (tipos físicos; atividade econômica na ordem extrativismo, agropecuária e indústria) e da divisão política e administrativa em cada uma das regiões da Terra e do país abordadas [LOPES, 2009, p. 74 e FERRACINI, 2012, p. 60]

O que os livros didáticos de Aroldo de Azevedo vão trazer, aproveitando a maior facilidade de reprodução de imagens introduzida pela impressão ofsete, é uma renovação dos padrões gráficos de apresentação e descrição dos fenômenos e fatos geográficos em relação aos livros anteriormente produzidos no Brasil. Grande número de ilustrações, produzidas pelo próprio autor ou em colaboração com J.S. (não identificado), elucidam o que é descrito no texto ou muitas vezes guiam a própria leitura deste. Esta participação da imagem como componente equivalente ao texto integrando o original de uma obra pode ser característico da própria disciplina, mas não deixa de chamar atenção o papel de um autor na definição da visualidade de toda uma produção de livros didáticos, com domínio de recursos de representação e seu traço característico (FIG. 5.26 e 5.27). O uso de fotografias, presente desde as edições impressas em tipografia mediante uso de clichês, é ampliado nas edições impressas em ofsete, sempre com função informativa (fig. 5.20).
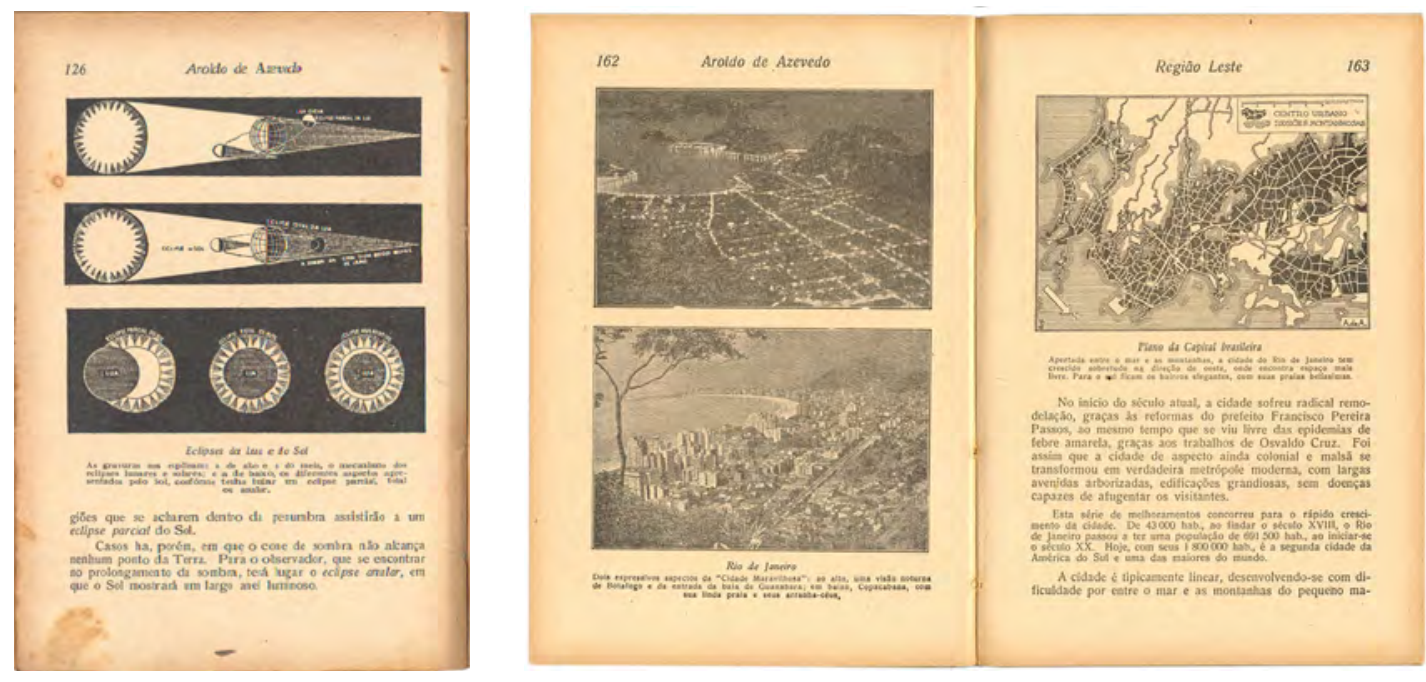

Fig. 5.26. Aroldo de Azevedo, Geografia do Brasil: as regiões geográficas, tomo II, BPB Série II, vol. 145, 1947 (13,2 x $19,2 \mathrm{~cm})$.

\footnotetext{
5 A par de atividade acadêmica como professor e pesquisador, Aroldo de Azevedo publicou, em 40 anos, 30 livros didáticos, alguns como o mesmo conteúdo atualizado, com venda superior a 11 milhões de exemplares e que monopolizaram o mercado dos livros de Geografia para o Ginásio e o Colégio [FERRACINI, 2012, p. 60-62].
} 

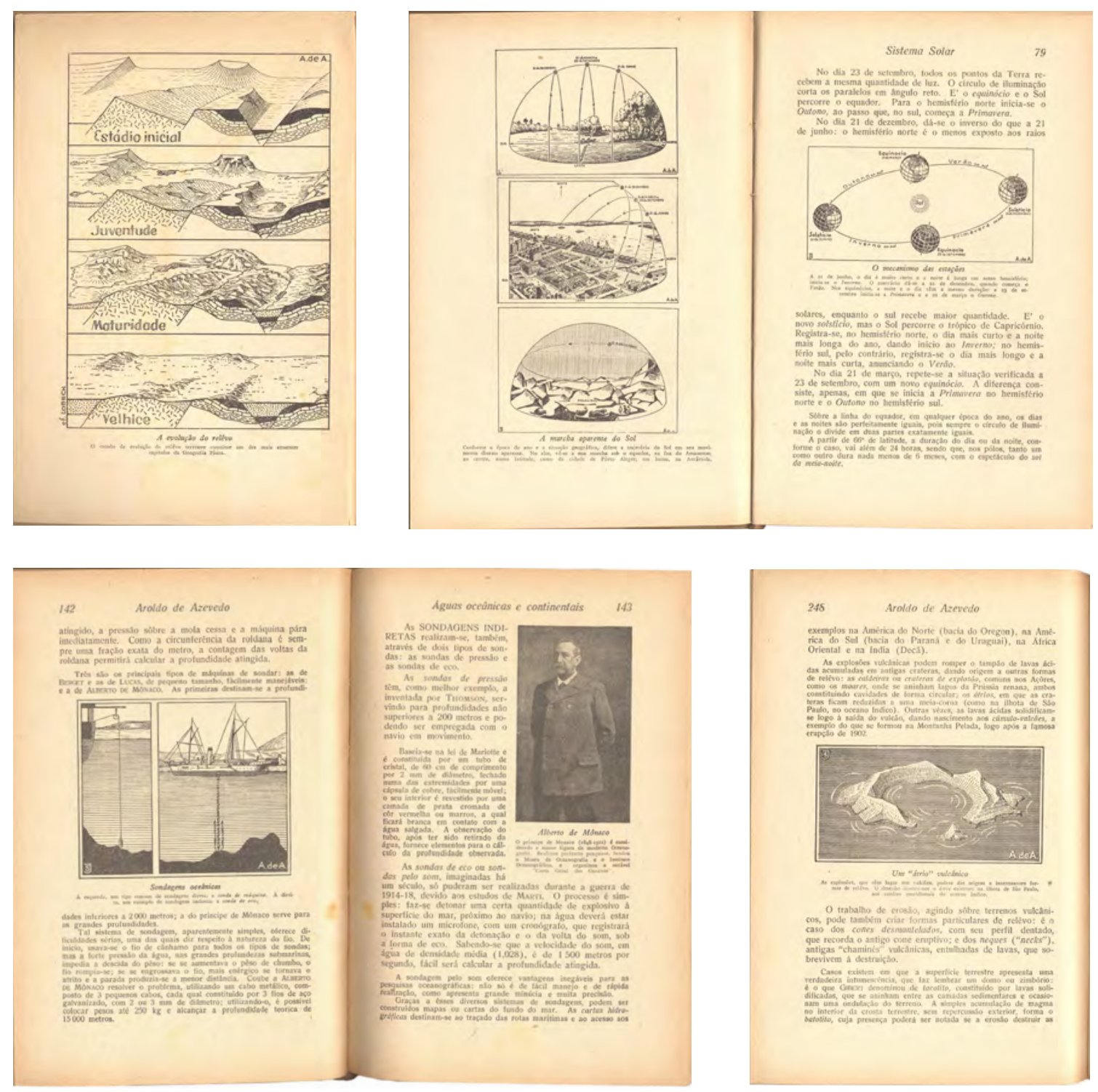

Fig. 5.27. Aroldo de Azevedo, Geografia física: 1a série colegial, 1949 (14,0 × 21,0cm). Ilustrações do próprio autor.

\section{Apropriação do design em línguas estrangeiras}

Por fim, cabe apontar o curioso reaproveitamento de design e ilustração da obra Mon Petit Univers, de Maria Junqueira Schmidt, para a obra English, de Isabel Junqueira Schmidt. Na verdade, parte significativa da base de arte do primeiro livro - ilustração, diagramação e paginação - parece ter comandado a elaboração de um novo original, para ensino de uma outra língua (FIG. 5.28, confrontar com FIG. 4.39). A relação entre imagem e texto construída em função de particularidades de uma língua e sua cultura teria sido transposta diretamente para o ensino de outra, mediante a substituição do componente textual, com o léxico da nova língua, restando saber se isto seria possível sem trazer prejuízos de ordem pedagógica e cultural. 

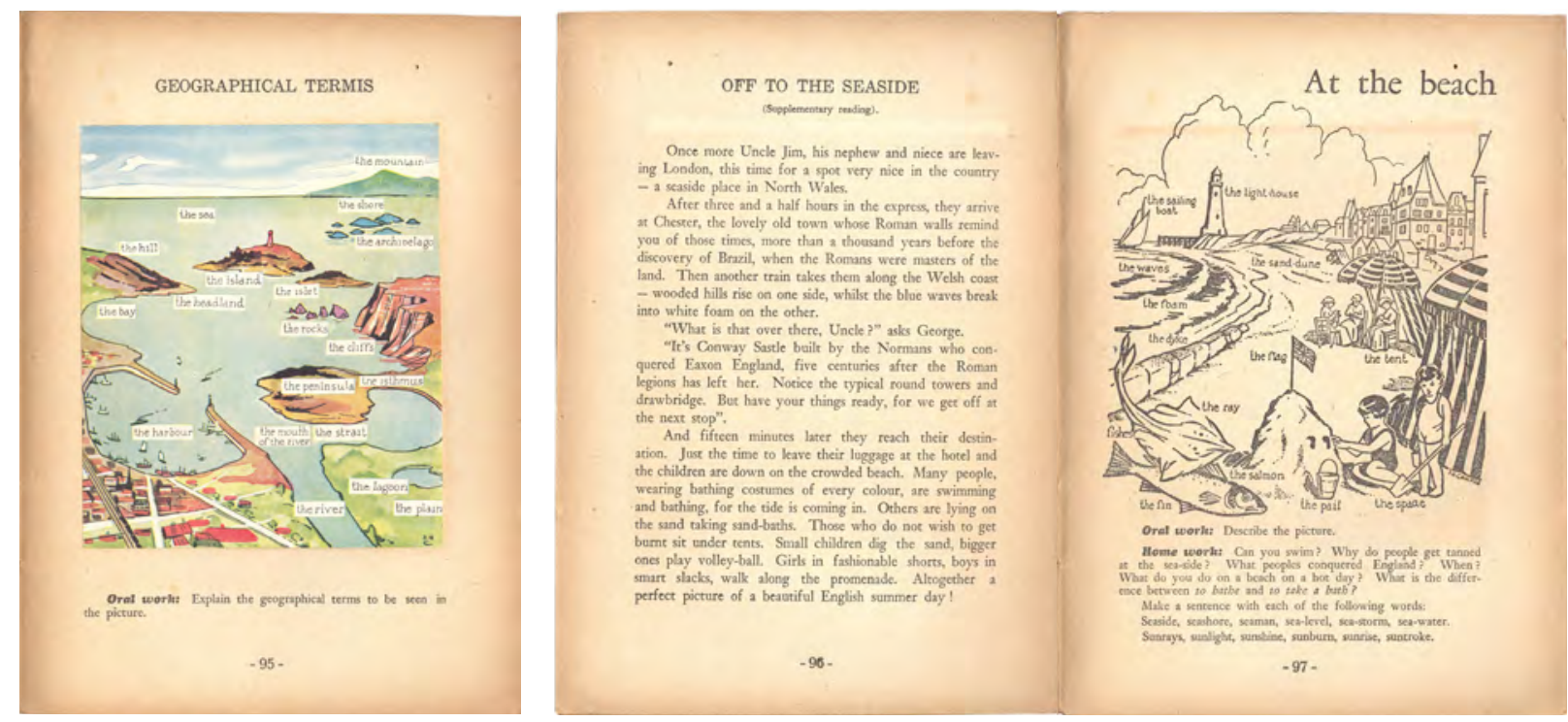

Fig. 5.28. Isabel Junqueira Schmidt, English: third grade, $1949(15,0 \times 21,0 \mathrm{~cm})$. Reaproveitamento de artes-finais e paginação de Mon Petit Univers, de Maria Junqueira Schmidt.

\section{Os livros do Ensino Primário}

Os livros didáticos deste segmento, no período abordado, são ainda cartilhas e livros de leitura, que apresentam uma estrutura gráfica semelhante independentemente do método de alfabetização a que se filiem. No caso das cartilhas da Nacional, trata-se principalmente dos métodos analítico e misto (combinação com a silabação), com as suas particularidades expressando as concretizações que cada autor faz como resultado da interpretação do método ou da combinação adotada, a partir de sua experiência como alfabetizador e das características de público que visam atingir. Essa liberdade e ecletismo é resultado da influência do trabalho teórico de Lourenço Filho com seus Testes $A B C$, que incorporam os estudos de psicologia do desenvolvimento infantil e acabam por propugnar uma "alfabetização sob medida" a partir da realidade de cada criança ou do conjunto de crianças a serem alfabetizadas [MORTATTI, 2000, p. 26, 203, 213-215]. As semelhanças na estrutura gráfica é também abordada pela autora, para quem:

No âmbito dessa tendência, as novas cartilhas vão sendo aprimoradas graficamente [...] mas algumas características da tradição herdada das primeiras cartilhas brasileiras vão-se consagrando como modelos e se repetindo até o presente, como é o caso das ilustrações que antecedem as lições, dos conjuntos de frases relacionadas entre si mediante nexos sintáticos, da silabação disfarçada em sentenciação, ou do controle da recorrência e diversidade de vocábulos apresentados em cada lição. [MORTATTI, 2000, p. 213]

Nas cartilhas e livros de leitura levantados nesse período, não só essa estrutura se mantém, como a linguagem das ilustrações permance sendo a do traço, sem uso de retícula, apesar de todas elas serem impressas em ofsete, demonstrando ser essa a linguagem estabelecida para o livro didático pela tradição da impressão tipográfica. 


\section{Cartilha Fácil}
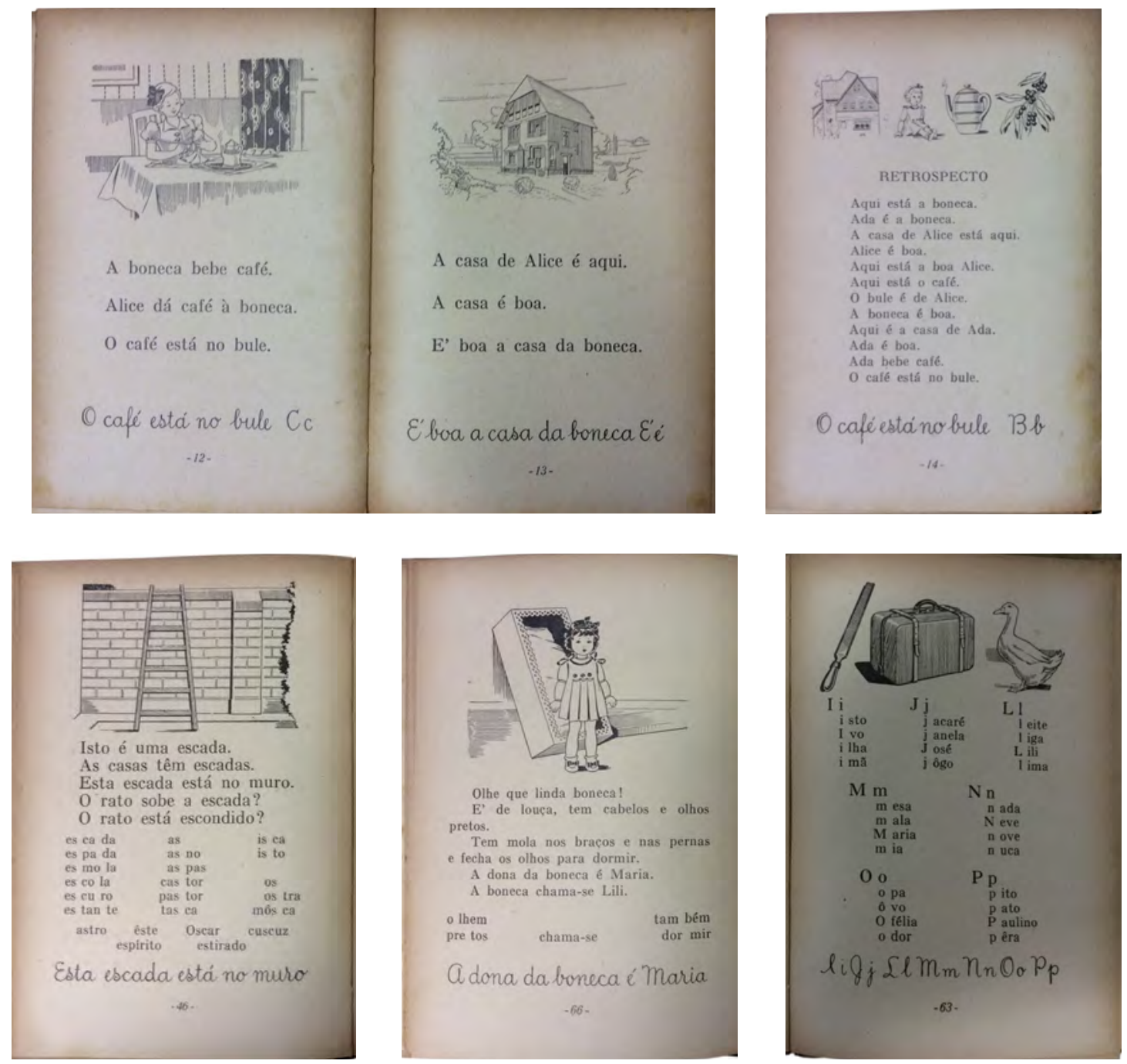

Fig. 5.29. Claudina de Barros, Cartilha Fácil, 17ạ edição, 1944 (13,0 x 19,0cm). [Fonte: AHECC/CRE Mario Covas/ EFAP/SEE-SP.]

Seguindo a tradição da cartilha brasileira já assinalada, as primeiras lições são iniciadas por ilustrações (FIG. 5.29), mas sua presença é justificada pela autora, nas orientações de uso do livro, como estímulo para as crianças formularem frases inteiras, como as três que o mestre irá explorar identificando as palavras, sendo que a última delas é repetida em tipo cursivo como modelo para a aula de caligrafia. Cada grupo de três lições é seguido de um retrospecto, que agrupa as palavras já ensinadas, e só após vinte lições começa a identificação das sílabas e seu isolamento, para aplicação na construção de outras palavras, com uma variação de desenho de página. Um último grupo de lições já apresenta pequenas histórias, seguidas de um último modelo de configuração de página, em que as letras aparecem destacadas, como iniciais de palavras já aprendidas, completando o ciclo típico do ensino analítico da leitura e de escrita, indo do mais geral — sentenças em que se identificam palavras -, passando pelo intermediário - as sílabas - e chegando ao signo isolado, a letras. 


\section{Vamos ler; leituras intermediárias}
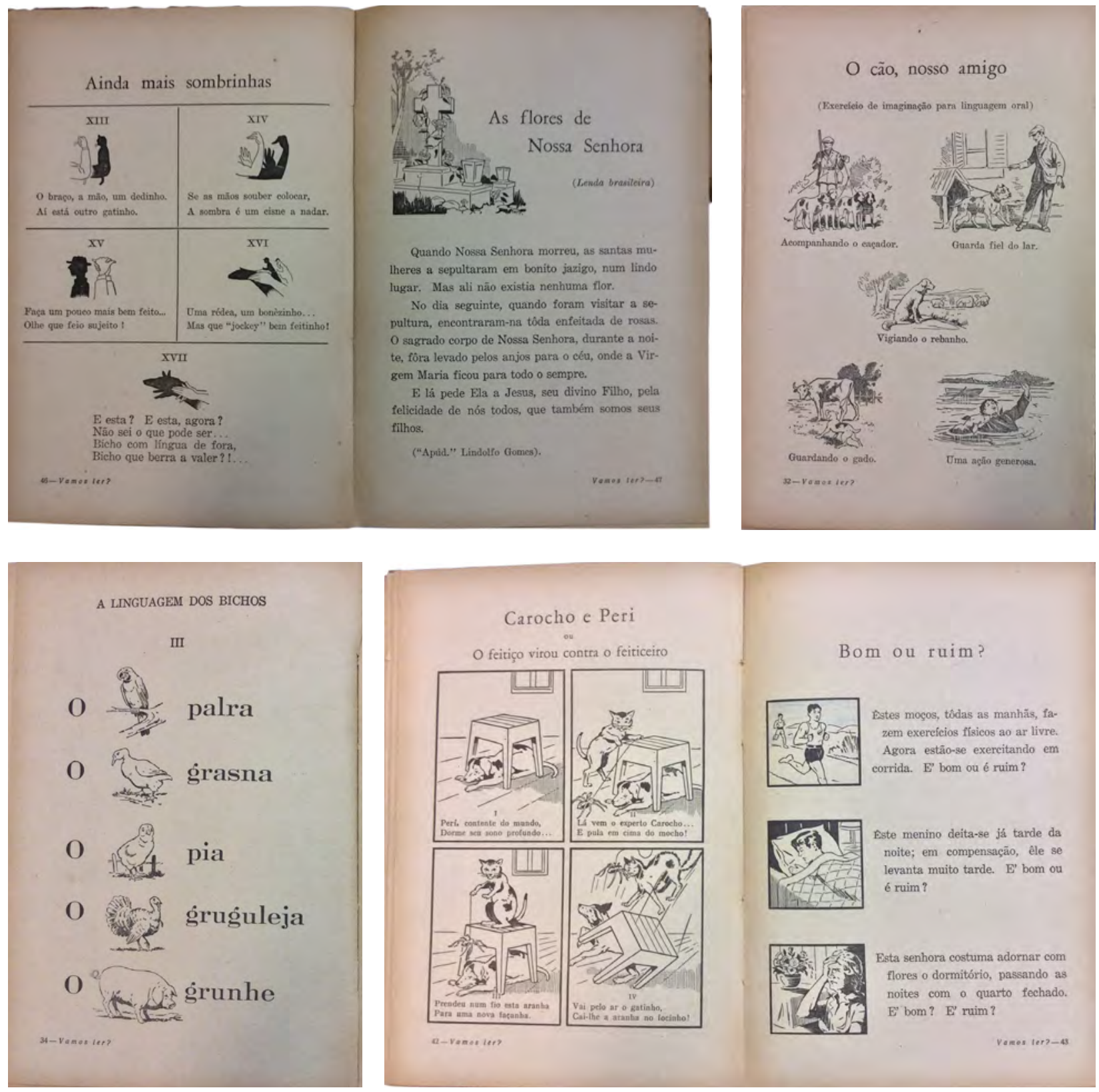

Fig. 5.30. Renato Sêneca Fleury, Vamos ler: leituras intermediárias, $1944(15,0 \times 23,0$ cm). [Fonte: Biblioteca Infantil Municipal Monteiro Lobato, São Paulo.]

Não obtivemos a cartilha Vamos Ler para identificar o partido de alfabetização adotado, nem outros volumes de leitura, mas este, de Leituras intermediárias (FIG. 5.30), apresenta uma diferença bastante grande em relação aos livros de leitura vistos até o momento, em que uma imagem localizada na parte superior da página ilustra o texto em prosa ou poema que a segue. Aqui, ao contrário, é apresentada uma grande variedade de tipos de texto, como narração ilustrada em quadrinhos, brincadeiras e adivinhas, em que as imagens têm papel decisivo, integram-se de diversas formas ao texto e geram grande diversidade de desenhos de página, propiciando surpresas ao longo da obra e certamente interesse para o leitor. 
A técnica de ilustração é a do traço, atestando a continuidade da tradição desse recurso, mesmo em livros que se propõem inovadores ou diferenciados e produzidos em período em que a editora já dispõe dos recursos da impressão ofsete como tecnologia corrente.

\section{Cartilha Sodré}
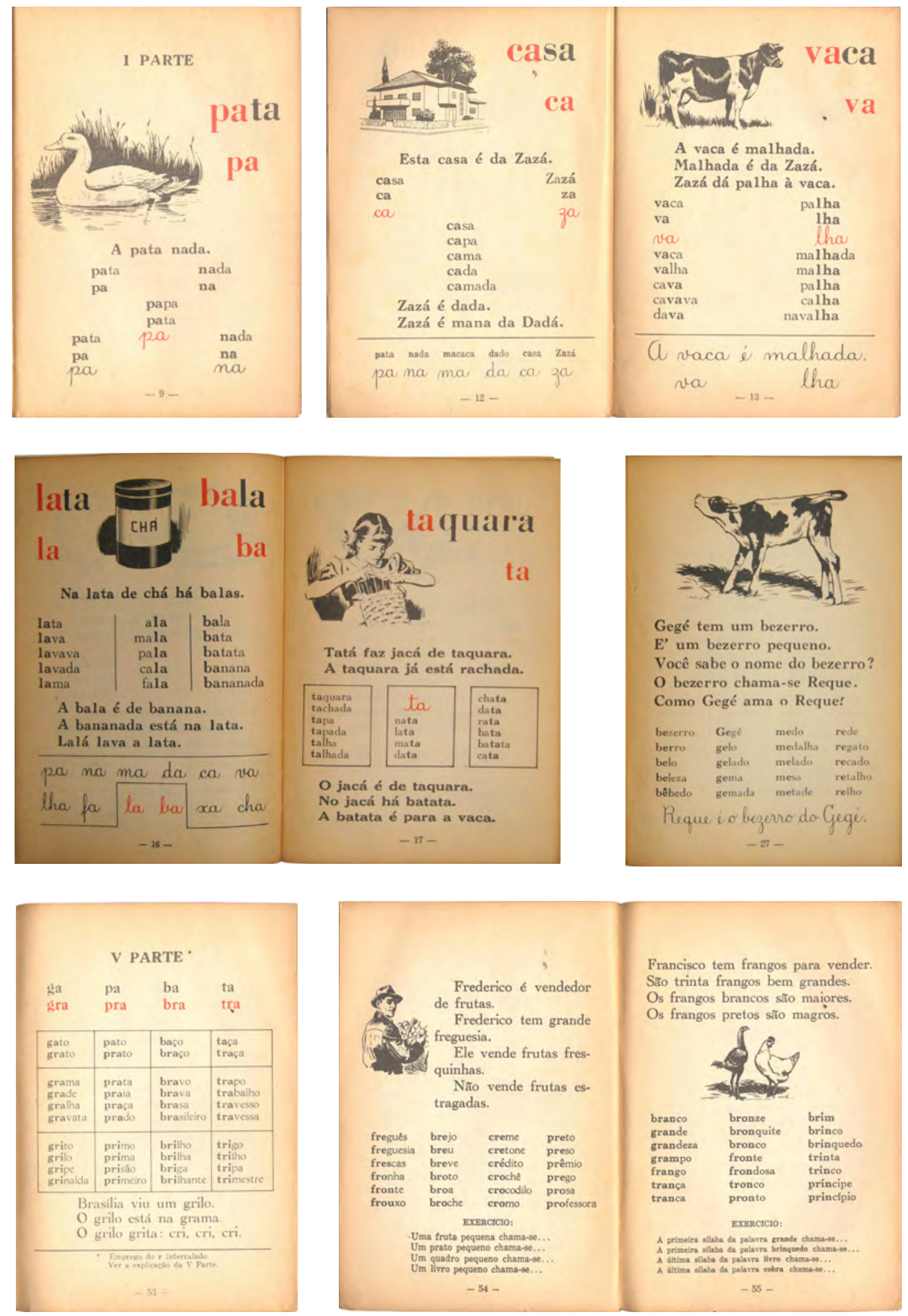

Fig. 5.31. Benedicta Stahl Sodré, Cartilha Sodré, 250ạ edição, $1977(13,0$ x 19,0cm). 
Da Cartilha Sodré não se obteve para reprodução um exemplar de edição localizada dentro do período tratado. No entanto, como foi possível confrontar exemplares de diversas edições, desde a primeira, de 1948, até a 250ミ e 1977, no acervo histórico da Companhia Editora Nacional antes de seu fechamento, pode-se constatar que tanto o partido pedagógico adotado como a forma de apresentação não foram afetados por alterações pontuais de conteúdo e troca de ilustrações ao longo desse tempo ${ }^{6}$.

As páginas da primeira parte, dedicadas às sílabas formadas com a vogal $a$, indicam um método que parte da silabação, com a sílaba em estudo sendo destacada em vermelho, na palavra, e isoladamente, abaixo dela (FIG. 5.31). Um desenho, em linguagem de traço, ilustra a palavra. Um grupo de frases faz parte desse primeiro conjunto, seguido de outro com palavras isoladas e destaque em negrito das sílabas e eventuais destaques na segunda cor (vermelho). Mesmo nessa primeira parte, não há uma regularidade de diagrama na página, com o método e o conteúdo determinando leiautes bastante variados. Nas demais partes (são sete no total), a diversidade de leiaute é maior ainda, para atender as situações de ensino sempre coordenado de leitura e escrita de palavras e frases, partindo do reconhecimento das sílabas, indo das mais simples com outras vogais além do $a$, ditongos e hiatos e chegando às situações mais complexas, como re / intercaladas e ditongos nasais, por exemplo. As páginas ficam mais cheias e pequenas histórias ou relatos ocorrem, seguidas de listas de palavras e exercícios. Assim, embora parta da silabação e apresente imagens associada a palavras, como as cartilhas vistas até agora, o método ou "Processo Sodré" leva a leiautes de páginas que se diferenciam bastante dos apresentados por elas.

\subsection{Considerações gerais sobre o design dos livros didáticos da CEN do período 1943-1952}

O esgotamento da política de coleções para os livros didáticos não significou o abandono de uma de suas práticas, a padronização de soluções de capa e miolo para viabilizar a produção extensiva de títulos, ainda mais ampliada com a continuidade da expansão do ensino no país.

No caso das capas, um novo formato decorrente da aquisição de equipamento ofsete pela principal fornecedora de serviços gráficos e do interesse em diferenciar os títulos destinados ao nível Colegial estabelecido pela Lei Orgânica do Ensino Secundário, levou à criação de um novo modelo. De produção facilitada, por ser exclusivamente tipográfico e poder correr parale-

\footnotetext{
6 Uma nova configuração, formato e recursos de impressão estará presente nas edições que se seguiram a 1978, como será visto no capítulo 7. Segundo Maria do Rosario Longo MoRTATTI [2000, p. 204-206], onde se pode encontrar mais informações sobre esta cartilha e o método que emprega, a Cartilha Sodré foi a segunda mais adotada no estado de São Paulo e vendeu mais de 30 milhões de exemplares até 1996, quando parou de ser produzida.
} 
lo e independente da produção do miolo, o novo modelo de capas traz uma modernização de linguagem, apoiada na impressão ofsete, que se prestou simultanemente a identificar e trazer uma imagem de atualização da editora e marcar nova produção didática voltada para a nova estrutura do Ensino Secundário.

No caso dos miolos, o pequeno acréscimo no formato não propiciou o surgimento de novo leiaute de página, mas a facilidade de reprodução de imagens reticuladas e com melhor qualidade trouxe um maior uso da fotografia, particularmente em livros de História, Geografia e, em menor medida, em línguas estrangeiras, gerando uma ampliação de iconografia "autêntica" nesses livros e uma possível contribuição à que a cultura visual escolar se aproximasse da cultura visual presente na sociedade.

Com relação às ilustrações, a maior facilidade de reprodução de imagens possibilitada pela impressão ofsete possibilitou que os livros de Geografia, particularmente os de Aroldo de Azevedo, ganhassem importante incremento na representação gráfica dos fenômenos abordados pela disciplina. Mas era ainda cedo para que o uso corrente da impressão ofsete modificasse a prática estabelecida da ilustração em traço originária da impressão tipográfica, que continuou sendo empregada por contar com profissionais que atendiam com competência as necessidades dos livros escolares de todos os níveis.

Embora a solução dominante de capa fosse tipográfica, aparecem as primeiras capas ilustradas em cores para o segmento didático secundário, prática que até o período anterior se encontrava apenas nas cartilhas e livros de leitura, destinados ao Ensino Primário. Há aqui também uma aproximação da visualidade escolar com o que circulava na sociedade.

Assim, esse período é marcado por importantes modificações na materialidade e na visualidade dos livros didáticos da Companhia Editora Nacional, como resultado de mudanças tecnológicas realizadas para atender o potencial de crescimento de produção de livros didáticos decorrentes da procura por educação e maior oferta nos níveis Primário e Secundário, mas também nos segmentos do ensino técnico e comercial. A editora efetivamente preparou o salto que a transformou na maior editora brasileira, com a associação à São Paulo Editora, uma das maiores gráficas de livros do país, e a aquisição dos equipamentos mais modernos à época. E completou essa preparação com o desenvolvimento de projetos gráficos e o estabelecimento de procedimentos adequados ao emprego de uma tecnologia que já era corrente na produção de revistas mas que pela primeira vez foi utilizada em larga escala na produção de livros.

O resultado foi um novo aprimoramento gráfico e atualização da visualidade do livro didático brasileiro. 

CAPÍtULO 6

\section{3-1960:}

A generalização das capas ilustradas coloridas

nos livros didáticos da Companhia Editora Nacional 

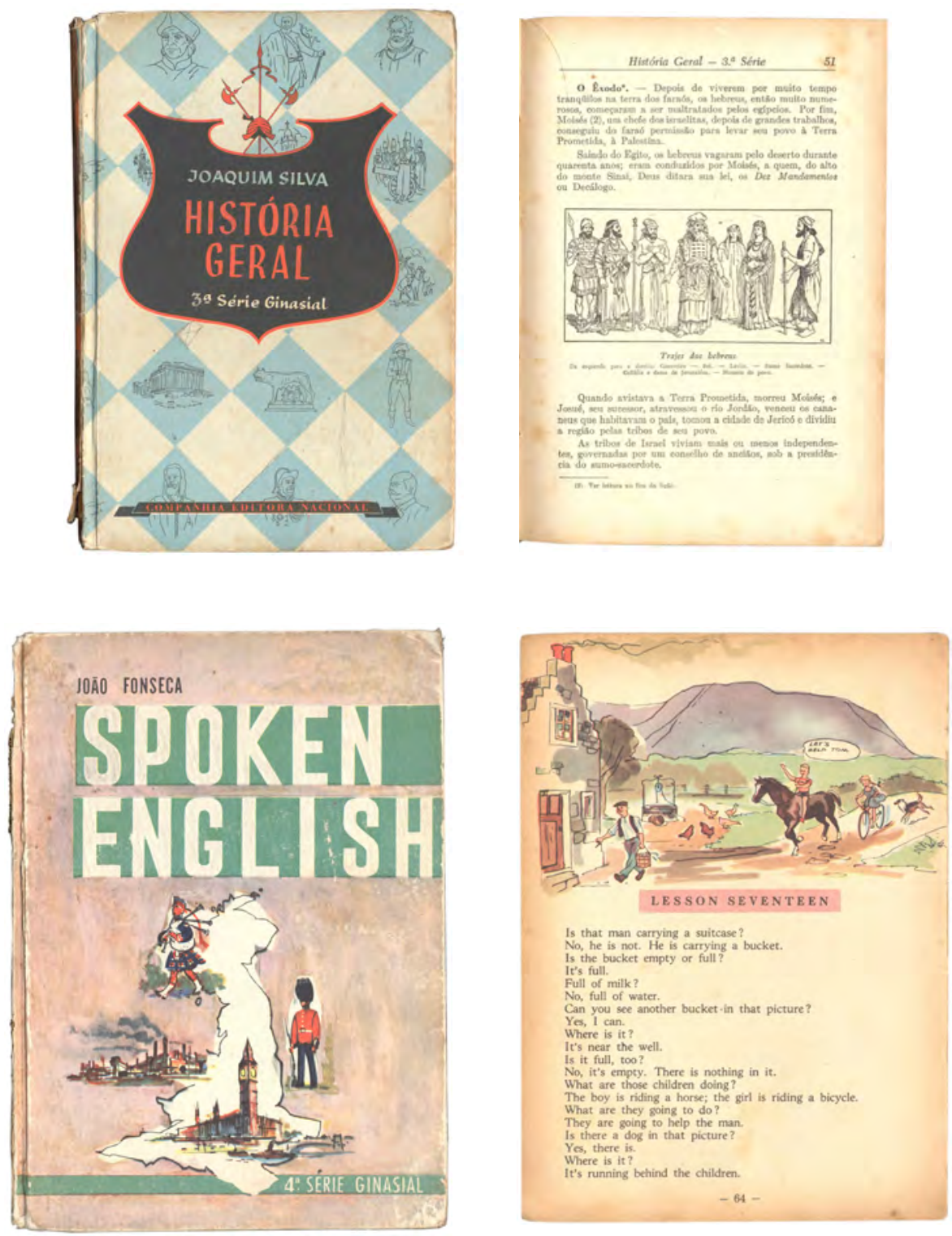

As duas obras aqui reproduzidas apresentam algumas das características encontradas no design e na materialidade de livros didáticos da CEN no período 1953-1960:

- capas ilustradas em cores chapadas ou com ilustração reproduzida por impressão ofsete em quadricromia;

- miolos em impressão monocromática com ilustração em traço, presente em grande número dos livros:

- miolos em impressão de quadricromia reproduzindo ilustração, em número menor de livros;

- predomínio da encadernação em capa dura como acabamento dos volumes. 
$N^{2}$ a trajetória do design de livros didáticos da Companhia Editora Nacional, a delimitação de um quarto período, tratado neste capítulo, é justificada primordialmente por uma inflexão fundamental na abordagem da solução das capas. Até aqui, cada um dos períodos anteriores foi marcado pelo predomínio de uma variação particular de uma mesma abordagem para o design das capas - a tipográfica -, enquanto que o início deste período é definido pela aparição de um volume significativo de títulos que trazem uma abordagem oposta - as soluções apoiadas na ilustração em cores.

Soluções, no plural, não só porque a abordagem da ilustração implica diversidade de linguagens e técnicas decorrente da individualidade de cada ilustrador capista, mas também porque a editora abandonou os diagramas e chassis fixos vigentes nos períodos anteriores e optou por uma particularização maior de cada obra, obtida por diagramas originais para cada uma delas, em que ilustração e tipografia se combinam de forma livre e específica. Ou seja, a diferença com os períodos anteriores é dada também pelo abandono da padronização extrema que caracterizava a produção de capas de livros didáticos da editora, numa aproximação relativa com os procedimentos e as linguagens presentes nos livros dos outros segmentos não pertencentes a coleções ou quando estas comportam leiautes mais livres, também uma abordagem recente mesmo para os títulos não didáticos.

Indo além dessa aproximação com a produção livreira mais ampla, as capas dos didáticos da Nacional trarão também linguagens de ilustração afins à encontrada na publicidade, nas revistas populares e até na vertente do design modernista construtivo que se estabelecia no Brasil a partir da década de 1950, que forneceu referências para algumas soluções gráficas abstratas e tipográficas. A presença da fotografia em cores, em menor número mas inaugurando uma tendência que se afirmará nas décadas seguintes, completa o leque de capas do período que se apoiavam na imagem, referencial ou abstrata, e na letra como imagem, todas elas permitidas pelas tecnologias da impressão ofsete e da seleção quadricrômica.

Diferentemente do que ocorreu com as capas, a materialidade e o design do miolo não sofreram transformações que serviram para delimitar o início desse novo período de design. Nos primeiros anos, para a grande maioria das obras produzidas seguiam vigindo os mesmos procedimentos encontrados no período 1943-1952. No entanto, passado alguns anos, terá início a generalização da impressão de miolo em duas e três cores e em quadricromia, para títulos de Geografia, Admissão ao Ginásio, Inglês e Francês, dando consistência à configuração do período como realmente diferenciado dos anteriores.

Com relação à organização escolar e aos conteúdos disciplinares, os livros do período não respondem a nenhuma nova demanda, pois prossegue em vigor a estrutura de ensino estabelecida pelas Leis Orgânicas do Ensino, promulgadas em 1942 e 1943, completadas pelo governo que se seguiu ao fim da ditadura do Estado Novo e consagradas pela Constituição de 1946. 


\subsection{Os livros não didáticos da CEN no período 1953-1960}

A consolidação da Companhia Editora Nacional como a maior editora do país, posição alcançada já na década de 1940, é reafirmada na década de 1950 por alguns números obtidos em duas fontes secundárias. Segundo HalleweELl [2005, p. 372], em 1954, a CEN produziu 368 edições, num total de 5.141 .500 exemplares, e em 1955, 349 edições, num total de 6.002.500 exemplares. Para efeito de comparação, o autor traz a relação das demais editoras brasileiras, em que a Melhoramentos comparece com 203 edições, a Francisco Alves com 137, a Editora do Brasil, com 100 - todas principalmente escolares, atestando o peso dessa produção -, seguidas de quase cinquenta outras, com números de edições bem menores cada uma, totalizando 2.696 títulos para todo o país, mas não é fornecido o número de exemplares correspondentes. Ephraim BeDA [1987, p. 327] por sua vez menciona os números divulgados por ocasião da comemoração dos 30 anos de existência da Nacional, em janeiro de 1957: 14 mil edições, representadas por 2.416 títulos, perfazendo 70 milhões de exemplares impressos, sendo que o ano de 1956 teve produção superior a 6 milhões de exemplares.

Sem dispor de catálogos e estudos sobre as principais coleções e autores da Nacional, é difícil obter informações abrangentes sobre os títulos e coleções mais significativos lançados no período. Ephraim Beda apresenta uma extensa relação das coleções e títulos avulsos que tiveram venda expressiva ao longo de toda a história da Nacional [BEDA, 1987, p. 277-323], mas sem precisar todas as datas. No entanto, a partir de suas informações e consultas a sites de vendas de livros usados, foi possível levantar alguns títulos e coleções que merecem ser citados para apresentar um quadro mínimo da produção não didática da editora e de sua visualidade.

As coleções de literatura popular da editora continuam tendo grande aceitação. A Biblioteca das Moças e a Coleção Paratodos apresentam novos projetos de capa, com novas ilustrações, enquanto a Coleção Terramarear mantém o mesmo leiaute, baseado apenas na forte ilustração colorida sangrada na capa, sendo que muitos volumes mantém as mesmas ilustrações das edições da década de 1930 (FIG. 6.1)

Como visto no capítulo anterior, a Biblioteca do Espírito Moderno, mesmo com um número menor de lançamentos na década de 1950, mantém grandes tiragens e prestígio, sendo ampliada com importantes títulos de literatura universal, com autores como Ernest Hemingway e George Orwell, e apresentando uma renovação na linguagem de suas capas com o trabalho de Walter Lewy (FIG. 6.2).

Com um título avulso lançado em 1949, Noções de psicologia experimental, que obteve grande aceitação pela linguagem simplificada e clara, Theobaldo Miranda Santos tem seus novos títulos lançados na década de 1950 sob o nome geral de coleção Curso de Psicologia e Pedagogia, voltado principalmente para os estudantes de escolas normais, mas que também 
obteve aceitação em faculdades de educação e de filosofia. Na tradição dos livros para o ensino médio e superior, as capas são exclusivamente tipográficas (FIG. 6.3)
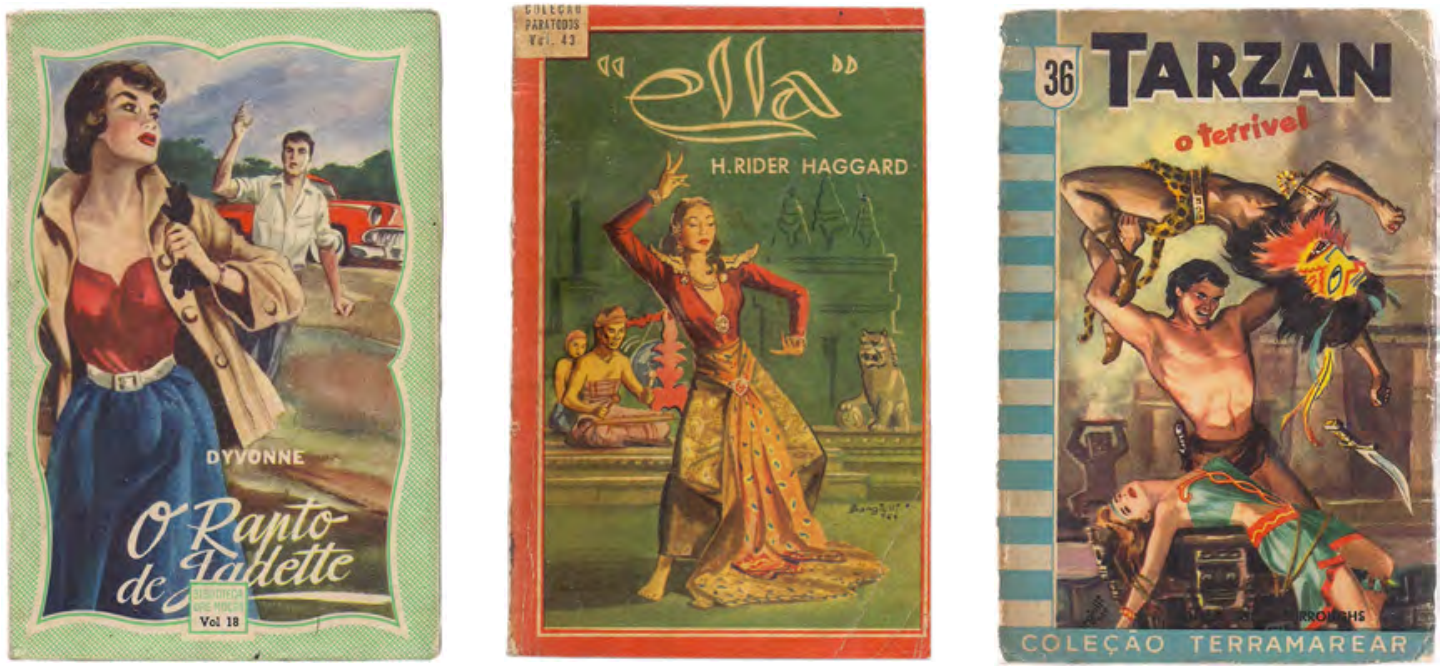

Fig. 6.1. Volumes das coleções Biblioteca das Moças (1956), Paratodos (1957, ilustração de João Gargiulli) e Terramarear (1958, ilustração de João Gargiulli). [Fonte: acervo pessoal.]
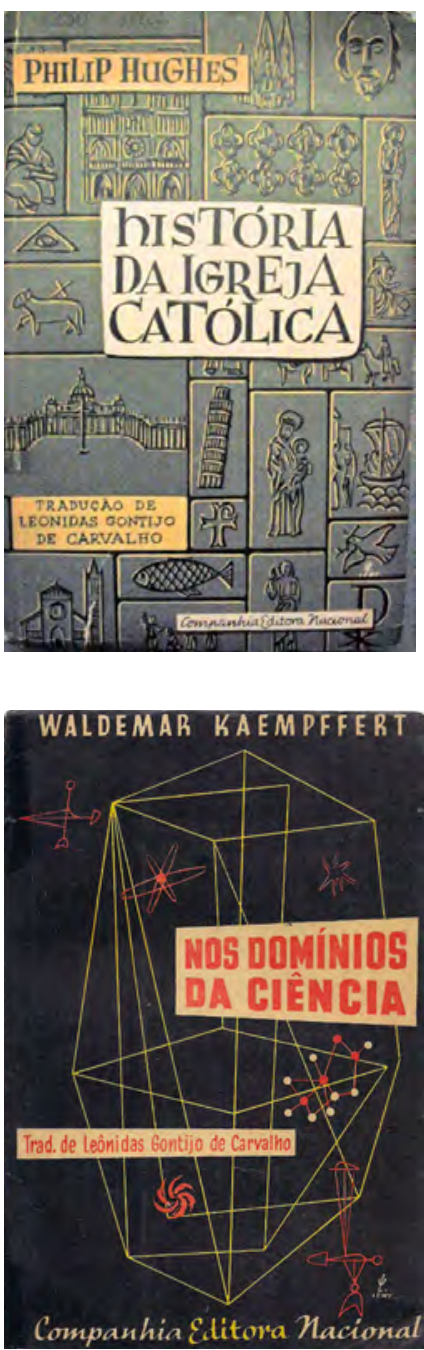
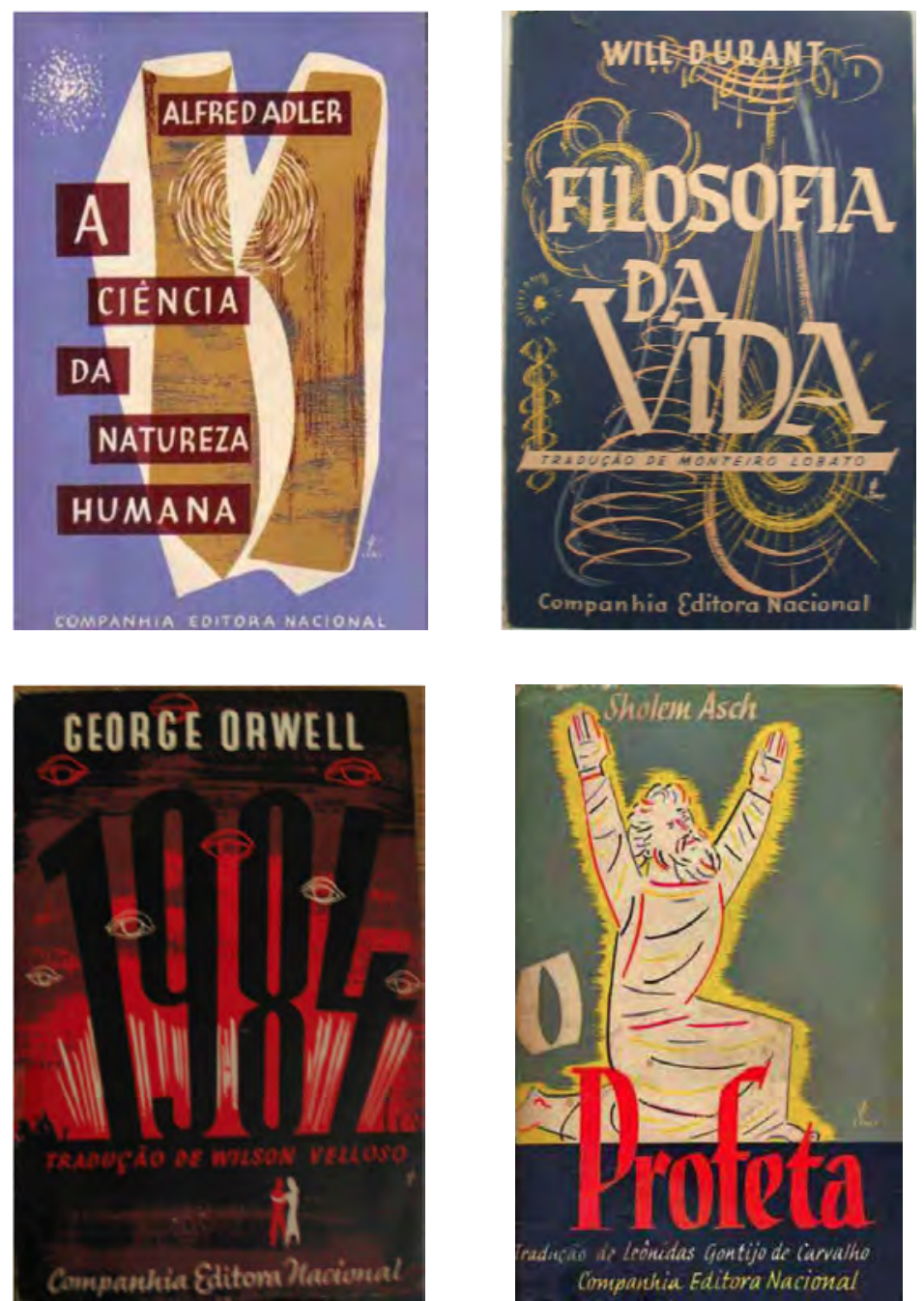

Fig. 6.2. Volumes da Biblioteca do Espírito Moderno, da década de 1950, com capas de Walter Lewy. [Fonte: FONSECA, 2010 e acervo pessoal]. 

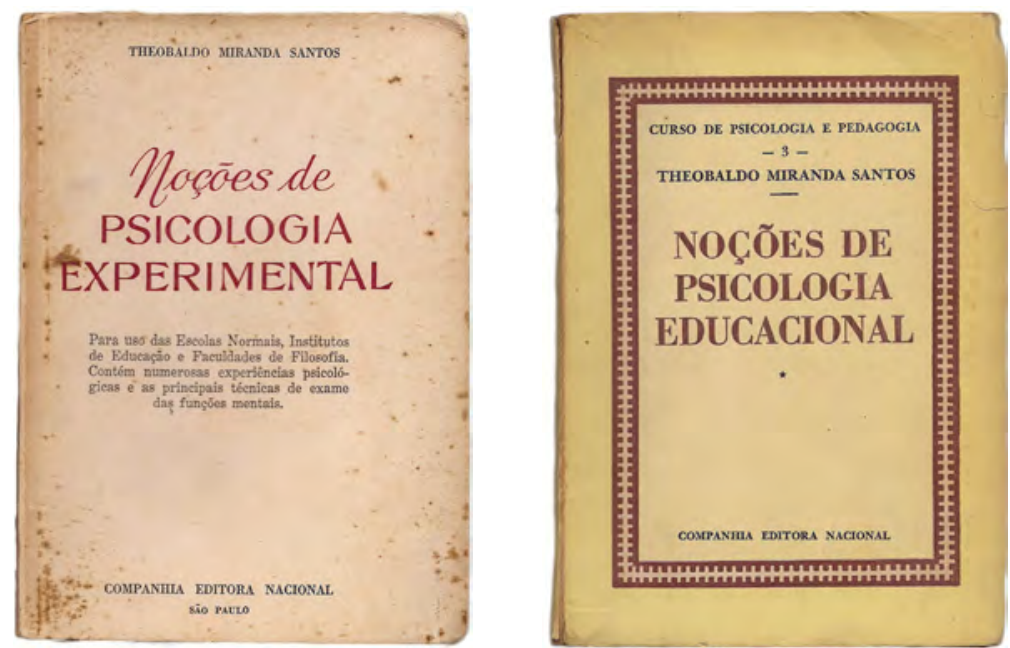

Fig. 6.3. Theobaldo Miranda Santos, Noções de Psicologia Experimental, 1949 e Curso de Psicologia e Pedagogia, vol. 3 - Noções de Psicologia Educacional, 1954. [Fonte: acervo pessoal.]

A modernização na linguagem das capas dos livros da CEN, iniciada na década de 1940 e acentuada na década de 1950, é atribuída por Beda ao papel de Rubens de Barros Lima como encarregado do departamento de produção gráfica, como foi visto no capítulo anterior. Com relação ao miolo dos livros, Hallewell menciona uma "revolução do design gráfico, que remonta ao final da década de 1940", atribuindo a Rubens de Barros Lima a responsabilidade pela introdução de "marcantes inovações no estilo da editora, chegando a criar escola", com a "adoção de um estilo despojado, equilibrado, limpo, na ficção e nos livros de interesse geral". Mas o autor também menciona a "qualidade dos desenhos de capa e ilustrações, decorrente da colaboração de artistas como Carlos Bastos, Carybé, Darcy Penteado, Walter Lewy e outros" [HaLleWell, 2005, p. 382].

Essa predisposição e abertura para novas soluções gráficas vai se manifestar especialmente nos livros didáticos, em que o papel de Rubens de Barros Lima é também mencionado por Hallewell e poderá ser comprovado pela apresentação do design de capa e miolo que será feita adiante neste capítulo. No entanto, neste tópico relativo à história da editora e suas publicações no período tratado, como condição para a apropriação das linguagens que circulavam em outros meios deve ser mencionada a apropriação das técnicas de fotomecânica para a produção de fotolitos para a impressão ofsete, em particular da quadricromia, por parte do principal fornecedor da CEN, a São Paulo Editora.

Também pode-se supor que a contratação de Thomaz de Aquino Queiroz, em 1954, como assistente de Rubens de Barros Lima no departamento de produção gráfica, tenha contribuído para os avanços em linguagem gráfica mencionados. Queiroz já fornecia trabalhos de ilustração e desenho de títulos como freelancer para a editora e assim que foi contratado seguiu cursos de artes gráficas, "melhorando muito a estética dos livros editados" [BEDA, 
1987, p. 271-272]. Tendo adquirido alguma experiência e participado das mudanças iniciais na visualidade dos livros didáticos que serão apresentados, Queiroz assume a Diretoria Editorial, em substituição a Ênio Silveira - genro de Octalles Ferreira - , que iria se dedicar exclusivamente à direção da Civilização Brasileira, no Rio de Janeiro, editora do grupo desde os anos 1930 mas que teria desenvolvimento independente e importante papel na cultura brasileira na década de 1960.

Em entrevista concedida a Ephraim Beda, Thomaz de Aquino Queiroz relata seu trabalho, que ia desde a seleção de originais não pertencentes a coleções com editor responsável, até a organização e acompanhamento da programação, prestando contas diretamente a Octalles Ferreira. E menciona a preocupação particular de conferir maior qualidade editorial mediante um cuidado mais sistemático com o tratamento editorial dos originais,

que compreendia a preparação de originais, revisão de originais - coisas que, naquela época, em geral no Brasil, não era só na Nacional, coisas que não se faziam com muito cuidado [...] Os originais chegavam tumultuados [...] Os autores nem sempre tinham idéia de como apresentar isso ou aquilo. [BEDA, 1987, p. 272]

A introdução de maior rigor editorial, por parte de quem trazia experiência na produção gráfica, indica a possibilidade de uma complementaridade e interlocução com o responsável pela produção gráfica, Rubens de Barros Lima, na configuração global dos livros produzidos a partir desse período.

\subsection{A educação brasileira no período 1953-1960}

O período de design de livro didático da CEN definido e abordado por este capítulo não é iniciado nem finalizado por nenhuma transformação na estrutura de ensino vigente no país. Os livros didáticos produzidos entre 1953 e 1960 visam atender o Ensino Primário e o Ensino Secundário tais como foram definidos pelas Leis Orgânicas do Ensino criadas no final do Estado Novo - a Reforma Capanema - e no início do regime democrático que o sucedeu, leis essas reafirmadas pela Constituição de 1946. Tanto a estrutura de ensino, suas limitações em termos de reproduzir a dualidade classista no ensino e suas contradições, que permitiram um crescimento da oferta de ensino nos níveis primário e secundário e mesmo um acesso maior de camadas médias ao Ensino Secundário podem ser vistas no capítulo anterior, às páginas 182 a 186, como referência ao contexto educacional em que os livros que serão analisados neste capítulo estavam inseridos.

A tabela 6.1 apresenta a evolução da matrícula nos níveis primário e médio (dividididos em secundário e profissional) entre 1950 e 1960, e seu confronto com a população em idade 
escolar correspondente1. Além da evidente defasagem de oferta de ensino, atesta-se também a interrupção da educação no nível primário para grande parte da população, o que caracteriza o dualismo e seu viés classista já mencionado. Do ponto de vista das editoras de livros didáticos, mesmo sendo muito aquém das necessidades do país, a expansão ocorrida garantia um crescimento considerável.

Tabela 6.1. Expansão da matrícula geral do Ensino Primário e médio e população escolar entre 1950 e 1960

\begin{tabular}{|c|c|c|c|c|c|}
\multirow{2}{*}{ Ano } & \multirow{2}{*}{ Ensino Primário } & \multicolumn{2}{|c|}{ Ensino Médio } & \multirow{2}{*}{ Total } & $\begin{array}{c}\text { População entre } \\
5 \text { e } 19 \text { anos }\end{array}$ \\
\cline { 3 - 6 } & & Secundário & Profissional & & 18.826 .409 \\
1950 & 4.364 .852 & 406.959 & 150.475 & 4.922 .286 & 18.46 \\
1960 & 7.458 .002 & 868.178 & 309.249 & 8.635 .429 & 25.876 .581 \\
\hline
\end{tabular}

Fonte: RomANELLI, 2007, p. 76 Quadros 9 e 10 e p. 113 Quadro 40.

A tabela mostra também que as Leis Orgânicas do Ensino, por si só, não resolveram nem a defasagem entre demanda e oferta de educação nem as exigências para o próprio desenvolvimento do país em termos de capitalismo dependente, até mesmo sob a ótica das próprias classes dominantes. Assim, a necessidade de um reforma mais profunda na educação no país continuava em pauta e o próprio ministro da educação do governo Dutra, Clemente Mariani, apresenta, em 1948, um anteprojeto da Lei de Diretrizes e Bases da Educação, agora para ser discutido, modificado e aprovado pelo Congresso Nacional. Sob um regime de maiores liberdades democráticas, com eleições diretas em todos os níveis - mas sem voto para analfabetos e com o Partido Comunista proscrito - a pressão por educação pública e gratuita em todos os níveis, não garantida pela Constituição de 1946, encontra canais de expressão popular e engaja setores mais amplos que os antigos Pioneiros da Escola Nova e educadores progressistas em geral, envolvendo sindicatos, organizações estudantis e movimentos populares.

Novamente se dá um confronto entre posições que defendiam o ensino público, gratuito e laico, organizado e fiscalizado pelo Estado, e os antigos defensores do ensino privado, numa aliança de setores católicos e proprietários de escolas mesmo laicas. Seus representantes no Congresso chegaram a redigir substitutivos que comprometiam o Estado com o financiamento e manutenção de escolas privadas, em detrimento da própria expansão do ensino oficial público e gratuito, o que motivou a eclosão de uma grande Campanha em Defesa da Escola Pública, que envolveu os setores já mencionados e conseguiu barrar os dispositivos mais comprometedores. Um processo de marchas e contramarchas, que não serão aqui apresentadas, prolonga o processo de formulação da lei a uma duração de treze

\footnotetext{
1 Embora a tabela cruze dados de tabelas produzidas a partir de dados estátisticos de origens diversas e a idade para ingresso no curso primário ser a de 6-7 anos, a imprecisão resultante não compromete a percepção estimada pretendida, dada a ordem de grandeza dos números envolvidos.
} 
anos, até sua aprovação final em 20 de dezembro de 1961, já no governo João Goulart.

Assim, se o período de design tratado neste capítulo não traz transformações na estrutura do ensino e mesmo no currículo dos cursos, com incidência na organização do conteúdo e na visualidade dos livros escolares, ele está contido num período único da história do país em que o exercício da democracia e a compreensão do alcance social da educação fez com que sua discussão extrapolasse o campo dos especialistas e comprometesse setores mais amplos da sociedade.

\subsection{O design e a materialidade dos livros didáticos da Companhia Editora Nacional de 1953 a 1960}

O corpus da pesquisa material para este período, obtido na totalidade no acervo da Biblioteca do Livro Didático da FEUSP, é constituído de 115 títulos ou edições de obras didáticas, assim distribuídos:

- Livros para o Ensino Primário e de Admissão ao Ginásio: 7 títulos ou edições;

- Livros para o Ginásio: 72 títulos ou edições;

- Livros para o Colégio (ou Médio): 36 títulos ou edições.

Como característica material mais evidente está a manutenção do acabamento encadernado para a grande maioria dos títulos para o Ginásio e o Colégio, com maior incidência de brochuras para este segmento e para as cartilhas primárias. O formato predominante é 13,0 x 19,0 cm, havendo um retorno para ele de parte dos livros destinados ao Colegial, que no período anterior adotaram o formato $14,0 \times 21,0$ cm. Exceção são os livros de línguas para o Ginásio, que apresentam formato maior, $15,0 \times 21,0 \mathrm{~cm}$.

Como nos capítulos anteriores, serão apresentados separadamente design de capas e de miolos, pois sua produção corre independente e não se encontra relação formal entre os dois componentes, mesmo no caso de algumas obras de Inglês para o Ginásio, que pode eventualmente ter o mesmo ilustrador para capa e miolo, embora a ausência ou incompletude de créditos não confirme o fato.

\subsubsection{O design de capas de livros didáticos no período 1953-1960}

Embora a marca do período seja a generalização de capas ilustradas, as soluções tipográficas criadas no período anterior têm ainda forte presença no decorrer da década de 1950, não só nas reedições mas mesmo em títulos novos, o que justifica iniciar por sua apresentação. 
O design de capas tipográficas remanescente do período 1943-1952

Os títulos destinados ao Colegial seguem o modelo tipográfico do título vazado em área retangular colorida criado no período anterior, mas com o retorno para o formato 13,0 × 19,0 cm e um trabalho maior de particularização dos volumes pela combinação de desenho de letras e maior variação tipográfica (FIG. 6.4).

Um segundo modelo tipográfico também adotado no período 1943-1952 para os livros destinados ao Ginásio, em formato 13,0 × 19,0 cm permanece sendo aplicado, e com ao menos um exemplo em que incorpora uma pequena ilustração a traço (FIG. 6.5). Os dois modelos, para Ginásio e Colégio, aparecem com maior frequência no início da década e deixam de ser adotados, vindo a aparecer apenas em algumas reimpressões na década de 1960.
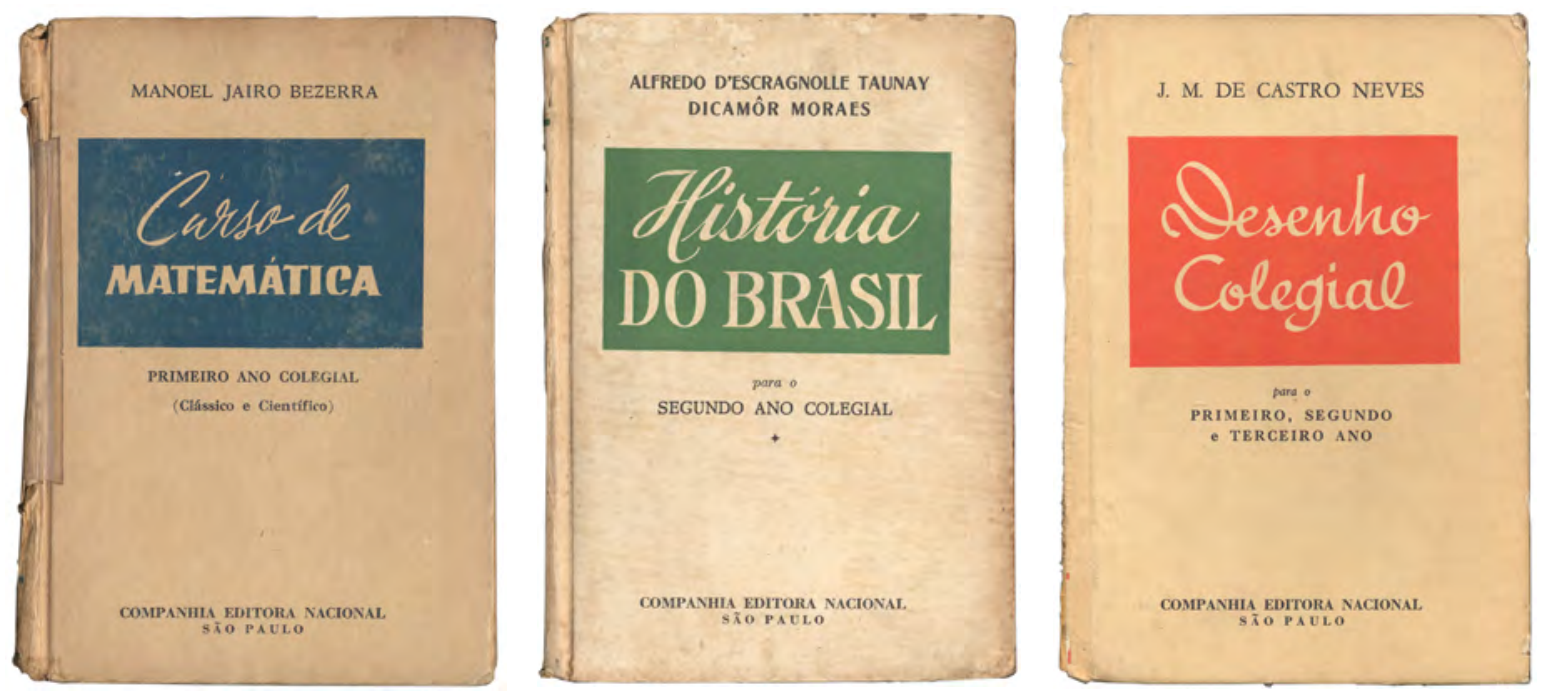

Fig. 6.4. Capas tipográficas conforme o modelo criado para os livros de Colegial em 1943: Curso de Matemática, 1953; História do Brasil, 1955; Desenho Colegial, 1956 (13,0 x 19,0cm).
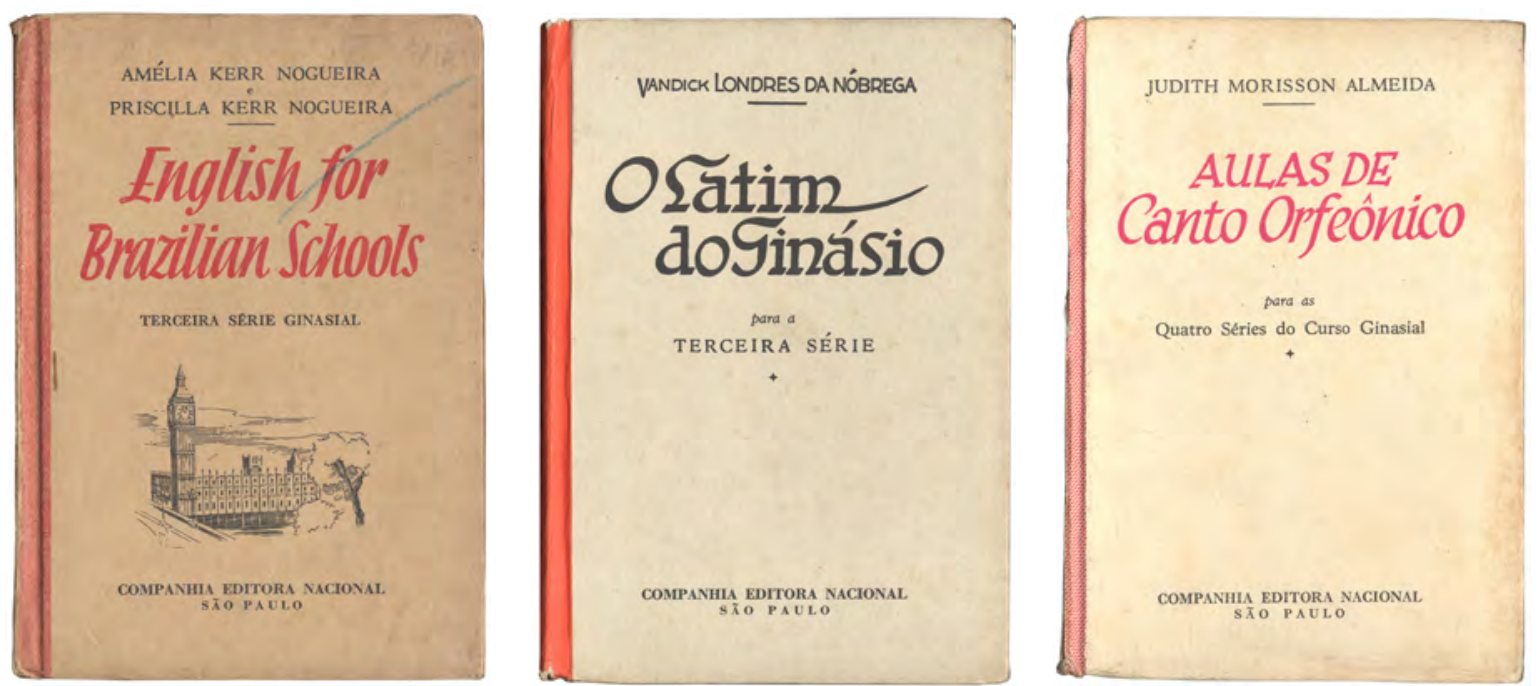

Fig. 65. Capas tipográficas conforme modelo criado para os livros do Ginásio do período 1943-1952: English for brasilian schools, 1954; O Latim no Ginásio, 1958; Aulas de canto orfeônico, 1958 (13,0 x 19,0cm). 


\section{Um novo modelo de capa tipográfica}

Um novo modelo para obras em formato $13,0 \times 19,0 \mathrm{~cm}$ aparece no início do período, aparentemente com a mesma finalidade dos modelos anteriores, a de propiciar uma solução pronta para uso conforme necessidades do cronograma. O procedimento também é o mesmo das capas tipográficas desde a Biblioteca Pedagógica Brasileira Série II, a particularização dos títulos e volumes pelo desenho das letras e cor, mas agora com um chassi de fundo colorido que inclui um linha curva e linhas horizontais vazadas, numa impressão total de duas cores mais o preto das demais informações (FIG. 6.6). Malgrado o fundo total colorido, é uma solução de aparência mais conservadora que os outros dois modelos remanescentes do período anterior apresentado acima.
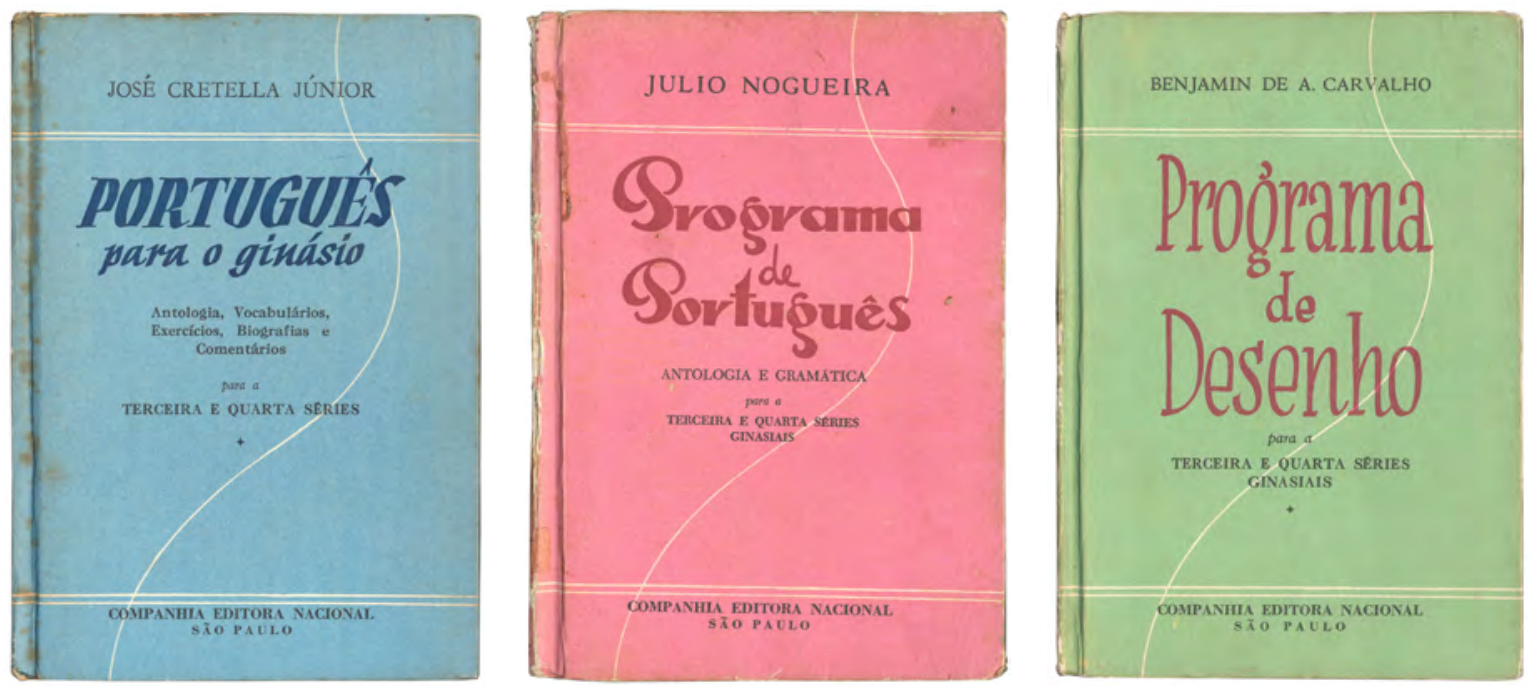

Fig. 6.6. Novo modelo de capa tipográfica: Português para o Ginásio, 1954; Programa de Português, 1955; Programa de desenho, $1958(13,0 \times 19,0 \mathrm{~cm})$.

\section{Primeiras capas ilustradas do período}

Como a maior parte das capas ilustradas do período anterior, um primeiro grupo de capas ilustradas encontradas a partir de 1953 tem como característica técnica principal a impressão de cores chapadas, sem uso de retícula para obtenção de tons e cores misturadas. Há, em primeiro lugar, a simples manutenção de soluções de design criadas no período anterior, de que é um exemplo a Cartilha Sodré (FIG. 5.16), que continuaram tendo edições com a mesma capa impressa em cores chapadas ao longo da década de 1950 e mesmo nas que se seguiram. Mas há também soluções novas e em linguagens bastante diversificadas e atualizadas.

Um primeiro exemplo, mas que utiliza retículação para a tonalidade de pele das personagens, é a obra Francês (FIG. 6.7). Relevando a pouca graça do desenho das crianças, há clareza construtiva e informativa, em composição baseada na simetria do eixo central e constituição de planos e contraste por jogo de inversão de cores. 


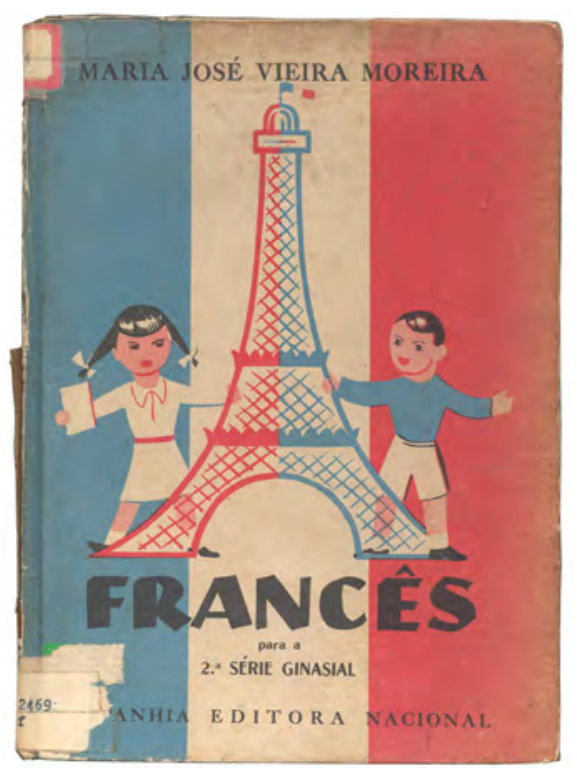

Fig. 6.7. Maria José Vieira Moreira, Francês: para a segunda série ginasial, $1954(15,5$ × 21 cm).

Os volumes da obra História Geral (FIG. 6.8) apresentam uma composição não simétrica, formada por áreas de cor verticais atravessadas por faixa branca horizontal em que se destaca ilustração de J. U. Campos reaproveitada de obra de Lobato de 1933 (FIG. 4.4). Relacionado cromaticamente à faixa estreita esquerda, o grande título traz sua cor para o centro e a inicial isolada na forma heráldica ecoa a faixa ilustrada inferior. É uma solução organizada, clara e bastante diferenciada das capas ilustradas da editora até então, incluindo as não didáticas, mas que também prescinde do uso de retícula.
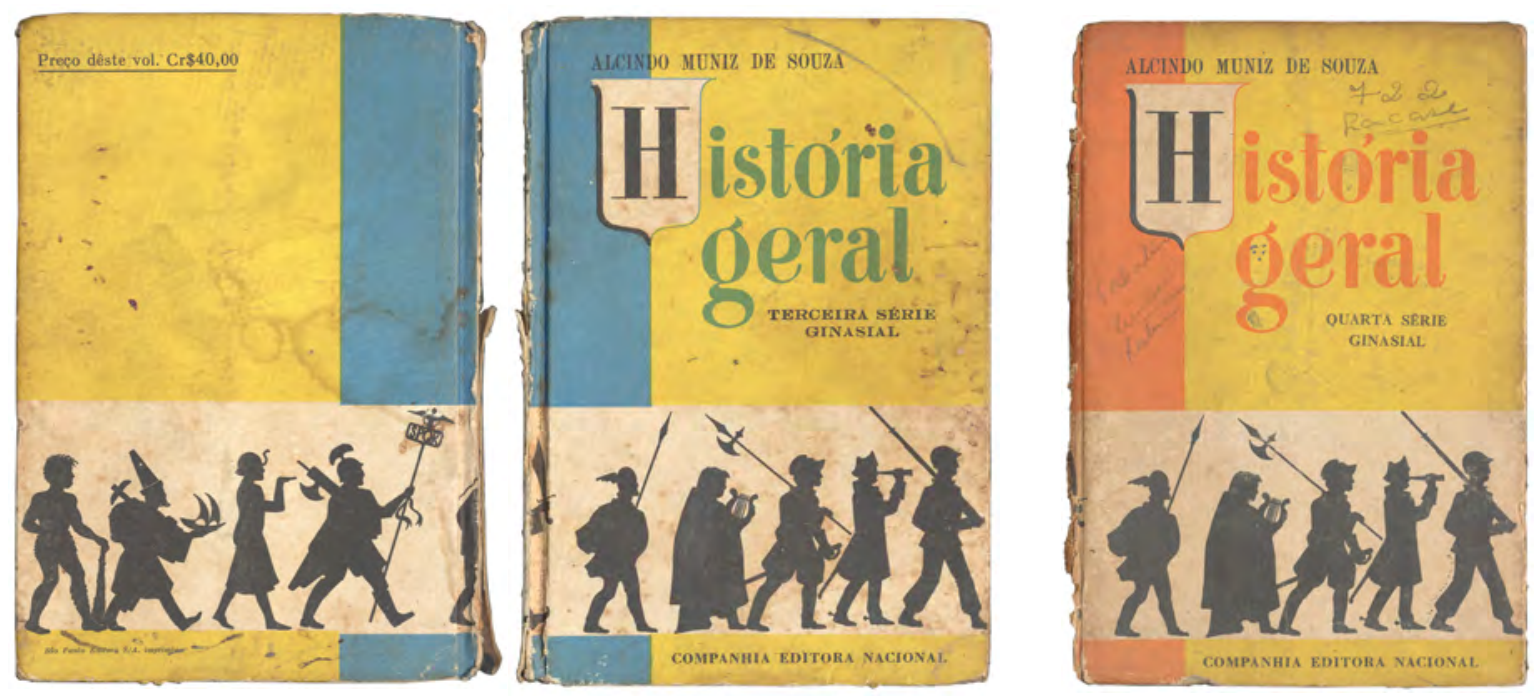

Fig. 6.8. Alcindo Muniz de Souza, História geral: terceira série ginasial, 1956 e História geral: quarta série ginasial, $1953(13,0$ x 19, cm). Impressão em preto mais duas cores.

Também diferenciada é a capa do livro de religião História Sagrada (FIG. 6.9), que apresenta uma composição simétrica de eixo central mas movimentada pelo desenho irregular e informal do título e da ilustração. Ambos se relacionam formalmente pela irregularidade e abertura 
dos contornos e se destacam pela alternância com as áreas pretas das informações textuais, numa organização elaborada e clara, embora em linguagem não especialmente dirigida para o aluno de curso primário.

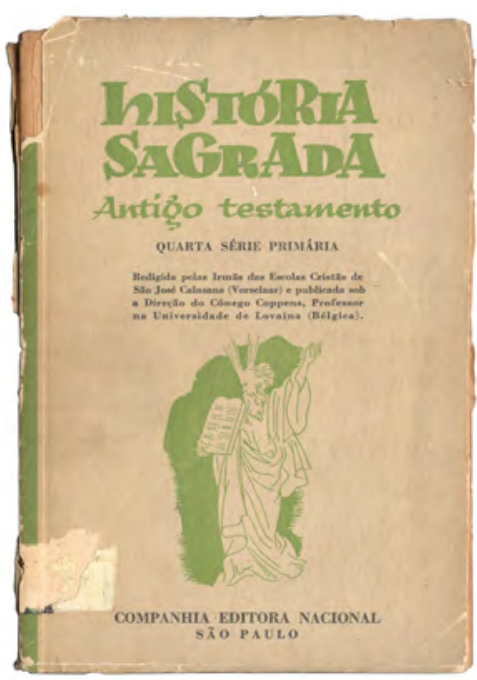

Fig. 6.9. História Sagrada, $1955(13,0$ × 19,0cm).

Também com resultado direto, movimentado e atraente são as capas da coleção de francês de Louise Jacquier (FIG.6.10), assinadas por Walter Lewy, em solução gráfica mais abstrata, com possível referência ao mapa e à heráldica francesa, bem diferente de suas capas ilustradas para a Biblioteca do Espírito Moderno (ver fIG. 5.1 e 6.2) e utilizando impressão chapada de apenas duas cores.
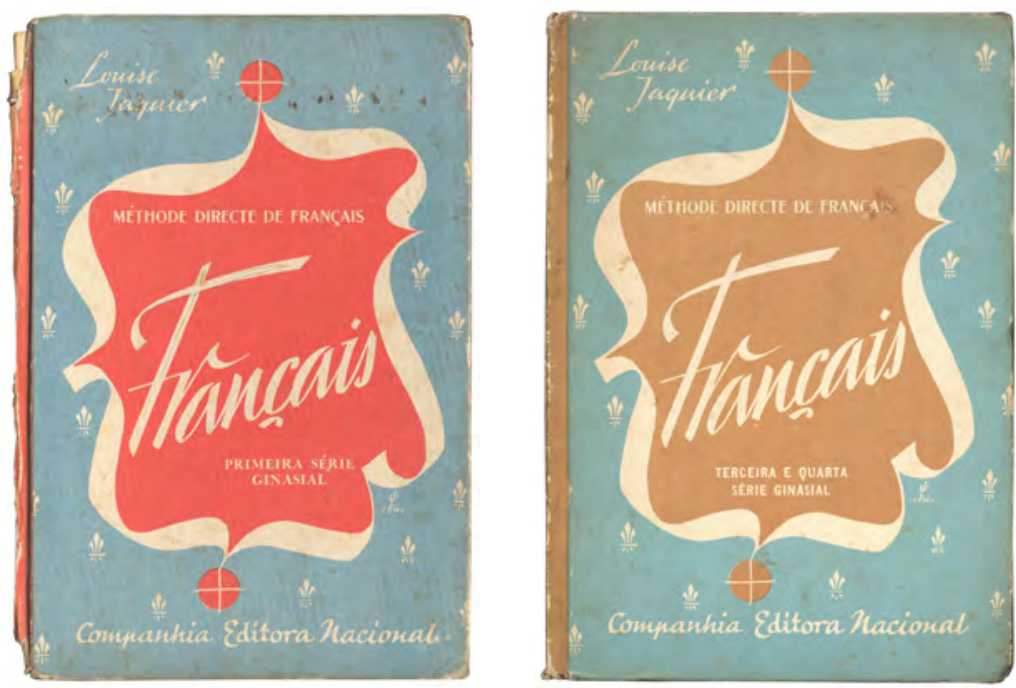

Fig. 6.10. Louise Jacquier, Français: primeira série ginasial, 1957 e Français: terceira e quarta série ginasial, 1959 (13,0 $\mathrm{x} 19,0 \mathrm{~cm})$

Os volumes da coleção de francês de Paulo Rónai e Pierre Hawelka (FIG. 6.11) apresentam composição baseada em dois planos, com ilustração em traço vazado sobre fundo de cor clara, sobreposto pelas informações textuais. A simetria básica originária da composição é altera- 
da pela distribuição escalonada das três linhas do título, pela perspectiva da ilustração, pelo deslocamento da informação de série e pela presença da faixa da lombada, que se relaciona cromaticamente com o título. A hierarquia das informações, obtida por contraste tipográfico (tipo, caixa, cor) e posição, é clara, em solução de impressão ofsete sem uso de retícula.

As obras Geografia geral e Geografia do Brasil de Aroldo de Azevedo, oriundas da BPB Série I/ destinadas ao Ginásio não apresentam estrutura gráfica fixa, com grande variação no desenho dos títulos, autoria e ilustração, mas guardam certa identidade pelos recursos e linguagem utilizados (FIG.6.12). Letras desenhadas, área de fundo e faixa da lombada em cores chapadas, posição da ilustração e das informações de série e assinatura da editora contribuem para essa identidade. No caso de Geografia Geral, a particularização dos volumes é obtida pela variação de uma das cores, permanecendo a cor de fundo e os textos em preto idênticos para os dois.
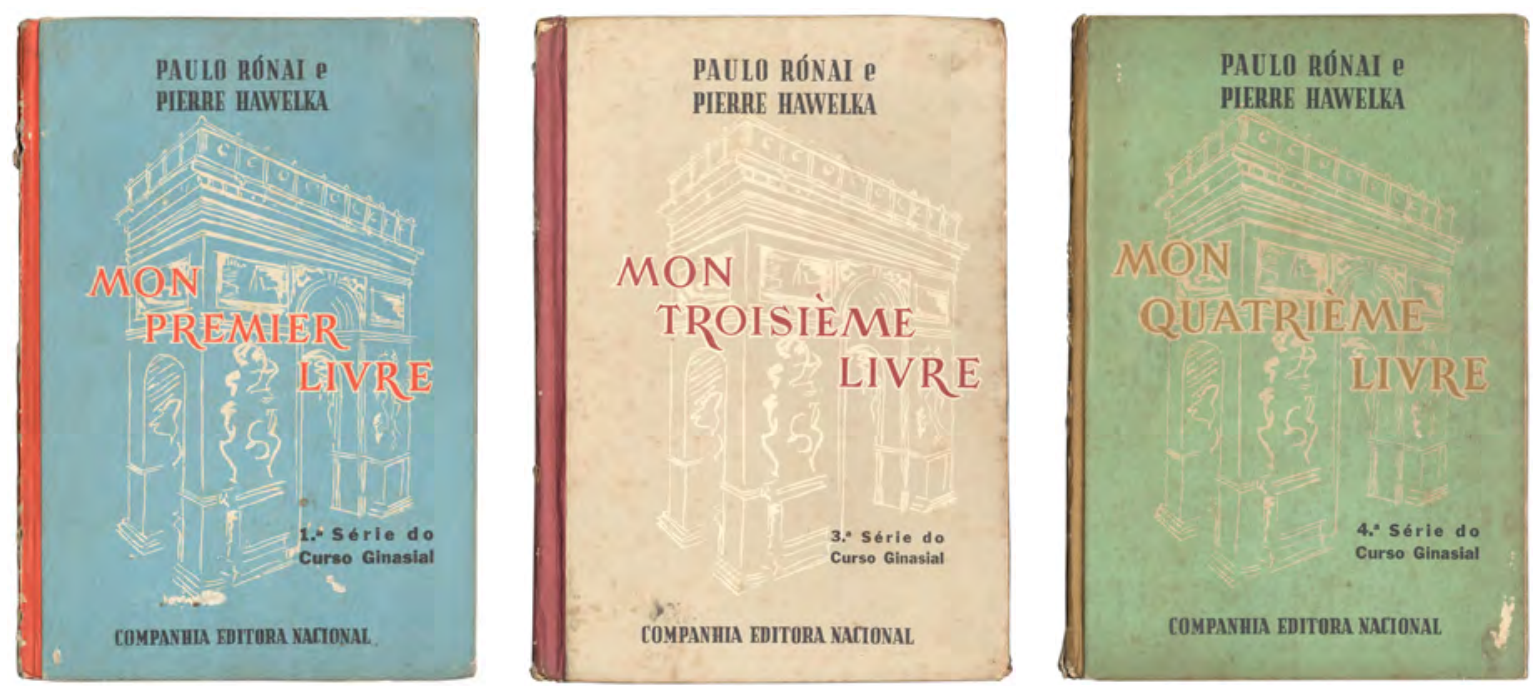

Fig. 6.11. Paulo Rónai e Pierre Hawelka, Mon premier livre, 1958; Mon troiseéme livre, 1959 e Mon Quatriéme livre, 195 ? $(13,0 \times 19,0 \mathrm{~cm})$.
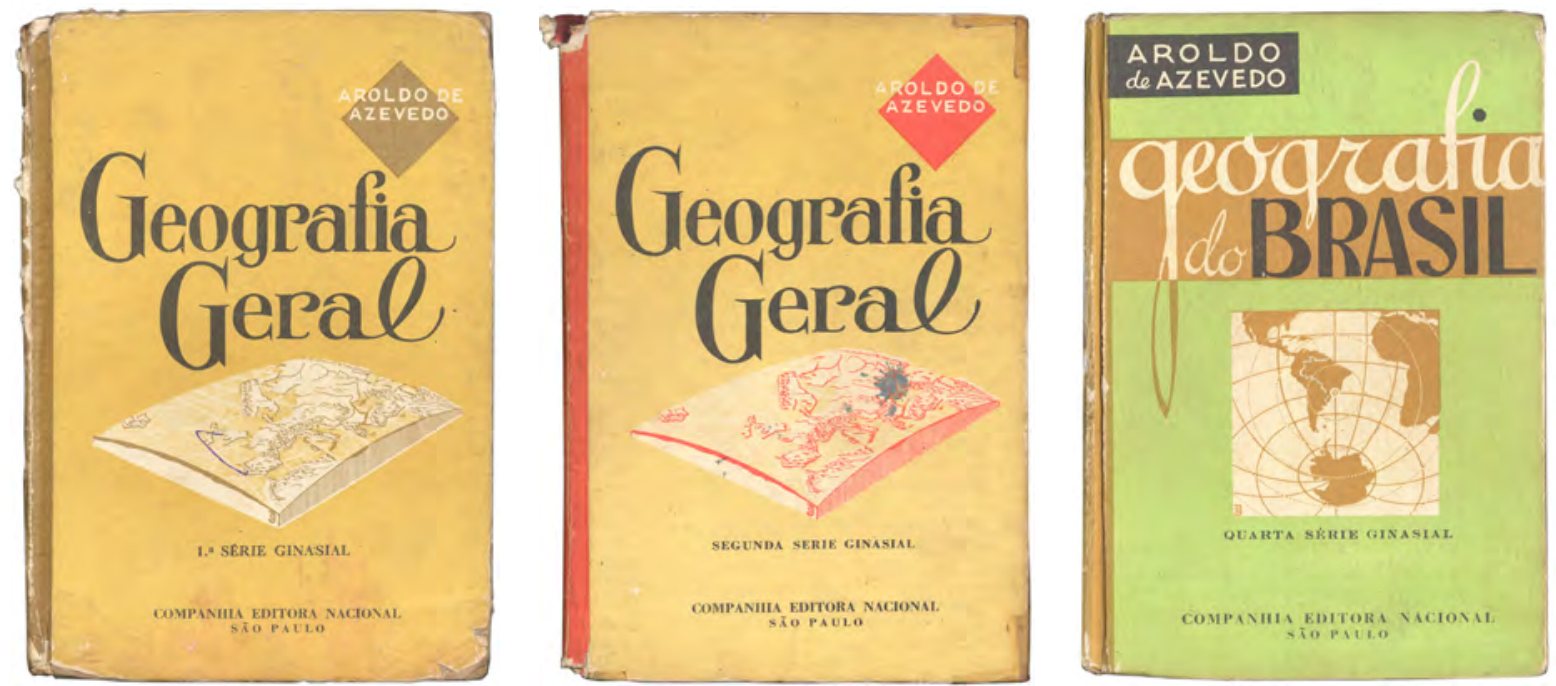

Fig. 6.12. Aroldo de Azevedo, Geografia geral: 1a série ginasial, 1955, Geografia geral: 2ª série ginasial, 1954 e Geografia do Brasil: quarta série ginasial, 1956 (13,0 × 19,0 cm). 
As soluções mais sofisticadas utilizando a impressão de cores chapadas, sem uso de retícula para a obtenção de tons e misturas cromáticas, são encontradas nas capas criadas por Walter Lewy referenciadas em sua extensa produção para a Biblioteca do Espírito Moderno. Nos dois primeiros exemplos da FIGURA 6.13, as informações textuais e imagens referenciais são organizadas em estrutura gráfica plana, com a capa do Programa de Admissão apresentando também um grafismo linear abstrato. As demais, apresentam a preocupação com volumetria, integrando imagens referenciais, informações textuais e elementos de suporte em composição gráfica únitária.
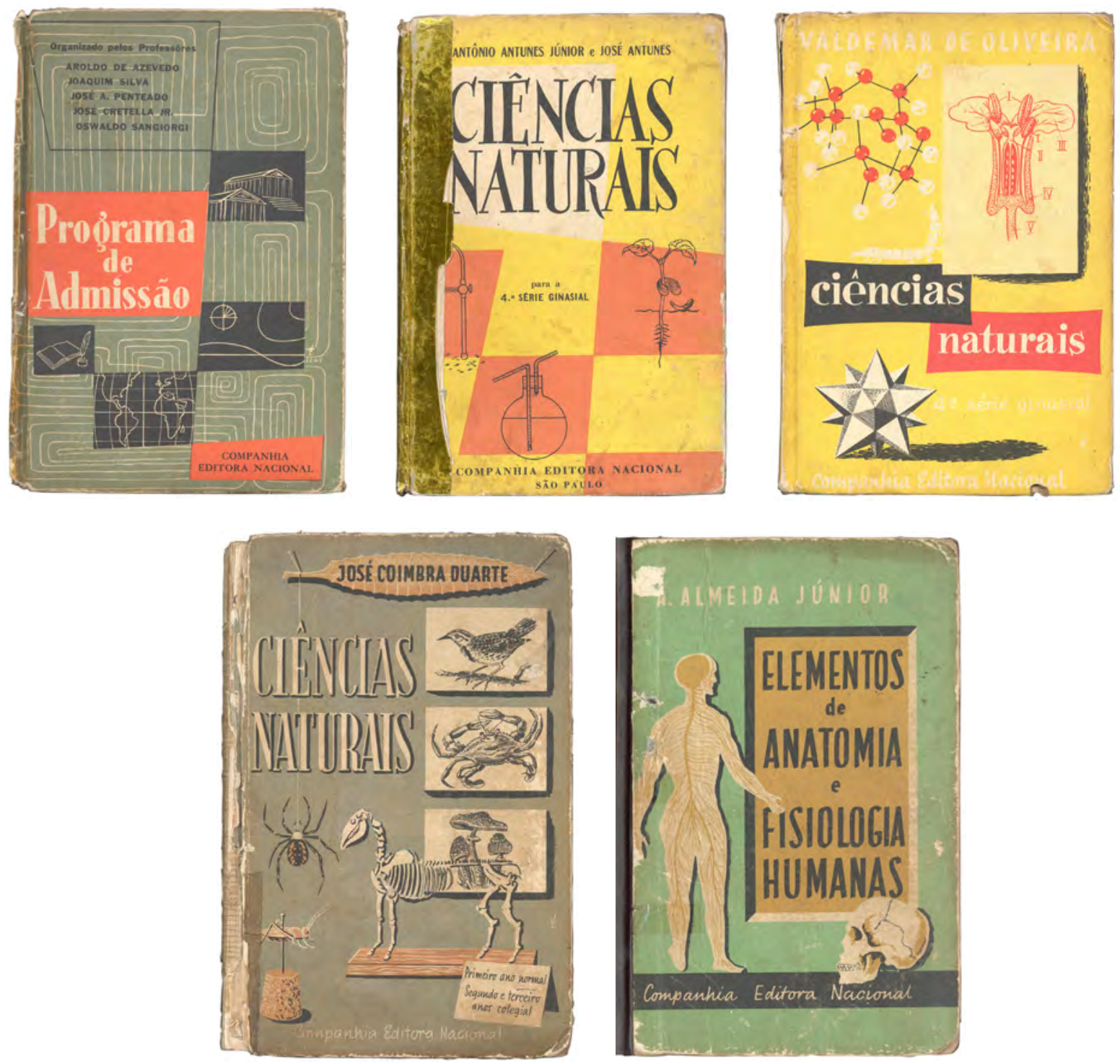

Fig. 6.13. Capas de Walter Lewy: Diversos autores, Programa de Admissão, 1956; António Antunes Júnior e José Antunes, Ciência naturais, 1958; Valdemar de Oliveira, Ciências Naturais, 1958; José Coimbra Duarte, (13,0 × 19,0 cm); Ciências Naturais, 1958; Almeida Júnior, Elementos de anatomia e fisilogia humanas, 1960 $(13,5 \times 20,5 \mathrm{~cm})$.

Duas soluções de desenho diversas utilizando a definição de áreas de impressão chapada podem ser vistas na figura 6.14. Curso de desenho, em capa provavelmente dos autores da obra, traz fundo e figuras geométricas em cores primárias e branco em distribuição assimétrica, 
compondo o plano sobre o qual são aplicadas as informações textuais e a figura central. Título e desenho em preto, como sketch, dominam o primeiro plano, com o conjunto aludindo ao conteúdo da disciplina por um viés que se entendia como moderno e atual, a arte geométrica e o figurativismo não realista, pouco usuais em livros escolares. A brochura de alfabetização de adultos Viva o Brasil tem capa assinada por Augustus, trazendo composição simétrica com organização das informações por inversão de cores, separadas por faixa branca com ilustração em terceira cor e contraste tipográfico entre as informações. Na área maior, título e sua qualificação, com grande destaque por dimensão e contraste de desenho de letra, em solução simples e direta, com apelo nacionalista e traduzindo o caráter pretendido para a obra. Pelo número da edição, é provável que seu design tenha sido criado em período anterior.
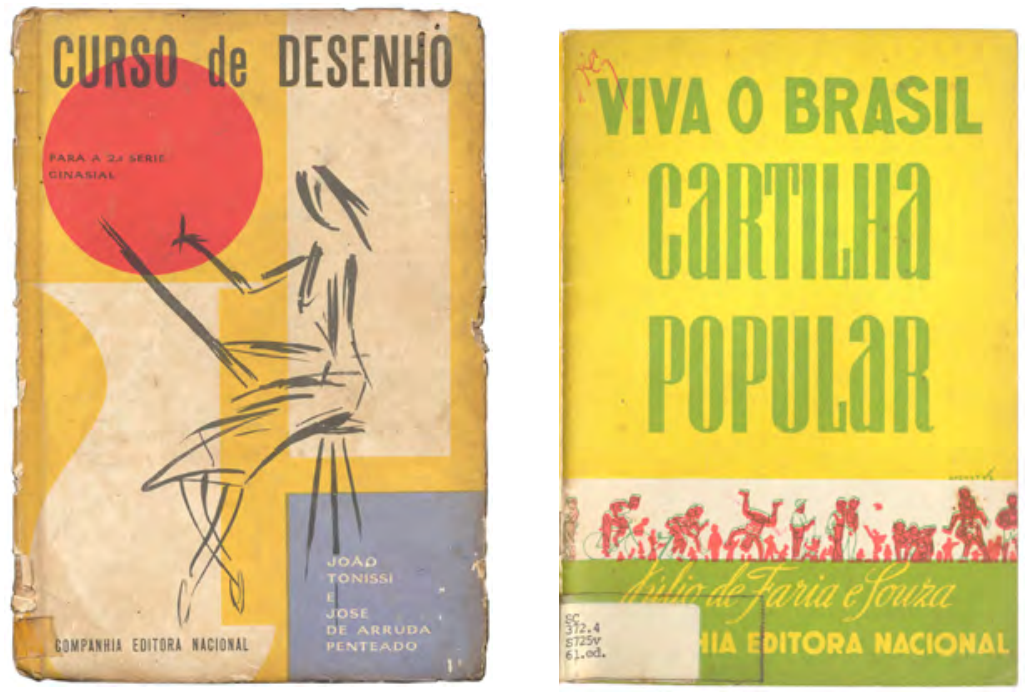

Fig. 6.14. João Tonissi e José de Arruda Penteado, Curso de desenho, 1955 (13,3 × 19,0cm); Júlio de Faria de Souza, Viva o Brasil: cartilha popular, 1956 (brochura, 13,3 × 19,0 cm).

As capas da fIGURA 6.15 lançam mão do uso de retícula mas o efeito é de definição de áreas chapadas de cor. Em História da América (com título rasurado), as áreas de cor reticuladas são mínimas (pele e botas), prevalecendo o impacto do contraste preto-vermelho-amarelo e o papel do contorno preto definindo o desenho. Em Elementos de canto orfeônico, a obtenção da cor laranja por retícula da cor vermelha sobre área chapada amarela tem papel mais determinante na composição, assimétrica e movimentada, alusiva ao espaço das catedrais góticas.

As capas das obras de geografia de Francisco da Gama Filho (FIG. 6.16) são impressas em três cores mas apresentam maior número de tonalidades pelo uso de retícula, mas no caso não constituída de pontos minúsculos, mas de linhas retas visíveis, como mostra o detalhe, o que também confere um efeito de textura gráfica à ilustração. Aqui há uma identidade de coleção, com os volumes sendo particularizados pela variação cromática, em que se dispensa a impressão em preto sobreposta. 

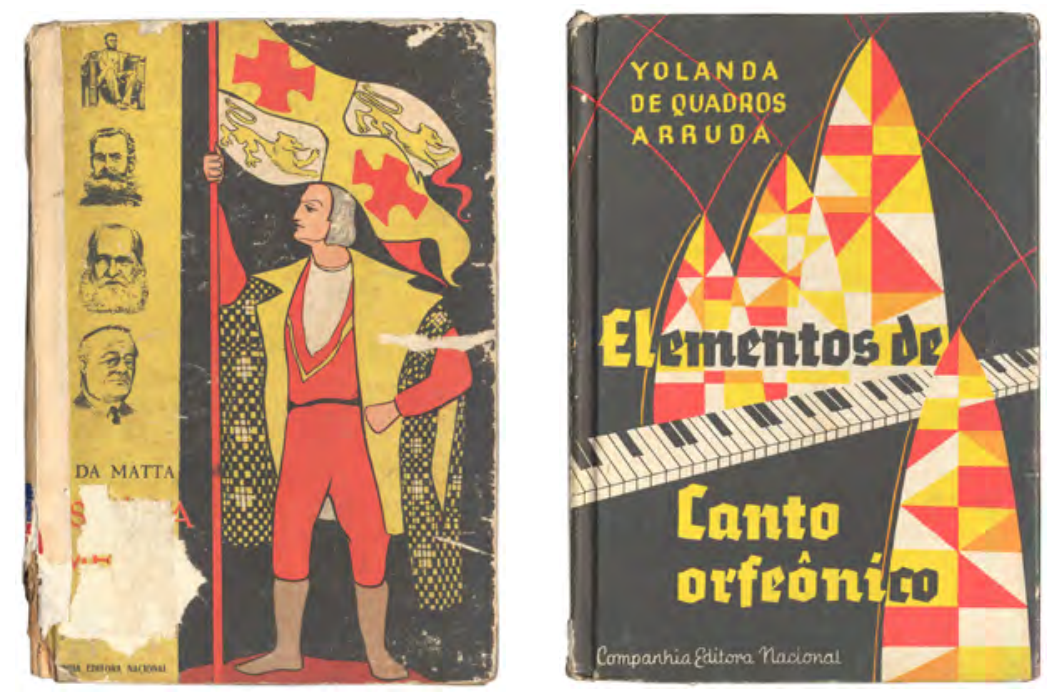

Fig. 6.15. Ary da Matta, História da América, 1955; Yolanda de Quadros Arrunda, Elementos de canto orfeônico, $1958(13,0 \times 19,0 \mathrm{~cm})$.
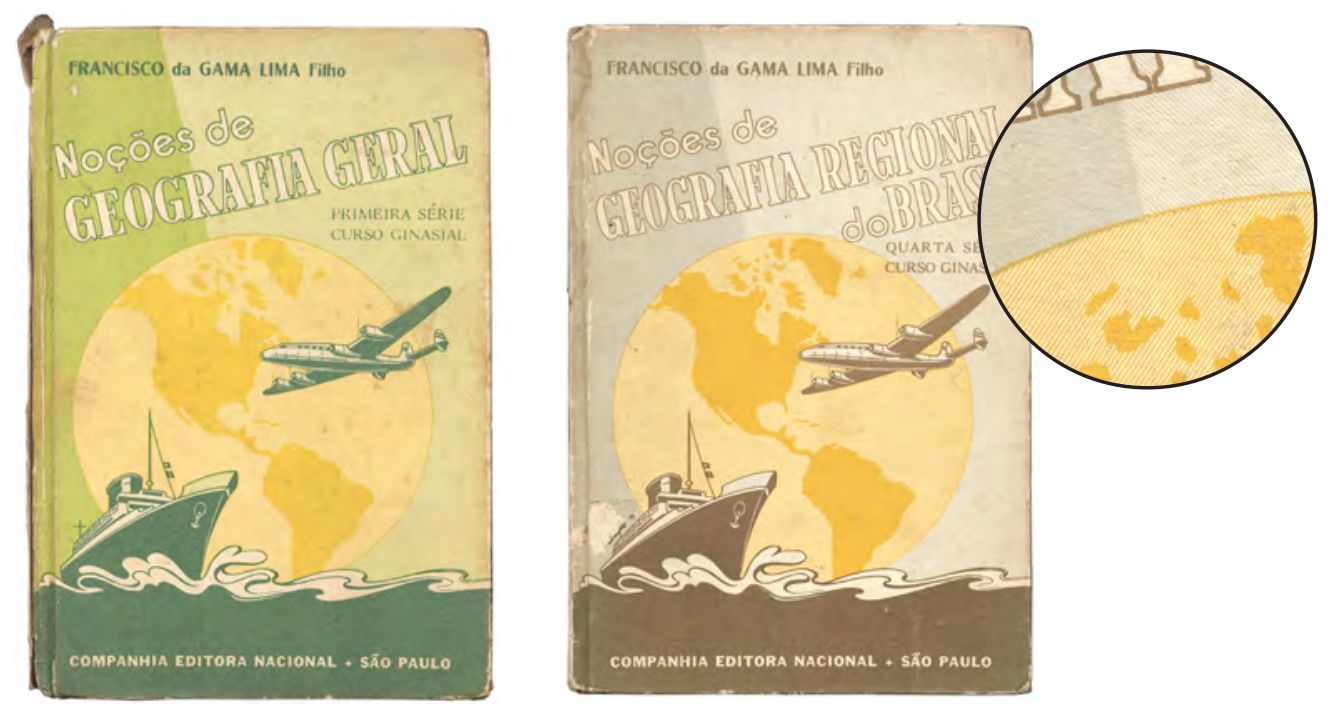

Fig. 6.16. Francisco da Gama Lima Filho, Noções de geografia geral, 1957 e Noções de geografia do Brasil, 1957 (13,0 $\times 19,0 \mathrm{~cm})$.

Um padrão de losangos, com vinhetas em desenho de traço fino relativas ao conteúdo de cada volume, decoram o plano de fundo de cada um dos volumes que recebem o brasão preto com as informações textuais específicas na coleção de história de Joaquim Silva, numa solução bastante delicada e elegante para livros que até então tinham capas tipográficas bastante sóbrias (FIG. 6.17). O contraste entre as duas áreas do padrão gráfico é amenizado com a tonalização do branco pelo emprego de fina retícula de pontos impressa na mesma cor das áreas chapadas, deixando o conjunto mais delicado (apenas a capa azul não utiliza o recurso).

As capas da coleção de língua portuguesa de Aníbal Bruno (FIG. 6.18) também apresentam um padrão geométrico, mas não com efeito decorativo "tradicional" e sim em uma composição claramente referenciada na pintura construtiva brasileira que aparecia nas primeiras 
bienais de arte de São Paulo. Mesmo a caixa de texto e o intervalo entre os grupos inferior e superior de losangos obedecem à modulação estabelecida por eles, denotando rigor construtivo próprio da arte e do design modernista construtivo que se produzia no país, num exemplo de apropriação quase imediata pelo segmento didático, até então mais distante de referências externas consideradas eruditas ou de vanguarda. Embora desenhadas com bastante conhecimento de causa, essas capas não aparecem assinadas nem creditadas. A influência do design modernista é encontrada também nas capas dos principais autores de matemática da editora.

As do curso ginasial de Osvaldo Sangiorgi (FIG. 6.19), também não assinadas, não apresentam uma divisão modular da superfície, mas um tratamento gráfico e cromático e uma distribuição não simétrica de tipografia e figuras geométricas, próprias do design gráfico de matriz bauhasiana. A integração de desenho de primeira capa, quarta capa e lombada, com um desenho específico para esta e não a rotineira composição tipográfica das informações, também é um procedimento novo no design de didáticos da editora.
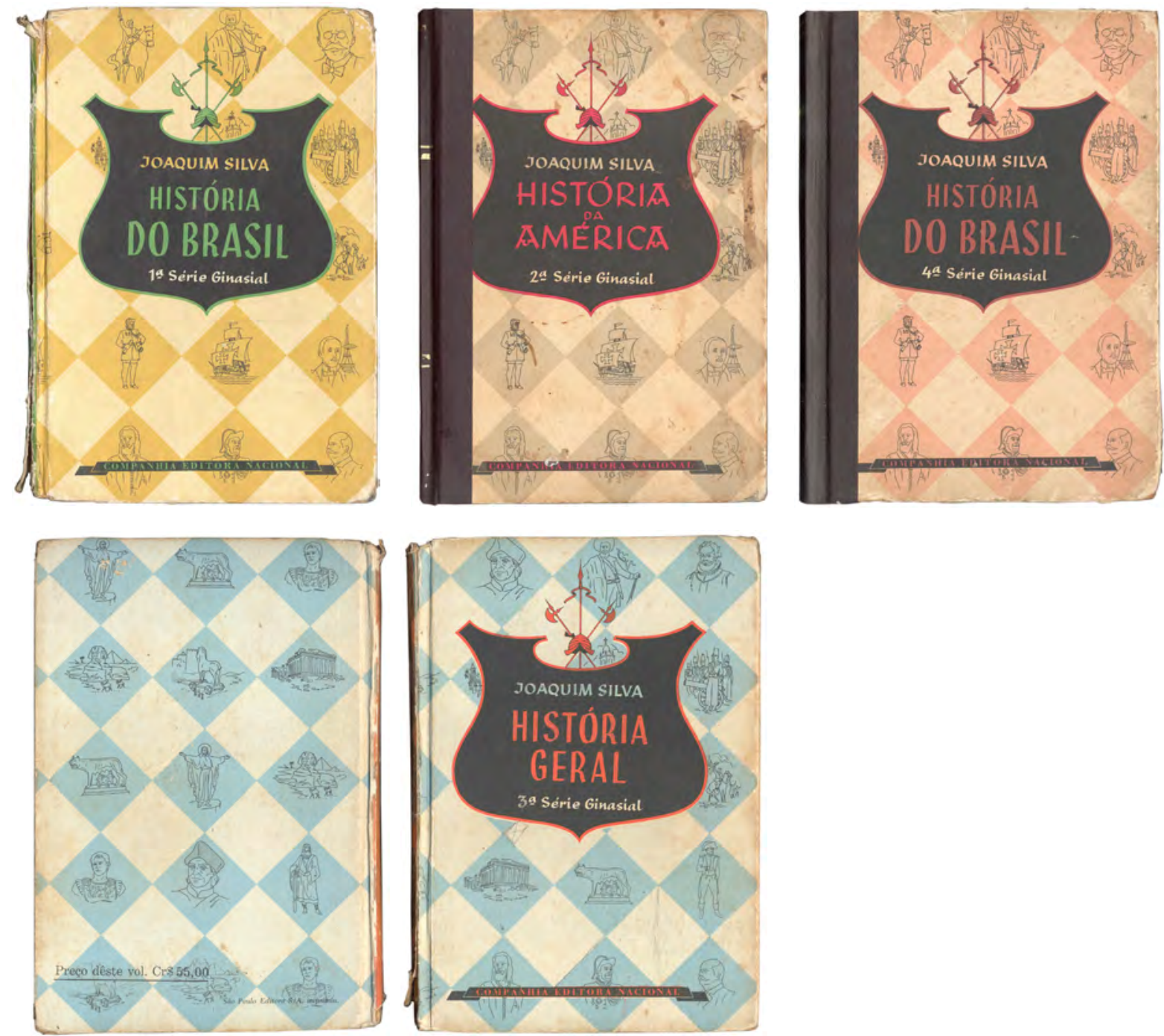

Fig. 6.17. Joaquim Silva. História do Brasil: 1aa série ginasial, 1953; História da América: 2ª série ginasial, 1958; História do Brasil: 4a série ginasial, 1954; História geral: 3a série ginasial, 1957 (13,0 × 19,0cm). 

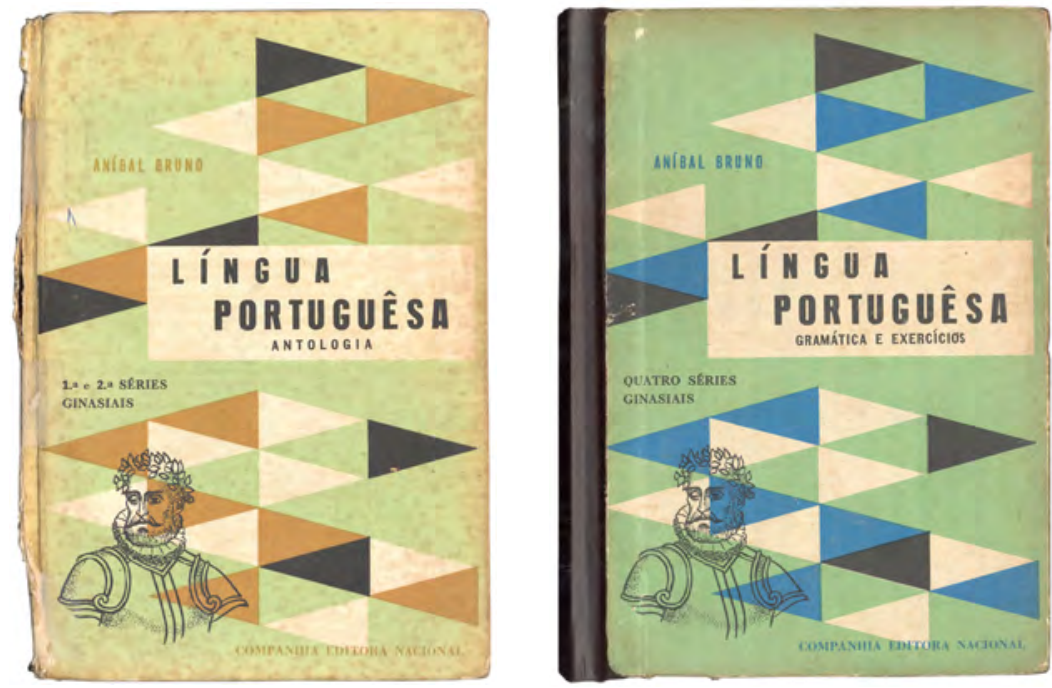

Fig. 6.18. Aníbal Bruno. Língua Portuguesa: antologia, 1955; Língua Portuguesa: gramática e exercícios, 195? (13,0 x $19,0 \mathrm{~cm})$.
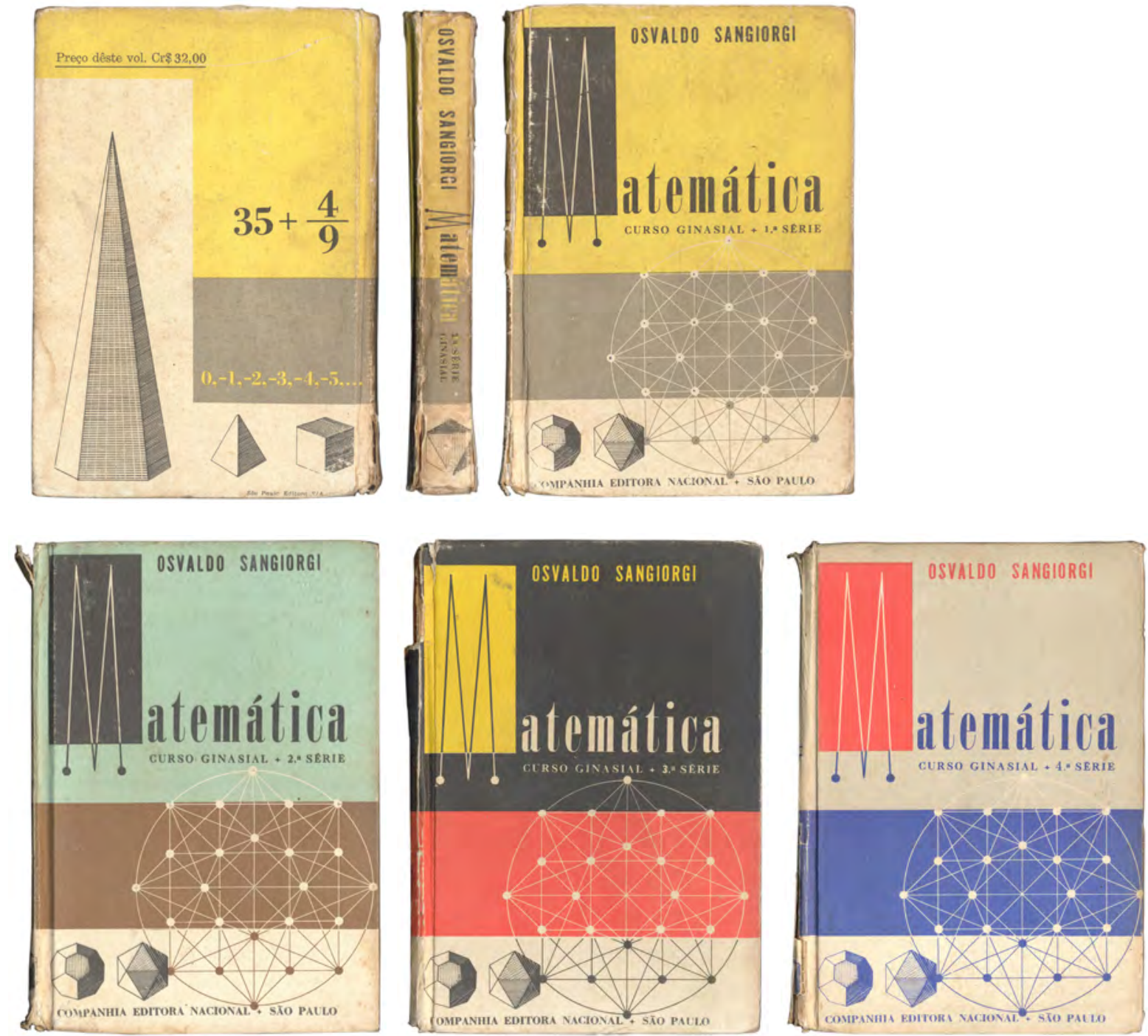

Fig. 6.19. Osvaldo Sangiorgi. Matemática: curso ginasial - 1a série, 1955; Matemática: curso ginasial - 2ª série, 1955; Matemática: curso ginasial - 3a série, 1955; Matemática: curso ginasial - 4aㅗ série, 1956 (13,0 × 19,0cm). 
Nas capas das coleções de Ary Quintella, a afinidade entre obras de um mesmo autor para os segmentos ginasial e colegial é dada pela ilustração geométrica central, embora o tratamento gráfico seja diferenciado. Na coleção para o Ginásio (FIG. 6.20) há maior rigor construtivo, com uso de tipografia única e sem serifa e alinhamento preciso dos blocos de texto, enquanto na de Colégio (FIG. 6.21) há maior variação tipográfica e título italizado mais informal. Creditadas como sendo do "arquiteto Hugo Ribeiro", essas capas indicam o recurso da editora a um segmento profissional identificado com a linguagem modernista e, na ausência de escolas de design, envolvido com essa prática.
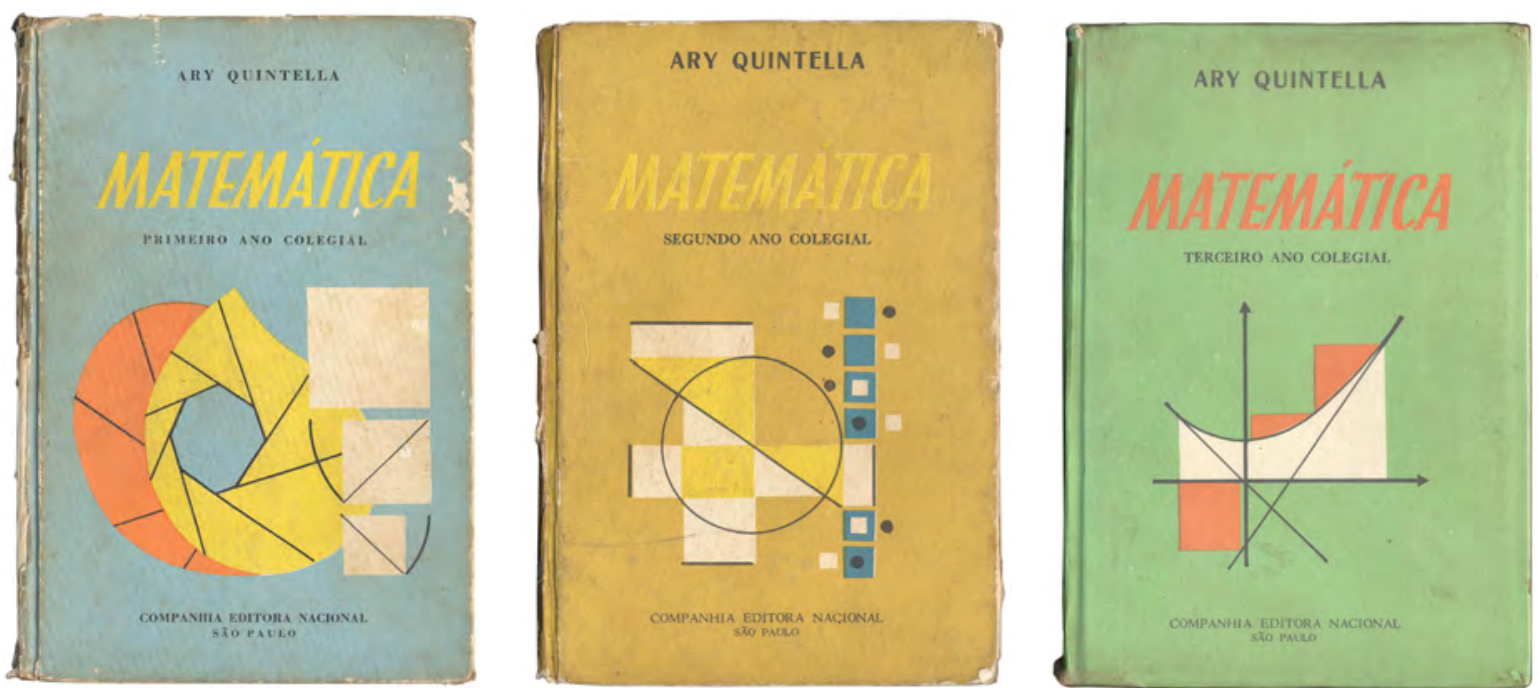

Fig. 6.20. Ary Quintella. Matemática: primeiro ano colegial, 1961; Matemática: segundo ano colegial, 1957; Matemática: primeiro ano colegial, $1959(13,0 \times 19,0 \mathrm{~cm})$.
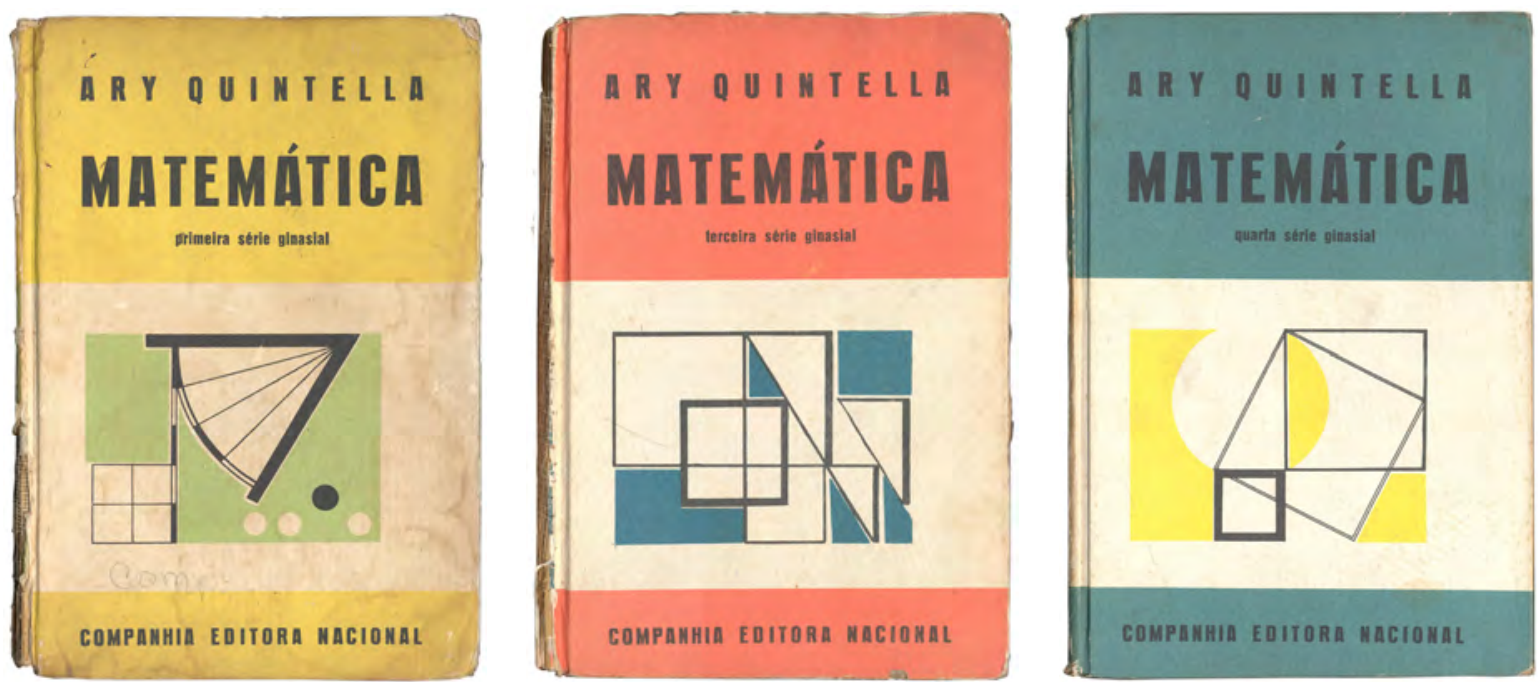

Fig. 6.21. Ary Quintella. Matemática: primeira série ginasial, 1959; Matemática: terceira série ginasial, 1958; Matemática: quarta série ginasial, $1960(13,0 \times 19,0 \mathrm{~cm})$. 


\section{Capas ilustradas com impressão em quadricromia}

Embora desde os anos 1930 as coleções de romances populares da editora trouxessem capas ilustradas impressas em quadricromia, até o final da década de 1950 elas são quase inexistentes no segmento didático, generalizando-se apenas a partir de 1958. Uma produção significativa e de grande impacto é aquela feita por Augustus (ver p. 200), trazendo a linguagem que empregava em sua experiência publicitária, mais presente no primeiro exemplo da FIGURA 6.22, mas também sabendo adaptá-la ao meio editorial didático, como nos outros dois exemplos da mesma figura.
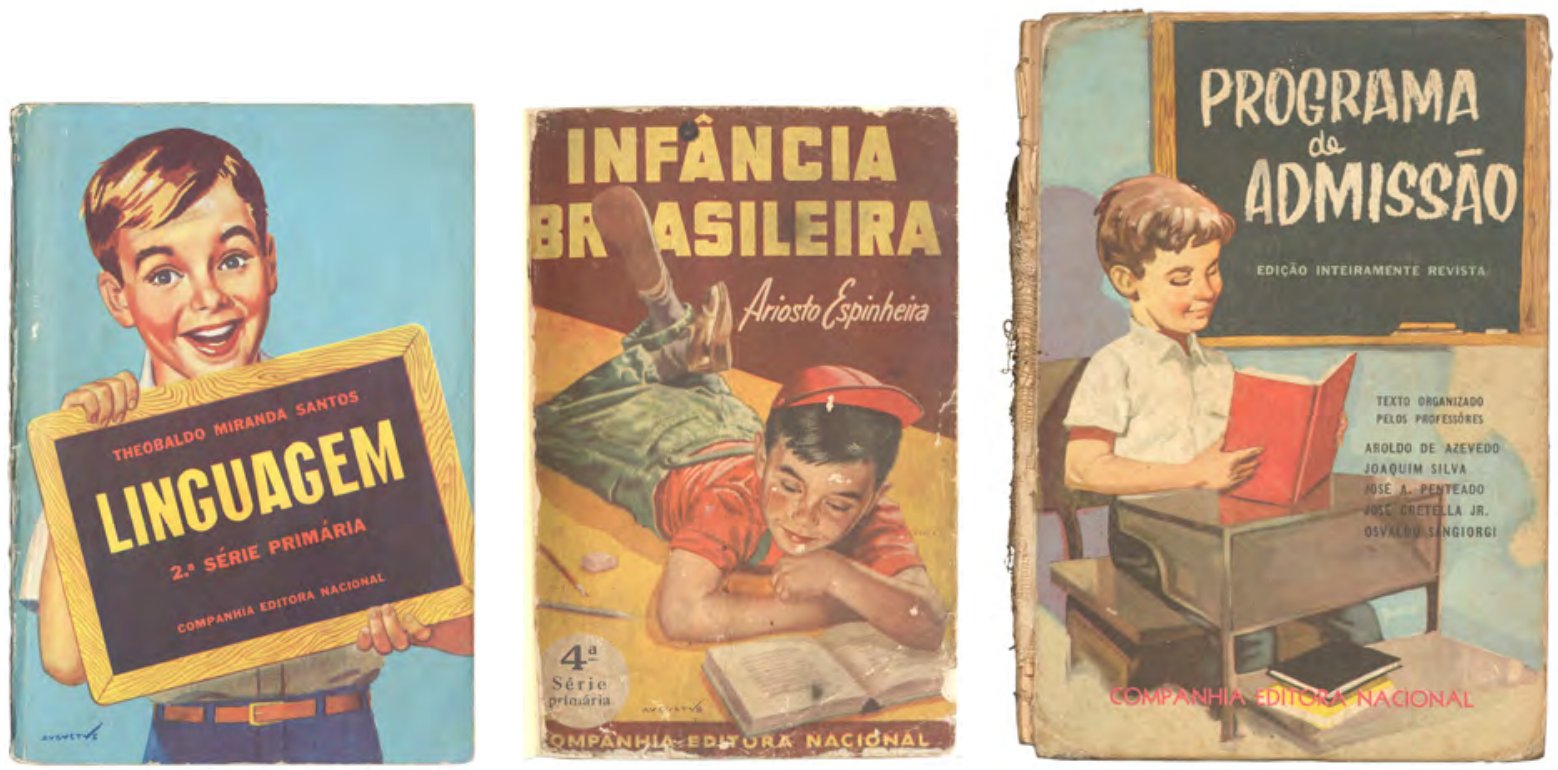

Fig. 6.22. Capas de Augustus: Theobaldo Miranda Santos, Linguagem: 2ª série primária, 1960 (brochura, 13,5 × 19,3 cm); Ariosto Espinheira, Infância brasileira: 4로 série primária, 1961 (brochura, 13,0 x 19,0cm); Diversos autores, Programa de admissão, $1958(15,5 \times 21,0 \mathrm{~cm})$.

A coleção ginasial de Joaquim Silva ganha em 1958 capas ilustradas em que um diagrama básico permite a identidade do conjunto, mas a ilustração, variação cromática e inversão de posição dos elementos de suporte particularizam e dão variedade e maior interesse para os volumes (FIG. 6.23).

A coleção de Ginásio de Borges Hermida (FIG. 6.24) apresenta um leiaute mais inusitado e linguagem de ilustração mais ousada e atraente. A inversão de posições das informações e ilustrações deixa o conjunto mais rico e interessante sem nenhuma perda de indentidade da coleção. A dominância da ilustração executada para ser reproduzida por tecnologia de seleção de cores atesta uma modernização de linguagem gráfica até em relação à produção não didática da editora. Dada a qualidade da ilustração, é curioso não estar assinada, prática que substituia a costumeira ausência de créditos ao trabalho de arte no meio editorial. 

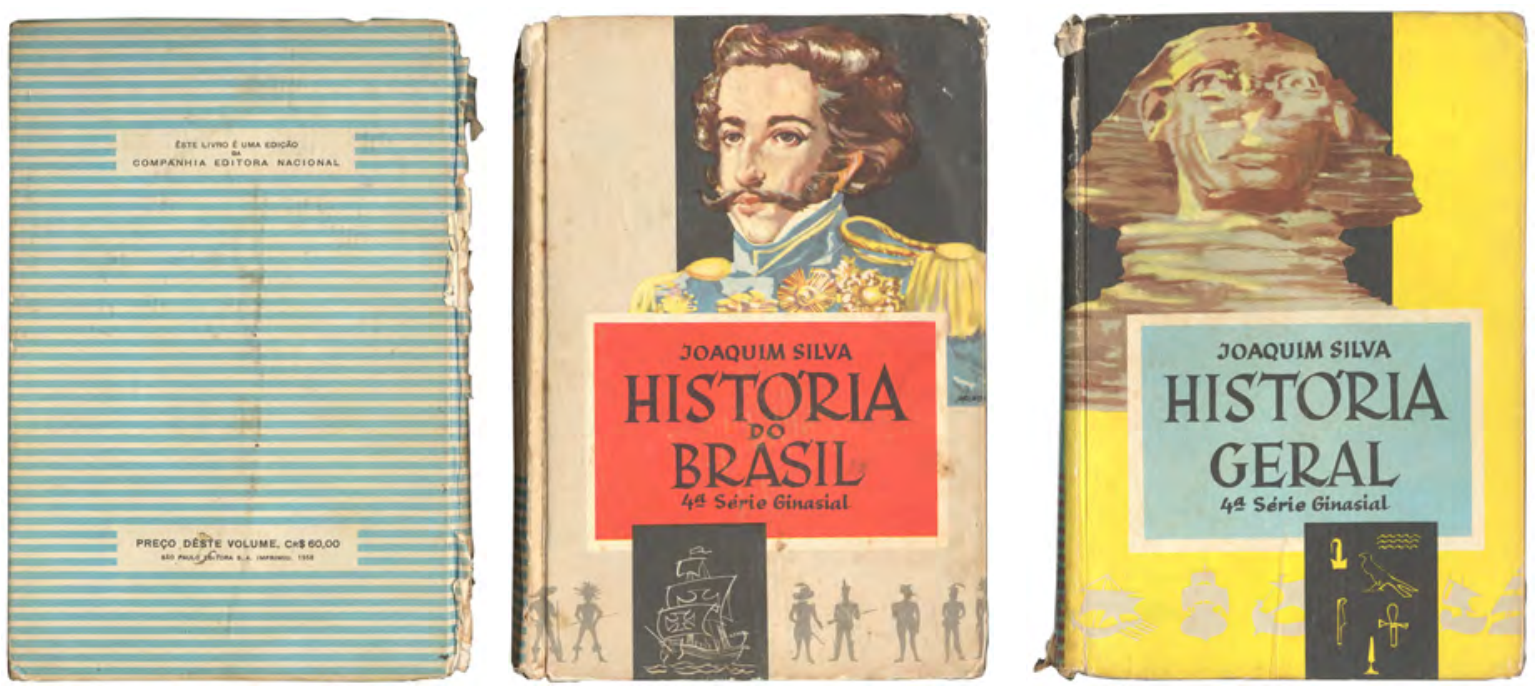

Fig. 6.23. Joaquim Silva. História do Brasil: 4ª̣ série ginasial, 1958; História Geral: 4ª série ginasial (13,0 x 19,0cm).
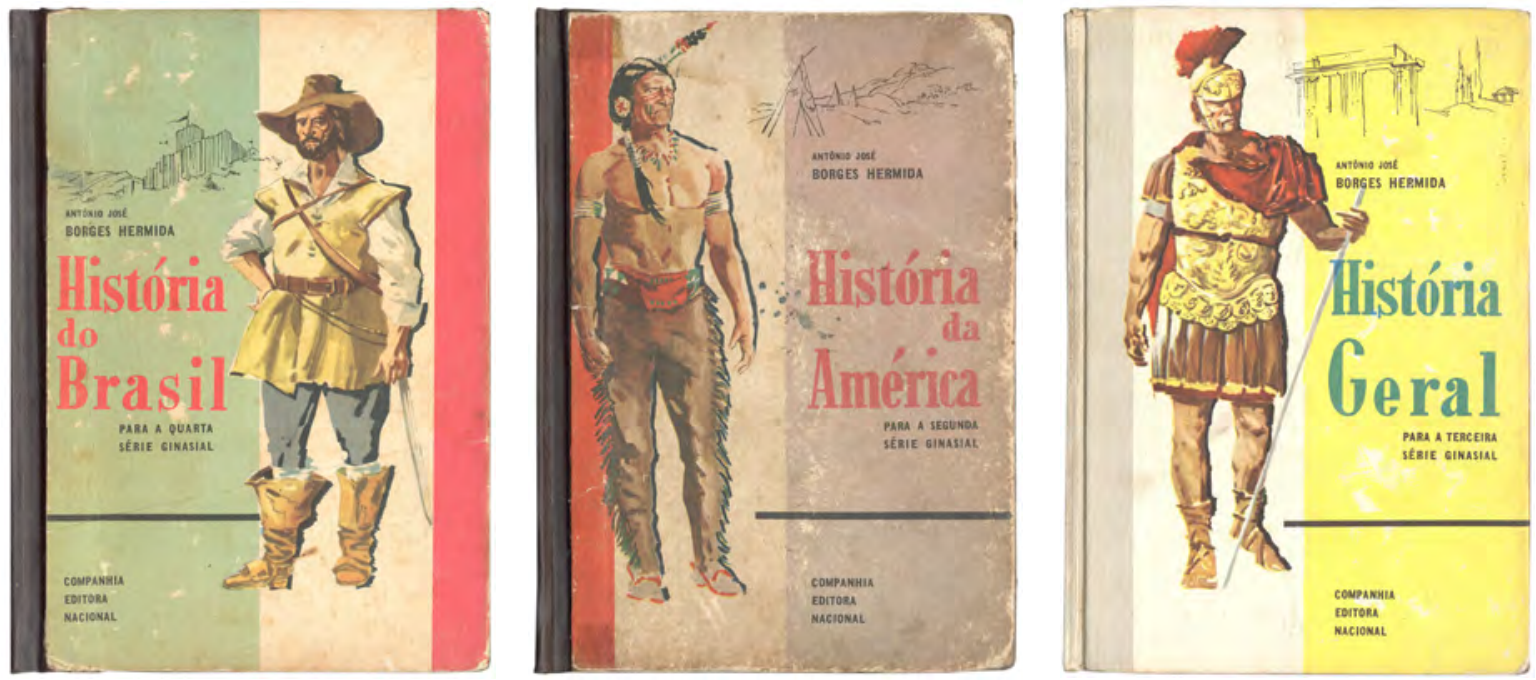

Fig. 6.24. Antonio José Borges Hermida. História do Brasil: para a quarta série ginasial, 1959; História da América: para a segunda série ginasial, 1959; História geral: para a terceira série ginasial, 1959 (13,0 × 19,0cm).

Ilustrações com traço mais informal e mesmo com viés humorístico, referenciado no design editorial de revistas estrangeiras, aparecem respectivamente nas duas edições de Spoken English (FIG. 6.25), provavelmente pela abertura da disciplina e seus docentes às linguagens de comunicação de massas próprias do uso da língua inglesa, numa aproximação ao repertório extra-escolar. As duas têm ilustração de capa de João Gargiulli, ilustrador de capas da coleção Paratodos, mas o miolo da primeira têm ilustração de José Maria C. Canto. 

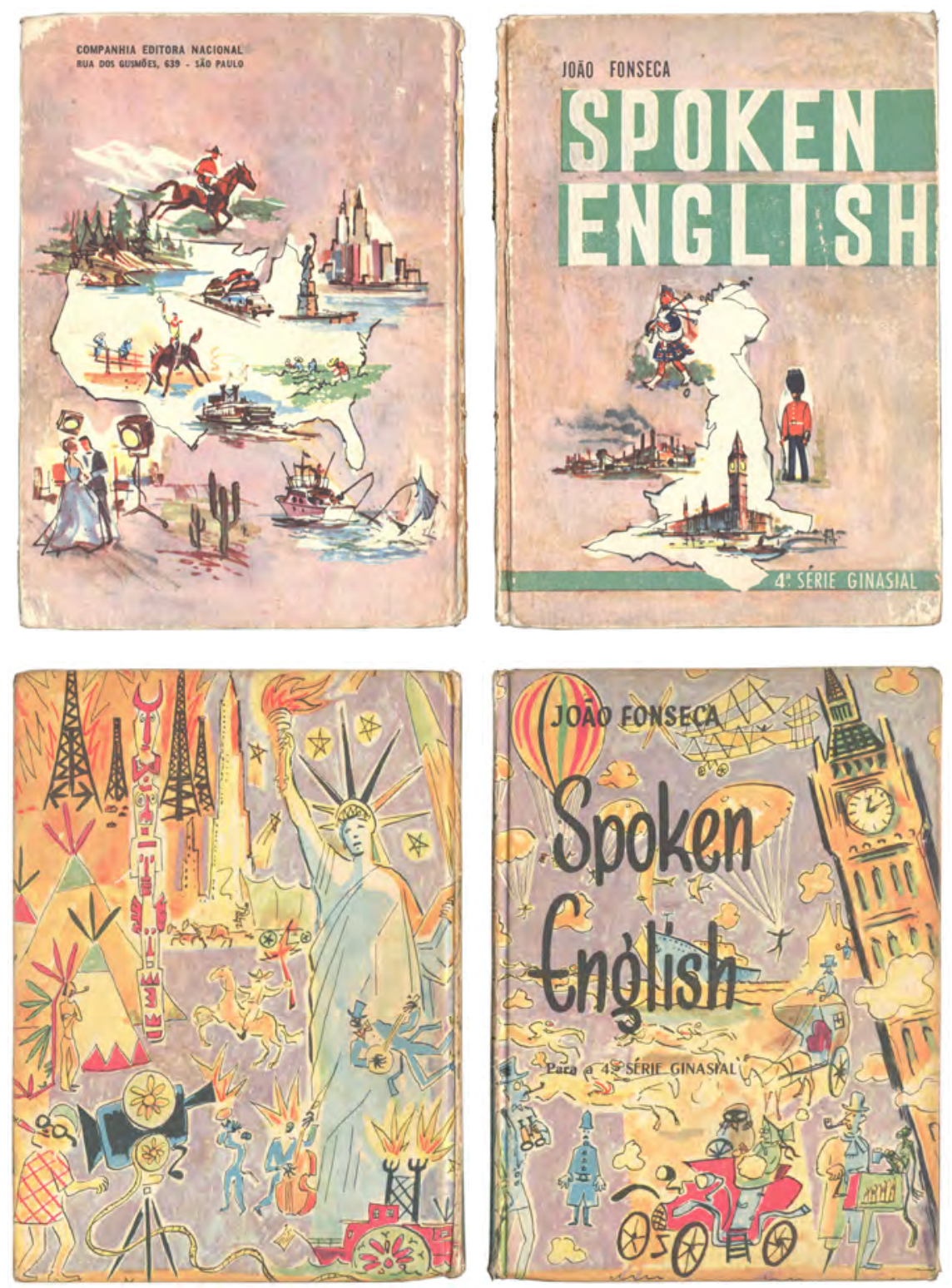

Fig. 6.25. João Fonseca. Spoken English: para a 4a série ginasial, 1958, ilustração de capa de João Gargiulli; Spoken English: para a 4ạ série ginasial, 1959, ilustração de capa de João Gargiulli (15,0 x 21 cm).

\section{Capas fotográficas}

Em menor número no período, aparecem capas fotográficas, com um exemplo de fotografia em PB para o volume de História Geral da coleção de Ary da Matta, contrastando com a solução ilustrada do volume de História da América (FIG. 6.26) do mesmo autor, em que um mesmo leiaute de coleção comporta as duas linguagens. Já a coleção de geografia para o Ginásio de Aroldo de Azevedo (FIG. 6.27), traz os primeiros exemplos de uso de fotografia colorida em capas de didáticos da Nacional, reproduzidas por seleção de cores em uso pleno dos recursos de impressão ofsete em quadricromia, embora o volume de Geografia Geral pareça ter sido colorizado artificialmente, dando um caráter pictórico à imagem. O leiaute, simétrico, separa claramente imagem e informações textuais, que tem sua hierarquia estabelecida por contraste tipográfico e e cromático, mantido com rigor em todas as capas, o que reforça a identidade da coleção. 


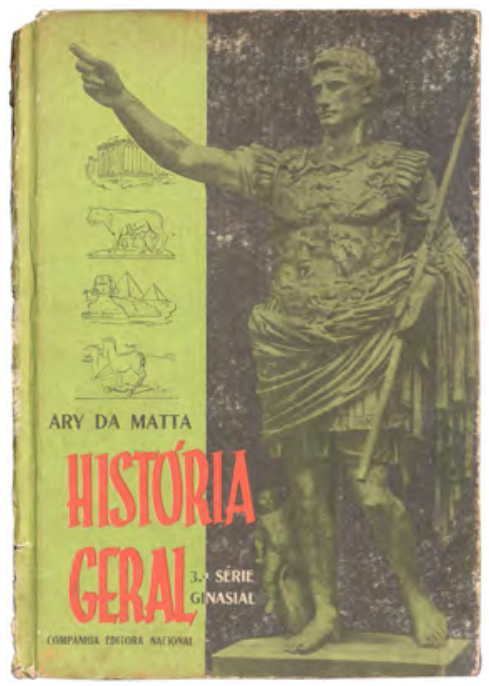

Fig. 6.26. Ary da Matta, História Geral, 1954 (13,0 × 19,0cm).
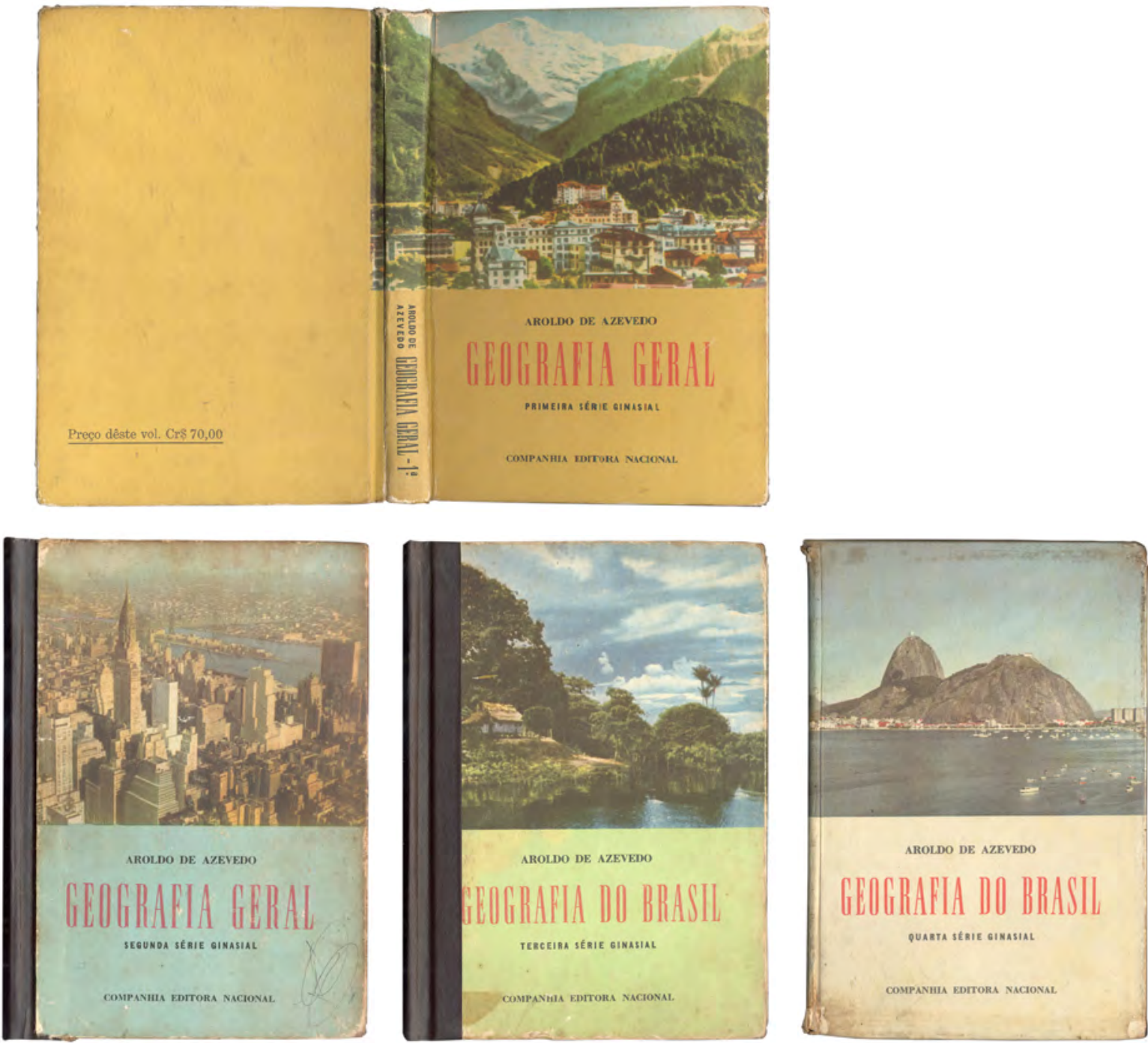

Fig. 6.27. Aroldo de Azevedo. Geografia geral: primeira série ginasial, 1958; Geografia geral: segunda série ginasial, 1960, Geografia do Brasil: terceira série ginasial, 1960, Geografia do Brasil: terceira série ginasial, 1962 (13,0 x 19,0 cm). Embora algumas edições reproduzidas sejam da década de 1960, seguem o leiaute e a solução fotográfica da edição de 1958. 


\section{Texto como imagem}

As capas de Français, de Irma Aragonés Forjaz (FIG. 6.28), são aqui apresentadas à parte das soluções tipográficas do início do período porque, diferentemente daquelas, as letras integram uma composição gráfica que vai além da disposição de um texto para leitura linear. A associação de tipografia, formas e cores, em superfície maior decorrente do formato do volume, cria uma imagem de grande pregnância e significado, em que as informações textuais complementares são também organizadas de forma a integrarem a composição geral e ressaltarem sua força. A solução, não creditada, indica um procedimento calcado no design modernista construtivo, mas a escolha tipográfica e obviamente as cores parecem ligá-la muito naturalmente ao universo e à cultura visual francesa.
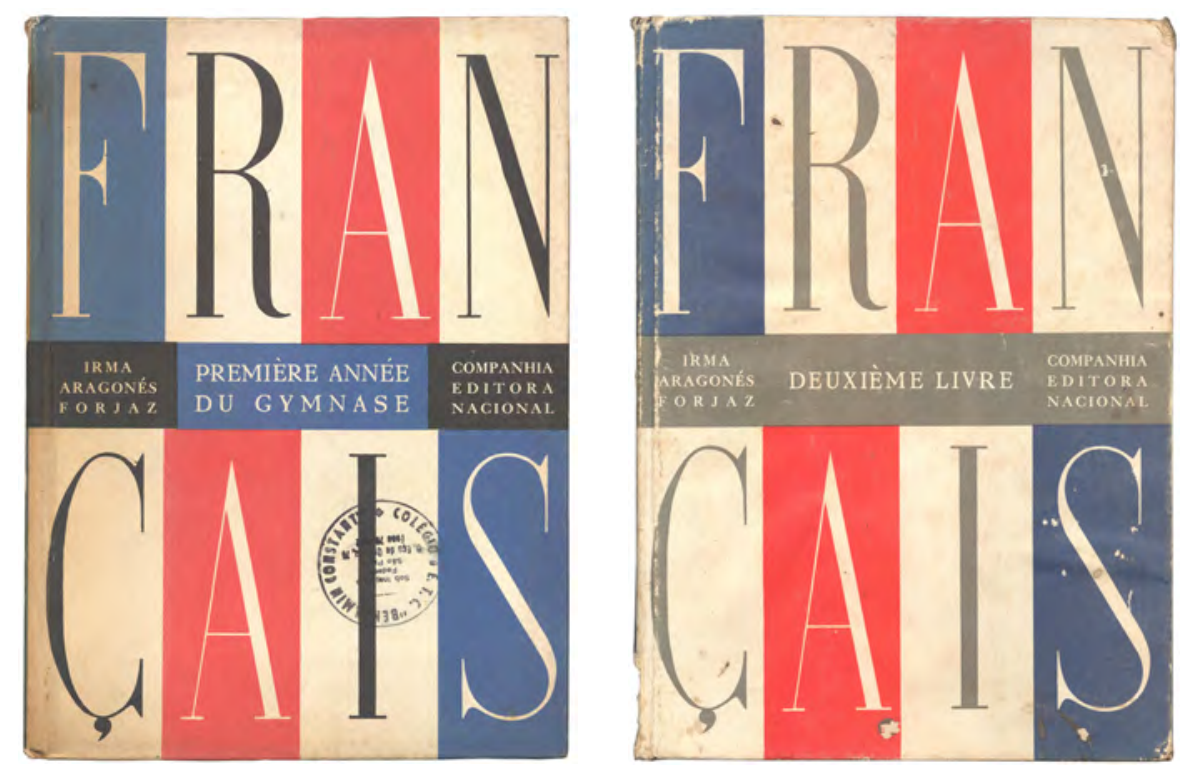

Fig. 6.28. Irma Aragonés Forjaz. Français: première anée du Gymnase, 1958; Français: deuxième livre, 1963 (15,0 x $21,0 \mathrm{~cm})$. 


\subsubsection{O design de miolo dos livros didáticos do período 1953-1960}

A grande maioria dos livros encontrados nesse período trazem os padrões de diagramação, linguagens de ilustração e uso de fotografia verificados no período anterior, conforme as particularidades das disciplinas a que pertencem. Assim é que livros de Língua Portuguesa e de Matemática para o Ensino Secundário apresentam as mesmas características visuais e gráficas observadas na década de 1940, com os primeiros não contendo ilustrações e os últimos apresentando ilustrações de tipo "técnico", em traço (FIG. 6.29).
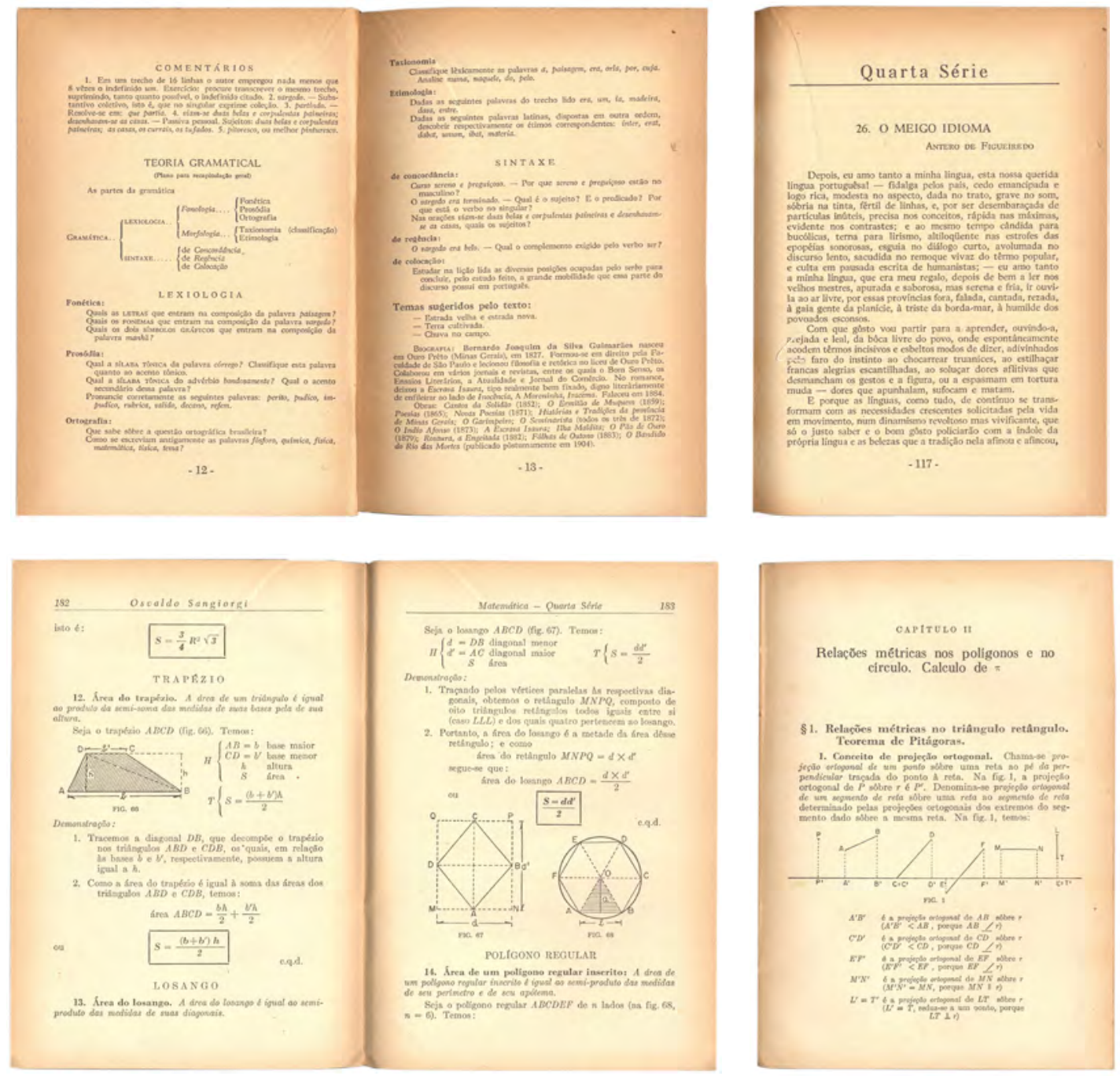

Fig. 6.29. José Cretellla Júnior, Português para o Ginásio, 1954; Osvaldo Sangiorgi, Matemática: curso ginasial - 4a série, $1956(13,0 \times 19,0 \mathrm{~cm})$.

Nos livros de Ginásio e Colégio que contém imagens, a ilustração em traço é absolutamente dominante e a fotografia ocorre com menor frequência, provavelmente a mesma verificada no período anterior, como pode ser visto em livros de Ciências, Geografia e Desenho (FIG. 6.30). 

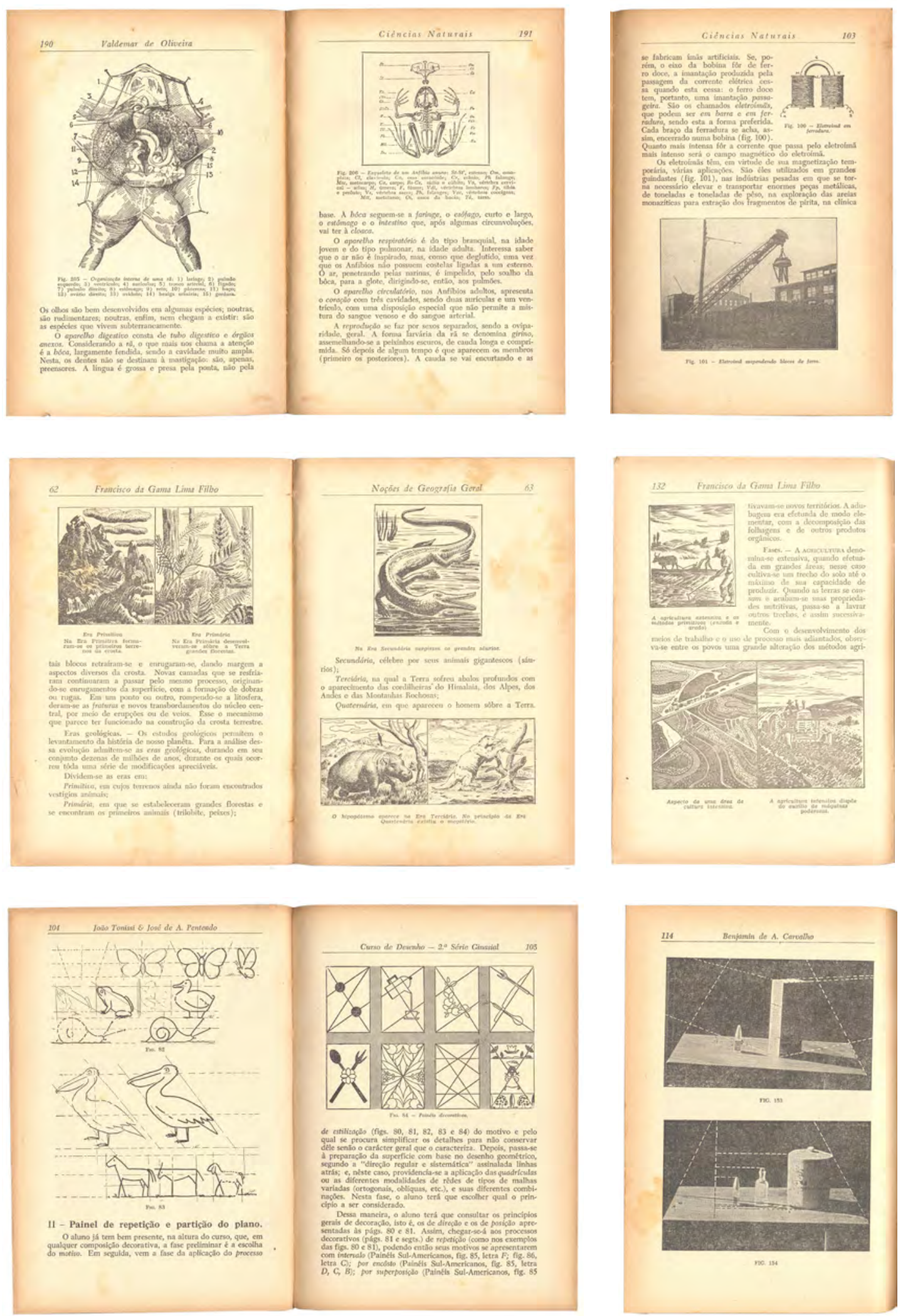

Fig. 6.30. Valdemar de Oliveira, Ciências Naturais, 1958; Francisco da Gama Lima Filho, Noções de geografia geral, 1957; João Tonissi e José de Arruda Penteado, Curso de desenho, 1955 (13,0 x 19,0 cm).

As coleções de História também apresentam o mesmo tipo de iconografia observado no capítulo anterior, mesmo em obra do último ano do período analisado, com maior presença de ilustração interpretativa do que reproduções fotográficas (FIG. 6.31). 

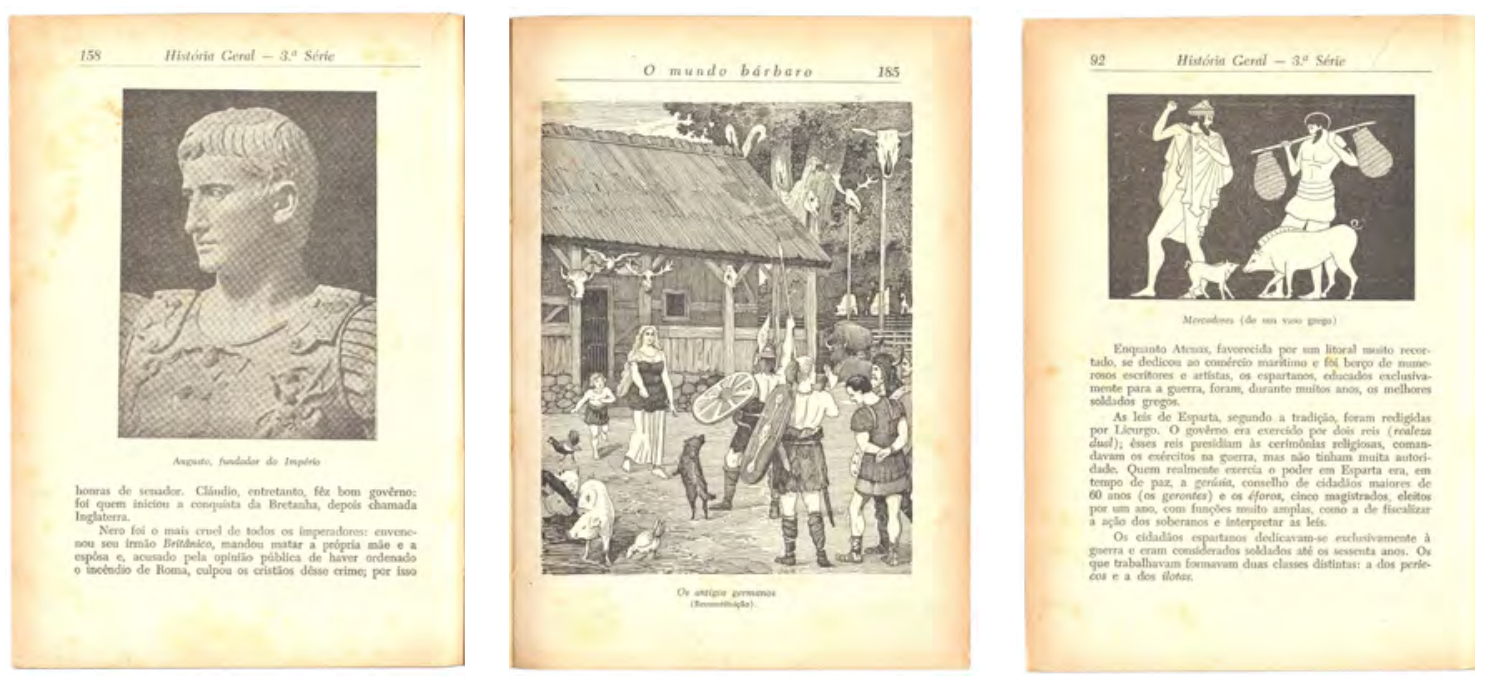

Fig. 6.31. Antonio José Borges Hermida, História geral: para a terceira série ginasial, 1959 (13,0× 19,0cm).

As obras de Geografia de Aroldo de Azevedo para Ginásio e para Colégio, como no período anterior, são as que apresentam maior investimento e diversidade iconográfica, com desenhos em traço do próprio autor, fotografias e mapas, assinados por J. S., que agora utilizam retícula aplicada (FIG. 6.32).
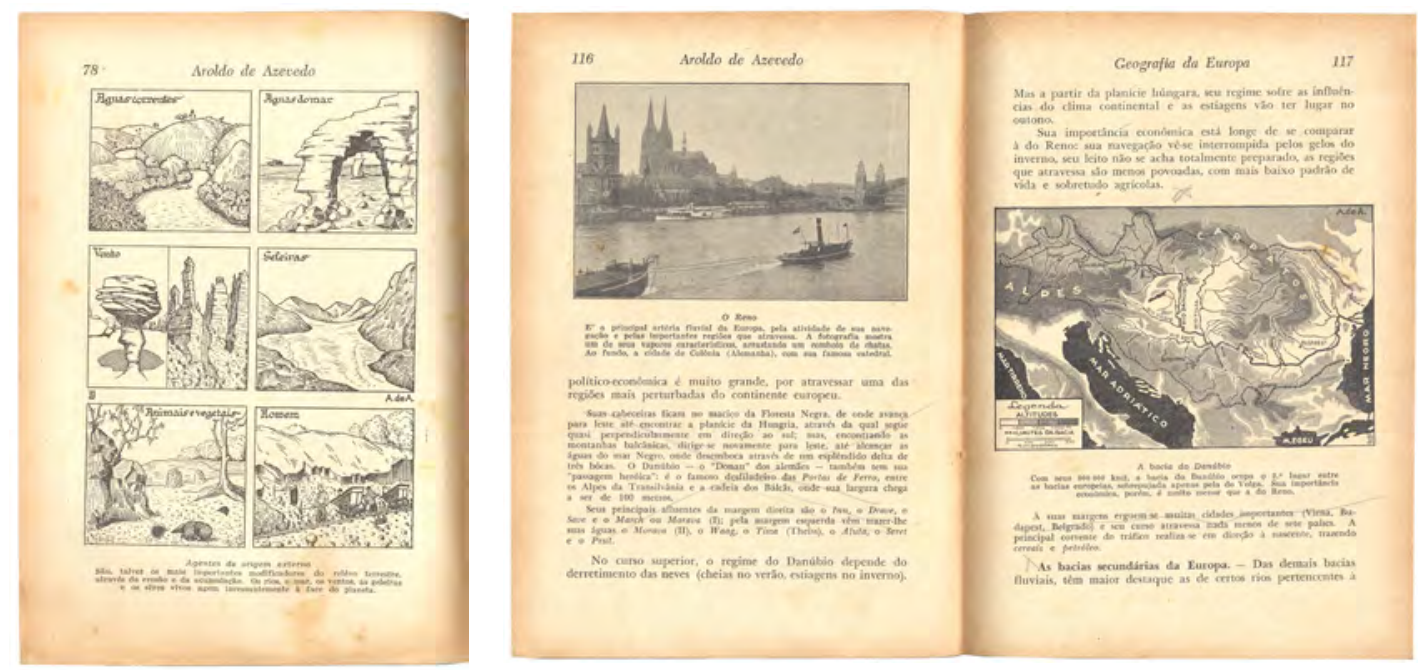

Fig. 6.32. Aroldo de Azevedo, Geografia geral: 1ª série ginasial, 1955 (13,0 × 19,0cm).

Excetuando as edições da Cartilha Sodré, (ver FIG. 5.31) que tinham impressão em preto mais uma cor, as obras destinadas ao Ensino Primário encontradas no período eram impressas apenas em preto, como o livro de leitura Meu Brasil (FIG. 6.33) e Infância Brasileira (FIG. 6.34). Lançado em 1954, com conteúdos de Língua Portuguesa, História, Geografia e Ciências, esta obra chegou a 292 edições, 20 reimpressões e 1.877.744 exemplares impressos [BEDA, 1987, p. 289]. A Cartilha Popular, destinada à alfabetização de adultos, provavelmente tem design originário no período anterior e também traz ilustrações em traço e impressão em preto (FIG. 6.35). 

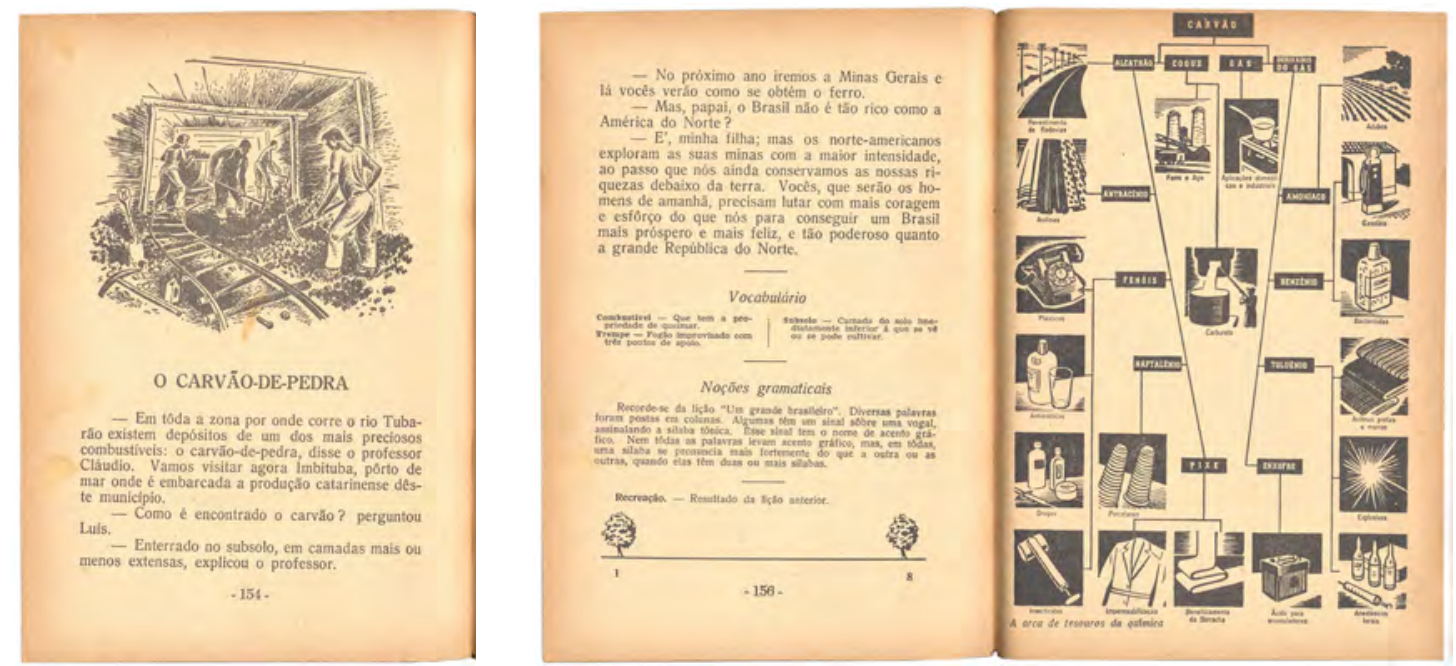

Fig. 6.33. Hildebrando de Lima, Nosso Brasil: 3o grau primário, 1953; Luiz Amaral Wagner, Nosso Brasil: 4o grau primário, 195? (13,0 × 19,0 cm).
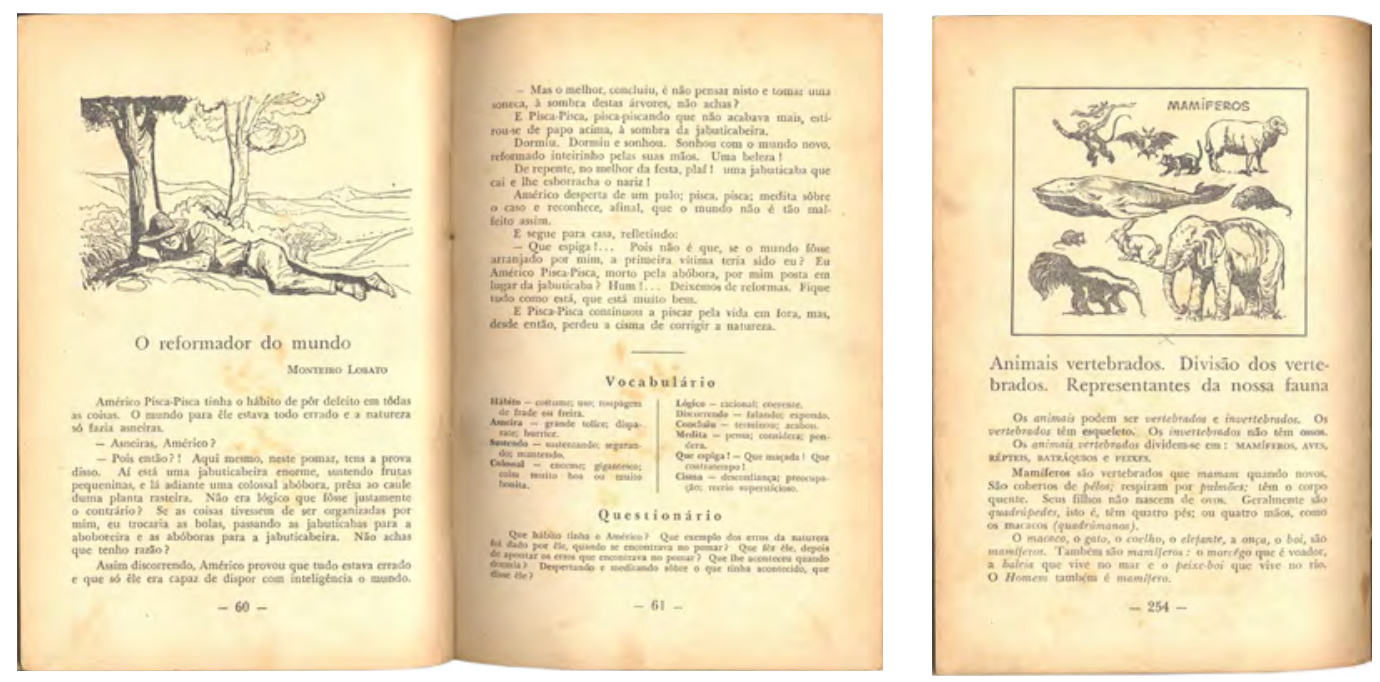

Fig. 6.34. Ariosoto Espinheira, Infância Brasileira, edição de 1961 (brochura, 13,0 x 19,0cm).
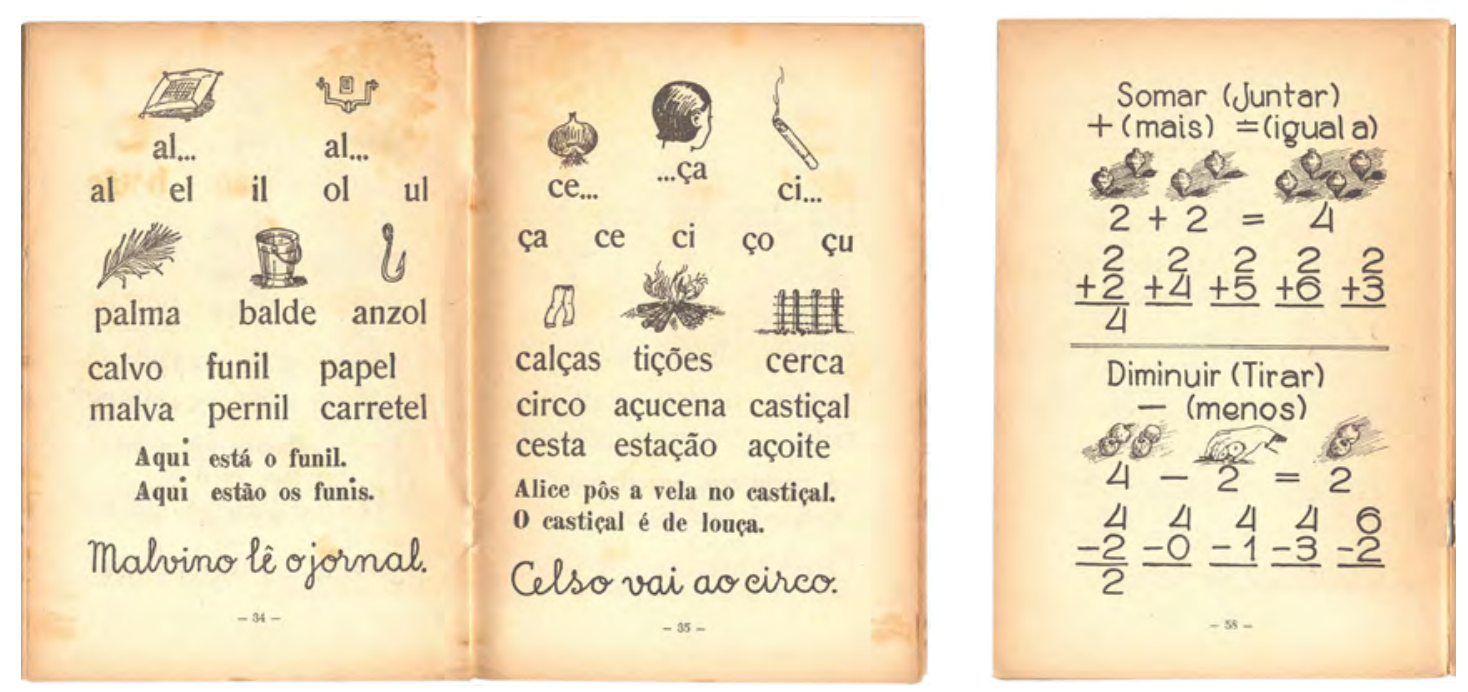

Fig. 6.35. Júlio de Faria de Souza, Viva o Brasil: cartilha popular, 1956 (brochura, 13,3 × 19,0 cm). 
Embora predomine a impressão monocromática, este período marca também a introdução da impressão em duas ou três cores para livros destinados ao Ensino Secundário e da quadricromia para ilustrações e fotografia. Mais uma vez, os livros de Aroldo de Azevedo estão entre os primeiros que trazem um aperfeiçoamento gráfico, como o uso de uma segunda cor, com a finalidade de clarificar a leitura de mapas e gráficos (FIG. 6.36).
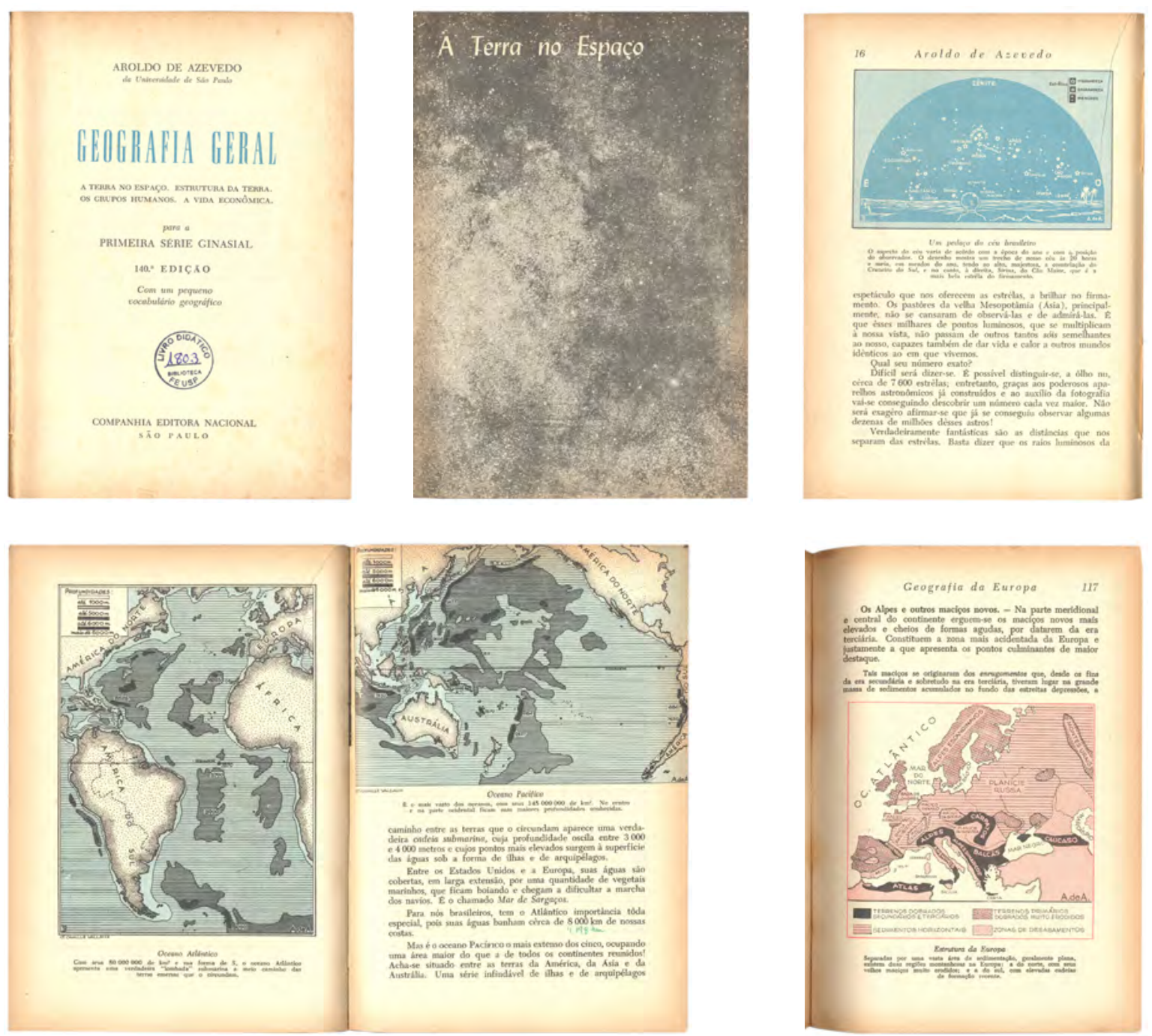

Fig. 6.36. Aroldo de Azevedo. Geografia geral: primeira série ginasial, 1958; Geografia geral: segunda série ginasial, $1960(13,0 \times 19,0 \mathrm{~cm})$.

Os livros de línguas modernas da editora, Francês e Inglês, sempre foram bastante ilustrados e dois deles foram os primeiros a receber impressão em tricromia, já nas décadas de 1930 e 1940 (ver FIG. 4.39 e 5.28), mas em pranchas coladas. Agora, na segunda metade da década de 1950, com a disponibilidade de impressoras ofsete para livros, títulos novos dessas disciplinas trazem todas as suas páginas impressas em três cores separadas ou mesmo quadricromia. A edição de 1958 de Français: première année du gymnase, traz algumas páginas com impressão em quadricromia (FIG.6.37), enquanto que a edição de 1959 apresenta ilustrações em traço preto 
com áreas preenchidas com ciano e magenta chapados ou reticulados e raramente combinados por sobreposição de retícula (fIG. 6.38).
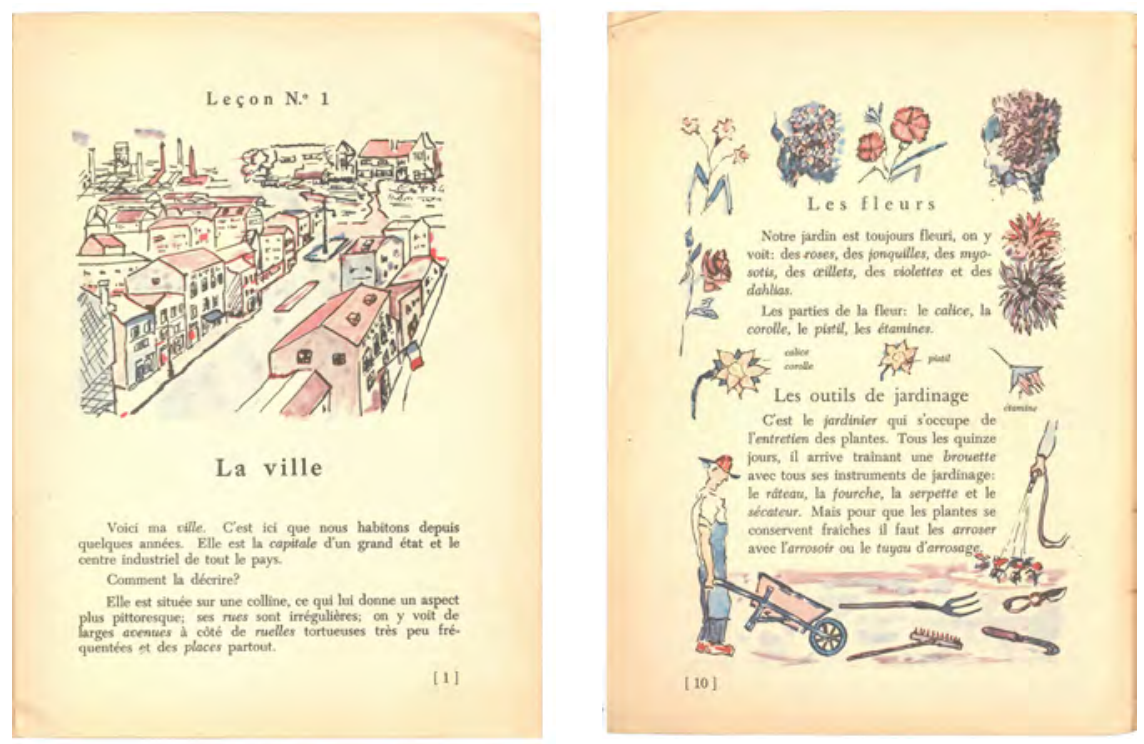

Fig. 6.37. Irma Aragonés Forjaz. Français: première anée du Gymnase, 1958 (15,0 × 21,0cm).
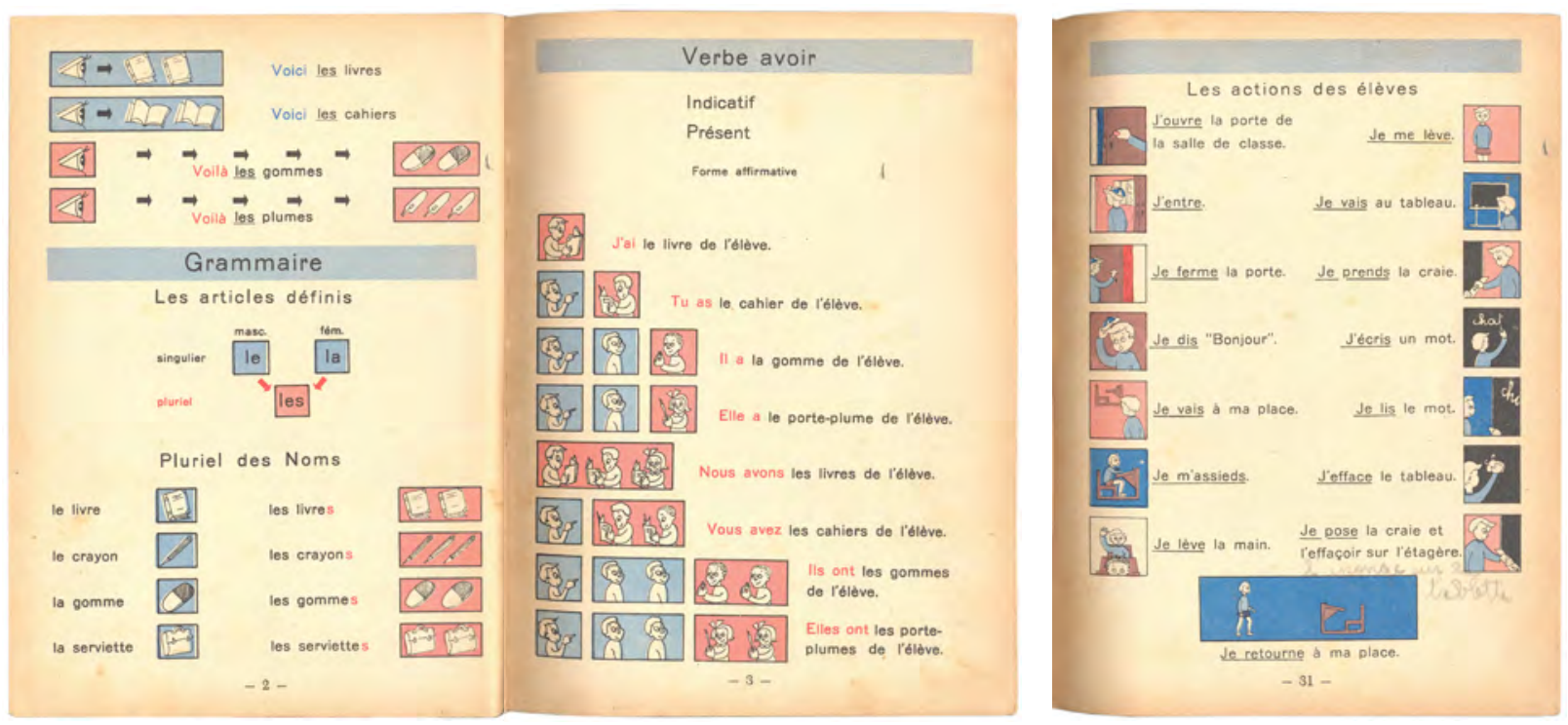

Fig. 6.38. Irma Aragonés Forjaz. Français: première anée du Gymnase, 1959 (15,0 x 21,0cm).

A edição de 1957 de Spoken English, 3ำ ano, traz ilustrações de capa e miolo (fig. 6.39) creditadas a João Gargiulli, com impressão em quadricromia, mas as últimas utilizam as cores da escala quadricrômica (ciano, magenta, amarelo e preto) chapadas ou misturadas por aplicação de retícula indicada nas áreas definidas pelo desenho de traço preto, para o estúdio de fotolito realizar, técnica de colorização das histórias em quadrinho da época, e não por processo de captura fotográfica de original colorido pelo próprio ilustrador e transposição para chapa de impressão mediante reticulação do fotolito. 
EIGHTEENTH LLSSSON

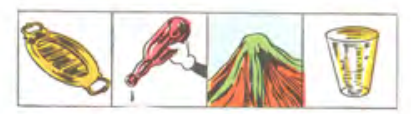

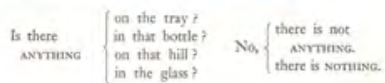

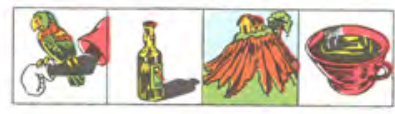

Is thicte
Asrrassog $\left\{\begin{array}{l}\text { on Jack's amm? } \\ \text { in that bottle? } \\ \text { on that hill? } \\ \text { in the cup? }\end{array}\right.$

$-68-$

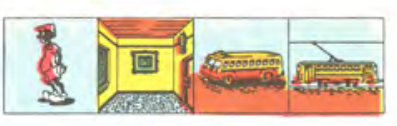

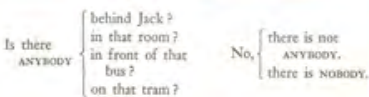

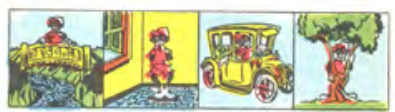
Is there
Nwrwoor $\begin{aligned} & \text { on the bridge? } \\ & \text { near the window ? } \\ & \text { in that car? } \\ & \text { behind the tree? }\end{aligned}$

Fig. 6.39. João Fonseca, Spoken English: para a 2ª série ginasial, $1958(15,0 \times 21 \mathrm{~cm})$. Ilustrações de miolo de João Gargiulli.

O volume de quarto ano tem ilustrações internas de José Maria C. Canto, reproduzidas em quadricromia, também com a técnica de colorização das histórias em quadrinho (FIG. 6.40)

Já a edição de 1958 da mesma obra, com ilustrações de capa (FIG. 6.25) e miolo (FIG. 6.41) de João Gargiulli, utiliza a quadricromia plena, com a técnica de aquarela sendo reproduzida pelo processo de fotomecânica que transforma os tons contínuos em retículas com pontos de diversos tamanhos, que definem tonalidades não chapadas.
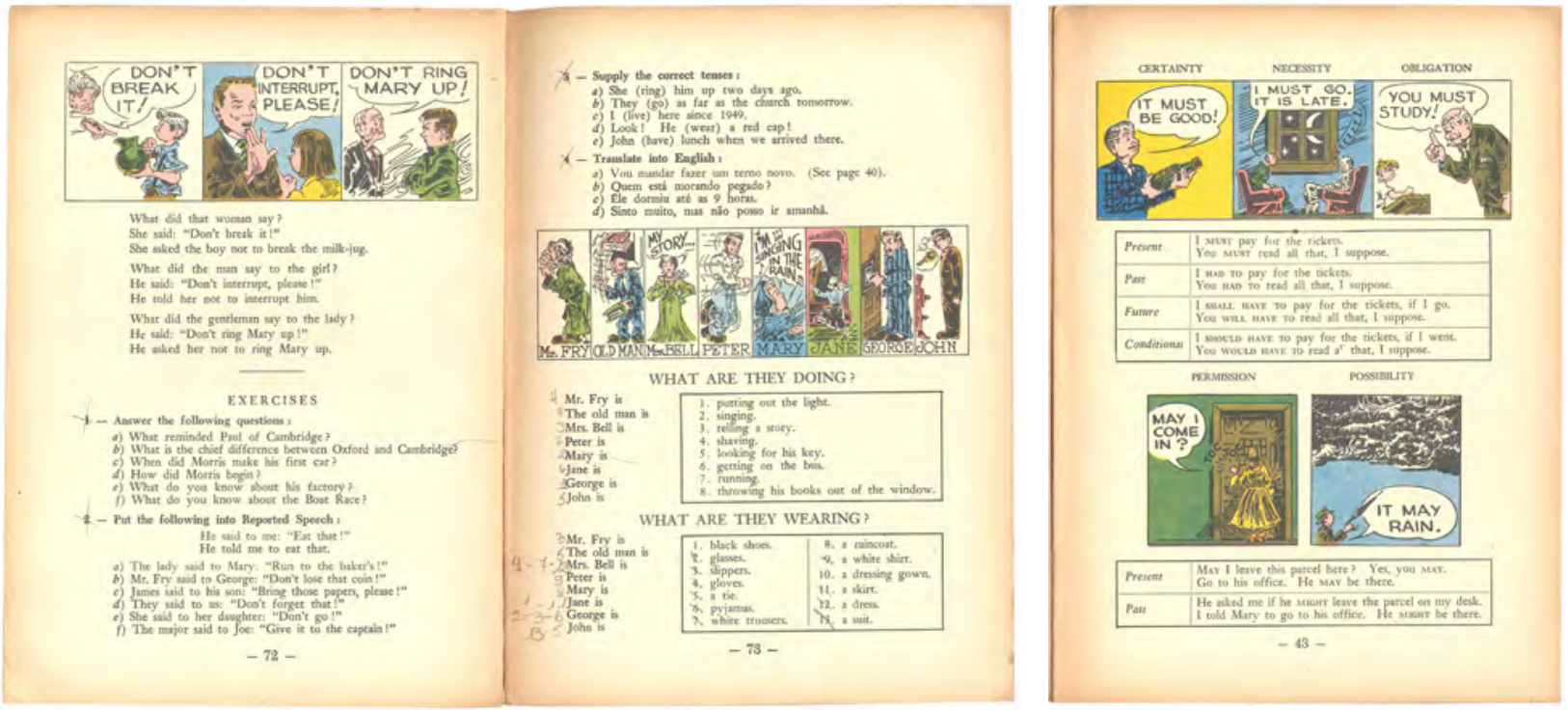

Fig. 6.40. João Fonseca, Spoken English: para a 4a série ginasial, 1961 (15,0 × 21 cm). Ilustrações de miolo de José Maria C. Canto. 

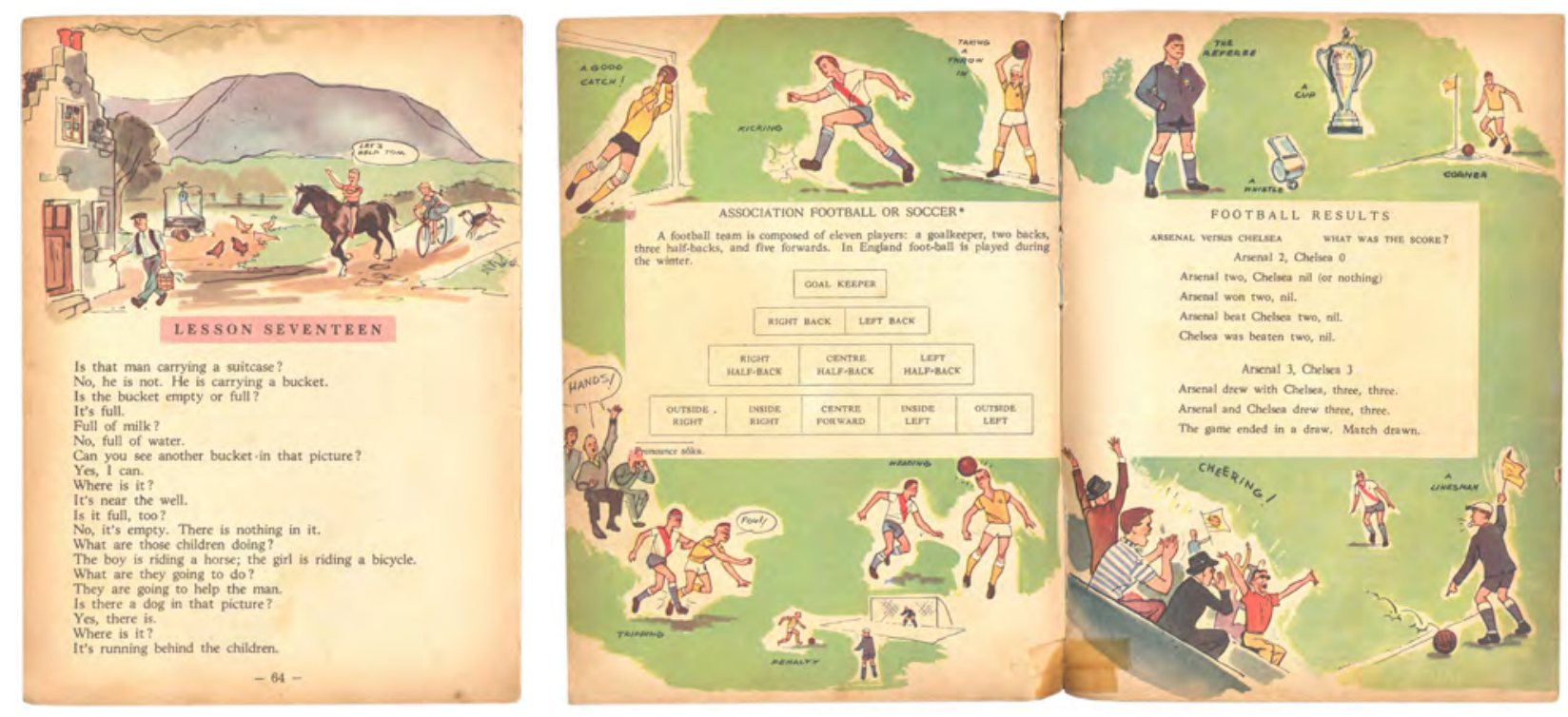

Fig. 6.41. João Fonseca, Spoken English: para a 3aㅗ série ginasial, 1958 (15,0 x 21 cm). Ilustrações de miolo de João Gargiulli.

As edições de 3a e 4aㅡ série ginasiais de 1938 têm guardas ilustradas, que foram suprimidas nas edições seguintes obtidas na pesquisa material (FIG.6.42), mas que de qualquer forma atestam o investimento feito nas obras de línguas, em particular as coleções de Inglês de João Fonseca.
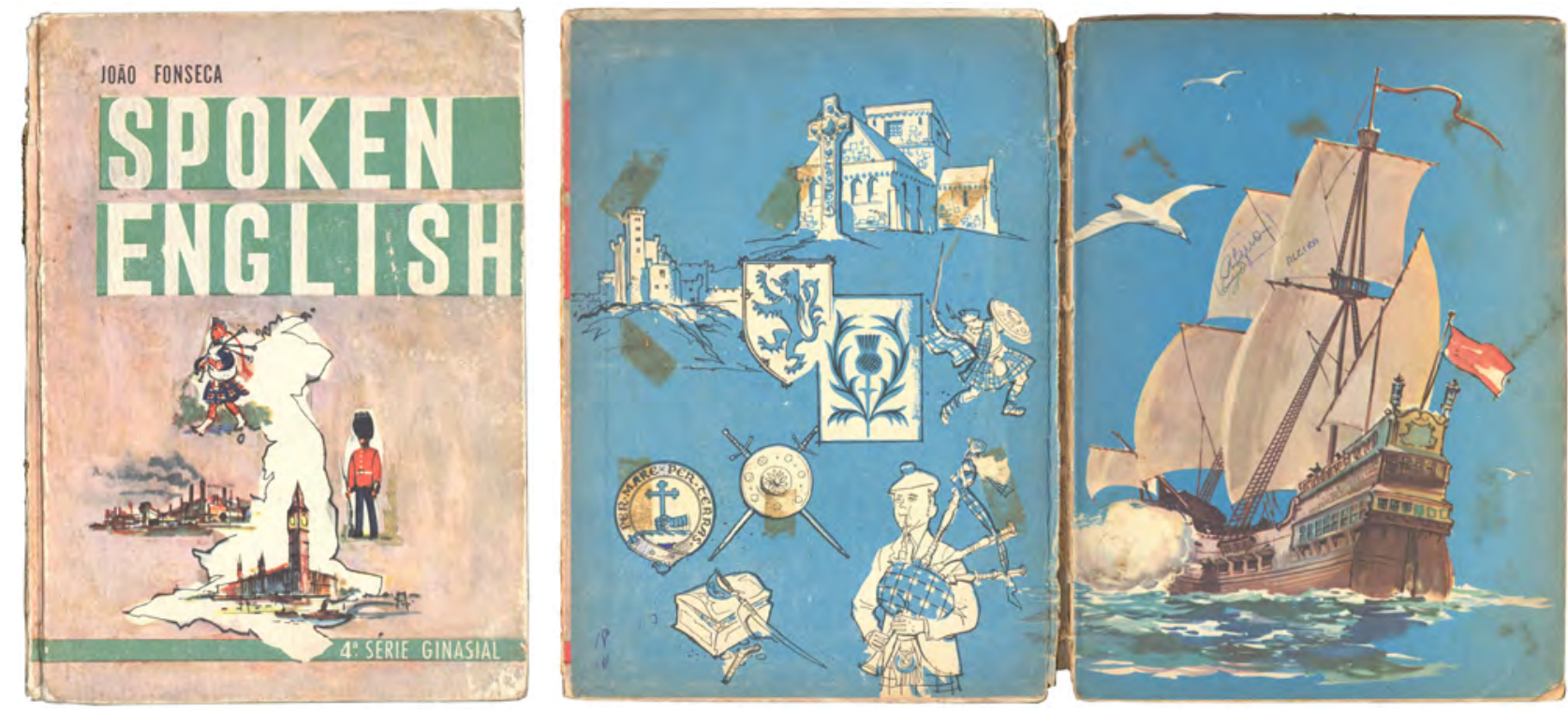

Fig. 6.42. João Fonseca, Spoken English: para a 4ํㅗ série ginasial, 1958 (15,0 × 21 cm). Capa e guardas.

Mas a obra que primeiro utiliza plenamente a quadricromia, para reprodução de fotografias coloridas e mapas, é o Programa de Admissão, ainda em 1956 (FIG. 6.43). Este livro, destinado aos alunos que concluíram o primário e se preparariam para o exame de ingresso no Ginásio, reunia as disciplinas de Português, Matemática, História e Geografia. O investimento na obra 
se reflete na produção gráfica diferenciada e pela primeira vez o trabalho de planejamento gráfico aparece creditado, com os nomes de Rubens de Barros Lima e Theobaldo de Nigris. $O$ primeiro, como vimos, era o encarregado da produção da Nacional, e o segundo um dos gerentes da São Paulo Editora, comprovando o envolvimento desta na produção didática da CEN.
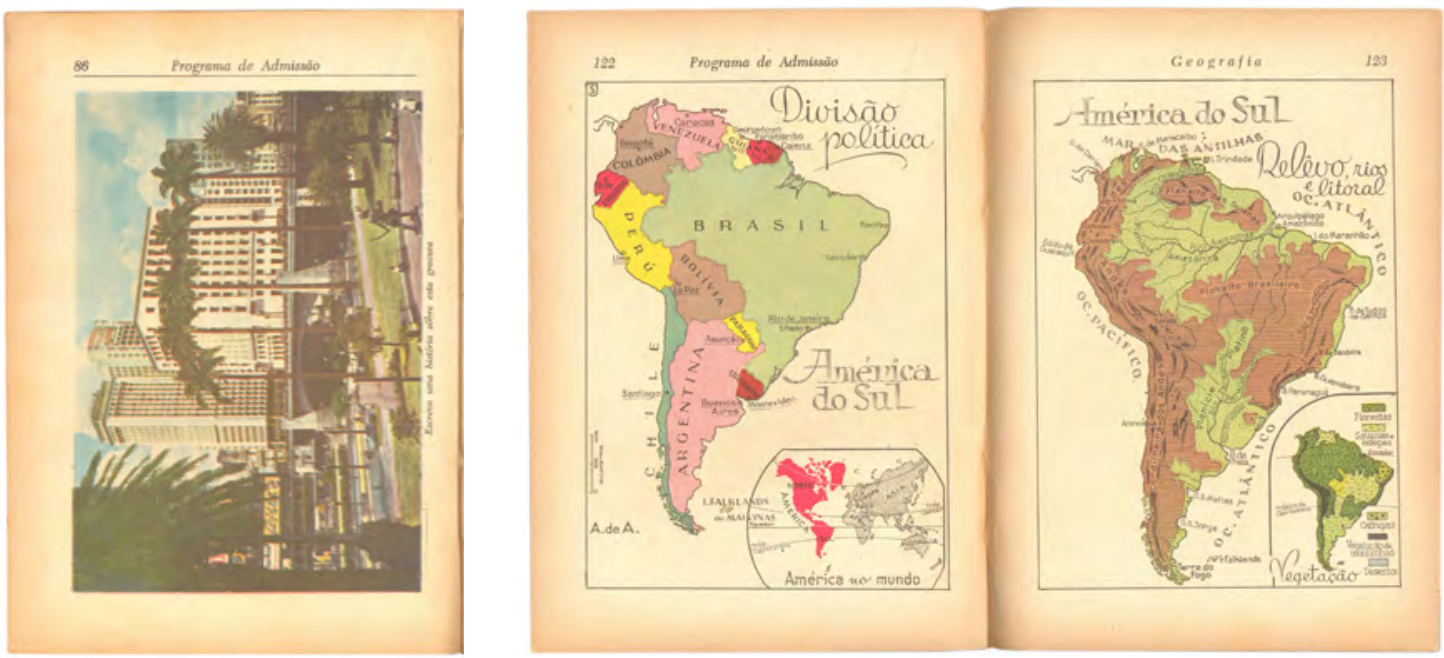

Fig. 6.43. Diversos autores, Programa de Admissão, $1956(13,0$ × 19,0 cm).

\subsection{Considerações gerais sobre o design dos livros didáticos da CEN do período 1953-1960}

De início, foi bastante difícil estabelecer o marco temporário que delimitava o período anterior e o tratado neste capítulo. Com relação à materialidade e visualidade dos miolos dos livros, ocorreu uma continuidade de procedimentos, a manutenção de formatos e diagramas, a ilustração em traço para a maior parte das obras, o maior uso de fotografia em algumas disciplinas, a impressão monocromática dominante, utilizando os mesmos recursos estabelecidos pela generalização da impressão ofsete ocorrida no período anterior, que não foi substituída ou atualizada por nenhuma nova tecnologia. Mesmo com relação ao design de capas, o início do uso de soluções ilustradas para livros do Ensino Secundário deu-se ainda no final da década de 1940, com livros de Inglês.

O que permitiu estabelecer o ano de 1953 como início de um novo período foi uma combinação de aspectos quantitativos e qualitativos, referentes exclusivamente ao design das capas. Quantitativo, porque é quando um número maior de disciplinas começa a receber capas ilustradas coloridas, até então característica de livros primários e de línguas estrangeiras. E qualitativos pela diversidade de referências que essas primeiras soluções traziam, logo ampliadas pela produção que se seguiu. 
Em primeiro lugar, a nova produção traz referências à linguagens de ilustração encontradas nas capas nos livros não didáticos da editora, como as obras de divulgação científica e humanidades e de ficção popular. Assim, o "modernismo expressionista" de Walter Lewy das capas da Biblioteca do Espírito Moderno, vai aparecer em capas de livros de Ciências, e a linguagem figurativa de apelo mais popular de João Gargiulli vai aparecer mais modernizada em capas e miolos de livros de Inglês. As novas capas trazem também referências à linguagem publicitária e das revistas ilustradas, com as contribuições de Augustus e exemplos de ilustração informal com toque de humor e de fotografia em cores. Por fim, há também capas com referências à linguagem da arte e do design modernista construtivo, uma apropriação pioneira ou bastante precoce pelo segmento didático de algo que se produzia naquele exato momento fora do circuito mais amplo da indústria cultural de massas, como as Bienais de Arte de São Paulo e as mostras de artistas e publicações de poetas concretos.

Pode-se então dizer que, não só a editora abandona as soluções tipográficas padronizadas e em geral conservadoras, que distanciavam o livro escolar da produção visual circulante na sociedade brasileira, como dá uma guinada até radical, incorporando linguagens desde as mais aceitas e conhecidas até as mais inusitadas e vinculadas a uma produção considerada erudita, todas elas em soluções com qualidade, numa permeabilidade inédita a influências de outros veículos da indústria cultural que contribuiu para uma ampliação do repertório e da cultura visual escolar.

Deve-se ressaltar que a adoção de soluções baseadas em ilustração não excluiriam a estratégia do uso de "chassis" ou diagrama fixo, que simplesmente seriam preenchidos com as informações textuais específicas e uma ilustração particularizadora para cada obra, numa continuidade da estratégia adotada para as capas tipográficas da coleção BPB Série /l ou nas diversas soluções tipográficas para livros de Ensino Secundário anteriores. Há no entanto aqui um abandono explícito dessa estratégia, com a adoção de diagrama comum apenas para os livros de um mesmo autor para um mesmo nível de ensino, para atribuir identidade de coleção a eles. Assim, embora os títulos e a iconografia sejam em grande parte caracterizadores de uma visualidade que continua particularizando o livro didático em relação aos demais, a diversidade de soluções e linguagens trazidas por essa produção da Nacional certamente modifica a percepção que seu público tem deste objeto impresso, provavelmente propiciando maior identificação com ele.

A predominância de capas com impressão de cores chapadas é absoluta nos primeiros anos do período, dando lugar a poucos exemplos que fazem uso da retícula para obtenção de tons e matizes diferentes mas principalmente a um número maior de capas impressas em quadricromia, ilustradas, e um primeiro caso de capa com fotografia em cores. Há aqui uma provável correspondência com o design de capas da indústria livreira em geral, em que o mais 
comum era o emprego de duas ou três cores, com apenas as edições populares de grande tiragem trazendo capas com ilustrações em impressão quadricrômica, pelos custos envolvidos.

Assim, exatamente pelos custos, o miolo dos livros é o que vai por último e em menor grau incorporar os recursos plenos propiciados pelas tecnologias da impressão ofsete e da seleção de cores para impressão quadricrômica. O uso de preto mais uma cor aparece em livros de Geografia de Aroldo de Azevedo, que no período anterior já mereceram cuidado gráfico diferenciado, e de preto mais duas cores em livro de Francês, sempre cores da escala quadricrômica (magenta e ciano) e quase sem combinação de retículas gerando outros tons e matizes. A quadricromia aparece poucas vezes e sob diversas formas: reprodução de fotografias em cores (Admissão) e de ilustrações (Francês e Inglês), mediante seleção e reticulagem; colorização indicada de ilustrações (Inglês e Francês), mas aparentemente sem pleno domínio dessa técnica trazida da produção de histórias em quadrinhos, dada a quantidade limitada de matizes e tons obtidos; e colorização de mapas e gráficos (Admissão).

De qualquer forma, a introdução da cor e da fotografia nas capas e, ainda que mais limitadamente nos miolos, faz desse período aquele em que importantes transformações na visualidade de livro didático ocorriam e teriam continuidade e desdobramentos na produção que se seguiu a ele. 
CAPÍTULO 7

1961-1969:

A valorização do design de miolo

nos livros didáticos da Companhia Editora Nacional 

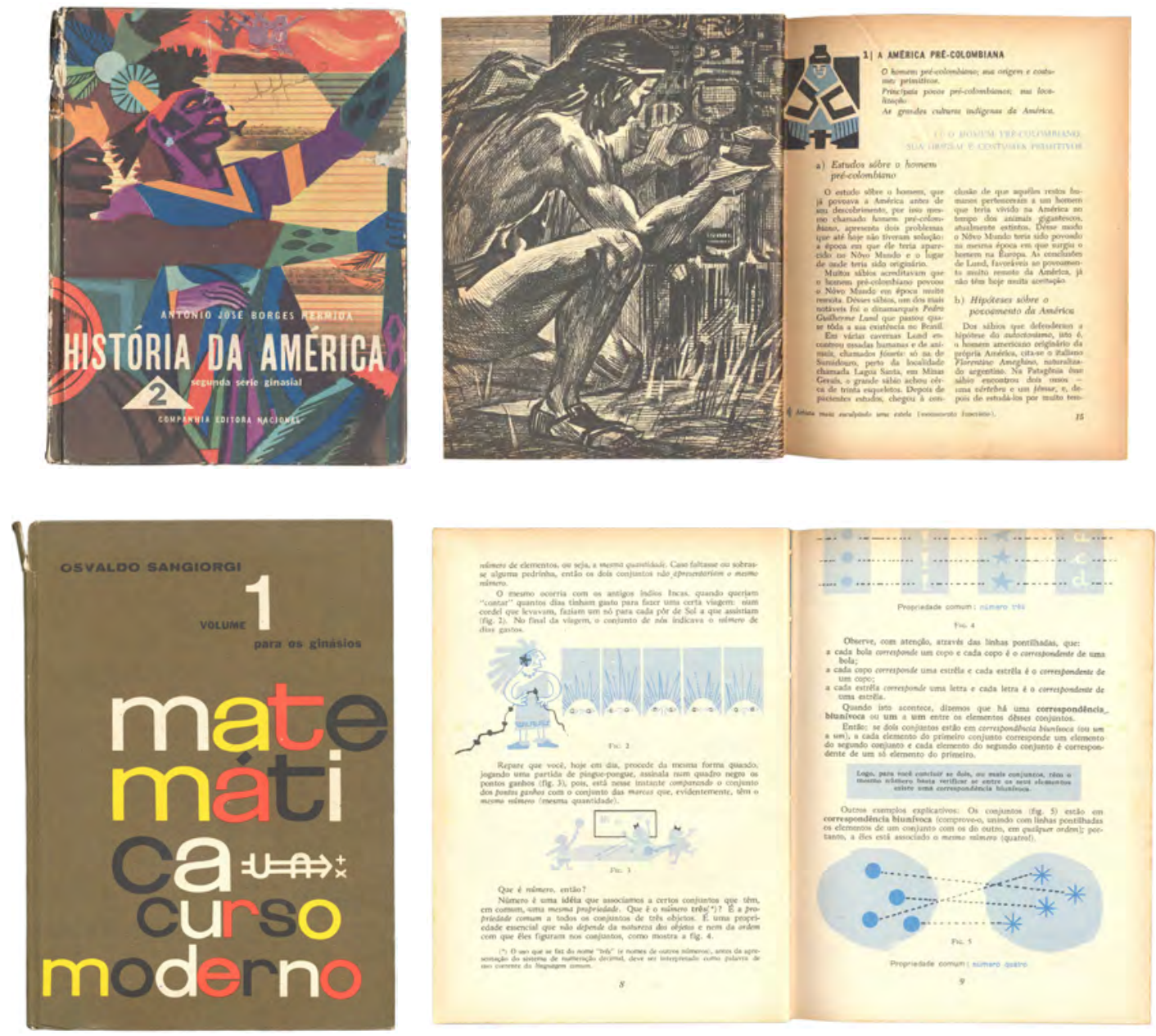

As duas obras aqui reproduzidas trazem as características que definem parte significativa do design e da materialidade encontrados nos livros didáticos da CEN no período 1961-1969:

- particularização de projeto gráfico de miolo para cada obra, em alguns casos integrando formalmente capa e miolo sob concepção gráfica unitária;

- atualização da linguagem das ilustrações de capa e miolo, sob influência de correntes do design modernista e de revistas e fascículos;

- impressão em quadricromia e em cores especiais nas capas;

- impressão em bicromia nos miolos;

- encadernação em capa dura. 

estabelecimento de um quarto período para o design de livros didáticos da Companhia Editora Nacional, tratado no capítulo anterior, teve como fato determinante uma mudança de procedimento relativo à produção das capas, com estas passando a ter uma solução exclusiva, geralmente ilustrada, para as obras de cada autor, e não mais uma solução tipográfica genérica, particularizada apenas pelo desenho das letras. O estabelecimento de um quinto período de design, tratado neste capítulo, deve-se à extensão desse procedimento para o design dos miolos, que passaram também a ter um projeto exclusivo para as novas obras ou edições, e não um modelo de diagramação único, em que a diferença de visualidade dos livros ocorria apenas pela iconografia específica de cada disciplina.

Com relação exclusivamente ao design das capas, há uma continuidade entre estes quarto e quinto períodos, no sentido de que prosseguiu a particularização das obras por meio de soluções exclusivas para elas e uma aproximação com linguagens encontradas na produção livreira geral da editora. Mas a sequência de linguagens e estilos decorrente da influência de novas tendências gráficas e do engajamento de novos profissionais vai atualizar a linguagem das capas e também diferenciá-las da produção anterior, aproximando-as ainda mais da visualidade encontrada em outros veículos impressos, na direção da modernização visual dos livros escolares começada no período precedente.

É também desse período a ocorrência de projetos gráficos de livros com uma concepção mais integral ou unitária de design, em que capa e as diversas partes do miolo são mais fortemente relacionadas em termos formais e gráficos. Embora essa relação seja mais frequente no design de miolo, há alguns exemplos em que capa e miolo não só foram desenvolvidos pelo mesmo profissional ou estúdio, como são intencionalmente integrados.

Justamente a obra que definiu o estabelecimento do ano de 1961 como o marco do novo período de design da Nacional teve desenho da capa às páginas internas envolvendo intervenção projetual global, com desenho da capa, guardas, pré-textuais e textuais sob mesmos princípios gráficos, distribuição de textos e imagens em páginas vistas como duplas e linguagem das ilustrações, mapas e de capa participando da identidade da obra. Essa abordagem serviu de modelo para as novas obras do período ou mesmo reedições de obras já existentes, mesmo que a relação capa-miolo não tenha sido tão estreita ou mesmo inexista em alguns casos.

Esta transformação pode ter tido como estopim um acaso, a colaboração de um profissional que trazia na bagagem uma visão de design ainda inédita para os livros escolares, mas de qualquer forma a adoção de seus procedimentos expressou uma sensibilidade e uma permeabilidade por parte da editora ao que ocorria em outros meios da indústria cultural. Essa postura será extremamente útil e adequada para promover uma renovação visual nos livros da editora, particularmente aqueles que deviam comunicar a filiação a novas abordagens pedagógicas de algumas disciplinas. 


\subsection{A educação brasileira no período 1961-1969}

O ano de 1961, início deste período de design estudado, foi justamente aquele em que, após treze anos de debate no Congresso Nacional, foi promulgada a Lei de Diretrizes e Bases da Educação Nacional. Como vimos no capítulo anterior, o tempo dispendido se deveu primordialmente ao embate entre posições em defesa do papel do Estado no oferecimento da educação pública e gratuita em todos os níveis e posições defensoras da educação privada, porém subsidiada pelo Estado, com estas últimas acabando por prevalecer na nova lei. Assim, segundo Otaiza de Oliveira Romanellı [2007, p. 179-180], o conteúdo geral da lei não modificou as características básicas do sistema de ensino no país estabelecidas pelas Leis Orgânicas do Ensino e reafirmadas pela Constituição de 1946, conforme vimos no capítulos 5 e 6, nem sua defasagem em relação às necessidades do desenvolvimento econômico e o atendimento pleno da demanda de educação no país.

Com relação ao sistema de ensino, este continuou organizado da mesma forma, com alguma diferença de nomenclatura apenas:

1. Ensino Pré-primário, com escolas maternais e jardim de infância;

2. Ensino Primário, de 4 anos, com possível extensão de 2 anos;

3. Ensino Médio, subdividido em dois ciclos, incluindo o ramo do ensino técnico (industrial, agrícola e comercial) e o da formação de professores (normal):

- Ginasial, de 4 anos;

- Colegial, de 3 anos, ainda subdividido em cursos Clássico e Científico (ver capítulo 5, p. 185);

4. Ensino Superior, com a mesma estrutura anterior. [RomAnelLI, 2007, p. 181]

A lei também não prescreveu um currículo fixo e rígido para cada nível e ramo em todo o país, admitindo acréscimos regionais e locais ao currículo mínimo nacional, o que aconteceu muito limitadamente dada a escassez de recursos materiais e humanos na maioria de estados e municípios.

Em relação à defasagem entre a estrutura e conteúdos estabelecidos pela LDB e as demandas do desenvolvimento econômico e da sociedade, aspectos abordados exaustivamente pela autora mas que fogem de nosso objetivo apresentar, é necessário no entanto ressaltar que a aliança dos setores conservadores que resultou na aprovação da lei (ver capítulo 6, p. 224) colocou os rumos e a expansão da educação sob seu controle. Isto significou, por um lado, que a LDB não criou uma estrutura escolar necessária à demanda de recursos humanos criada pela expansão econômica da década de 1950, que se deu com a implementação das indústrias multinacionais, dos serviços e da administração pública e privada decorrentes. Segundo a autora, permanecia uma estrutura baseada nos valores próprios daqueles grupos, ligados ao me- 
nos ideologicamente à velha ordem social aristocrática e oligárquica, que propugnavam uma escola de tipo acadêmico, sobretudo no ensino secundário e superior, voltada para o preparo do exercício das profissões liberais e da administração estatal. Por outro lado, este controle da educação pelos grupos conservadores, através principalmente de sua representação no Conselho Federal de Educação, resultou também numa contenção da expansão do ensino em limites mais estreitos do que os reivindicados pela demanda social da educação, com dispositivos legais que mantiveram a rigidez, a inelasticidade, a seletividade e a discriminação [RoMANELLI, 2007, p. 191 e 206]. Por exemplo, o exame de admissão ao Ginásio continuou em vigor até 1971, bem como a seleção às melhores escolas secundárias da rede oficial.

Essa insuficiência de atendimento às necessidades de educação da população pode ser vista na tabela 7.1, comparando-se suas duas últimas colunas, que apresentam o total de matrículas e o total da população em idade escolar, em que se vê que no final do período uma defasagem superior a 50\%. No entanto, o exame das outras colunas aponta um crescimento acentuado de oferta de matrículas no Ensino Médio (secundário e profissional), que mais que triplicou, superior ao do Ensino Primário, que não chegou a duplicar.

Tabela 7.1. Expansão da matrícula geral do ensino primário e médio e população escolar entre 1960 e 1970

\begin{tabular}{|c|c|c|c|c|c|}
\hline \multirow{2}{*}{ Ano } & \multirow{2}{*}{ Ensino Primário } & \multicolumn{2}{|c|}{ Ensino Médio } & \multirow{2}{*}{$\begin{array}{l}\text { Total de } \\
\text { matrículas }\end{array}$} & \multirow{2}{*}{$\begin{array}{l}\text { População entre } \\
5 \text { e } 19 \text { anos }\end{array}$} \\
\hline & & Secundário & Profissional & & \\
\hline 1960 & 7.458 .002 & 868.178 & 309.249 & 8.635 .429 & 25.876 .581 \\
\hline 1970 & 12.812 .029 & 3.055 .652 & 1.030 .421 & 16.898 .102 & 35.170 .643 \\
\hline
\end{tabular}

Fonte: RomANeLLI, 2007, p. 76 Quadros 9 e 10 e p. 113 Quadro 40.

Esse crescimento não foi uniforme ao longo da década, com o ano de 1964, em que ocorreu o golpe militar, constituindo um ponto de inflexão no crescimento da matrícula no Ensino Primário, que entre 1960 e 1964 cresceu 36\%, e de 1964 a 1968 cresceu apenas 16\%, por contenção mesmo de investimentos na educação com vistas a aplicação em infraestrutura em função do modelo econômico que se implantava no país [RoMANELLI, 2007, p. 208].

Assim é que, a situação da escolarização da população, por faixa etária, apresenta os seguintes números em 1970:

- 7 a 11 anos - 73,61\%;

- 12 a 14 anos - 52,24\%;

- 15 a 18 anos - 27,9\% [RomanelLI, 2007, p. 186].

Mesmo insuficientes do ponto de vista das necessidades da população, estes números indicam um crescimento da escolarização em relação aos períodos anteriores, que terá como resultado uma demanda maior de livros escolares, que favorecerá não só as editoras consolidadas como a Nacional, como propiciará o engajamento de outras neste segmento, além do 
surgimento de novas, que concorrerão com a Nacional, como veremos no próximo tópico.

Com relação ao maior crescimento do Ensino Médio, não se pode deixar de relacioná-lo com a pressão por educação por parte das camadas médias da população que ocorreu nesse período. Os canais tradicionais de ascensão social para as classes médias tinham sido até um passado então recente as profissões liberais, postos na administração estatal e o comércio, mas que vinham cada vez mais reduzindo sua capacidade de absorver todos os seus aspirantes, pela combinação de crescimento populacional e expansão econômica com características que minavam aquelas atividades. As indústrias multinacionais e os negócios monopolistas que se implantavam no país a partir da segunda metade da década de 1950 exigiam trabalhadores especializados para a atividade produtiva direta, mas também toda uma cadeia hierárquica de quadros técnicos e administrativos intermediários e superiores, tanto nas empresas privadas como em autarquias estatais - o que, diga-se de passagem acentuava a já mencionada inadequação entre um ensino de viés acadêmico e humanista e as exigências do tipo de desenvolvimento que o país atravessava.

O Ensino Médio, como passagem obrigatória para o Ensino Superior - seja para os indivíduos ainda ideologicamente orientados pela valorização da educação humanista e que almejavam ainda profissões liberais, como por aqueles que pretendiam exercer as novas profissões e postos criados pela indústria e pelos serviços decorrentes -, cresce com base nessa pressão, tanto em termos de vagas públicas como privadas.

O número de vagas no Ensino Superior, destino pretendido pela grande maioria que cursava o Ensino Médio, também crescerá ao longo da década, mas de forma totalmente insuficiente em relação à demanda, levando à chamada crise dos excedentes, candidatos aprovados no vestibular com a nota mínima exigida mas que não encontravam vagas na universidade. Esta será uma das motivações para a eclosão de um forte movimento estudantil em 1968, por mais vagas e verbas para a universidade, e que terá como resposta medidas de força por parte do regime militar, bem como a mudança de regra para o vestibular, que se torna classificatório, e o início da implantação de uma Reforma Universitária para adequar este nível de ensino aos fins do desenvolvimento econômico propugnado pelo Estado e aos recursos que ele pretendia investir.

Por fim, da mesma forma que o crescimento do Ensino Médio, incluindo a disseminação de cursos preparatórios aos vestibulares em todo o país, foi um fator de impulso à indústria livreira didática para este segmento, também o crescimento do Ensino Superior teve como reflexo a ampliação do mercado do livro didático universitário, com a Companhia Editora Nacional passando também a investir em sua produção. 


\subsection{A Companhia Editora Nacional no período 1961-1969}

Segundo Laurence Hallewell, a produção da Companhia Editora Nacional estabilizou-se em torno de seis milhões de exemplares por ano durante a década de 1960, o que correspondia a cerca de $10 \%$ do total da produção livreira do país. No entanto, o número de edições novas anuais teria sofrido um decréscimo. Se no capítulo 6 registrou-se 349 edições novas para o excepcional ano de 1955 (ver p. 220) e a média anual a partir daí oscilava entre 250 e 200 edições, ao longo da década este número cairá bastante: 133 em 1963, 94 em 1964, 76 em 1968, 81 em 1969 e 77 em 1970 [HALLEWELL, 2005, p. 381]. No entanto, o autor alerta que essa aparente estagnação quantitativa foi compensada por um crescimento qualitativo, definido por uma mudança programática, que ainda manteve a Nacional como a maior e mais lucrativa empresa do ramo editorial.

Para Hallewell, a mencionada mudança programática consistiu em uma deliberada e consciente melhora material e conteudística das inúmeras séries didáticas do catálogo da editora, como uma reação ao aumento da concorrência, com o surgimento de novas editoras como Ática, Ibep, Moderna e a nova FTD, e o engajamento de outras neste segmento, como a Saraiva e Ao Livro Técnico por exemplo, que pretendiam também aproveitar o grande crescimento da escolarização no país e da consequente demanda por livros didáticos, como vimos no tópico anterior.

De fato, poderemos constatar no próximo tópico, dedicado ao design de capa e miolo, esse investimento na visualidade dos livros, com a maior variação de formatos, incremento do uso da cor em ilustrações, fotografia e elementos gráficos e, destacadamente, a particularização de projetos gráficos de miolo para cada obra. No entanto, é preciso que se diga que essas editoras surgiram e passaram realmente a concorrer com a Nacional somente a partir da segunda metade da década de 1960 e principalmente na década de 1970. Com isso se quer dizer que a mudança programática mencionada por Hallewell, ao menos no aspecto da visualidade, deveu-se mesmo a um movimento da própria editora, iniciado nos anos 1950 e aprofundado já no início dos anos 1960, com o investimento em projetos gráficos particulares para cada obra, justificando a definição de um novo período de design apoiando-se nesse fato.

De qualquer forma, a ênfase que o autor dá ao livro didático e a uma mudança programática em sua concepção corresponde realmente ao seu papel como carro-chefe da editora, confirmado pela aferição de que, em 1966, 55\% dos livros didáticos vendidos no país provinham da Nacional [Hallewell, 2005, p. 372]. Daí termos tomado a produção didática como ponto de partida desta seção de contextualização de sua produção, diferentemente de outros capítulos em que abordamos primeiramente a produção livreira geral, não didática, para em seguida nela inserir a especificamente didática. 
Com relação à produção não didática, se em geral houve uma diminuição de lançamentos, títulos de grande tiragem continuavam constando do catálogo da editora. Alguns deles pertenciam à Biblioteca do Espírito Moderno, como História da Filosofia Ocidental, de Bertrand Russel, História da Filosofia, de Will Durant, Estudos de História Contemporânea, de Arnold Toynbee, mas principalmente os romances de Ernest Hemingway (Adeus às armas e Por quem os sinos dobram), de George Orwell (1984), de Rudyard Kipling (O livro da Jangal e Kim), de Lin Yutang (Uma folha na tempestade e Momentos em Pequim), dentre outros [FonSECA, 2010, p. 243, e 269-270].

Alguns livros avulsos, não pertencentes a coleções, obtiveram reimpressões e grandes tiragens durante a década de 1960, como: Dona Benta - Comer bem (livro de receitas); Como fazer amigos e influenciar pessoas, de Dale Carnegie; Guia de boas maneiras, de Marcelino Pires de Carvalho; Pollyanna e Pollyanna moça, de Eleanor H. Porter, dentre outros citados por BedA [1987, p. 322], que menciona números de edições e tiragens, alguns com centenas de milhares. Os livros de Thales de Andrade, Saudade, e de Viriato Correa, Cazuza, continuam sendo editados e tendo grandes tiragens, com as mesmas capas da década anterior, mas História do Brasil para crianças ganha capa nova, de Eugênio Hirsch (FIG. 7.1).

A editora tinha também livros de referência, como dicionários de línguas e de ortografia do português, que também chegaram a centenas de milhares de exemplares em todas suas edições. Mas foi justamente em 1963 que Octalles Ferreira reteve para a Nacional os direitos autorais do Pequeno Dicionário Brasileiro da Língua Portuguesa, supervisionada por Aurélio Buarque de Hollanda e editado pela Civilização Brasileira, até aquela data subsidiária da Nacional, embora já fosse dirigida por Enio Silveira, genro de Octalles. Em 1969, o dicionário passou a sair com o selo da CEN e até 1973 teve tiragem de 182.000 exemplares, quando retornou para Civilização Brasileira. Em 1975, sem acordo com esta editora, Aurélio Buarque de Hollanda lança um novo dicionário pela Nova Fronteira, derivado do antigo Pequeno Dicionário editado pelas editoras de Octalles Ferreira desde a década de 1950 [BEDA, 1987, p. 323-325].

Das antigas coleções de romances populares da Nacional, em pesquisa em sebos não se encontrou exemplares da década de 1960 da Biblioteca das Moças e da Paratodos, o que pode indicar sua descontinuidade, e apenas alguns poucos títulos da Terramarear para volumes da série Tarzan, com as mesmas capas da década de 1950 (ver FIG. 6.1). Mas a antiga coleção Brasiliana, integrante da Biblioteca Pedagógica Brasileira como série V (ver p. 140-141), continua recebendo títulos novos, agora com formato maior, de 14,0 x 21,0 cm, conhecido como americano, e novo leiaute de capa, que não menciona a antiga coleção de que fazia parte (FIG. 7.2).

Em 1968, a Nacional iniciou a publicação de livros de arte relacionados à história do Brasil, com o álbum Minas: Cidades barrocas, com desenhos de Renée Lefèvre e texto de Sílvio Vasconcellos, seguido de outros como Vale do Paraíba: Velhas Fazendas, com desenhos de Tom Maia e texto de Sérgio Buarque de Holanda, em coedições com a Editora da Universidade de São Paulo. 
Por fim, com o crescimento do ensino universitário e a consequente ampliação do mercado de livros para este segmento, a Nacional lança, ainda no início da década de 1960, a Biblioteca Universitária, com várias séries (Filosofia, Ciências Sociais, Ciências Puras, Ciências Aplicadas, Letras e Linguística) (FIG. 7.1), organizada por acadêmicos como João Cruz Costa, Florestan Fernandes e Antonio Candido, dentre outros da Universidade de São Paulo, numa iniciativa que Laurence Hallewell considera como pioneira, por seu caráter sistemático e abrangência [HALlEWELL, 2005, p. 376]. Com as obras que a editora já publicava para este segmento, mais a Biblioteca Universitária, com seus quase cem títulos, e as que se seguiram a ela, como a coleção Cultura, Sociedade, Educação, a coleção Ensaio (dirigida por Antonio Candido) e a coleção Roteiro do Brasil (dirigida por Rubens Borba de Morais), a Nacional chegou a mais de 300 títulos para o segmento universitário [BEDA, 1987, p. 308-310 e HALLEWELL, 2005, p. 374-376].
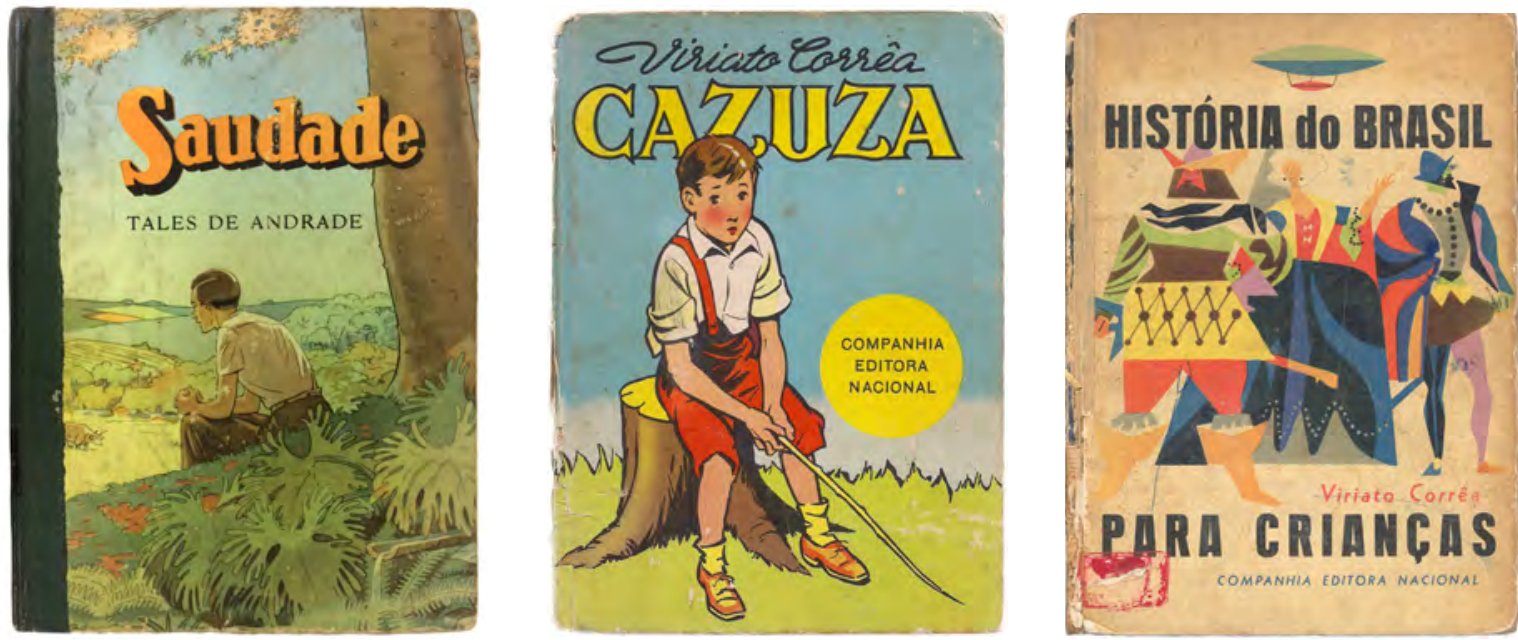

Fig. 7.1. Tales de Andrade, Saudade, 1962 e Viriato Corrêa, Cazuza, 1967, ambas com capas de J. G. Guillin, da década de 1940. Viriato Corrêa, História do Brasil para crianças, 1961, capa de Eugênio Hirsch. [Fontes: AHECC/CRE Mario Covas/EFAP/SEE-SP, acervo pessoal e BLDFEUSP.]
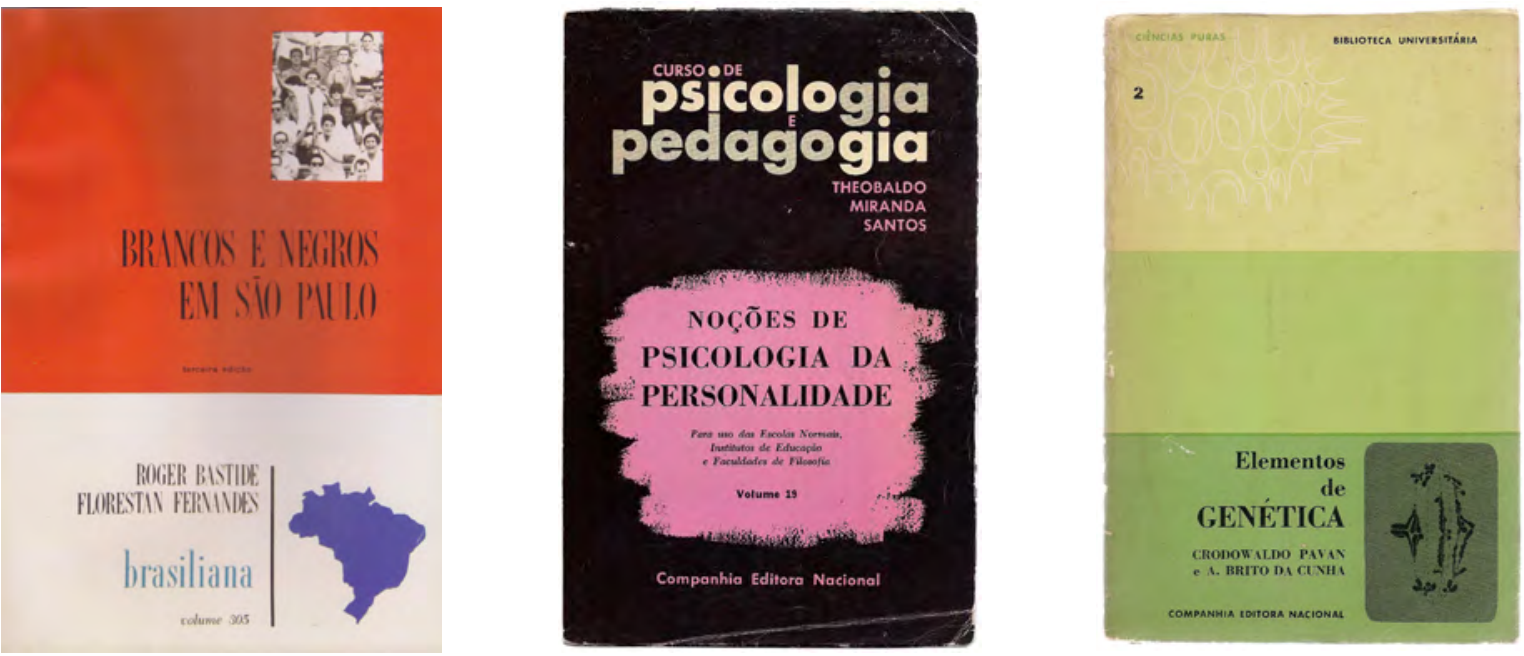

Fig. 7.2. Capas da Coleção Brasiliana (s/d), do Curso de Psicologia e Pedagogia (1967) e da Biblioteca Universitária (1966). [Fontes: IBEP, 2005 e acervo pessoal.] 


\subsection{O design e a materialidade dos livros didáticos da Companhia Editora Nacional de 1961 a 1969}

O corpus da pesquisa material para este período, obtido na totalidade no acervo da $\mathrm{Bi}$ blioteca do Livro Didático da FEUSP, é constituído de 69 títulos ou edições de obras didáticas, assim distribuídos:

- Livros para o Primário e de Admissão ao Ginásio: 9 títulos ou edições;

- Livros para o Ginásio: 39 títulos ou edições;

- Livros para o Colegial: 21 títulos ou edições.

Neste período predomina o acabamento em capa dura, com ocorrência de brochuras para - Colegial e para as cartilhas e livros de leitura, estes últimos considerados livros de perfil mais popular desde períodos anteriores. Há uma maior diversidade de formatos, predominando os de 13,0 x 19,0 cm e 15,0 × 21,0 cm, mas aparecendo formatos intermediários, como consequência da particularização maior que algumas obras recebem em função de projetos gráficos específicos que passam a ser desenvolvidos já nos primeiros anos da década. Embora cada obra receba agora seu projeto específico, o texto corrente, legendas e atividades continuam compostos em fonte serifada e suas variações itálico, negrito, versalete e negrito itálico, com apenas as paginas pré-textuais e títulos utilizando fontes não serifadas.

Diferentemente dos períodos tratados nos capítulos anteriores, em que a produção independente de capa e miolo e a aplicação de projeto gráfico e procedimentos padronizados para grande número de obras justificou a apresentação separada do design desses componentes, neste capítulo as obras serão apresentadas com design de capa e miolo reunidos. O motivo é justamente a mudança geral de procedimento da editora, em que parte considerável dos livros didáticos produzidos no período trazem projetos gráficos específicos, principalmente para as disciplinas de História, Matemática, Ciências, Geografia e Línguas, com casos em que capa e miolo são desenvolvidos por um mesmo designer. Como as mudanças de design tenderam a se estabelecer para um conjunto de obras de cada disciplina, os livros estão agrupados por disciplina em sequência cronológica.

Mesmo nos inúmeros casos em que a autoria comum de capa e miolo não ocorre, e uma relação formal entre capa e miolo é mais fraca ou ausente, a apresentação conjunta foi mantida pois as capas produzidas no período são exclusivas para cada livro, e não mais padronizadas para um conjunto deles. Além disso, se nessas capas não se encontra a coesão e coerência formal que o olhar de hoje sabe identificar, acostumado com um design que procura integrar sintaticamente com bastante rigor os dois componentes, para o olhar da época é possível que a identificação entre capa e miolo se desse pela presença em ambos de um repertório então percebido de forma genérica como "moderno" ou "atual". 


\subsubsection{Os livros de História e o trabalho de Eugênio Hirsch}

A edição de 1961 de História do Brasil, de Joaquim Silva, encontrada no acervo histórico da Companhia Editora Nacional em 2008 quando ele estava aberto à pesquisadores, já tinha o design da edição de 1965, apresentado nas FIGURAS 7.3 a 7.5, e trazia como crédito "diagramação Eugênio Hirsch". Foi certamente um dos primeiros trabalhos no país do designer austríaco, chegado da Argentina na segunda metade da década de 1950, em atividade que antecedeu sua marcante atuação na Editora Civilização Brasileira como autor das capas que conferiram a imagem gráfica daquela editora e revolucionaram o design dos livros no país, na década de 1960, conforme pode ser visto em Mariz, 2005, Nogueira, 2009 e Von Metzen, 2013.

O crédito "diagramação" foi provavelmente o que se encontrou na ocasião para nomear um trabalho de design e edição de arte mais abrangente do livro, pouquíssimo praticado na editora, ao menos nos didáticos', que se caracterizou por uma concepção gráfica geral unitária, que envolveu a realização da capa e o desenho página a página de parte significativa da obra, incluindo a execução de ilustrações, vinhetas e mapas.
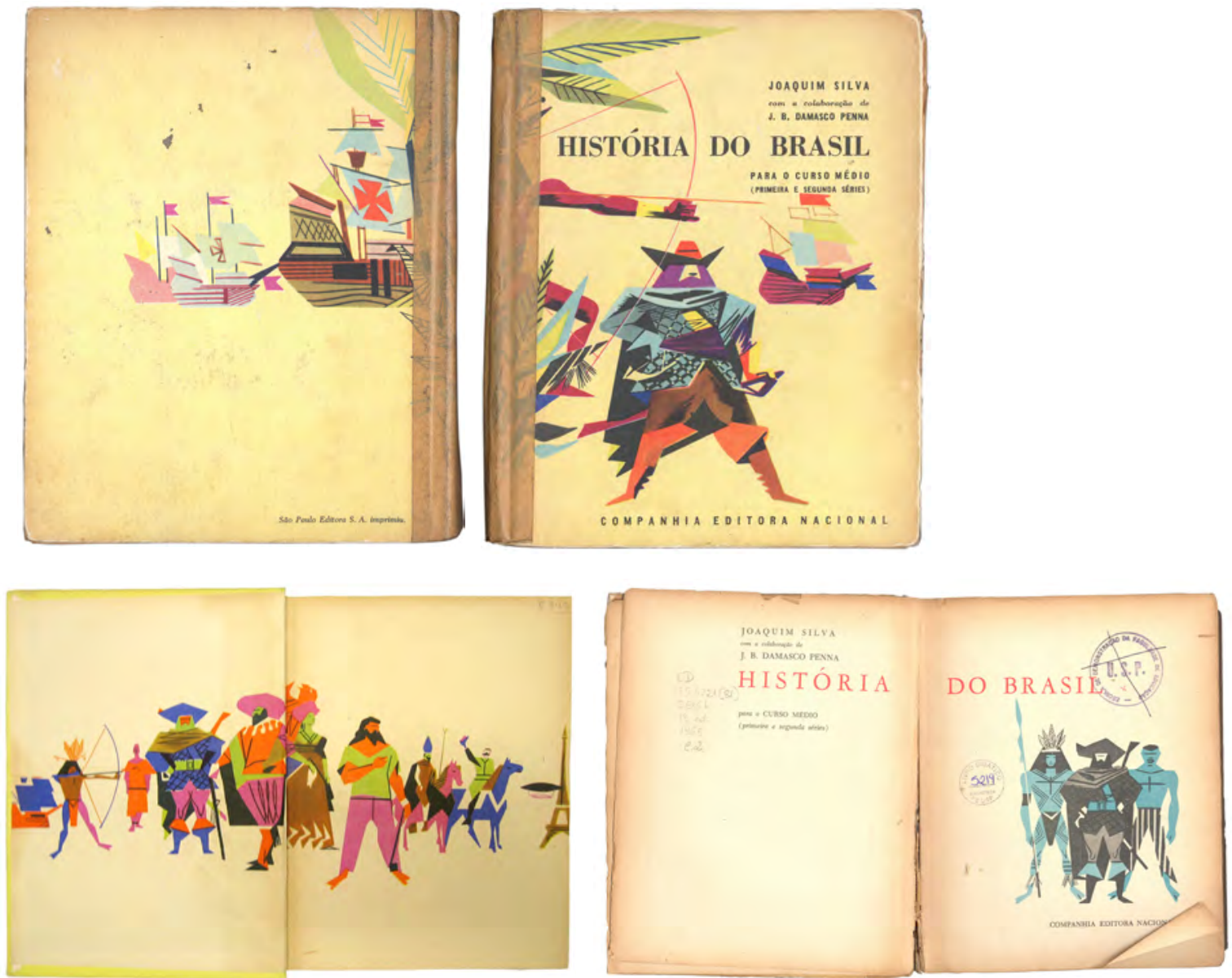

Fig. 7.3. Joaquim Silva, História do Brasil para o curso médio, 1965 (15,2 × 18,8cm). Capa, guardas e dupla de rosto.

Dois antecedentes encontrados nessa pesquisa são a Cartilha de hygiene, de 1928, por Belmonte (ver p. 122-124) e Mon Petit Univers, por J. U. Campos, de 1934 (ver p. 171-172) 

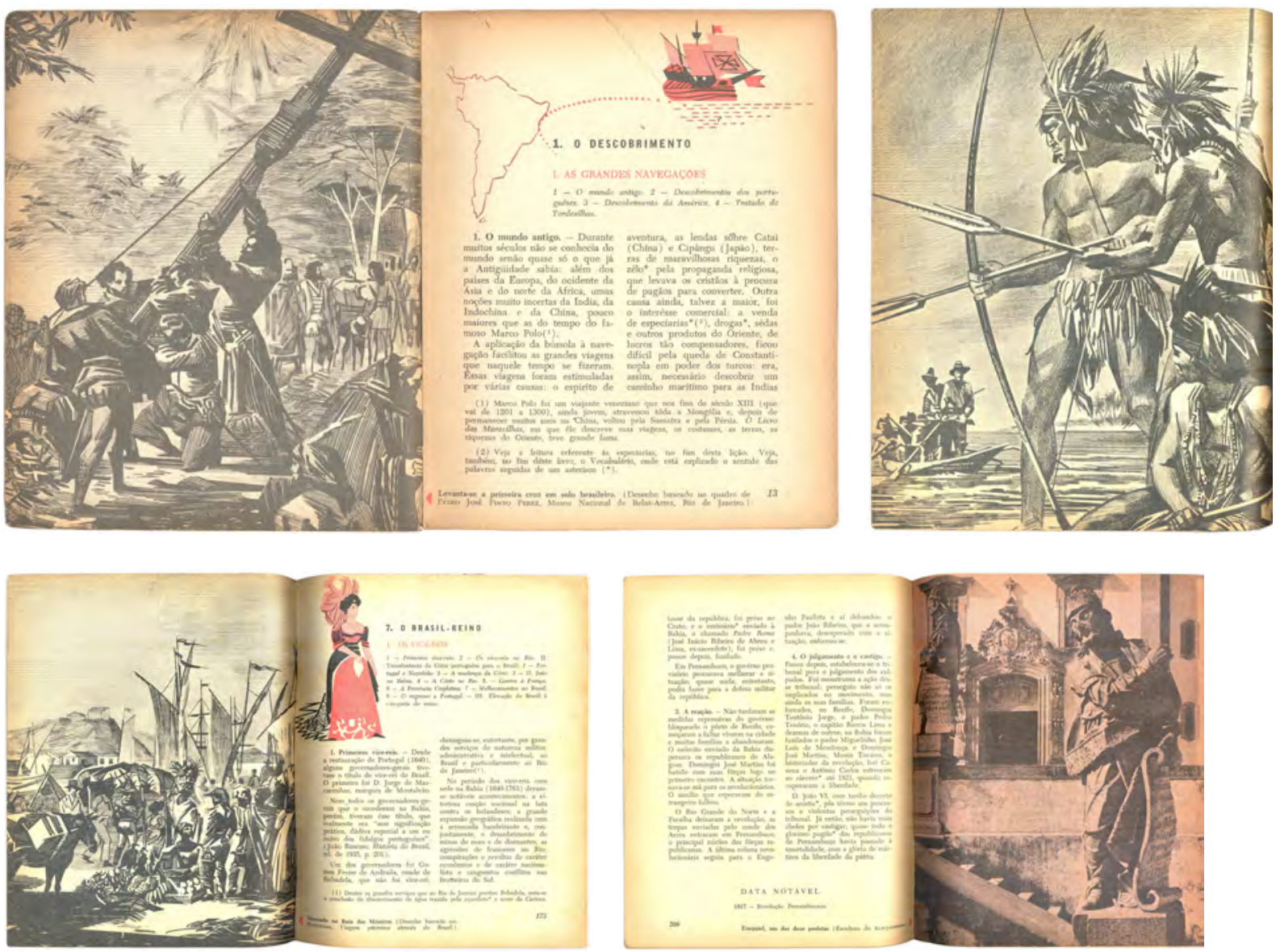

Fig. 7.4. Joaquim Silva, História do Brasil para o Curso Médio, 1965 (15,2 × 18,8cm). Páginas textuais.

A sequência inicial, da capa (com ilustração passando da primeira para a quarta), guarda e rosto, concebido como duplas (FIG. 7.3), tem em comum a linguagem da ilustração inovadora e peculiar de Hirsch, inédita no país não só em livros escolares. Essa unidade é mantida a despeito da passagem da quadricromia da capa e das guardas para a bicromia do miolo, em que a solução das ilustrações estilizadas está presente nas vinhetas e até em mapas (FIG. 7.4 e 7.5). Ilustrações formadas por áreas chapadas e de contornos retilíneos, conservam no entanto detalhes suficientes para se identificar sua referência na iconografia tradicional da história pátria, revelando a pesquisa feita para produzi-las, mas trazendo uma renovação na visualidade dos livros da disciplina e certamente produzindo um interesse pelo conteúdo do livro.

De grande força gráfica e também responsável pela unidade sintática do livro são as as duplas de abertura dos capítulos, constituídas por uma grande "gravura" em traços pretos vigorosos, sangrado na página da esquerda, algumas referenciadas em iconografia histórica, outras mais imaginativas e em ângulos cinematográficos, em linguagem mais "realista" contrastante com a vinheta da página oposta e demais ilustrações "estilizadas".

Também característico dessa obra é a diagramação em duas colunas do conteúdo expositivo e em uma coluna das seções de final de capítulo (Notas, Leituras, Questionário), numa diferenciação funcional até então pouco empregada. 

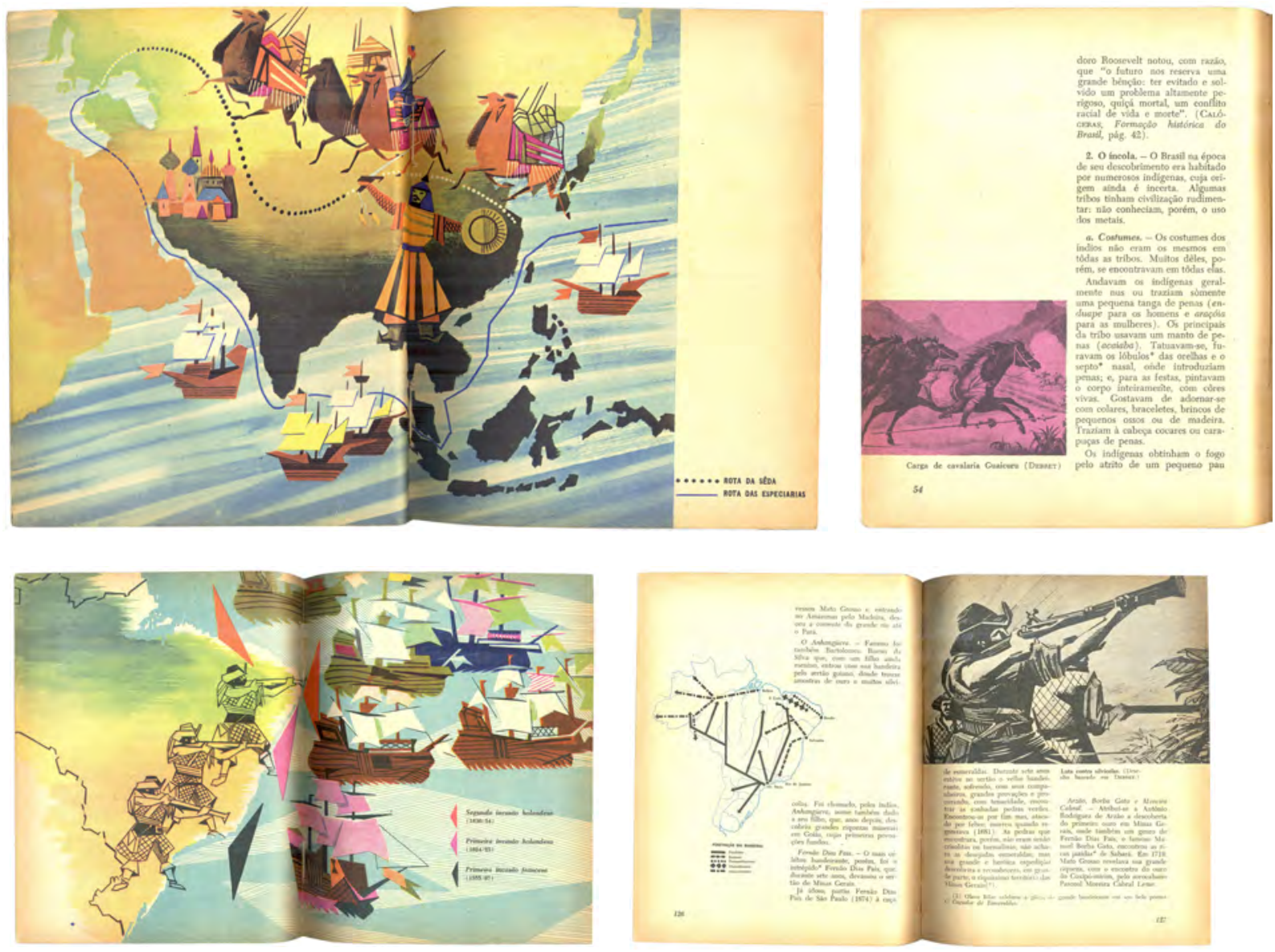

Fig. 7.5. Joaquim Silva, História do Brasil para o curso médio, 1965 (15,2 × 18,8cm). Páginas textuais.

A distribuição das ilustrações informativas e mapas de apoio ao texto também obedeceu a uma diagramação concebida em páginas duplas, e não a uma simples intercalação de materiais iconográficos e textuais ao longo de páginas vistas isoladamente. Igualmente inovadora é a estilização de parte dos mapas, em que a veiculação de informação histórica prescinde do tradicional traçado geográfico preciso, e em alguns casos recebe um tratamento mais livre, com a agregação de personagens e outros elementos que transformam os mapas em ilustrações de grande presença.

A segunda cor, empregada nos títulos, mapas, vinhetas, ilustrações e fundos de fotografias, varia ao longo do livro conforme a distribuição dos cadernos, e em alguns casos há inserção de uma terceira cor e até de páginas duplas impressas em quadricromia, caso dos mapas-ilustração mencionados. O resultado é uma obra graficamente diversa, rica e atraente, certamente com algum efeito na disposição para o aprendizado por parte de seu leitor.

Antecedendo o trabalho de Hirsch, deve-se creditar o trabalho de atualização de conteúdo, linguagem e forma de exposição feito pelo experiente editor J. B. Damasco Penna, para a obra de um autor não-historiador, classificado como tradicional e adotado principalmente em escolas confessionais [PINTO JúNIOR, 2010, p. 144], que no entanto ganhou a visualidade mais atualizada no período. 

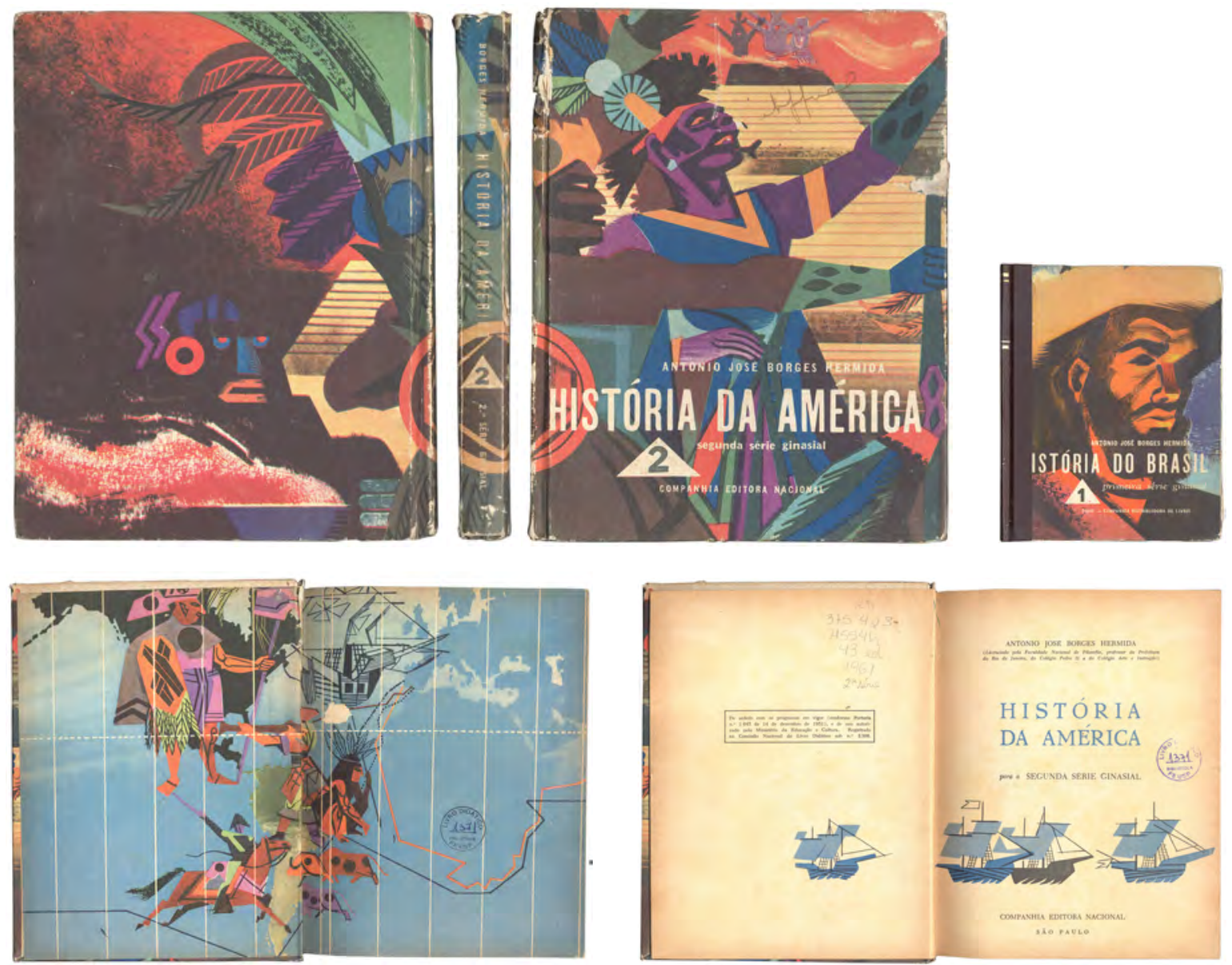

Fig. 7.6. Borges Hermida, História da América, 1961 (14,7 × 18,8cm). Capa, guardas e frontispício. Em reprodução reduzida, capa de História do Brasil, 1961, editado pela Codil.

Embora não creditada, pela data e afinidade formal com a História do Brasil para o curso médio de Joaquim Silva, História da América, de Borges Hermida traz capa, projeto gráfico e ilustrações que podem seguramente ser atribuídas a Eugênio Hirsch, se não a própria diagramação, pelas soluções encontradas (FIG. 7.6). Seria portanto a segunda colaboração do designer para a Nacional.

Voltada para o nível ginasial a capa é mais ousada e vistosa do que a da obra de Joquim Silva e segue um projeto gráfico de coleção, aplicado ao menos ao volume 1, de História do Brasil. Este saiu editado pela Codil (Companhia Distribuidora de Livros), empresa ligada à CEN, numa transição entre a editora anterior da obra, a Editora do Brasil, e a nova editora, a Nacional [BRAUNA, 2013, p. 9].

Guardas coloridas, página de rosto, linguagem das ilustrações, leiaute específico para as aberturas de capítulo, diferenciação tipográfica e de colunagem entre texto principal e seções finais, desenho das páginas como duplas, enfim, as características básicas do projeto encontrado na obra de Joaquim Silva são trazidos para esta obra de outro autor e nível de ensino (FIG. 7.7 e 7.8$)$. 
Na verdade, essas características são aprofundadas, com um número maior de páginas com ilustrações originais, maior intervenção de fundos gráficos em iconografia de época e solução gráfica para todos os mapas de apoio ao texto, com contornos retilíneos e texturas diferentes do padrão geográfico adotado também em livros de história.

Embora utilizando texto composto sobre ilustração sangrada, nas duas capas apresentadas as informações textuais são perfeitamente integradas à ilustração, sendo que em História da América aparece a preferência de Hirsch por fontes serifadas estreitas que caracterizarão parte significativa da produção do designer para a Civilização Brasileira, como pode ser visto em Nogueira, 2009 [p. 69-71 e 107-108].
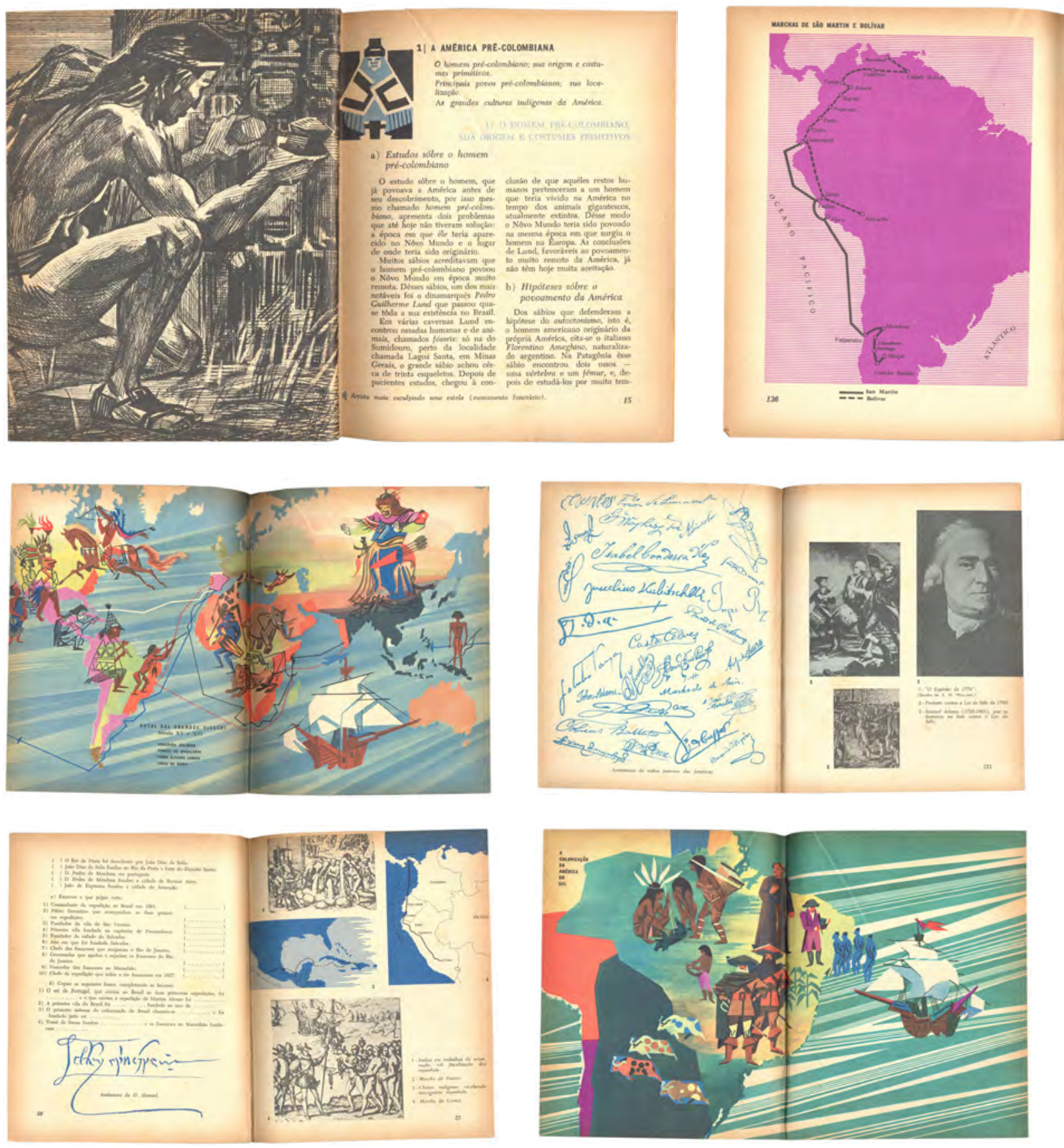

Fig. 7.7. Borges Hermida, História da América, 1961 (14,7 × 18,8cm). Páginas de miolo. 
O projeto gráfico original de Eugênio Hirsch para o miolo do volume de História do Brasil de Joaquim Silva foi aplicado também em obra concorrente destinada ao mesmo nível de ensino, o Compêndio de História do Brasil, de Borges Hermida, na edição de 1965 (FIG. 7.8). Inúmeras ilustrações são reaproveitadas e é possível que algumas ilustrações de páginas duplas ainda tenham sido encomendadas a ele, mas os créditos de produção gráfica a Theobaldo de Nigris e Rubens de Barros Lima indicam a inexistência de atuação de Hirsch como editor de arte nesta obra. A capa apresenta características diferentes de linguagem de ilustração de outros livros creditados a Hirsch, mas traz uma ilustração de qualidade passível de ser atribuída ao designer, com o imperador D. Pedro II retratado jovem, fugindo da iconografia usual que sempre o apresenta idoso.
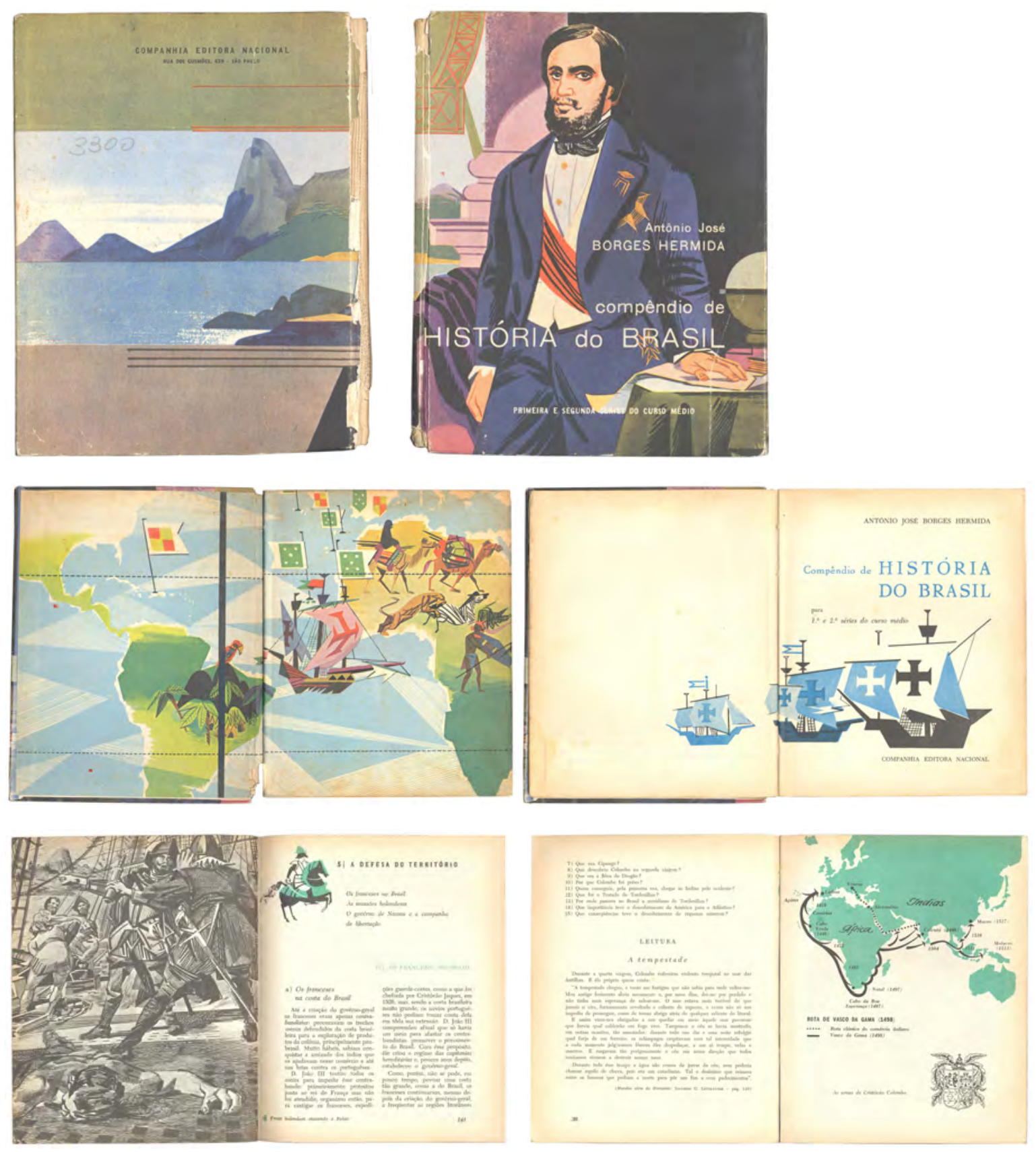

Fig. 7.8. Borges Hermida, Compêndio de História do Brasil: primeira e segunda séries do Ensino Médio, 1965 (14,8 x $18,5 \mathrm{~cm})$. Capa, guardas, pré-textuais e textuais. 
A edição de 1969 do Compêndio de História do Brasil, de Borges Hermida, já se distancia do trabalho de Hirsch presente nesta e em outras obras do autor, mas ainda traz formato, diagrama em duas colunas e aproveitamento de algumas ilustrações. Sua capa, no entanto, rompe a sequência de apoio no uso de ilustrações (FIG. 7.9).

Com uma solução fotográfica, a limitação cromática ao preto (e cinza resultante da reprodução PB do quadro), ao dourado sugerido em textos e ao cobre da moeda, sobre fundo branco, resultam em sensação de sofisticação, completada pela fonte serifada do título. A disposição das formas fechadas (quadro e moeda) e abertas (linhas de texto) e a alternância das cores resultam no equilíbrio dinâmico, não simétrico, e mesmo sem utilizar um efeito de sombra simulando a moeda sobre o papel, um contraste volume/plano é obtido e acrescenta um interesse maior à composição.
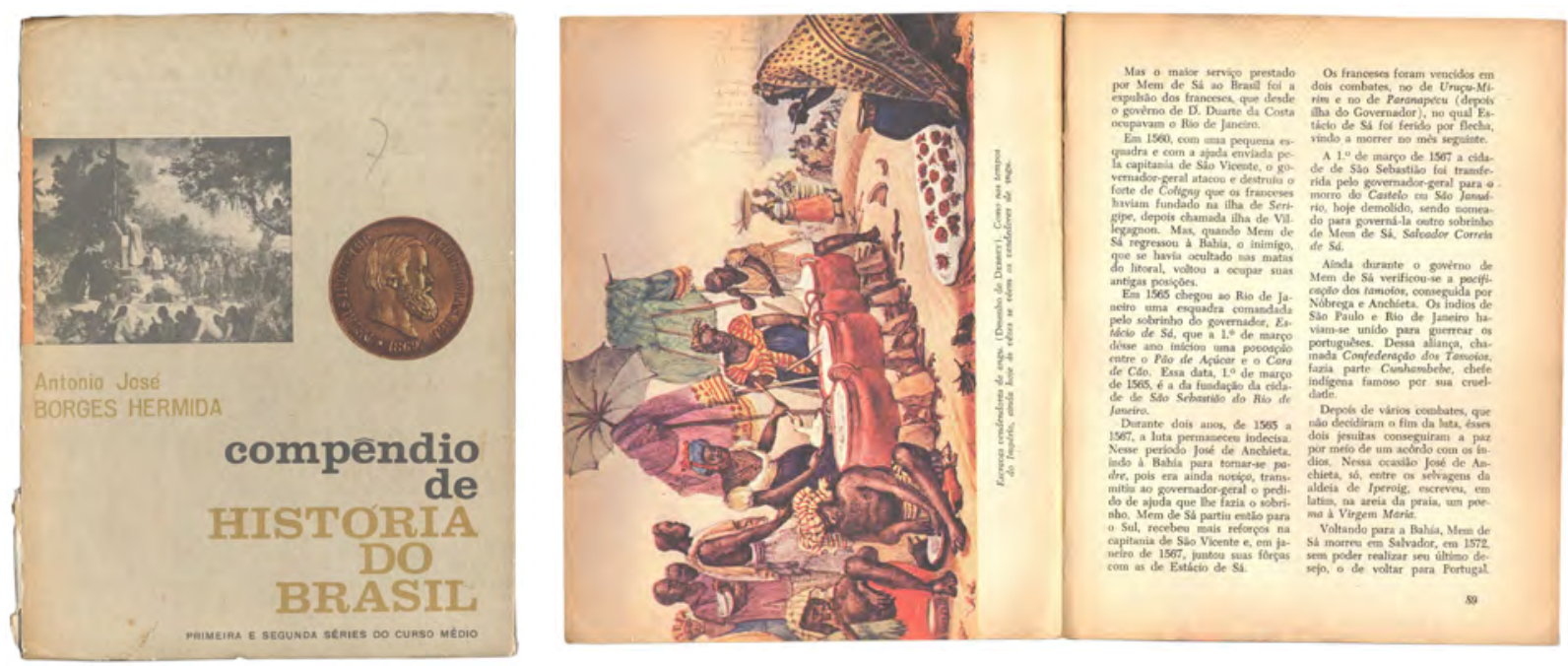

Fig. 7.9. Borges Hermida, Compêndio de História do Brasil: primeira e segunda séries do Ensino Médio, 1969 (14,8 x $18,5 \mathrm{~cm})$. Capa, guardas, pré-textuais e textuais.

O Compêndio de História Geral (FIG. 7.10), embora tenha a produção gráfica creditada a Theobaldo de Nigris e Rubens de Barros Lima, traz reaproveitamento de algumas ilustrações de Eugênio Hirsch, páginas pré-textuais desenhadas como dupla, como o rosto reproduzindo a ilustração da capa, e características de diagramação de miolo inauguradas pelo designer, mas numa edição impressa apenas em preto.

A capa, não creditada, traz uma solução apoiada em ilustração e é muito bem realizada. A subdivisão em três da área central, criando retângulos coloridos que suportam as ilustrações, cortam o campo branco criando três áreas também na direção vertical, em proporções que equilibram a relação entre imagens e informações textuais de autoria e título. Nestas, o contraste tipográfico e cromático interno, com o preto ressaltando o azul, comum também à área central da ilustração como uma ponte entre elas, amarra a composição. A delicadeza do 
traço das ilustrações, a suavidade das cores e a proporção de branco completam o efeito de clareza e tranquilidade da composição geral, que se prolonga para a quarta capa. A impressão é em quadricromia.
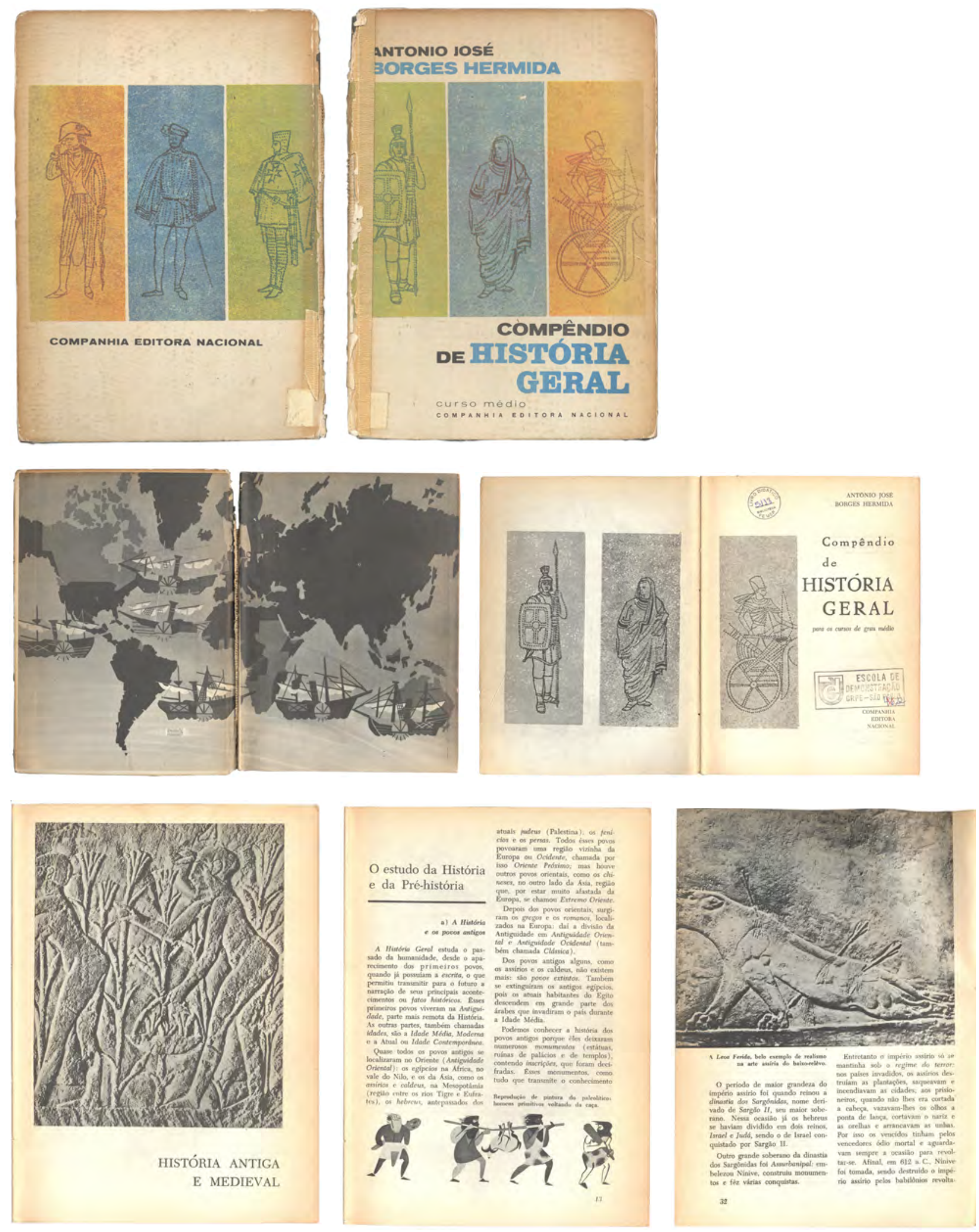

Fig. 7.10. Borges Hermida, Compêndio de História Geral: curso médio, 1969 (15,0 × 20,7cm). Capa, guardas, rosto e páginas textuais. 


\subsubsection{O design dos novos livros de Matemática, Ciências e Desenho}

Se o projeto gráfico e a edição de arte dos livros de Joaquim Silva e Borges Hermida ofereceram uma visualidade mais atualizada para obras de conteúdo tradicional do ponto de vista historiográfico e pedagógico [BRAUNA, 2013, p. 4-5], novas obras que a editora queria oferecer como renovadoras do ensino precisariam mais ainda ser associadas a uma visualidade renovada. Assim, Matemática, curso moderno, de Osvaldo Sangiorgi, introdutor da Matemática Moderna no Brasil2, recebeu um tratamento da editora que teve como antecessor - se não um modelo mesmo - a abordagem inaugurada por Hirsch nos livros de História. Em Matemática: curso moderno, a visualidade corresponde mais estreitamente ainda às intenções autorais, pedagógicas e comerciais da coleção e o impacto de seu lançamento po de ser medido pela obtenção do prêmio Jabuti na categoria Ciências Exatas em 1963.
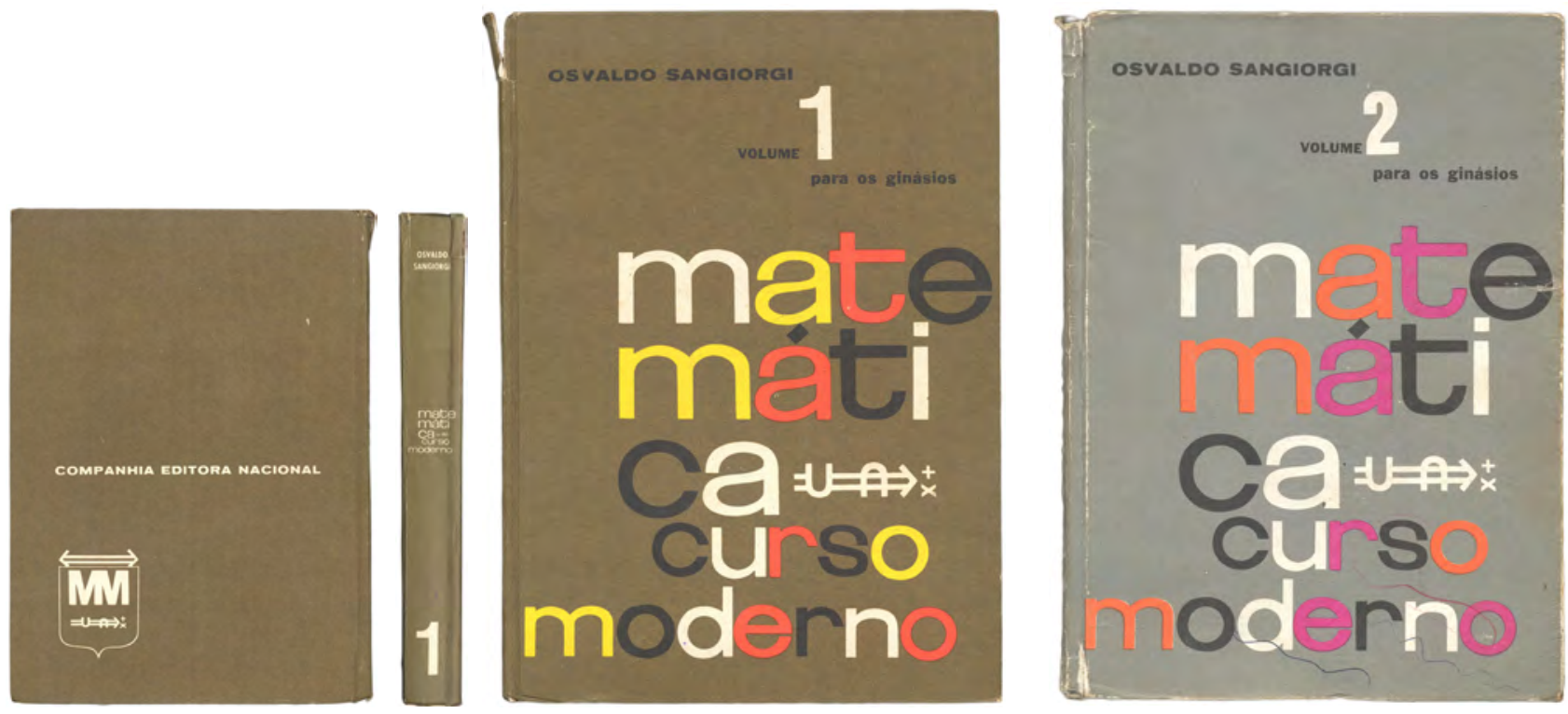

Fig. 7.11. Osvaldo Sangiorgi, Matemática: curso moderno, $1964(15,0$ × 21, 0 cm). Capas dos volumes 1 e 2.

Embora diferentemente das obras de História mencionadas não haja uma relação formal estreita entre a linguagem das capas (FIG. 7.11 e 7.12) e dos miolos (FIG. 7.13 a 7.16), ainda mais que cada volume teve intencionalmente um partido gráfico próprio, o conjunto oferece a mensagem de que se trata de uma obra nova, moderna.

A solução exclusivamente tipográfica, com o título transformado numa grande imagem, grafado em letras sem serifa semelhantes à fonte Helvetica, uso exclusivo de caixa baixa e quebra de palavras indicam uma referência a formas do chamado Estilo Internacional, particularmente a vertente conhecida como tipografia funcional [ver MEGGS; PURVIS, 2009, p. 471-

\footnotetext{
2 A Matemática Moderna foi um movimento de reformulação do ensino da disciplina, iniciado na França nos anos 1950 e que rapidamente obteve alcance mundial, alterando programas, sequências, forma de ensino e gerando livros didáticos bastante diferenciados no conteúdo e na forma em relação às obras anteriores (para aprofundamento ver VALENTE, 2008).
} 
472 e FRIEDL; OTT; STEIN, 1998, p. 32 e 457], mas em arranjo orgânico e desenho à mão das letras com liberdade na configuração de alguns caracteres, como o r e o t, que mostram uma apropriação mais livre daquele repertório. A impressão é com cores especiais.

As capas dos volumes 3 e 4, lançados posteriormente, trazem solução gráfica com organização das informações mais convencional, com a disposição linear e extremamente clara das informações textuais, o recurso à ilustração e o maior apelo cromático (FIG. 7.12), mas ainda assim comunicando a abordagem diferenciada e nova da disciplina. A impressão é em quadricromia.
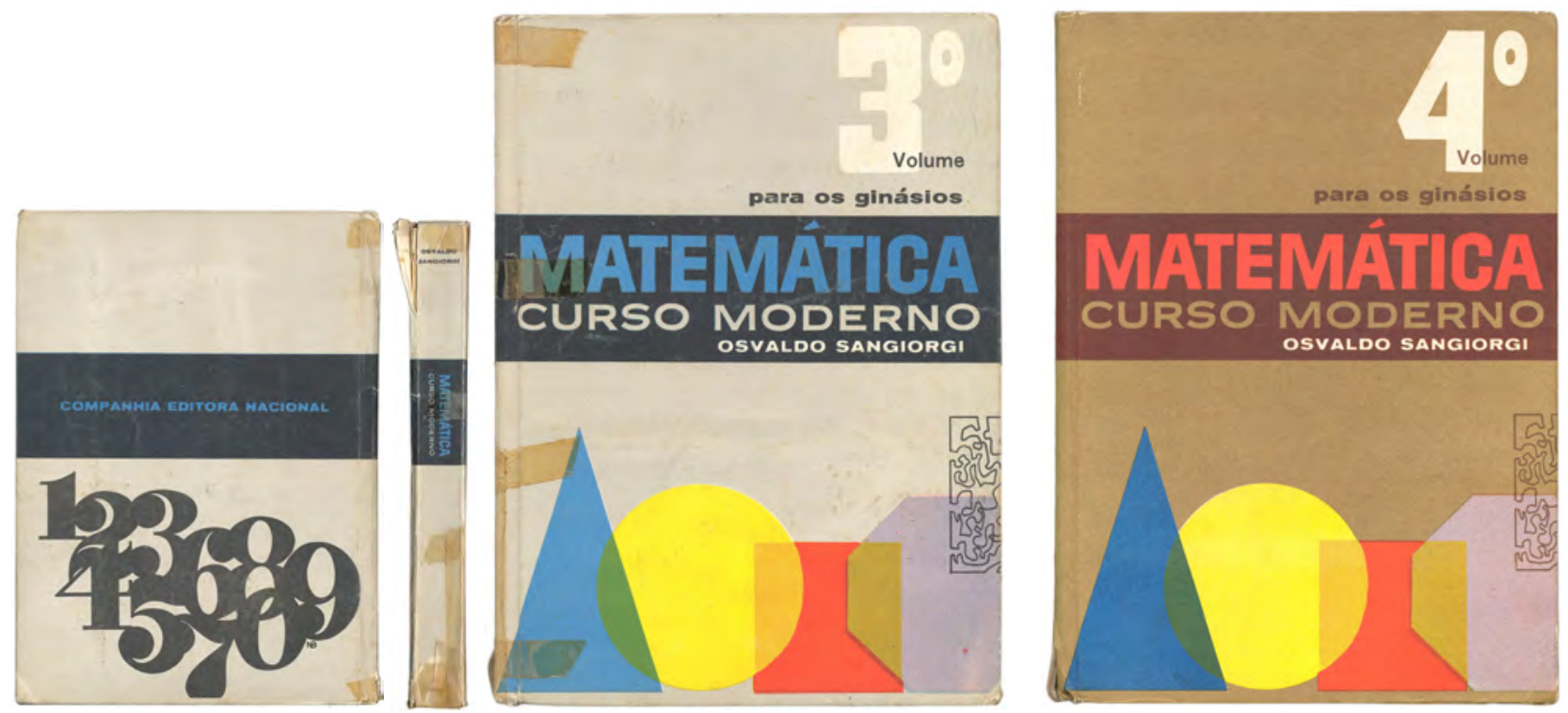

Fig. 7.12. Osvaldo Sangiorgi, Matemática: curso moderno, $1966(15,0 \times 21,0 \mathrm{~cm})$. Capas dos volumes 3 e 4 .

O design de miolo, diferenciado para cada volume, traz elementos gráficos derivados de números, sinais ou símbolos da disciplina e os arranja de maneira bastante livre e variada ao longo dos livros, em guardas e páginas pré-textuais e aberturas de capítulo e suas partes concebidas como duplas (FIG. 7.13 a 7.16), tal qual os livros desenhados por Hirsch.

Embora conste o nome de Nestor Batagliero como ilustrador dos volumes 1 a 3, a presença das ilustrações nas guardas, pré-textuais e textuais, em perfeita integração com os textos, permitem supor que este profissional atuou também como designer e editor de arte. Créditos idênticos em outra obra (Iniciação à Ciência, FIG. 7.21), com capa com trabalho tipográfico semeIhante, indicam ser ele também o autor das capas ao menos dos volumes 1 e 2 .

O volume 4 tem crédito de ilustração de Joel Link, com um estilo que traz a marca da expressão gestual do crayon, mas utiliza o personagem gráfico criado por Batagliero no volume 3 e fotografia nas aberturas de capítulo (FIG. 7.16). Também não se obteviram informações sobre Link e seu regime de colaboração, que é creditado como ilustração mas provavelmente inclui participação no desenho das páginas e indicações para diagramação.

Fig. 7.13. (página oposta) Osvaldo Sangiorgi, Matemática: curso moderno, volume 1, $1964(15,0$ × 21,0 cm). Guardas, páginas pré-textuais e textuais 

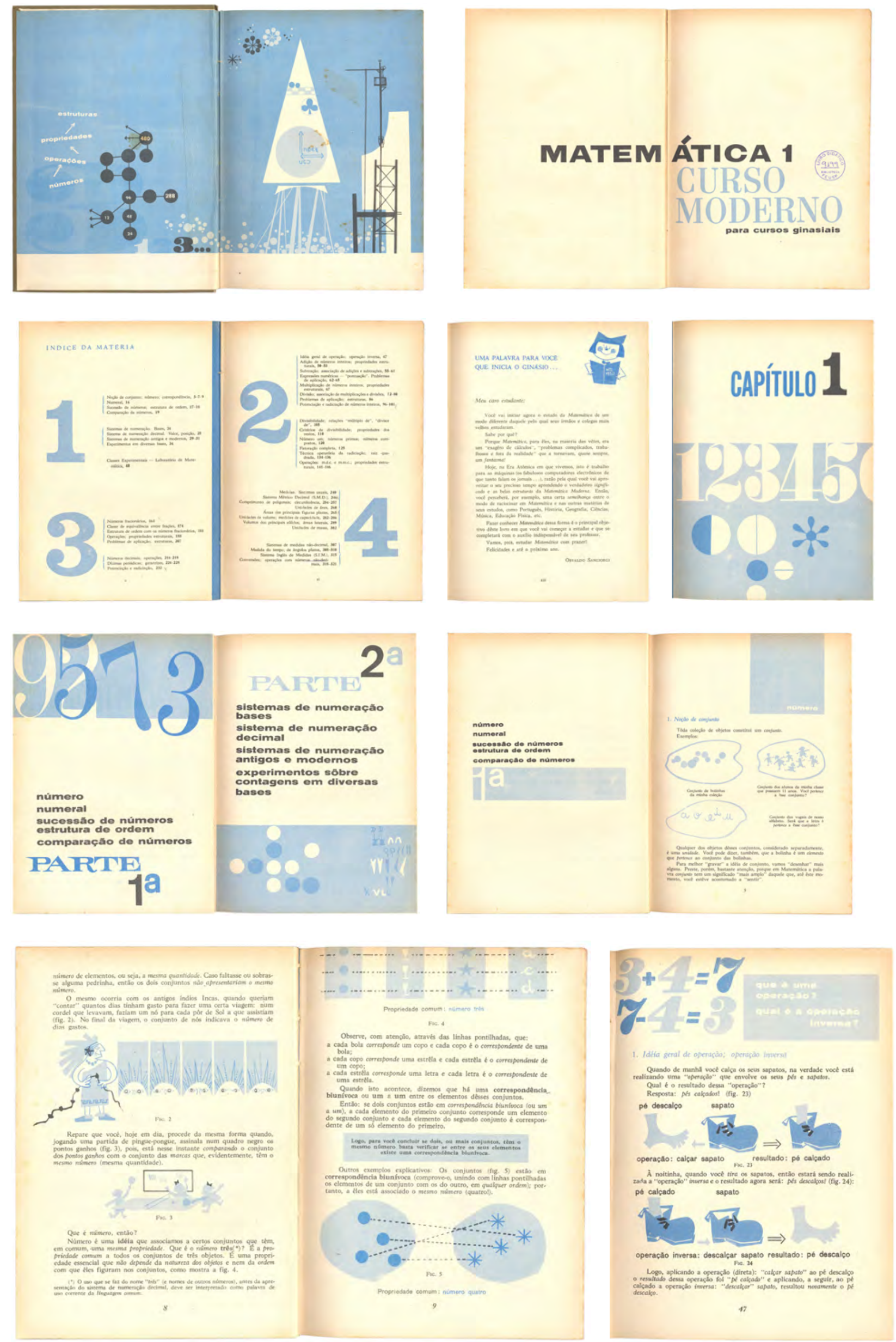

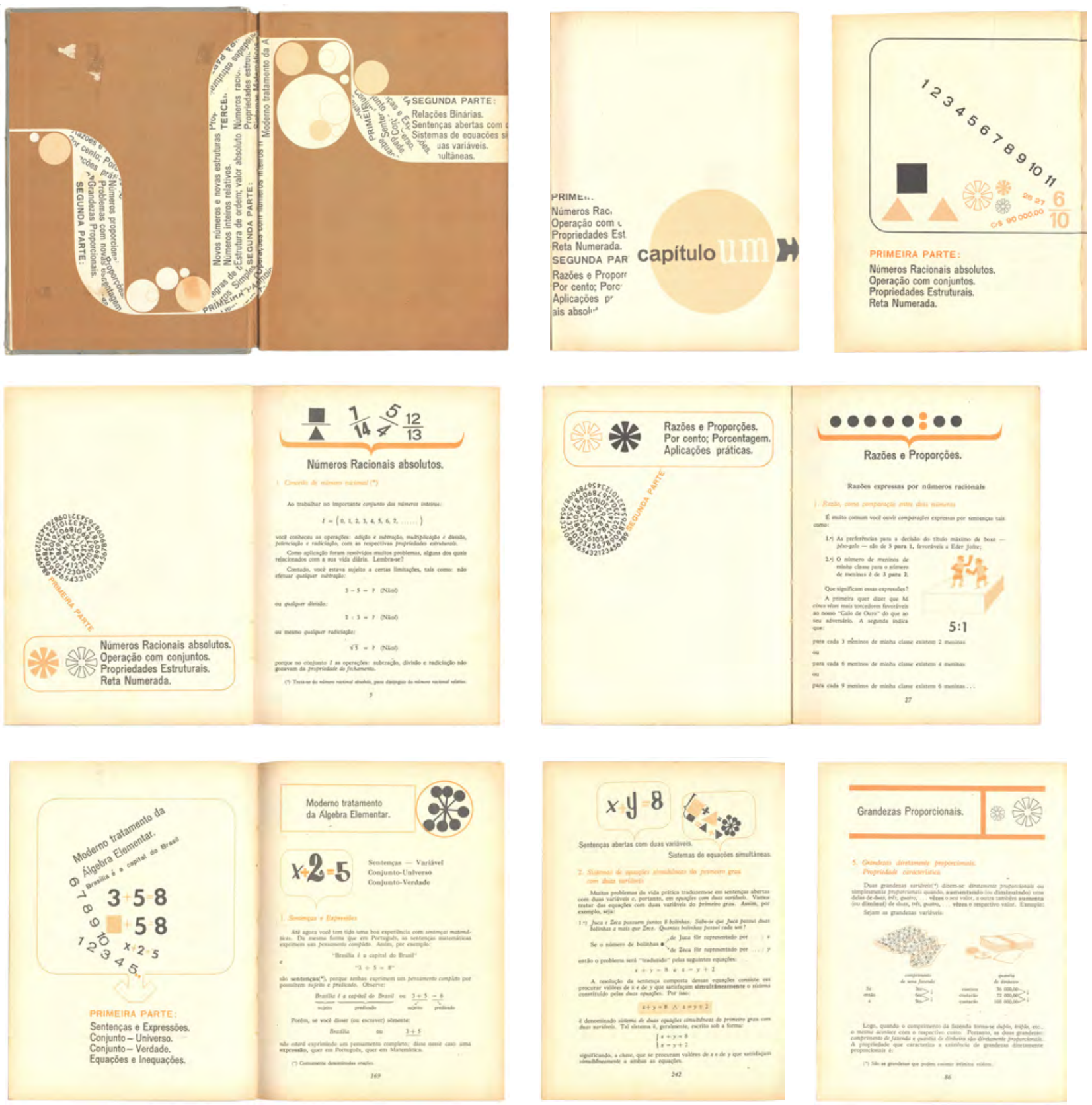

Fig. 7.14. Osvaldo Sangiorgi, Matemática: curso moderno, volume 2, 1965 (15,0 x 21, 0 cm). Capa, guardas e aberturas de capítulo e parte.

Não se obtiveram informações sobre Nestor Batagliero e Joel Link, se eram profissionais autônomos ou internos da editora. Em suas ilustrações gráficas ou tipográficas, utilizavam letras e sinais obtidos em composição e impressão tipográfica, além de alguns desenhados à mão, os quais, segundo o processo usual da época, eram recortados e colados em pranchas denominadas "artes-finais", com as indicações de quais elementos pertenceriam a um ou outro fotolito correspondente ao preto ou à segunda cor sendo marcadas em folhas transparentes sobrepostas a essas artes, conhecidas como overlays [CRAIG, 1980, p. 166-173]. 

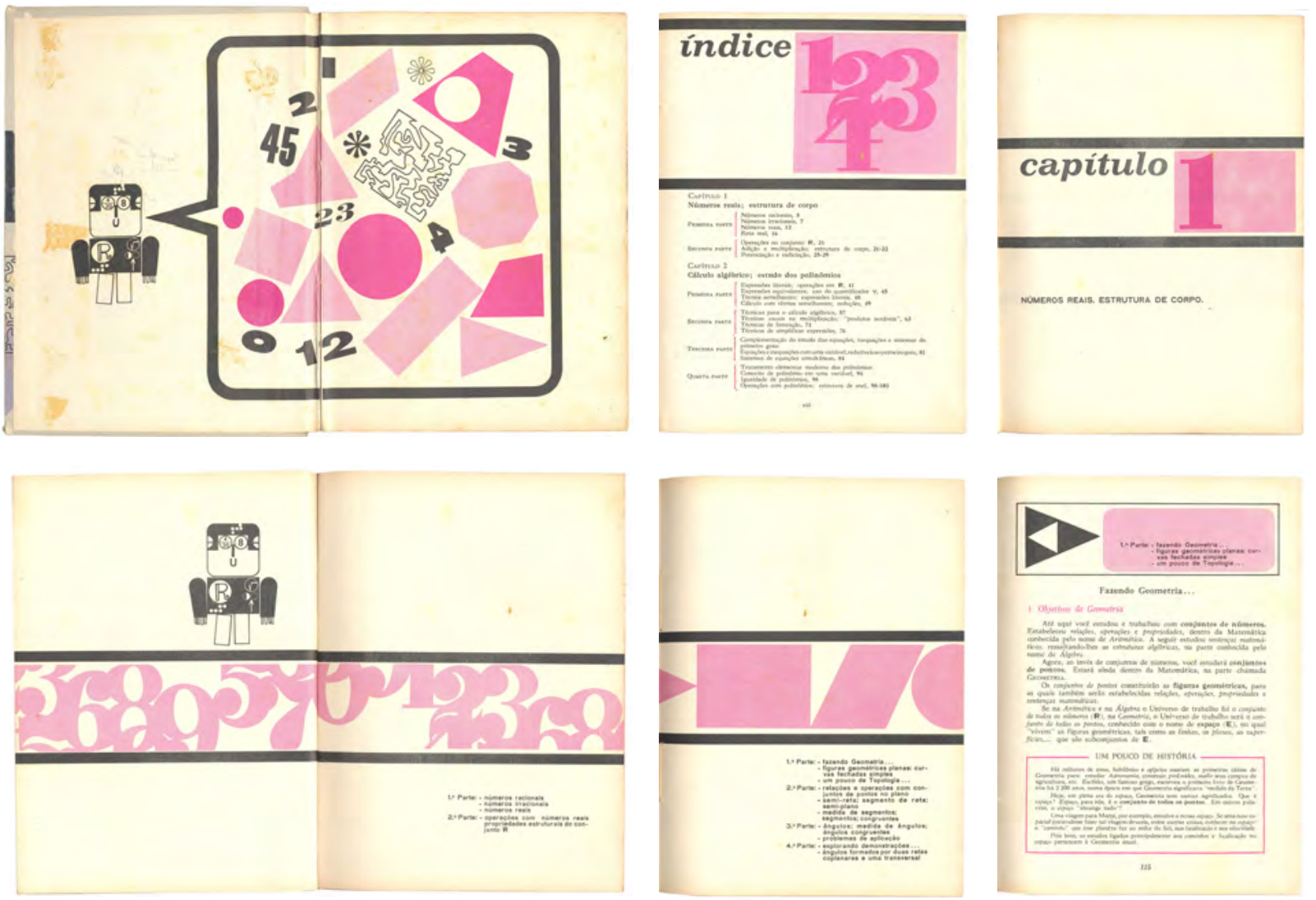

Fig. 7.15. Osvaldo Sangiorgi, Matemática: curso moderno, volume 3, 1968 (15,0 × 21, 0 cm). Guardas e páginas textuais, ilustrações Nestor Batagliero.
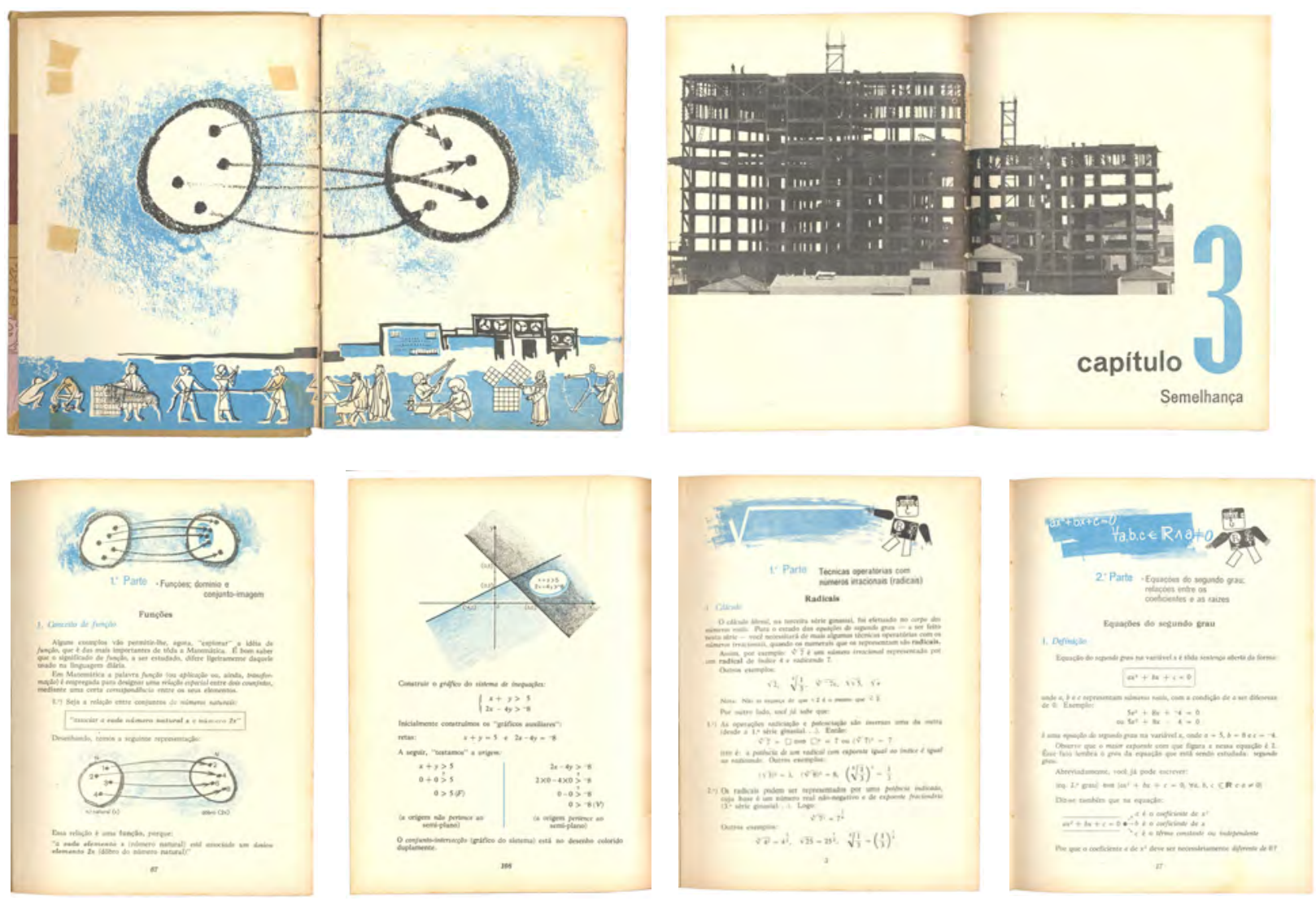

Fig. 7.16. Osvaldo Sangiorgi, Matemática: curso moderno, volume 4, 1968 (15,0 x 21, 0 cm). Capa, guardas e páginas textuais, ilustrações Joel Link. 
Os volumes de primeira a terceira séries de Matemática de Ary Quintella para o Ginásio (FIG. 7.17) não trazem um trabalho de diagramação de miolo tão evidentemente renovador como nas obras de Sangiorgi, mas as ilustrações, creditadas ao "arquiteto Hugo Ribeiro", colaborador das edições do autor desde a década de 1950, têm aqui um traço mais livre, como reflexo da modernização geral de visualidade dos livros da disciplina. Isto pode ser confirmado pela encomenda das capas a Eugênio Hirsch, com elas trazendo ilustração e tipografia característicos de seus trabalhos para a Civilização Brasileira.
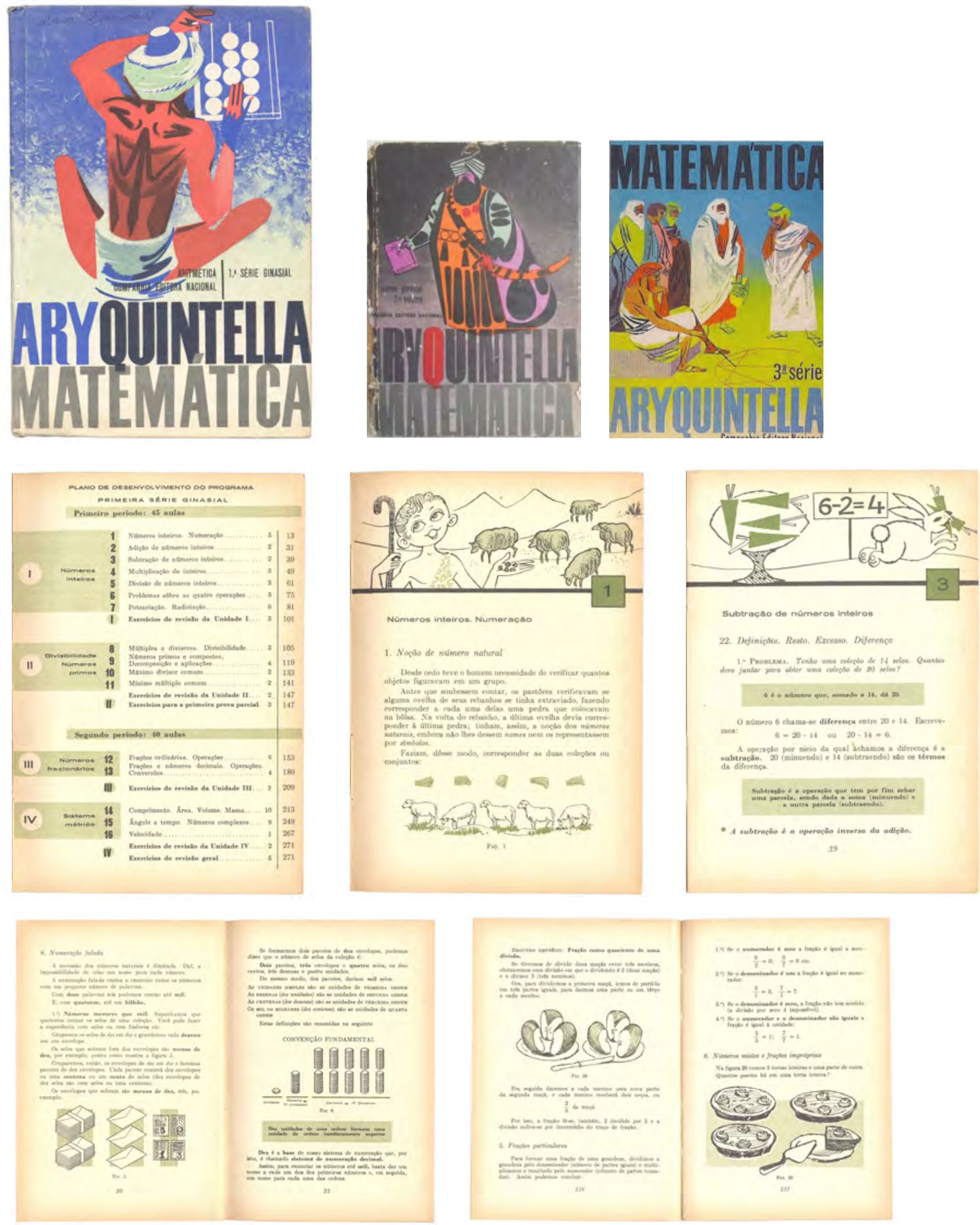

Fig. 7.17. Ary Quintella, Matemática: 1a série ginasial, $1965(13,0 \times 19,0 \mathrm{~cm})$. Capa e páginas de miolo. Imagens em maior redução de capas dos volumes de $2^{\underline{a}}$ e $3^{\mathfrak{a}}$ séries, obtidas em site de busca na Internet. 
O volume de quarta série da mesma coleção já não traz capa de Hirsch, mas o miolo, com ilustrações de Hugo Ribeiro, traz páginas pré-textuais e aberturas de parte e capítulo em linguagem gráfica próxima da encontrada na obra de Sangiorgi, particularmente o volume 4 ilustrado por Joel Link. Sem créditos, a capa deve ser também de Ribeiro.
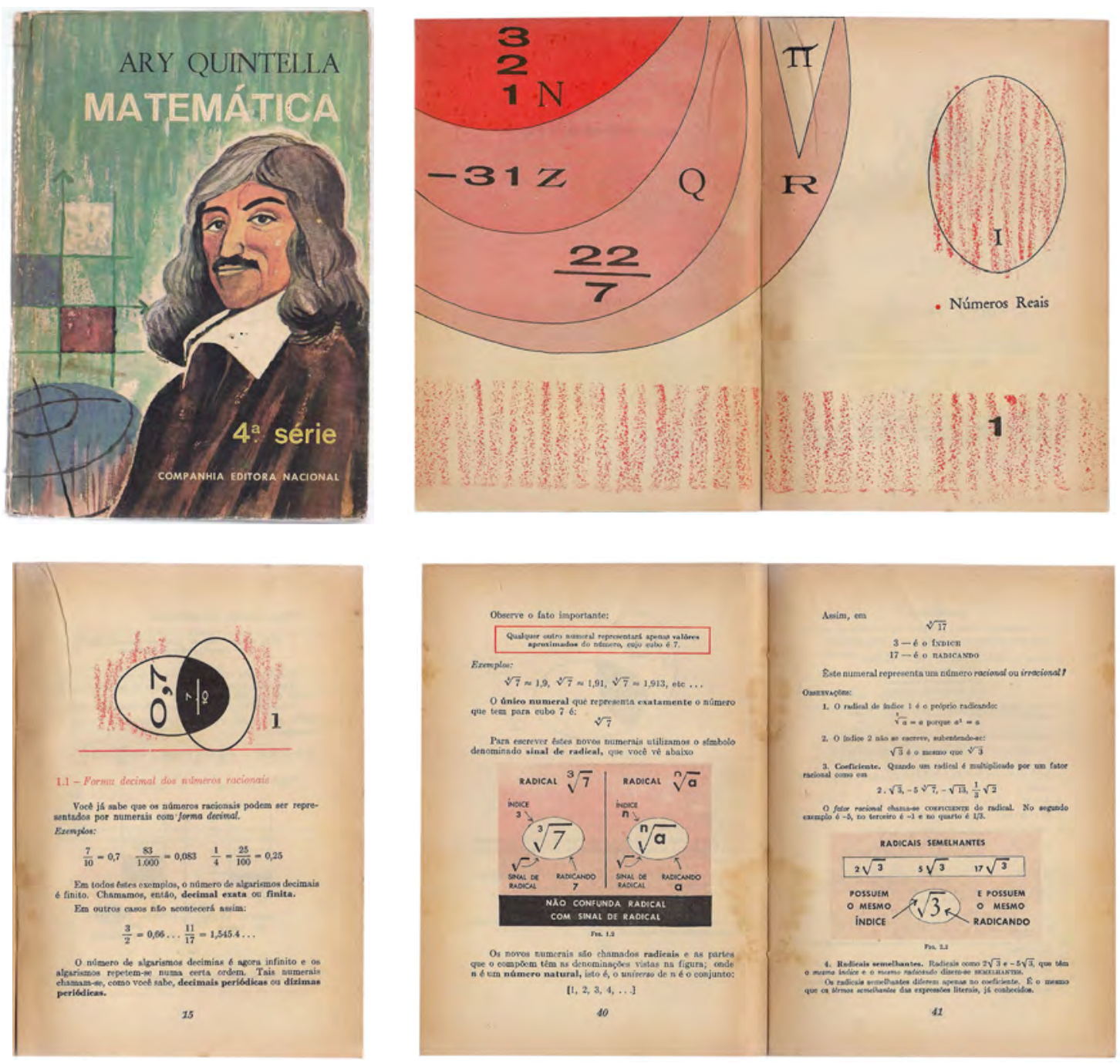

Fig. 7.18. Ary Quintella, Matemática: 4aㅗ série ginasial, 1968 (13,0 × 19,0cm). Capa e páginas de miolo. [Fonte: acervo pessoal.]

Curso de Desenho, de José Arruda Penteado, obra que pelo conteúdo da disciplina já merecera uma produção de arte diferenciada (ver FIG. 6.14 e 6.30), teve em 1965 uma reedição com um investimento especial em visualidade com as mesmas características "modernizadoras" das obras de História e Matemática já vistas (FIG. 7.19 e 7.20).

No miolo, além do uso de segunda cor especial, todas as páginas, das guardas, pré-textuais e textuais recebem desenho especial, não padronizado e concebido em duplas. Note-se a combinação de fontes serifadas e não serifadas, estreitas e largas, e de uso de caixa baixa em títulos. As ilustrações combinam alternância de preto e segunda cor, em linguagem de áreas 
chapadas e silhuetas sem contorno, que também contribuem para uma visualidade percebida como "moderna" na época.

Mesmo sem relação formal estreita com o miolo, a exemplo de Matemática: curso moderno, a capa de Curso de desenho comunica atualidade, tendo solução gráfica com características que indicam provável autoria comum. Como aquela, tem letras desenhadas à mão, numa composição compacta que inclui sobreposição de caracteres e alternância de cores, com impressão em cores especiais e ilustração geométrica.
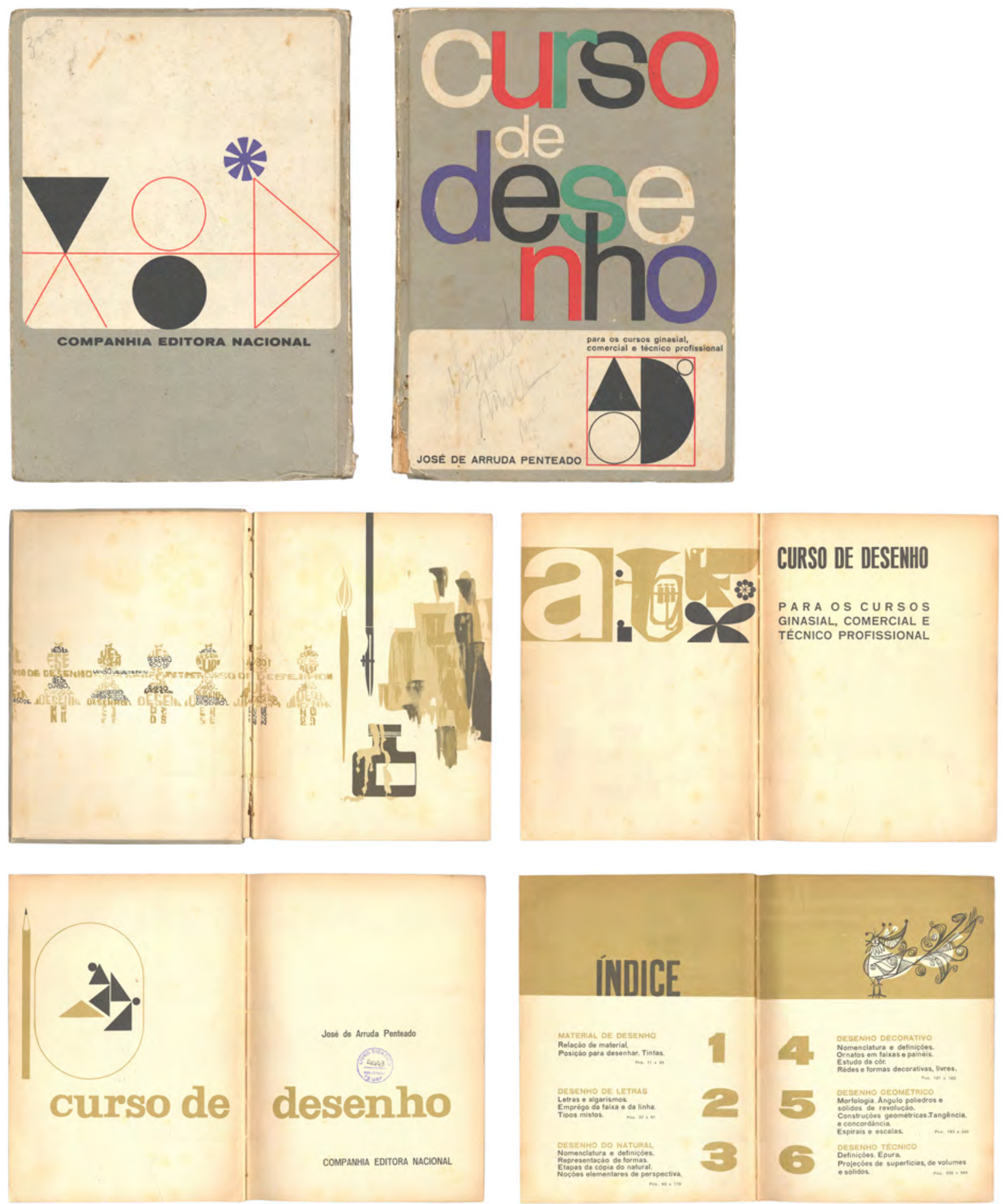

Fig. 7.19. José de Arruda Penteado, Curso de desenho, 1965 (15,0 x 21,0cm). Capas, guardas e pré-textuais. 

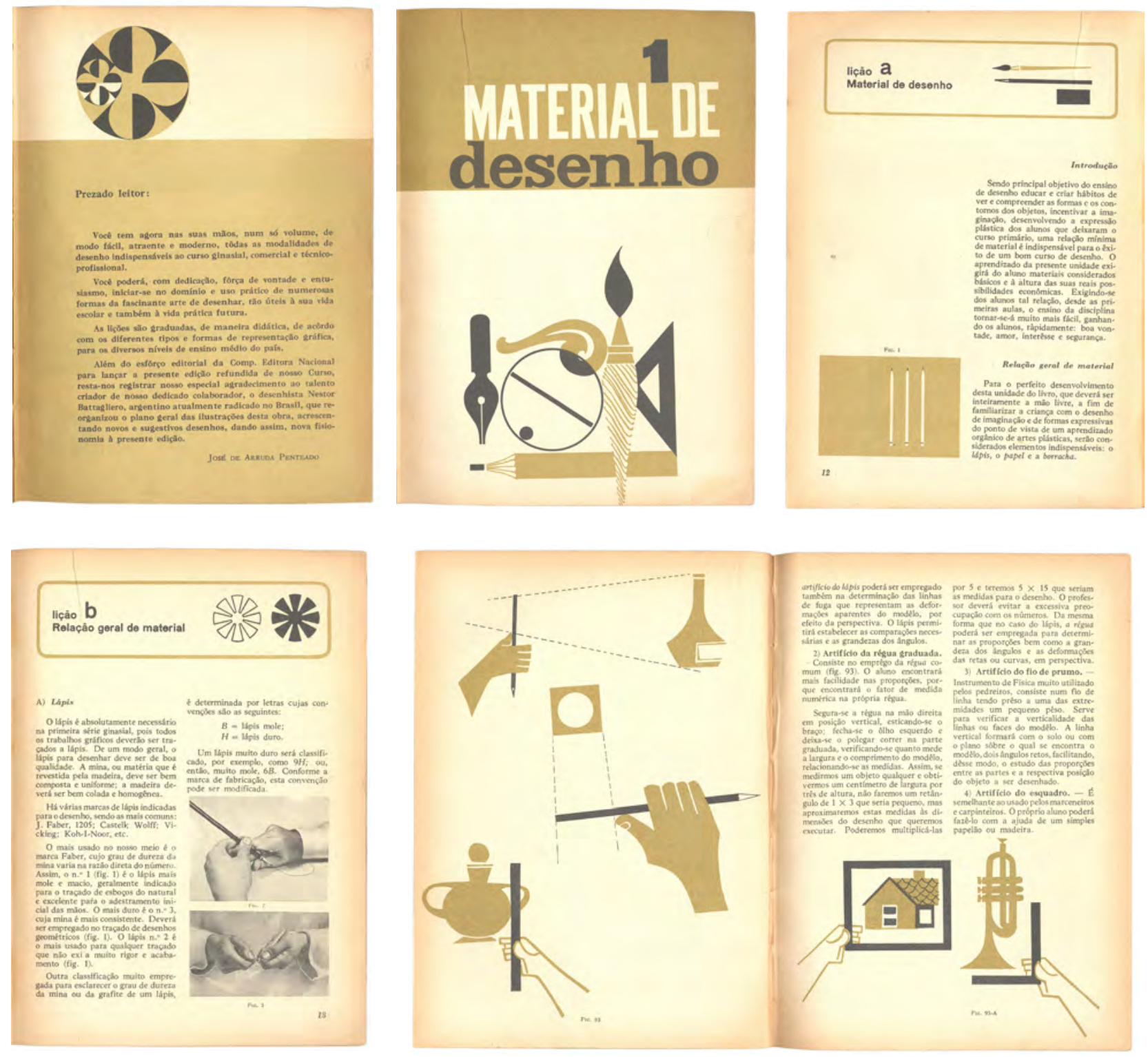

Fig. 7.20. José de Arruda Penteado, Curso de desenho, 1965 (15,0 × 21,0cm). Páginas pré-textuais.

O lettering e alternância de cores do título e os elementos gráficos associados aproximam a capa de Iniciacão à ciência (FIG. 7.21) às de Matemática: curso moderno e Curso de desenho, com provável autoria comum de Nestor Batagliero, creditado como ilustrador. Com informações textuais na primeira capa restritas a título e autoria, a composição geral é clara e eficiente, com lombada e quarta capa integradas à primeira capa. A impressão é em três cores especiais mais o preto, com combinações de retícula.

As guardas, páginas pré-textuais e abertura de capítulos distribuídas em três páginas, em linguagem gráfica combinando preto mais cor especial, correspondem ao novo procedimento de desenho dos livros adotado pela editora, embora a diagramação e as ilustrações do conteúdo didático sejam mais convencionais que as dos livros acima citados. Creditadas a José Gonçalves, essas ilustrações são feitas em traço em preto, com áreas preenchidas por retícula na segunda cor, diferentes da solução mais gráfica das pré-textuais e aberturas de capítulo. 

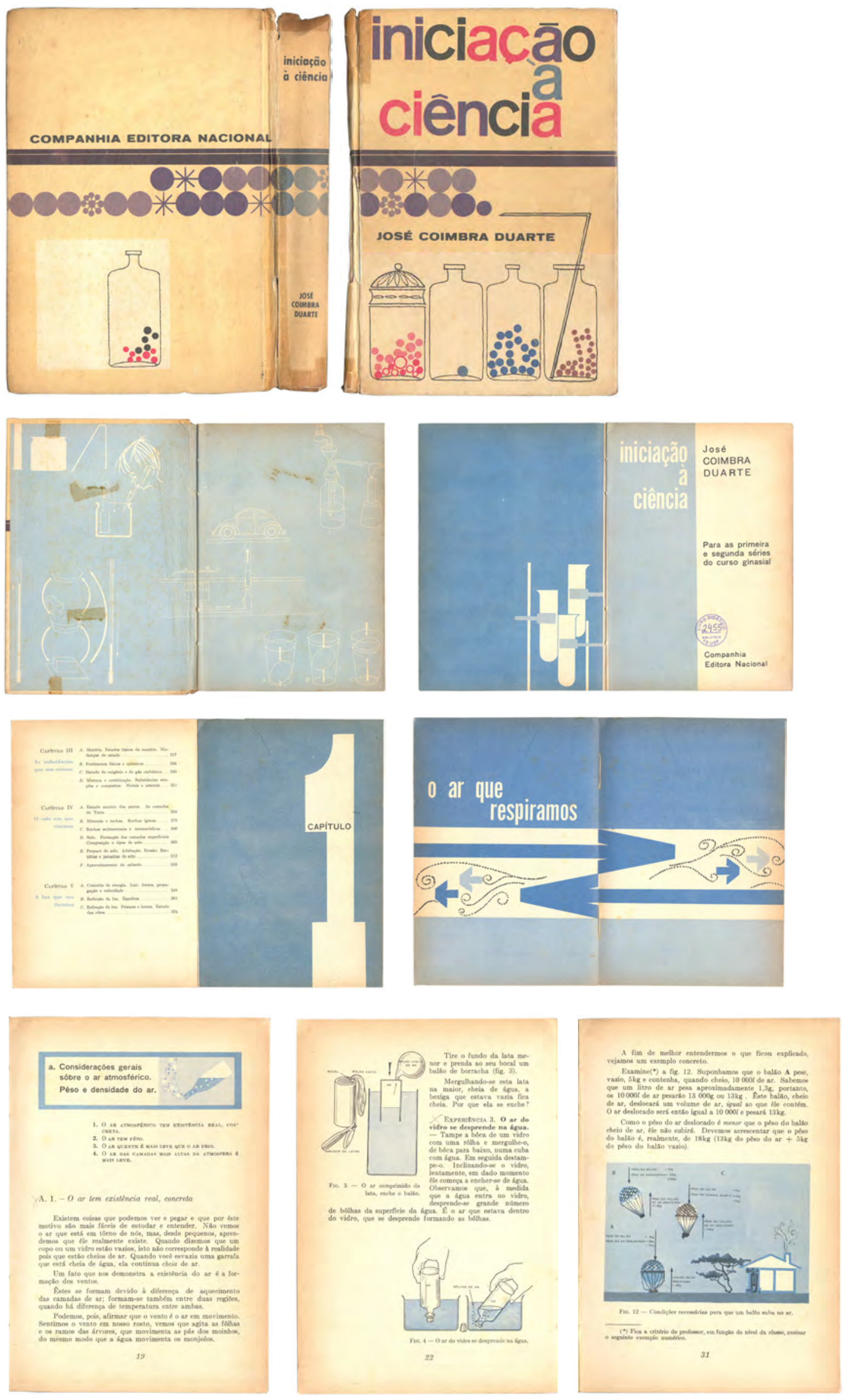

Fig. 7.21. José Coimbra Duarte, Iniciação à ciência, 1964 (13,0 × 19,0cm). Capa, guardas e pré-textuais. 
Outra obra, Iniciação à ciência (FIG. 7.22), vai ser a primeira a atualizar a forma de apresentação dos conteúdos didáticos da disciplina, com diagramação e ilustrações creditadas a Heitor Dulce Lyra que combinam linguagem de ilustração referenciada em revistas de divulgação científica de origem norteamericana, formato maior, distribuição de texto e imagem em páginas concebidas como duplas, leiaute de duas colunas, fotografia nas aberturas de capítulo e impressão de parte das páginas em quadricromia. A capa tem linguagem, abordagem do conteúdo e técnica de ilustração para impressão com cores especiais relacionadas às capas dos livros de José Coimbra Duarte e Antônio Antunes e José Antunes (FIG. 7.24).
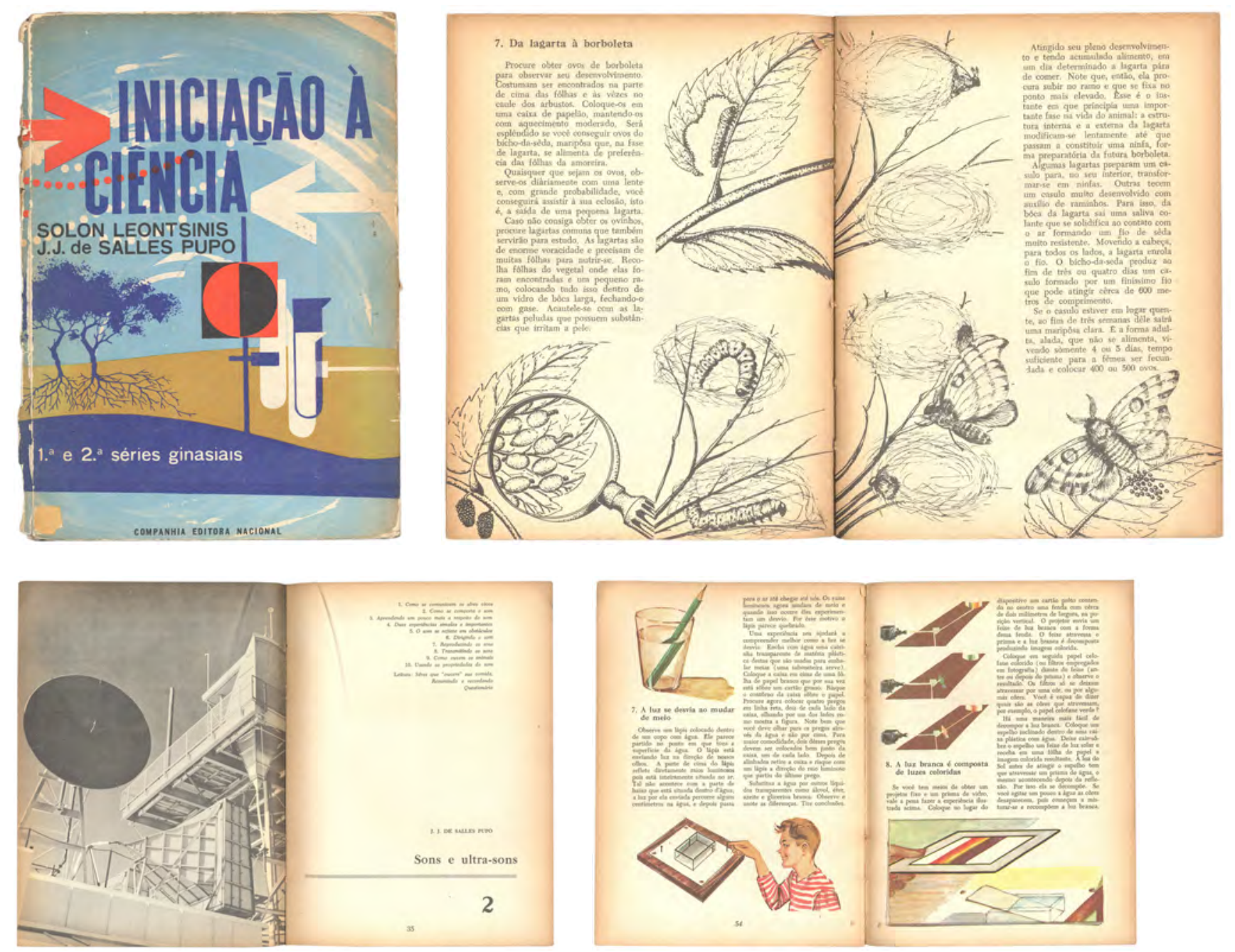

Fig. 7.22. Leontsinis e Pupo, Iniciação à ciência, $1965(15,3 \times 21,0$ cm). Capa e páginas de miolo.

Outra obra que recebeu um investimento de arte diferenciado é Ciências físicas e biológicas, de José Coimbra Duarte. Mesmo com o miolo totalmente impresso em preto, a qualidade do trabalho de ilustração, a presença de imagens "artísticas" na página de rosto e de abertura de capítulo, as ilustrações em meio tom, e não apenas traço, a reticulação de fundos como suporte de desenhos e sobretudo a distribuição mais livre e integrada ao texto, em páginas 
concebidas como duplas, tiram partido dos recursos oferecidos pela impressão ofsete - não plenamente aproveitados em períodos anteriores - e criam variação e interesse maior para o conteúdo didático veiculado (FIG. 7.23).
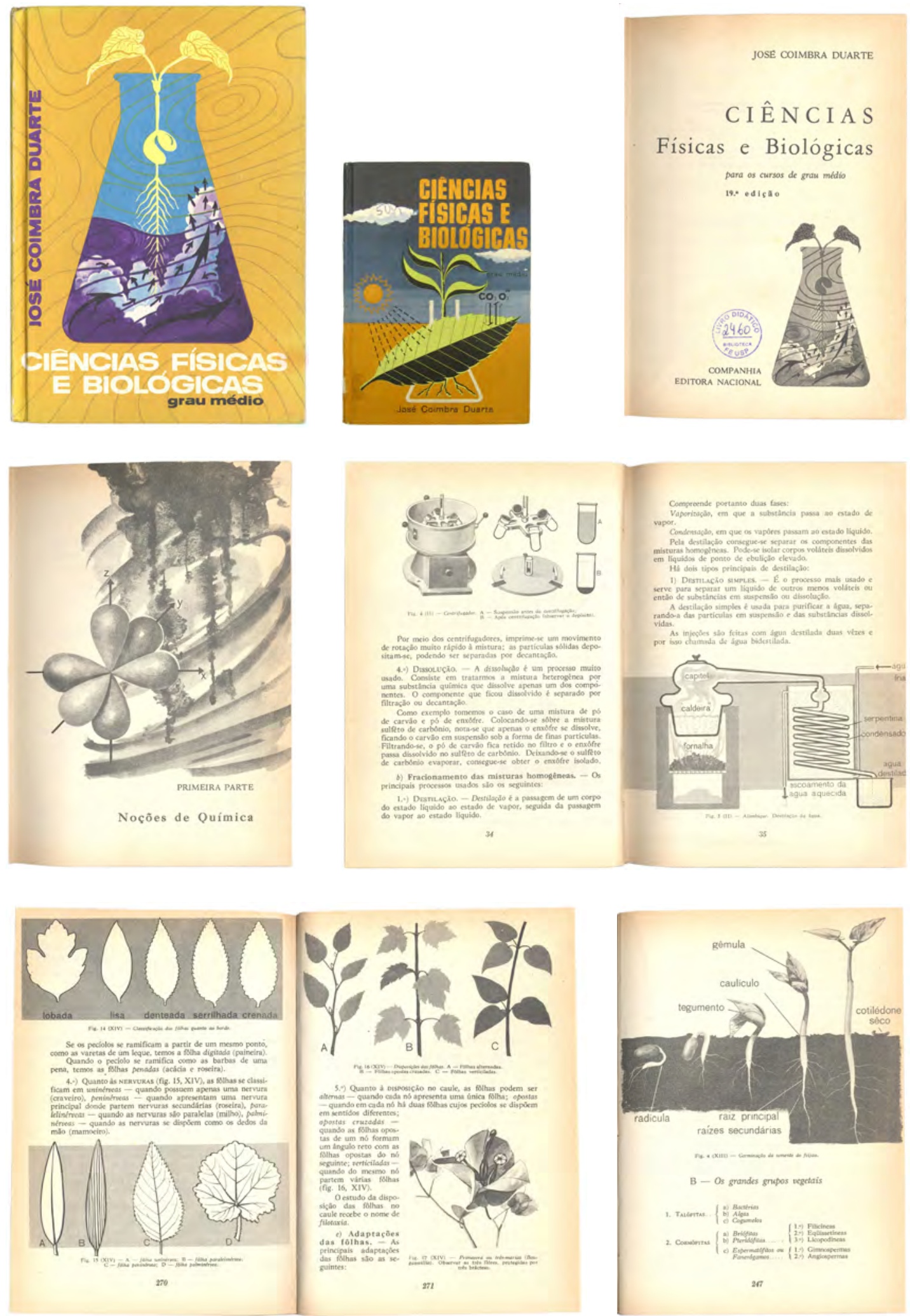

Fig. 7.23. José Coimbra Duarte, Ciências físicas e biológicas: grau médio, 1967 (13,0 x 19,0cm). Capa, rosto e páginas de miolo. Capa da edição anterior, de 1963, em tamanho menor. 
Sua capa tem total afinidade formal e de significado com a de edição anterior (FIG. 7.23), com o conteúdo informativo - fenômenos naturais, físicos e biológicos - sendo igualmente representado de forma esquemática com estilização de seus componentes, não mais em espaço aberto, mas "capturado" num ambiente de laboratório, numa metáfora da atividade de experimentação científica. A impressão é em quatro cores, com a indicação de reticulagem para combinação de três cores especiais mais preto para obtenção de tonalidades e matizes indicando grande perícia do ilustrador e do trabalho de estúdio. A semelhança de linguagem e técnica de execução com a capa de Iniciação à Ciência (FIG. 7.22) e Ciências físicas e biológicas, de A. Antunes Júnior e José Antunes (7.24), também não creditadas, indica provável autoria comum a todas elas.
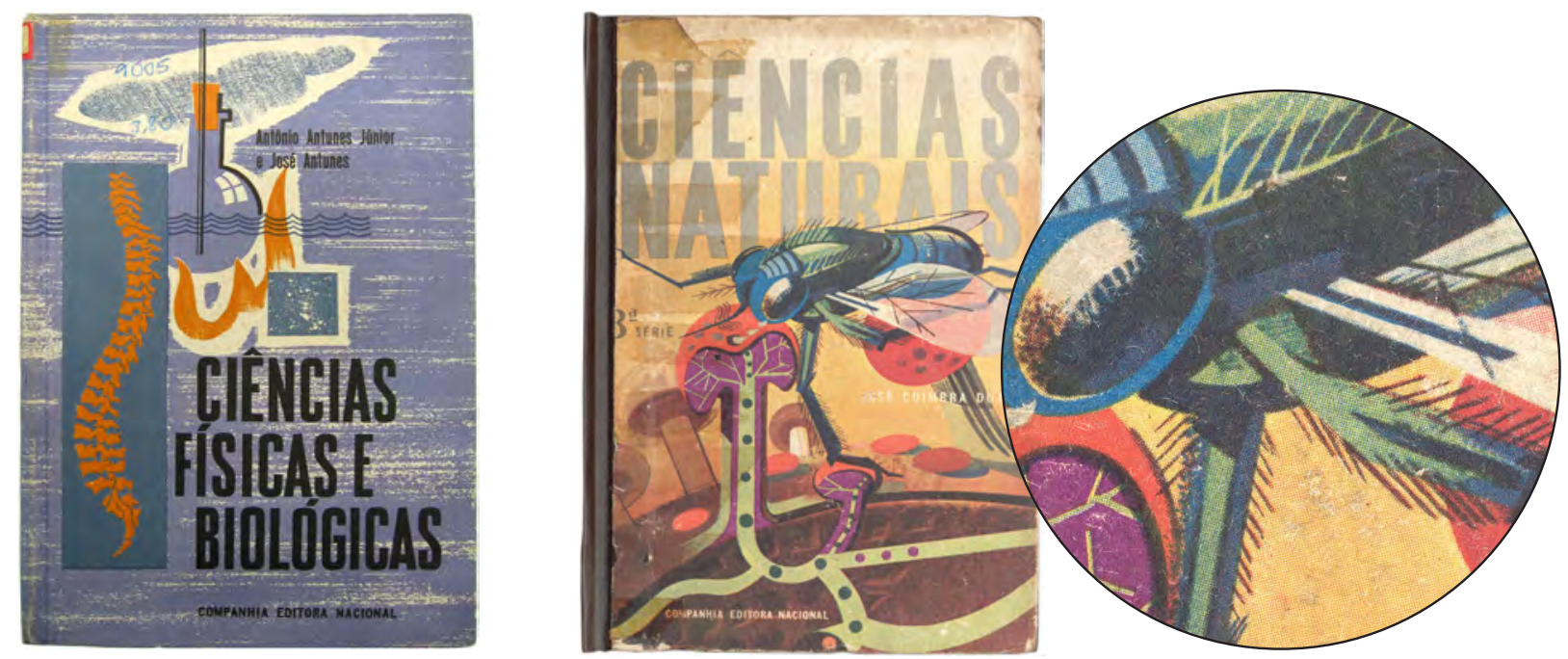

Fig. 7.24. A. Antunes Júnior e José Antunes, Ciências físicas e biológicas, 196? (13,0 × 19,0cm). Capa. [Fonte: acervo histórico da CEN.]

José Coimbra Duarte, Ciências naturais: para a terceira série ginasial, 1961 (13,0 × 19,0cm). Capa, com detalhe ampliado.

A afinidade formal entre elas indica a mesma estratégia utilizada nos livros de Ciências na década de 1950, a de chamar um mesmo artista gráfico para executá-las, naquele caso Walter Lewy (ver FIG. 6.13). Todas elas apresentam um domínio da técnica de ilustrar para impressão com cores especiais, mas a capa de Ciências Naturais, de Coimbra Duarte (FIG. 7.24) apresenta uma complexidade sem paralelo. A identificação de impressão de cinco cores especiais, mistura obtida por reticulação criando outros matizes e rebaixamento por reticulação para simular a transparência das asas, indicam um trabalho muito mais complexo tanto para o ilustrador como para o estúdio de fotomecânica do que a execução de ilustração colorida para ser capturada fotograficamente pelo processo normal de produção da quadricromia. Num período em que o número de entradas em máquina eram tantos quantas fossem as cores especiais empregadas, tem-se noção da dificuldade e do inverstimento necessário para a impressão de uma capa como essa. 
Já do fim da década de 1960, Iniciação científica (FIG. 7.25) traz um diferencial gráfico marcante, com formato maior e linguagem gráfica atualizada, tanto nas capas como no miolo, referenciada na visualidade encontrada em fascículos de divulgação científica vendidos em bancas de todo o país ${ }^{3}$. Creditadas a Lenci \& Fisher, de quem não se obteve informações, as capas dos três volumes têm impressão em quadricromia, com os volumes 1 e 3 tendo uma quinta cor especial para faixa inferior que contém as informações textuais. Trazem ilustração baseada em informação fotográfica mas com tratamento gráfico gestual, reproduzindo evento dos mais significativos na época, a corrida especial. O investimento feito na obra é também confirmado pelo tratamento dispensado ao miolo, com grande número de ilustrações impressas em bicromia, creditadas a Joel Link (FIG. 7.26)
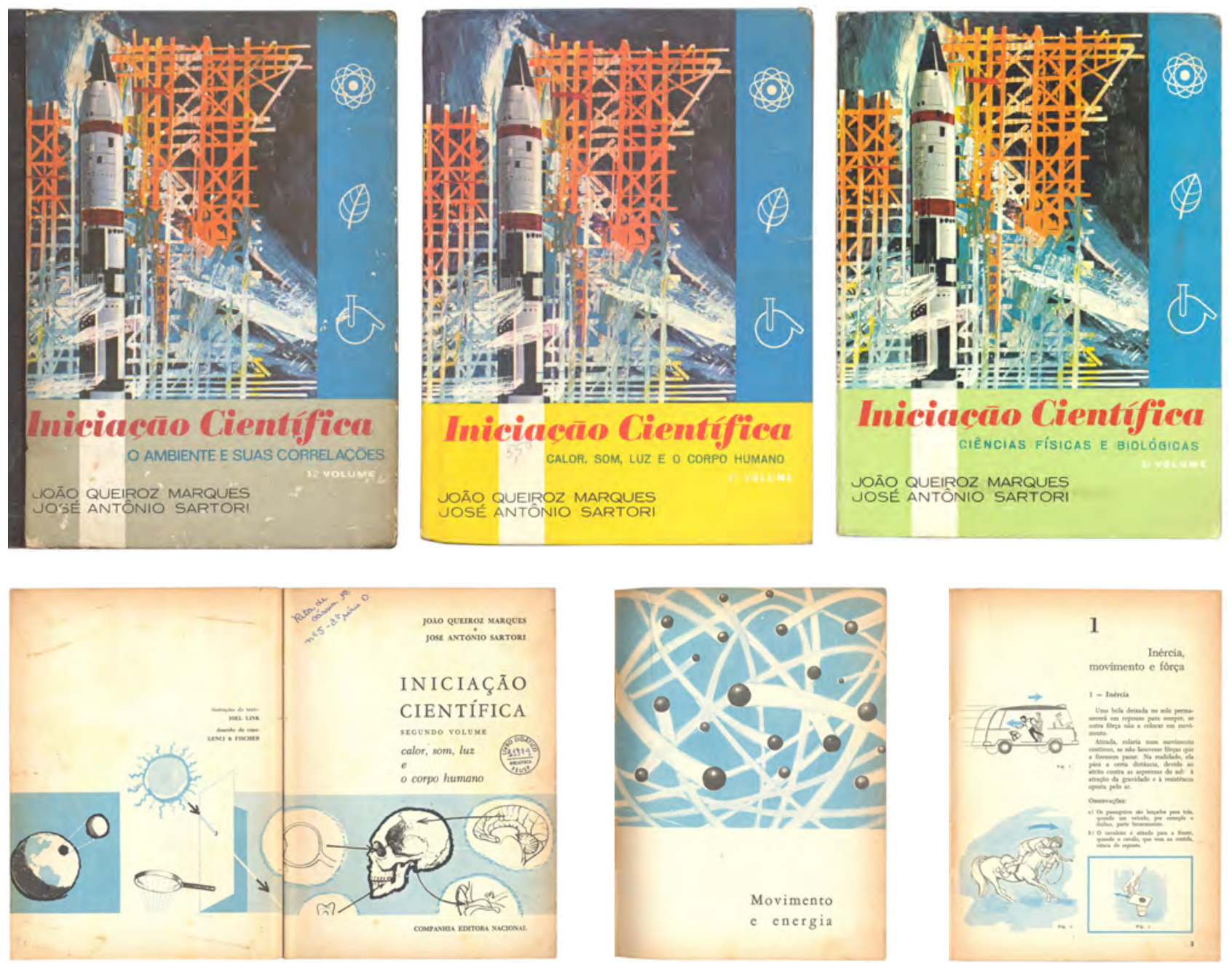

Fig. 7.25. Marques e Sartori, Iniciação científica, 1968 e 1969 (15,0 x 21,0 cm). Capas dos três volumes e dupla de rosto, abertura de parte e capítulo do volume 2.

\footnotetext{
3 Os fascículos colecionáveis foram introduzidos no país pela Editora Abril, em 1965, seguida pela espanhola Codex, e abarcavam temas como ciência e tecnologia (Tecnirama, Ciência ilustrada), saúde (Medicina e Saúde), biologia (Naturama), trabalhos manuais (Mãos de ouro), arte (Gênios da pintura, Arte nos séculos), religião (A bíblia mais bela do mundo), enciclopédia (Conhecer), música (Grandes compositores da música universal, Música Popular Brasileira), etc. Eram vendidos semanalmente e, agrupados, constituíam volumes que eram encadernados com capas também fornecidas pelas editoras.
} 

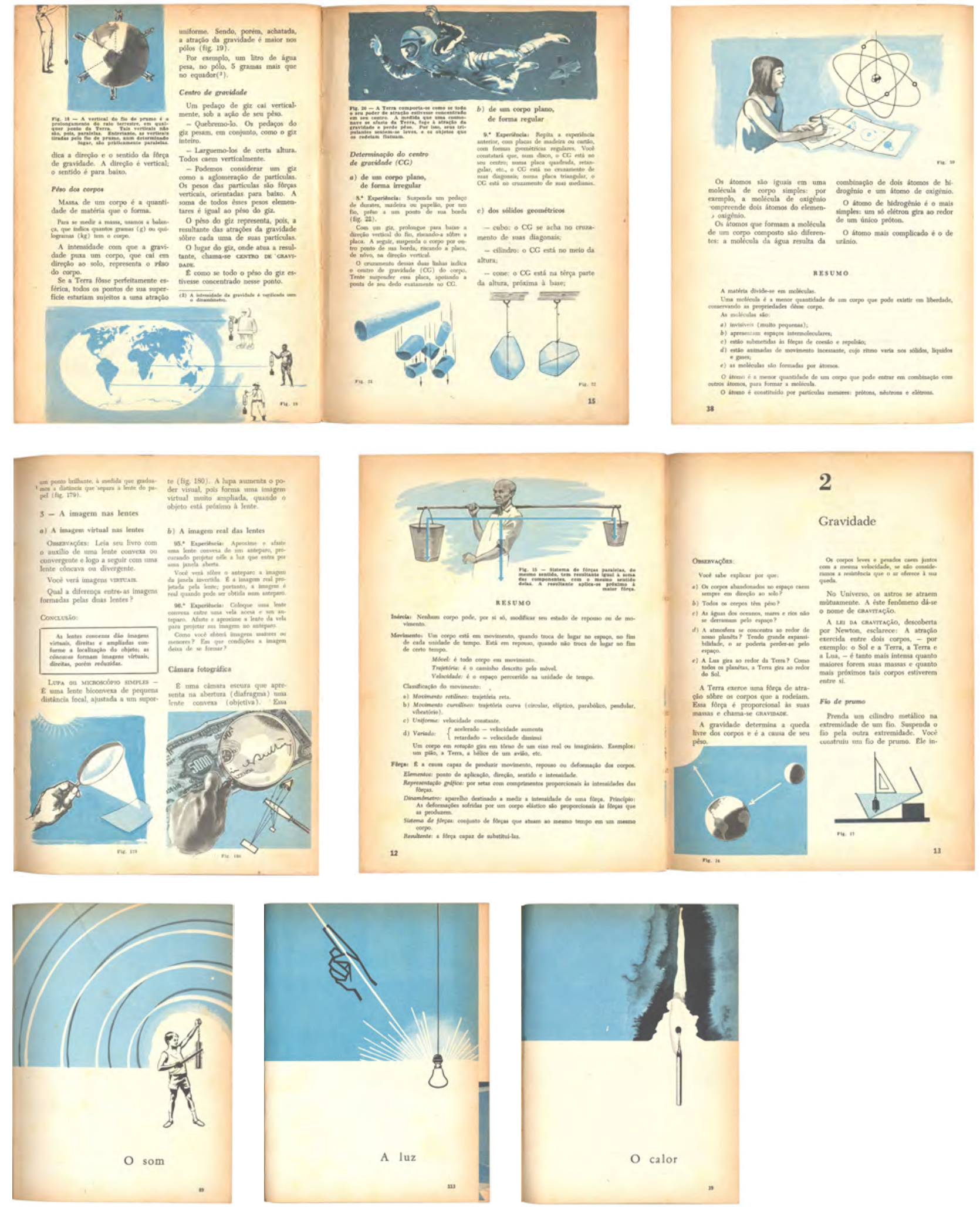

Fig. 7.26. Marques e Sartori, Iniciação científica, 1968 e 1969 (15,0 × 21,0cm). Páginas internas do volume 2. 


\subsubsection{As mudanças no design dos livros de Geografia}

A primeira reedição da década de 1960 da coleção de Aroldo de Azevedo para o Ginásio, agora com o nome O Brasil e o mundo, apresenta as mesmas características de sua coleção anterior (ver FIG. 6.36): formato, impressão em bicromia, aberturas com fotografia sangrada e solução fotográfica de capa com impressão em quadricromia, com a diferença de uma composição assimétrica e destaque para o nome da coleção, em tipografia gestual (FIG. 7.27).
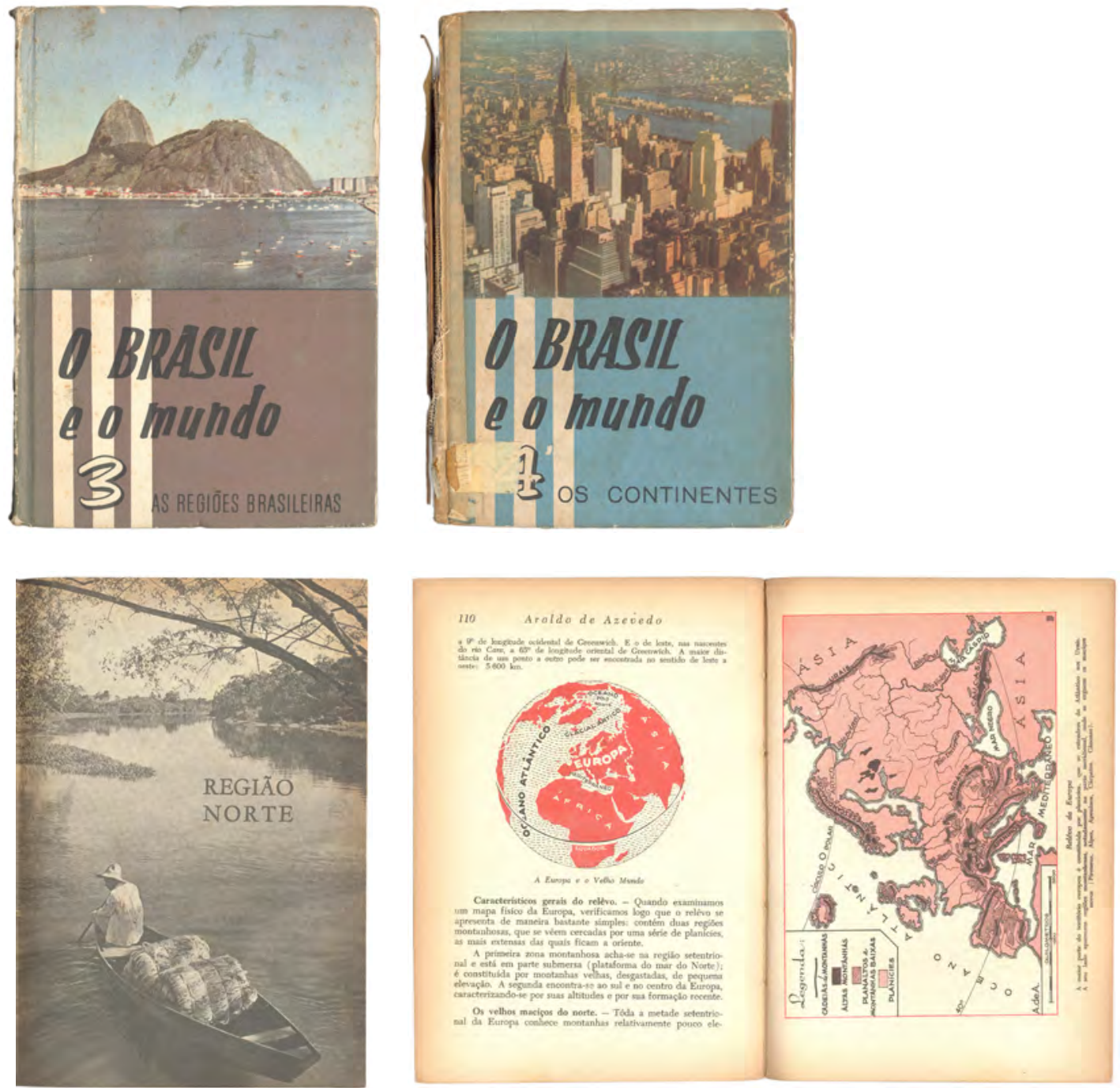

Fig. 7.27. Aroldo de Azevedo, O Brasil e o mundo, vol. 3, $1962(13,0$ × 19,0 cm). Capa e miolo; capa do volume 4.

Já o design de capa das últimas edições da década da coleção O Brasil e o mundo (FIG. 7.28), trazem uma solução nova, combinando uma representação gráfica esquemática do globo, quase um símbolo da Geografia, com a fotografia, também sempre presente desde o período anterior nas capas da disciplina. A disposição inclinada e o contraste tonal da representação do globo estruturam dinamicamente o campo, as informações textuais (restritas a título e autoria) e a iconografia fotográfica. A identidade e a apreensão das informações é bastante direta, mesmo 
sendo três as fotografias, já que estão dispostas em estrutura organizada e assim participam da explicitação do conteúdo do volume em associação ao título. Ressalte-se que, além da impressão em quadricromia, todas as capas apresentam duas cores especiais para os fundos chapados.
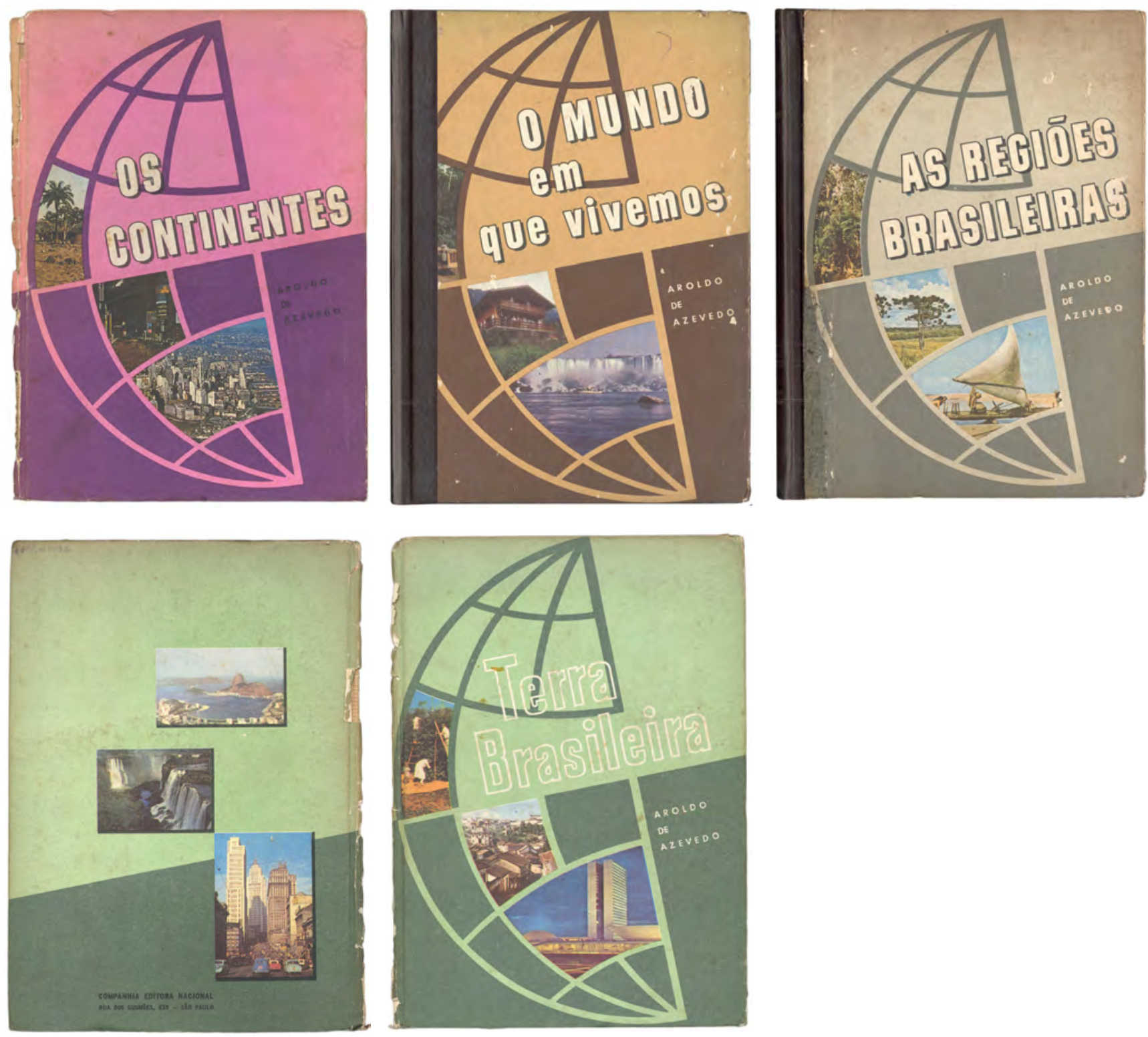

Fig. 7.28. Aroldo de Azevedo, O Brasil e o mundo, diversos volumes, 1966 a 1969 (15,0 × 20,7 cm). Capas.

O miolo apresenta guardas, rosto e aberturas de capítulos em dupla de páginas, diagramação em duas colunas e, principalmente, a impressão em quadricromia, um aperfeiçoamento em relação às edições anteriores. A iconografia, bastante extensa, vai dos mapas, esquemas e gráficos às fotografias em cor e PB e reprodução de gravuras e desenhos, como o de Percy Lau na página mostrada (FIG. 7.29). A produção gráfica é creditada a Theobaldo de Nigris e Rubens de Barros Lima. O investimento diferenciado nas obras de Aroldo de Azevedo é explicado pelo fato de elas serem as mais vendidas em todos os segmentos [FERRACINI, 2012, p. 60-62]. 

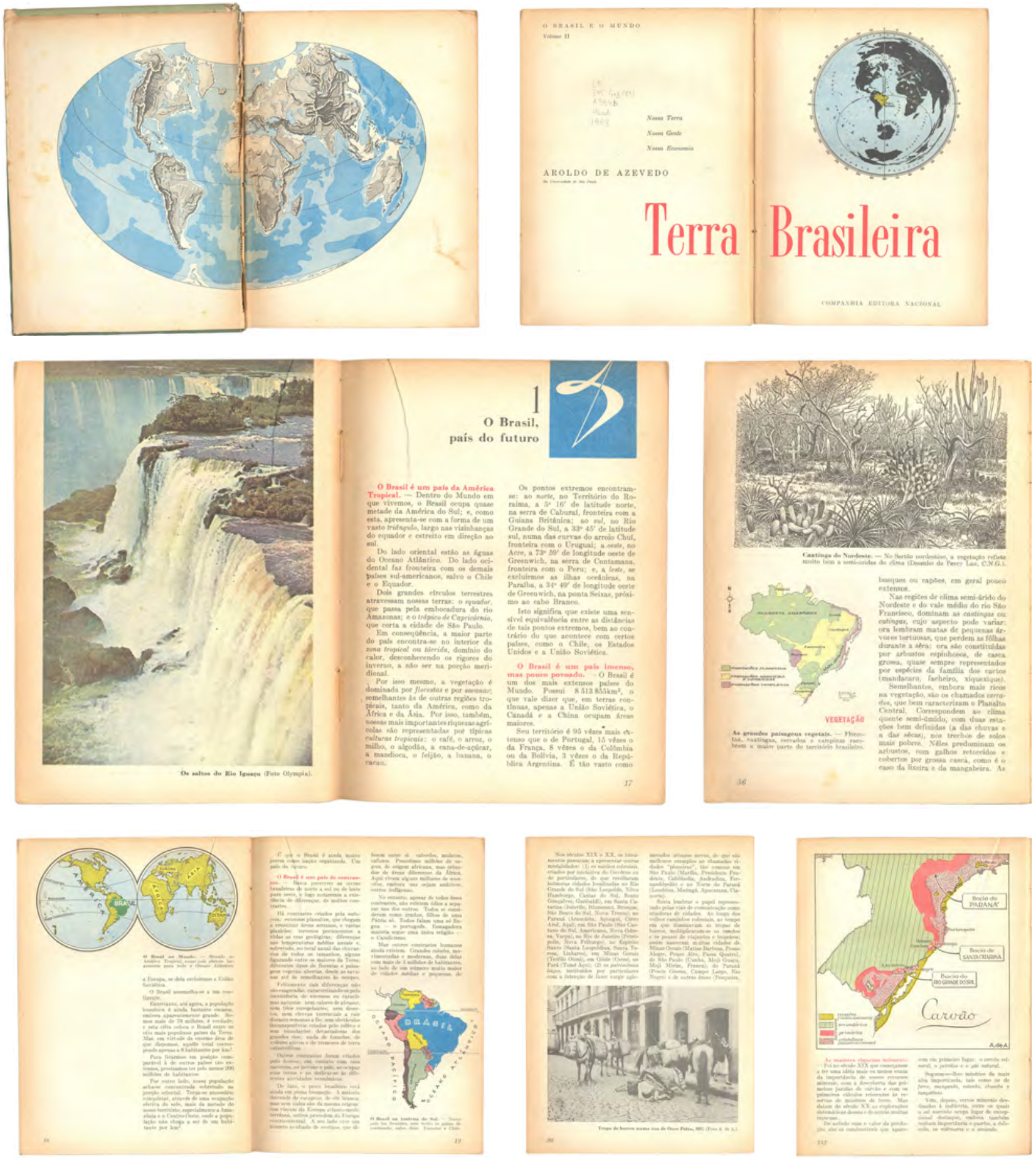

Fig. 7.29. Aroldo de Azevedo, O Brasil e o mundo, Terra brasileira; 1968 (15,0 x 20,7 cm). Guardas, dupla de rosto e páginas textuais.

A coleção de Geografia de Otacílio Dias (FIG. 7.30) traz um formato diferenciado, não encontrado em nenhuma outra obra, com diagramação em três colunas e impressão quadricrômica, já tornada um padrão em geografia. A solução parece adequada a um obra de caráter mais popular, pelo enfoque e iconografia mais simples que as assinadas por Aroldo de Azevedo. A produção gráfica é creditada a Theobaldo de Nigris e Rubens de Barros Lima, e certamente inclui o planejamento visual e edição de arte. 
Nas capas, o esquema de representação planográfica é aproveitado em solução que dispensa fotografia referencial e se apoia primordialmente na cor e intervenção na imagem para promover a particularização dos volumes. A variação tipográfica (serifa, largura do tipo) também participa, mas motivada pela necessidade de ocupação da área do título.
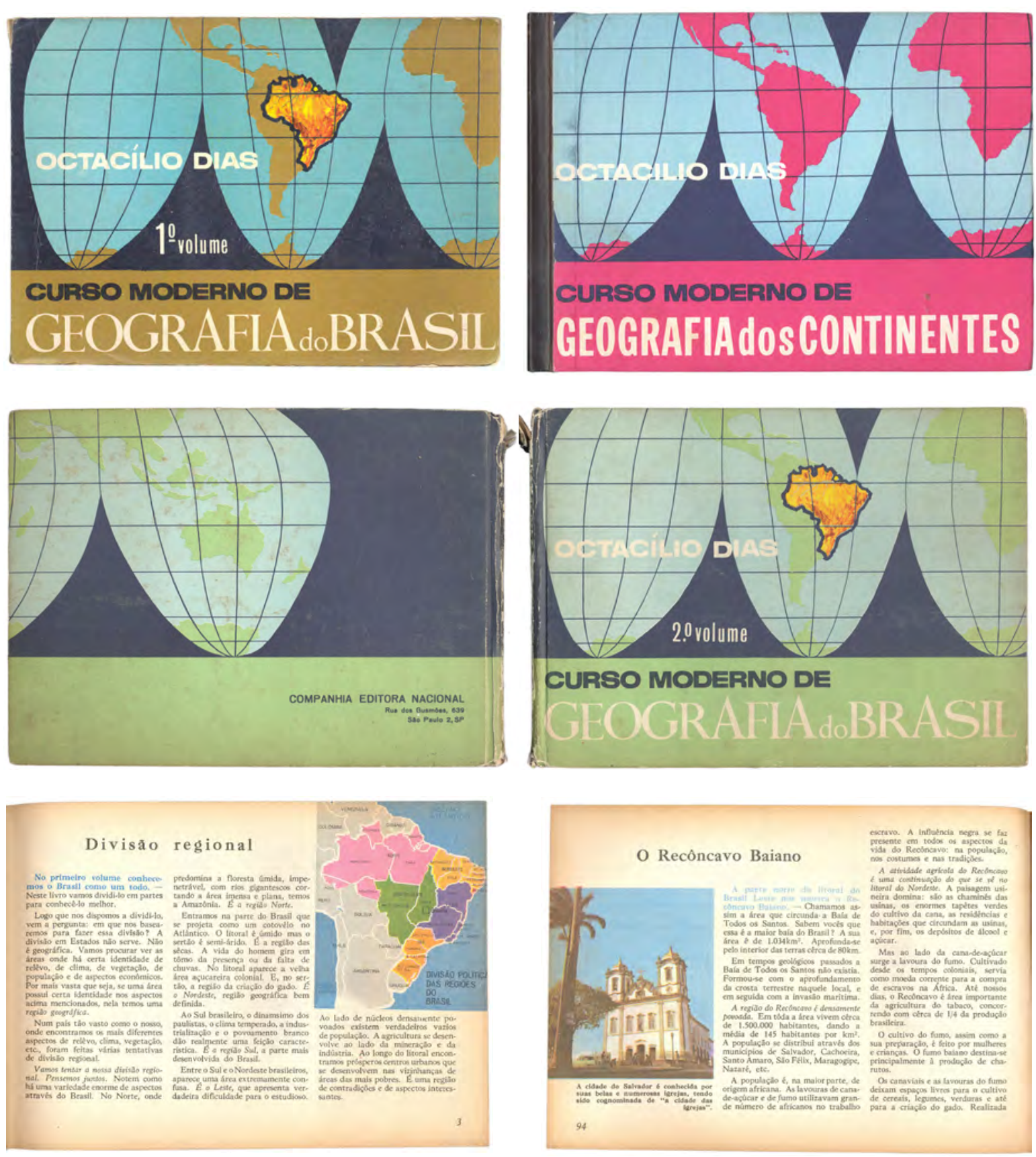

Fig. 7.30. Otacílio Dias, Curso moderno de Geografia do Brasil, 1969 (21,0 × 15 cm). Capas e páginas internas do segundo volume. 


\subsubsection{Os livros de Português}

Diferentemente de outras disciplinas, os livros de Português ao longo da década de 1960 não apresentaram transformações significativas na visualidade de seus miolos, provavelmente porque a didática da disciplina permaneceu apoiada na sequência leitura e estudo de texto, pontos gramaticais e exercícios e prescinde de ilustrações, não demandando a intervenção gráfica no miolo como as que foram feitas nas obras de Ciências e Matemática do mesmo período. As capas seguiram a tendência, iniciada no período anterior, de trazer uma visualidade genéricamente associada à arte e ao design modernista.
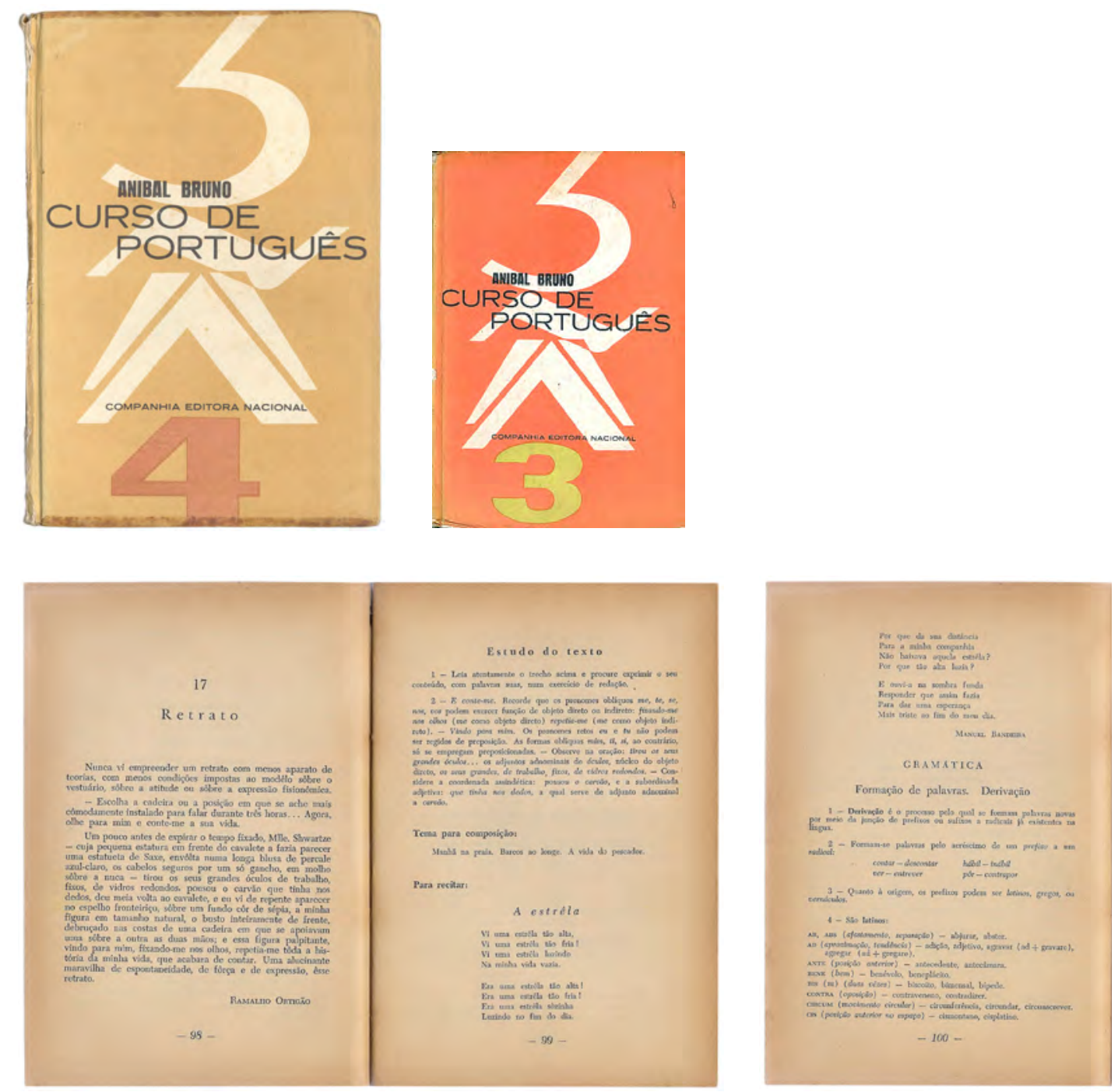

Fig. 7.31. Aníbal Bruno, Curso de Português: 4a série, 1962 (13,0 × 19,0 cm). Capa e páginas de miolo. Em tamanho menor, capa do volume de $3^{a}$ série, obtida em site de busca na Internet.

Assim, a composição e a diagramação de Curso de Português, de Aníbal Bruno (FIG. 7.31) segue o padrão encontrado em livros de Língua Portuguesa para o ensino secundário desde os períodos anteriores, caracterizado por coluna única e texto em tipo romano com as variações itálico, negrito e versal-versalete. Sua capa, impressa em duas cores especiais mais preto, tem como 
elemento dominante uma composição com diacríticos ampliados formando uma ilustração abstrata tipográfica, associada ao número do volume e sobreposta pelas informações textuais dispostas assimetricamente no primeiro plano.

Na capa da Novíssima gramática (FIG. 7.32), a referência à arte modernista construtiva, que já apareceu no período anterior em capa da disciplina (ver FIG. 6.18), estabelece a idéia de atualidade e novidade da obra. A modulação forma uma imgaem de fundo, com sobreposição dos textos e quedro em preto, sem uma integração completa entre tipografia e imagem.

As capas de Português, do mesmo autor (FIG.7.32), também comunicam modernidade por meio de uma solução tipográfica minimalista, em que a letra inicial do título é tomada isoladamente e transformada em imagem dominante, tirando partido de um desenho largo com hastes verticais espessas que preenche o campo e equilibra suas contraformas. O título também atravessa o campo e as demais informações formam bloco alinhado à direita.
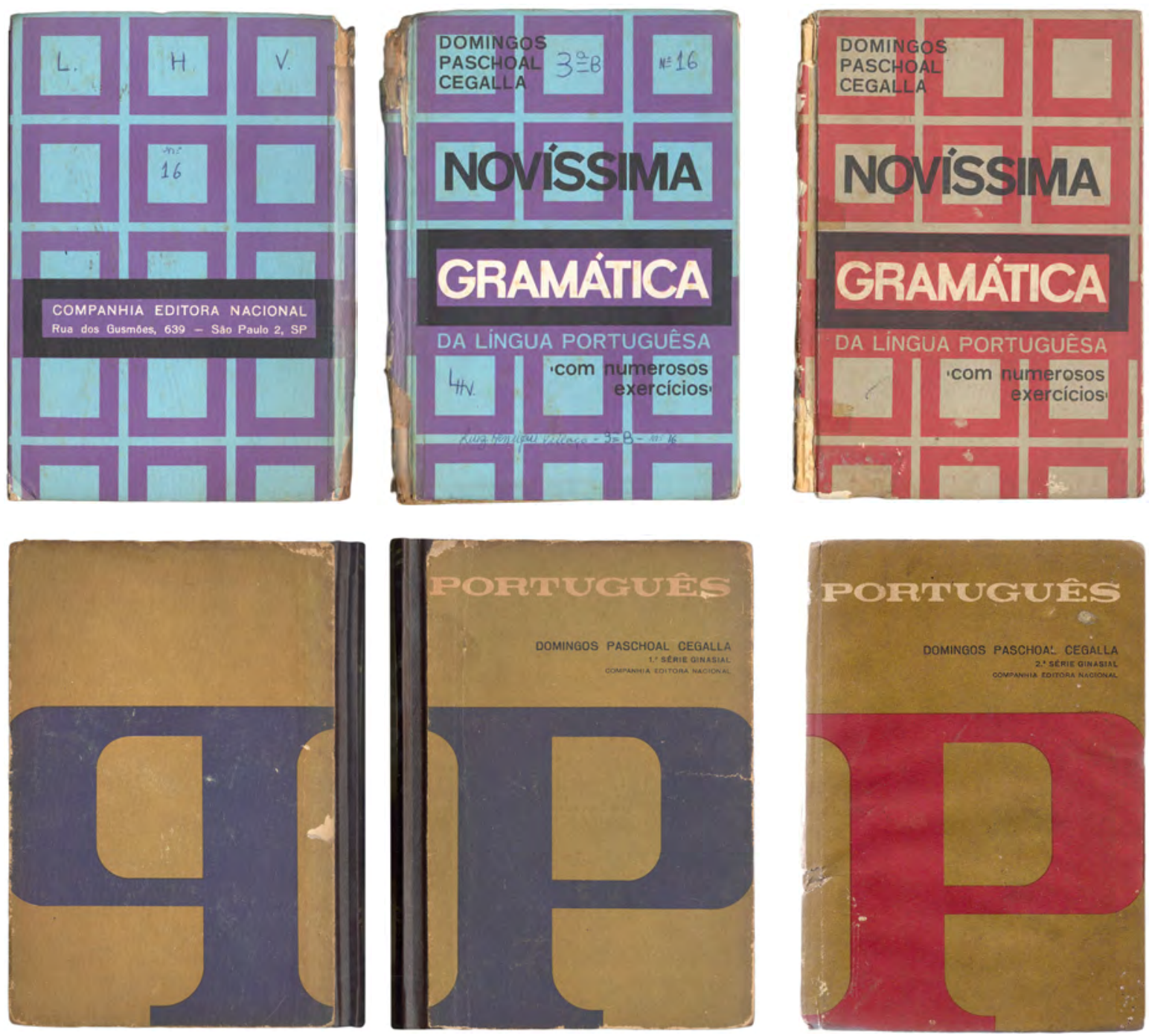

Fig. 7.32. Domingos Paschoal Cegalla, Novíssima Gramática da Língua Portuguesa $(13,0 \times 19,0 \mathrm{~cm})$. Capas das edições de 1963 e 1967.

Domingos Paschoal Cegalla, Português, 1965 (13,0 × 19,0 cm). Capas da 1aㅡ e 2aa séries ginasiais. 
Com a Novíssima Gramática e a coleção Português, Domingos Paschoal Cegalla tornou-se o principal autor da disciplina na Companhia Editora Nacional, com as obras mais vendidas no mercado e edições frequentemente renovadas. A edição de 1968 de Português traz capas também tipográficas (FIG. 7.33), mas com maior complexidade que a edição de 1965 (FIG. 7.32): padrão gráfico de fundo formado por letras em disposição aleatória, em tom rebaixado de cor, particularizando o volume; composição sugerindo a letra $P$ formada por elementos tipográficos/letras em primeiro plano, em cor fixa para todos os volumes, se relacionando com o título e autoria pelo preto; título em fonte não serifada em caixa baixa com sombra sugerindo volume e atravessando o campo, em contraste com o nome do autor, em caixa alta. A impressão é em três cores (preto mais duas especiais).
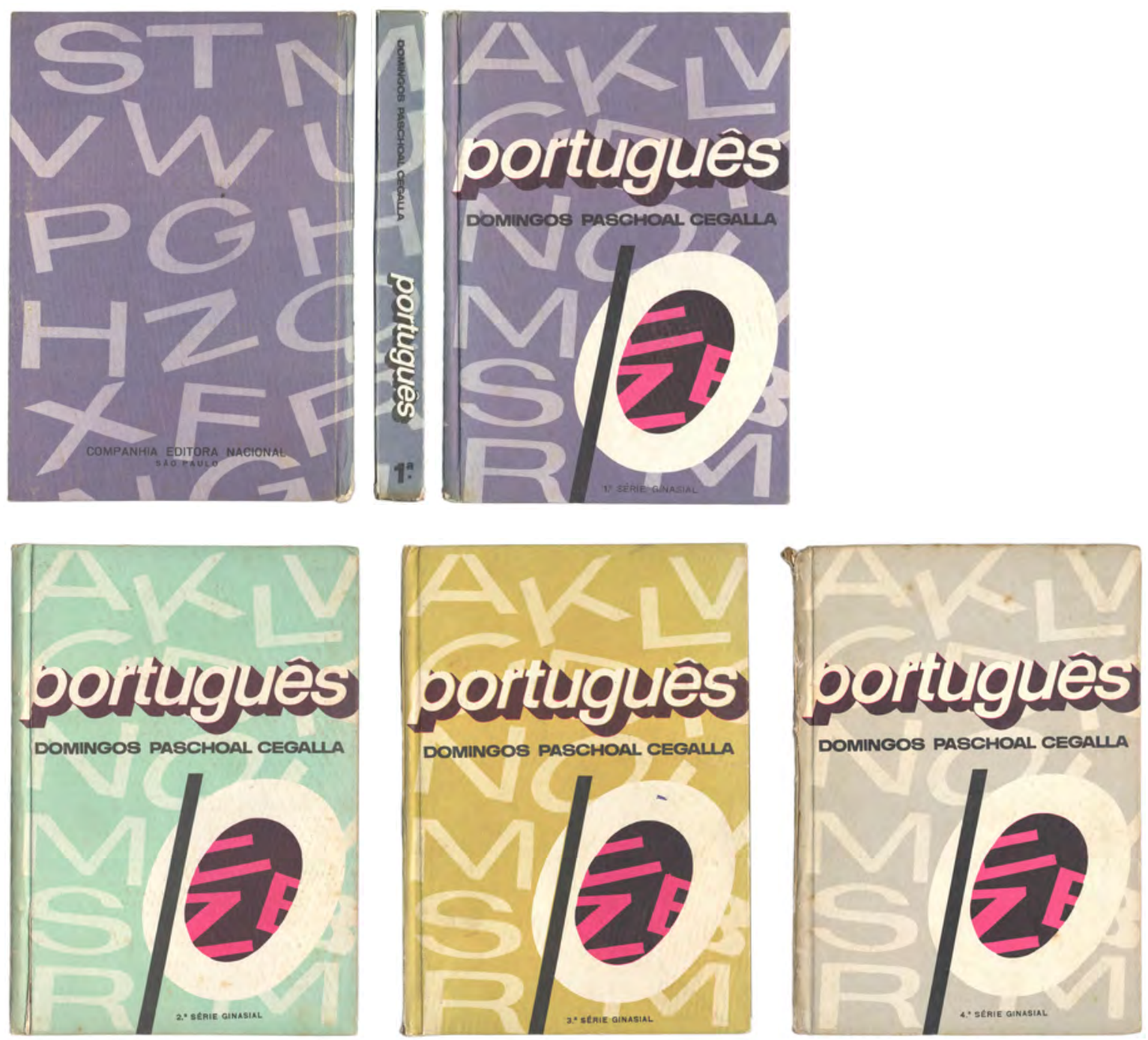

Fig. 7.33. Domingos Paschoal Cegalla, Português, $1968(13,0 \times 19,0 \mathrm{~cm})$. Capas de todas as séries ginasiais.

A edição de 1969 de Português, da qual só se conseguiu um volume (FIG. 7.34), tem capa com imagem de fundo formada por retrato em alto contraste não muito evidente de Camões, devido ao corte, com sobreposição de faixas e à frente título e autoria perfeitamente justifi- 
cados em forte contraste de peso, largura e dimensão de tipos, sublinhados por fio preto e envoltos por quadro de cantos curvos. As páginas de miolo reproduzidas, em confronto com as da fIGURA 7.34 mostram a similitude de design em obras de Português de autores diferentes e edições dos primeiros e últimos anos da década, mas já trazem espaço para resposta do aluno, recurso que vai se generalizar na década de 1970.
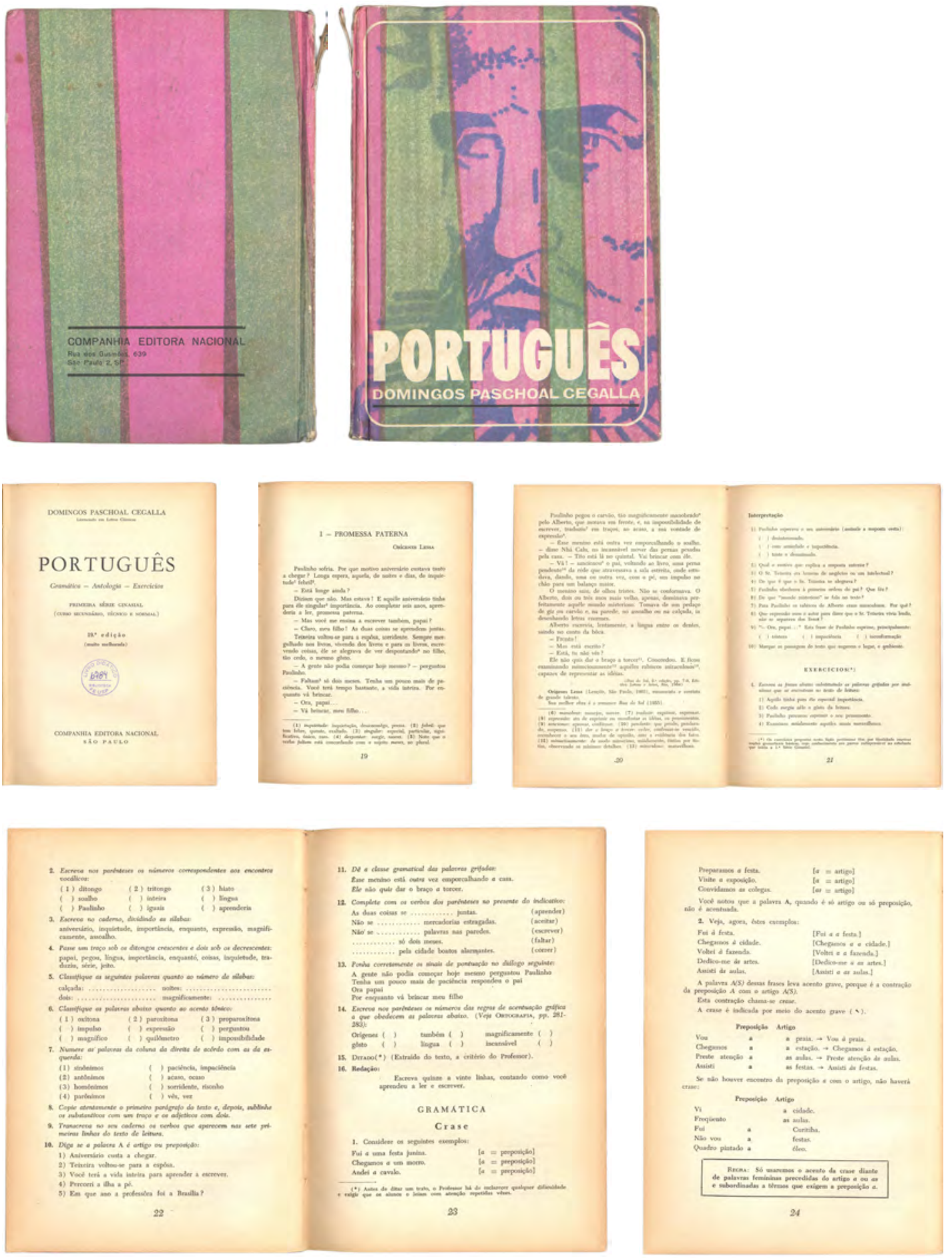

Fig. 7.34. Domingos Paschoal Cegalla, Português: 1ạ série ginasial, 1969 (13,0 × 19,0cm). Capa e miolo. 


\subsubsection{Os livros de línguas estrangeiras}

Como vimos nos períodos anteriores, os livros de línguas estrangeiras modernas foram os primeiros a terem miolo mais extensamente ilustrado e a serem impressos em duas e até quatro cores e em formatos maiores (ver fIG. 4.38, 4.39 e 6.37 a 6.41), e de forma geral seguem esse padrão nas novas obras e reedições do período. Cours de Français (FIG. 7.35), por exemplo, é uma reedição atualizada de obra da BPB Série II - Livros didáticos (ver FIG. 4.8), em grande formato, com capa e ilustrações creditadas a Dorca, de quem não se conseguiu informações. Seu primeiro volume faz uso de quadricromia plena não só nas ilustrações como na sinalização gráfica do conteúdo didático, com aplicação de cores puras de escala (ciano, magenta e amarelo), sem combinações, nos fundos de apoio e em títulos e palavras destacadas, evitando falhas de registro.
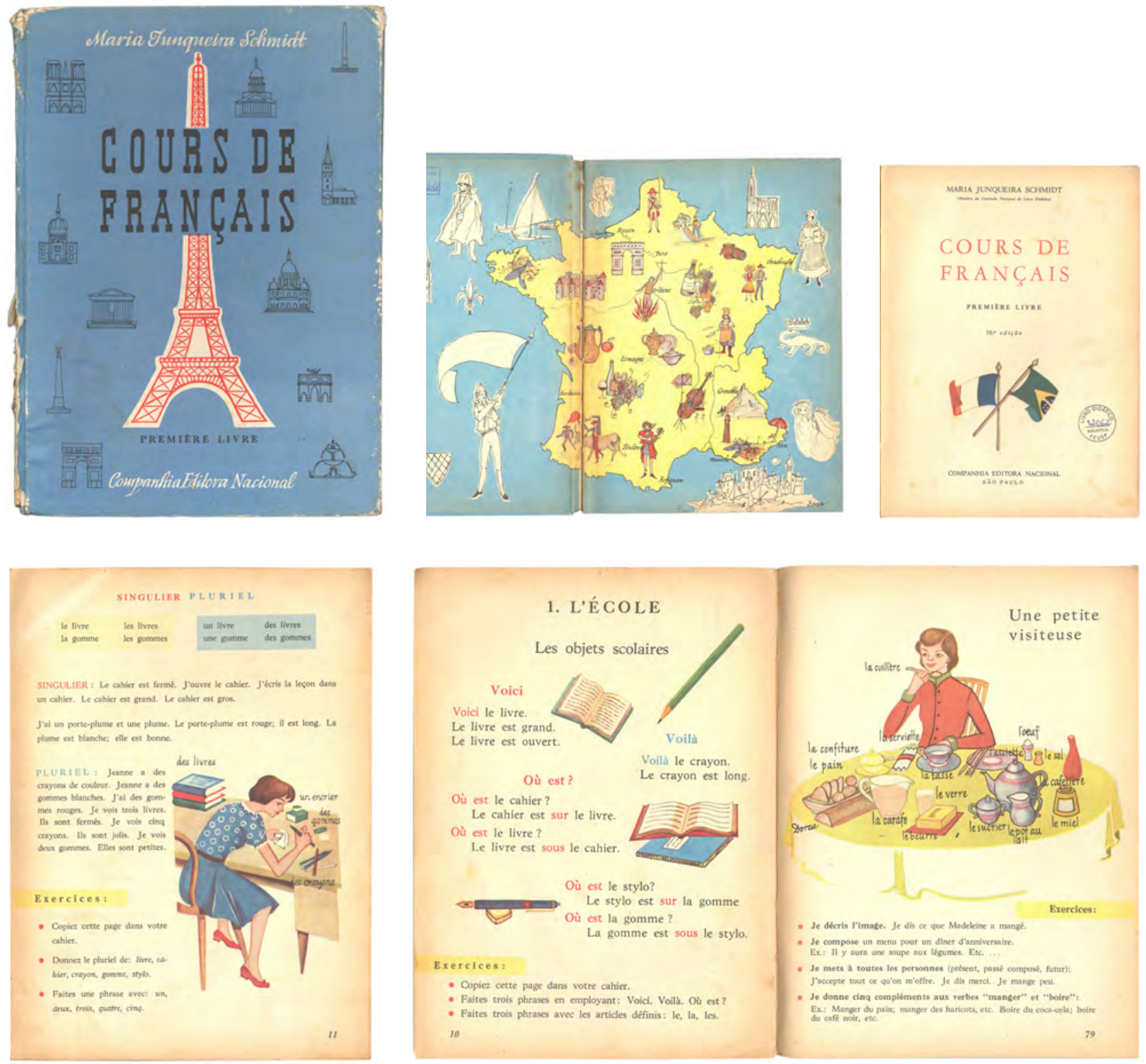

Fig. 7.35. Maria Junqueira Schmidt, Cours de Français: première (sic) livre, 1963 (15,4 x 21,0 cm). Capa, guardas, rosto e páginas de miolo. 

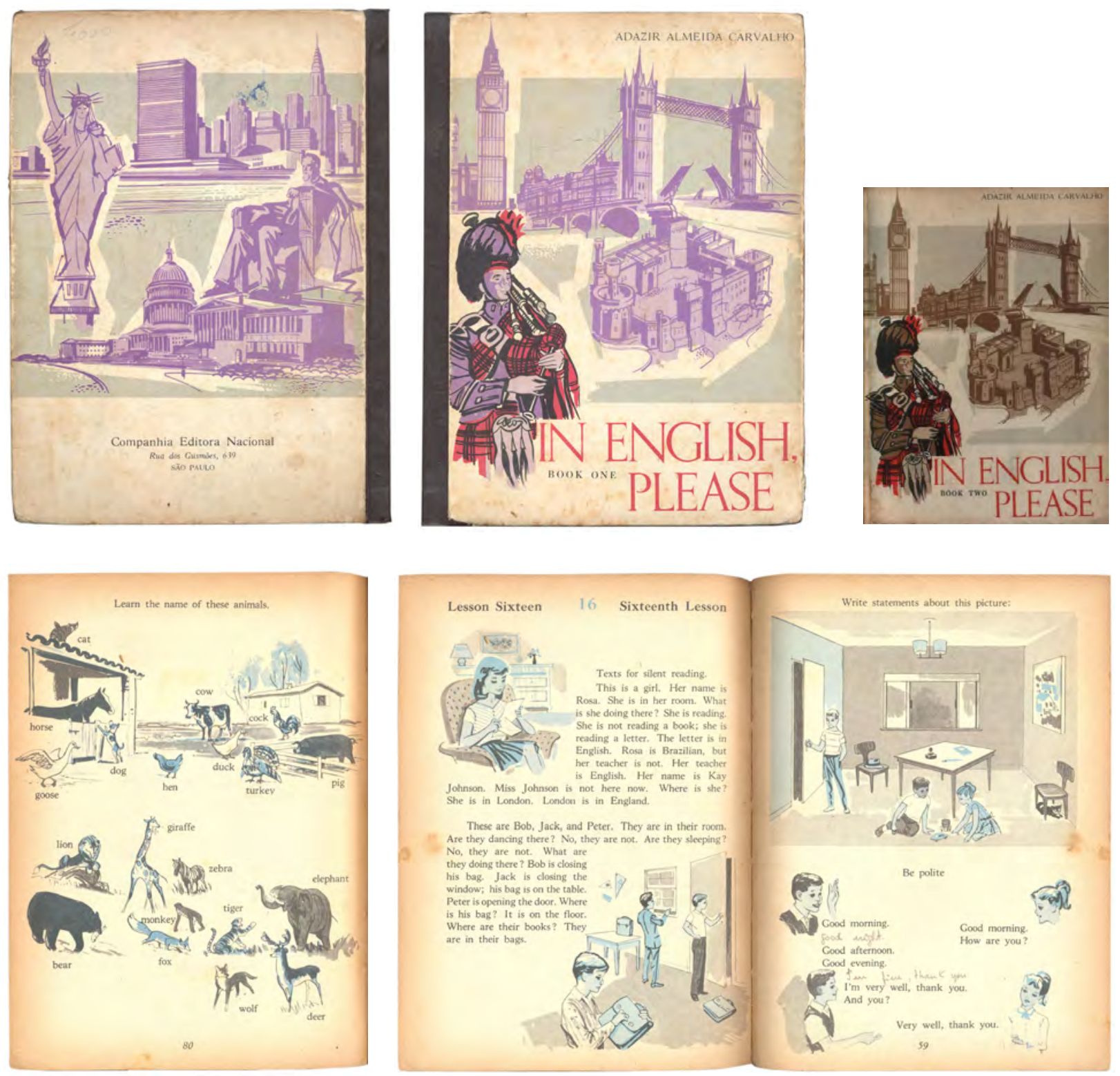

Fig. 7.36. Adazir Almeida Carvalho, In English, Please: book one, 1964 (15,0 x 21,0 cm). Capa e páginas de miolo, com reprodução de imagem de capa do volume 2 obtida em site de busca na Internet.

Com capa creditada a Renzo Lenci, impressa em preto mais três cores especiais, e ilustrações de miolo em bicromia com reprodução de tom contínuo, de João Gargiulli, In English, please (FIG. 7.36) apresenta evidente atualizacão de linguagem gráfica em relação aos títulos de línguas do período anterior, apesar dos exemplos de investimento diferenciado e uso de quadricromia encontrados naquelas obras (ver FIG. 6.40 a 6.42).

Na primeira capa é estabelecida uma relação do título com a ilustração em plano próximo ao leitor, na parte inferior, à frente de uma "paisagem" criada pela justaposição de ícones arquitetônicos-históricos britânicos, enquanto na quarta capa aparecem os norte-americanos. A particularização dos volumes é obtida por diferenciação cromática. 


\subsubsection{Os livros para o Primário: cartilhas e Programa de Admissão}

Cartilhas e livros de leitura apresentados em períodos anteriores, com a Coleção Sodré, Infância brasileira e Linguagem continuaram neste período a serem reeditados com a mesma configuração gráfica de capa e miolo (ver FIG. 5.31 e 6.22). Uma obra nova é Minha cartilha, de Renato Sêneca Fleury (FIG. 7.37). Filiada à tradição brasileira das cartilhas (ver. p. 210), suas lições trazem uma ilustração antecedendo as informações textuais, mas apresenta uma visualidade bastante atualizada em sua época, com a linguagem da ilustração de João Gargiulli, que combina traço preto e segunda cor em áreas irregulares e abertas, formando conjunto coeso com o grupo tipográfico das palavras, sílabas e letras a que se associa. A sequência desse conjunto por blocos de frases, palavras, letras e sílabas expressa uma combinação do método analítico (ver p. 121) com uma explicitação prévia das sílabas e letras ensinadas.

A capa, não creditada, traz título em letra manuscrita, pequena ilustração, etiqueta para preenchimento pelo aluno e informações textuais, sobre fundo chapado claro, com pequena quebra de simetria dada pelo alfabeto manuscrito justaposto ao título, em solução geral bastante simples que praticamente não deixa perceber o recurso da impressão em quadricromia.
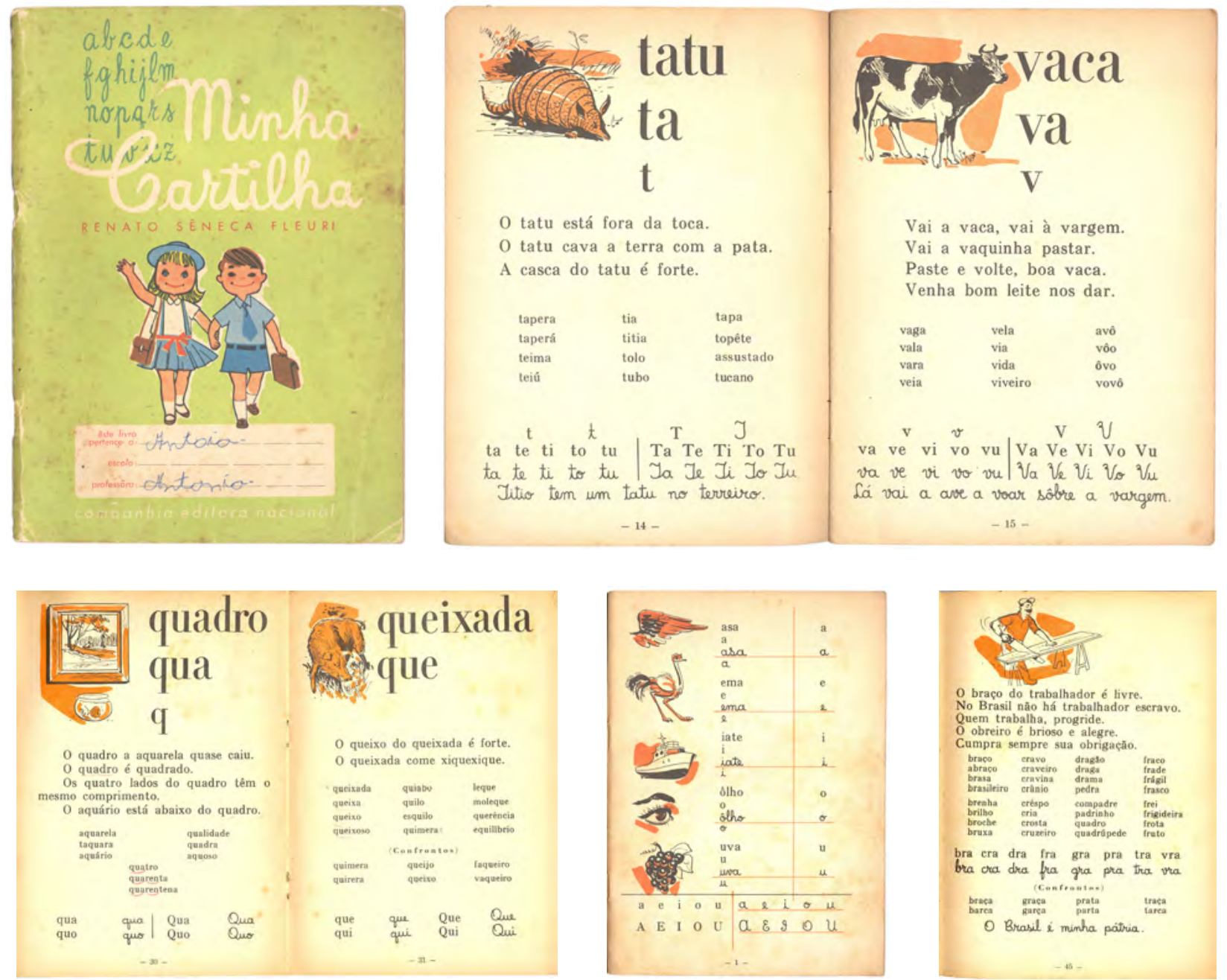

Fig. 7.37. Renato Sêneca Fleury, Minha Cartilha, 1962 (brochura, $15,0 \times 21,0 \mathrm{~cm}$ ). Capa e páginas de miolo. 
A coleção Alvorada segue o modelo predominante para os livros de leitura da Nacional editados desde a década de 1930, com uma ilustração encabeçando a página, seguida do texto, vocabulário e exercícios (FIG. 7.38). O miolo, impresso em bicromia, traz ilustrações creditadas a Augusto Mendes da Silva, que é na realidade Augustus (ver p. 200), em linguagem acadêmica, em consonância com a escolha de textos patriótica e francamente católica do autor, embora pedagógicamente ele se filiasse à Escola Nova [TREVISAN, 2007, p. 28, 40 e 85]. Assim, talvez essa obra tenha um design estabelecido em período anterior, mas não se encontrou nenhuma edição que o confirmasse.

A capa, não creditada e idêntica para as quatro séries, inclusive sem variação cromática, é impressa em quadricromia. Traz as informações textuais principais totalmente integradas à ilustração, formada por traço preto delimitando áreas de cor chapada, em linguagem dirigida a público infantil e de caráter popular, como o usualmente presente nas cartilhas e livros de primeiro grau, de acabamento brochura.
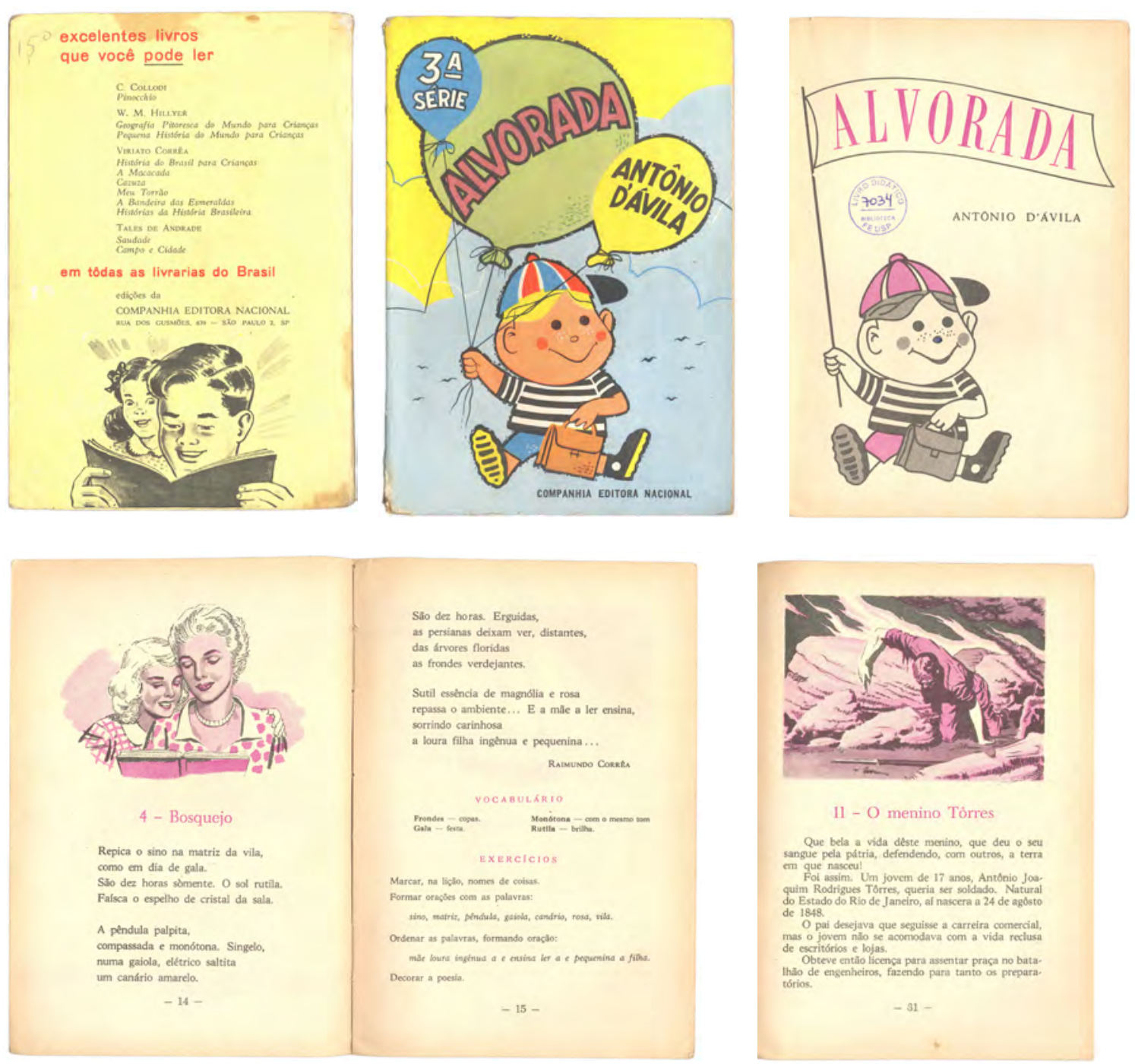

Fig. 7.38. António D’Ávila, Alvorada: 3ạ série, 1967 (brochura, 13,0 x 19,0cm). Capa e páginas de miolo. 
As edições de Programa de Admissão já na década de 1950 tinham produção complexa, por reunirem quatro disciplinas, daí serem as primeiras a apresentarem crédito de "planejamento gráfico", atribuído a Theobaldo de Nigris e Rubens de Barros Lima (ver p. 250). Também foram as primeiras a serem impressas integralmente em quadricromia, provavelmente por serem dirigidas aos alunos do primário que se preparavam para a seleção de ingresso ao ginásio, o que também garantia grandes tiragens que compensavam o investimento. Nesta edição (FIG. 7.39), a capa apresenta um leiaute com separação clara de informações textuais e imagem, com ilustração de Augustus, em linguagem atualizada encontrada em publicidade e revistas, que foi mantida até a edição de 1971, quando foi abolido este exame.
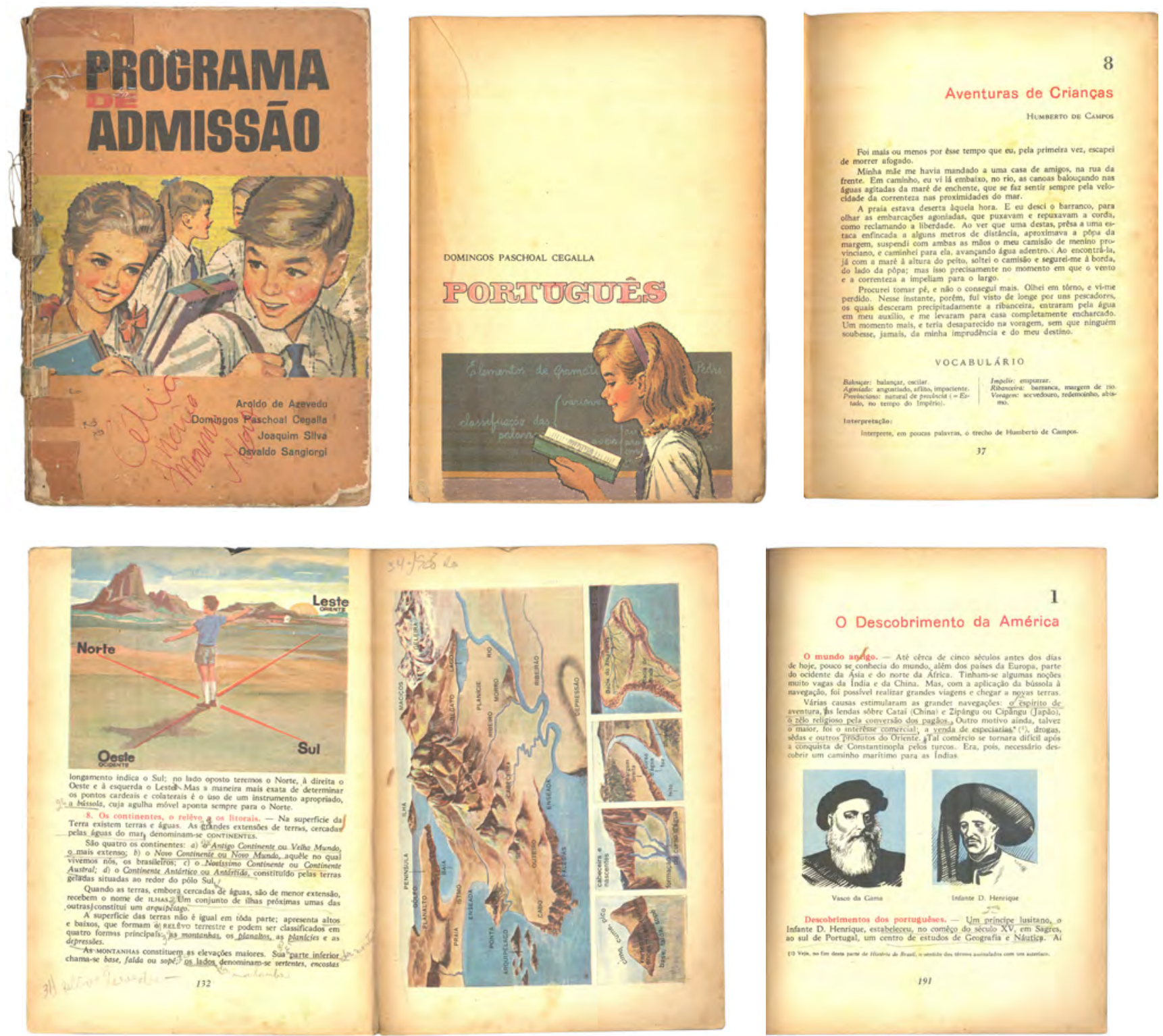

Fig. 7.39. Aroldo de Azevedo, P. P. Cegalla, Joaquim Silva e Osvaldo Sangiorgi, Programa de Admissão, 1965 (15,3 $\times 21,0 \mathrm{~cm}$ ). Capa e páginas do miolo. 


\subsection{Considerações gerais sobre o design dos livros didáticos da CEN do período 1961-1969}

A característica marcante dos novos livros do período é uma maior particularização visual e gráfica das novas obras ou reedições, que deixa de ser dada apenas pela capa mas passa a envolver também a visualidade dos miolos, a partir de uma atividade projetual que se referencia em linguagens gráficas já encontradas em outros meios impressos e as aplica de forma a articular e relacionar visualmente as partes componentes dos livros - capa, guardas, páginas pré-textuais, aberturas de capítulo e demais páginas internas, concebendo-as como duplas e integrando linguagens de ilustração, intervenção gráfica na aplicação da iconografia, mapas e esquemas.

Esse procedimento aparece pela primeira vez e de forma mais completa em obras de História encomendadas a Eugênio Hirsch, inclusive relacionando fortemente capa e miolo e produzindo identidade e apreensão do livro como objeto unitário. Mas a ocorrência em obras de Ciências, Matemática e Desenho, e de forma mais diluída em muitas outras, indicam que Hirsch forneceu um exemplo de procedimento no tratamento da visualidade do livro didático que a editora adotou como modelo na produção geral de sua obras. No caso de uma obra de Matemática para atender a necessidade de veicular conteúdos e abordagens pedagógicas novas, enfatizando a atualidade e a modernidade dos novos livros. No caso de obras de Ciências e Desenho para atender necessidades específicas de conteúdo didático das disciplinas, mas também em consonância com visualidades que se impunham em outros meios de comunicação impressa principalmente. E de forma geral para comunicar uma atualização e modernização visual dos produtos da editora, mesmo que a intervenção se limite às capas, como no caso de Português.

Assim, na sequência do trabalho de Hirsch, surgem em seguida os nomes de Nestor Batagliero e Joel Link creditando o trabalho de ilustração - e acreditamos de projeto, edição de arte e mesmo de capas - em obras de Matemática e Ciências principalmente, e os nomes de Lenci \& Fisher creditando capas ${ }^{4}$.

No entanto, chama a atenção o fato de o projeto de Hirsch e mesmo suas ilustrações serem utilizadas em diversas obras, bem como a linguagem de capas de Ciências, Matemática

\footnotetext{
4 Não se encontrou referências às formas de colaboração nem informações biográficas desses profissionais, como também pouco se sabe do início da atividade de Eugênio Hirsch (Viena, 1923 - Rio de Janeiro, 2001) no Brasil. Ana Sofia MARIz [2005, p. 81-85] menciona o convite de Lobato ao ilustrador de suas edições na Argentina para vir ao país, um provável contrato de trabalho com a Brasiliense, que não teria sido cumprido, o ano de 1957 como o de sua mudança para o Brasil e a sua atuação em agências de publicidade no Rio de Janeiro. Sua colaboração com a Nacional era até agora aparentemente ignorada e provavelmente antecedeu e se sobrepôs ao seu trabalho na Civilização Brasileira, certamente pelos laços existentes entre as duas editoras, ambas pertencentes a Octalles Marcondes Ferreira antes da transferência definitiva da última, em 1963, para seu genro, Ênio Silveira.
} 
e Desenho serem mais relacionadas entre si do que com os respectivos miolos. No primeiro caso, há um prosseguimento da prática de aproveitamento de arquivo de imagens e soluções que caracterizou a atividade de arte da editora em todos os períodos 5 . No caso das três obras mencionadas, a afinidade não se deve a uma solução padronizada para relacionar as obras entre si ou por política de economia de produção, mas ao estilo ou linguagem adotada pelo designer num mesmo momento para comunicar a modernidade das obras. Como não só em livros didáticos, mas na produção livreira em geral, a tradição era o design de capa como invólucro dissociado formalmente do design do miolo, a simples presença na capa e miolo de um livro de formas associadas a um novo repertório encontrado em outros veículos impressos, mesmo que não completamente coerente entre si, talvez as relacionasse na comunicação da idéia geral de modernidade para o objeto como um todo.

Ainda com relação ao design de capas, foi dito no início do capítulo que este quinto período não inaugura um novo procedimento, uma vez que já havia sido definido no período anterior a particularização das obras por soluções de capas específicas para elas. No entanto diferenças de linguagem e execução vão se acentuando entre as capas dos dois períodos, relacionadas ao surgimento de novas tendências gráficas, domínio das tecnologias e colaboração de novos profissionais.

Primeiramente, há um aumento de ocorrência de capas impressas em quadricromia e, em particular, com reprodução de fotografia, provavelmente traduzindo maior capacitação técnica e barateamento do processo. Mas mesmo no caso do grande número de capas que ainda continuam concebidas para serem impressas em cores especiais, nota-se um refinamento e um maior domínio do processo, como mostram as capas de Ciências das figuras 7.23 e 7.24 .

Há também um aumento do número de capas com solução tipográfica, utilizando principalmente letras sem serifa desenhadas à mão tomando como modelo fontes como Helvetica ou Univers, agora frequentemente usadas em caixa baixa, provavelmente uma manifestação da influência do chamado Estilo Internacional. Mas da mesma forma que a influência da arte e do design construtivos encontrada em capas do período anterior, trata-se mais de uma apropriação de formas de um repertório do que exatamente uma filiação a essas vertentes do design modernista. Este fato pode indicar uma abertura ao que ocorria em meios mais restritos e considerados elevados da produção de linguagem e o quanto pode ter sido significativa a influência deles, provavelmente por veicular formas apreendidas como signos de modernidade,

\footnotetext{
5 Beda menciona a existência desse arquivo, que guardava também clichês e chapas [BEDA, 1987, p. 275]. Além do estabelecimento de padrões e diagramas comuns aos livros que imperou até o período anterior, há ao menos um caso de reaproveitamento de design e ilustrações integral de miolo, relatado nas páginas 209 e 210. E, a par das mudanças de design de capa e miolo para um conjunto maior de obras novas, sempre houve a reedição de títulos sem qualquer alteração em capa e miolo por períodos superiores a uma década e quase chegando a três décadas, do que é exemplo a Cartilha Sodré (ver p. 213-214).
} 
que se desejava agregar a determinadas obras ou mesmo a um conjunto maior da produção da editora.

Quanto ao uso da fotografia em cores, ele praticamente se restringiu às capas de Geografia, prosseguindo a abordagem documental já presente nas últimas capas da disciplina do período anterior e provavelmente acompanhando o que era trazido por outros meios impressos, como as revistas semanais de reportagem fotográfica.

Com relação à linguagem das ilustrações, constata-se uma significativa atualização, seja sob influência do design modernista, seja da ilustração de revistas e fascículos, em que as capas de Ciências ilustram os dois casos. Mas as capas de História e de Matemática ilustradas por Eugênio Hirsch são as que certamente trouxeram maior impacto, seja pela ousadia e ineditismo no segmento didático, seja pela qualidade da realização.

Assim, se em relação ao período anterior se disse que a introdução de cor nas capas, em ilustrações, tipografia como imagem e fotografia, trouxe importantes transformações na visualidade do livro didático, as transformações introduzidas no período aqui tratado - extensão mais acentuada do uso de cor para os miolos e principalmente a concepção dos livros como objetos mais unitários, alguns desenhados da capa às páginas internas -, estabelecem um novo paradigma no design do livro didático no Brasil, com consequente ampliação do repertório visual da cultura escolar e das expectativas em relação a esse artefato impresso por quem os utilizava. 

CAPÍtULO 8

1970-1980:

O design dos últimos anos da Companhia Editora

Nacional e as transformações do livro didático brasileiro 

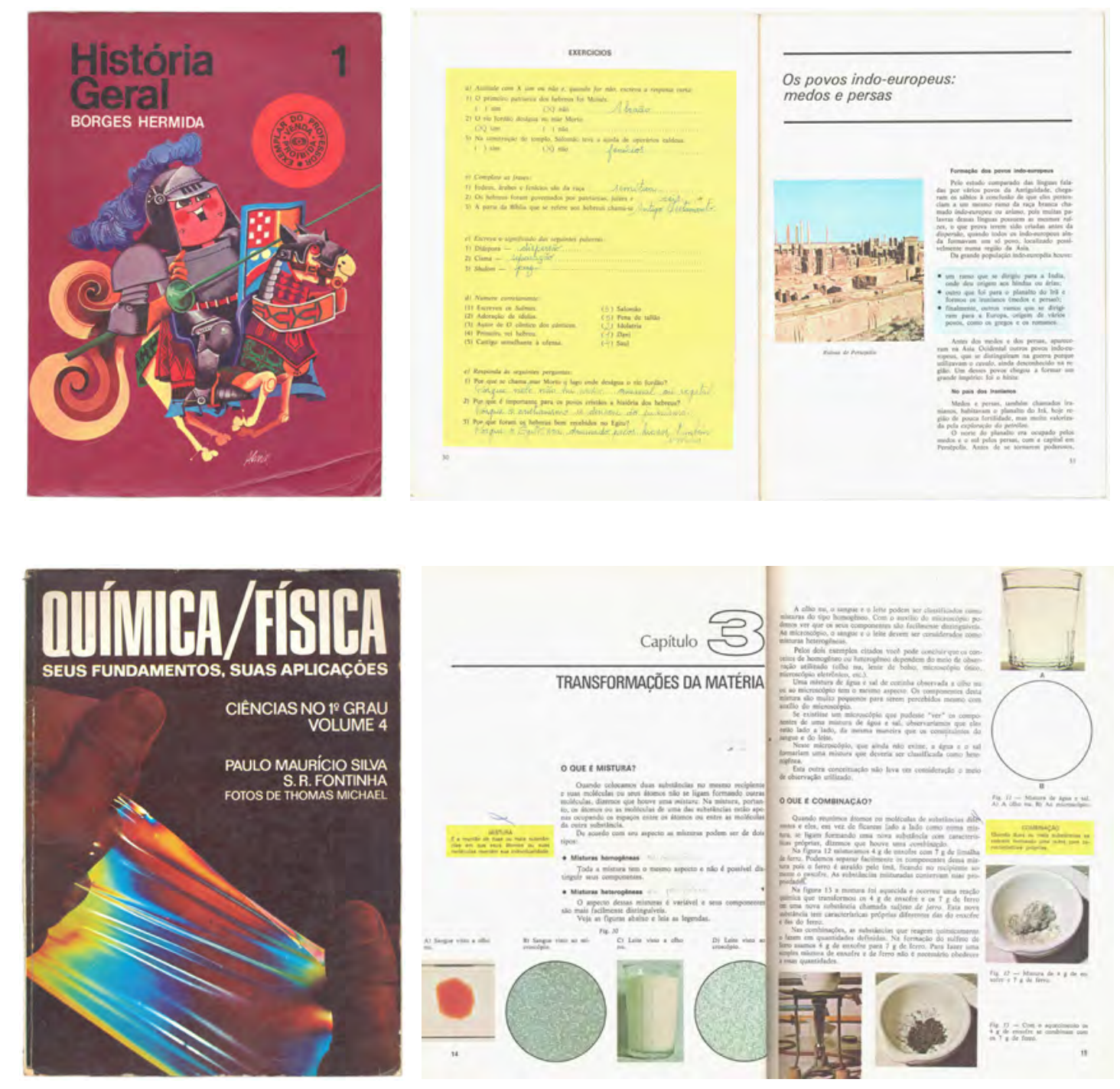

As duas obras aqui reproduzidas apresentam algumas das principais características encontradas no design e na materialidade de livros didáticos da CEN no período 1970-1980:

- a generalização das capas ilustradas e fotográficas impressas em quadricromia;

- a adoção de formatos maiores e o acabamento em brochura;

- a diagramação em duas colunas e a impressão em quadricromia dos miolos;

- a criação do livro "consumível", com espaço para a escrita do aluno;

- a criação do livro do professor, com respostas em letra manuscrita. 
D eve-se o estabelecimento de um sexto período para o design dos livros didáticos publicados pela Companhia Editora Nacional a um conjunto de significativas transformações em sua visualidade e materialidade. A primeira delas é a adoção de formatos maiores para os livros de ensino de Primeiro Grau, que com a reforma do ensino de 1971 abrange os antigos Primário e Ginásio. Ainda com relação à materialidade, esses novos livros não vêm mais protegidos por capa dura, mas passam a ter o acabamento brochura. Decorrente dos novos formatos, uma transformação no leiaute de página também se fez necessária, com a distribuição dos conteúdos textuais e imagéticos em diagrama de duas colunas. Uma quarta transformação também se fez muito evidente: a adoção da impressão em quadricromia para a maioria das capas e miolos das obras destinadas ao Primeiro Grau, mas também para parte das obras de Segundo Grau, denominação para o nível correspondente ao antigo Colegial. As novas capas e miolos trazem também novos desenhos de letras, não mais produzidas manualmente ou compostas tipograficamente, mas por novas tecnologias e materiais. Capas e miolos exibirão também novos estilos e linguagens de ilustração e sobretudo fotografias em cores.

Essas transformações têm como base mudanças tecnológicas maiores: na composição de textos, a entrada no país dos processos de fotocomposição (ver p. 314, nota 1), para produção de texto corrente e de títulos em corpos maiores, mas também das letras transferíveis (ver p. 315, nota 2); na impressão, o emprego de máquinas ofsete rotativas, que utilizando bobinas de papel e não folhas avulsas permitiam a impressão das quatro cores com uma única entrada de máquina e em formatos maiores.

Com relação ao uso, os livros didáticos produzidos já no início da década de 1970 trazem também uma inovação importante: seções de exercícios para serem realizadas no próprio livro, tornando-os "consumíveis", ou a existência de volumes ou cadernos de atividades acompanhando o livro principal, além da produção de um livro dirigido exclusivamente ao professor, com orientações didáticas, respostas e comentários dos exercícios.

Por fim, a visualidade geral do livro didático desse período é marcada por uma influência muito mais incisiva dos meios de comunicação de massa do que em períodos anteriores, com a disseminação da imagem fotográfica e televisiva em cores estabelecendo novos padrões de realismo e a difusão de produtos culturais dirigidos aos extratos jovem e infantil da população trazendo linguagens diferenciadas e particulares.

Este sexto e último período se encerra em 1980, não porque a Nacional tenha deixado de existir e publicar livros didáticos, mas porque sua aquisição pelo Ibep (Instituto Brasileiro de Edições Pedagógicas) a integrou a um sistema de produção de livros já existente e encerrou sua existência como editora independente. 


\subsection{A educação brasileira no período 1970-1980}

A exemplo do capítulo anterior, iniciamos este também por uma apresentação sumária da situação da educação no país, suas transformações e sua expansão durante a década de 1970, porque são elas que estão na base das transformações materiais e visuais dos livros escolares, da Companhia Editora Nacional e das demais editoras que com ela concorriam.

O primeiro fato relevante na situação da educação no Brasil no período estudado é o decreto e implementação da reforma de ensino de Primeiro e Segundo Graus (Lei 5.692, de 11 de agosto de 1971). Dentre diversas medidas, esta lei estabeleceu:

- a ampliação da obrigatoriedade escolar para oito anos, para a faixa etária dos 7 aos 14 anos;

- a junção do curso Primário e do curso Ginasial num só curso fundamental, denominado Primeiro Grau, de oito séries, correspondendo à educação escolar obrigatória para a criança e pré-adolescente, com caráter não só de formação geral, mas também de "sondagem vocacional" e iniciação para o trabalho;

- estabelecimento do curso de Segundo Grau, com 3 a 4 anos de duração, para a formação do adolescente, com objetivo primordial de habilitacão profissional, ou seja, de caráter profissionalizante;

- junção das disciplinas História e Geografia numa única denominada Estudos Sociais, para o Primeiro Grau.

- mudanças no ensino supletivo destinado a suprir a educação que jovens e adultos não tiveram no tempo certo, com estrutura, duração e características diferentes do ensino regular e ministrado livremente pelos meios de comunicação de massa (TV e rádio, com apostilas adquiridas em bancas de jornal ou pelo correio) [RomANELLI, 2007, p. 237-238].

A ampliação da obrigatoriedade do ensino para um curso fundamental de oito anos implicou necessariamente um maior comprometimento do Estado com a educação da população, com a expansão da rede escolar oficial, bem como uma grande ampliação do mercado para livros escolares. A unificação dos antigos cursos primário e ginasial, com o consequente fim dos exames de admissão, eliminou um dos obstáculos responsáveis pela seletividade que excluía grande parte da população pobre da continuidade dos estudos - embora fatores econômicos, como a redução de ganhos e expulsão do campo, continuassem obrigando essa população a interromper os estudos para ingressar prematuramente no mercado de trabalho -, concorrendo também para a ampliação do mercado editorial didático.

A reforma eliminou também a separação entre Ensino Secundário de formação geral preparatória ao Ensino Superior e ensino técnico, criando uma escola única de Primeiro e Segundo Graus, ambos apresentando o duplo caráter de continuidade e de terminalidade, em tese eliminando o antigo dualismo classista entre os dois níveis de ensino e os ramos secundário e 
técnico. No caso do Primeiro Grau, o currículo dava ênfase à educação geral, mas os anos finais apresentariam disciplinas de formação especial, para sondagem de aptidões e aquisição de capacitação mínima para iniciação ao trabalho não especializado para quem não prosseguisse o estudo no Segundo Grau.

No caso do Segundo Grau, parte do currículo era formado por disciplinas voltadas para a formação geral, mas a ênfase era dada a disciplinas de formação especial, que permitiria a habilitação profissional e o ingresso no mercado de trabalho em carreiras de nível médio (terminalidade), ao mesmo tempo que não impediria o prosseguimento dos estudos em nível superior para quem o desejasse (continuidade) [RoMANELLI, 2007, p. 238-239].

A lei e suas regulamentações estabeleceram para cada nível um núcleo comum de disciplinas, obrigatório nacionalmente, que seria complementado com disciplinas definidas estadualmente e mesmo em cada estabelecimento de ensino, além de matérias obrigatórias. De forma resumida e adaptando a nomenclatura para traduzir as diferenças de abordagem pedagógica existente entre os dois níveis (atividades = iniciação; disciplina = sistematização de conhecimento), a organização curricular dos núcleos mínimos obrigatórios ficou assim definida:

\section{Primeiro Grau}

- Área de Comunicação e Expressão: Atividades de Comunicação e Expressão (1a a 5ạ série), disciplina de Língua Portuguesa (6a a 8a série);

- Área de Estudos Sociais: Atividades de Integração Social (1a a 5a série), disciplina de Estudos Sociais (conteúdos de História e Geografia, 6a a 8 série);

- Área de Ciências: Atividades de Iniciação às Ciências (1aa 5ํㅗ série), disciplinas de Matemática e Ciências (6a a 8 série);

- Disciplinas obrigatórias: Educação Moral e Cívica, Educação Física, Educação Artística e Programas de Saúde.

\section{Segundo Grau}

- Área de Comunicação e Expressão: disciplinas de Língua Portuguesa, Literatura Brasileira e Língua Estrangeira;

- Área de Estudos Sociais: disciplinas de História, Geografia, Organização Social e Política Brasileira;

- Área de Ciências: disciplinas de Matemática, Ciências Físicas e Biológicas.

- Disciplinas obrigatórias: Educação Moral e Cívica, Educação Física, Educação Artística e Programas de Saúde [RomanelLi, 2007, p. 238-239].

Para os últimos anos do Primeiro Grau e o Segundo Grau, agora com pleno caráter profissionalizante, o Conselho Federal de Educação estabeleceu 130 habilitações e as matérias 
técnicas especiais para os estabelecimentos federais, que podiam ser acrescidas de outras pelos Conselhos Estaduais, conforme as várias áreas econômicas (por exemplo: Primária Agricultura, Pesca, Criação de Animais, etc.; Secundária - Organização Industrial, Mecânica, Metalurgia e Siderurgia, Artes Gráficas, Construção Civil, etc.; Terciária - Comércio, Administração, Contabilidade, Turismo, Comunicações, Enfermagem, Tecelagem, etc.).

Não cabe aqui aprofundar uma crítica à reforma, apenas informar muito sumariamente suas motivações, processo de implantação, limitações e alcance real. Em primeiro lugar, essa reforma teve um tempo de tramitação de apenas trinta dias, num Congresso controlado pelo regime de exceção implantado pelo golpe militar de 1964, sem qualquer processo de discussão mais ampla na sociedade. Sua elaboração ficou a cargo de uma comissão nomeada diretamente pelo executivo e seguiu recomendações produzidas por consultores norteamericanos definidos pela colaboração conhecida como acordos MEC-Usaid (United States Agency for International Development), que também orientaram a formulação da Reforma Universitária implantada a partir de 1968. Teve o aspecto duplo de responder à pressão social por educação básica e média e fornecer graus de qualificação compatíveis com o modelo de desenvolvimento econômico adotado. Para a educação básica obrigatória, a cargo do Primeiro Grau, previa uma qualificação mínima para o exercício de atividades na indústria e nos serviços que o Ensino Primário restrito a quatro anos não atendia. Para o Segundo Grau, o caráter de profissionalização combinava dois objetivos: fornecer quadros médios para a indústria e serviços e ao mesmo tempo esvaziar a pressão pelo acesso ao Ensino Superior exercida pelas camadas médias da população. É fato bastante conhecido que esse caráter profissionalizante não se concretizou, principalmente pelo alto nível de investimentos que implicava. Tanto o Estado brasileiro não se dispôs a custear de fato sua implantação, particularmente devido a escassez de recursos resultante da crise ecômica iniciada em 1973, como as instituições privadas encontraram brechas na legislação para contornar a criação de verdadeiros cursos de formação profissional [LIRA, 2010, p. 276-297].

Em termos legais e formais, a nova legislação aboliu o caráter dualista classista do ensino brasileiro que viemos apontado ao longos dos períodos aqui estudados, no entanto o próprio objetivo de terminalidade do ensino de Primeiro Grau não deixa de reiterá-lo, apenas jogando para uma idade mais avançada, 14 anos, a interrupção dos estudos, quando ela não ocorria antes devido às precárias condições de uma população submetida ao forte arrocho salarial que caracterizou os anos da ditadura militar.

No entanto, a escolarização da população brasileira, acompanhando um fenômeno ocorrido em termos mundiais [LIRA, 2010, p. 328], prosseguiu aumentando na década de 1970 ao menos no mesmo ritmo da década anterior, mostrado na tabela 7.1 no capítulo anterior. A tabela 8.1 apresenta números para os três níveis de ensino para o final da década de 1960 e o meio e o final da década de 1970, em que se observa um crescimento de 40\% no número 
matrículas no Primeiro Grau entre os anos de 1970 e 1980, mas a quase triplicação do número de matrículas para o Segundo e para o Terceiro Grau no mesmo período.

A magnitude desses números, que nessa tabela incorpora também o ensino universitário, explica a continuidade do extraordinário crescimento da indústria editorial didática iniciado na década de 1960, como vimos no capítulo anterior, mas que nos anos 1970 atingirá um volume de produção muito superior e contará com a participação de novos empreendimentos dividindo esse mercado.

Tabela 8.1. Matrícula no início do ano no 1ำ 2ำ e 3ํgraus para os anos de 1970 , 1975 e 1980

\begin{tabular}{|c|c|c|c|c|}
\hline Ano & Primeiro Grau & Segundo Grau & Terceiro Grau & Total Brasil \\
\hline 1970 & 15.894 .627 & 1.003 .475 & 425.478 & 17.323 .580 \\
\hline 1975 & 19.549 .249 & 1.935 .903 & 1.072 .548 & 22.557 .700 \\
\hline 1980 & 22.148 .809 & 2.823 .544 & 1.377 .286 & 26.349 .639 \\
\hline
\end{tabular}

Fontes: IBGE, 1981, p. 202 e IBGE, 1982, p. 213, 222 e 232.

\subsection{A Companhia Editora Nacional no período 1970-1980}

Como vimos no capítulo anterior, a CEN chega ao fim da década de 1960 ainda como a maior editora do país, devido à sua expressiva venda de livros didáticos, embora contasse, tanto no segmento didático como no segmento não didático, com novos concorrentes. A oferta de produtos para o consumo das classes médias, base do modelo de industrialização do país, envolveu também bens da indústria cultural, com a expansão de todos os seus ramos - cinema, $T V$, imprensa e também livros de literatura e interesse geral. No caso do mercado editorial, um grande número de novas e antigas editoras passam a ter mais expressão do que a Nacional, mas esta, por seu grande volume de produção didática, ainda permanece a primeira em vendas dentre todas elas.

Justamente no ano de 1970, para comemorar 45 anos de existência, a editora lança o álbum de arte Quarenta paisagens inéditas do Rio de Janeiro, São Paulo, Paraná e Santa Catarina, de Jean-Baptiste Debret, em cujo prefácio informa ter produzido 12 mil edições e 200 milhões de exemplares, sendo que a edição no 12.000 foi sugestivamente A galáxia de Gutenberg, de Marshall MacLuhan [HALLEWELL, 2005, p. 377].

Como reflexo de duas décadas de expansão do ensino, mostrada no capítulo anterior e complementada pela tabela 8.1 acima, a produção anual de livros didáticos de todos os níveis saltou de 24,8 milhões em 1966 para 134,5 milhões em 1979, embora essa trajetória tenha apresentado oscilações e no ano de 1980 tenha recuado para 100,3 milhões [HALLEWELL, 2005, p. 559]. Essas condições favoráveis incentivaram o surgimento de novas empresas editoras, o que não impediu que a Nacional, já com um sólido catálogo construído, continuasse mantendo excelente desempenho comercial e o primeiro lugar em vendas. 
Como vimos no capítulo anterior, HALleWell [2005, p. 381-382] atribui ao surgimento dessas editoras na segunda metade da década de 1960 - Saraiva, Ática, Moderna, nova FTD etc. - o movimento de Octalles Ferreira por uma "melhora material e conteudística" dos livros didáticos da Nacional, que conduziu à visualidade apresentada naquele capítulo mas que nós atribuímos principalmente a um movimento próprio da editora. No entanto, agora, no início da década de 1970, provavelmente a concorrência se fez sentir mais forte, com mais editoras entrando no mercado, como a Scipione e a Atual, mas principalmente com a introdução por elas de inovações na configuração dos livros didáticos.

Algumas dessas inovações são a criação do chamado "livro consumível", em que atividades são feitas pelo aluno escrevendo no próprio livro, dos cadernos de atividades, que acompanhavam o livro principal, também para serem preenchidos, e também do livro do professor, que continha as respostas dessas atividades e orientações de uso do livro. A proliferação de ilustrações em cores e a introdução de histórias em quadrinho para a veiculação de conteúdos didáticos também ocorreu nos primeiros anos da década. Várias editoras reivindicam essas inovações, mas pode-se supor que a origem de uma editora como a Ática no setor de publicações de apostilas do Curso Supletivo Santa Inês, em 1965, teve algum papel na criação de livros com essas características, particularmente os títulos que empregavam a metodologia do "trabalho dirigido", em que atividades remetiam às conceituações [PAIXÃo, 1995, p. 216-217]. Também a origem de outras editoras, como a Moderna e a Atual, na decisão de professores de cursinhos preparatórios ao vestibular serem seus próprios editores, trazendo uma experiência de ensino bastante particular e diferenciada da fornecida nos cursos regulares, pode ter gerado obras que se diferenciavam das até então produzidas. A reação favorável do mercado de um ensino que então se massificava certamente favoreceu a generalização dessas inovações e influenciou uma editora tradicional como a Nacional a também produzir livros com essas características.

Mas no início da década de 1970, a Nacional ainda se mantém na dianteira, ao lançar livros inovadores no conteúdo e na forma, de que um exemplo é a coleção de História para 5 a 8 ano de Primeiro Grau, de Sérgio Buarque de Holanda, em formato maior $(19,0 \times 26$ $\mathrm{cm}$ ), com projeto gráfico diferenciado, ampla iconografia fotográfica e ilustrada e impressão em quadricromia, iniciada em 1971. A editora também retoma com êxito a produção de livros para o nível 1 do Primeiro Grau (antigo Primário), com obras de Matemática, Estudos Sociais, cartilhas e livros de leitura, aproveitando a nova organização curricular deste nível de ensino.

E justamente para preparar a produção de obras com novas características materiais, como formato ainda maior (21,0 × 28,0cm), impressão em quadricromia e o econômico acabamento em brochura, a Nacional contou com a sua participação na São Paulo Editora para definir a aquisição dos mais modernos equipamento para produção de livros à época. Em 1972, essa gráfica adquire uma impressora rotativa Solna 4 cores, que começa a operar em 1973, e máquinas para 
encadernação em brochura colada (sem costura dos cadernos), que definirão a materialidade e visualidade dos livros didáticos da Nacional a partir de então [BEDA, 1987, p. 248-249].

No entanto, toda essa antecipação não serviu para manter a editora na liderança em que estava desde a década de 1940. Em 1974, a Nacional ainda ocupava o primeiro lugar entre as editoras do país, para cair de posição ano a ano e chegar ao quinto lugar em 1979, quando apresentou prejuízo contábil [HALlewelL, 2005, p. 384]. A morte de Octalles Marcondes Ferreira, em 1973, evidenciou a ausência de sucessor experiente dentro da própria família, levando esta a decidir pela venda da empresa, que foi oferecida a diversos grupos nacionais e estrangeiros, dentre eles a José Olympio, a Saraiva, a Abril e a McGrawHill. A primeira quase efetivou o negócio, com financiamento total do BNDE (Banco Nacional de Desenvolvimento Econômico), mas por também estar em crise o processo resultou na compra pelo banco estatal das duas editoras, em função do temor do governo de que um grupo estrangeiro as adquirisse. Assim, a Nacional foi estatizada, em fins de 1974, pelo valor equivalente a 16 milhões de dólares na época, quando teve início um processo de gestão burocrática e sem conhecimento do ramo, que levou a uma sequência de resultados insatisfatórios, grande aumento de despesas e queda de rentabilidade, que conduziu a uma depreciação do valor da empresa e sua venda para o Ibep - Instituto Brasileiro de Edições Pedagógicas pelo valor equivalente a apenas 4,5 milhões de dólares em 1980 [HALLEWELL, 2005, p. 382-384 e 479].

Mas antes disso, ainda em 1974, às vésperas da venda para o BNDE, três diretores da empresa, incluindo o diretor editorial Thomaz de Aquino Queiroz, e um grupo de funcionários de nível intermediário, dentre eles Rubens de Barros Lima, responsável pela arte e produção gráfica, desligam-se da editora [BedA, 1987, p. 268 e HALLEWELL, 2005, p. 384], com consequências para a gestão e, como veremos adiante, para a qualidade gráfica das obras.

No entanto, apesar de o ano de 1974 marcar um ponto de inflexão na trajetória da Companhia Editora Nacional, seu amplo catálogo construído ao longo de décadas, as obras que tinham sido recentemente negociadas e estavam em produção e as iniciativas tomadas no terreno tecnológico constituíam um capital que colocava a editora como um participante decisivo no mercado dos livros didáticos por ainda alguns anos, tendo sido sua compra pelo Ibep, segundo Hallewell, um negócio extremamente vantajoso.

No terreno editorial didático, os lançamentos para o ensino universitário continuavam ocupando o espaço aberto pelo crescimento desse nível de ensino, com títulos de grande importância em todos os campos (FIG. 8.1). BEDA [1987, p. 309] fornece o número de 140 títulos para a Biblioteca Universitária, com tiragem de quase 1,5 milhão de exemplares, e de 19 títulos para a coleção Cultura, Sociedade, Educação, interrompida em 1972 com a morte de seu organizador, Anísio Teixeira, com tiragem de 70.403 exemplares. Dois volumes da obra Política \& Sociedade, de Fernando Henrique Cardoso e Carlos Estevam Martins são lançados em 1979 
e 1980. Mas uma coleção idealizada por Octalles Ferreira e dirigida por Florestan Fernandes, Grandes Cientistas Sociais, tem sua produção interrompida e acaba sendo transferida para a Ática em 1980 [Hallewell, 2005, p. 376].
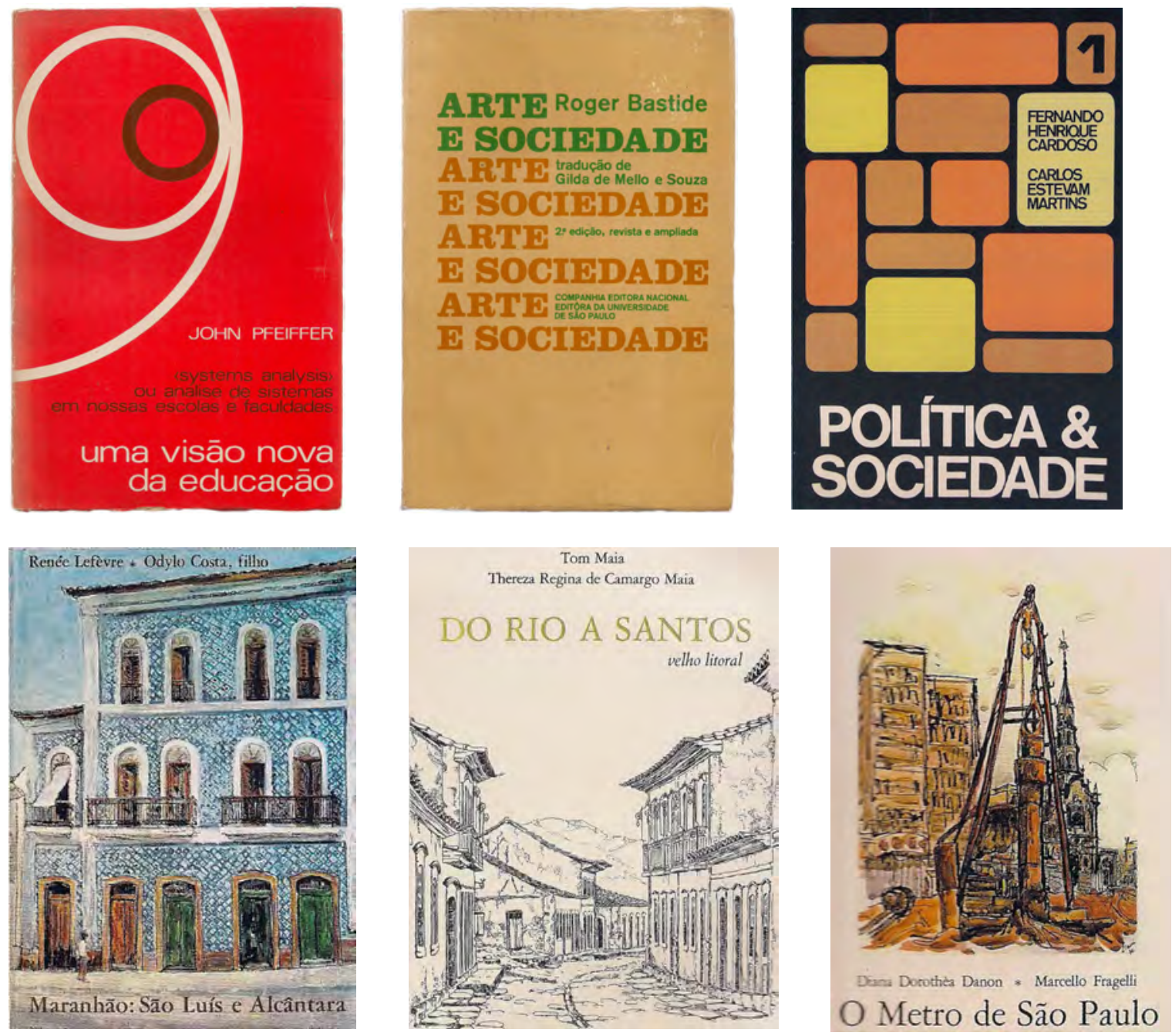

Fig. 8.1. Capas de livros universitários da CEN da década de 1970. [Fonte: acervo pessoal e IBEP, 2005.] Capas de livros da série de artes sobre patrimônio histórico e arquitetônico. [Fonte: IBEP, 2005.]

A série de livros de arte dedicadas ao patrimônio histórico e arquitetônico de cidades brasileiras iniciada em 1968 prossegue com o lançamento de novos títulos e inclui um dedicado à construção do metrô de São Paulo (FIG 8.1). Mas as antigas coleções de literatura popular ou mesmo a Biblioteca do Espírito Moderno foram efetivamente interrompidas, tendo alguns de seus títulos ainda publicados de forma avulsa. A editora, mesmo ainda sob a direção de Octalles Ferreira, não ocupava plenamente o espaço pela demanda mais diversificada de literatura e obras de interesse geral ocorrida com aumento de consumo de produtos culturais, que era suprida por editoras como Nova Fronteira, Brasiliense, Ática, Globo, dentre muitas outras. Assim, a Nacional chega à década de 1970 caracterizada como uma editora quase que exclusivamente didática.

Por fim, é do período sob gestão do BNDE a criação de um novo logotipo para a Nacional, que aparecerá em algumas quartas capas aqui reproduzidas. 


\subsection{A cultura de massas, a imagem fotográfica e o "poder jovem"}

O crescimento da oferta de ensino e das editoras dedicadas à produção de livros didáticos ocorre no mesmo contexto de uma nova expansão da indústria cultural de massas e da afirmação de uma "cultura jovem" em oposição a uma "cultura adulta", num processo que teve início no pós Segunda Guerra Mundial e se aprofundou nas décadas de 1960 e 1970.

Segundo Eric Hobsbawn, o que caracteriza a nova cultura jovem nas sociedades urbanas é o seu internacionalismo, com o blue jeans e o rock como signos de uma juventude moderna, refletindo a hegemonia cultural dos Estados Unidos na cultura popular e nos estilos de vida, tendo como intermediária cultural a Grã-Bretanha. Esses estilos de vida eram difundidos pelos discos e fitas, pelo rádio, pela ditribuição mundial de imagens e pela moda, marcando a existência de uma cultura jovem global [HOBSBAWN, 1996, p. 320].

Edgar MoRIn [2009, p. 138-39], refere-se a uma dominante juvenil na nova cultura de massas, não apenas porque jovens e adultos jovens sejam consumidores de jornais, revistas, discos, programas de rádio e televisão, mas porque os temas da cultura de massa são também juvenis.

Se a indústria cultural em si não é novidade, com os veículos impressos e o rádio trazendo linguagens e estéticas que geram e modificam permanentemente uma cultura de massas no país desde o início do século $X X$, o que surge como novo é a presença de uma indústria cultural voltada para a juventude, apresentando produtos gráficos com determinadas características de visualidade e com apelo a um público até então desconsiderado.

Também novidade é a expansão da televisão, que no Brasil, a partir de 1970, se torna o veículo de maior penetração para a circulação de imagens e estilos de comportamento. $E$ como parte integrante da cultura trazida pelos novos meios da indústria cultural, "uma linguagem não mais sincrética, porém universal no que tem de imediatamente concreta, também se propala: a linguagem das imagens, fotografias, filmes, comics, publicidade, cartazes [MORIN, 2009, p. 160].

Sobre o alcance e os efeitos da cultura visual numa sociedade como a brasileira daqueles anos, Morin aponta que, ao contrário das sociedades ocidentais desenvolvidas, em que as transformações econômicas, principalmente o progresso industrial, é que tranformaram as mentalidades, nos países não desenvolvidos a indústria "ligeira" das comunicações (rádio, cinema e depois a televisão) começa a revolucionar as mentalidades antes mesmo das transformações econômicas. Assim, se nos países ocidentais, o alfabetismo foi difundido antes da cultura audiovisual, nos países não desenvolvidos a cultura audiovisual se propaga por zonas ainda analfabetas [MoRIN, 2009, p. 161].

É essa cultura audiovisual, em que domina a imagem - fixa ou em movimento, mas principalmente em cores, oferecida pelos dispositivos fotográficos como a perfeita repre- 
sentação do real -, e em que dominam signos de uma valorizada cultura jovem, a referência que a indústria do livro didático vai procurar trazer para seus produtos a fim de atingir seu público.

\subsection{O design e a materialidade dos livros didáticos da CEN de 1970 a 1980}

O corpus da pesquisa material para este período, obtido quase na totalidade no acervo da Biblioteca do Livro Didático da FEUSP, é constituído de 95 títulos ou edições de obras didáticas, assim distribuídos:

- Livros para a Pré-escola: 2 títulos;

- Livros para o Primeiro Grau nível 1 (1a a 4a série): 18 títulos ou edições, incluindo cartilhas, admissão, Estudos Sociais, Ciências, Matemática e Comunicação e Expressão;

- Livros para o Primeiro Grau nível 2 (5a a 8a série): 53 títulos ou edições;

- Livros para o Segundo Grau: 22 títulos ou edições.

Até 1973, a encadernação em capa dura é o acabamento mais recorrente para os livros de 5a a 8a série do Primeiro Grau e aparece em vários títulos de Segundo Grau, numa continuidade de padrão vigente no período anterior. Dele também provém a variação de formatos (13,0 x 19,0 cm; 14,0 x 21,0 cm e 15,0 × 21,0 cm), aparecendo também o formato maior de 19,0 x 26,0 cm, mas somente após 1973 é que ele se generaliza e surge o formato 21,0 × 28,0 cm em acabamento brochura e impressão em quadricromia, atestando a mencionada aquisição de equipamentos pela São Paulo Editora. No entanto, após 1974, um número maior de gráficas dentre elas a Impress, a Bloch e a Melhoramentos -, vai atender a Nacional, provavelmente pela quebra do vínculo entre as duas empresas, depois da estatização da editora.

Os livros em formato maior - 19,0 × 26,0 cm e 21,0 × 28,0 cm - apresentam diagrama em duas colunas, com composição de texto em fotocomposição como indica a página de créditos das obras, atestando a entrada desta tecnologia a partir de 1970'. Um padrão comum de diagramação, com larguras fixas de coluna e composição de texto em fonte com serifa (geralmente alguma versão da Times) e de intertítulos em fonte sem serifa (geralmente Helvetica, Univers, Franklin Gothic ou Futura), ambas com suas variações romana, itálico, negrito e negrito itálico, é encontrado em grande número de obras. A impressão em quadricromia favorece o uso de fundos coloridos para boxes e titulagens em cor, também recorrentes em várias obras, além da generalização do uso de fotografia em cores. Os livros do aluno trazem atividades com

\footnotetext{
A fotocomposição era um processo de composição tipográfica em que o texto digitado em teclado produzia informações em fita perfurada ou que eram transmitidas diretamente para uma unidade óptica dotada de um filme em forma de disco ou grade com caracteres que eram selecionados e projetados por um sistema de lentes, que definiam o tamanho do tipo e posicionamento em função de parâmetros prévios de ajuste e alinhamento, sobre papel ou filme fotográfico, sensibilizando-os e produzindo tiras com blocos de texto que eram coladas nas folhas de diagramação ou artes finais [Rossı FILHO, 2001, p. 284 e CRAIG, 1980, p. 29-30].
} 
espaço para respostas constituído de corondéis (linhas de pontos) para serem preenchidos pelo estudante, sendo que no livro do professor este espaço é preenchido por respostas em letra manuscrita, impressas na cor ciano da escala quadricrômica.

Com relação às capas, a solução dominante passa a ser o uso de fotografia, seguida da ilustração, esta última principalmente para os livros de 1aa a 4ํㅗ série do Primeiro Grau, ambas coloridas. A tipografia utilizada é obtida por dois processos, a fotocomposição de letras em corpos de maior dimensão, conhecida por fotoletras, e as letras transferíveis, sendo as mais usadas a da marca Letraset ${ }^{2}$, pelo que indica o reconhecimento do desenho das letras em catálogo do produto, ambos permitindo uma variação maior de desenhos.

A apresentação das obras será feita agrupando-as de forma que se ressaltem as soluções dominantes para capa e miolo em cada grupo, que podem ser por nível de ensino ou disciplina, em ordem cronológica evidenciando a preferência por uma ou outra solução ao longo do período, reunindo capa e miolo ou apresentando grupos de capa com omissão dos miolos para evitar redundância quando estes não apresentam diferenças.

\subsubsection{O predomínio da ilustração nas capas e miolos dos livros de Pré-escola e 1a a 4⿳亠口冋 série do Primeiro Grau}

Com a nova organização do ensino estabelecida pela reforma de 1971, a Nacional aumenta seu investimento em títulos para o nível 1 do Primeiro Grau, com obras para todas as disciplinas, além da reformulação das cartilhas e livros de leitura. Como nessas, em que capas e miolos tradicionalmente traziam a ilustrações como solução dominante, os novos livros continuarão adotando esse partido para as capas e miolos, mas agora terão formatos maiores, impressão em quadricromia e novas linguagens de ilustração.

Assim, a Cartilha do Tutu e o Primeiro livro do Tutu (FIG. 8.2), lançados em 1970, trazem atualização de linguagem de capa e de ilustrações de miolo, mas enquanto as ilustrações do livro de leitura são mais convencionais em sua relação com o texto, a diagramação e ilustrações do miolo da cartilha trazem linguagem de quadrinhos e recursos gráficos para destacar as imagens.

As capas, com ilustração tomando a frente e o verso de cada volume, que são particularizados por formatos diferentes e pelas cores, trazem bastante movimento, ação e sugestão de espaço em imagem que extravasa o campo da capa. As informações textuais são perfeitamente integradas ao conjunto, em área chapada no primeiro plano com a mesma forma dos elementos que predominam na capa, mas em contraste com o volume deles.

\footnotetext{
2 A Letraset era um produto constituído por folhas de letras de desenhos diversos, texturas, retículas e elementos gráficos que eram transferidas por pressão manual com instrumento especial para as pranchas de arte-final. Constituiu uma verdadeira revolução no design, por propiciar a designers, diagramadores e ilustradores um acervo de fontes totalmente à mão, muitas com desenhos então recentes, sem depender de fornecedores de composição, e a possibilidade de integração com as imagens antes inexistente. Segundo Melo; Ramos [2011, p. 468], a Letraset "cumpria um papel análogo ao dos programas de computador na era digital: era a plataforma a partir da qual os projetos eram concebidos e formatados."
} 

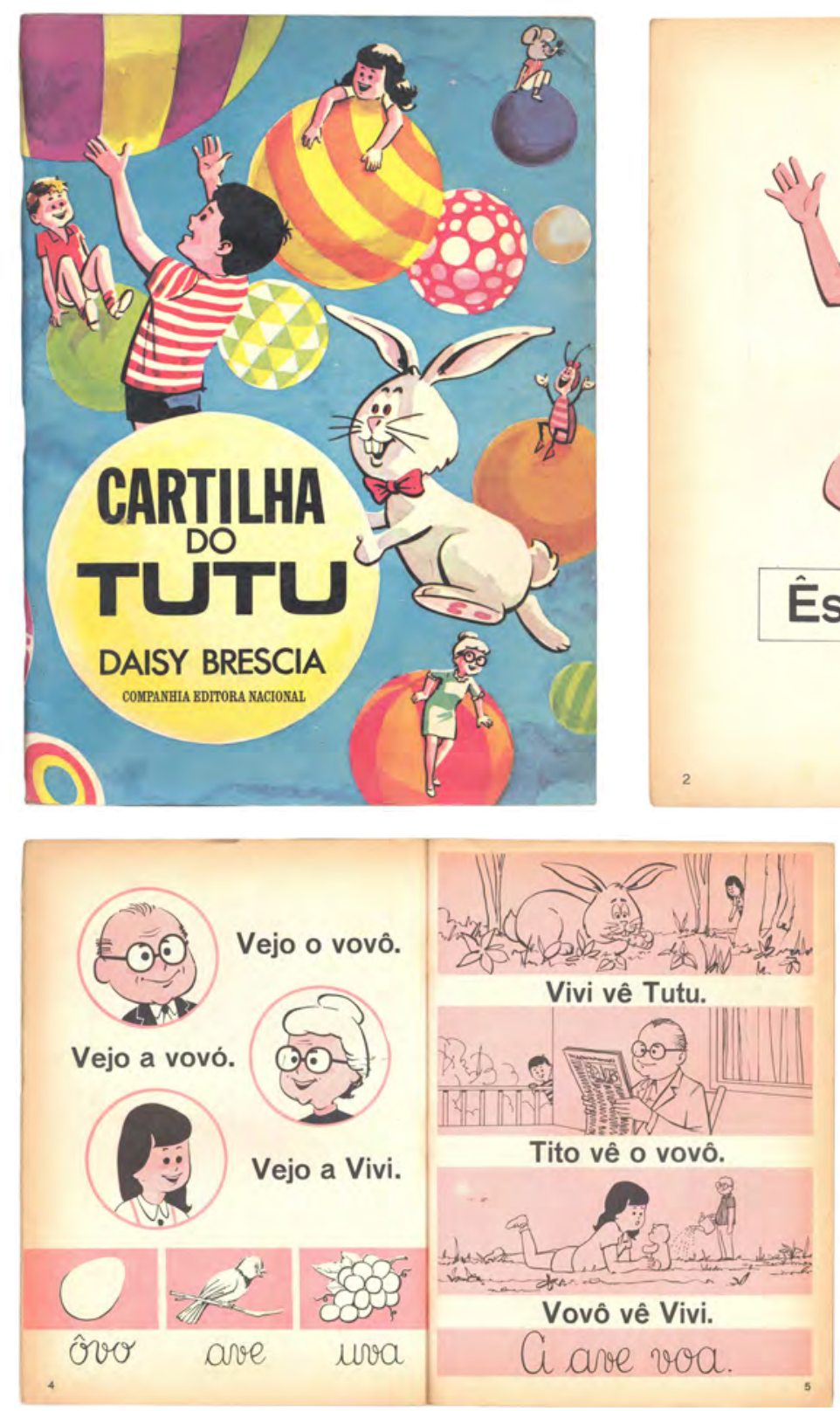

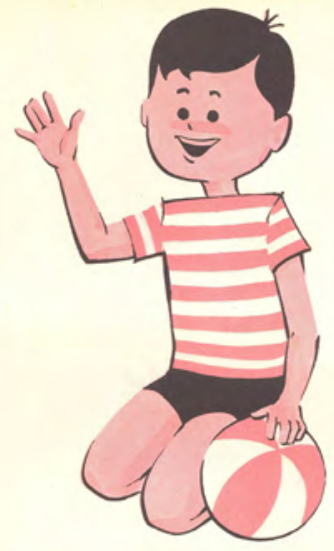

Êste é o Tito.

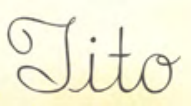

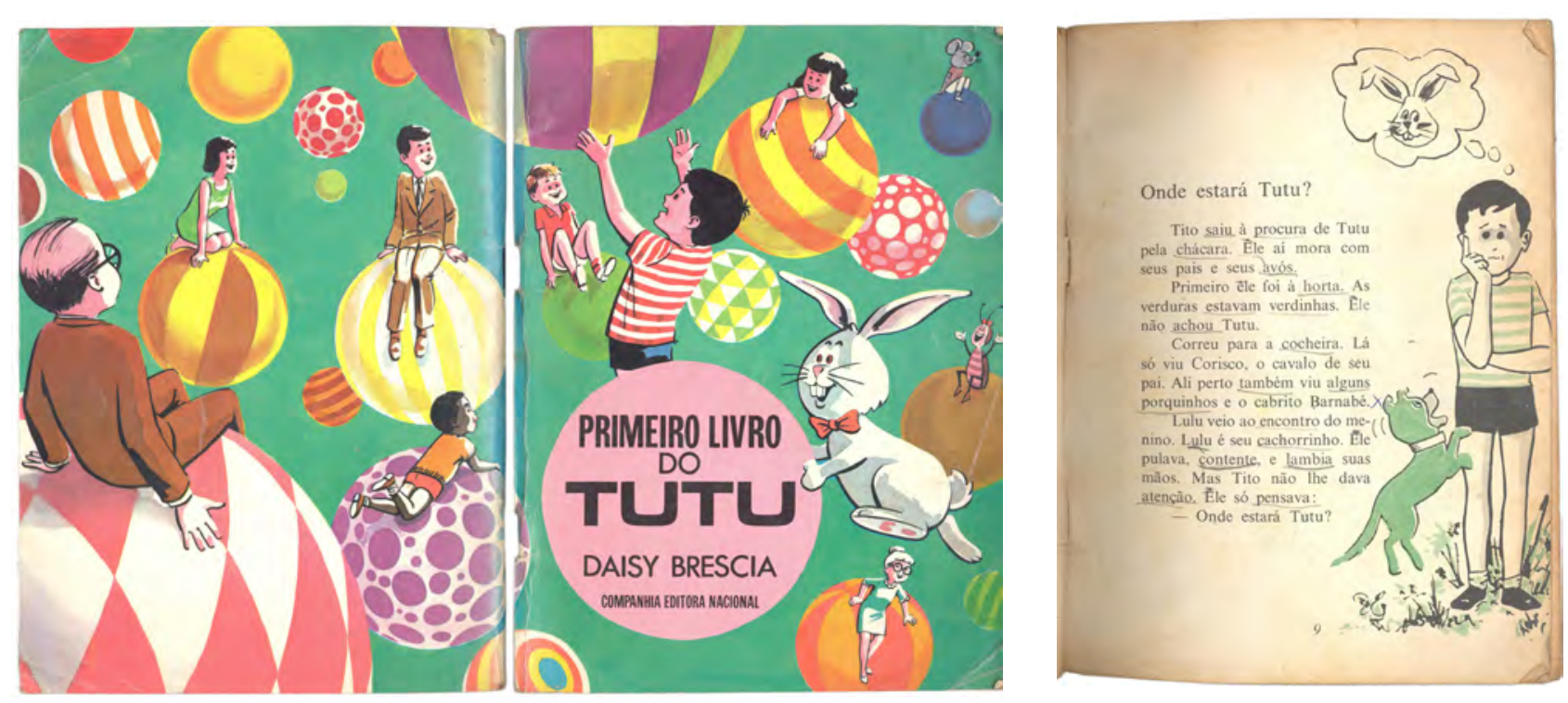

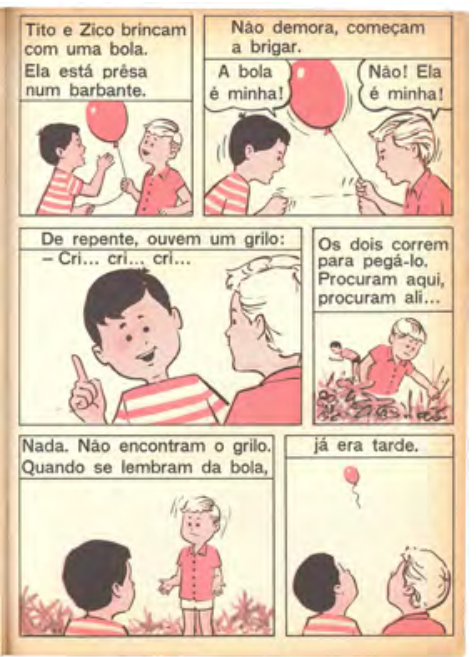

Fig. 8.2. Daisy Brescia, Cartilha do Tutu e Primeiro livro do Tutu, 1970 (brochuras grampeadas, $19,0 \times 26,0 \mathrm{~cm}$ e 15,0 x 21,0 cm). Capa e páginas de miolo, com ilustrações de Francisco Solera e Maria Cecília Solera. 
Estudando São Paulo (FIG. 8.3), destinado à disciplina de Estudos Sociais para o 3o ano do Primeiro Grau teve edições adquiridas pelo governo estadual para distribuição na rede escolar. Tem capa impressa em quadricromia, com diagrama simétrico, ilustração baseada em fotografia de monumento emblemático de uma história heróica do estado e tipografia formal e dura, o que dá uma aparência de publicação oficial, não voltada especialmente para a faixa etária a que se destina. As imagens da quarta capa complementam a idéia de trabalho, tradição e modernidade encarnada pelo estado. Já o miolo apresenta um caráter mais amigável, com o grande formato permitindo uma diagramação de miolo em duas colunas que integra texto e imagens, com alternância de ilustrações coloridas e em traço preto, estas de caráter mais descritivo, resultando em um conjunto bastante rico e variado.
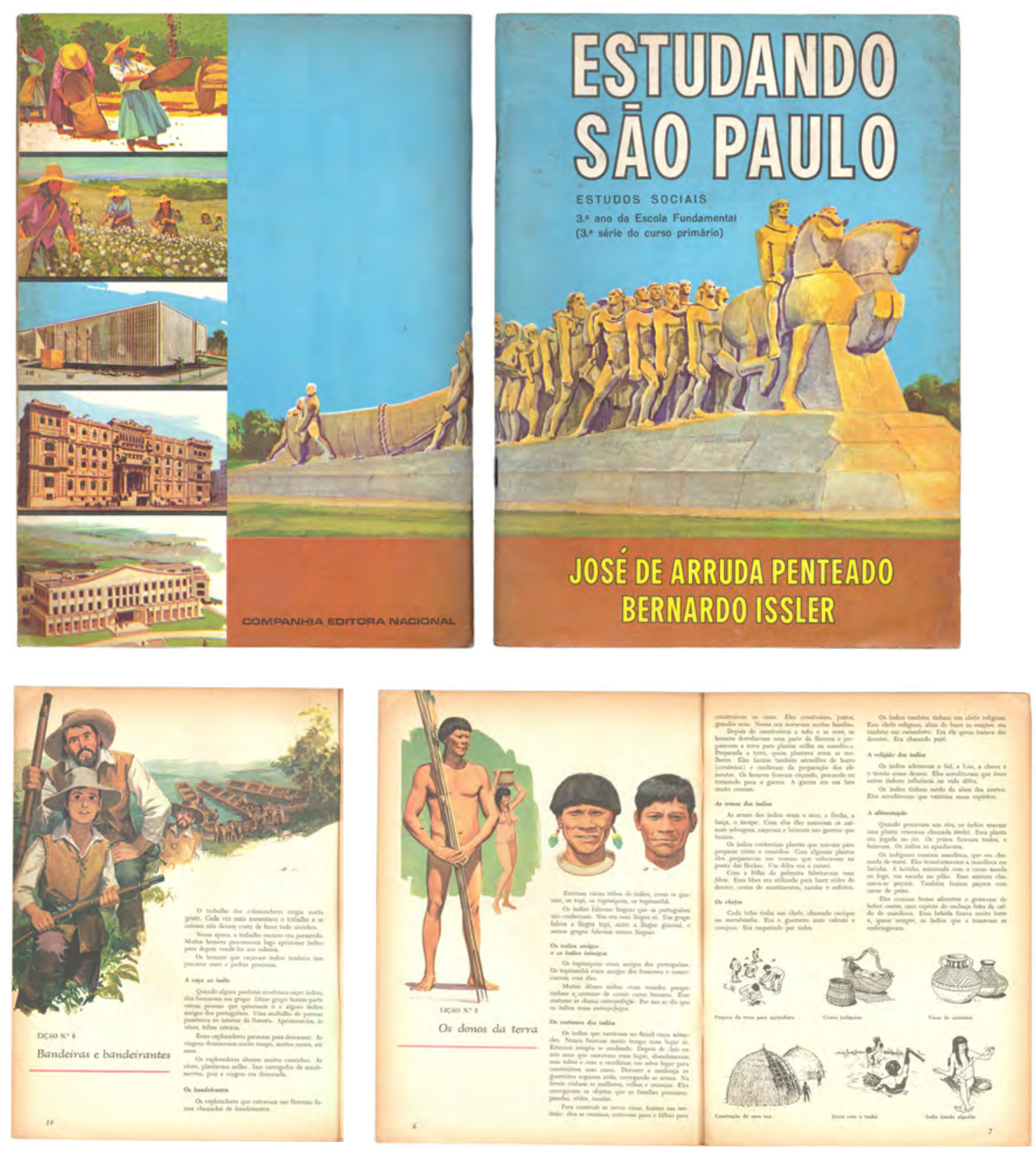

Fig. 8.3. José de Arruda Penteado e Bernardo Issler, Estudando São Paulo: Estudos Sociais, 1971 (brochura grampeada, $19,5 \times 26,0$ cm). Capa e páginas de miolo, com ilustrações de João Gargiulli. 

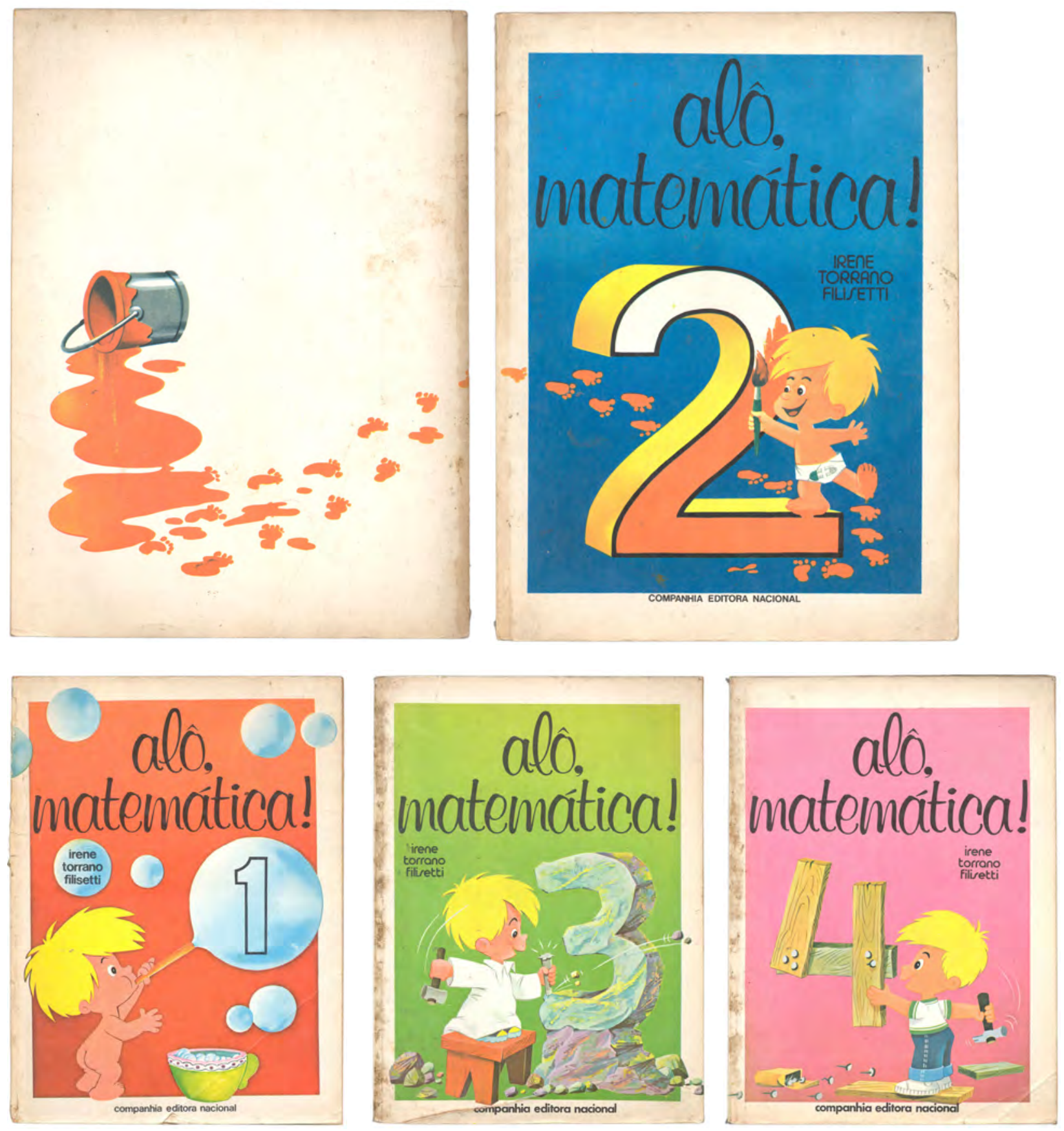

Fig. 8.4. Irene Torrano Filsetti, Alô, matemática!: primeiro grau, 1974 (brochura, $21,0 \times 28,0 \mathrm{~cm}$ ). Capas, com ilustrações de José Roberto Martins.

Alô, Matemática! é a primeira obra de Primeiro Grau que conjuga todas as características deste novo período de design: formato maior, acabamento em brochura, impressão de capa e miolo em quadricromia, com ilustrações em maior acordo com linguagens de outras mídias para a faixa etária, como quadrinhos e desenhos animados, e uso da cor como recurso para a exposição dos conteúdos e sinalização gráfica (FIG. 8.4 e 8.5). O próprio título faz alusão ao mundo da comunicação e seu lettering (com a fonte Murray Hill Bold, da Letraset), ajusta-se à coloquialidade pretendida. O humor e diversão também são elementos novos nos livros escolares e essas capas fazem uso do verso do volume para completar a narrativa. 

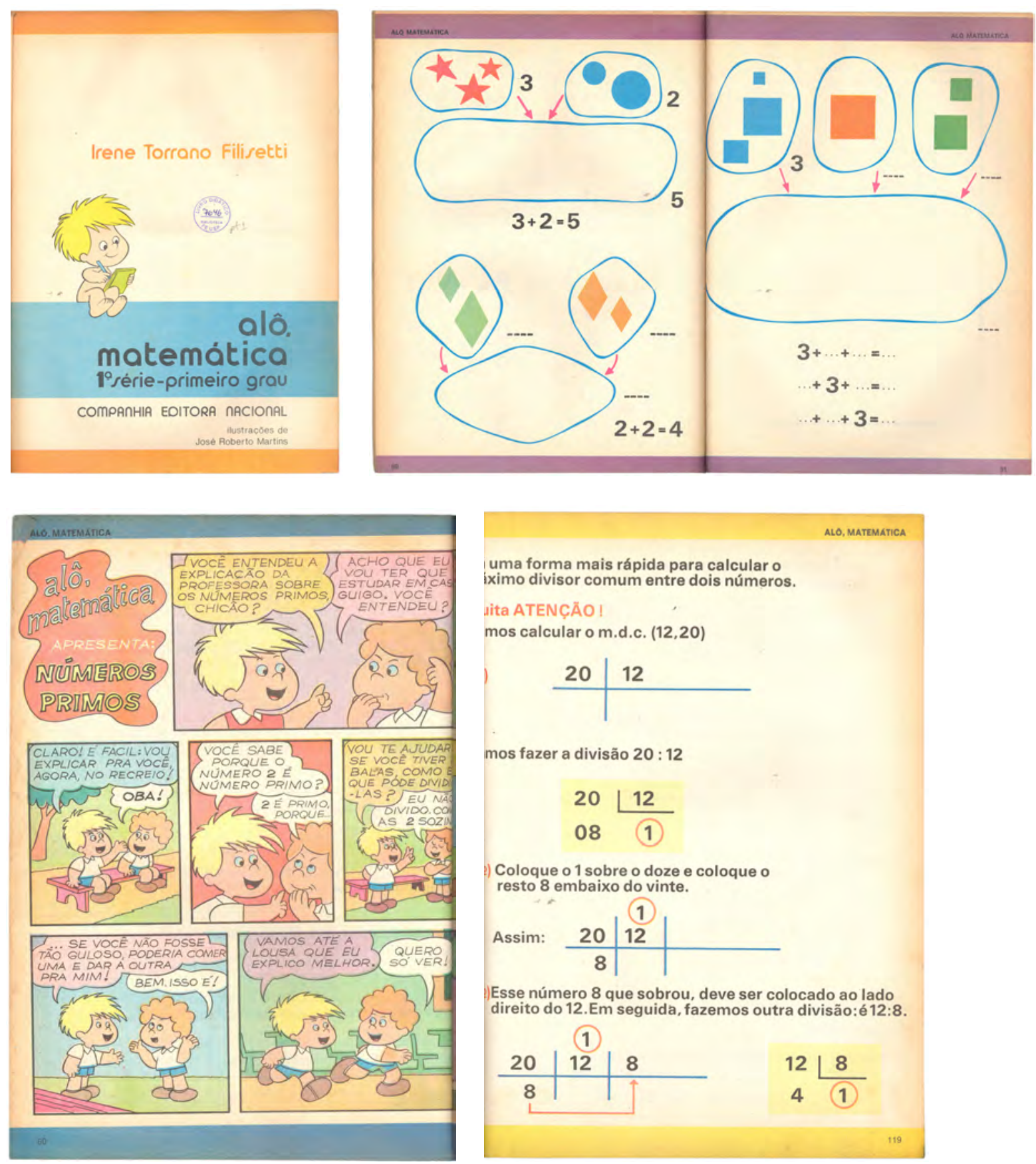

Fig. 8.5. Irene Torrano Filsetti, Alô, matemática!: primeiro grau, 1974 (brochura, 21,0 × 28,0 cm). Miolo da 1aㅡ série, com ilustrações de José Roberto Martins.

A adoção de um personagem para a coleção, que aparece nas capas e em histórias em quadrinhos que introduzem ou explicam conteúdos, é um dos novos recursos que refletem a influência da cultura de massas na concepção dos livros didáticos do período. O miolo traz composição de texto em fonte não serifada, um uso até então reservado para títulos, e emprego disseminado de cor, tanto como recurso de exposição de conteúdo como de suporte gráfico e sinalização dos assuntos tratados, nas margens superior e inferior, o que deixa as páginas bastante cheias e o conteúdo espremido. Embora o personagem esteja presente na capa e no miolo, a relação gráfica entre os dois componentes é fraca e o próprio rosto não utiliza a mesma fonte da capa. 

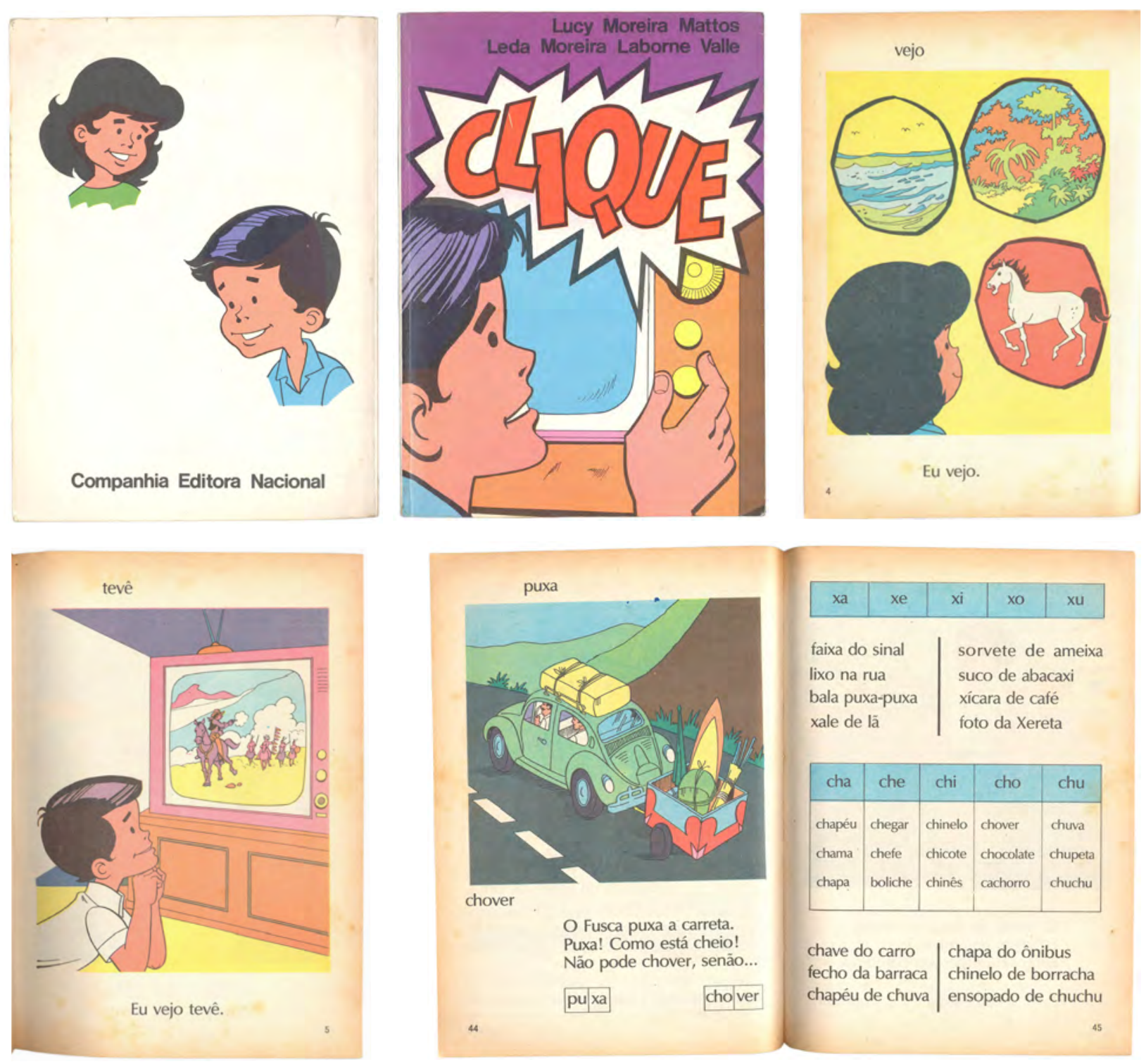

Fig. 8.6. Lucy Moreira Mattos e Leda Moreira Valle, Clique, $1975(15,0 \times 21,0 \mathrm{~cm})$. Capa e páginas de miolo, com ilustrações de Walmir Amaral de Oliveira e Milton Sardella.

A cartilha Clique é mais uma obra que procura atingir o público pelas referências a imagens e palavras do mundo da comunicação e do consumo de massas. Título e imagens de capa e de miolo aludem à experiência televisiva e dos quadrinhos e o próprio léxico utilizado para ensino da leitura e escrita é atualizado, incorporando palavras novas em frases alusivas a situações mais próximas da vivência do público infantil urbano (FIG. 8.6).

A linguagem de ilustração provém dos quadrinhos, com traço preto delimitando áreas preenchidas por cor chapada, em desenho de personagens e objetos por vezes duro e esquemático, que numa situação de capa talvez não sustentasse atração e interesse além das primeiras visualizações. 

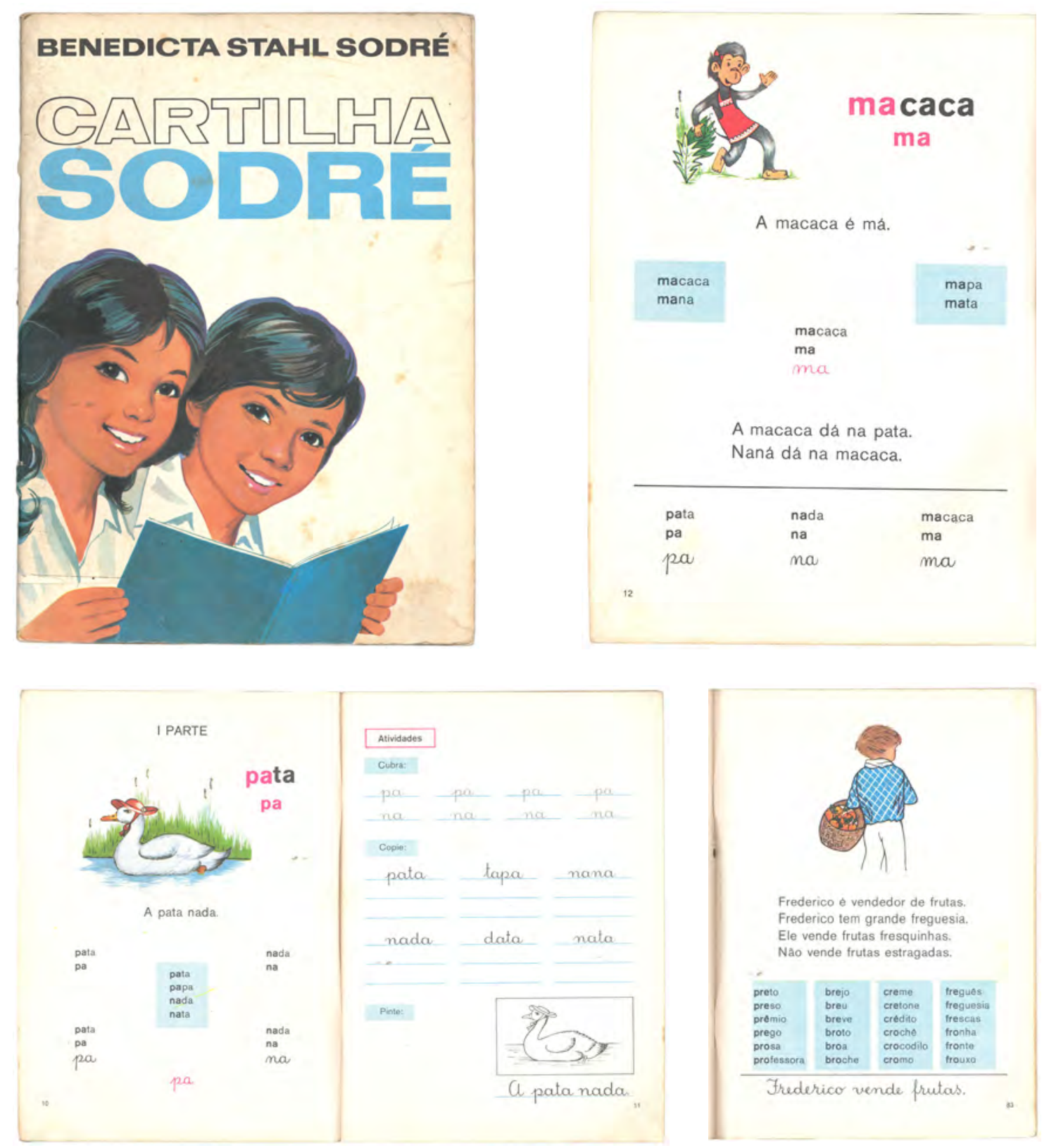

Fig. 8.7. Benedita Stahl Sodré, Cartilha Sodré, $1978(19,0$ × 26,0cm). Capa, não creditada, e páginas de miolo, com ilustrações de Lenisa Sodré Vergamini.

Depois de 30 anos sem modificação em seu design de capa e miolo (ver FIG. 5.16 e 5.31), em 1978 a Cartilha Sodré tem sua 252 ${ }^{\text {a }}$ edição produzida em formato maior, capa e miolo impressos em quatro cores e principalmente uma reformulação de seu conteúdo que a transforma em livro "consumível", com atividades de escrita para o aluno (FIG. 8.7). Em linguagem de ilustração atualizada, a capa ainda mantém a mesma estratégia de busca de identificação com o leitor, mas agora com dois personagens dirigindo o olhar para ele. Embora impressa em quadricromia, o que permite modulação tonal mais realista e atraente, trabalha basicamente com o branco, preto e duas cores complementares, em áreas claramente definidas e alternadas, na ilustração e nas informações textuais, o que confere impacto e clareza. A disposição destas na largura total do campo completa a estrutura simples e eficiente para a recepção. 

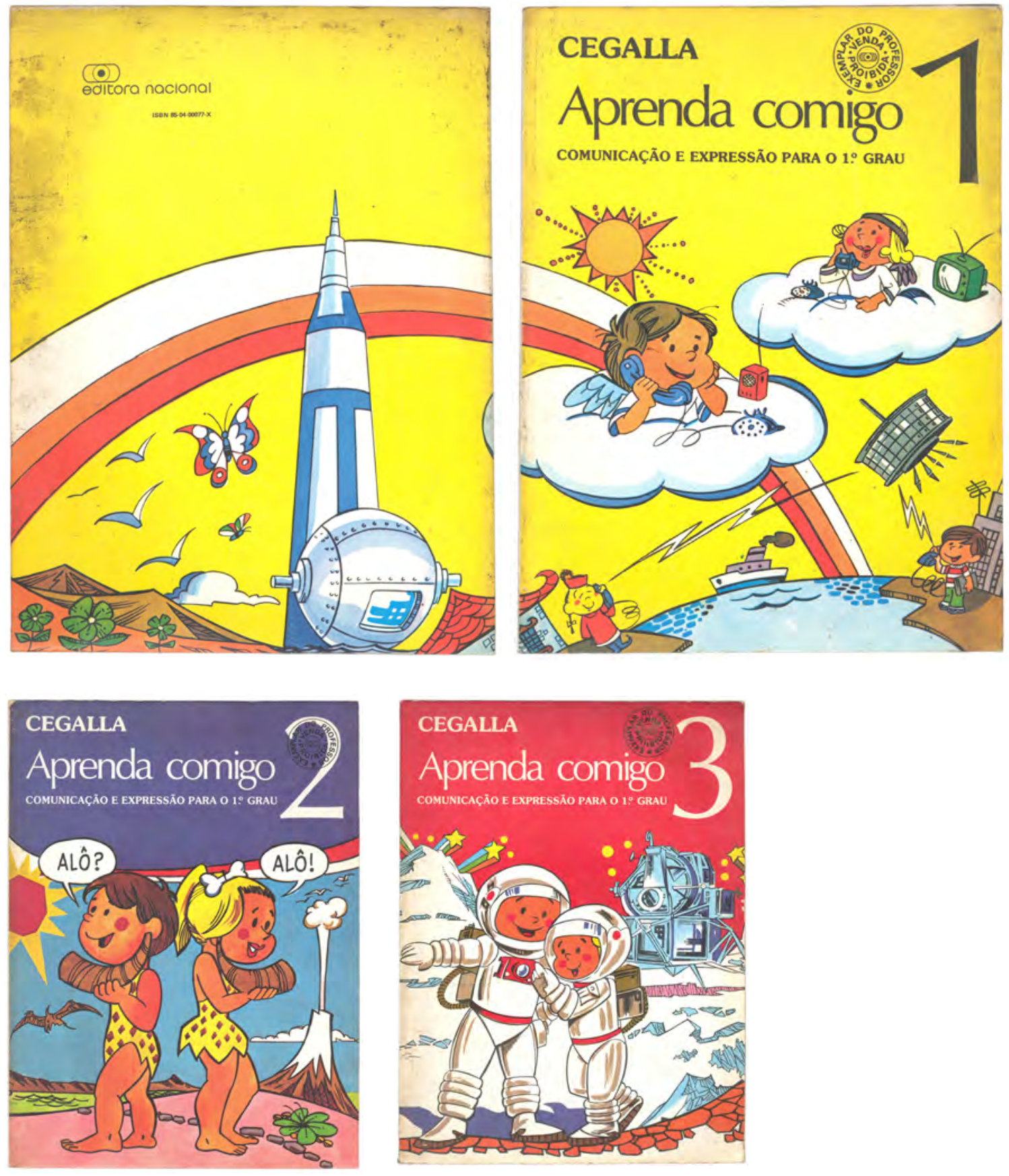

Fig. 8.8. Domingos Paschoal Cegalla, Aprenda comigo: Comunicação e expressão para o 1o grau, 1980 (brochura, $21,0 \times 28,0$ cm). Capas dos volumes 1, 2 e 3, Estúdio Edmundo Rodrigues.

A coleção Aprenda comigo é a única incursão encontrada do principal autor de Português da editora no ensino do nível 1 de Primeiro Grau, em obra lançada pouco antes da venda da empresa para o Ibep e que traz todas as características materiais e visuais do livro didático do período: brochura de grande formato, impressão de capa e miolo em quadricromia e consumibilidade (FIG. 8.8 e 8.9). As capas trazem ilustrações que ocupam frente e verso dos volumes, com temas tomados do universo dos quadrinhos e meios audiovisuais que atingem o público infantil. 0 miolo tem diagramação funcional e limpa, com as páginas reproduzidas mostrando as respostas para o professor. 

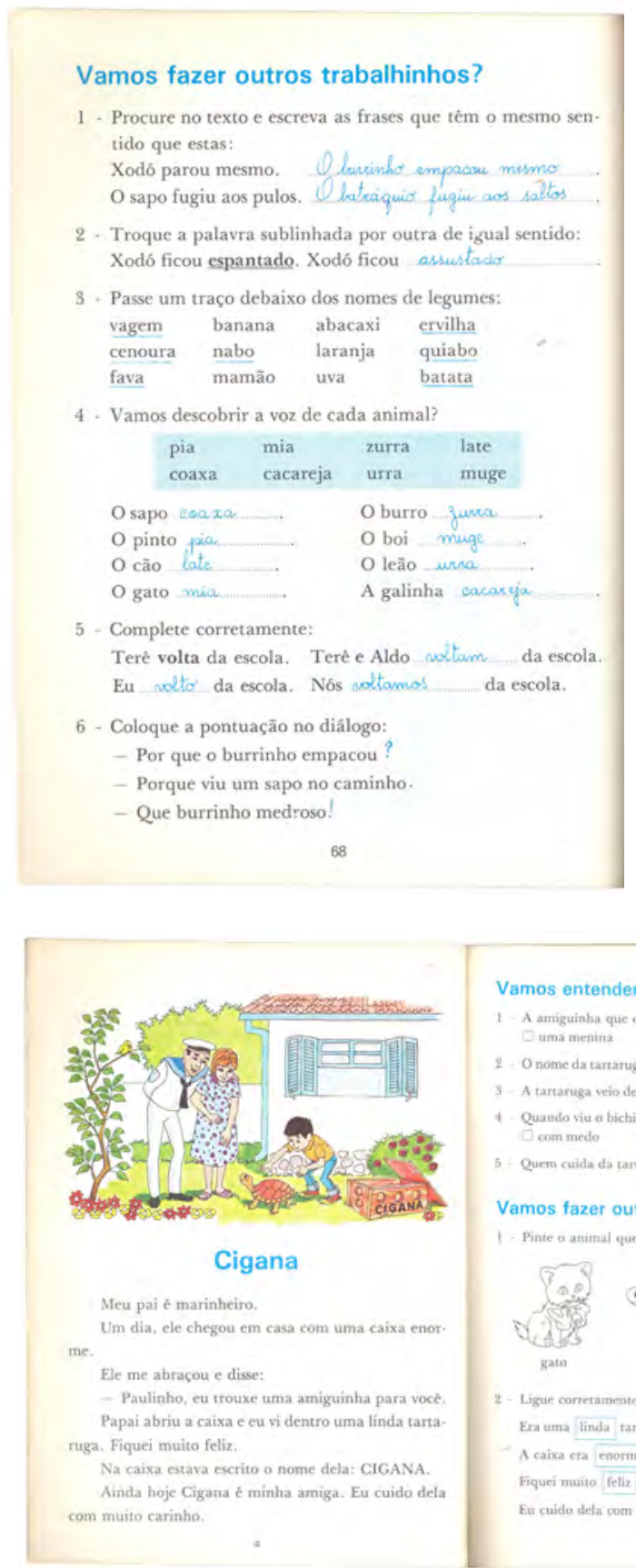

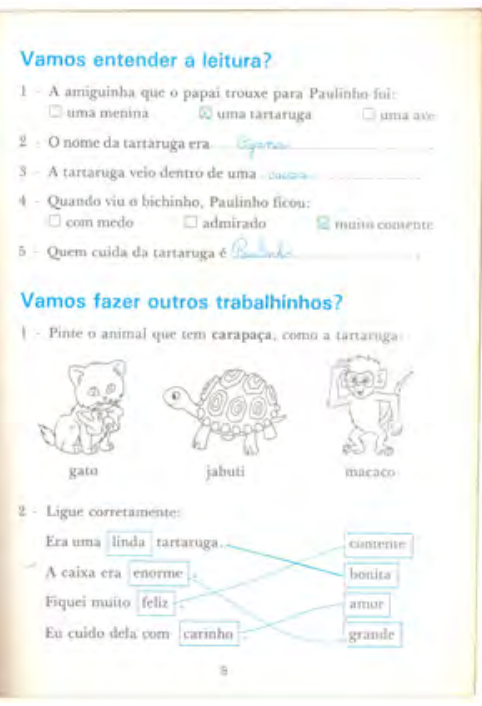

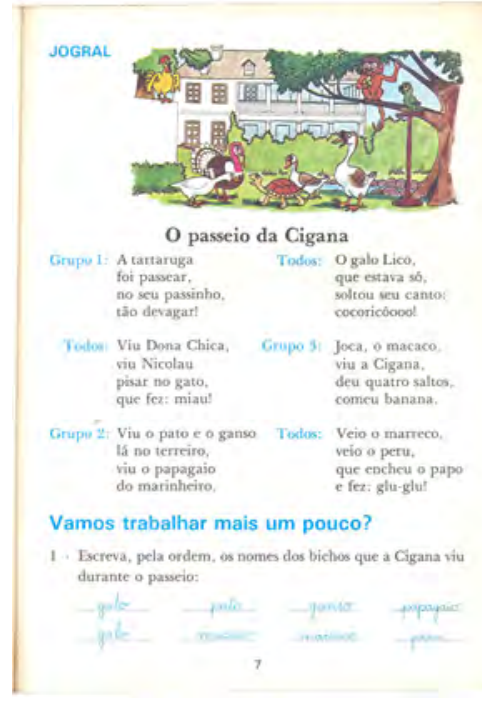

Fig. 8.9. Domingos Paschoal Cegalla, Aprenda comigo: Comunicação e expressão para o 1o grau, volume 1, 1980 (brochura, 21,0 x 28,0 cm). Páginas de miolo, Estúdio Edmundo Rodrigues.

Quatro títulos para Pré-escola e nível 1 do Primeiro Grau, todos lançados em 1976, vão se diferenciar bastante na linguagem das ilustrações, trazendo qualidades plásticas superiores, mais características de livros infantis não escolares. O primeiro deles, destinado à Pré-escola, é o livro preparatório à alfabetização Minha Abelhinha, coedição com o MEC para o Fundo Nacional de Material Escolar, com ilustrações coloridas seguidas de frases manuscritas em diagramação simples e limpa (FIG. 8.10). O segundo título, também para a Pré-escola, é Começando a descobrir, voltado para a iniciação em Ciências, com espaço para o aluno realizar atividades de observação do mundo natural e construído (FIG. 8.11). 

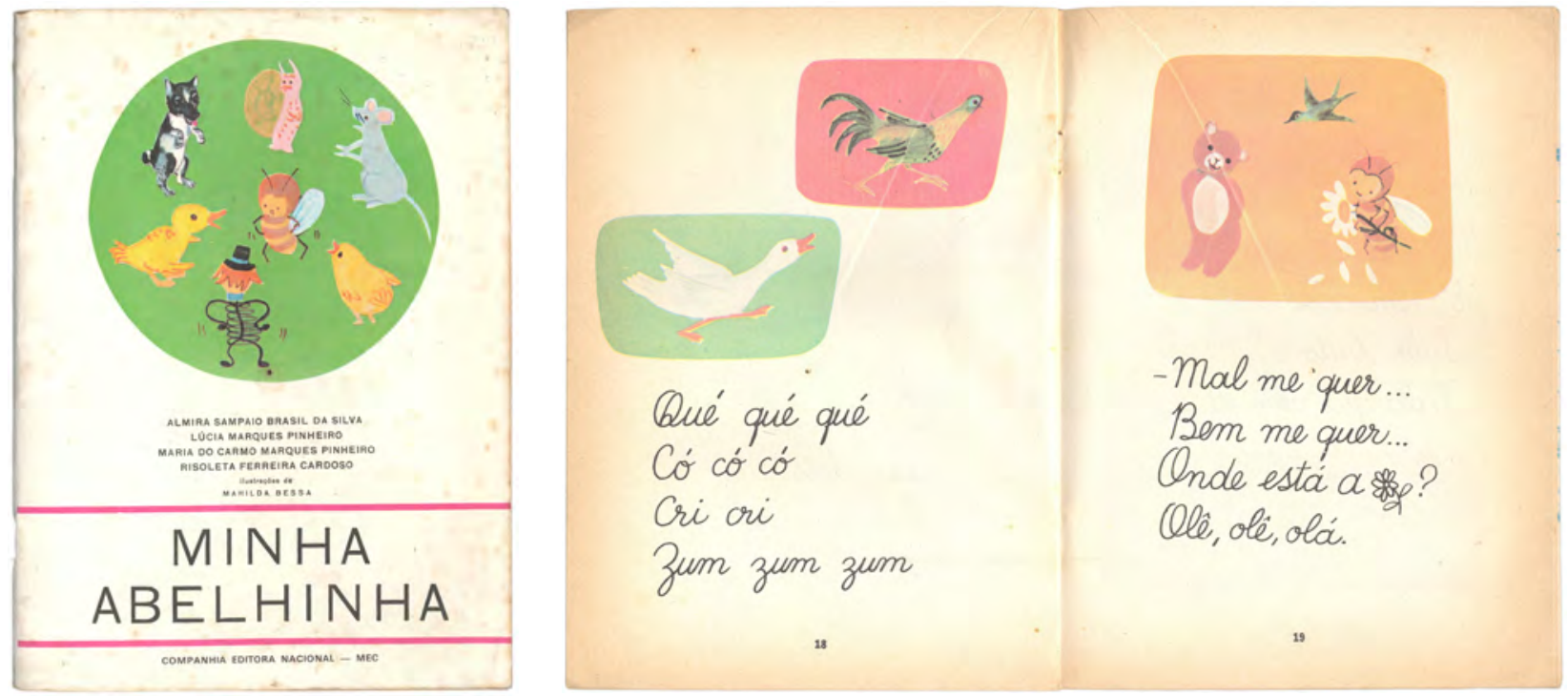

Fig. 8.10. Almira Sampaio Brasil da Silva e outros, Minha abelinha, 1976 (brochura grampeada, 15,0 x 21,0 cm). Capa e páginas de miolo.
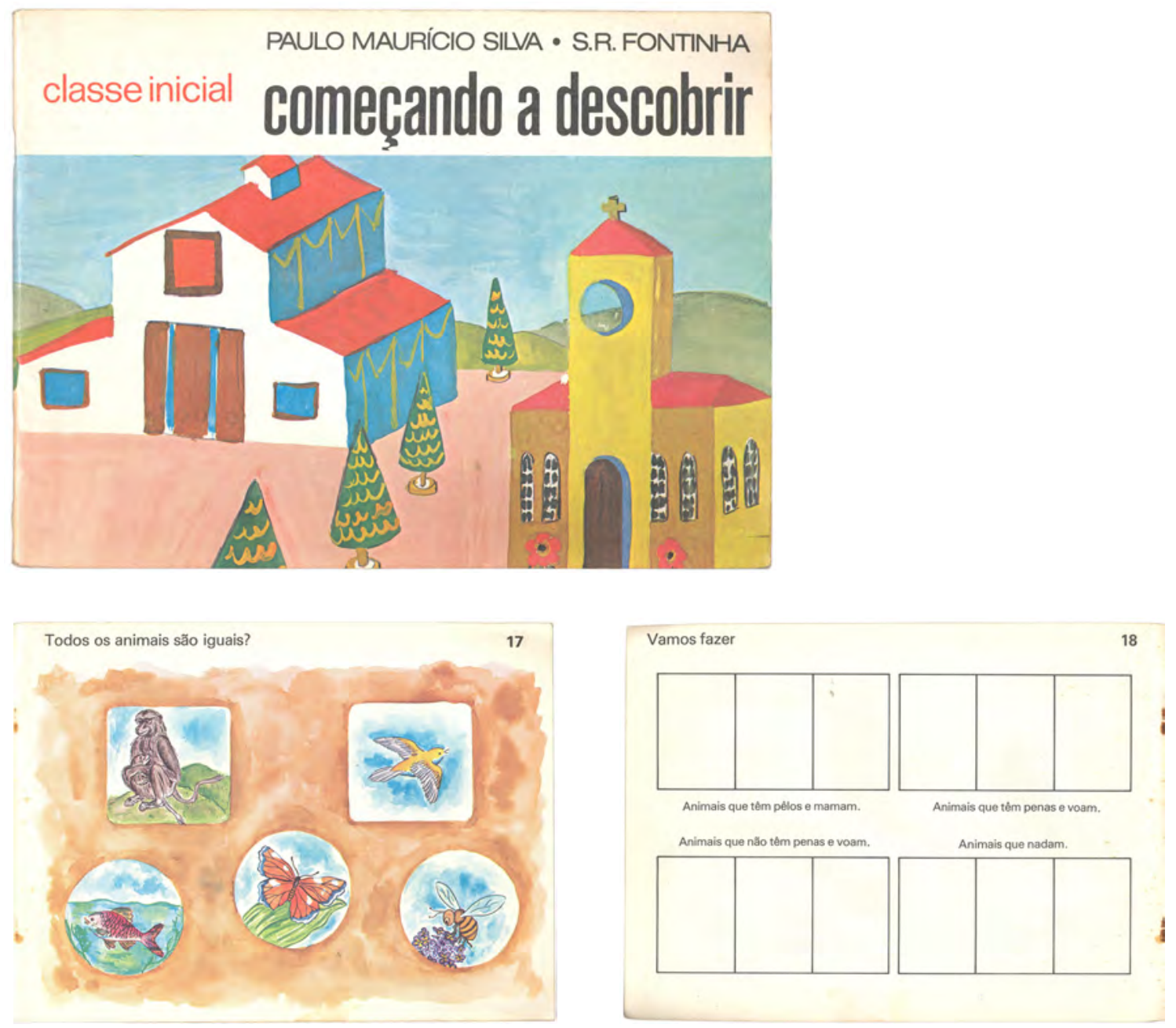

Fig. 8.11. Paulo Maurício da Silva e S. R. Fontinha, Começando a descobrir, 1976 (28,0 × 21,0 cm). Capa e páginas de miolo, com ilustrações de Fátima Conde Caldas e Everton Vieira Ouriques. 

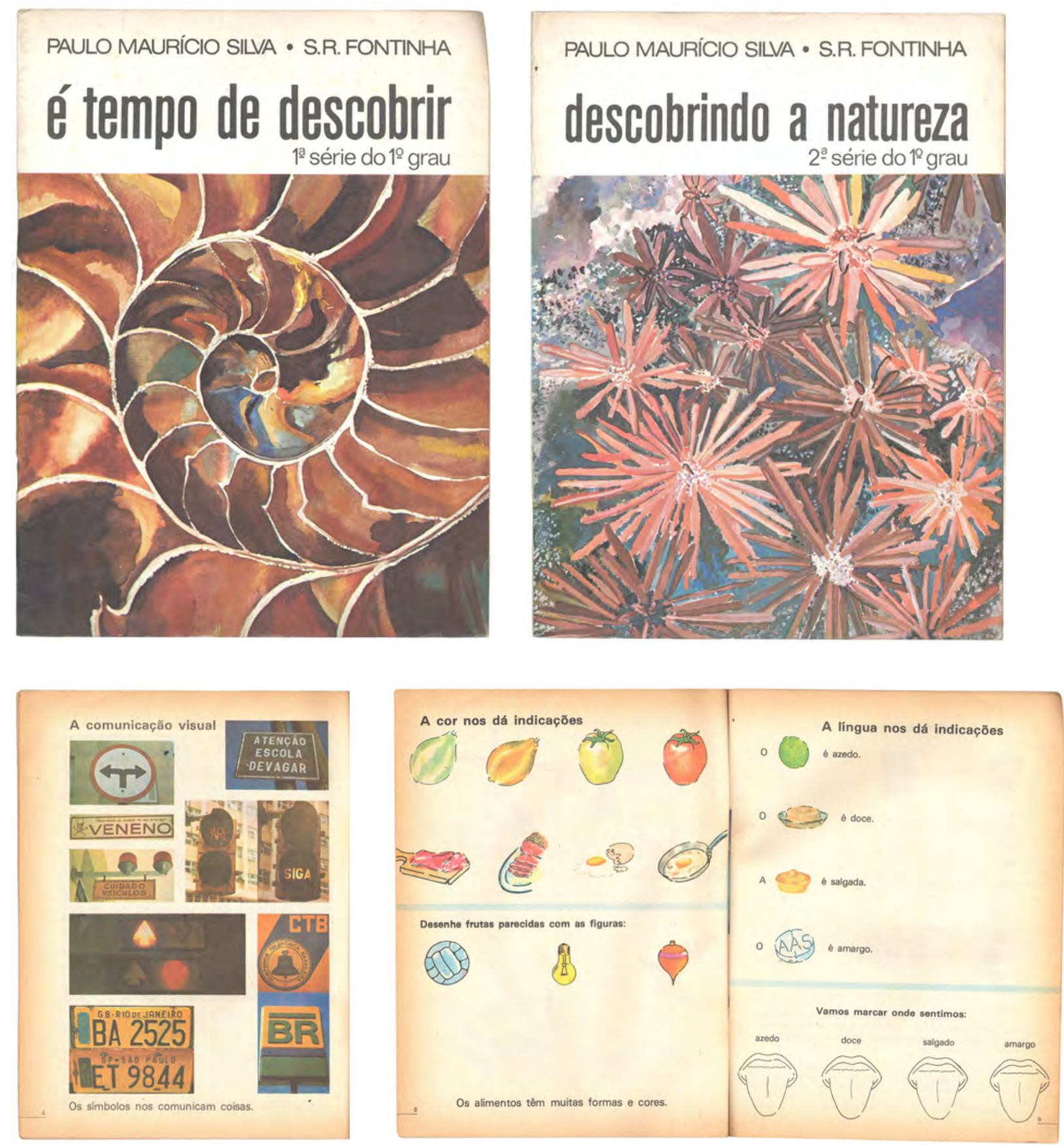

Fig. 8.12. Paulo Maurício da Silva e S. R. Fontinha, É tempo de descobrir e Descobrindo a Natureza, 1976 (21,0 × 28,0 $\mathrm{cm}$ ). Capas (Noemi Flores) e páginas de miolo, com ilustrações de Fátima Conde Caldas e Everton Vieira Ouriques.

Os dois últimos títulos que trazem ilustrações menos convencionais em livros didáticos, no caso mais na capa do que no miolo, são também de Ciências e dos mesmos autores da obra de Pré-escola. É tempo de descobrir e Descobrindo a natureza (FIG. 8.12) têm abordagem da disciplina como de Atividades de Iniciação, definida pela reforma de 1971. As capas trazem um diagrama bastante recorrente na época em livros não escolares, com área superior estreita para título e autoria e grande espaço para a ilustração colorida. Note-se a composição do título em caixa baixa. O miolo traz fotografias e ilustrações, com espaço para a intervenção do aluno. 


\subsubsection{Das soluções tipográficas à ilustração e à fotografia nas capas e miolos dos livros de Português}

Diferentemente do ocorrido com outras disciplinas, os livros de Português no período anterior não tiveram grandes transformações na visualidade de seu miolo. Estas vão ocorrer a partir de 1970, não apenas acompanhando as transformações dos livros didáticos em geral, mas por decorrência das novas abordagens pedagógicas da disciplina, ligadas ao enfoque que a línguística disseminava naquele momento e que se consubstanciou em termos oficiais no nome "Comunicação e Expressão" dado à disciplina pela Reforma de 1971.

Assim, Português funcional (FIG. 8.13) traz uma configuração de miolo diferente e mais variada do que a encontrada nos livros do período anterior, com soluções de diagramação apoiadas em maior uso da cor, espaço para intervenção do aluno e linguagens de ilustração em maior sintonia com a de outras mídias impressas. Sua capa mantém ainda a abordagem tipográfica, com uma solução minimalista e objetiva, sem outra imagem do que a formada pelo título, ocupando todo o espaço gráfico e expressando o sentido de funcionalidade.
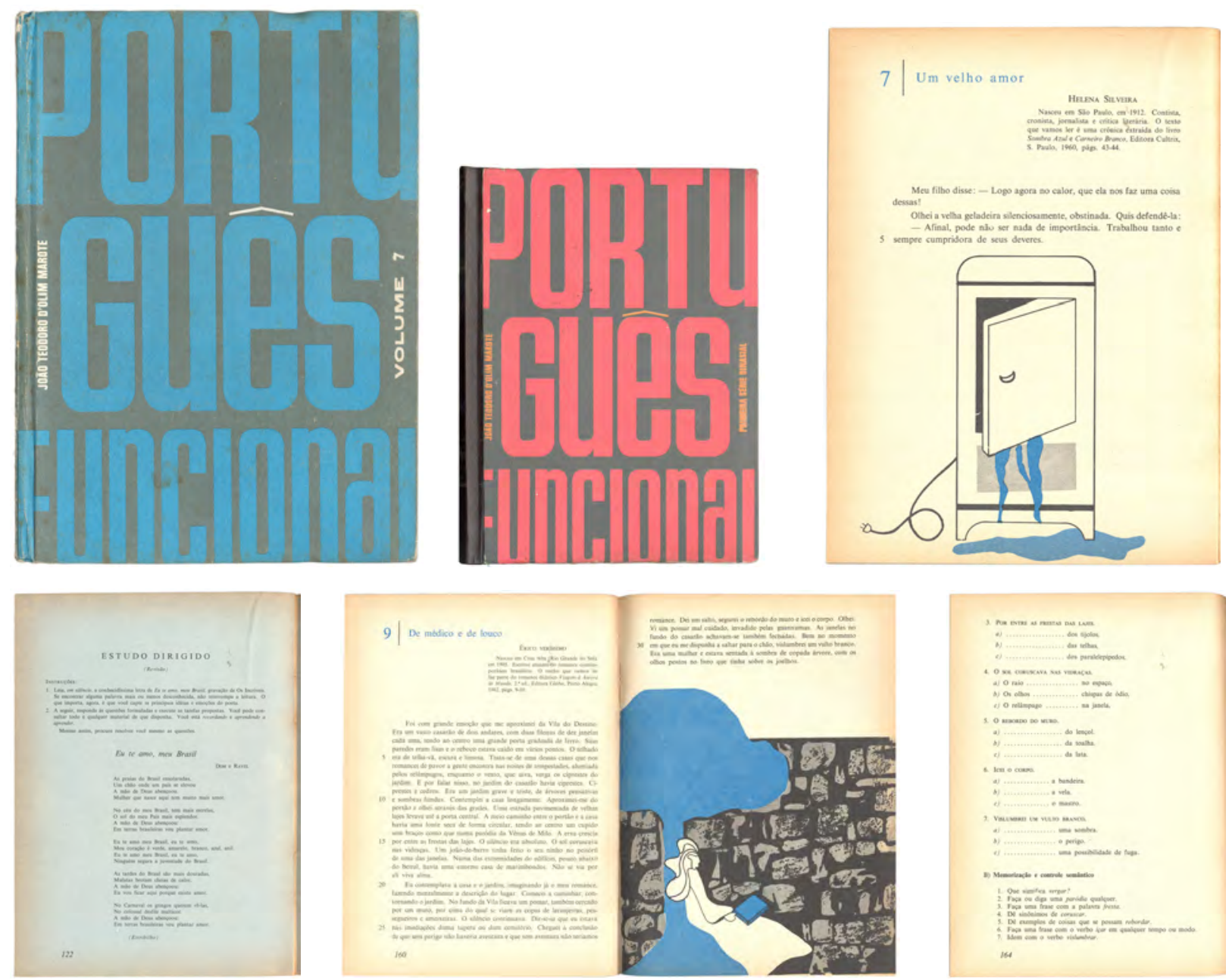

Fig. 8.13. D'Olim Marote, Português funcional: volume 7, $1972(15,0 \times 20,7 \mathrm{~cm})$. Capa e páginas de miolo e capa do volume de 1aㅗ série, 1970, anterior à Reforma de 1971. 
A capa das edições anteriores à Reforma de 1971 de Ensino Renovado do Português traz também solução tipográfica, em que grande coesão é obtida entre a moldura tritonal de linhas grossas e a tipografia preenchendo o campo cinza interior, sutilmente separado pelo fio branco, que valoriza a moldura, com o conjunto constituindo uma imagem gráfica forte identificadora da coleção (FIG. 8.14). O acabamento ainda á a encadernação com capa dura.

Já a edição adaptada à reforma, com alteração no título, tem capa em brochura e apresenta solução com componentes do repertório modernista do período, de uso geralmente dirigido a público adulto: diagrama não simétrico, com texto alinhado à direita, economia tipográfica, título com contraste cromático interno e fotografia em alto contraste (FIG. 8.15).
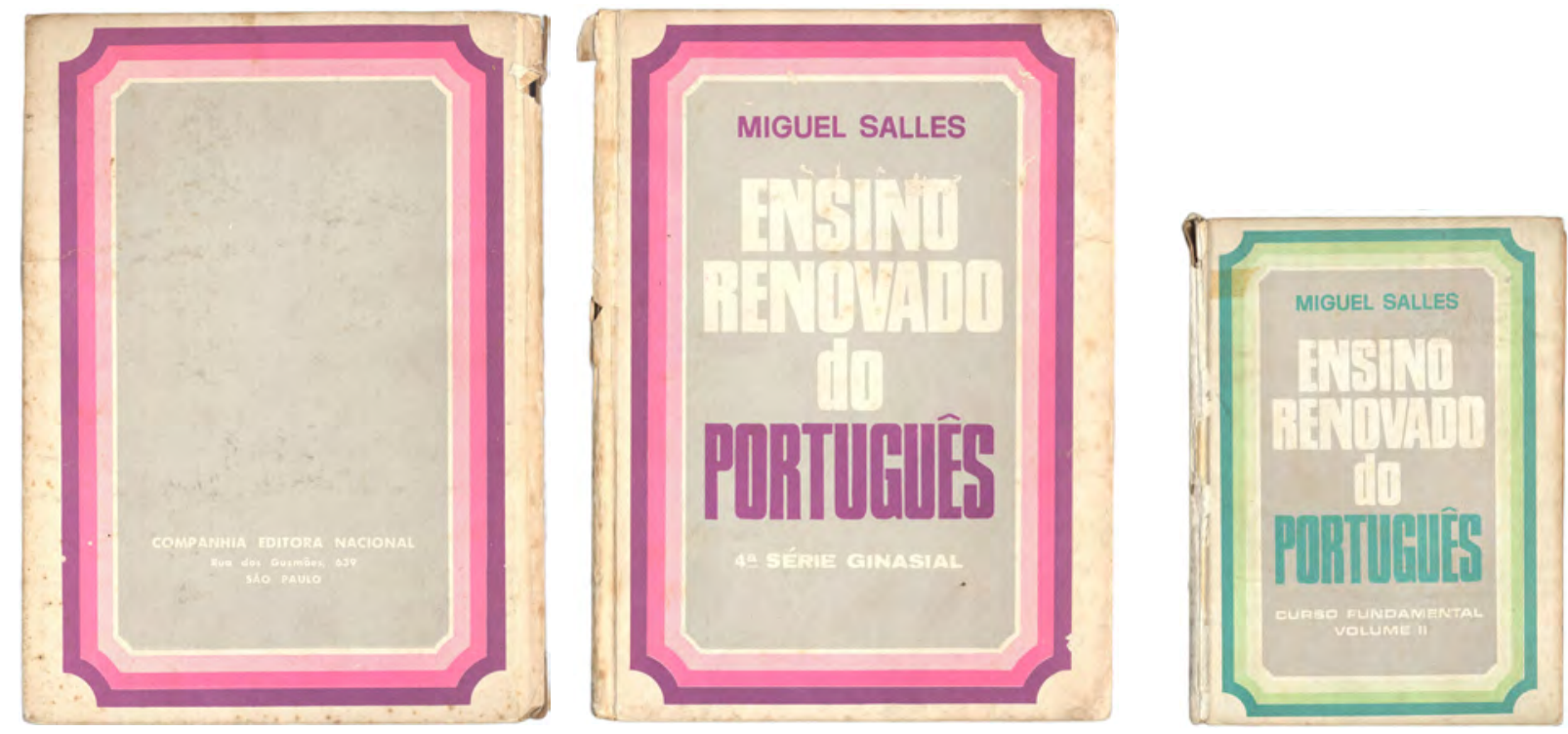

Fig. 8.14. Miguel Sales, Ensino renovado do Português: 4a série ginasial e Ensino renovado do Português: Curso Fundamental volume II, $1971(15,0 \times 20,5 \mathrm{~cm})$. Capas.
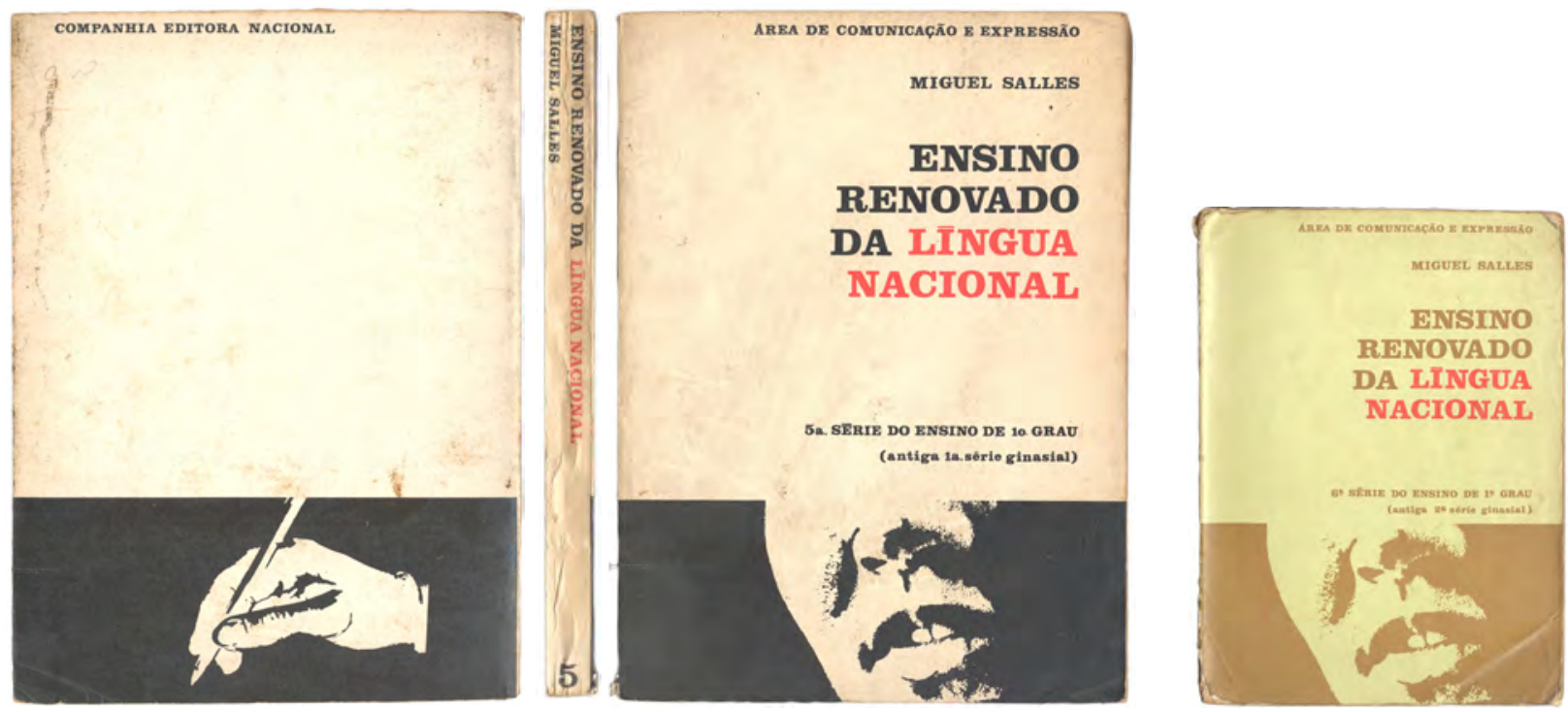

Fig. 8.15. Miguel Sales, Ensino renovado da língua nacional: $5^{5}$ série do ensino de 10 grau e Ensino renovado da língua nacional: 6aㅗ série do ensino de 1o grau, 1971 (brochura, 15,0 × 21,0cm). Capas. 
Os livros de Domingos Paschoal Cegalla para 5a a 8a série do Primeiro Grau também acompanham as mudanças da disciplina e do livro didático, e sua primeira reformulação, de 1973, recebe novo nome, formato maior, ilustrações, impressão em bicromia, caderno de atividades (e não espaço para preenchimento do aluno em livro consumível) e uma nova capa, em acabamento brochura. Assim, a capa de Português Fundamental (FIG 8.16) não é mais tipográfica, constituindo um exemplo da expansão do uso da fotografia colorida nos livros escolares, para atender possíveis expectativas de realismo de um público que o encontra nos meios de comunicação de massa e visando sua identificação por retratar situação e ambiente escolar. A aplicação do texto vazado sobre a fotografia e não em área separada - uma dos recursos recorrentes nas revistas, em capas e páginas de reportagem -, em direção vertical de leitura e com a imagem atravessando o volume também comparecem como signo de modernidade e atualização visual.
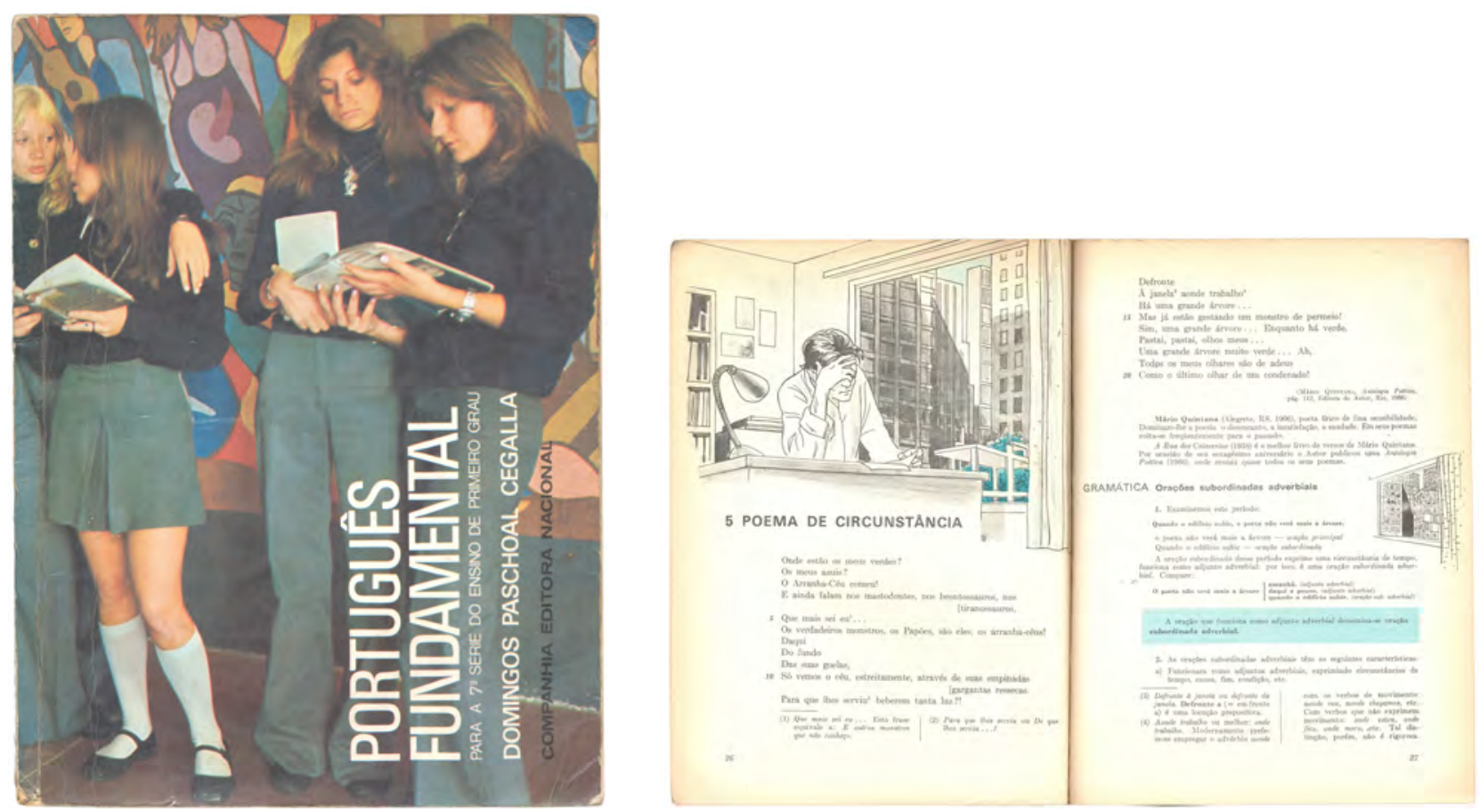

Fig. 8.16. Domingos Paschoal Cegalla, Português fundamental: para a 7ạ série do ensino de Primeiro Grau, 1975 (brochura, 19,0 × 26,0 cm). Primeira e quarta capas.

A reformulação seguinte da obra, sob maior influência das novas tendências do ensino da língua e da expansão dos meios tecnológicos audio-visuais enfatizando o conteúdo da disciplina de Português como sendo de "comunicação e expressão" assumiu o nome Hora de Comunicação, com este termo definindo o tema de capas ilustradas (FIG. 8.17). As imagens trazem os meios de comunicação ao longo da história, dispostos nas duas áreas em que se divide o campo, com uma figura compondo com o título. A quarta capa traz uma circunstância contemporânea de comunicação sem um nexo imediato com a primeira, apenas a idéia geral de comunicação. O formato permanece o mesmo da coleção anterior, mas o miolo é impresso em quadricromia. 

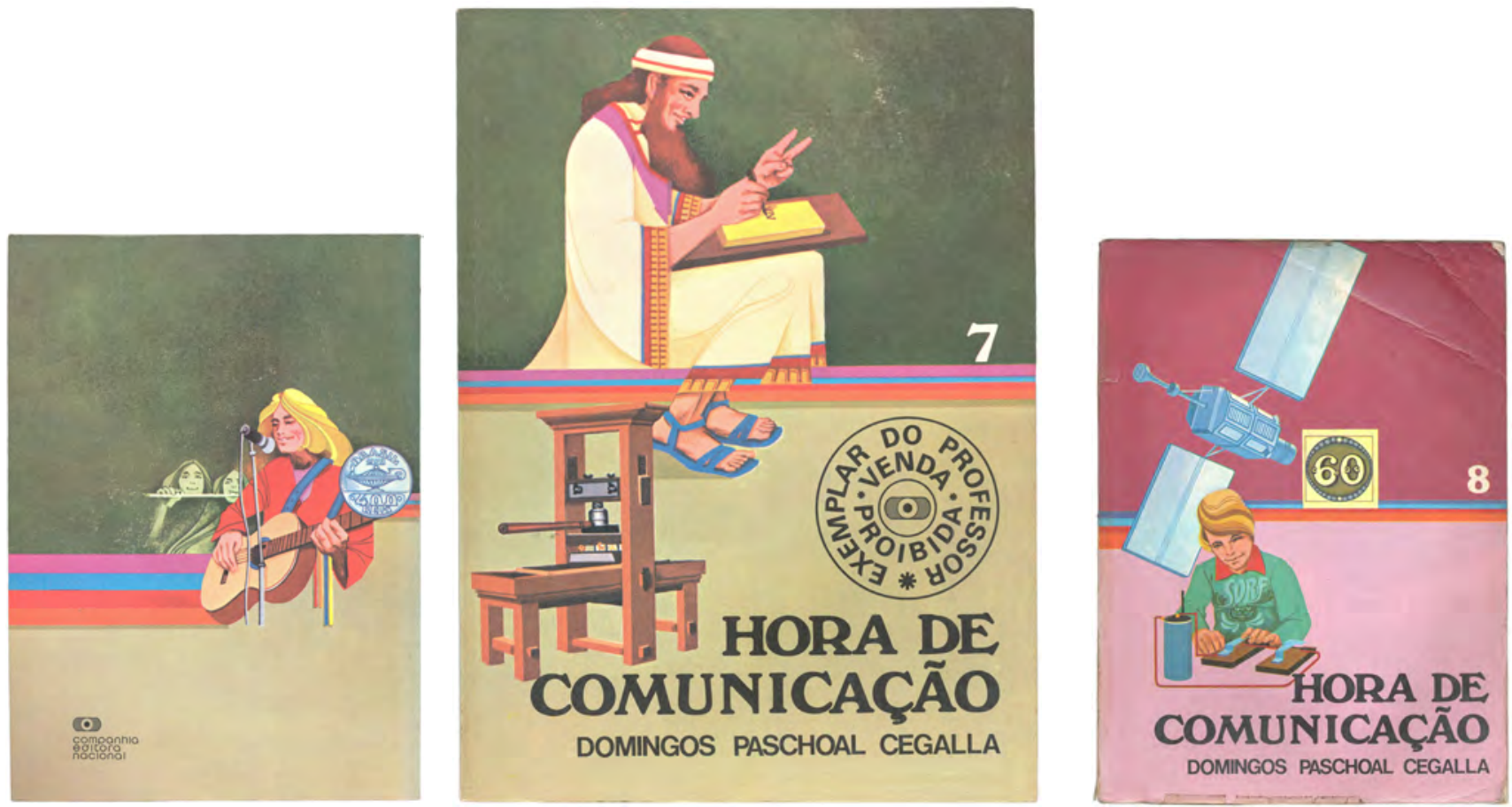

Fig. 8.17 Domingos Paschoal Cegalla, Hora da Comunicação: 7ạ série, 1978 (19,0 x 26,0 cm). Primeira e quarta capa (note-se o uso de novo logotipo da CEN). Primeira capa do volume de 8a série. Ilustração provavelmente de Ademir Pontes, ilustrador do miolo.
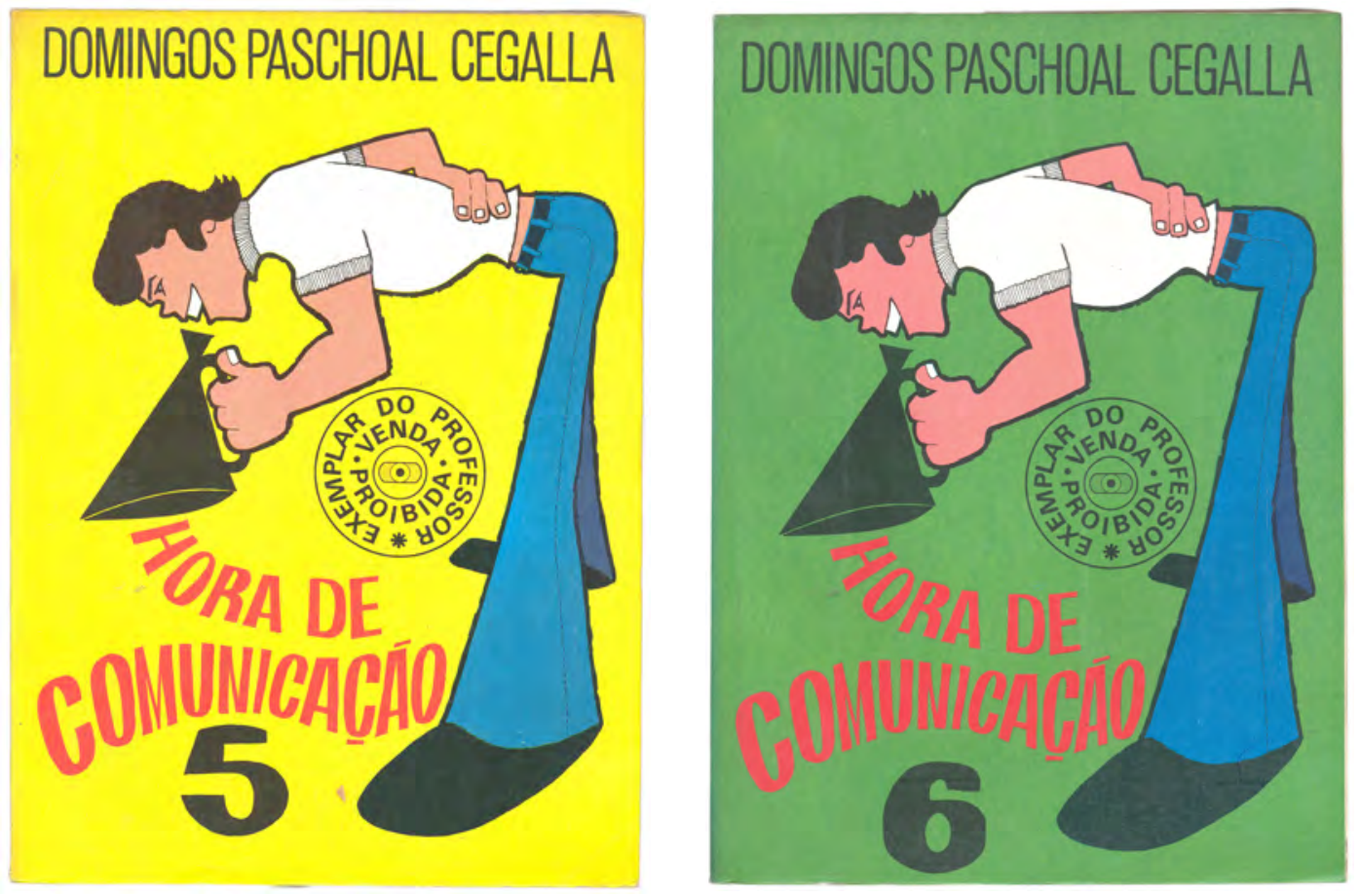

Fig. 8.18 Domingos Paschoal Cegalla, Hora da Comunicação, 5 e Hora da Comunicação, 6, 1980 (19,0 x 26,0cm). Capas, com ilustração de Haniel.

A capa da edição de 1980 de Hora da Comunicação, ao contrário da anterior, que trazia maior carga informativa em cada volume, tem os quatro volumes da coleção portando a mesma imagem, apenas diferenciados por sua cor (FIG. 8.18). Aqui a intenção da sedução se dá pela referência ao universo jovem da ilustração em linguagem de cartum, mas em 
desenho duro e esquemático que se repete em todos os volumes. O miolo traz de forma completa as características dos livros desse período: impressão em quadricromia, espaços para preenchimento do aluno, respostas na edição do professor, com ilustrações também em linguagem de cartum, em consonância com as capas, e presença de quadrinhos (FIG. 8.19).
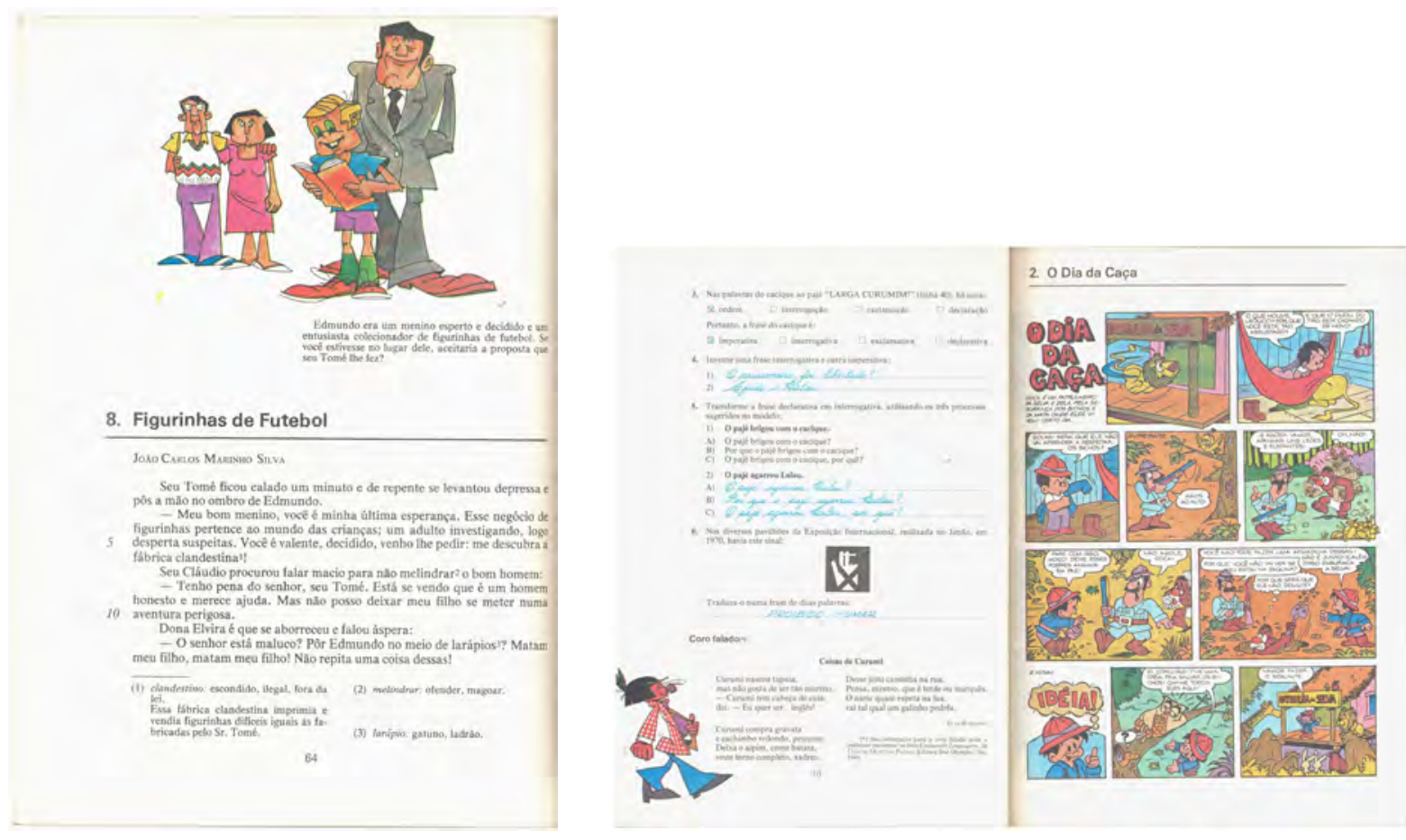

Fig. 8.19. Domingos Paschoal Cegalla, Hora da Comunicação: 5ํㅗérie, $1980(19,0 \times 26,0$ cm). Páginas de miolo, com ilustrações de Haniel.

Uma obra de novos autores, Comunicação/Expressão em língua nacional (FIG. 8.20) traz de forma mais completa a nova abordagem da disciplina, utilizando os conceitos da linguística e da teoria da comunicação que então chegavam ao país, como mensagem, emissor, receptor, código, etc. O miolo tem produção bastante qualificada, com interação de texto e imagem, ilustrações e fotografia, na exposição desses conteúdos e não a inserção de imagens com função meramente ilustrativa do texto.

As capas fotográficas traduzem essa abordagem, com o volume de 6a série, de 1975 , trazendo imagem bastante recorrente nas mídias da época, relativas à integração nacional via satélite, enfatizando a idéia de comunicação por meios tecnologicamente avançados. A aplicação de texto vazado sobre fotografia sangrada vai se consolidando como procedimento usual em livros didáticos.

Comunicação Interpretação, dos mesmos autores, mas em formato menor, traz capas com solução diversa da anterior, com diagrama com áreas definidas para a imagem - selos postais com índice da comunicação via correspondência escrita -, que juntamente com o número particularizam os volumes, que têm faixa e título com cor inavariável na coleção (FIG. 8.21). 

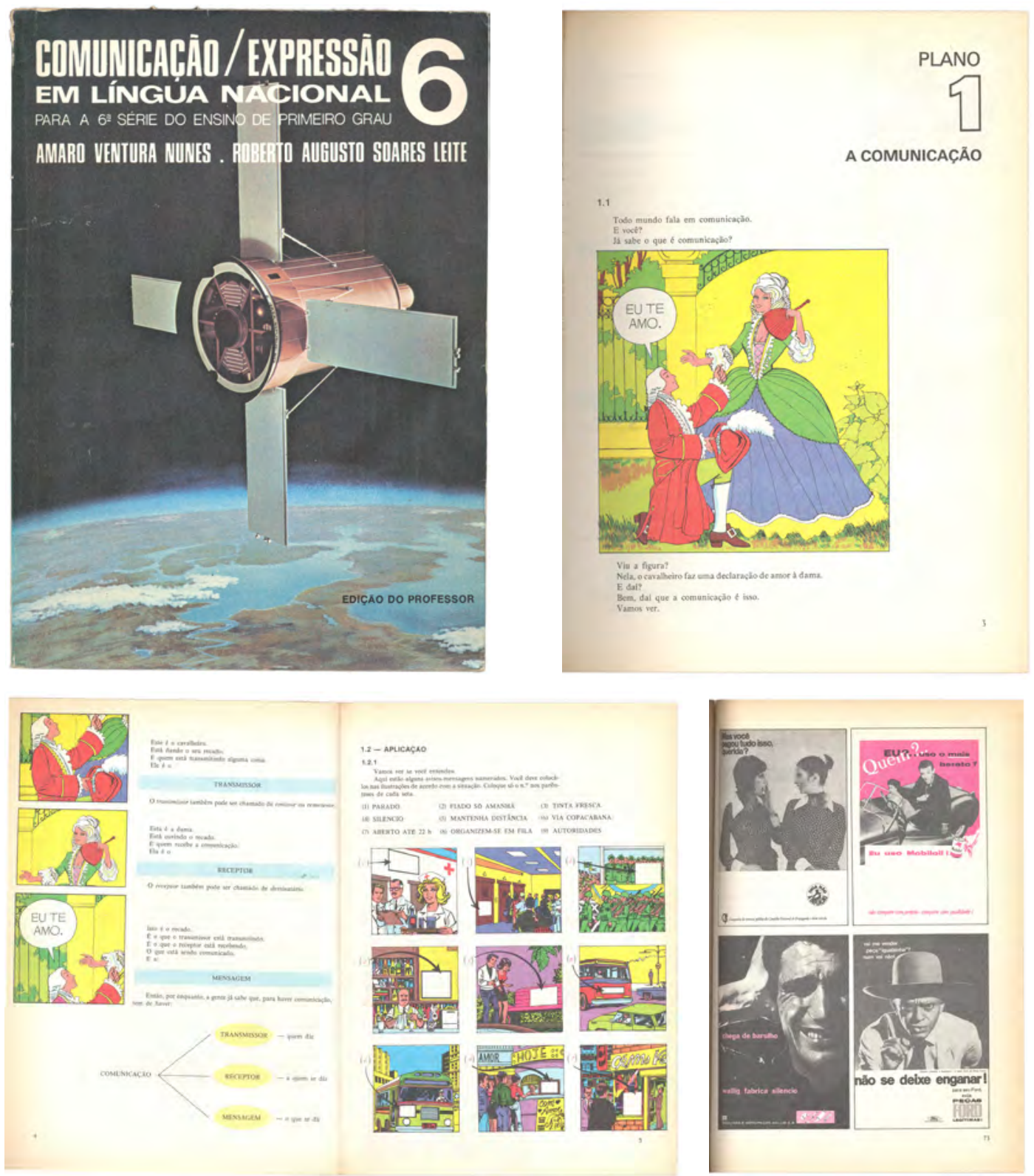

Fig. 8.20. Amaro V. Nunes e Roberto A. S. Leite, Comunicação/Expressão em língua Nacional: para a 6a série do ensino de Primeiro Grau, 1975 (brochura, 19,0 × 26,0cm). Capa e páginas de miolo.
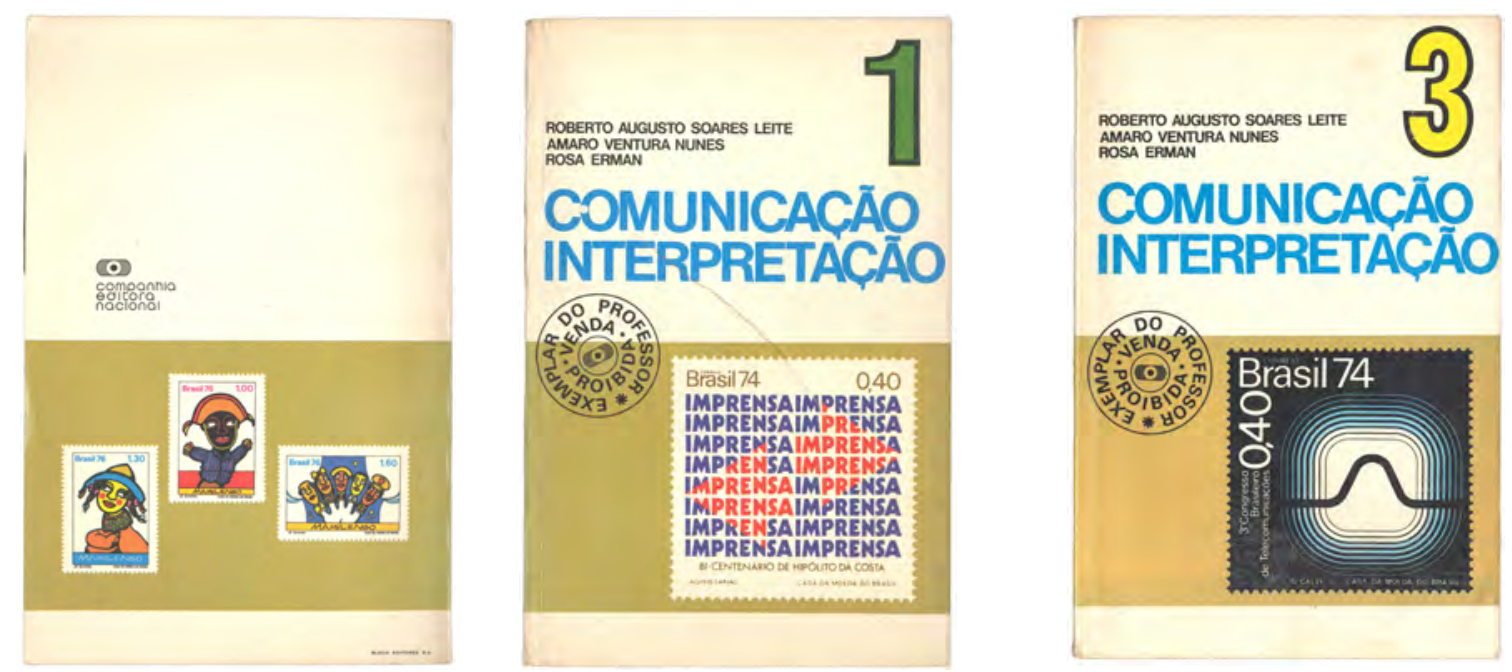

Fig. 8.21. R. A. S. Leite, A. V. Nunes, R. Erman, Comunicação/Interpretação, 1977 (brochura, 13,5 × 21,5cm). Capas. 
Português oral e escrito, do professor de Letras da Universidade de São Paulo, Dino Pretti, traz um conteúdo atualizado quanto às novas abordagens do ensino da língua (FIG. 8.22), e seu miolo reúne todas as características dos livros didáticos do período: grande formato, impressão em quadricromia, com muitas ilustrações e fotografias, e a consumibilidade, com espaço para escrita do aluno e respostas em letra cursiva e instruções impressas em ciano no exemplar do professor.

As capas trazem outra das soluções fotográficas adotados no período, o mosaico de imagens, em janelas formando desenho que circunscreve número de volume e autor e delimita o título, em tipografia particular, com a estrutura gráfica geral sobre fundo chapado oferecendo identidade inequívoca para a coleção mas com fraca relação formal e semântica entre as imagens.
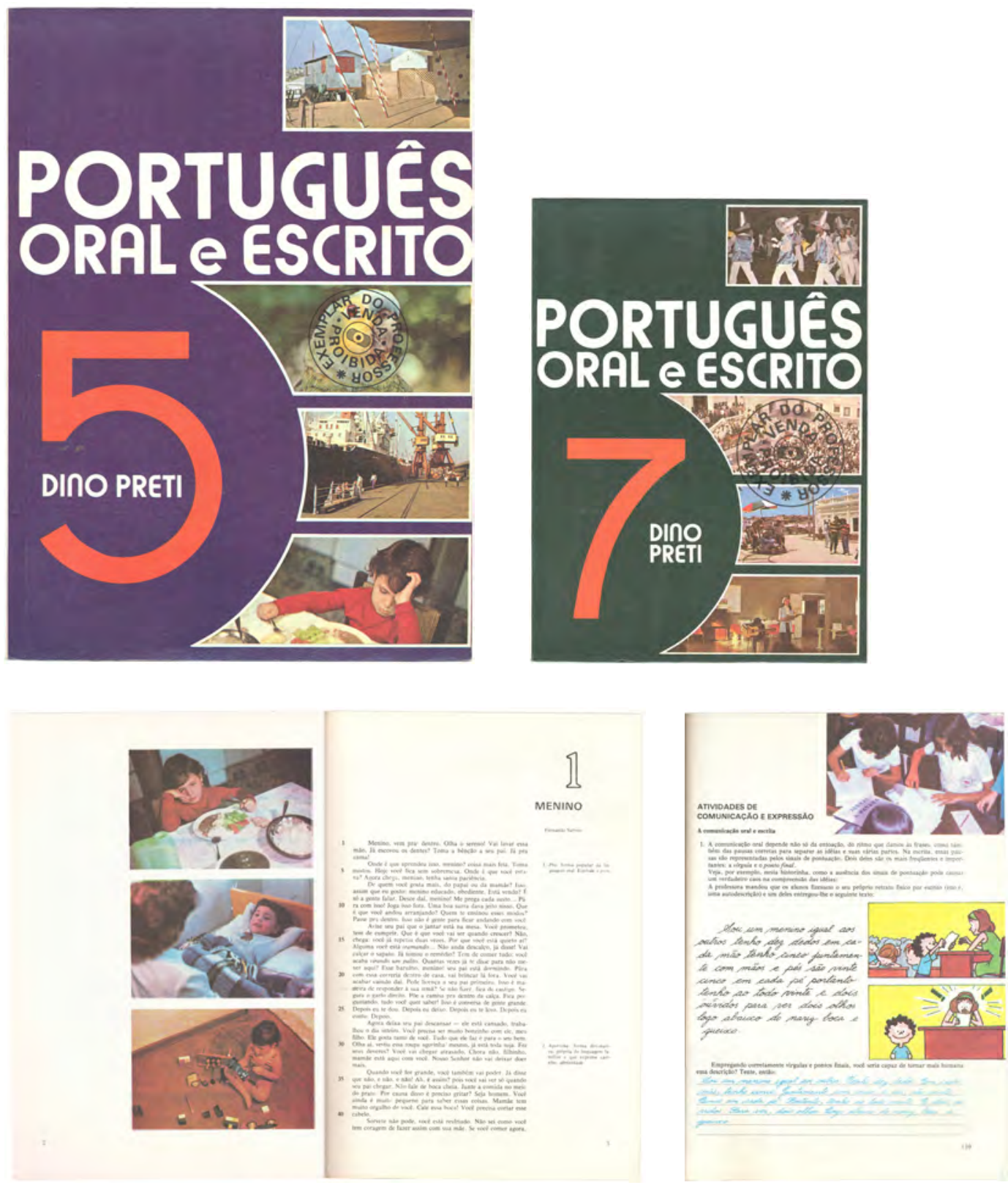

Fig. 8.22. Dino Preti, Português oral e escrito, 5, 7 e 8, $1980(19,0 \times 26,0 \mathrm{~cm})$. Capas e páginas de miolo, com ilustrações de Ademir Pontes. 

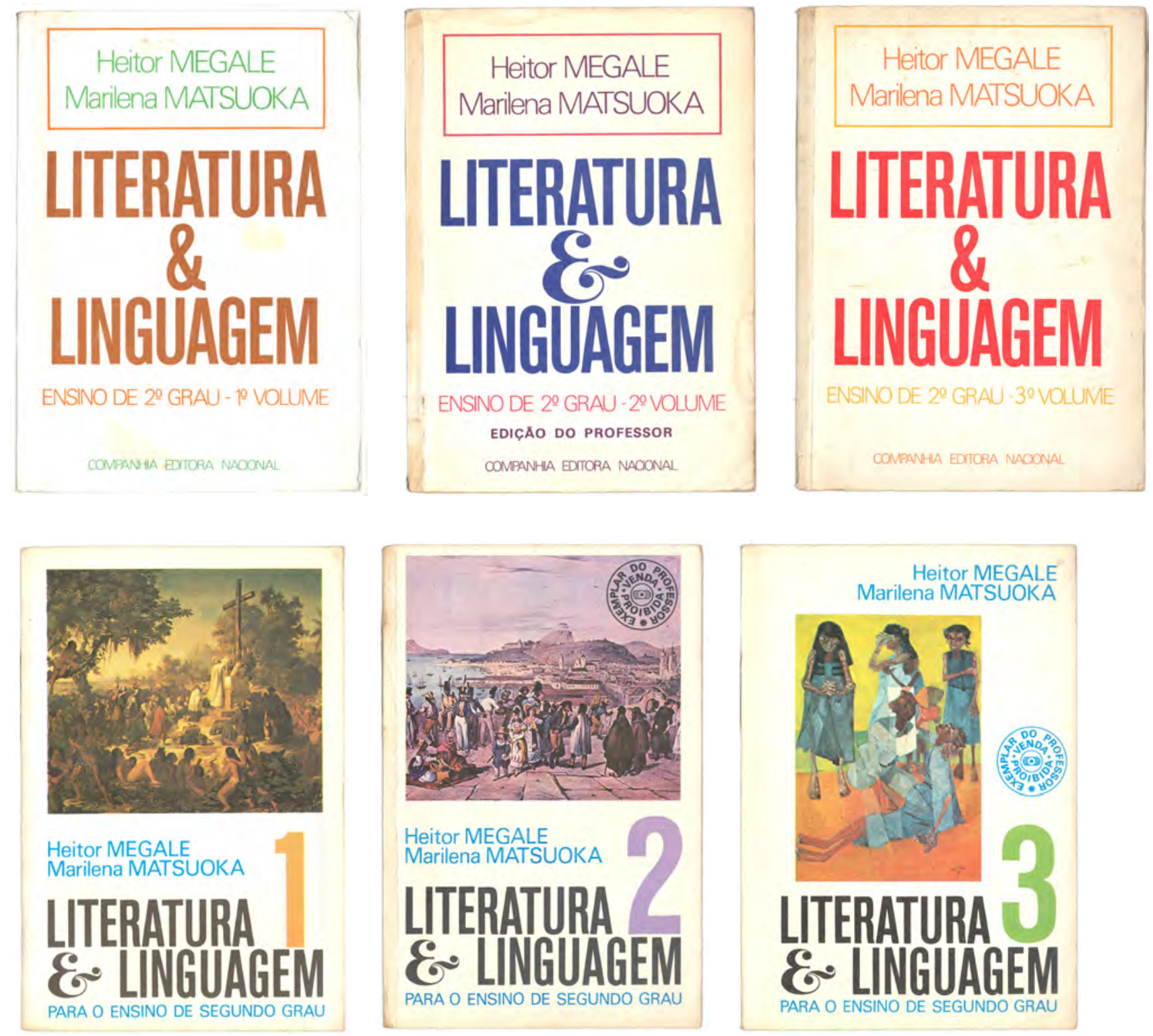

Fig. 8.23. Heitor Megale e Marilena Matsuoka, Literatura \& Linguagem: 1, 2 e 3; 1975 e 1977 (15,0 x 21,0 cm). Heitor Megale e Marilena Matsuoka, Literatura \& Linguagem: 1, 2 e 3; 1979 (14,0 × 21,0 cm). Capas.

As capas da edição de 1975, de Literatura \& linguagem, para o esino de Segundo Grau, são tipográficas e têm diagrama comum para todos os volumes, com leiaute simétrico e informações textuais ocupando todo o campo, com peso central dado para o título, em contraste acentuado com as demais informações. A solução é séria e formal, ainda que na edição de 1977 a forma do ampersand (e comercial) acrescente um interesse maior ao conjunto (FIG. 8.23).

Já a edição de 1979, na mesma figura, traz uma solução menos sóbria e com mais apelo, com leiaute que estrutura título e número do volume como imagem, incluindo o ampersand, em relação com a iconografia - pinturas referenciadas aos períodos colonial, imperial e contemporâneo - e com as demais informações textuais, em variações de diagrama para comportar formatos diferentes da imagem reproduzida. O fundo branco estabelece o contraste cromático que valoriza os elementos gráficos. 


\subsubsection{Fotografia e ilustração nas capas e miolos dos livros de História}

A primeira obra da Nacional a trazer capa com fotografia sangrada em todo o campo uma solução então presente em capas e diagramação de revistas -, com a imagem indo da primeira à quarta capa, é História Geral, de Armando Souto Maior, de 1970 (FIG. 8.24). Como obra para o Colegial, o miolo tem impressão apenas em preto, com diagramação em duas colunas, mas a solução fotográfica da capa, aplicada na sequência em obras de outras disciplinas, inaugura essa nova tendência que participa da configuração deste novo período de design. Devido à qualidade da imagem, com impressão em papel cuchê brilhante revestindo capa dura e apresentando o monumento de forma talvez pouco visualizada na época e envolvendo todo o volume, supõe-se que tenha produzido um efeito bastante impactante.

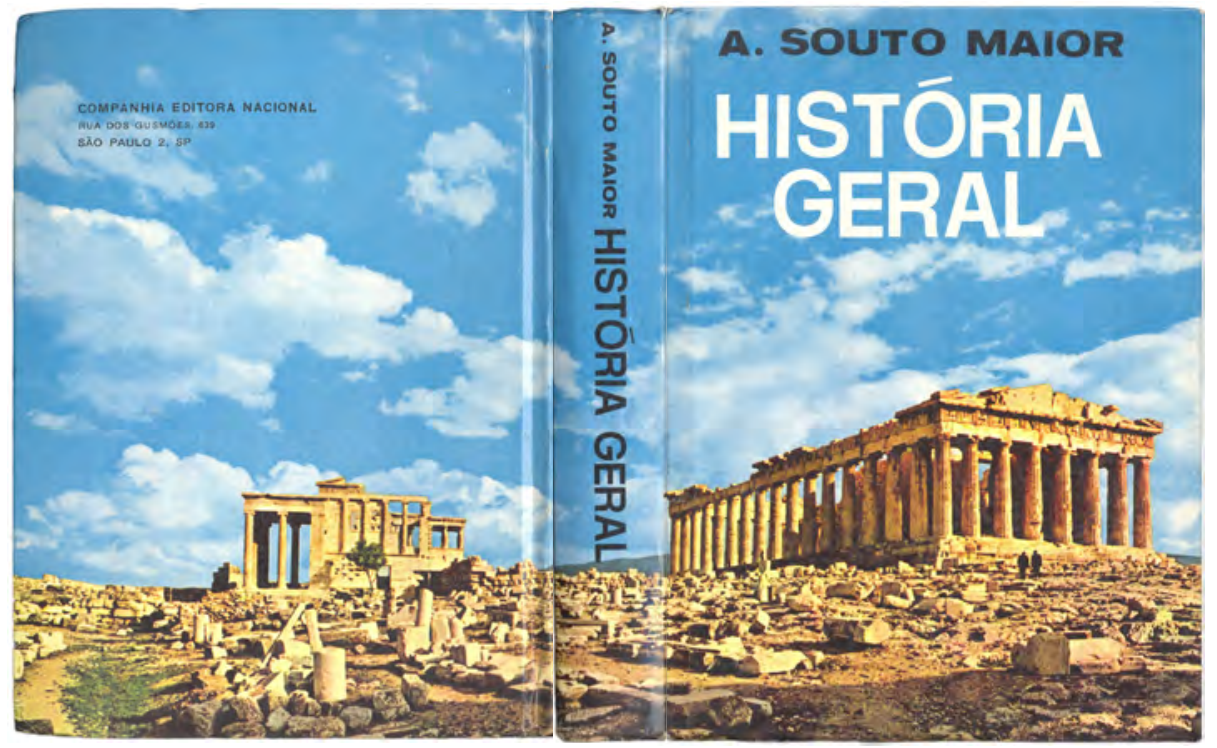

Fig. 8.24. A. Souto Maior, História Geral, 1970 (15,0 × 20,7cm). Capa.

Mas a obra que trouxe uma reformulação mais profunda na materialidade e visualidade dos livros didáticos de História desse período foi a coleção para Primeiro Grau concebida e supervisionada por Sérgio Buarque de Holanda. Planejada e publicada ainda na gestão de Octalles Marcondes Ferreira, sob responsabilidade do diretor editorial Thomaz de Aquino Queiroz, a coleção uniu o interesse da editora em renovar sua produção didática com o compromisso do prestigiado intelectual e dos autores arregimentados - Virgílio Noya Pinto, Carla Queiroz e Sylvia Barboza Ferraz - em criar uma obra inovadora tanto na abordagem da disciplina como na definição de seu conteúdo e, sobretudo, na forma de apresentá-lo.

Assim, segundo José Cássio Másculo [2008, p. 56, 126-128, 137-138, 165-170, 177-181, 223-225 ], a obra, em primeiro lugar, se propôs a refletir as novas concepções da história e as pesquisas mais avançadas realizadas na universidade brasileira, trazendo uma abordagem que estabelecia relações entre fatos econômicos, sociais e culturais, em contraposição explícita e 
consciente ao relato factual e a ênfase na ação de heróis e governantes que caracterizavam absolutamente todas as obras de história produzidas para a escola até então. Em segundo lugar, propunha conteúdos e abordagens inéditas, como por exemplo o estudo do folclore brasileiro e a presença da diversidade cultural na formação do povo brasileiro, não apresentando negros, índios e brancos como grupos homogêneos, como faziam todas as outras obras escolares, mas cada um deles constituído de populações com histórias e culturas diversificadas. Em terceiro lugar, dava ênfase à produção material e cultural de cada período estudado, por exemplo na seção intitulada Panorama cultural, que trazia uma iconografia vasta e inédita de realizações simbólicas e materiais significativas das sociedades e dos povos, que eram analisadas tanto quanto os fatos e processos estudados, e não meras reproduções para ilustração do texto. Por fim, a coleção inovava também ao trazer para o professor orientações metodológicas e subsídios para o ensino de história, em um Livro do professor que constituía um verdadeiro "minicurso de prática de ensino e formação básica nos conteúdos conceituais da disciplina" [MÁsculo, 2008, p. 152] 3 .

A coleção era composta de dois volumes de História do Brasil, para 5a e 6a séries, lançados em 1971, e um de História da Civilização, para 7a e 8a séries, lançado em 1974, cada um possuindo um Caderno de trabalhos práticos, adquirido à parte, e um Livro do Professor, ambos brochuras (FIG. 8.25 e 8.26).
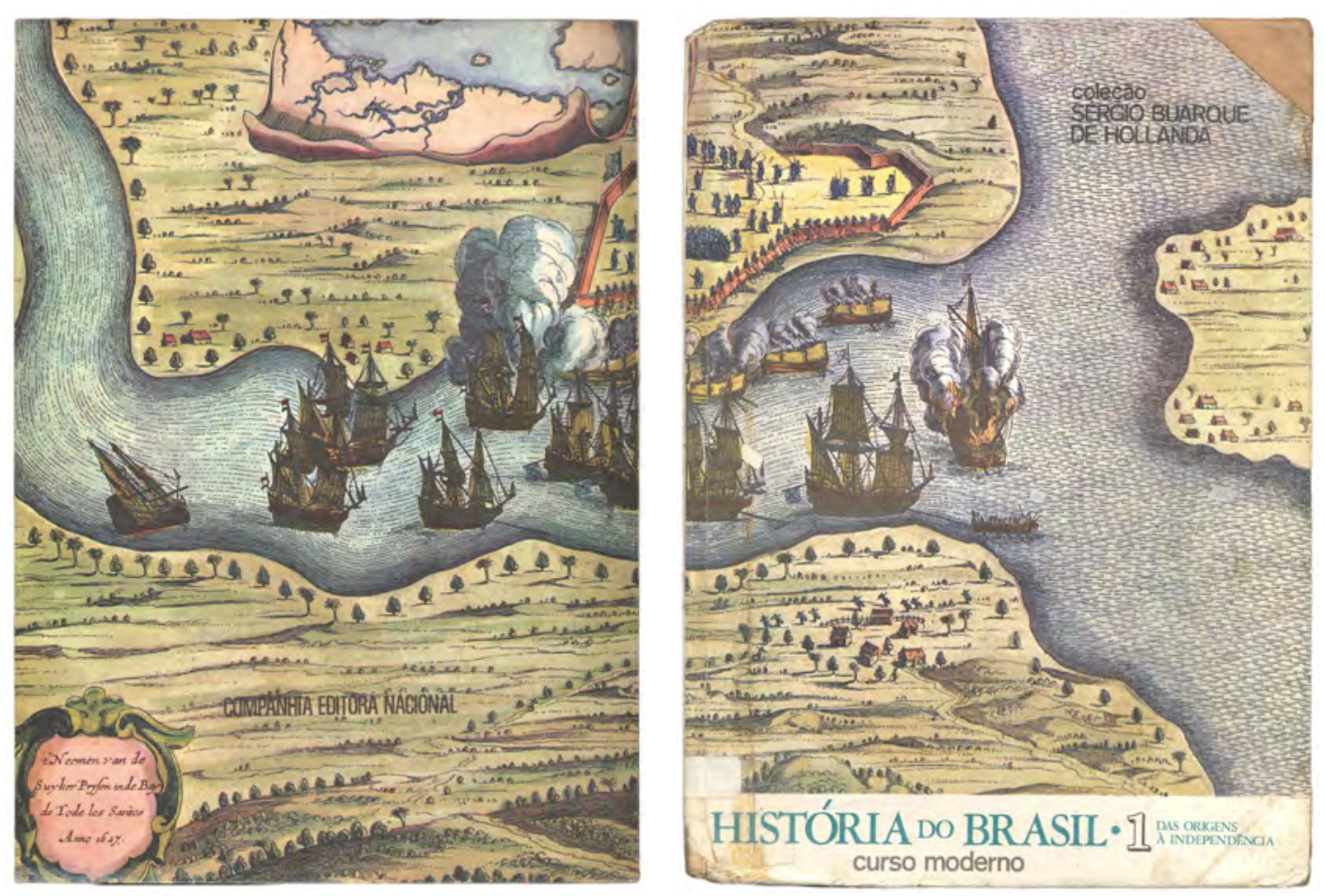

Fig. 8.25 Coleção Sérgio Buarque de Hollanda, História do Brasil 1: curso moderno, 1971 (19,0 x 26,0cm). Capa.

\footnotetext{
3 O autor, em sua tese de doutorado, faz um amplo estudo da coleção, abordando o processo de autoria e edição, referências estrangeiras pesquisadas, decisões editoriais e comerciais, circunstâncias políticas, relação da obra com a reforma do ensino de 1971, projeto gráfico e visualidade, comparação com obras concorrentes, circulação e recepção da obra e conflitos de interesse entre os autores e a editora, que levaram à descontinuidade da publicação na década de 1980.
} 

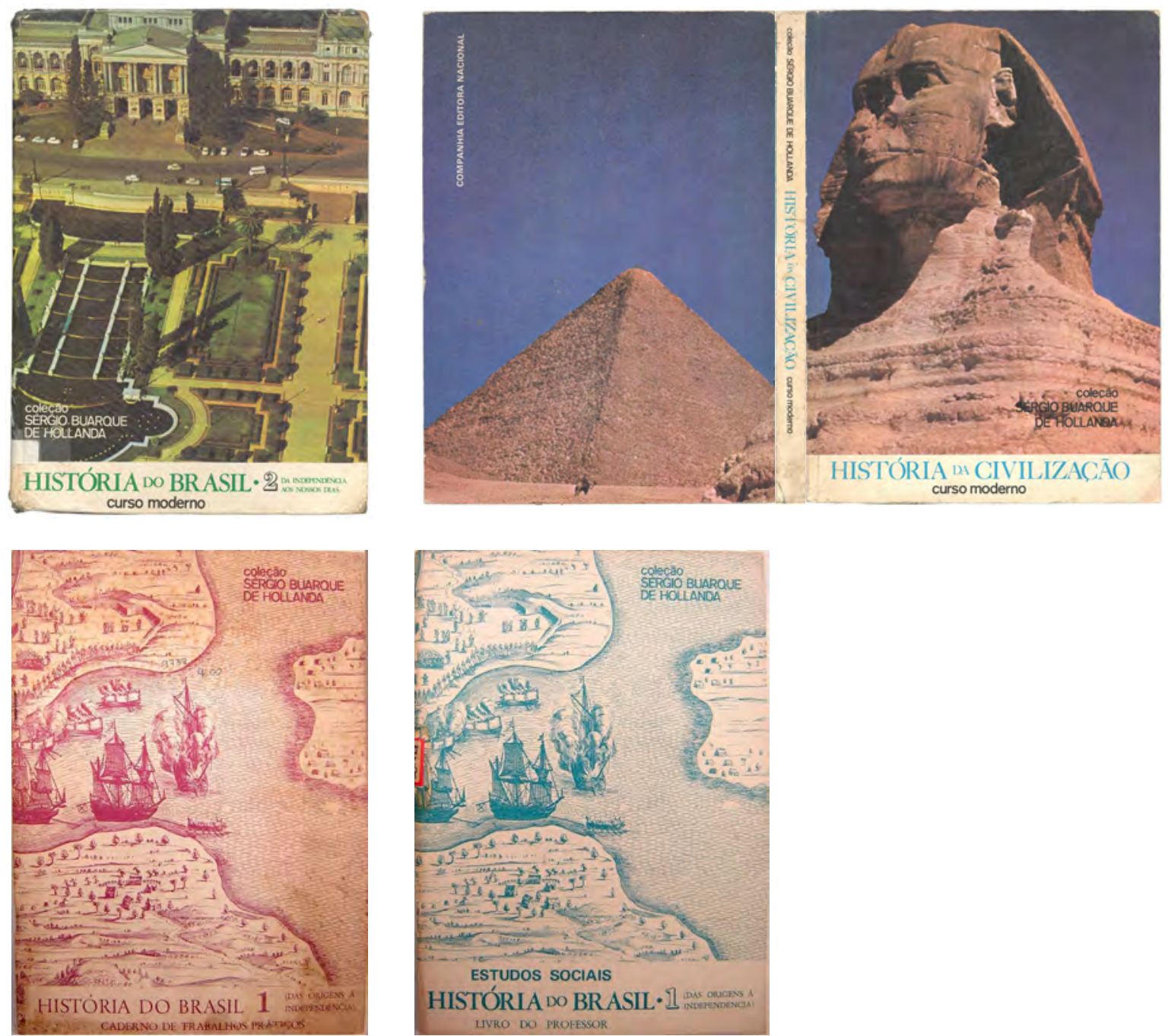

Fig. 8.26 Coleção Sérgio Buarque de Hollanda, História do Brasil 2: curso moderno, 1972. História da civilização: curso moderno, 1974 (brochura). Livro do Professor e Caderno de trabalhos práticos do volume $1(19,0 \times 26,0 \mathrm{~cm}$ para todos). [Fonte: Másculo, 2008]. Capas.

Essa nova concepção teve como decorrência projeto gráfico, edição de arte e produção gráfica diferenciados em relação à produção corrente da própria editora e, em conjunto, inéditos no mercado didático: formato maior do que todos os livros produzidos até então; livro-texto com diagrama de duas colunas de largura diferenciada para texto principal, boxes complementares, glossário e legendas explicativas; uso de fundos sangrados em cores diferentes sinalizando as diversas seções, diagramadas em páginas duplas; grande número de reproduções fotográficas em cores, com produção especial de várias delas; grande número de mapas e esquemas ilustrados; variação tipográfica, com uso de fonte serifada para texto principal e fonte sem serifa para as seções especiais, compostos no então recente processo de fotocomposição, conforme indicado na página de créditos; papel de primeira qualidade para garantir a reprodução em cores; etc. (FIG. 8.27 e 8.28). 

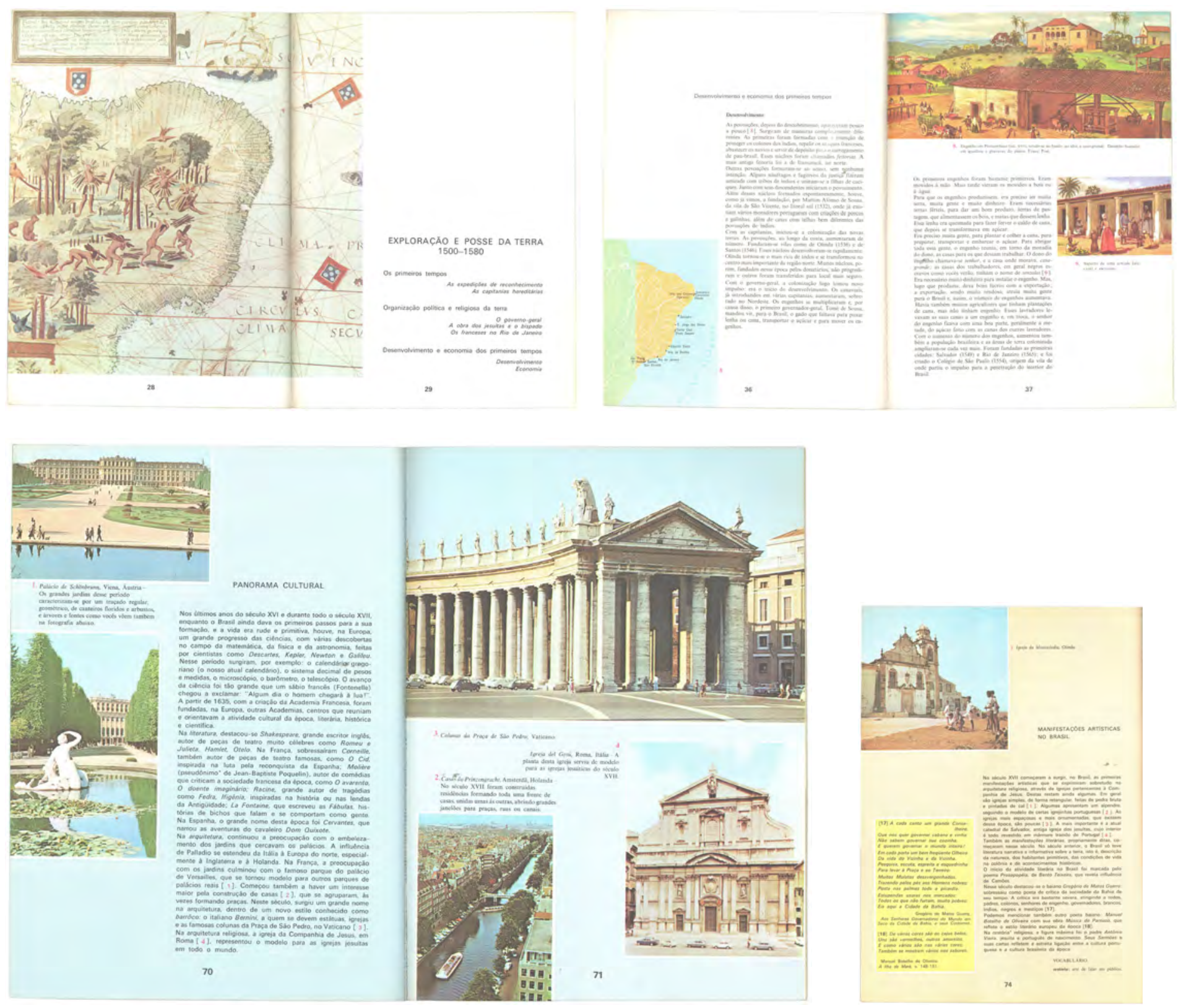

Fig. 8.27. Coleção Sérgio Buarque de Hollanda, História do Brasil 1: curso moderno, 1971 (19,0 × 26,0cm). Páginas de miolo, com planejamento gráfico e ilustrações de Joel Link.

Formato, cores, grande número de fotografias, mapas e esquemas gráficos e distribuição assimétrica de texto e imagem, em diagramação mais dinâmica, conferiram à obra aspecto moderno e inovador, semelhante ao das revistas ilustradas, com a função de atrair o leitor e o predispor à leitura, pois, na visão dos autores, "é preciso que o ensino procure compensar a concorrência dos veículos de informação visual, como o cinema e a televisão, que, para os alunos atuais, tornaram os textos puramente verbais desinteressantes" [Livro do professor do volume 1, apud MÁsculo, 2008, p. 128]. Essa percepção, não exclusiva dos autores mas que em outras obras se manifestava no uso de ilustrações e quadrinhos para ilustrar um conteúdo ainda convencional, aqui se combinava com o rigor historiográfico no uso da imagem. Assim, as ilustrações originais produzidas para o livro restringiam-se a mapas e esquemas gráficos para 
explicitar processos históricos, estruturas sociais ou técnicas de produção, e não episódios ou personagens. E obras artísticas, normalmente a pintura e escultura acadêmica que aparecem em todos os livros de história para ilustrar esses episódios e personagens, simplesmente estão ausentes nessa coleção ou aparecem como documento histórico ou manifestação cultural da época em que foram produzidas, sempre com as indicações de autoria, data, dimensões, características materiais, local onde se encontram e legenda ou texto com remissão comentando seu significado. Note-se também que os livros-texto não continham resumos e atividades, estas eram propostas pelo professor com base no livro a ele destinado, além das encontradas no Caderno de trabalhos práticos.
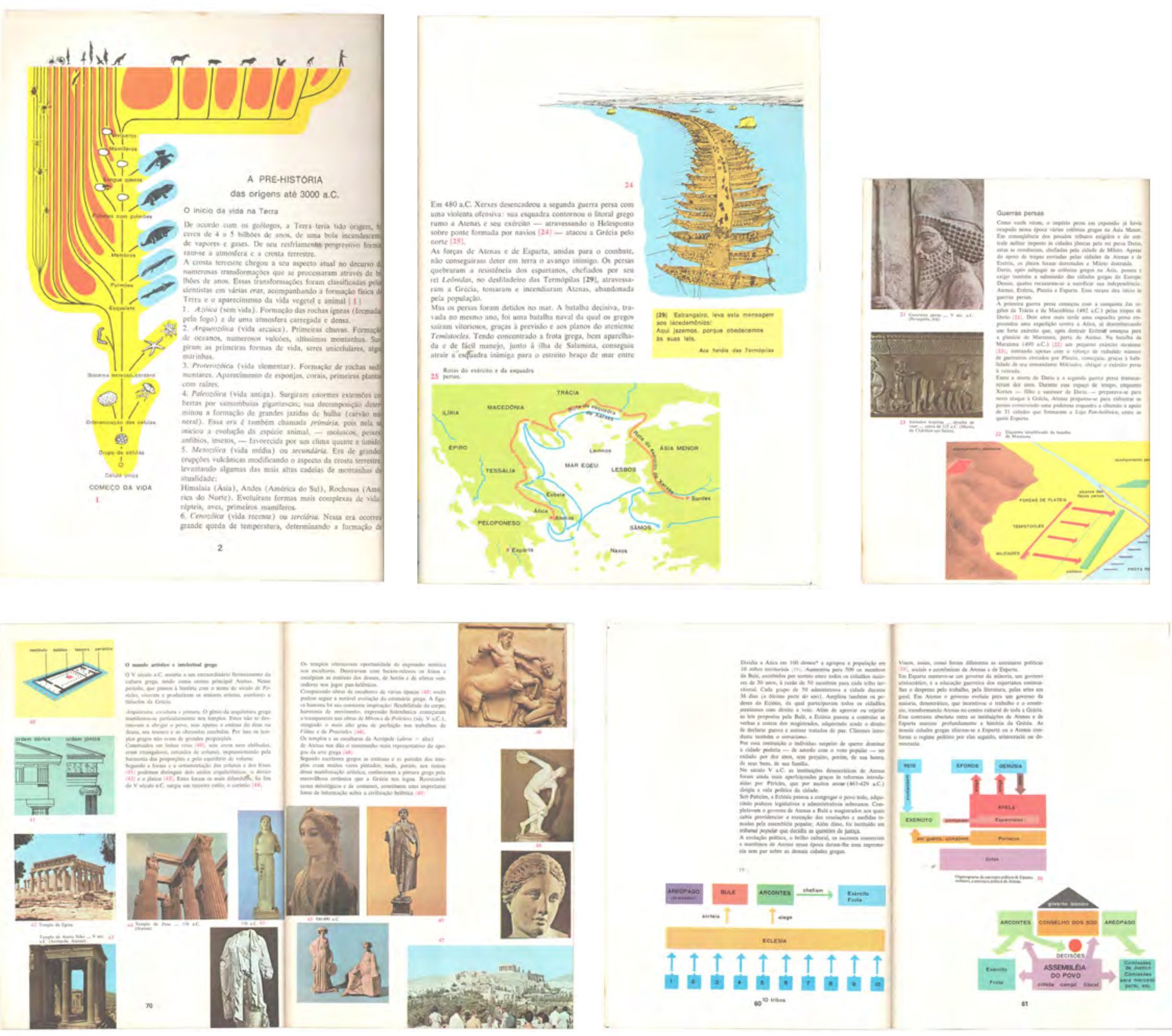

Fig. 8.28 Coleção Sérgio Buarque de Hollanda, História da civilização: curso moderno, 1974 (brochura, 19,0 × 26,0 $\mathrm{cm}$ ). Páginas de miolo, com ilustrações de Antonio Celso Sparapan, Ricardo José Azevedo e Sérgio Santos Debonis e fotos de Caio Marcondes Ferreira, Casemiro O'Czerni e Thomaz de Aquino Queiroz. 
A receptividade da coleção pode ser avaliada pela comparação de sua tiragem - 1.702.802 exemplares para livros-texto, cadernos de exercícios e libr do professor - com a dos livros de Borges Hermida, que até então ocupava o primeiro lugar em vendas da Nacional - 1.008.123 exemplares para os mesmos componentes [MÁsculo, 2008, p.211 e 221]. Esta receptividade pode ter influído tanto no delineamento de novas obras para a disciplina como no design e materialidade da produção subsequente da editora ${ }^{4}$.

Outra obra de história da CEN que trouxe uma nova concepção do ensino da disciplina e uma visualidade diferenciada foi Brasil, uma história dinâmica, com o volume 1 lançado em 1971 e o volume 2 no ano seguinte (Fig. 8.29). Segundo Monteiro; Ralejo; Cicarino [2012, p. diversas], a obra teve uma abordagem metodológica ousada e precursora ao trazer para o ensino na escola procedimentos referenciados à então recentíssima disciplina histórica conhecida como "história do tempo presente". Na obra isto foi feito substituindo a narrativa da sucessão de fatos típica dos compêndios por uma narrativa multifocal em que tanto a história e o cotidiano do aluno como a vida e a cultura da sociedade naquele momento eram tomados como ponto de partida para o conhecimento do passado e o estabelecimento de relações e analogias, para que o conhecimento histórico se tornasse significativo para o estudante.
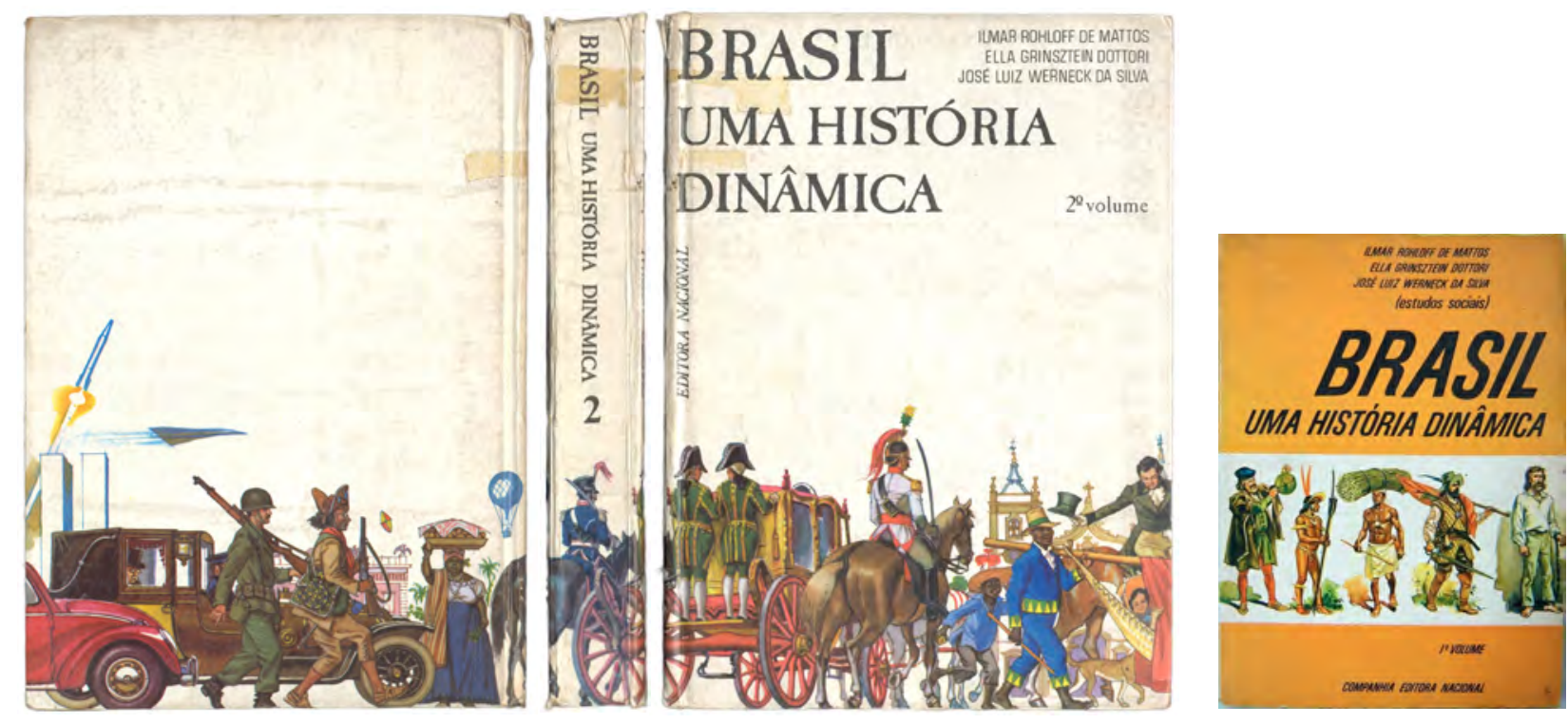

Fig. 8.29. Mattos, Dottori e Werneck, Brasil, uma história dinâmica: 2o volume, $1972(15,0$ × 21,0 cm). Capa, com ilustração de Ivan Wasth Rodrigues. Em tamanho menor, capa do volume 1, 1971. [Fonte: MÁscuLo, 2008, p. 68.]

\footnotetext{
4 Segundo José Cássio Másculo, a coleção conseguiu driblar tanto a censura política, trazendo um conteúdo que falava em lutas sociais na história do Brasil que outros livros omitiam, como a legislação da educação que substituía as disciplinas de História e Geografia pela de Estudos Sociais. No entanto, apesar de ter constituído um inegável sucesso editorial a trajetória posterior da obra refletiu os problemas de gestão da Nacional após sua estatização e a saída de sua equipe dirigente, pois seus autores não obtiveram o aval para fazer as reformulações e atualizações necessárias e a obra entrou em declínio de vendas ainda na década de 1970.
} 

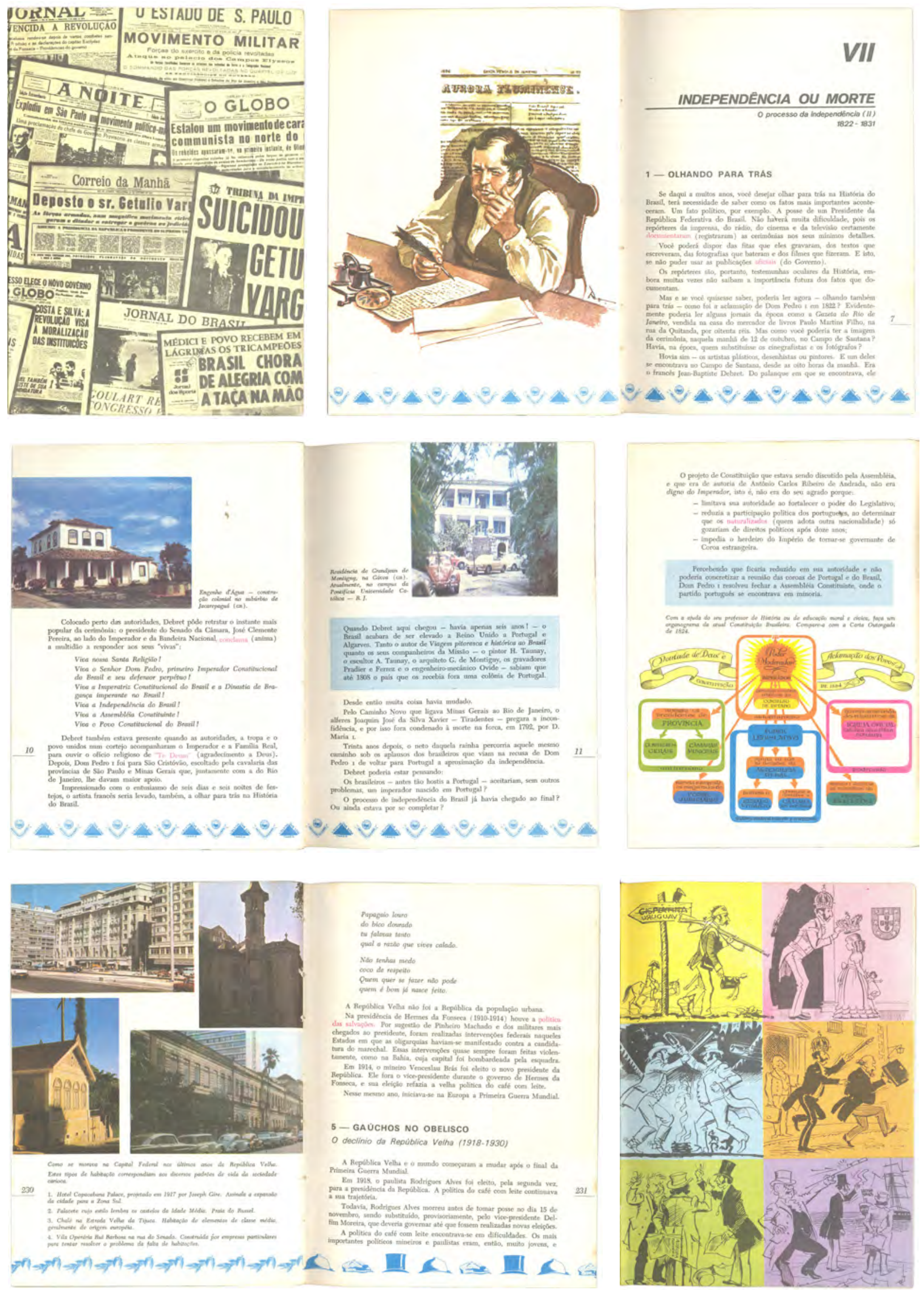

Fig. 8.30. Mattos, Dottori e Werneck, Brasil, uma história dinâmica: 2º volume, $1972(15,0$ × 21,0cm). Páginas de miolo, com ilustrações de Ivan Wasth Rodrigues. 
A capa do volume 2 expressa essa abordagem "dinâmica" que dá nome à obra, com a visualização da quarta capa revelando desfile de rua com personagens e veículos ligando o passado ao presente, com rica ilustração de Ivan Wasth Rodrigues, valorizada pelo fundo branco e pela elegante tipografia serifada em caixa alta. A capa do volume 1, do qual só se obteve a imagem, não teve a mesma produção, reunindo apenas ilustrações de personagens do miolo, e traduzindo o sentido do título pela tipografia inclinada, que sugere movimento e velocidade.

O miolo (FIG. 8.30), trazendo aberturas de capítulos com personagens, reais ou fictícios, também desenhados por Ivan Wasth Rodrigues, e seções fixas de leitura, de contextualização mundial do recorte temporal abordado nos capítulos e de atividades que visavam comprometer o estudante com pesquisa em jornais, revistas e livros e realização de entrevistas, tem grande número de ilustrações, fotografias, mapas e esquemas. Esta produção só foi superada pela realizada na Coleção Sérgio Buarque de Hollanda, e como aquela, aparece inteiramente creditada, com menção aos nomes de pesquisador iconográfico e diagramador, além de fotógrafos e do ilustrador.

A reformulação das obras de Borges Hermida para a nova estrutura do ensino de Primeiro Grau (FIG. 8.31 e 8.32) implicou mudança de formato e consumibilidade, com os miolos assumindo as características de design dos outros livros para o segmento já vistas em outras disciplinas e produção indepente das capas. Estas trazem solução ilustrada, executada por Almir, de quem não se encontrou outro trabalho para a editora, em linguagem de cartum colorido, dominante no campo com fundo chapado sangrado, com um personagem por volume, em traço referenciado no trabalho de Ziraldo e de Zélio, cartunistas de muita presença no período.
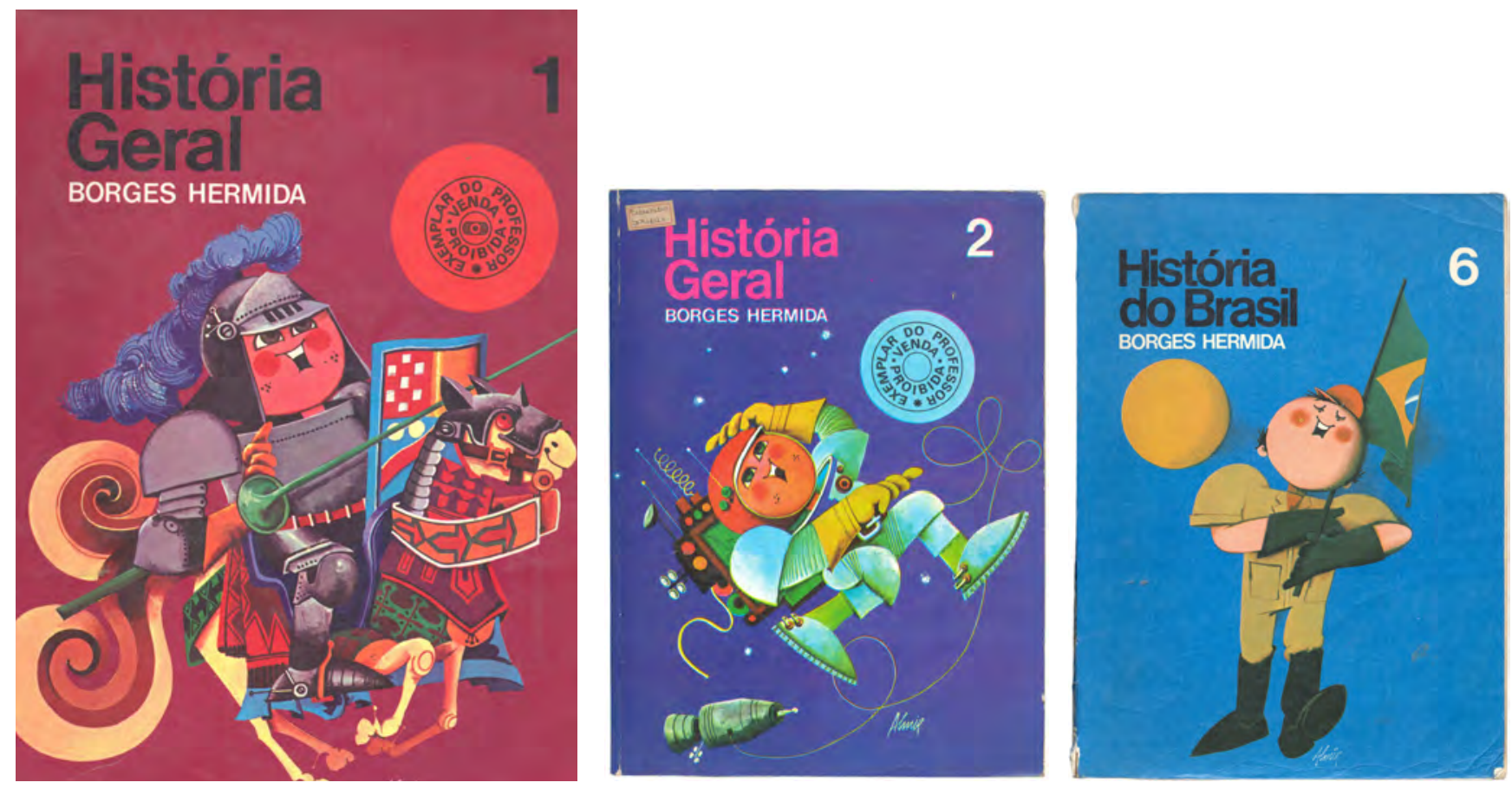

Fig. 8.31. Borges Hermida, História geral:1e2,1979 (19,0 ×26,0 cm). Capas (ilustração de Almir) e páginas de miolo. Borges Hermida, História do Brasil: 6, 1978 (19,0 × 26,0 cm). Capa (ilustração de Almir). 
Os hebreus, o povo da Bíblia
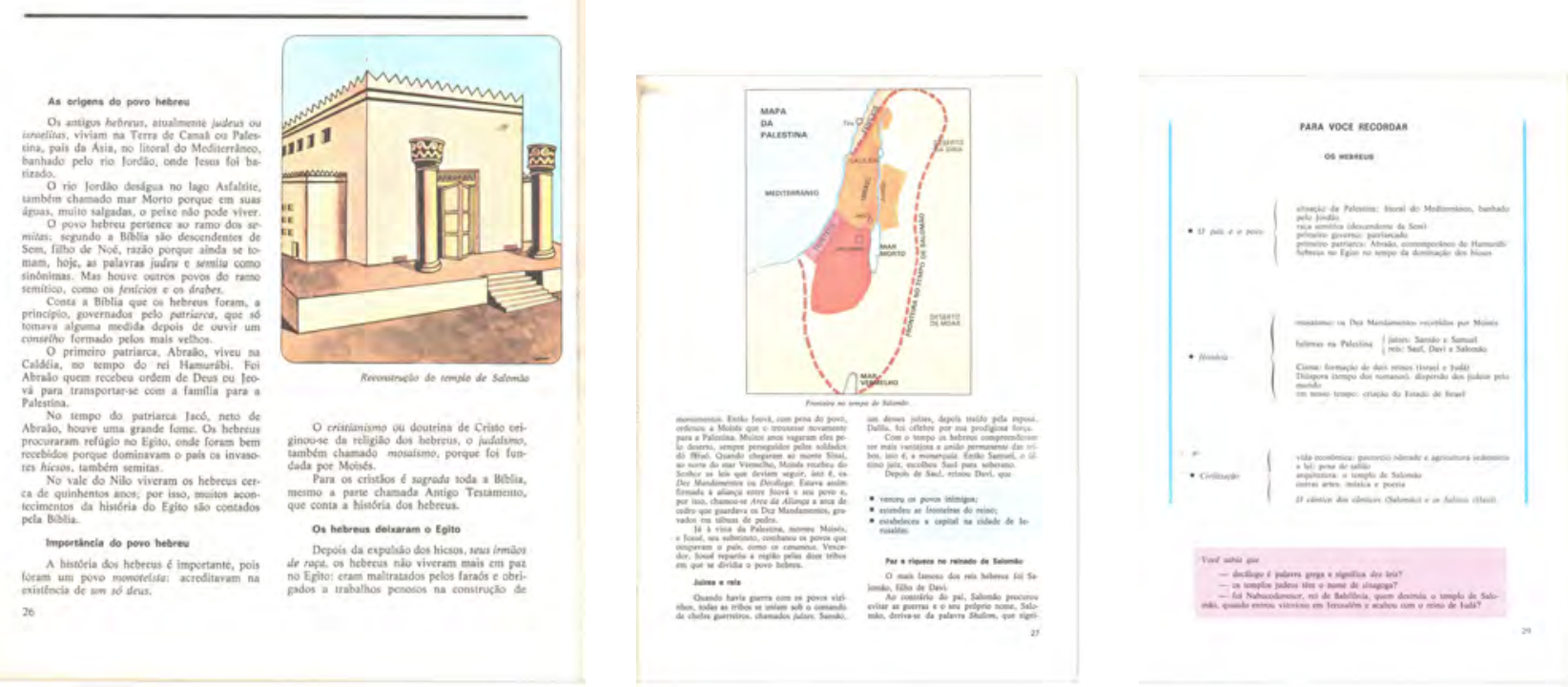

Fig. 8.32. Borges Hermida, História geral: 1, $1979(19,0 \times 26,0$ cm). Páginas de miolo.

História do Brasil, da Américo Jacobina Lacombe, é uma obra para o Segundo Grau que apresenta formato maior e diagramação em duas colunas, como os livros de Primeiro Grau, mas impressão apenas em preto. A capa também tem solução mais adulta e sóbria, com o uso do mapa lembrando o volume 1 da Coleção Sérgio Buarque de Holanda, com o recorte da imagem, as proporções entre as áreas de imagem e informações textuais, a tipografia e a cor produzindo um efeito de grande elegância.
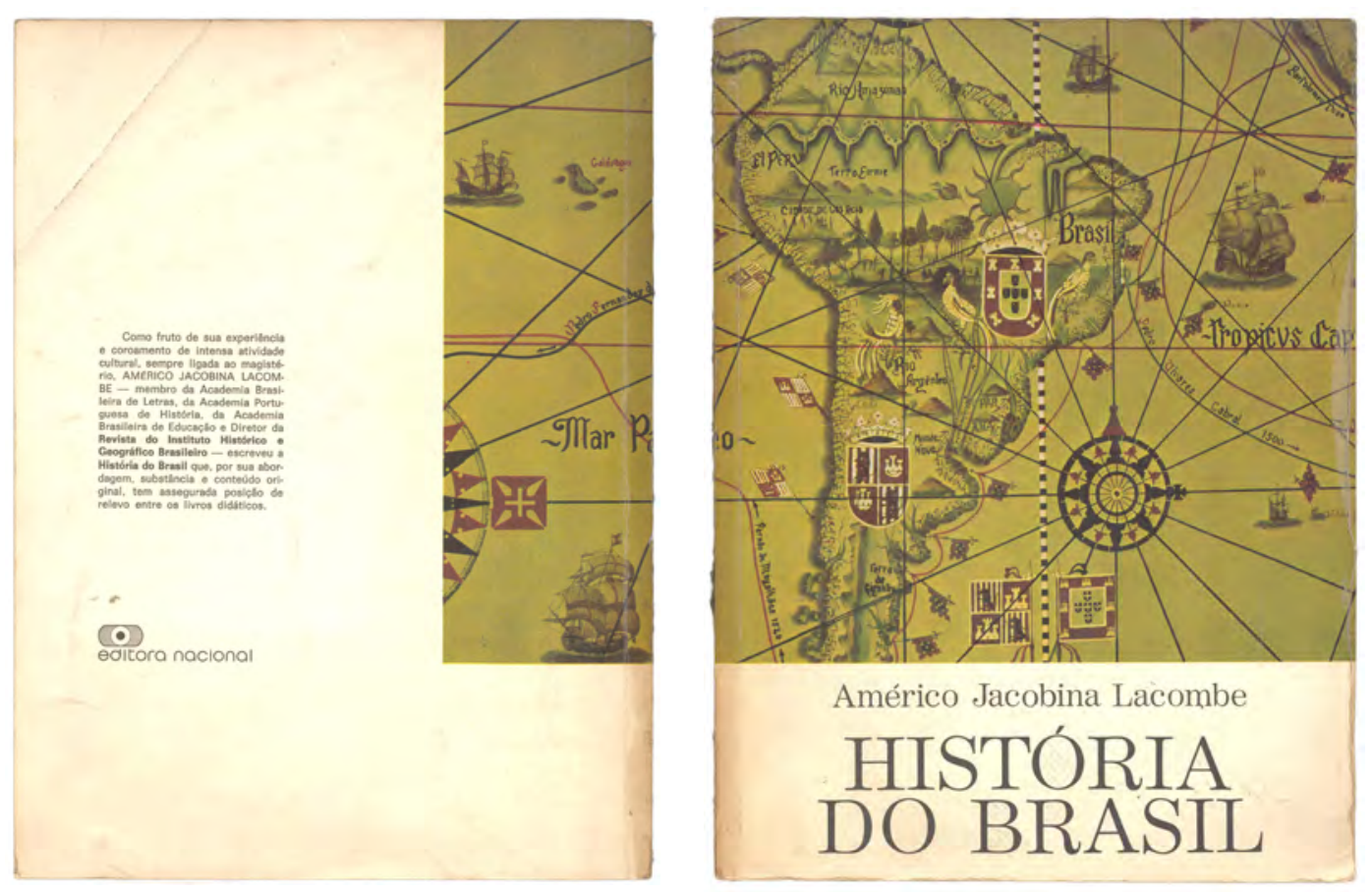

Fig. 8.33. A. Jacobina Lacombe, História do Brasil, 1979 (brochura 19,0 × 25,5cm). Capa. 


\subsubsection{Livros de Geografia: presença da llustração mas predomínio da fotografia nas capas}

Geografia é a disciplina que primeiro apresentou capas fotográficas (ver capítulos 6 e 7), e esta é a solução mais recorrente também neste último período. No entanto, a reedição da obra de Aroldo de Azevedo que faz uma fusão de O mundo em que vivemos e Terra brasileira (ver p. 287-288), O Brasil no mundo (FIG. 8.34) traz capa dura plastificada com atualização também de linguagem em relação às obras anteriores, com ilustração formada por justaposição de imagens e utilizando um material de desenho surgido na época, a caneta hidrográfica, percebida no contorno e no preenchimento de áreas de cor. A ilustração está contida em janela irregular que atravessa primeira e quarta capas, sobre fundo chapado com as informações textuais.
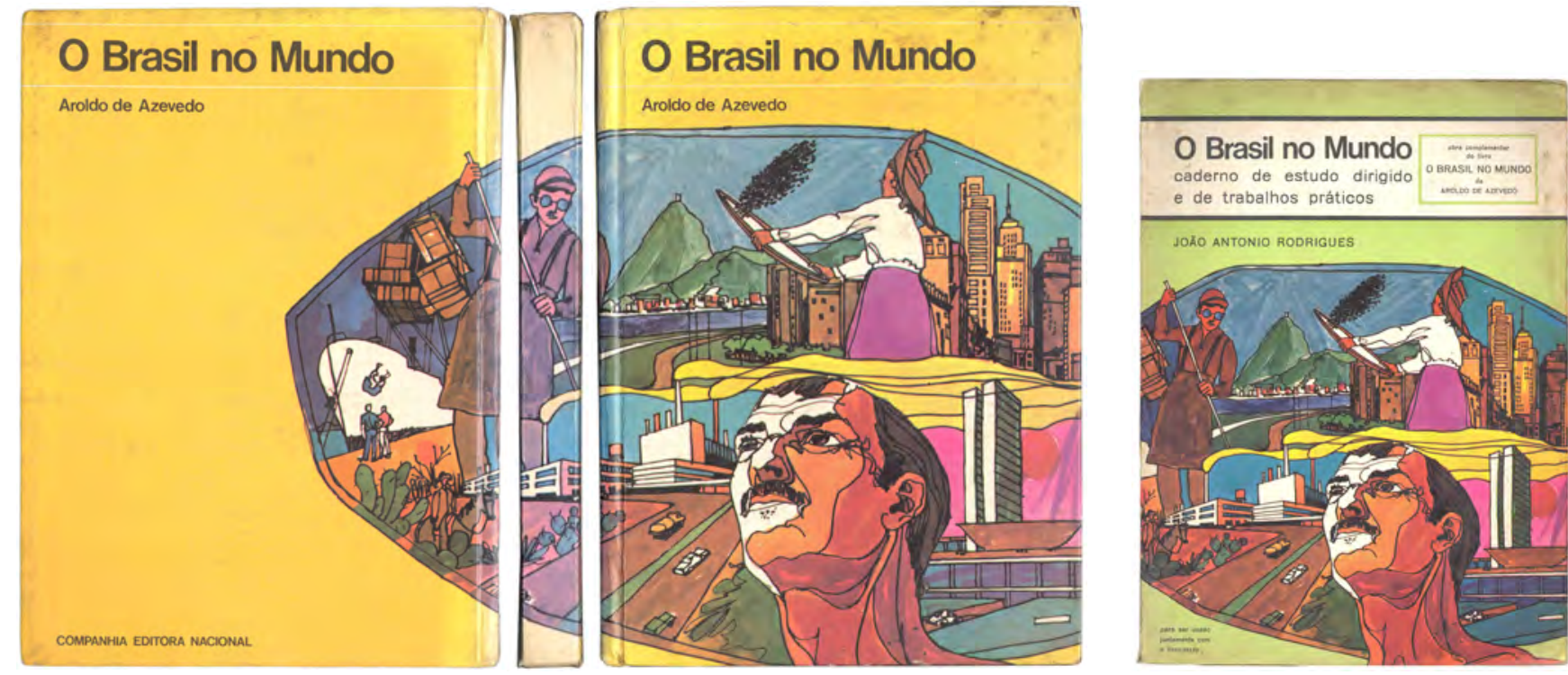

Fig. 8.34. Aroldo de Azevedo, O Brasil no mundo, $1971(15,0 \times 19,5 \mathrm{~cm})$. Capas do livro-texto e do Caderno de estudo dirigido, por João Antonio Rodrigues (brochura, 19,0 × 26,5 cm). llustrações de Joel Link.

Mas a reedição de outra obra de Aroldo de Azevedo, O Brasil e suas regiões (FIG. 8.35) retorna à solução fotográfica para a capa, com a imagem sangrada trilateralmente tomando quase todo o campo, apenas interrompido pela faixa preta inferior que suporta o título e com o nome do autor aplicado sobre a parte superior da foto, correspondendo à continuidade da solução fotográfica típica da disciplina, mas com novo padrão de dominância da foto em relação ao texto.

As duas obras tem miolo completamente impresso em quadricromia, com reformulação das ilustrações em relação à linguagem de traço característica das obras anteriores do autor. 0 diagrama de miolo é também diferente dos padrões anteriores, com duas colunas de medidas diferentes, uma mais larga para o texto principal e outra mais estreita, para textos complementares e outras informações, impressos na cor ciano da escala quadricrômica. Ambas são acompanhadas de caderno de atividades. 

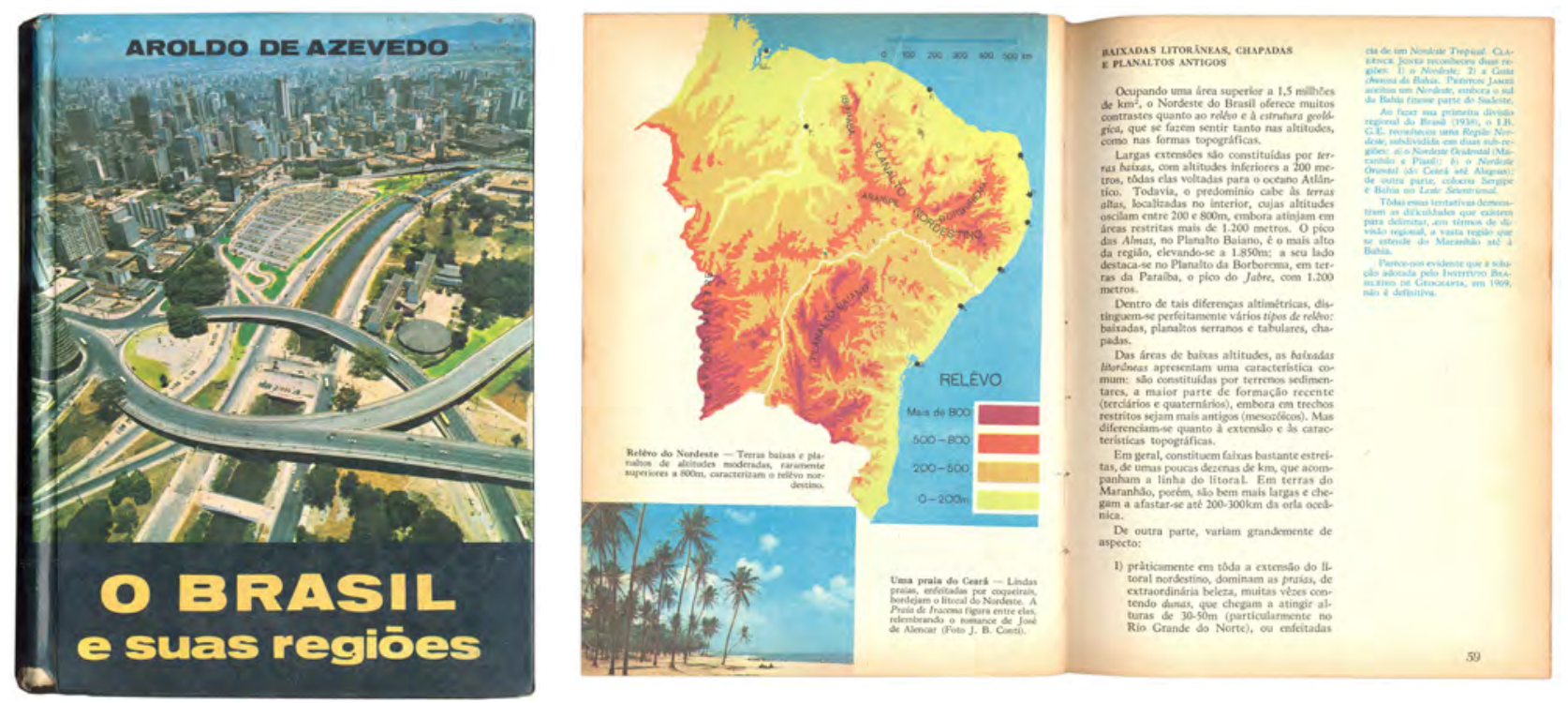

Fig. 8.35. Aroldo de Azevedo, O Brasil e suas regiões, 1971 (15,0 × 20,5cm). Capa (Everton Stúdio) e páginas de miolo, com ilustrações de Joel Link. Também possui caderno de estudo dirigido e atividades.

Além da capa de O Brasil no mundo (FIG. 8.34), a primeira edição de uma nova obra da editora, Nossa terra nossa gente (FIG. 8.36) também recorreu à ilustração, em linguagem mais lúdica e menos referencial, como decorrência de sua forte presença no miolo e para melhor comunicar uma abordagem diferenciada da disciplina. No entanto, outro volume, de edição posterior e em formato maior, retorna à solução fotográfica, mas com a configuração de mosaico, de menor impacto que as capas fotográficas sangradas com texto sobreposto (FIG. 8.37).
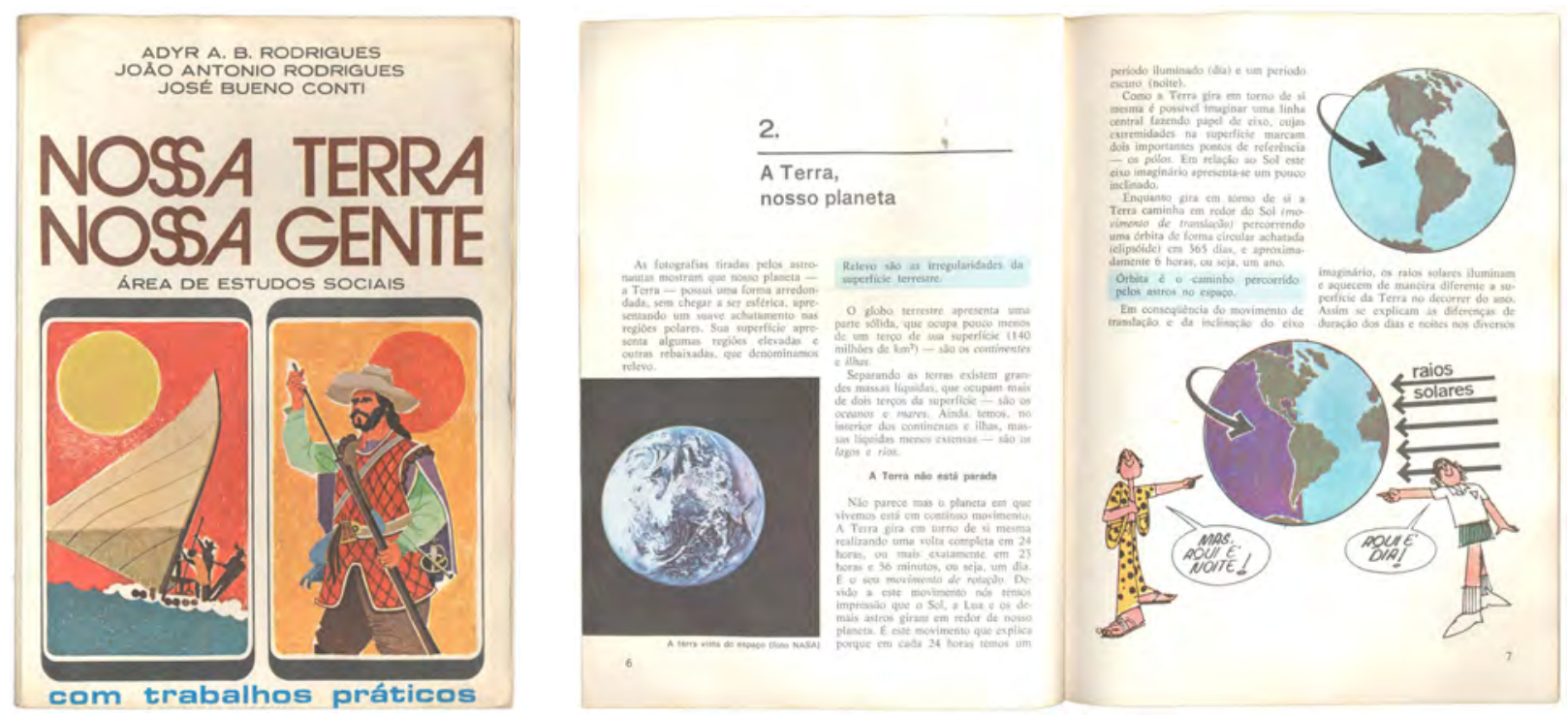

Fig. 8.36. Adyr Rodrigues, João A. Rodrigues e José B. Conti, Nossa terra nossa gente: área de Estudos Sociais, 1975 $(15,0 \times 21,0 \mathrm{~cm})$. Capa e páginas de miolo. 

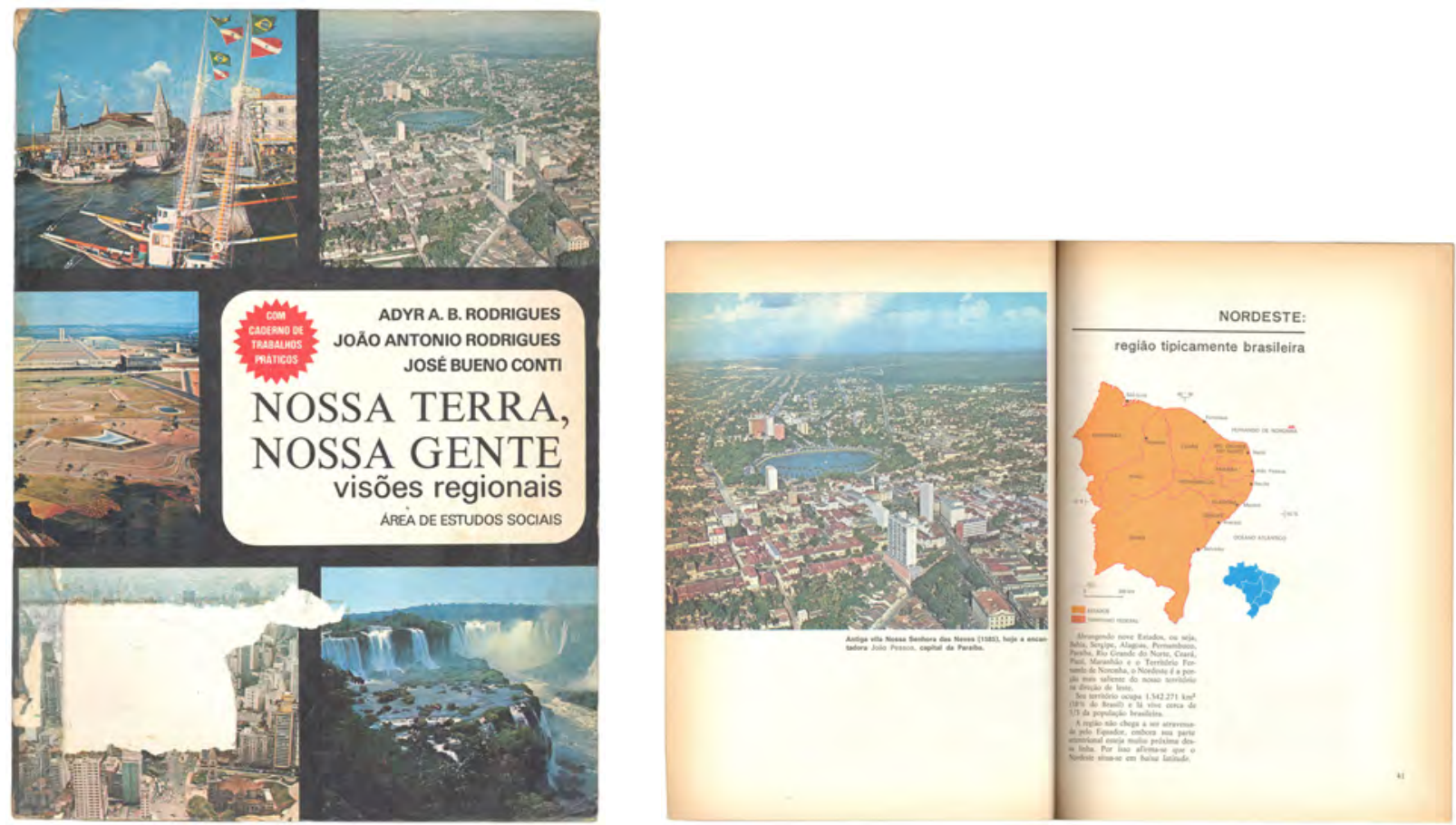

Fig. 8.37. Adyr Rodrigues, João A. Rodrigues e José B. Conti, Nossa terra nossa gente: visões regionais, 1976 (19,0 x 26,0 cm). Capa e páginas de miolo.

Outras obras da disciplina também trazem capas fotográficas, dentre elas os dois volumes de Geografia dinâmica (FIG. 8.38), de diversos autores, com impressão em quadricromia também no miolo. A fotografia em alto contraste, tipografia condensada em caixa baixa e impressão em única cor de O mundo político no final do século XX (FIG. 8.39) traz uma linguagem muito utilizada na época, mas mais presente em publicações adultas. As grandes paisagens da superfície do globo traz a solução fotográfica mais recorrente nos períodos anteriores, com áreas distintas para imagem e informações textuais, mas modernizada pelo contraste tipográfico de peso, caixa e cor, e o uso reiterado de caixa baixa para o título (FIG. 8.39).
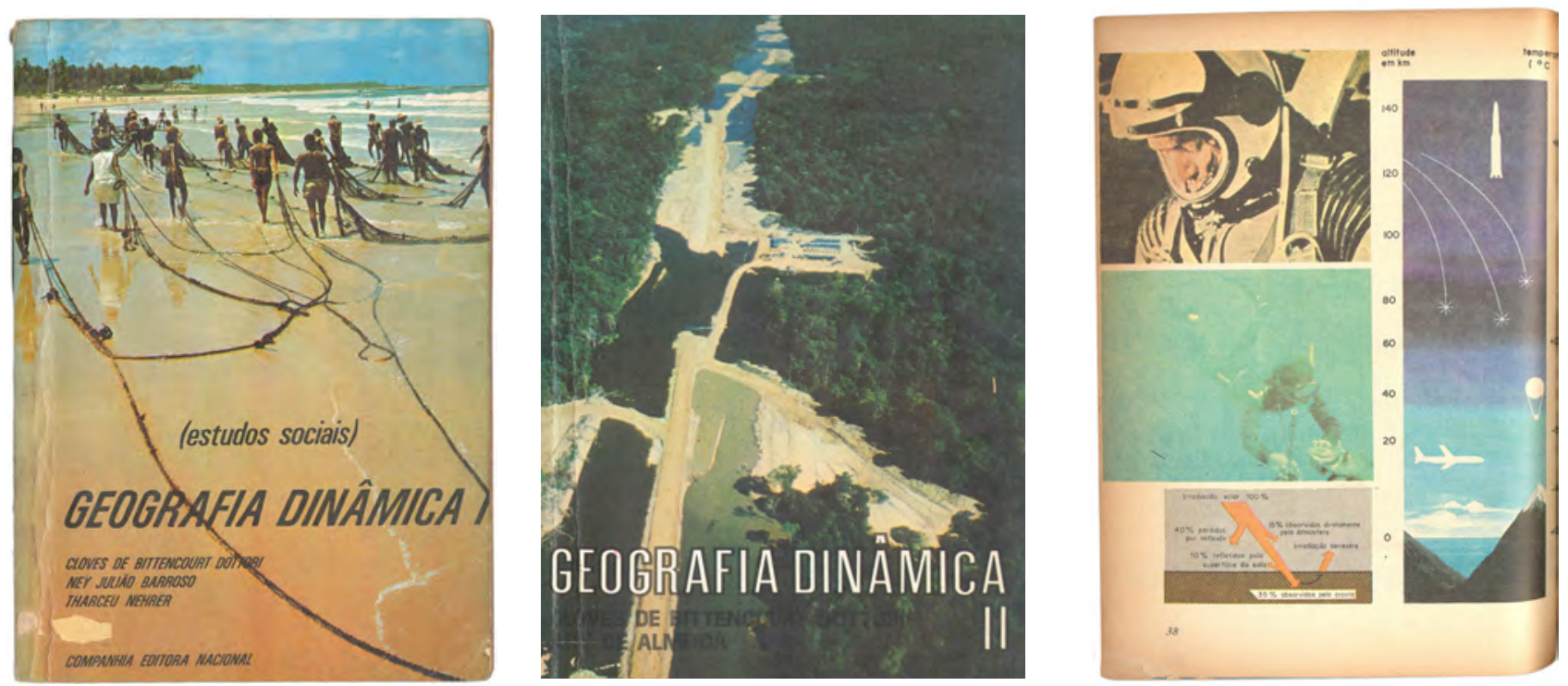

Fig. 8.38. C. Dottori, N. Barroso e T. Nehrer, Geografia dinâmica: / e II, 1974 (15,0 × 21,0cm). Capas e página de miolo. 

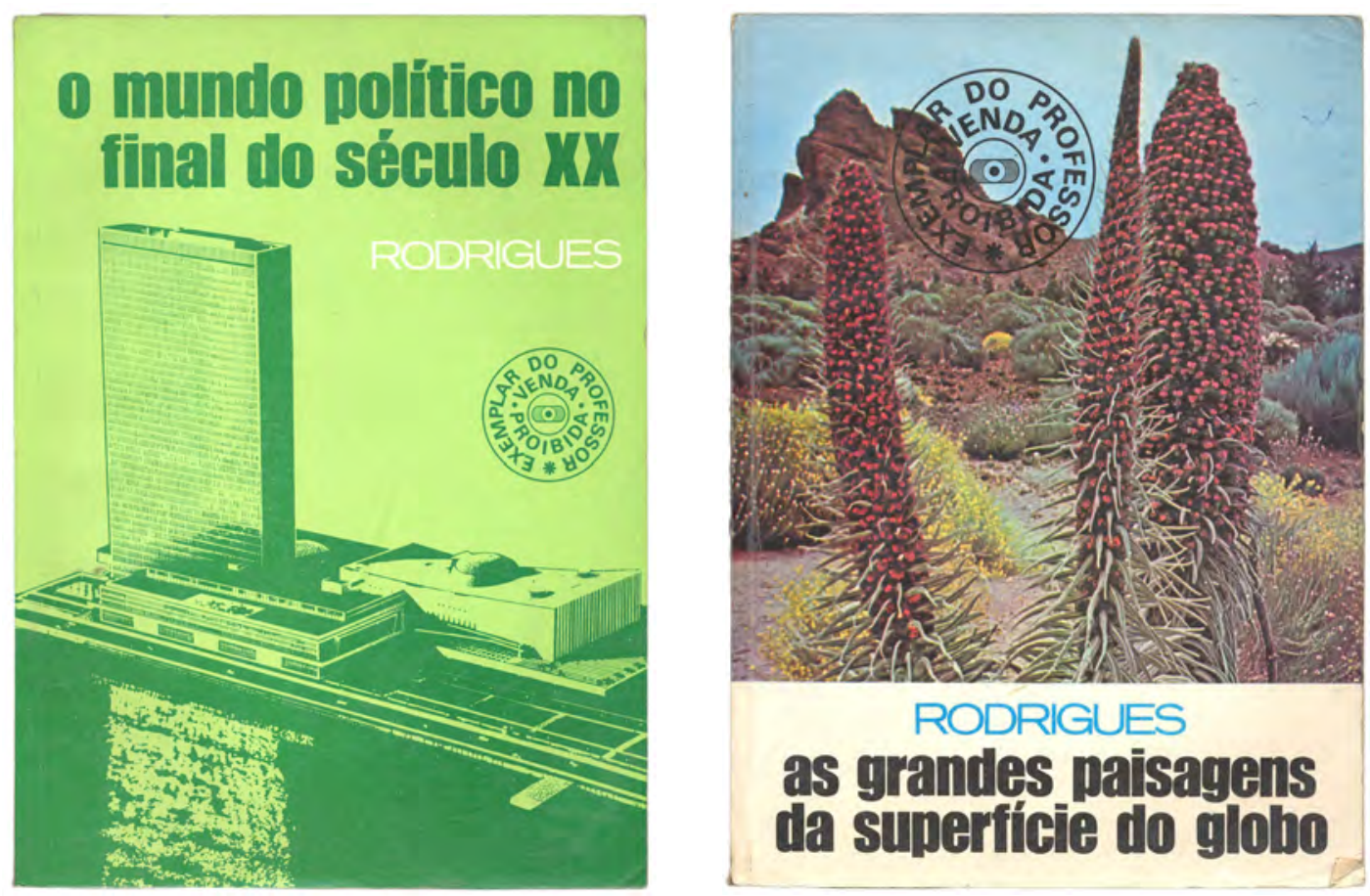

Fig. 8.39. Rodrigues, O mundo político no final do século XX, 1979 e As grandes paisagens da superfície do globo, 1979 $(19,0 \times 26,0 \mathrm{~cm})$. Capas.

\subsubsection{Fotografia e soluções tipográficas nas capas de livros de Matemática}

Os livros de Matemática de Osvaldo Sangiorgi também passaram para o novo formato de 19,0 × 26,0 cm e tiveram também capas fotográficas, ainda em encadernação com capa dura até 1973 e em brochura a partir de 1974 (FIG. 8.40). No volume de 5a série, o apelo e originalidade estaria na fotografia sangrada de uma situação cotidiana de sala de aula, com aplicação das informações textuais sobre ela. Já a capa de 8o ano traz uma solução elaborada e original, não pelo assunto em si mas pela realização. Uma montagem fotográfica traz o apreciado realismo da materialidade dos objetos e dos traços de giz desenhados, pairando num primeiro plano de um espaço indefinido, com luzes difusas, estabelecendo uma abordagem abstrata e conceitual e revelando a presença de tecnologia para a obtenção da imagem, algo bastante valorizado na época e talvez um atrativo em si.

O miolo dos dois volumes é impresso em bicromia e traz parte da concepção gráfica da obra anterior do autor (Matemática, curso moderno, ver p. 271-275), com páginas textuais concebidas em dupla e forte integração entre texto e ilustrações, porém com a incidência de pequenas vinhetas nas margens do conteúdo textual sem relação direta com ele. O volume de 8 a série traz uma particularidade não encontrada em nenhuma outra obra: uma narrativa ilustrada paralela ao texto, iniciada nas pré-textuais, segue por todas as textuais e conclui na última página do livro. 

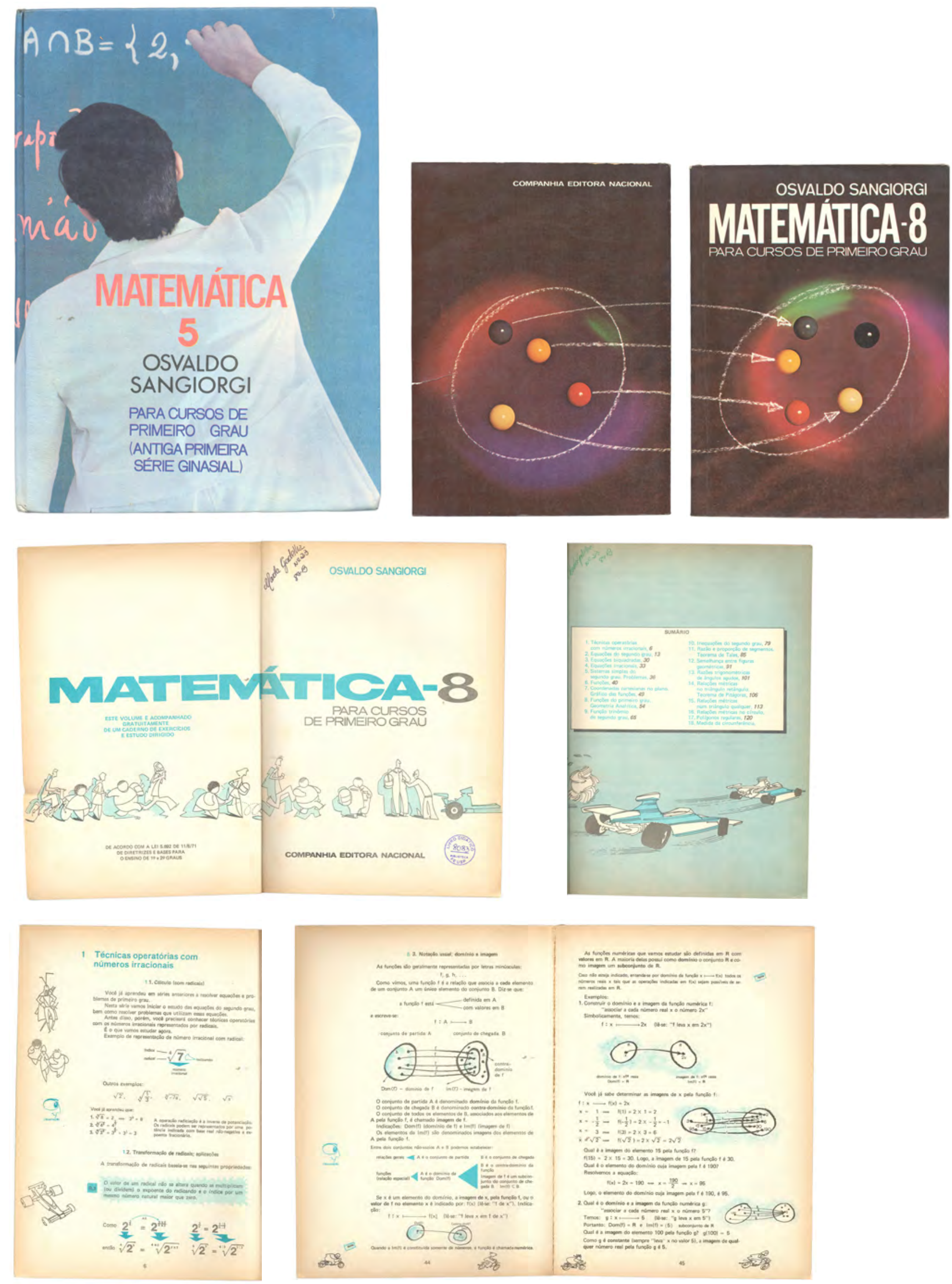

Fig. 8.40. Osvaldo Sangiorgi, Matemática 5: para cursos de Primeiro Grau, $1973(19,0 \times 26,0$ cm). Capa. Osvaldo Sangiorgi, Matemática 8: para cursos de Primeiro Grau, 1974 (brochura, 19,0 × 26,0cm). Capa, de Roberto de Guglielmo, e páginas de miolo, com arte de Joel Link. 
A coleção Curso moderno de matemática, segundo lugar em vendas da Nacional [VILLELA, 2009, p. 156] traz capas com solução com poucos elementos e a econômica impressão em duas cores (FIG. 8.41). Uma imagem central, formada pelo desenho à mão de contorno de números justapostos, evidenciando suas formas e contraformas, traz o número do volume colocado em destaque, em desenho com alguma variação entre os volumes. $O$ uso de fonte única, em caixa baixa e quebra ortogonal de direção, completam a intenção de comunicar a modernidade expressa pelo título. O miolo traz a segunda cor para os elementos gráficos de apoio e ilustrações.
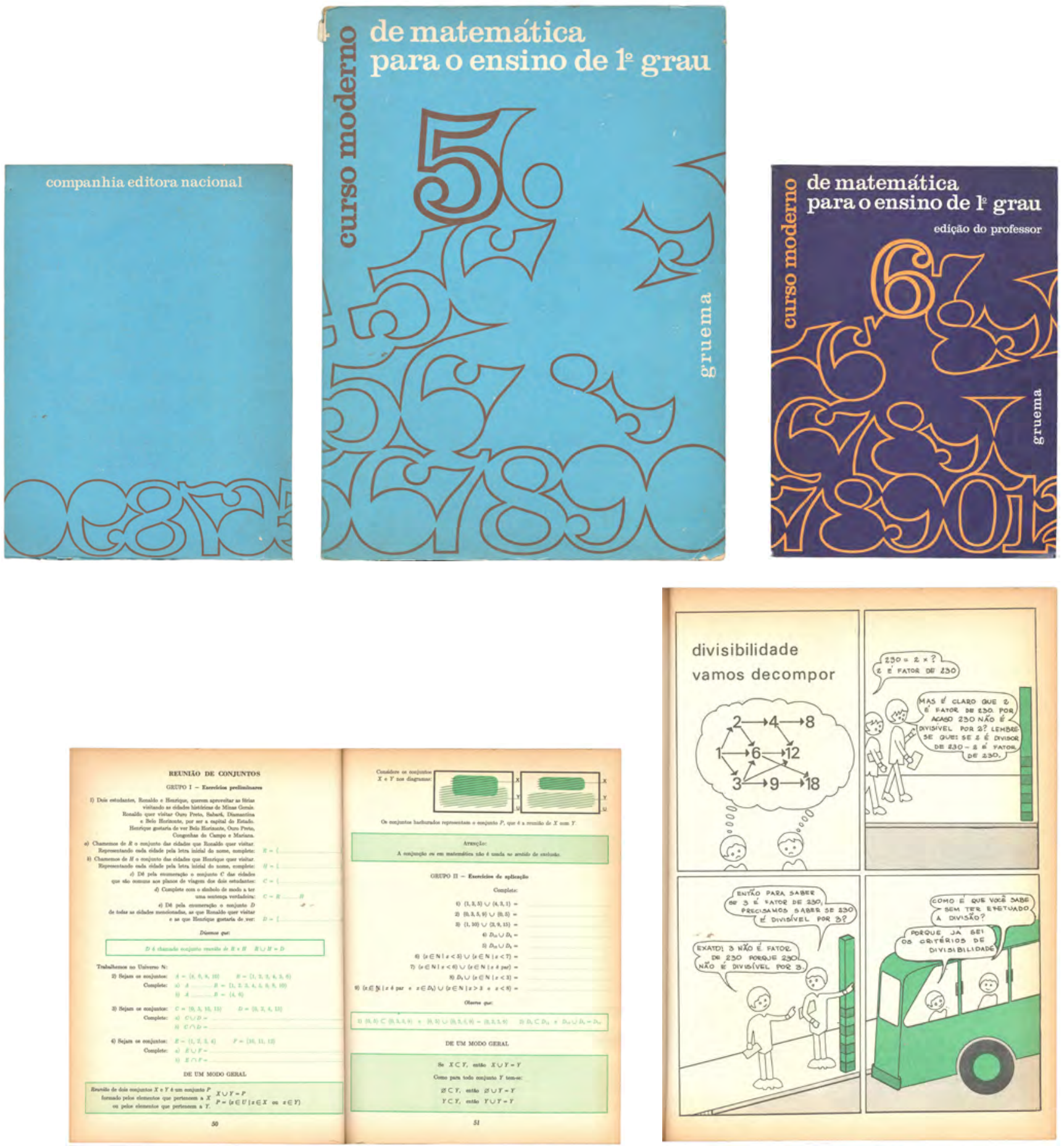

Fig. 8.41. Gruema, Curso moderno de matemática para o ensino de 1o grau: 5 e 6, 1975 (19,0 × 26,0 cm). Capas. 
Matemática, um processo de criação traz também solução apoiada basicamente em texto mas com presença forte de malha gráfica sangrada em todo o campo do fundo (FIG. 8.42), que recebe a informação textual, disposta em quebras de direção ortogonal. O desalinhamento do título e sua direção, os elementos irregularmente desenhados, os grandes corpos e o contraste cromático expressariam a idéia de criatividade trazida pelo subtítulo. Apenas as cores e o número de volume particularizam os livros da coleção. O miolo traz uso da segunda cor para apoio e elementos gráficos e tipografia fazendo referência à computação.
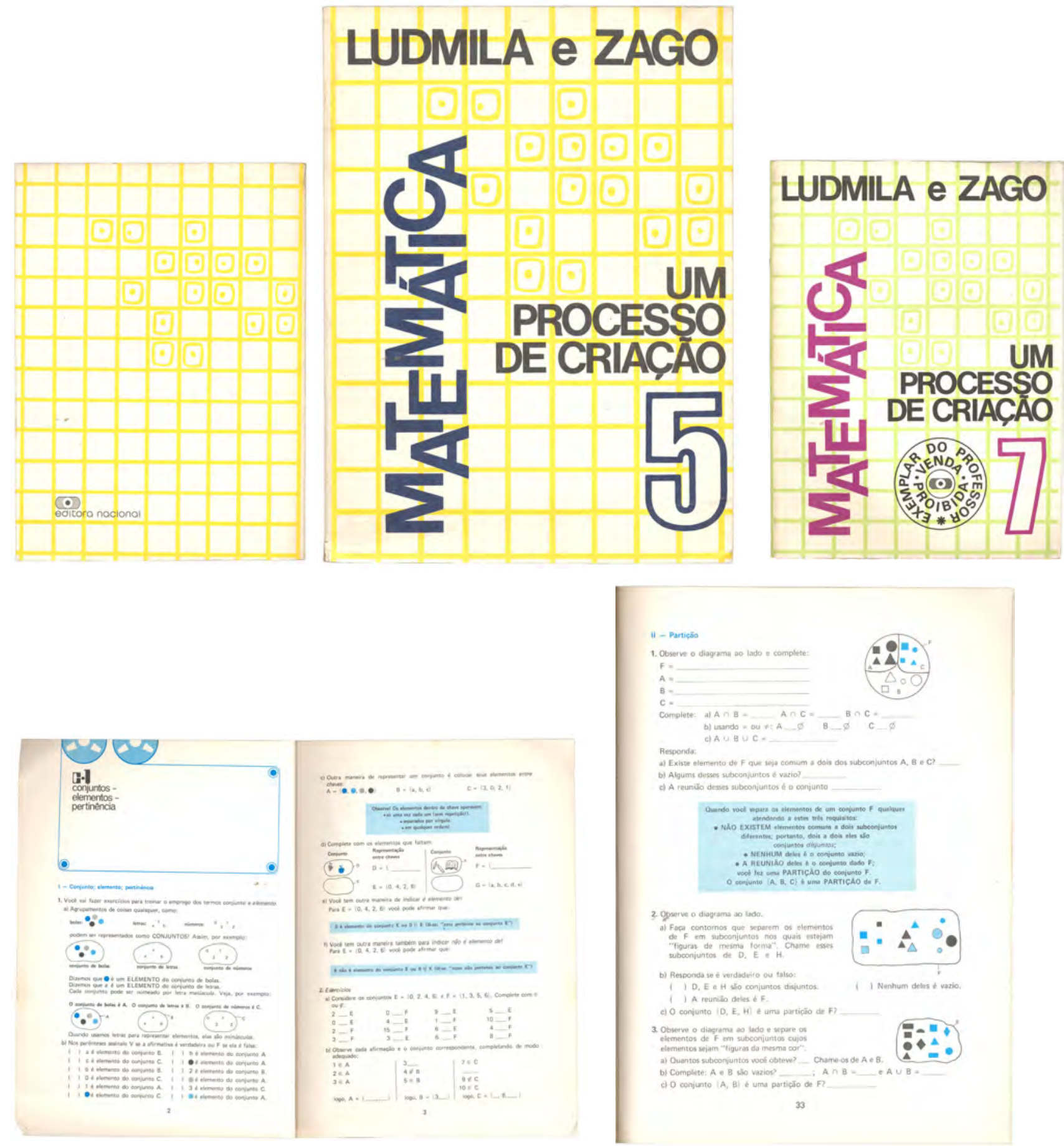

Fig. 8.42. Ludmila e Zago, Matemática: um processo de criação, volumes 5 e 7, 1978 (19,0 × 26,0 cm). Capas, de Haniel. 


\subsubsection{Da ilustração à fotografia nas capas e miolos dos livros de Ciências}

As duas obras da fIGURA 8.43 mostram a trajetória do design do livro didático no período em títulos da disciplina Ciências. A primeira, O corpo Humano, tem capa ilustrada impressa em duas cores, miolo totalmente ilustrado, formato menor, diagramação em duas colunas e utiliza exclusivamente fonte serifada. A segunda, Química/Física, tem capa fotográfica, uso extensivo de fotografia no miolo, motivando seu crédito na capa, formato maior, diagramação em colunas com medidas diferentes e uso de fontes serifadas e sem serifa.
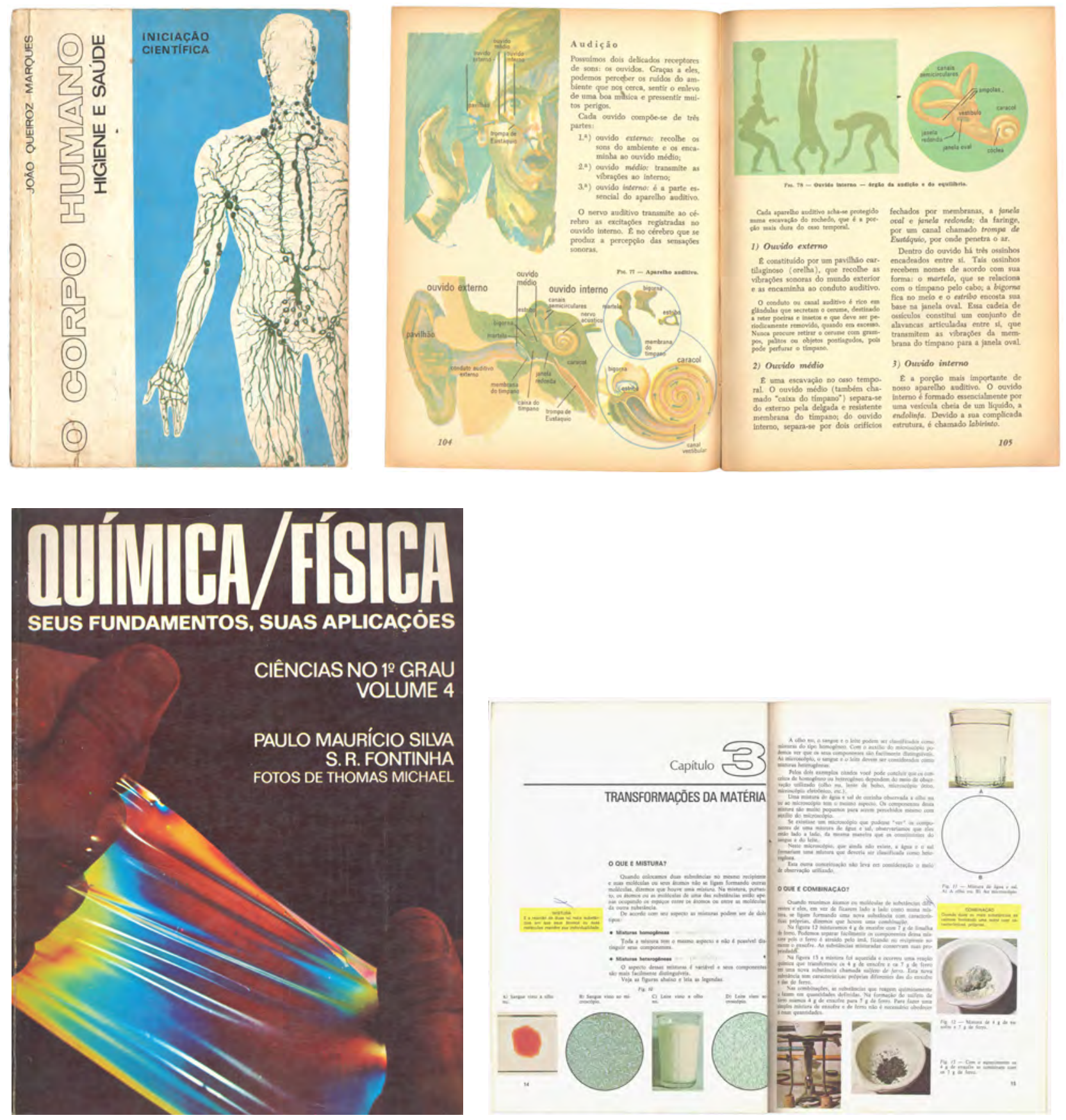

Fig. 8.43. João Queiroz Marques, O corpo humano: higiene e saúde, 1974 (15,0 × 21,0 cm). Capa e páginas de miolo, com ilustrações de Joel Link.

Paulo M. Silva e S. R. Fontinha, Química/Física: seus fundamentos, suas aplicações, 1977 (19,0 × 26,0cm). Capa e páginas de miolo, com fotos de Thomas Michael e desenhos de Fátima Caldas e Everton Ouriques. 


\subsubsection{Fotografia e ilustração nas capas de livros de Inglês}

As capas da fIGURA 8.44 mostram as soluções adotadas nas capas de Inglês. A coleção English for high school traz uma incursão do artista plástico Evandro Carlos Jardim no design gráfico, com reproduções fotográficas das artes visuais britânicas — tapeçaria de William Morris, detalhe de móvel de Arthur Mackmurdo e escultura de Henry Moore -, com a página de créditos trazendo nota sobre as obras e biografia dos artistas britânicos, fazendo das capas veículo de informação cultural.
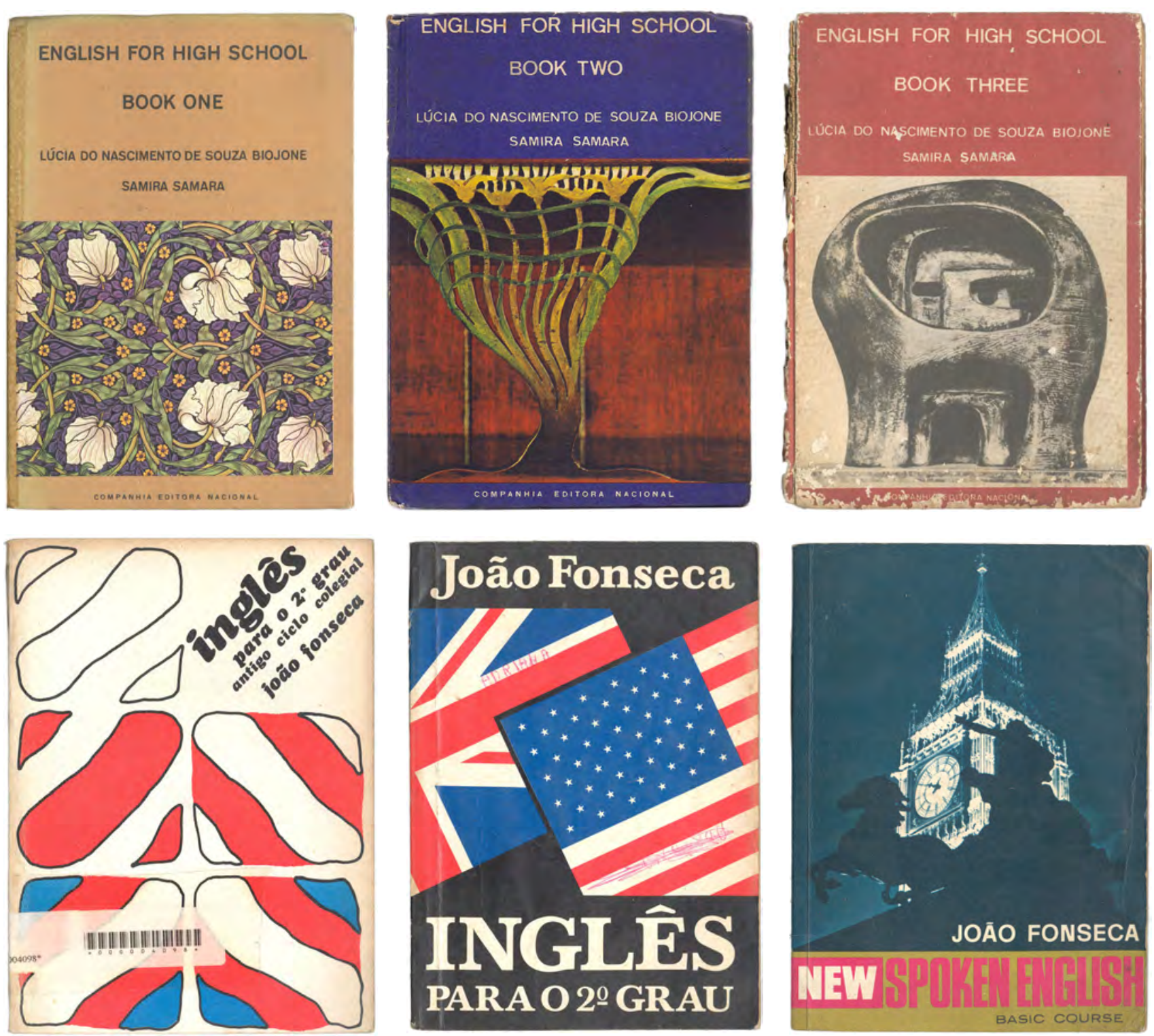

Fig. 8.44. Lúcia N. S. Biojone e Samira Samara, English for high school: book one, book two e book 3, 1971 a 1973 (15,0 x 21,0 cm). Capas.

João Fonseca, Inglês para o 2ํgrau, $1972(15,5 \times 21,0 \mathrm{~cm})$. Inglês para o 2ํgrau; $1977(15,0 \times 21,0 \mathrm{~cm})$. New Spoken English, Basic course; 1976 (15,0 × 21,0 cm). Capas.

Inglês para o 2ํgrau, de 1972, tem capa com diagrama, iconografia e traço referenciados na visualidade pop. As informacões textuais, em tipografia (Cooper Black) oferecida pelo sistema 
Letraset ou pelo processo de fotoletras, em caixa baixa, insere-se no leiaute acompanhando a direção dos elementos gráficos da imagem (faixas da bandeira inglesa). A edição de 1977, na mesma figura, tem solução também sintética e direta, mas mais explícita e formal.

New Spoken English, do mesmo autor, já traz solução fotográfica, direta e eficiente, com escolha de imagem com qualidade plástica e semântica (FIG. 8.44). A inserção do nome do autor na área da fotografia, em branco como a torre iluminada e parte do título, quebra a rigidez da separação das áreas e aproxima imagem e tipografia. O contraste tipográfico interno ao título, sintaticamente consistente, é eficaz na comunicação da renovação da obra.

\subsection{Considerações gerais sobre o design dos livros didáticos da CEN do período 1970-1980}

A adoção de fotografia sangrada nas capas, principalmente com textos vazados sobre ela, e de ilustrações em novas linguagens referenciadas em outros meios impressos, a adoção de formatos maiores com diagramação em duas colunas com grande número de ilustrações e fotografias e impressão em quadricromia e o surgimento do livro com espaço para o aluno escrever formam um conjunto de procedimentos suficiente para produzir uma visualidade diferente da encontrada nos livros do período anterior e permitir a definição de um novo período de design dos didáticos da Nacional já a partir do ano de 1970. O fim do acabamento de encadernação com capa dura, com a adoção do acabamento brochura para todos os livros, a adoção de um formato maior ainda em alguns livros, a flexibilização no uso de fontes não serifadas, com novos desenho, a generalização do livro consumível, com exemplar para o professor, e a maior influência dos meios de comunicação de massas nas capas e miolos dos livros completaram o processo de configuração de uma nova visualidade do livro didático da Companhia Editora Nacional a partir do ano de 1974.

Essa nova visualidade é resultado da combinação de três fenômenos de natureza distinta mas que se relacionam e se completam. O primeiro é a expansão da oferta do ensino em todos os níveis, associada a recursos e técnicas com características de massificação, como o estudo dirigido, os testes de múltipla escolha e o fornecimento de respostas prontas para o professor, dentre outros. O segundo é a atualização das tecnologias de produção e reprodução de imagens e texto, impressão e acabamento do livro escolar. O terceiro é a presença avassaladora dos meios de comunicação de massas, particularmente a televisão, mas também a mídia impressa, gerando novas expectativas de consumo material e simbólico e transformações no gosto de alunos, professores, autores e editores de livros didáticos. O realismo fotográfico e uma iconografia e visualidade relacionadas à expressão de uma cultura jovem, e mesmo infantil, diferenciadas, serão modelos incontornáveis também para a produção de livros escolares. 
Mas a indústria do livro didático, como um segmento da indústria cultural com sua história e tradição próprias, fortemente ligadas à cultura escolar em função do fornecimento de um produto com características muito específicas, vai expressar essa relação com a cultura de massas de forma também particular. No caso da Nacional, que ocupava um lugar proeminente na produção de livros escolares no país como a maior editora por quatro décadas, eventos relacionados à sua gestão e à estrutura produtiva se refletiram na forma como seus livros incorporaram as novas tendências e recursos que caracterizavam os livros didáticos em geral produzidos naquela época no Brasil.

Assim é que, se obras como a Coleção Sérgio Buarque de Holanda, Brasil, uma história dinâmica e Química/Física, seus fundamentos, suas aplicações (FIG. 8.25 a 8.30 e 8.43), dentre outras, apresentavam características materiais e visuais correspondentes às novas demandas do ensino e de visualidade e ao emprego de novas tecnologias, mas mantinham uma qualidade de produção e um grau de unidade gráfica mais próximo da concepção de projeto unitário que apareceu no período anterior, particularmente o esforço em integrar capa e miolo, grande parte da produção subsequente teriam esses atributos muito enfraquecidos. Não há como não relacionar esse fato com a ruptura que significou a saída dos principais dirigentes editoriais e de arte no momento da troca de propriedade e gestão da empresa em 1974.

A partir dessa data, as páginas de crédito dos livros evidenciam a dispersão da produção de arte dos livros por um grande número de fornecedores externos, não só de fotocomposição - o que poderia ainda se dar sob o controle da editora, que especificaria e realizaria a diagramação internamente segundo critérios próprios - , mas de projeto, diagramação, ilustração e até produção de capas. Ao possível enfraquecimento da direção de arte interna pode-se acrescentar uma submissão da editora a condições gerais do mercado de serviços de arte, que pode ter se expandido para acompanhar a demanda das novas editoras sem condições de se lastrear na necessária qualificação.

Com relação às capas, a adoção de desenho único e simplificado para todos os volumes de diversas coleções, o uso de fotografias muito correntes em outros meios impressos e o uso de ilustração do miolo em linguagem apropriada à apresentação de conteúdos didáticos mas não para finalidades de atração e persuasão e obtenção de resultados equivalentes aos modelos de outras mídias que as inspiravam podem ser manifestações desse enfraquecimento do trabalho de arte.

Com relação ao miolo, há bons exemplos de trabalho de diagramação eficiente e clara, mas são raras as obras com solução de projeto mais particularizado e trabalho de ilustração diferenciado. A adoção da fotocomposição serviu bem ao propósito de facilitar a produção de miolos em duas colunas em diagramas com medidas fixas para os formatos maiores e com muita intercalação de imagens, mas são poucos os exemplos de maior flexibilidade de 
diagrama e variedade de uso de fontes que o novo processo em tese permitiria, resultando em padronização das soluções também entre as diversas editoras, várias delas atendidas por fornecedores comuns.

No entanto, a despeito desses fatos, pode-se identificar no livro didático produzido pela Companhia Editora Nacional em seu último período de design conforme nossa classificação, identificado com a década de 1970, atributos como formato, cores, presença de imagens e forma de uso que participam da configuração material e visual do livro didático que ainda hoje circula nas escolas brasileiras. 
Considerações finais 
E stabeleceu-se como primeiro objetivo da pesquisa construir a trajetória do design dos livros didáticos da Companhia Editora Nacional pela sequência de momentos ou períodos definidos pela predominância de soluções e características gráficas e materiais próprias para cada um deles.

Como resultado, dentre toda a produção da Nacional realizada entre 1926 e 1980, conseguiu-se reconhecer seis grandes tendências ou agrupamentos de obras com unidade formal ou características de materialidade e visualidade que as aproximava em intervalos de tempo comum, que definiram os seguintes períodos, com suas características assim elencadas:

- 1ำ período, 1926-1931. Visualidade e materialidade marcadas por continuidade da atividade editorial das empresas antecedentes e por pouca especialização da editora em edição de didáticos: capas tipográficas no modelo francês (diagrama simétrico conforme página de rosto), extremamente sóbrias; miolo dos livros em linguagem definida pela tecnologia da tipografia em chumbo e sua tradição; composição dos miolos com recursos de diferenciação tipográfica condicionados ao oferecido pelos fornecedores, com grande variação de qualidade e de adequação à finalidade didática.

- 2º período, 1932-1942. Design definido pela política de coleções, com grande padronização de soluções de capa e miolo: capas com solução tipográfica de diagrama único para as coleções, ainda simétrico, não mais reproduzindo a página de rosto mas ainda sóbrias, com particularização dos volumes por títulos com letras desenhadas à mão, com impressão mista (tipografia e litografia); composição e diagramação dos miolos conforme padrões gráficos estabelecidos para atender todos os níveis de complexidade exigidos pelas disciplinas, elevando a qualidade da produção didática em relação ao período anterior; impressão dos miolos em tipografia cilíndrica, com reprodução de fotografia por clichê reticulado em obras de Geografia e História e de ilustrações em linguagem de traço com impressão por clichê; formato padrão para a grande maioria dos livros de 13,0 x 19,0 cm; capas ilustradas apenas para o Primário.

- 3o período, 1943-1952. Visualidade definida pelo surgimento de nova solução gráfica para a capa e aperfeiçoamentos decorrentes da adoção da impressão ofsete: capa em linguagem atualizada, em solução tipográfica com título desenhado à mão e vazado em retângulo colorido, menos sóbria mas ainda padronizada para os títulos do mesmo nível de ensino; surgimento das primeiras capas ilustradas para o Secundário; ampliação do uso de imagens no miolo (fotografia PB em livros de História, Geografia e línguas; ilustrações em duas cores nas cartilhas), mas sem modificação na linguagem de ilustração, que continua baseada no traço, característica da impressão tipográfica; surgimento de novo formato, o "americano" (14,0 x 21,0 cm); acabamento em capa dura para o Secundário e brochura para o Primário. 
- 4o período, 1953-1960. Visualidade marcada pela generalização das capas ilustradas coloridas e ampliação do uso da cor no miolo: substituição das soluções tipográficas padronizadas das capas por soluções ilustradas com combinação livre de imagem e tipografia, em linguagens variadas (referências na publicidade, revistas, design modernista construtivo e aplicação, ainda limitada, de fotografia colorida); impressão predominante em preto nos primeiros anos do período, mas adoção de impressão em duas e três cores e quadricromia para livros de Geografia, Admissão ao Ginásio, Inglês e Francês; formato maior (15,0 × 21,0cm) para livros de línguas, mas retorno ao antigo formato 13,0 x 19,0 cm, que predomina para a maior parte das obras de Ginásio e Colégio; permanência do acabamento em capa dura para títulos do Ginásio, com brochura para o Primário e o Colegial.

- 5o período, 1961-1969. Visualidade definida pela valorização do design do miolo e atualização das linguagens das capas: miolos passam a ter projeto gráfico exclusivo, com desenho das guardas, pré-textuais e textuais sob mesmos princípios gráficos, com presença de elementos pictóricos, não apenas tipográficos e, em alguns casos, com total identidade entre capa e miolo; colaboração de novos profissionais na produção de capas e influência de novas tendências gráficas, incluindo o Estilo Internacional em capas tipográficas; impressão de maioria das capas em cores especiais com maior refinamento técnico, e algumas em quadricromia com ilustração e fotografia; impressão dos miolos majoritariamente em bicromia, com quadricromia em em obras de Geografia, Inglês, Francês e Admissão; predomínio dos formatos $13,0 \times 19,0$ e 15,0 × 21,0 cm mas surgimento de formatos intermediários, com acabamento em brochura apenas para cartilhas e algumas obras de Colegial.

- 60 período, 1970-1980. Visualidade e materialidade definidas por um conjunto de tranformações: grande aumento nos formatos (19,0 x 26,0 e 21,0 × 28,0 cm), com mudança de diagrama para duas colunas; adoção do acabamento brochura; generalização da impressão em quadricromia para capas e miolos, com aplicação de maior número de ilustrações e fotografia; criação do livro consumível e dos cadernos de atividades, com espaço para respostas do aluno; criação do livro do professor, com respostas e comentários; generalização do uso da fotografia nas capas, particularmente sangradas com texto vazado sobre elas; surgimento de temas ligados à cultura juvenil e novas linguagens de ilustração, refletindo maior influência dos meios de comunicação de massa; utilização de fontes tipográficas com desenhos antes inexistentes; flexibilização no uso de fontes não-serifadas.

Embora essa periodização tenha por base as tendências e características materiais e visuais da produção majoritária em cada época, é uma operação de classificação e interpretação que não se contrapõe à compreensão da trajetória do design dos didáticos da editora como um fluxo contínuo, e não uma justaposição de momentos isolados e separados por rupturas. Os agentes envolvidos na produção de design dos livros, na maior parte das situacões não tinham o 
design como preocupação isolada ou foco separado da produção dos livros em si, nem o objetivo de estabelecer mudanças ou marcos divisórios pela visualidade e materialidade. No máximo pode-se dizer que em alguns momentos sua atividade foi marcada por decisões conscientes de oferecer soluções de design a problemas ou necessidades mais abrangentes, que levaram à elaboração de soluções de maior alcance e evidência.

Os períodos também não são "puros", pois as transformações que os caracterizam não foram aplicadas a toda a produção e soluções correspondendo a tecnologias ou visualidade suplantadas para um conjunto maior da produção sempre sobreviveram, pela simples razão que mudanças implicam custos nem sempre comercialmente justificáveis. O que reforça a idéia de trajetória como um fluxo contínuo de produção de design.

Um segundo objetivo da pesquisa foi o de procurar explicar o design que caracterizou cada período a partir de suas relações com as demandas da educação e as com condições de produção. Isto porque as formas só podem ser compreendidas como resultado da interação entre produção (materiais, técnica, organização de trabalho, repertório de formas dos produtores) e finalidade (circulação, demandas, consumo/uso), sem ignorar a inserção das formas produzidas em cada momento em um processo de produção de formas ao longo do tempo, como componente e manifestação da cultura, com relativa autonomia e dinâmica próprias.

Os aspectos concernentes à esfera da educação incidentes na visualidade dos livros didáticos percebidos nessa trajetória são de duas ordens: os institucionais - reformas de ensino e mudanças na educação de forma mais ampla - e os relativos aos originais das obras e abordagens pedagógicas. No caso das reformas de ensino e mudanças gerais na educação, como as sucessivas ampliações de vagas em níveis de ensino, pudemos ver que os efeitos sobre a visualidade dos livros se davam como decorrência de mudanças da política editorial e da estrutura da produção dos livros para atender a nova situação e conduziam a soluções padronizadas para o conjunto da produção.

É o caso da política de coleções que a editora utilizou para se engajar no crescimento de seu segmento didático aproveitando a expansão do Ensino Secundário produzido pela Reforma Francisco Campos, em 1931. A solução de capas tipográficas corresponderia a uma prática consolidada e à uma cultura escolar em que a imagem não era fundamental, e a padronização adotada se destinou sobretudo a responder necessidades de produção, sem conflituar com o conteúdo político-ideológico do projeto editorial em que se inseria. No caso da Reforma Capanema, de 1942, a nova solução de capa e formato para os livros do novo nível de ensino que ela criou, o Colegial, veio em decorrência de um investimento prévio em tecnologia, a aquisição de impressoras ofsete, para a editora acompanhar uma nova expansão do Ensino Secundário. Nesse caso também a solução seguiu a abordagem da padronização, ao que tudo indica também por motivos de produtividade, ao mesmo tempo em que essa solução pareceu não conflitar com 
as expectativas vigentes no campo da cultura escolar e ainda trazia uma modernização visual e gráfica para os livros.

Já as transformações mais amplas da educação ocorridas no início da década de 1970, com a expansão do ensino adotando recursos pedagógicos como o ensino dirigido e os testes objetivos, levaram à transformações mais radicais dos livros didáticos. Os tempos eram outros e as soluções não foram padronizadas em termos de desenho das capas, num prosseguimento da abordagem diferenciada para capas iniciada na década de 1950 porém contando com novos recursos tecnológicos. Mas não se deixou de trabalhar com padrões de composição e diagramação e formatos comuns para os livros, apenas que a maior presença de imagens diferenciava mais os livros entre si.

Quanto aos aspectos relativos às disciplinas, abordagens pedagógicas e ao conteúdo das obras, a incidência sobre a configuração visual dos livros é mais direta e leva a configurações mais particularizadas. A editora estabeleceu padrões de diagramação e composição já no início da década de 1930, que com alguns aperfeiçoamentos provavelmente devidos à atualização de equipamentos chegaram até obras da década de 1960, mantendo por exemplo a diferenciação tipográfica baseada em uma única família de fonte serifada. Assim, livros de uma mesma disciplina do Ensino Secundário, em cada um dos períodos definidos, guardavam grande semelhança, pelo conteúdo textual e imagético comum decorrente de mesmos programas curriculares e mesma abordagem pedagógica. É por exemplo o caso dos livros de leitura, que seguiam um mesmo modelo de ensino da língua, que implicava uma mesma ordem de desenvolvimento que resultava numa configuração geral comum aos livros (e, em termos de cultura escolar, no estabelecimento de um protocolo de leitura, ou melhor, de uso, praticamente invariável). Mas nas cartilhas, mesmo filiadas a uma abordagem geral comum, certas particularidades dos métodos de cada autor implicavam diferenciações na estrutura do original e, consequentemente, na disposição gráfica e na aplicação de imagens, com maior variedade visual entre elas.

Livros de História, Geografia e Ciências de Ensino Secundário são exemplos de obras com particularização visual mais acentuada, principalmente devido à iconografia muito específica de cada um deles, mas livros de autores diferentes de cada uma dessas disciplinas guardavam muita semelhança entre si, principalmente no intervalo de tempo que abarcou os quatro primeiros períodos (1926 a 1960), quando vigiram os mesmo padrões e o sistema de composição em linotipo e monotipo. Uma exceção são os livros de Geografia de Aroldo de Azevedo, em que o autor era responsável pela maior parte das ilustrações e mesmo por algumas fotografias, o que garantia exclusividade de uso.

No caso de abordagens diferentes para uma mesma disciplina, além das citadas cartilhas, encontrou-se o exemplo do livro Matemática Moderna, de Osvaldo Sangiorgi, na década de 
1960, em que a visualidade padrão da disciplina foi rompida e os livros de cada autor apresentaram visualidade bastante diferenciada. Ressalve-se que no caso citado, a ruptura foi mais radical pois, além de se contar com novos recursos tecnológicos, pretendia-se ressaltar a novidade da abordagem e valorizar sua modernidade, o que ocorreu com a apropriação de signos do repertório do design modernista, além dos próprios recursos tecnológicos empregados, como a impressão ofsete e o uso de duas cores.

O caráter panorâmico e abrangente da pesquisa não permitiria uma investigação aprofundada das relações do design produzido com as características dos originais, com sua estrutura textual e abordagem pedagógica, nas obras coletadas. No entanto, buscou-se informações sobre elas e quando se obteve procurou-se estabelecer algumas dessas relações. Foi o caso de algumas cartilhas, em que aplicações particulares do método de alfabetização predominante, o analítico, puderam ser genericamente compreendidas por sua configuração gráfica, como na Cartilha Fácil ou na Cartilha Sodré. Também se dispuseram de informações valiosas sobre obras como a Coleção Sérgio Buarque de Holanda, História Dinâmica e livros de Joaquim Silva, dentre outras obras que foram estudadas por trabalhos acadêmicos.

Com relação aos aspectos relacionados à produção, de que se pode elencar as tecnologias de composição de texto, de impressão e de acabamento, as práticas, procedimentos e regimes de trabalho das várias atividades de arte e produção gráfica envolvidas (projeto gráfico, composição, diagramação, ilustração, clicheria, fotomecânica, impressão) e as linguagens gráficas vigentes, conseguiu-se aceder a alguns deles pelas marcas físicas e visuais nas obras, por informações sobre processos tecnológicos da época e por informações sobre a editora obtidos em bibliografia. Com isso, foi possível relacionar as soluções de design às tecnologias disponíveis e a algumas práticas de trabalho relatadas em bibliografia técnica em todos os períodos, o que permitiu ter-se um quadro razoavelmente preciso das tecnologias empregadas e as linguagens gráficas que elas suportavam.

Assim, investiu-se na compreensão dos procedimentos e critérios utilizados na composição tipográfica do primeiro e segundo períodos, nesse caso relacionando-os mais diretamente à configuração de obras das diversas disciplinas, pois isto propiciou o confronto que revelou o progresso e profissionalização da editora na configuração dos seus livros didáticos que levou à própria definição do segundo periodo, bem como apresentou o padrão que vigorou em obras do Ensino Secundário até a década de 1970. Ou seja, os procedimentos de composição e diagramação estabelecidos sob o regime da composição tipográfica por linotipo e monotipo, mas lastreados na grande tradição da composição de tipos móveis em chumbo, abarcou o período da impressão em relevo (tipografia) e da impressão plana (litografia e ofsete), tendo convivido com os novos sistemas fotográficos computadorizados (fotocomposição), que na trajetória tratada por esta pesquisa abarcou todos os períodos. 
A aplicação de método de reconhecimento de processos de impressão permitiu distinguir num mesmo período, o segundo (1932-1942), a convivência dos sistemas de impressão tipográfico e litográfico e o predomínio do primeiro na maioria das obras, com a bibliografia confirmando o emprego de impressoras cilíndricas. A combinação dos dois sistemas na impressão de uma mesma peça, as capas tipográficas da Biblioteca Pedagógica Brasileira - Série II surpreendeu, gerando bastante dúvida sobre sua factibilidade, mas os vestígios gráficos são decisivas para sustentar essa afirmação. A coincidência entre informações obtidas em bibliografia e as provas físicas também permitiu estabelecer o momento preciso da introdução da impressão com máquina ofsete, que também coincidiu com mudança de formato e introdução de novo design de capa, marcando o início do terceiro período (1943-1952).

As relações entre tecnologia e linguagem das imagens foram identificadas de forma bastante clara no caso da impressão tipográfica, que vigiu no primeiro e segundo períodos (1926 a 1942): uso de retículas com pontos mais distantes (lineatura baixa) e linguagem de desenho de traço, para impressão com clichês. Mas a linguagem do traço, em livros didáticos, praticamente não foi substituída até o quarto período (1953-1960) e persistiu em muitas obras do quinto período (1961-1970), quando a impressão ofsete já havia substituído a tipográfica nas obras didáticas da editora.

Um exemplo de relações entre tecnologia e disciplinas verificadas diz ainda respeito ao uso de imagens. As necessidades específicas das disciplinas incluíam não só a aplicação mais particularizada dos padrões tipográficos mas também a produção de iconografia adequada, dentro da cultura da disciplina. Assim, ainda no período da impressão tipográfica a fotografia aparece mais em livros de História, Geografia, Inglês e Francês. Ilustrações em traço aparecem em livros de História, como interpretação de fatos ou obras de arte do passado, em Geografia, como interpretação gráfica dos fenômenos tratados, e em cartilhas como referência imediata às palavras apresentadas. Assim, apenas necessidades mais específicas impuseram aproveitamento pleno de recursos tecnológicos disponíveis, prevalecendo uma visualidade já estabelecida em períodos anteriores e constitutiva da cultura escolar e do livro didático.

Um último aspecto que foi relacionado à esfera da produção, o repertório de linguagens a que os produtores do design dos livros didáticos se referenciariam em sua atividade, na verdade poderia ser tratado como um contexto externo à produção, na medida em que pode ser entendido como uma cultura visual mais ampla, de toda a sociedade, exercendo maior ou menor influência sobre os profissionais da visualidade do livro. No entanto, não haveria como saber de antemão quais seriam essas referências, para produzir um painel prévio como foi feito com a educação e com a história da editora. Mas essas referências apareceram pelo caminho inverso, ou seja, se manifestaram nas peças gráficas produzidas.

Mesmo assim, fez-se uma apresentação da visualidade dos livros não-didáticos da editora 
e das editoras que a antecederam, bem como dos livros didáticos no primeiro momento de formação da editora, o que permitiu situar aquela primeira produção e identificar como uma opção a que a editora tomou pela sobriedade de suas capas didáticas até o terceiro período (1943-1952) e mais fortemente no primeiro e no segundo (1926 a 1942).

Tanto o acabamento de encadernação em capa dura como o modelo de capa exclusivamente tipográfica pareciam corresponder a um padrão estabelecido para o livro didático que, junto com livros de literatura elevada e ensaística, se diferenciavam de obras mais populares ou que pretendiam atingir um público mais amplo, que já adotavam as capas ilustradas e coloridas. Foi identificada apenas uma obra, de caráter mais popular, destinada ao Ensino Primário, editada em brochura e com capa e miolo totalmente ilustrados. Assim, essas soluções mais sóbrias e formais, correspondentes à seriedade da atividade educadora, tornaram-se componentes da cultura escolar que permaneceram em vigor por muito tempo ainda, além do primeiro período em que apareceram.

Na ausência de registros de qualquer manifestação dos agentes responsáveis pela produção na época, uma tentativa de explicação dessa opção parte necessariamente de inferições. Se se assumia que os livros de interesse geral precisavam de capas chamativas para atrair compradores, e a Nacional as utilizava, no caso dos didáticos, escolhidos pelos professores pelo nome ou abordagem dos autores, a capa seria um elemento secundário para a venda. Assim, por exemplo, os livros de Joaquim Silva iriam até a década de 1950 com capas tipográficas seguindo o antigo modelo francês. Vemos aqui a cultura escolar sendo alimentada pela cultura editorial e assumindo a permanência de linguagens que a tecnologia já permitia superar e que de fato já haviam sido substituídas em outros veículos impressos, como as revistas que tinham capas ilustradas nas décadas de 1910 e 1920 e capas fotográficas a partir da década de 1920. Não se dispõe de testemunhos nem favoráveis nem contrários, mas acredita-se que essa "defasagem" de visualidade não era nenhum problema para o livro didático. Como no caso específico dos consumidores das obras da Nacional não deveria ser problema a presença de solução padronizada para grande parte das obras.

Essa política de sobriedade de soluções de capas foi interrompida na década de 1950, o que serviu para definir o quarto período de design de didáticos da Nacional (1953-1960). Acredita-se que, se até esse momento prevaleceu uma autoreferência na visualidade da cultura escolar, essa produção do início dos anos 1950 indica uma permeabilidade à influência de outras fontes de informação visual. As referências no caso vieram desde a publicidade, a partir da atividade direta de um de seus ilustradores, Augustus, até o design modernista construtivo, aparentemente pela apropriação de seu repertório por capistas internos da editora.

Essa relação com linguagens "externas" à tradicionalmente encontrada na literatura escolar prosseguiu no período seguinte, o quinto (1960-1969), com novas referências de linguagem 
nas capas, mas principalmente com a valorização do design de miolo. Aqui encontrou-se o trabalho pioneiro de Eugênio Hirsch, que com uma abordagem global de design do livro compreendido como objeto único, introduziu um novo padrão de produção dos livros na editora. Estes passaram a ter uma edição de arte que integrava texto e imagem, traziam impressão em duas cores e até em quadricromia e maior número de ilustrações e fotografia, aproximando mais a visualidade dos didáticos à de outros produtos impressos.

Mas as transformações mais radicais na visualidade e materialidade dos livros didáticos tiveram início no último ano da década de 1960, definindo o sexto e último período de design de didáticos da Nacional (1970-1980), com a introdução de formatos maiores, acabamento brochura, impressão em quadricromia de capa e miolo, maior uso de fotografia, ilustrações referenciadas em temas de uma cultura jovem diferenciada da cultura adulta, livro do aluno com espaço para preenchimento de respostas, livro do professor com orientações didáticas e respostas, etc. Essas transformações foram resultado da combinação de três fenômenos distintos: 1) a expansão da oferta de educação em todos os níveis, associada a recursos e técnicas de massificação do ensino, como o estudo dirigido, testes de múltipla escolha e o fornecimento de respostas prontas para o professor; 2) a atualização das tecnologias de produção e reprodução de imagens e texto, impressão e acabamento do livro escolar, com a introdução das ofsetes rotativas e equipamentos de encadernação em brochura sem costura; 3) a influência dos meios de comunicação de massa, televisão e publicações, com a veiculação de linguagens associadas a culturas segmentadas, jovem e infantil, e um incremento da qualidade da reprodução fotográfica e em movimento, gerando novos padrões de realismo.

Assim, um resultado importante da pesquisa, referente à trajetória do design do livro didático da Nacional para todo o período estudado, é o reconhecimento de um percurso iniciado por um momento em que a visualidade do livro didático reflete maior isolamento e retração a influências externas à cultura editorial-escolar, chegando a outro momento caracterizado por grande abertura à influência da cultura visual presente na sociedade, particularmente àquela produzida pelos meios de comunicacão de massas, tendo os anos 1950 como o ponto de inflexão nesse processo.

Notou-se, no entanto, uma debilitação do trabalho de direção de arte interno e uma submissão da editora a condições do mercado de serviços de arte, em que se perdeu parte do esforço realizado no período anterior por uma maior unidade gráfica e particularização das obras. As causas teriam sido a saída da equipe de arte anterior e a rápida e grande expansão das editoras e serviços para atendê-las, sem tempo para a necessária qualificação.

Mas independentemente da qualidade e propriedade com que a influência da indústria cultural de massas e suas visualidades eram absorvidas pelo meio editorial didático, isto se dava conforme as condições e possibilidades desse meio, que incluía sua própria tradição de 
produção, relações com a cultura escolar, qualificação e mesmo gosto de seus agentes, não só os executores mas quem tinha poder de decisão sobre a visualidade. Assim, se desta trajetória pode-se depreender um movimento geral do livro didático em direção à cultura visual de massas manifestada em outras mídias, ele continua com uma visualidade guardando certa distância delas, não só pela sua especificidade de artefato de ensino-aprendizagem, mas por condições definidas por seu espaço de produção específico e por seu espaço de consumo.

Sobre os produtores da visualidade do livro didático da Nacional, a pesquisa revelou o trabalho de Belmonte e J. U. Campos como ilustradores e designers de obras didáticas nos anos 1920 e 1930, o trabalho de Augustus, Walter Lewy e João Gargiulli como capistas entre 1943 e 1969, o trabalho pontual com didáticos de Eugênio Hirsch no início dos anos 1960 e o trabalho de design e ilustração dos que seguiram seu exemplo nos anos seguintes, Nestor Batagliero, Joel Link e Lenci\&Fisher. No entanto, a ausência de créditos nos livros entre o primeiro e o quinto períodos (1926 a 1969) impediu a identificação dos ilustradores e desenhistas de letras da maior parte da produção de didáticos da Nacional.

Este é o conjunto dos principais resultados que a pesquisa propiciou sobre a história do design do livro didático da Companhia Editora Nacional e suas relações com a educação, a tecnologia e a cultura visual. Por se tratar de uma investigação panorâmica e inicial, muitas possibilidades de aprofundamentos futuros ficaram indicadas, o que também pode constituir uma contribuição importante para a pesquisa sobre o livro didático e sua visualidade.

Recortes focados na obras dos designers e ilustradores "descobertos", nas transformações de visualidade de coleções didáticas de grande duração, na visualidade específica de disciplinas, no design de didáticos de outras importantes editoras e nas relações entre a visualidade do livro didático e de outros veículos da indústria cultural são algumas possibilidades de investigação promissoras.

Assim, acredita-se que o terceiro objetivo traçado para esta pesquisa também se cumpriu, qual seja, o de contribuir para inserir o livro didático no rol dos artefatos impressos recuperados pelos estudos de memória gráfica e investigados pela história do design no Brasil. 
Referências bibliográficas e fontes primárias 


\section{Referências bibliográficas}

ALEXANDRE, Fernando Luiz. Literatura e educação na memória de uma cidade: um olhar sobre Thales Castanho de Andrade. Dissertação (Mestrado em História e Historiografia da Educação). Faculdade de Educação, Universidade de São Paulo, São Paulo, 2007.

ALVES, Cláudia. Educação, memória e identidade: dimensões imateriais da cultura material escolar. História da Educação, ASPHE/FaE/UFPel, Pelotas, v. 14, n. 30, p. 101-125, jan./abr. 2010. Disponível em: http//fae. ufpel.edu.br/asphe

ASSMANN, Jan. Communicative and Cultural Memory. In: ERLL, Astrid; NÜNNING, Ansgar (Eds.). Cultural Memory Studies: An International and Interdisciplinary Handbook. Berlin/New York: 2008.

AZEVEDO, Carmen Lúcia; CAMARGOS, Márcia; SACCHETTA, Vladimir. Monteiro Lobato: furacão na Botocúndia. São Paulo: SENAC, 2001.

BAINES, Phil; HASLAM, Andrew. Tipografía: función, forma y diseño. México/Barcelona: Gustavo Gili, 2002.

BARBOSA, Maria Aparecida S. A produção dos livros das coleções série 2 da Biblioteca Pedagógica Brasileira e Biblioteca Escolar Brasileira da Companhia Editora Nacional (1931 a 1960): análise da mediação editorial. Iniciação Científica. Faculdade de Educação, Pontifícia Universidade Católica de São Paulo, Conselho Nacional de Desenvolvimento Científico e Tecnológico, São Paulo, 2009.

BEDA, Ephraim de Figueiredo. Octalles Marcondes Ferreira: formação e atuação do editor. Dissertação (Mestrado em Comunicações). Escola de Comunicação e Artes, Universidade de São Paulo, 1987.

BIGNOTTO, Cilza Carla. Novas Perspectivas sobre as práticas editoriais de Monteiro Lobato (1918-1925). Tese (Doutorado em Literatura Brasileira). Instituto de Estudos da Linguagem, Universidade Estadual de Campinas, Campinas 2007.

BITTENCOURT, Circe Maria Fernandes. Livro didático e conhecimento histórico: uma história do saber escolar. Tese (Doutorado), Faculdade de Filosofia, Letras e Ciências Humanas, Universidade de São Paulo, São Paulo, 1993

BITTENCOURT, Circe Maria Fernandes. Disciplinas escolares: história e pesquisa. In: OLIVEIRA, Marcos Aurelio Taborda de; RANZI, Serlei Maria Fischer. História das disciplinas escolares no Brasil: contribuições para o debate. Bragança Paulista: Edusf, 2003.

BRAGION, Alexandre Mauro. Saudade: a utopia ruralista de Thales Castanho de Andrade. Dissertação (Mestrado em Literatura Brasileira). Instituto de Estudos da Linguagem, Universidade Estadual de Campinas, Campinas, 2007.

BRAUNA, Diogo dos Santos. A obra História do Brasil de Borges Hermida: da coleção ao livro (1948-1961). XXVII Simpósio Nacional de História. Natal: ANPUH, 2013.

BUCAILLE, Richard; PESEZ, Jean-Marie. Cultura Material. In: Enciclopédia Einaudi. Vol 16 - Homo - Domesticação - Cultura Material, p. 11-47. Lisboa: IN-CM, 1989.

CARDOSO, Rafael. Uma introdução à história do design. 2 ed. São Paulo: Edgard Blücher, 2004.

CARDOSO, Rafael. O design brasileiro antes do design: aspectos da história gráfica, 1870-1960. São Paulo: Cosac Naify, 2005.

CARVALHO, Marta Maria Chagas de. Sampaio Dória. Recife: Fundação Joaquim Nabuco/Editora Massangana, 2010. Disponível em: http://www.dominiopublico.gov.br/download/texto/me4716.pdf

CAVALHEIRO, Edgard. Monteiro Lobato vida e obra. São Paulo: Brasiliense, 1962.

CHOPPIN, Alain. História dos livros e das edições didáticas: sobre o estado da arte. Educação e Pesquisa, São Paulo, v. 30, n. 3, p. 549-566, set./dez. 2004.

COELHO, Luiz Antonio L. (Org.). Conceitos-chave em design. Rio de Janeiro: PUC-Rio/Novas Idéias, 2008.

COMENIUS, Iohannis Amos. Didactica Magna. Lisboa: Fundação Calouste Gulbenkian, 2001. Versão para ebook: eBooksBrasil.com.

COMPANHIA EDITORA NACIONAL. Catálogo Geral: 1931. São Paulo: Nacional, 1931. 
COUTINHO, Solange. O Sistema informacional nos rótulos comerciais de cachaça em Pernambuco (19401970). In: CAMPELLO, Silvio Barreto; ARAGÃO, Isabella. Imagens comerciais de Pernambuco: ensaios sobre os efêmeros da Guaianases. Recife: Néctar, 2011.

CRAIG, James. Produção gráfica. São Paulo: Mosaico/Edusp, 1980.

CROSS, N. Designerly Ways of Knonwing. Design Studies, v. 3, n.ำ 4, p. 221-227, oct. 1982.

DE FUSCO, Renato. Projeto, produção, Venda, Consumo. In: Design em aberto. Lisboa: Centro Português de Design, 1993.

DENIS, Rafael Cardoso. Design, Cultura material e o fetichismo dos objetos. Arcos, ESDI/UERJ, Rio de Janeiro, vol. 1, número único, p. 15-39, 1998.

DONATO, Hernâni. 100 anos da Melhoramentos: 1890-1990. São Paulo: Melhoramentos, 1990.

DUTRA, E. de F. Companhia Editora Nacional: tradição editorial e cultura nacional no Brasil dos anos 30. In: I Seminário Brasileiro sobre Livro e História Editorial. Rio de Janeiro: Fundação Casa de Rui Barbosa/Universidade Federal Fluminense, 8 a 11 de nov. 2004.

EDITORA ABRIL. A revista no Brasil. São Paulo: Abril, 2000.

EISENSTEIN, Elizabeth E. Literacy And The Future Of Printing: The Emergence of Print Culture in the West. Journal of Communication, vol. 30, n.1, pp. 99-106, 1980.

FARIAS, Priscila L. On graphic memory as a strategy for design history. In: BARBOSA, Helena; CALVERA, Anna (Eds.). Tradition, transition, trajectories: major or minor influences? Proceedings of the $9^{\text {th }}$ International Committee for Design History and Design Studies. Aveiro: UA Editora, 2014.

FERRACINI, Rosemberg Aparecido Lopes. A África e suas representações no(s) livro(s) escolar(es) de Geografia no Brasil - 1890-2003. Tese (Doutorado em Geografia Humana). Faculdade de Filosofia, Letras e Ciências Humanas, Universidade de São Paulo, São Paulo, 2012.

FILGUEIRAS, Juliana Miranda. As avaliações dos livros didáticos na Comissão Nacional do Livro Didático: a conformação dos saberes escolares nos anos 1940. Revista Brasileira de História da Educação, Campinas, v. 13, n. 1 (31), p. 159-192, jan./abr. 2013.

FONSECA, Sílvia Asam da. A coleção Bibliotheca do Espírito Moderno: um projeto para alimentar espíritos da Companhia Editora Nacional (1938-1977). Tese (Doutorado em Educação: História, Política, Sociedade). Pontifícia Universidade Católica, São Paulo, 2010.

FORTY, Adrian. Objetos de desejo: design e sociedade desde 1750. São Paulo: Cosac Naify, 2007.

FRIEDEL, Friedrich; OTT, Nicolaus; STEIN, Bernard. Typography: an encyclopedic survey of type design and techniques throughout history. New York: Black Dog \& Leventhal, 1998.

FRIEDMAN, K. Design knowledge: context, content and continuity. In: Foundations for the future: Doctoral Education in design. Staffordshire: Staffordshire University Press, 2000.

GASCOIGNE, Bamber. How to identify prints: a complete guide to manual and mechanical processes from woodcut to inkjet. London: Thames \& Hudson, 2011.

GRANDE DICIONÁRIO HOUAISS DA LÍNGUA PORTUGUESA. Versão eletrônica, 2012.

HALLEWELL, Laurence. O livro no Brasil: sua história. 2. ed. São Paulo: Editora da Universidade de São Paulo, 2005.

HAMILTON, David. What is a texbook? Paradigm - Journal of the Textbook Colloquium, n. 3. Jul. 1990. Disponível em http://faculty.education.lllinois.edu/westbury/paradigm/hamilton.html

HAMILTON, David. Instruction in the making: Peter Ramus and the beggining of modern schooling. Annual Convention of the American Educational Research Association, Chicago, 21-25 April 2003. Disponível em http://onlineassessment.nu/onlineas_webb/contact_us/Umea/David/ramustext030404.pdf

HOBSBAWN, Eric. Era dos extremos: O breve século XX, 1915-1991. São Paulo: Companhia das Letras, 1996.

HOMEM DE MELO, Chico; RAMOS, Elaine (Orgs). Linha do tempo do design gráfico no Brasil. São Paulo: Cosac Naify, 2011.

IBEP. Homens e livros. Edição comemorativa dos 40 anos do Ibep e e dos 80 anos da Companhia Editora Nacional. São Paulo, Ibep/Nacional, 2005. 
JAY, Martin. Scopic regimes of modernity. In FOSTER, Hal (Ed.). Vision and visuality. Seattle: Bay Press, 1988.

JULIA, Dominique. A cultura escolar como objeto histórico. Revista Brasileira de História da Educação, Autores Associados, Campinas, no 1, p. 9-43, jan./jun. 2001.

KOSHIYAMA, A.M. Monteiro Lobato: intelectual, empresário, editor. São Paulo: Edusp/Com-Arte, 2006.

LAJOLO, Marisa; ZILBERMAN, Regina. A formação da leitura no Brasil. São Paulo: Ática, 1999.

LAJOLO, Marisa e CECCANTINI, João Luís (Orgs.). Monteiro Lobato livro a livro, obra infantil. São Paulo: Editora da Unesp/Imprensa Oficial, 2008.

LAJOLO, Marisa (Org.). Monteiro Lobato livro a livro, obra adulta. São Paulo: Editora da Unesp, 2014.

LAWSON, Bryan. Como arquitetos e designers pensam. São Paulo: Oficina de textos, 2011

LARAIA, Roque de Barros. Cultura: um conceito antropológico. Rio de Janeiro: Zahar, 2001.

LIRA, Alexandre Tavares do Nascimento. A legislação da educacão no Brasil durante a ditadura militar (1964-1985): um espaço de disputas. Tese (Doutorado em História Social). Instituto de Ciências Humanas e Filosofia, Universidade Federal Fluminense, Rio de Janeiro, 2010.

LOBATO, J. B. Monteiro. A barca de Gleyre: Quarenta anos de correspondência literária entre Monteiro Lobato e Godofredo Rangel. v. 2. São Paulo: Brasiliense, 1951.

LOPES, Lucineide Fábia Rodrigues. A região nordeste nos livros didáticos de geografia: uma análise histórica. Dissertação (Mestrado em Geografia). Centro de Ciências Exatas e da Natureza, Universidade Federal da Paraíba, João Pessoa, 2009.

MARIZ, Ana Sofia. Editora Civilização Brasileira: O design gráfico de um projeto editorial (1959-1970). Dissertação (Mestrado em Design). Departamento de Artes, Pontifícia Universidade Católica, Rio de Janeiro, 2005.

MARTINS, Wilson. A palavra escrita: História do livro, da imprensa e da biblioteca. São Paulo: Ática, 2002.

MÁSCULO, José Cássio. A Coleção Sérgio Buarque de Hollanda: livros didáticos e ensino de História. Tese (Doutorado em Educação: História, Política, Sociedade). Pontifícia Universidade Católica, São Paulo, 2008.

MEGGS, Philip B.; PURVIS, Alston W. História do design gráfico. São Paulo: Cosac Naify, 2009.

MENESES, Ulpiano T. Bezerra de. Memória e cultura material: Documentos pessoais no espaço público. Revista de Estudos Históricos, São Paulo, v. 11, n. 2, p. 89-103, 1998.

MENESES, Ulpiano T. Bezerra de. Fontes visuais, cultura visual, História visual. Balanço provisório, propostas cautelares. Revista Brasileira de História, São Paulo, v. 23, no 45, p. 11-36, 2003.

MILLER, Daniel. Consumo como cultura material. Horizontes Antropológicos, Porto Alegre, ano 13, n. 28, p. 33-63, jul./dez. 2007.

MIORIM, Maria Ângela. A Biblioteca Pedagógica Brasileira da Companhia Editora Nacional e o ensino de matemática: livros, atores e estratégias editoriais. Horizontes, Universidade São Francisco, Itatiba, v.24, n.1, p. 9-21, jan./jun. 2006.

MIORIM, Maria Angela. A escrita de livros didáticos de matemática na década de 1920: o caso de Saverio Cristofaro. Zetetiké, Revista de educação matemática, Faculdade de Educação, Universidade Estadual de Campinas, Campinas, v. 17, n. 32, p. 136-164, jul/dez 2009.

MIJKSENAAR, Paul. Visual function: an introduction to Information Design. Rotterdam: 010 Publishers, 1997.

MIRZOEFF, Nicholas. What is visual culture. In: MIRZOEFF, Nicholas (Ed.). The visual cultural reader. London/N. York: Routledge, 1998.

MONTEIRO, Ana Maria; RALEJO, Adriana Soares; CICARINO, Vicente. "Brasil: uma história dinâmica": Desafios didáticos no ensino de história. Anais do 8 Encontro Nacional Perspectivas do Ensino de História, Universidade Estadual de Campinas, Campinas, 2012.

MORAES, Didier D. C. D. Visualidade do livro didático no Brasil: o design de capas e sua renovação nas décadas de 1970 e 1980. Dissertação (Mestrado em Educação). Faculdade de Educação, Universidade de São Paulo, São Paulo, 2010.

MORIN, Edgar. Cultura de massas no século XX. v. 1: Neurose. 9. ed. Rio de Janeiro: Forense Universitária, 2009. 
MORTATTI, Maria do Rosáro Longo. Os sentidos da alfabetização (São Paulo/1876-1994). São Paulo: Editora Unesp/Conped, 2000.

MUNAKATA, Kazumi. Produzindo livros didáticos e paradidáticos. Tese (Doutorado em História e Filosofia da Educação). Pontifícia Universidade Católica, São Paulo, 1997.

NAGLE, Jorge. Educação e sociedade na Primeira República. 2. ed. Rio de Janeiro: DP\&A, 2001.

NOGUEIRA, Julio Cesar Giacomelli. Letra e imagem: a tipografia nas capas de livros desenhadas por Eugênio Hirsch. Dissertação (Mestrado em Artes). Instituto de Artes, Universidade Estadual de Campinas, Campinas, 2009.

OLSON, David. R. O mundo no papel: As implicações conceituais e cognitivas da leitura e da escrita. São Paulo: Ática, 1997.

ONG, Walter J. Orality and Literacy: The Technologizing of the Word. London/N. York: Routledge, 2002.

PAIXÃO, Fernando [Coord.]. Momentos do Livro no Brasil. São Paulo: Ática, 1995.

PEREIRA, Bárbara Cortella. Theodoro de Moraes (1877-1956): um pioneiro no ensino da leitura pelo método analítico no Brasil. Dissertação (Mestrado em Educação). Faculdade de Filosofia e Ciências, Universidade Estadual Paulista "Júlio de Mesquita Filho", Marília, 2009.

PINTO JÚNIOR, Arnaldo. Professor Joaquim Silva, um autor da história ensinada do Brasil : livros didáticos e educação moderna dos sentidos (1940-1951). Tese (Doutorado. em Educação). Faculdade de Educação, Universidade Estadual de Campinas, Campinas, 2010.

PORTA, Frederico. Dicionário de artes gráficas. Porto Alegre: Globo, 1958.

PROWN, Jules David. The truth of material culture: history or fiction. In: LUBAR, S.; KINGERY, W. D. (Orgs.). History from things: essays on material culture. Washington: Smithsonian Institution Press, 1993.

RAZZINI, Marcia P. G. São Paulo: cidade dos livros escolares. In: BRAGANÇA, Aníbal; ABREU, Márcia (Orgs.). Impresso no Brasil: Dois séculos de livros brasileiros. São Paulo: Editora Unesp, 2010.

REDE, Marcelo. História a partir das coisas: tendências recentes nos estudos de cultura material. Anais do Museu Paulista, São Paulo, N. Sér., v. 4, p. 265-282, jan./dez. 1996.

ROCHA, Heloísa Helena Pimenta. Alfabetização, saneamento e regeneração nas iniciativas de difusão da escola primária em São Paulo. Pro-Posições, Campinas, v. 22, n. 2 (65), p. 151-172, mai./ago. 2011.

ROMANELLI, Otaiza de Oliveira. História da educação no Brasil: 1930/1973. 32. ed. Petrópolis: Vozes, 2007. ROSSI FILHO, Sérgio. Graphos: glossário de termos técnicos em comunicação gráfica. São Paulo: Cone Sul, 2001.

SILVA, Libanio da. Manual do Typographo. Rio de Janeiro: Francisco Alves, 1921.

SIMIONATO, Juliana Siani. Monteiro Lobato \& Cia.: uma experiência editorial. São Paulo: Com-Arte, 2010.

SORÁ, Gustavo. Brasilianas: José Olympio e a gênese do mercado editorial brasileiro. São Paulo: Edusp/ Com-Arte, 2010

STANISLAVSKI, Cleila de Fátima Siqueira. A coleção de leitura escolar: Série Thales de Andrade (19281964). Reflexões sobre a leitura escolar no Brasil. Tese (Doutorado em Educação). Faculdade de Filosofia e Ciências, Universidade Estadual Paulista, Marília, 2011.

TOLEDO, Maria Rita de Almeida. Coleção "Atualidades Pedagógicas": do projeto político ao projeto editorial (1931-1981). Tese (Doutorado em Educação). Pontifícia Universidade Católica de São Paulo, São Paulo, 2001.

TOLEDO, Maria Rita de Almeida. A Companhia Editora Nacional e a política de editar coleções: entre a formação do leitor e o mercado de livros. In: BRAGANÇA, Aníbal; ABREU, Márcia (Orgs.). Impresso no Brasil: Dois séculos de livros brasileiros. São Paulo: Editora Unesp, 2010.

TRAVASSOS, Nelson Palma. Nos bastidores da literatura. São Paulo: Brasiliense, 1944.

TREVISAN, Thabata Aline. A pedagogia por meio de Pedagogia: Teoria e prática (1954), de Antônio D’ Ávila. Dissertação (Mestrado em Educação). Faculdade de Filosofia e Ciências, Universidade Estadual Paulista, Marília, 2007. 
TWYMAN, M. A schema for the study of graphic language. In: KOLERS, P. A.; WROLSTAD, M. E. , BOUMA, H. (Eds. ). Processing of visible language. vol. 1. New York/London: 1979.

TWYMAN, Michael. Articulating Graphic Language: A Historical Perspective. In: Merald E. Wrolstad; Dennis F. Fischer (Eds.). Toward a New Understanding of Literacy. New York: Praeger Publishers, 1986.

VALENTE, Wagner Rodrigues. Osvaldo Sangiorgi e o Movimento da Matemática Moderna no Brasil. Diálogo Educional, Pontifícia Universidade Católica do Paraná, Curitiba, v. 8, n. 25, p. 583-613, set./dez. 2008.

VILLELA, Lucia Maria Aversa. "GRUEMA": uma contribuição para a história da Educação Matemática no Brasil. Tese (Doutorado em Educação Matemática). Universidade Bandeirante de São Paulo, São Paulo, 2009.

VON METZEN, Mélanie Mondl. Arte e poética nas capas de Eugênio Hirsch. Trabalho de Conclusão de Curso. Escola de Comunicações e Artes, Universidade de São Paulo, São Paulo, 2013.

WOODWARD, Kathryn. Identidade e diferença: uma introdução teórica e conceitual. In: SILVA, T. T. da (Org.). Identidade e diferença: a perspectiva dos estudos culturais. Petrópolis: Vozes.

\section{Fontes primárias: livros didáticos da Companhia Editora Nacional}

ABREU, Modesto de. Idioma Pátrio: 2o volume para terceira e quarta séries. São Paulo: Companhia Editora Nacional 1943.

ALMEIDA JÚNIOR, A. Elementos de anatomia e Fisiologia Humanas: para ginásios, colégios e escolas normais. 26. ed. São Paulo: Companhia Editora Nacional, 1960.

ALMEIDA JÚNIOR, A. Cartilha de Hygiene: para uzo das escolas primárias. 14. ed. São Paulo: Companhia Editora Nacional, 1928.

ALMEIDA JÚNIOR, A.. Elementos de Anatomia e Physiologia Humanas: para os gymnasios e as escolas normaes. São Paulo: Companhia Editora Nacional, 1931

ALMEIDA JÚNIOR, Dr. A. Elementos de anatomia e fisiologia humanas: para ginásios e escolas normais. 6. ed. São Paulo: Companhia Editora Nacional, 1941. 11 v. (Biblioteca Pedagógica Brasileira, Livros didáticos).

ALMEIDA, Antonio Figueira de; SILVESTRE, Honorio. Noções de Physiographia. São Paulo: Companhia Editora Nacional, 1931

ALMEIDA, J. L. de. Latinidade: terceira série ginasial. 6. ed. São Paulo: Companhia Editora Nacional, 1953.

ALMEIDA, Judith Morisson. Aulas de Canto Orfeônico: para as quatro séries do curso ginasial. 29. ed. São Paulo: Companhia Editora Nacional, 1958.

ANDRADE, Thales de. Saudade. 13. ed. São Paulo: Companhia Editora Nacional, 1928.

ANDRADE, Thales de. Alegria: leitura intermediária. 2. ed. São Paulo: Companhia Editora Nacional, 1938.

ANDRAUS, Sylvio; SANTOS, Udmyr P. Matemática: Matemática no ensino de segundo grau. São Paulo: Companhia Editora Nacional, 1974. 1 v.

ANTUNES JÚNIOR, Antônio; ANTUNES, José. Ciências Naturais: para quarta série ginasial. 30. ed. São Paulo: Companhia Editora Nacional, 1958

ARRUDA, Yolanda de Quadros. Elementos de Canto Orfeônico. 27. ed. São Paulo: Companhia Editora Nacional, 1958.

ATAYDE, Alcias Martins de. Geografia Geral: para primeiro ano colegial. 2. ed. São Paulo: Companhia Editora Nacional, 1952.
AZEVEDO FILHO, Leodegário A. de; et. al. Português: no segundo ciclo. São Paulo: Companhia Editora Nacional, 1971. AZEVEDO, Aroldo de. Geografia do Brasil: as regiões geográficas, tomo segundo. 9. ed. São Paulo: Companhia Editora Nacional, 1947. 145 v. (Biblioteca Pedagógica Brasileira, Livros didáticos).

AZEVEDO, Aroldo de. Geografia do Brasil: bases físicas, vida humana e vida econômica. 4.ed. São Paulo: Companhia Editora Nacional, 1971.

AZEVEDO, Aroldo de. Geografia Física: primeira série do curso colegial. 3. ed. São Paulo: Companhia Editora Nacional, 1949

AZEVEDO, Aroldo de. Geografia Regional: segunda série do curso colegial. São Paulo: Companhia Editora Nacional, 1949.

AZEVEDO, Aroldo de. Geografia: para a quarta série secundária. 6. ed. São Paulo: Companhia Editora Nacional, 1938. 38 v. (Biblioteca Pedagógica Brasileira, Livros didáticos).

AZEVEDO, Aroldo de. Geografia: para a quinta série secundária. 4. ed. São Paulo: Companhia Editora Nacional, 1938. 68 v. (Biblioteca Pedagógica Brasileira, Livros didáticos).

AZEVEDO, Aroldo de. Geografia: para a terceira série secundária. 6. ed. São Paulo: Companhia Editora Nacional, 1939. 49 v. (Biblioteca Pedagógica Brasileira, Livros didáticos).

AZEVEDO, Aroldo de. Geografia: para o curso comercial. São Paulo: Companhia Editora Nacional, 1939. 21 v. (Dom Bosco: Manual Técnico Comercial).

AZEVEDO, Aroldo. As Regiões Brasileiras: amazônia, meio-norte, nordeste, leste, sul, centro-oeste. 5. ed. São Paulo: Companhia Editora Nacional, 1969.

AZEVEDO, Aroldo. Brasil e o Mundo: as regiões brasileiras, curso médio. 15. ed. São Paulo: Companhia Editora Nacional, 1962. 3 v.

AZEVEDO, Aroldo. Brasil e o Mundo: os continentes, curso médio. 178. ed. São Paulo: Companhia Editora Nacional, 1966. 4 v.

AZEVEDO, Aroldo. Geografia do Brasil: a terra, o homem, a economia para terceira série ginasial. 109. ed. São Paulo: Companhia Editora Nacional, 1960. 
AZEVEDO, Aroldo. Geografia do Brasil: as regiões geográficas, para a quarta série ginasial. 52. ed. São Paulo: Companhia Editora Nacional, 1956.

AZEVEDO, Aroldo. Geografia do Brasil: as regiões geográficas para a quarta série ginasial. 95. ed. São Paulo: Companhia Editora Nacional, 1962.

AZEVEDO, Aroldo. Geografia Física: para o primeiro ano colegial. 24. ed. São Paulo: Companhia Editora Nacional, 1957.

AZEVEDO, Aroldo. Geografia Geral: a terra no espaço, estrutura da terra, os grupos humanos, a vida econômica, primeira série ginasial. 84. ed. São Paulo: Companhia Editora Nacional, 1955.

AZEVEDO, Aroldo. Geografia Geral: a terra no espaço, estrutura da terra, os grupos humanos, a vida econômica, primeira série ginasial. 140. ed. São Paulo: Companhia Editora Nacional, 1958

AZEVEDO, Aroldo. Geografia Geral: geografia física e humana dos continentes, segunda série ginasial. 59. ed. São Paulo: Companhia Editora Nacional, 1954.

AZEVEDO, Aroldo. Geografia Geral: geografia física e humana dos continentes, segunda série ginasial. 138. ed. São Paulo: Companhia Editora Nacional, 1960.

AZEVEDO, Aroldo. Geografia Humana do Brasil: para o terceiro ano do curso colegial. 5. ed. São Paulo: Companhia Editora Nacional, 1953.

AZEVEDO, Aroldo. Geografia Humana do Brasil: para o terceiro ano do curso colegial. 24. ed. São Paulo: Companhia Editora Nacional, 1961.

AZEVEDO, Aroldo. Geografia Humana do Brasil: para o terceiro ano do curso colegial. 2. ed. São Paulo: Companhia Editora Nacional, 1950

AZEVEDO, Aroldo. Geografia Regional: para o segundo ano colegial. 23. ed. São Paulo: Companhia Editora Nacional, 1959.

AZEVEDO, Aroldo. Leituras Geográficas: destinadas ao curso ginasial. 2. ed. São Paulo: Companhia Editora Nacional, 1958

AZEVEDO, Aroldo de. O Brasil e suas Regiões: Brasil, país de contrastes, Amazônia brasileira, Nordeste brasileiro, Sudeste do Brasil, Sul do Brasil, Centro-Oeste brasileiro. São Paulo: Companhia Editora Nacional, 1971.

AZEVEDO, Aroldo de. O Brasil no Mundo: nosso mundo, nossa terra. São Paulo: Companhia Editora Nacional, 1971.

AZEVEDO, Aroldo. O Mundo em que Vivemos: a terra no espaço, a natureza terrestre, o homem e suas atividades. 4 ed. São Paulo: Companhia Editora Nacional, 1966.

AZEVEDO, Aroldo. Os Continentes: nosso continente, o mundo europeu, o mundo asiático, o mundo africano, o mundo oceânico. São Paulo: Companhia Editora Nacional, 1967.

AZEVEDO, Aroldo. Terra Brasileira: nossa terra, nossa gente, nossa economia. 5. ed. São Paulo: Companhia Editora Nacional, 1963

AZEVEDO, Aroldo. Terra Brasileira: nossa terra, nossa gente, nossa economia. 41. ed. São Paulo: Companhia Editora Nacional, 1968
AZEVEDO, Aroldo; CEGALLA, Domingos Paschoal; SILVA, Joaquim; SANGIORGI, Oswaldo. Programa de admissão: novo, com matemática moderna. São Paulo: Companhia Editora Nacional, 1971.

AZEVEDO, Aroldo; et al. Programa de Admissão. São Paulo: Companhia Editora Nacional, 1956.

AZEVEDO, Aroldo; et al. Programa de Admissão. 4. ed. São Paulo: Companhia Editora Nacional, 1958.

AZEVEDO, Aroldo; et al. Programa de Admissão. 12. ed. São Paulo: Companhia Editora Nacional, 1965.

BARROS, Alencar. Curso de Biologia: biologia geral, noções de higiene e zoologia. 5. ed. São Paulo: Companhia Editora Nacional, 1956.

BARROS, Claudina de. Cartilha Fácil. São Paulo: Companhia Editora Nacional, 1944.

BECHARA, Lucilia; LIBERMAN, Manhúcia Perelberg. Curso Moderno de Matemática: para a escola elementar. São Paulo: Companhia Editora Nacional, 1969. 4 v.

BECKER, Idel. Compêndio de literatura espanhola e hispano-americana: história e antologia. São Paulo: Companhia Editora Nacional, 1943.

BECKER, Idel. Manual de Español: gramática, história literária, antologia. 2. ed. São Paulo: Companhia Editora Nacional, 1945.

BECKER, Idel. Manual de Español: gramática, ejercicios, lecturas, cuestionarios, notas prácticas, historia literaria. 11. ed. São Paulo: Companhia Editora Nacional, 1950.

BECKER, Idel. Manual de Español. 17. ed. São Paulo: Companhia Editora Nacional, 1953.

BECKER, Idel. Manual de Español: gramática y ejercicios de aplicion, lecturas, cuestionarios, vocabularios, historia literaria, antologia. 37. ed. São Paulo: Companhia Editora Nacional, 1959.

BECKER. Pequena História da Civilização ocidental. 6. ed. São Paulo: Companhia Editora Nacional, 1973.

BEZERRA, Manoel Jairo. Curso de Matemática: para o primeiro ano colegial (clássico e científico). São Paulo: Companhia Editora Nacional, 1953.

BEZERRA, Manoel Jairo. Curso de Matemática: para o terceiro ano colegial (clássico e científico). São Paulo: Companhia Editora Nacional, 1957.

BEZERRA, Manoel Jairo. Curso de Matemática: para os primeiro, segundo e terceiro anos do curso clássico e científico. 15. ed. São Paulo: Companhia Editora Nacional, 1964.

BEZERRA, Manoel Jairo; QUINTELLA, Ary; SILVA, Maria Helena. Iniciando a Matemática Moderna: curso elementar. São Paulo: Companhia Editora Nacional, 1967. 1 v.

BIOJONE, Lúcia do Nascimento de Souza; SAMARA, Samira. English for High School: book one. São Paulo: Companhia Editora Nacional, 1971

BIOJONE, Lúcia do Nascimento de Souza; SAMARA, Samira. English for High School: book two. 3. ed. São Paulo: Companhia Editora Nacional, 1973.

BIOJONE, Lúcia do Nascimento de Souza; SAMARA, Samira. English for High School: book three. São Paulo: Companhia Editora Nacional, 1970.

BRESCIA, Daisy. Cartilha do Tutu. São Paulo: Companhia Editora Nacional, 1970. 
BRESCIA, Daisy. Primeiro Livro do Tutu. São Paulo: Companhia Editora Nacional, 1970. 1 v.

BRUNO, Anibal. Curso de Português: Gramática e Antologia, 4a série dos ginásios. 12. ed. São Paulo: Companhia Editora Nacional, 1962.

BRUNO, Anibal. Curso de Português: Gramática e Antologia, 4a série dos ginásios. 9. ed. São Paulo: Companhia Editora Nacional, 1962.

BRUNO, Aníbal. Língua Portuguesa: antologia 1a e 2a séries. 21. ed. São Paulo: Companhia Editora Nacional, 1945. 18 v. (Biblioteca Escolar Brasileira)

BRUNO, Aníbal. Língua Portuguesa: antologia, para a primeira e segunda séries ginasiais. 58. ed. São Paulo: Companhia Editora Nacional, 1955.

BRUNO, Aníbal. Língua Portuguesa: gramática e exercícios, para as quatro séries ginasiais. 53. ed. São Paulo: Companhia Editora Nacional, 195?.

BRUNO, Aníbal. Língua Portuguesa: para a primeira série ginasial. São Paulo: Companhia Editora Nacional, 1938. 8 v. (Biblioteca Escolar Brasileira).

BUDIM, J.; ELIA, Sílvio. Compêndio de Língua e de Literatura: para o primeiro ano do curso colegial e para os candidatos a exame vestibular as faculdades de filosofia. São Paulo: Companhia Editora Nacional, 1953.

CALMON, Pedro. Pequena história da civilização brasileira: para a escola primaria. 3. ed. São Paulo: Companhia Editora Nacional, 1938. 32 v. (Biblioteca Pedagógica Brasileira, Livros didáticos).

CAMARGO, Alberto Mesquita de. Lições de Latim: gramática, exercícios, antologia, vocabulário para a primeira e segunda séries dos cursos ginasiais. 7. ed. São Paulo: Companhia Editora Nacional, 1951.

CAMPOS JR., J. L. Como se Aprende Inglez: how to learn english. 2. ed. São Paulo: Companhia Editora Nacional, 1935. 19 v. (Biblioteca Pedagógica Brasileira, Livros didáticos).

CAMPOS JR., J. L. Dicionário de Verbos Ingleses. São Paulo: Companhia Editora Nacional, 1935. 33 v. (Biblioteca Pedagógica Brasileira, Livros didáticos).

CAMPOS JUNIOR, J. L. Dicionário de Verbos Ingleses. São Paulo: Companhia Editora Nacional, 1935.

CAMPOS JÚNIOR, José luiz. The Master Key: an English Reading book and grammar. 2. ed. São Paulo: Companhia Editora Nacional, 1945.

CARVALHO, Adazir Almeida. In English, Please: book one. São Paulo: Companhia Editora Nacional, 1964.

CARVALHO, Benjamim de A. Programa de Desenho: para o primeiro, segundo e terceiro ano do curso colegial. 5. ed. São Paulo: Companhia Editora Nacional, 1960.

CARVALHO, Benjamim de A. Programa de Desenho: para primeira série ginasial. 13. ed. São Paulo: Companhia Editora Nacional, 1956

CARVALHO, Benjamim de A. Programa de Desenho: para terceira e quarta séries ginasiais. 6. ed. São Paulo: Companhia Editora Nacional, 1958.

CARVALHO, Benjamim de A. Programa de Desenho: para terceira série ginasial. São Paulo: Companhia Editora Nacional, 1953.
CARVALHO, C. M. Delgado de; GUIMARÃES, Inácia Ferreira. Programa de Ciências Sociais: edição preliminar: 4ํㅡำ e 5anos. São Paulo: Companhia Editora Nacional, 1934. (Departamento de Educação do Distrito Federal, Série C, Programas e Guias de Ensino).

CARVALHO, Carlos Delgado de. Geografia Regional do Brasil: para a quarta série ginasial. 4. ed. São Paulo: Companhia Editora Nacional, 1944.

CARVALHO, Delgado de. Geographia Humana: politica e economica. 2. ed. São Paulo: Companhia Editora Nacional, 1935. 40 v. (Biblioteca Pedagógica Brasileira, Livros didátiCOS).

CARVALHO, Geraldo Camargo de. Problemas de Química. 7. ed. São Paulo: Companhia Editora Nacional, 1967. 3 v.

CARVALHO, Geraldo Camargo; SAFFIOTI, Waldemar. Química: para segundo ano colegial. 10. ed. São Paulo: Companhia Editora Nacional, 1957.

CARVALHO, Geraldo Camargo; SAFFIOTI, Waldemar. Química: para segundo ano colegial. 4. ed. São Paulo: Companhia Editora Nacional, 1953.

CARVALHO, Geraldo Camargo; SAFFIOTI, Waldemar. Química: para terceiro ano colegial. 8. ed. São Paulo: Companhia Editora Nacional, 1958.

CARVALHO, Thales Mello. Matemática para os Cursos Clássico e Científico: terceira série. São Paulo: Companhia Editora Nacional, 1944.

CARVALHO, Thales Mello. Matemática: para a segunda série dos cursos comerciais técnicos. São Paulo: Companhia Editora Nacional, 1947.

CARVALHO, Thales Mello. Matemática: para os cursos clássico e científico, terceiro ano. 6. ed. São Paulo: Companhia Editora Nacional, 1956.

CAVALHEIRO, Luiz; ANGELINO, Nicolau. Ciências Físicas e Naturais: para a segunda série ginasial. 2. ed. São Paulo: Companhia Editora Nacional, 1940. (Dom Bosco).

CEGALLA, Domingos Paschoal. Aprenda Comigo: comunicação e expressão para o 1ํㅡ grau 1ำ série, livro do professor. São Paulo: Companhia Editora Nacional, 1980. 1 v.

CEGALLA, Domingos Paschoal. Aprenda Comigo: comunicação e expressão para o 10 grau $2^{a}$ série, livro do professor. São Paulo: Companhia Editora Nacional, 1980. 2 v.

CEGALLA, Domingos Paschoal. Aprenda Comigo: comunicação e expressão para o 1o grau 3a série, livro do professor. São Paulo: Companhia Editora Nacional, 1980. 3 v.

CEGALLA, Domingos Paschoal. Novíssima gramática da Língua Portuguêsa: com numerosos exercícios. 7. ed. São Paulo: Companhia Editora Nacional, 1967.

CEGALLA, Domingos Paschoal. Novíssima gramática da Língua Portuguêsa: com numerosos exercícios. São Paulo: Companhia Editora Nacional, 1963.

CEGALLA, Domingos Paschoal. Novíssima gramática da Língua Portuguesa: com numerosos exercícios. 13. ed. São Paulo: Companhia Editora Nacional, 1972.

CEGALLA, Domingos Paschoal. Português: gramática, antologia, exercícios, primeira série ginasial. 12. ed. São Paulo: Companhia Editora Nacional, 1965.

CEGALLA, Domingos Paschoal. Português: gramática, antologia, exercícios, primeira série ginasial. 18. ed. São Paulo: Companhia Editora Nacional, 1968. 
CEGALLA, Domingos Paschoal. Português: gramática, antologia, exercícios, primeira série ginasial. 19. ed. São Paulo: Companhia Editora Nacional, 1969.

CEGALLA, Domingos Paschoal. Português: gramática, antologia, exercícios, segunda série ginasial. 13. ed. São Paulo: Companhia Editora Nacional, 1965.

CEGALLA, Domingos Paschoal. Português: gramática, antologia, exercícios, segunda série ginasial. 17. ed. São Paulo: Companhia Editora Nacional, 1969.

CEGALLA, Domingos Paschoal. Português: gramática, antologia, exercícios, terceira série ginasial. 15. ed. São Paulo: Companhia Editora Nacional, 1969

CEGALLA, Domingos Paschoal. Português: gramática, antologia, exercícios, quarta série ginasial. 16. ed. São Paulo: Companhia Editora Nacional, 1969

CEGALLA, Domingos Paschoal. Hora de Comunicação: 5a série. São Paulo: Companhia Editora Nacional, 1980.

CEGALLA, Domingos Paschoal. Hora de Comunicação: 6a série, livro do professor. 7. ed. São Paulo: Companhia Editora Nacional, 1980

CEGALLA, Domingos Paschoal. Hora de Comunicação: 7 ạ série. São Paulo: Companhia Editora Nacional, 1978.

CEGALLA, Domingos Paschoal. Hora de Comunicação: comunicação e expressão e língua nacional, 8a série. 3. ed. São Paulo: Companhia Editora Nacional, 1978.

CEGALLA, Domingos Paschoal. Português Fundamental estudo dirigido, sétima série do primeiro grau. 4. ed. São Paulo: Companhia Editora Nacional, 1975.

CHACEL, Beatriz Magalhães de. El Español del Colegio: programa de la 1a serie de los cursos clásico y científico. São Paulo: Companhia Editora Nacional, 1944.

COPPEMA, Cônego. História Sagrada: antigo testamento para quarta série primária. São Paulo: Companhia Editora Nacional, 1955

COSTA, Carlos; PASQUALE, Carlos. Química: quarta série do curso fundamental. 4. ed. São Paulo: Companhia Editora Nacional, 1942. 95 v. (Biblioteca Pedagógica Brasileira, Livros didáticos).

COSTA, Dr. Carlos. Curso Elementar de História Natural. 2. ed. São Paulo: Companhia Editora Nacional, 1933. 15 v. (Biblioteca Pedagógica Brasileira, Livros didáticos).

COSTA, Dr. Carlos. Curso Elementar de História Natural: para quarta série ginasial. 2. ed. São Paulo: Companhia Editora Nacional, 1941. 22 v. (Biblioteca Pedagógica Brasileira, Livros didáticos)

COSTA, Dr. Carlos. Curso Elementar de História Natural: para quinta série ginasial. 2. ed. São Paulo: Companhia Editora Nacional, 1941. 36 v. (Biblioteca Pedagógica Brasileira Livros didáticos)

COSTA, Dr. Carlos. Elementos de Física, Química e História Natural: para o curso propedêutico das escolas de comércio. 3. ed. São Paulo: Companhia Editora Nacional, 1942. 20 v. (Coleção Dom Bosco)

COSTA, Dr. Carlos. Elementos de Física, Química e História Natural: para o curso propedêutico das escolas de comércio. 3. ed. São Paulo: Companhia Editora Nacional, 1942. 20 v. (Coleção Dom Bosco)

COSTA, Dr. Carlos. História Natural: para quarta série ginasial. 3. ed. São Paulo: Companhia Editora Nacional, 1940. 77 v. (Biblioteca Pedagógica Brasileira, Livros didáticos).
COSTA, Dr. Carlos. História Natural: para quinta série ginasial. 2. ed. São Paulo: Companhia Editora Nacional, 1939. 81 v. (Biblioteca Pedagógica Brasileira, Livros didáticos).

COUTINHO, Ismael de Lima. Pontos de Gramática Histórica. 2. ed. São Paulo: Companhia Editora Nacional, 1941.

CRETELLA JÚNIOR, José. Latim para o Ginásio: terceira e quarta séries. 16. ed. São Paulo: Companhia Editora Nacional, 1953

CRETELLA JÚNIOR, José. Latim para o Ginásio: terceira e quarta séries. 34. ed. São Paulo: Companhia Editora Nacional, 1957.

CRETELLA JÚNIOR, José. Português para o Colégio: primeiro ano. 6. ed. São Paulo: Companhia Editora Nacional, 1957. CRETELLA JÚNIOR, José. Português para o Colégio: segundo ano. 4. ed. São Paulo: Companhia Editora Nacional, 1955.

CRETELLA JÚNIOR, José. Português para o Ginásio: para terceira e quarta séries. 5. ed. São Paulo: Companhia Editora Nacional, 1948.

CRETELLA JÚNIOR, José. Português para o Ginásio: para primeira e segunda séries. 28. ed. São Paulo: Companhia Editora Nacional, 1953.

D'ÁVILA, Antônio. Alvorada: para a quarta série primária. 17. ed. São Paulo: Companhia Editora Nacional, 1963.

Departamento de Educação Distrito Federal. Progrâma de Matemática: edição preliminar. São Paulo: Companhia Editora Nacional, 1934. (Progrâmas e Guias de Ensino, Série C).

DIAS, Octacílio. Curso Moderno de Geografia do Brasil. 2. ed. São Paulo: Companhia Editora Nacional, 1969. 2 v.

DORIA, A. de Sampaio. Como se aprende a lingua: curso geral. 6. ed. São Paulo: Companhia Editora Nacional, 1931

DORIA, A. Sampaio. Como se Aprende a Língua: gramática. 9. ed. São Paulo: Companhia Editora Nacional, 1946.

DOTTORI, C.; BARROSO, N. J.; NEHRER, T. Geografia Dinâmica I: estudos sociais. 1. ed. São Paulo: Companhia Editora Nacional, 1974

DOTTORI, C.; BARROSO, N. J.; NEHRER, T. Geografia Dinâmica I: estudos sociais. 1. ed. São Paulo: Companhia Editora Nacional, 1974

DUARTE, José Coimbra. Ciências Físicas e Biológicas: para os cursos de grau médio. 10. ed. São Paulo: Companhia Editora Nacional, 1963

DUARTE, José Coimbra. Ciências Físicas e Biológicas: para os cursos de grau médio. 19. ed. São Paulo: Companhia Editora Nacional, 1967.

DUARTE, José Coimbra. Ciências Naturais: para quarta série ginasial. 38. ed. São Paulo: Companhia Editora Nacional, 1958.

DUARTE, José Coimbra. Ciências Naturais: para segundo e terceiro anos colegial. 2. ed. São Paulo: Companhia Editora Nacional, 1958.

DUARTE, José Coimbra. Ciências Naturais: para terceira série ginasial. 43. ed. São Paulo: Companhia Editora Nacional, 1958

DUARTE, José Coimbra. Ciências Naturais: para terceira série ginasial. 63. ed. São Paulo: Companhia Editora Nacional, 1961

DUARTE, José Coimbra. Iniciação à Ciência: para as primeira e segunda séries do curso ginasial. São Paulo: Companhia Editora Nacional, 1964. 
DUARTE, José Coimbra. O Corpo Humano. São Paulo: Companhia Editora Nacional, 1965.

ELIA, Sílvio. A Língua e a Literatura: no curso colegial. 2. ed. São Paulo: Companhia Editora Nacional, 1966.

ESPINHEIRA, Ariosto. Infância brasileira: para a quarta série primária. 134. ed. São Paulo: Companhia Editora Nacional, 1961.

FERNANDES Ary; MORAES, Fernando; BRANDÃO, Luiz. Matemática: para a 6a série do ensino de primeiro grau. 3. ed. São Paulo: Companhia Editora Nacional, 1975. 6 v.

FERREIRA, Tito Lívio. Deuxième Livre de Français: méthode directe et intuitive. 8. ed. São Paulo: Companhia Editora Nacional, 1943

FERREIRA, Tito Lívio. Deuxième Livre de Français: méthode directe et intuitive. 17. ed. São Paulo: Companhia Editora Nacional, 1954

FERREIRA, Tito Lívio. História do Brasil: para terceira e quarta séries ginasiais. 4. ed. São Paulo: Companhia Editora Nacional, 1947.

FILISETTI, Irene Torrano. Alô, Matemática!: primeira série, primeiro grau, livro do professor. São Paulo: Companhia Editora Nacional, 1974.

FILISETTI, Irene Torrano. Alô, Matemática!: segunda série, primeiro grau, livro do professor. São Paulo: Companhia Editora Nacional, 1975.

FILISETTI, Irene Torrano. Alô, Matemática!: terceira série, primeiro grau, livro do professor. São Paulo: Companhia Editora Nacional, 1975.

FILISETTI, Irene Torrano. Alô, Matemática!: quarta série, primeiro grau, livro do professor. São Paulo: Companhia Editora Nacional, 1975

FLEURY, Luiz Gonzaga. Meninice: 3ำ grau. São Paulo: Companhia Editora Nacional, 1937.

FLEURY, Renato Sêneca. Minha Cartilha. 37. ed. São Paulo: Companhia Editora Nacional, 1962.

FLEURY, Renato Sêneca. Vamos Ler?: leituras intermediárias. 14. ed. São Paulo: Companhia Editora Nacional, 1944

FONSECA, João. Inglês para o segundo grau: antigo ciclo colegial. São Paulo: Companhia Editora Nacional, 1972.

FONSECA, João. New Spoken English: basic course. 12. ed. São Paulo: Companhia Editora Nacional, 1976.

FONSECA, João. Spoken English: book three. 53. ed. São Paulo: Companhia Editora Nacional, 1962.

FONSECA, João. Spoken English: para segunda série ginasial. 20. ed. São Paulo: Companhia Editora Nacional, 1957.

FONSECA, João. Spoken English: para terceira série ginasial. 42. ed. São Paulo: Companhia Editora Nacional, 195?

FONSECA, João. Spoken English: para terceira série ginasial. 29. ed. São Paulo: Companhia Editora Nacional, 1961.

FONSECA, João. Spoken English: para quarta série ginasial. 12. ed. São Paulo: Companhia Editora Nacional, 1958.

FONSECA, João. Spoken English: para quarta série ginasial. 18. ed. São Paulo: Companhia Editora Nacional, 1959.

FONSECA, João. Spoken English: para quarta série ginasial. 29. ed. São Paulo: Companhia Editora Nacional, 1961.

FONSECA, João; BUTHLAY, Kenneth. English For Science: para o ciclo colegial. 3. ed. São Paulo: Companhia Editora Nacional, 1967.
FONSECA, João; BUTHLAY, Kenneth. College English: para os primeiro e segundo anos do curso colegial. 3. ed. São Paulo: Companhia Editora Nacional, 1960.

FORJAZ, Irma Aragonés. Le Français par L'Image. 4. ed. São Paulo: Companhia Editora Nacional, 1972.

FORJAZ, Irma Aragonês. Français: deuxième livre. 39. ed. São Paulo: Companhia Editora Nacional, 1963.

FORJAZ, Irma Aragonês. Français: première année du gymnase. 13. ed. São Paulo: Companhia Editora Nacional, 1959.

FREITAS, Paulo de. O Nosso Idioma: antologia e gramática aplicada: morfologia. São Paulo: Companhia Editora Nacional, 1936. 1 v. (Biblioteca Pedagógica Brasileira, Livros didáticos).

FREITAS, Paulo de. O Nosso Idioma: sintaxe das categorias gramaticais, parte III. 3. ed. São Paulo: Companhia Editora Nacional, 1941. 83 v. (Biblioteca Pedagógica Brasileira, Livros didáticos).

FREITAS, Paulo de. O Nosso Idioma: sintaxe das categorias gramaticais, parte III. 3. ed. São Paulo: Companhia Editora Nacional, 1941. 83 v. (Biblioteca Pedagógica Brasileira, Livros didáticos).

FREITAS, Paulo de. Técnica Comercial. 3. ed. São Paulo: Companhia Editora Nacional, 1938

GOMES FILHO, Francisco Alcântara. Física para o Primeiro Ano Colegial. 8. ed. São Paulo: Companhia Editora Nacional, 1953

GOMES FILHO, Francisco Alcântara. Física para o Segundo Ano Colegial. 8. ed. São Paulo: Companhia Editora Nacional, 1955.

GOMES FILHO, Francisco Alcântara. Física para o Terceiro Ano Colegial. São Paulo: Companhia Editora Nacional, 1953.

GOMES, Alfredo. História Antiga: para primeiro ano colegial. São Paulo: Companhia Editora Nacional, 1952.

GOMES, Alfredo. História da América: para segunda série ginasial. São Paulo: Companhia Editora Nacional, 1952.

GÓMEZ, Raul. Prática de Redação: para 3ำ e 4ํanos do curso elementar. 3. ed. São Paulo: Companhia Editora Nacional, 1939. 93 v. (Biblioteca Pedagógica Brasileira, Livros didáticos)

GONÇALVES, Antônio; RODRIGUES, Geraldo; MESQUITA, Marcelo. Programa de Admissão aos Cursos Ginasiais: pontos de português, aritmética, geografia e história do Brasil. 56. ed. São Paulo: Companhia Editora Nacional, 1954.

GONÇALVES, Antônio; RODRIGUES, Geraldo; MESQUITA, Marcelo. Exames de Admissão aos Cursos Ginasiais: pontos de português, aritmética, geografia, história do Brasil, morfologia geométrica e ciências físicas e naturais. 30. ed. São Paulo: Companhia Editora Nacional, 1941.

GRUEMA. Curso Moderno de Matemática: para o ensino de primeiro grau, livro do professor. São Paulo: Companhia Editora Nacional, $1975.6 \mathrm{v}$

GRUEMA. Curso Moderno de Matemática: para o ensino de primeiro grau, livro do professor. São Paulo: Companhia Editora Nacional, 1975. 5 v.

HERMIDA, Antônio José Borges. Compêndio de História do Brasil: estudos sociais. 58. ed. São Paulo: Companhia Editora Nacional, 1973

HERMIDA, Antônio José Borges. Compêndio de História do Brasil: para a primeira e segunda série do curso médio. 48. ed. São Paulo: Companhia Editora Nacional, 1965. 
HERMIDA, Antônio José Borges. Compêndio de História Geral: para os cursos de grau médio. 6. ed. São Paulo: Companhia Editora Nacional, 1969

HERMIDA, Antônio José Borges. História da América: para segunda série ginasial. 50. ed. São Paulo: Companhia Editora Nacional, 1961

HERMIDA, Antônio José Borges. História da América: para segunda série ginasial. 43. ed. São Paulo: Companhia Editora Nacional, 1961

HERMIDA, Antônio José Borges. História da América: para segunda série ginasial. São Paulo: Companhia Editora Nacional, 1959.

HERMIDA, Antônio José Borges. História do Brasil: para quarta série ginasial. 24. ed. São Paulo: Companhia Editora Nacional, 1961

HERMIDA, Antônio José Borges. História do Brasil: para quarta série ginasial. 11. ed. São Paulo: Companhia Editora Nacional, 1959

HERMIDA, Antônio José Borges. História Geral: para terceira série ginasial. 46. ed. São Paulo: Companhia Editora Nacional, 1963.

HERMIDA, Antônio José Borges. História Geral: para terceira série ginasial. 5. ed. São Paulo: Companhia Editora Nacional, 1959.

HERMIDA, Antônio José Borges. História Geral: para quarta série ginasial. 19. ed. São Paulo: Companhia Editora Nacional, 1961.

HERMIDA, Borges. História do Brasil 2. São Paulo: Companhia Editora Nacional, 1978.

HERMIDA, Borges. História Geral: o legado dos povos e a formação da civilização ocidental. 2. ed. São Paulo: Companhia Editora Nacional, 1979. 1 v.

JACQUIER, Louise. Français: première année. 31. ed. São Paulo: Companhia Editora Nacional, 1957.

JACQUIER, Louise. Français: troisième et quatrième annéss. 4. ed. São Paulo: Companhia Editora Nacional, 1959.

JUCÁ FILHO, Cândido. Curso de Português: segundo ano colegial. São Paulo: Companhia Editora Nacional, 1954.

LACERDA, Virgínia Côrtes de. Unidades Literárias: terceira série dos cursos clássico e científico. São Paulo: Companhia Editora Nacional, 1944

LACOMBE, Américo Jacobina. História do Brasil. São Paulo: Companhia Editora Nacional, 1979.

LANTEUIL, Henri de. Pages Françaises. São Paulo: Companhia Editora Nacional, 1940.

LEÃO, Arnaldo Carneiro. Ciências Físicas e Naturais: para a primeira série ginasial. São Paulo: Companhia Editora Nacional, 1937. 5 v. (Biblioteca Escolar Brasileira).

LEÃO, Arnaldo Carneiro. Química: iniciação ao estudo dos fenômenos químicos para a terceira série. 3. ed. São Paulo: Companhia Editora Nacional, 1938. 1 v. (Biblioteca Escolar Brasileira).

LEITÃO, Dr. Cândido Mello. Compendio Brasileiro de Biologia: biologia geral e botânica. 3. ed. São Paulo: Companhia Editora Nacional, 1943

LEITE, José Marques; CINTRA, Geraldo de Ulhoa. Língua Portuguesa: gramática, para as quatro séries ginasiais. 4 ed. São Paulo: Companhia Editora Nacional, 1959.
LEITE, Roberto Augusto Soares; NUNES, Amaro Ventura; ERMAN, Rosa. Comunicação e Interpretação: livro do professor. Rio de Janeiro: Companhia Editora Nacional, 1977. 1 v.

LÉLLIS, Raul Moreira. Comunicação: prosa e verso: moderna orientação para o estudo da língua e da teoria da literatura. São Paulo: Companhia Editora Nacional, 1976.

LÉLLIS, Raul Moreira. Português no colégio: primeiro e segundo anos dos cursos clássico, científico, normal e para iniciação às fac. de filosofia. São Paulo: Companhia Editora Nacional, 1963.

LÉLLIS, Raul Moreira. Português no Colégio:história literária do Brasil para o terceiro ano. 5. ed. São Paulo: Companhia Editora Nacional, 1967.

LIARD, L. Logica: para uso dos cursos gymnasiaes. São Paulo: Companhia Editora Nacional, 1930. Tradução de Godofredo Rangel

LIMA FILHO, Francisco da Gama. Noções de Geografia Regional do Brasil: quarta série ginasial. São Paulo: Companhia Editora Nacional, 195?.

LIMA FILHO, Francisco da Gama. Noções de Geografia Regional do Brasil: para quarta série ginasial. 2. ed. São Paulo: Companhia Editora Nacional, 1952

LIMA FILHO, Francisco da Gama. Noções de Geografia Regional do Brasil: para primeira série ginasial. 23. ed. São Paulo: Companhia Editora Nacional, 1957.

LIMA, Carlos Henrique da Rocha; LÉLIS, Raul Moreira; ROCHA, Mário Penna da. Português no Colégio: segundo ano dos cursos clássico e científico. 4. ed. São Paulo: Companhia Editora Nacional, 1959.

LIMA, Carlos Henrique da Rocha; LÉLIS, Raul Moreira; ROCHA, Mário Penna da. Português no Colégio: primeiro ano dos cursos clássico e científico. 7. ed. São Paulo: Companhia Editora Nacional, 1958.

LIMA, Hildebrando de. Nosso Brasil: para terceiro grau primário. 182. ed. São Paulo: Companhia Editora Nacional, 1953

LIMA, Mario Pereira de Souza. Grammatica Expositiva da Lingua Portuguesa: para uso das escolas secundarias. São Paulo: Companhia Editora Nacional, 1937. (Biblioteca Pedagógica Brasileira, Livros didáticos).

LOURENCCO, Oscar Bergstrom. Física: iniciação ao estudo da física experimental. 3. ed. São Paulo: Companhia Editora Nacional, 1935. 23 v. (Biblioteca Pedagógica Brasileira, Livros didáticos).

LOURENÇO, Oscar Bergstrom. Física: iniciação ao estudo da física experimental. 9. ed. São Paulo: Companhia Editora Nacional, 1941. 23 v. (Biblioteca Pedagógica Brasileira, Livros didáticos).

LOURENÇO, Oscar Bergstrom. Física: tratado elementar de física experimental para a quinta série dos ginásios. 3. ed. São Paulo: Companhia Editora Nacional, 19??. 56 v. (Biblioteca Pedagógica Brasileira, Livros didáticos).

LUDMILA E ZAGO. Matemática:um processo de criação 5. Rio de Janeiro: Companhia Editora Nacional, 1978.

MACEDO, Luiz. Química: segundo volume. São Paulo: Companhia Editora Nacional, 1944.

MAGALHÃES, Basílio de. História do Comercio, Industria e Agricultura. 2. ed. São Paulo: Companhia Editora Nacional, 1934. (Biblioteca de estudos comerciais e economicos). 
MAIOR, Armando Souto. História Contemporânea: terceiro ano colegial. 5. ed. São Paulo: Companhia Editora Nacional, 1962.

MAIOR, Armando Souto. História do Brasil: para o ensino de segundo grau e vestibulares. 10. ed. São Paulo: Companhia Editora Nacional, 1974.

MAIOR, Armando Souto. História Geral: para o curso colegial e vestibulares. 12. ed. São Paulo: Companhia Editora Nacional, 1970.

MAIOR, Armando Souto. História Medieval e Moderna: segundo ano colegial. 5. ed. São Paulo: Companhia Editora Nacional, 1962

MAROTE, D'Olim. Le Français courant par lês méthodes actives: course gymnasial. 3.ed. São Paulo: Companhia Editora Nacional, 1970.

MAROTE, João Teodoro D'Olim. Português Funcional primeira série: antologia, estudo do texto, vocabulário, gramática, exercícios, estudos dirigidos. 3. ed. São Paulo: Companhia Editora Nacional, 1970.

MAROTE, João Teodoro D'Olim. Português Funcional: antologia, estudo do texto, vocabulário, gramática, exercícios, estudos dirigidos. 4. ed. São Paulo: Companhia Editora Nacional, $1972.7 \mathrm{v}$.

MARQUES, João Queiroz; Sartori, José Antônio. Iniciação Científica: o ambiente e suas correlações. 7. ed. São Paulo: Companhia Editora Nacional, 1967. 1 v.

MARQUES, João Queiroz; Sartori, José Antônio. Iniciação Científica: calor, som, luz e o corpo humano. 6. ed. São Paulo: Companhia Editora Nacional, 1968. 2 v.

MARQUES, João Queiroz; Sartori, José Antônio. Iniciação Científica: ciências físicas e biológicas. 4. ed. São Paulo: Companhia Editora Nacional, 1969. 3 v.

MARQUES, João Queiroz. O Corpo Humano: higiene e saúde, iniciação científica. 4. ed. São Paulo: Companhia Editora Nacional, 1975.

MATA, Ary da. História Geral: para a segunda série. São Paulo: Companhia Editora Nacional, 1946.

MATTA, Ary da. História da América: para segunda série ginasial. 5. ed. São Paulo: Companhia Editora Nacional, 1955.

MATTA, Ary da. História Geral: para o primeiro e segundo ano do curso comercial básico. São Paulo: Companhia Editora Nacional, 1956.

MATTA, Ary da. História Geral: para terceira série ginasial. 2. ed. São Paulo: Companhia Editora Nacional, 1954.

MATTEI, R. Manual Teórico-Prático de Geometria Descritiva: para escolas industriais, técnicas e colégios. São Paulo: Companhia Editora Nacional, 1947.

MATTOS, IImar Rohloff de; DOTTORI, Ella Grinsztein; SILVA, José Luiz Werneck da. Brasil uma História Dinâmica: área de estudos sociais, da Independência a nossos dias. São Paulo: Companhia Editora Nacional, 1972. 2 v.

MATTOS, Lucy Moreira; VALLE, Leda Moreira Laborne. Clique. São Paulo: Companhia Editora Nacional, 1975.

MEGALE, Heitor; MATSUOKA, Marilena. Literatura e Linguagem: para 1a série do ensino de segundo grau. São Paulo: Companhia Editora Nacional, 1977. 2 v.

MEGALE, Heitor; MATSUOKA, Marilena. Literatura e Linguagem: para 3a série do ensino de segundo grau. 4. ed. São Paulo: Companhia Editora Nacional, 1979. 3 v.
MELO-LEITÃO, Dr. Cândido de. Biologia Geral. 2. ed. São Paulo: Companhia Editora Nacional, 1940. 42 v. (Biblioteca Pedagógica Brasileira, Livros didáticos).

MENDONÇA, Edgar Süssekind de. Curso de Desenho: para ensino secundário. 1. ed. São Paulo: Companhia Editora Nacional, 1936. 47 v. (Biblioteca Pedagógica Brasileira, Livros didáticos)

MORAES, Theodoro de. Sei Lêr: 2o livro de leitura. São Paulo: Companhia Editora Nacional, 1931.

MORAIS, Domingos de Vilhena; FONSECA, Orlando. Língua Latina: trechos escolhidos. São Paulo: Companhia Editora Nacional, 1936. 58 v. (Biblioteca Pedagógica Brasileira, Livros didáticos).

MORAIS, Teodoro de. Sei Ler: segundo livro: para os 4ํㅜ e 5ำ anos primários. 55. ed. São Paulo: Companhia Editora Nacional, 1930. (Livro de desenvolvimento de leitura Primário).

MOREIRA, Maria José Vieira. Francês: para segunda série ginasial. São Paulo: Companhia Editora Nacional, 1954.

MOTA, Othoniel. Lições de Português. 9. ed. São Paulo: Companhia Editora Nacional, 1941. (Biblioteca Pedagógica Brasileira, Livros didáticos).

MOTA, Othoniel. Selecta Moderna. 3. ed. São Paulo: Companhia Editora Nacional, 1932. 83 v. (Biblioteca Pedagógica Brasileira, Livros didáticos).

MOTTA, Othoniel. O Meu Idioma, 4aa anno do gymnasio. 5. ed. São Paulo: Companhia Editora Nacional, 1929

MOURA SANTOS. O Pequeno Escolar: quarto livro. 8. ed. São Paulo: Companhia Editora Nacional, 1936.

MUNZINGER, Marie. English: terceira série ginasial, método direto-fonético. São Paulo: Companhia Editora Nacional, 1950.

NASCENTES, Antenor. O Idioma Nacional. São Paulo: Companhia Editora Nacional, 1937. 3 v. (Biblioteca Pedagógica Brasileira, Livros didáticos).

NASCENTES, Antenor. O Idioma Nacional: volume IV. 3. ed. São Paulo: Companhia Editora Nacional, 1942.

NERY, P. J. de Castro. Filosofia:sumário e dicionário de acôrdo com o programa oficial. 3. ed. São Paulo: Companhia Editora Nacional, 1934.

NEVES, J. M. de Castro. Desenho Colegial: para o primeiro, segundo e terceiro ano. 3. ed. São Paulo: Companhia Editora Nacional, 1956.

NEWLAND, Thomaz; LEME, Paschoal. English: third grade. 6. ed. São Paulo: Companhia Editora Nacional, 1949.

NÔBREGA, Vandick Londres. O Latim do Colégio: primeiro ano. 5. ed. São Paulo: Companhia Editora Nacional, 1956.

NOBREGA, Vandick Londres. O Latim do Colégio: segunda série. São Paulo: Companhia Editora Nacional, 1945.

NOBREGA, Vandick Londres. O Latim do Colégio: terceira série. São Paulo: Companhia Editora Nacional, 1945.

NÔBREGA, Vandick Londres. O Latim do Ginásio: para terceira série. 34. ed. São Paulo: Companhia Editora Nacional, 1958.

NOGUEIRA, Amélia Keer. English for Brazilian Schools: para segundo ano colegial. 6. ed. São Paulo: Companhia Editora Nacional, 1951

NOGUEIRA, Amélia Keer; NOGUEIRA, Priscilla Keer. English for Brazilian Schools: para terceira série ginasial. 12. ed. São Paulo: Companhia Editora Nacional, 1954. 
NOGUEIRA, Júlio. Programa de Português: da 3a série secundária. São Paulo: Companhia Editora Nacional, 1939. 91 v. (Biblioteca Pedagógica Brasileira, Livros didáticos).

NOGUEIRA, Júlio. Programa de Português: da 4aㅗ série secundária. São Paulo: Companhia Editora Nacional, 1941. 105 v. (Biblioteca Pedagógica Brasileira, Livros didáticos).

NOGUEIRA, Júlio. Programa de Português: de 1a e 2a série secundárias. São Paulo: Companhia Editora Nacional, 1938. 82 v. (Biblioteca Pedagógica Brasileira, Livros didáticos).

NOGUEIRA, Júlio. Programa de Português: gramática. 2. ed. São Paulo: Companhia Editora Nacional, 1944. 123 v. (Biblioteca Pedagógica Brasileira, Livros didáticos).

NOGUEIRA, Júlio. Programa de Português: gramática. 7. ed. São Paulo: Companhia Editora Nacional, 1948. 123 v. (Biblioteca Pedagógica Brasileira, Livros didáticos).

NUNES, Amaro Ventura; LEITE, Roberto Augusto Soares. Comunicação e Expressão em Língua Nacional: para a 6 ${ }^{a}$ série do ensino de 1o grau, livro do professor. São Paulo: Companhia Editora Nacional, 1975.

OLIVEIRA, Ataide Lisboa. Meu Coração: para a primeira série do primeiro grau. 7. ed. São Paulo: Companhia Editora Nacional, 1973

OLIVEIRA, Valdemar de. Ciências Naturais: para quarta série ginasial. 22. ed. São Paulo: Companhia Editora Nacional, 1958.

OLIVEIRA, Valdemar de. Ciências Naturais: para a quarta série ginasial. 7. ed. São Paulo: Companhia Editora Nacional, 1946. v. 19. (Biblioteca Escolar Brasileira).

OLIVEIRA, Waldemar de. História Natural: para a quarta série ginasial. São Paulo: Companhia Editora Nacional, ???? 11 v. (Biblioteca Escolar Brasileira).

PASSOS, Celina de Morais. Noções Sobre Quimica Alimentar. São Paulo: Companhia Editora Nacional, 1938.

PENIDO FILHO, Raul. Le Français: Tème année. 4. ed. São Paulo: Companhia Editora Nacional, 1944. 132 v. (Biblioteca Pedagógica Brasileira, Livros didáticos).

PENIDO FILHO, Raul. Le Français: 2ème année. 3. ed. São Paulo: Companhia Editora Nacional, 1946. 144 v. (Biblioteca Pedagógica Brasileira, Livros didáticos).

PENIDO FILHO, Raul. Le Français: 2ème année. 8. ed. São Paulo: Companhia Editora Nacional, 1950. 144 v. (Biblioteca Pedagógica Brasileira, Livros didáticos).

PENTEADO, José de Arruda. Curso de Deesenho: para os cursos ginasial, comercial e técnico profissional. São Paulo: Companhia Editora Nacional, 1965.

PENTEADO, José de Arruda; ISSLER, Bernardo. Estudando São Paulo: estudos sociais, 3 ano da escola fundamental (3a série do curso primário). São Paulo: Companhia Editora Nacional, 1971.

PEREIRA, Eduardo Carlos. Grammatica Expositiva:curso superior. 60. ed. São Paulo: Companhia Editora Nacional, 1943 5 v. (Biblioteca Pedagógica Brasileira, Livros didáticos).

PEREIRA, Eduardo Carlos. Grammatica Expositiva: curso elementar. 134. ed. São Paulo: Companhia Editora Nacional 1952. 4 v. (Biblioteca Pedagógica Brasileira, Livros didátiCOS)

PEREIRA, Eduardo Carlos. Grammatica Expositiva:curso superior. 83. ed. São Paulo: Companhia Editora Nacional, 1952. 5 v. (Biblioteca Pedagógica Brasileira, Livros didáticos).
PEREIRA, Eduardo Carlos. Gramática Expositiva: curso superior. 111. ed. São Paulo: Companhia Editora Nacional, 1958. PINTO, V. N.; QUEIROZ, C.; FERRAZ, S. B. História da Civilização: área de estudos sociais, curso moderno. 1. ed. São Paulo: Companhia Editora Nacional, 1975. (coleção Sérgio Buarque de Hollanda).

PINTO, V. N.; QUEIROZ, C.; FERRAZ, S. B. História do Brasil: da independência aos nossos dias. 2. ed. Rio de Janeiro: Companhia Editora Nacional, 1972. (coleção Sérgio Buarque de Hollanda).

PINTO, V. N.; QUEIROZ, C.; FERRAZ, S. B. História do Brasil: das origens à independência. 6. ed. São Paulo: Companhia Editora Nacional, 1979. 1 v. (coleção Sérgio Buarque de Hollanda).

PRETI, Dino. Português Oral e Escrito: para 5a série do ensino de primeiro grau. 3. ed. São Paulo: Companhia Editora Nacional, 1980.

PUPO, J. J. de Salles; LEONTSINIS, Solon. Iniciação à Ciência: para as primeira e segunda séries do curso ginasial. São Paulo: Companhia Editora Nacional, 1965.

QUINTELLA, Ary. Matemática:primeiro ano ginasial. 15. ed. São Paulo: Companhia Editora Nacional, 1949. 104 v. (Biblioteca Pedagógica Brasileira, Livros didáticos).

QUINTELLA, Ary. Matemática, 1a série ginasial. 106. ed. São Paulo: Companhia Editora Nacional, 1963.

QUINTELLA, Ary. Matemática, 4a série ginasial. São Paulo: Companhia Editora Nacional, 1968.

QUINTELLA, Ary. Matemática: para primeira série ginasial. 68. ed. São Paulo: Companhia Editora Nacional, 1959.

QUINTELLA, Ary. Matemática: para primeira série ginasial. 121. ed. São Paulo: Companhia Editora Nacional, 1966

QUINTELLA, Ary. Matemática: para primeira série ginasial. ??. ed. São Paulo: Companhia Editora Nacional, 1968.

QUINTELLA, Ary. Matemática: terceiro ano ginasial. 11. ed. São Paulo: Companhia Editora Nacional, 1950. 130 v. (Biblioteca Pedagógica Brasileira, Livros didáticos).

QUINTELLA, Ary. Matemática: para terceira série ginasial. 32. ed. São Paulo: Companhia Editora Nacional, 1958.

QUINTELLA, Ary. Matemática: para quarta série ginasial. 35. ed. São Paulo: Companhia Editora Nacional, 1960

QUINTELLA, Ary. Matemática: para primeiro ano colegial. 14. ed. São Paulo: Companhia Editora Nacional, 1961.

QUINTELLA, Ary. Matemática: para segundo ano colegial. 2. ed. São Paulo: Companhia Editora Nacional, 1957.

QUINTELLA, Ary. Matemática: para terceiro ano colegial. 3. ed. São Paulo: Companhia Editora Nacional, 1959.

RABELLO, Célia. Cartilha de Vivi e Vavá. 17. ed. São Paulo: Companhia Editora Nacional, 1948.

RAEDERS, Georges; MORAES, Vilhena. Mon Premier Livre de Français: José, le bon élève brésilien. São Paulo: Companhia Editora Nacional, 1937. (Dom Bosco).

REIMANN, Louise; CINTRA, Geraldo de Ulhoa. Verbos Franceses. 11. ed. São Paulo: Companhia Editora Nacional, 1950. RICCHETTI, Henrique. Aleluia: nível I (básico) para 2a série, 2o livro de leitura. São Paulo: Companhia Editora Nacional, 1971.

RODRIGUES. As Grandes Paisagens da Superfície do Globo: 7a série do 10 grau. São Paulo: Companhia Editora Nacional, 1979 
RODRIGUES. Geografia do Continente Americano. São Paulo: Companhia Editora Nacional, 1980.

RODRIGUES. Nossa Terra, Nossa Gente. São Paulo: Companhia Editora Nacional, 1975

RODRIGUES. Nossa Terra, Nossa Gente. São Paulo: Companhia Editora Nacional, 1976

RODRIGUES. O Mundo Político no Final do Século XX: $8^{\text {a }}$ série do 10 grau, livro do professor. São Paulo: Companhia Editora Nacional, 1979

RÓNAI, Paulo. Parlons Français: supplémment au récit, le mystére du carnet gris. 2. ed. São Paulo: Companhia Editora Nacional, 1970

RÓNAI, Paulo; HAWELKA, Pierre. Mon Premier Livre: para primeira série ginasial. 19. ed. São Paulo: Companhia Editora Nacional, 1958

RÓNAI, Paulo; HAWELKA, Pierre. Mon Premier Livre: para primeira série ginasial. 24. ed. São Paulo: Companhia Editora Nacional, 1961

RÓNAI, Paulo; HAWELKA, Pierre. Mon Troisième Livre para terceira série ginasial. 14. ed. São Paulo: Companhia Editora Nacional, 1959

RÓNAI, Paulo: HAWELKA, Pierre. Mon Quatrième Livre: para quarta série ginasial. 10. ed. São Paulo: Companhia Editora Nacional, 1961

RÓNAI, Paulo; HAWELKA, Pierre. Mon Troisième Livre para terceira série ginasial. São Paulo: Companhia Editora Nacional, 1954

SACCONI, Luiz Antônio. Gramática em Tempo de Comunicação: livro de testes e exercícios, nível A. 4. ed. São Paulo: Companhia Editora Nacional, 1975.

SAFFIOTI, Waldemar. Fundamentos de Química: química geral, inorgânica e fisicoquímica. São Paulo: Companhia Editora Nacional, $1968.1 \mathrm{v}$.

SALLES, Miguel. Ensino Renovado do português: quarta série ginasial. 2. ed. São Paulo: Companhia Editora Nacional, 1971.

SALLES, Miguel. Ensino Renovado da Língua Nacional. 2 ed. São Paulo: Companhia Editora Nacional, 1972. 5 v.

SAMPAIO, F. Nerêo de. O Desenho ao Alcance de Todos para uso nos ginásios, nas escolas normais, profissionais e de belas artes. 2. ed. São Paulo: Companhia Editora Nacional, 1938. 2 v. (Biblioteca Pedagógica Brasileira, Livros didáticos)

SANGIORGI, Oswaldo. Matemática: curso moderno para os ginásios. São Paulo: Companhia Editora Nacional, 1964. 1 v.

SANGIORGI, Oswaldo. Matemática: curso moderno para os ginásios. 13. ed. São Paulo: Companhia Editora Nacional, 1969. $1 \mathrm{v}$.

SANGIORGI, Oswaldo. Matemática: curso moderno para os ginásios. São Paulo: Companhia Editora Nacional, 1965. 2 v.

SANGIORGI, Oswaldo. Matemática: curso moderno para os ginásios. 12. ed. São Paulo: Companhia Editora Nacional 1971. $2 \mathrm{~V}$.

SANGIORGI, Oswaldo. Matemática: curso moderno para os ginásios. 5. ed. São Paulo: Companhia Editora Nacional, 1968. $3 \mathrm{v}$

SANGIORGI, Oswaldo. Matemática: curso moderno para os ginásios. 3. ed. São Paulo: Companhia Editora Nacional 1968. 4 v.
SANGIORGI, Oswaldo. Matemática: para cursos de primeiro grau. 3. ed. São Paulo: Companhia Editora Nacional, 1973. $5 \mathrm{v}$.

SANGIORGI, Oswaldo. Matemática: para cursos de primeiro grau. São Paulo: Companhia Editora Nacional, 1974. 8 v.

SANGIORGI, Oswaldo. Matemática: para primeira série ginasial. 11. ed. São Paulo: Companhia Editora Nacional, 1955.

SANGIORGI, Oswaldo. Matemática: para segunda série ginasial. 13. ed. São Paulo: Companhia Editora Nacional, 1955.

SANGIORGI, Oswaldo. Matemática: para terceira série ginasial. 10. ed. São Paulo: Companhia Editora Nacional, 1955.

SANGIORGI, Oswaldo. Matemática: para quarta série ginasial. 10. ed. São Paulo: Companhia Editora Nacional, 1956.

SANTOS, Theobaldo Miranda. Organização Social e Política do Brasil. São Paulo: Companhia Editora Nacional, 1963.

SANTOS, Theobaldo Miranda. Linguagem: gramática, redação, leitura silenciosa para a segunda série primária. 28. ed. São Paulo: Companhia Editora Nacional, 1960.

SANTOS, Udmyr Pires dos. Física 1: mecânica para os cursos colegial e vestibular. São Paulo: Companhia Editora Nacional, 1967.

SCHENBERG, Mario. Física: para primeiro ano do curso colegial. São Paulo: Companhia Editora Nacional, 1945.

SCHIMIDT, Isabel Junqueira. English for College: primeiro e segundo ano dos cursos clássico e científico. 6. ed. São Paulo: Companhia Editora Nacional, 1951.

SCHIMIDT, Isabel Junqueira. English: third grade. 8. ed. São Paulo: Companhia Editora Nacional, 1949.

SCHMIDIT, Maria Junqueira. Cours de Français, $3^{\text {ème }}$ et $4^{\text {ème }}$ années. São Paulo: Companhia Editora Nacional, 1943.

SCHMIDIT, Maria Junqueira. Cours de Français: premier livre. 58. ed. São Paulo: Companhia Editora Nacional, 1963.

SCHMIDT, Maria Junqueira. Cours de Français: 3ème et 4ème année. São Paulo: Companhia Editora Nacional, 1943. 133 v. (Biblioteca Pedagógica Brasileira, Livros didáticos)

SCHMIDIT, Maria Junqueira. Cours de Français: troisième livre. São Paulo: Companhia Editora Nacional, 1964.

SCHMIDT, Maria Junqueira. La Littérature française: primeiro e segundo anos dos cursos clássico e científico. 21. ed. São Paulo: Companhia Editora Nacional, 1956.

SCHMIDT, Maria Junqueira. La Littérature Française: para os cursos clássico e científico. 6. ed. São Paulo: Companhia Editora Nacional, 1948.

SCHMIDT, Maria Junqueira. Mon Petit Univers: méthode vivante. São Paulo: Companhia Editora Nacional, 1934. 14 v. (Biblioteca Pedagógica Brasileira, Livros didáticos).

SILVA, Almira Sampaio Brasil da, et. al. Minha Abelhinha. 10. ed. Rio de Janeiro: Companhia Editora Nacional, 1976.

SILVA, Joaquim. História da América: para segunda série ginasial. 9. ed. São Paulo: Companhia Editora Nacional, 1952.

SILVA, Joaquim. História da América: para segunda série ginasial. 42. ed. São Paulo: Companhia Editora Nacional, 1958.

SILVA, Joaquim. História da Civilização:para o curso comercial. 2. ed. São Paulo: Companhia Editora Nacional, 1939.

SILVA, Joaquim. História da Civilização: para o primeiro ano ginasial. 2. ed. São Paulo: Companhia Editora Nacional, 1933. SILVA, Joaquim. História da Civilização: para o primeiro ano ginasial. 12. ed. São Paulo: Companhia Editora Nacional, 1936 
SILVA, Joaquim. História da Civilização: para o segundo ano ginasial. 19. ed. São Paulo: Companhia Editora Nacional, 1940.

SILVA, Joaquim. História da Civilização: para o terceiro ano ginasial. 9. ed. São Paulo: Companhia Editora Nacional, 1937.

SILVA, Joaquim. História da Civilização: para o quinto ano ginasial. 4. ed. São Paulo: Companhia Editora Nacional, 1938.

SILVA, Joaquim. História do Brasil: para curso médio (primeira e segunda séries). 18. ed. São Paulo: Companhia Editora Nacional, 1965.

SILVA, Joaquim. História do Brasil: para o curso médio (primeira e segunda séries). 22. ed. São Paulo: Companhia Editora Nacional, 1969.

SILVA, Joaquim. História do Brasil: para primeira série ginasial. 7. ed. São Paulo: Companhia Editora Nacional, 1952.

SILVA, Joaquim. História do Brasil: para primeira série ginasial. 21. ed. São Paulo: Companhia Editora Nacional, 1953.

SILVA, Joaquim. História Geral: para terceira série ginasial. 31. ed. São Paulo: Companhia Editora Nacional, 1957.

SILVA, Joaquim. História do Brasil: para quarta série ginasial. 27. ed. São Paulo: Companhia Editora Nacional, 1958.

SILVA, Joaquim. História do Brasil: para quarta série ginasial. 7. ed. São Paulo: Companhia Editora Nacional, 1954

SILVA, Joaquim. História Geral: para quarta série ginasial. 32. ed. São Paulo: Companhia Editora Nacional, 1958.

SILVA, Joaquim. História Geral: para o segundo ano ginasial. 41. ed. São Paulo: Companhia Editora Nacional, 1950.

SILVA, Joaquim. História do Brasil: terceiro ano ginasial. 16. ed. São Paulo: Companhia Editora Nacional, 1945.

SILVA, Paulo Maurício da; FONTINHA, S. R. Começando a Descobrir: classe inicial. São Paulo: Companhia Editora Nacional, 1976.

SILVA, Paulo Maurício da; FONTINHA, S. R. Descobrindo a Natureza: 2a série do 1o grau. São Paulo: Companhia Editora Nacional, 1976.

SILVA, Paulo Maurício da; FONTINHA, S. R. Química / Física: seus fundamentos, suas aplicações, ciências no 1 o grau. 4. ed. São Paulo: Companhia Editora Nacional, 1977. 4 v.

SILVA, Paulo Maurício da; FONTINHA, S. R. Tempo de Descobrir: 1ạ série do 1o grau. São Paulo: Companhia Editora Nacional, 1976.

SODRÉ, Benedicta Stahl. Cartilha Sodré: contendo o processo Sodré ou alfabetização rápida e as lições organizadas de acordo com o referido processo. 250. ed. São Paulo: Companhia Editora Nacional, 1977.

SODRÉ, Benedita Stahl. Cartilha Sodré: contendo o processo Sodré ou alfabetização rápida e as lições organizadas de acordo com o referido processo. 253. ed. São Paulo: Companhia Editora Nacional, 1978

SOUZA, Alcindo Muniz. História do Brasil: para terceira série ginasial. 3. ed. São Paulo: Companhia Editora Nacional, 1951.

SOUZA, Alcindo Muniz. História Geral: para quarta série ginasial. 2. ed. São Paulo: Companhia Editora Nacional, 1953.

SOUZA, Alcindo Muniz. História Geral: para terceira série ginasial. 6. ed. São Paulo: Companhia Editora Nacional, 1956.
SOUZA, Alcino Muniz. História Geral: para a segunda série ginasial. 11. ed. São Paulo: Companhia Editora Nacional, 1950.

SOUZA, Júlia de Faria e. Viva o Brasil: cartilha popular. 61. ed. São Paulo: Companhia Editora Nacional, 1956.

SOUZA, Verissimo de; SOUZA, Lourenço. Pontos de nossa História. 8. ed. São Paulo: Companhia Editora Nacional, 1930.

STÁVALE, Jacomo. Elementos de Matemática: para primeira série do curso ginasial. 9. ed. São Paulo: Companhia Editora Nacional, 1943. 113 v. (Biblioteca Pedagógica Brasileira, Livros didáticos)

STÁVALE, Jacomo. Exercicios de Mathematica: quarto anno. São Paulo: Companhia Editora Nacional, 1938.

STÁVALE, Jacomo. O Segundo ano de Matemática: para o segundo ano dos cursos ginasiais seriados e dos cursos fundamentais das escolas normais. 3. ed. São Paulo: Companhia Editora Nacional, 1934. 13 v. (Biblioteca Pedagógica Brasileira, Livros didáticos).

STÁVALE, Jacomo. O Segundo ano de Matemática: para o segundo ano dos cursos ginasiais seriados e dos cursos fundamentais das escolas normais. 13. ed. São Paulo: Companhia Editora Nacional, 1942. 13 v. (Biblioteca Pedagógica Brasileira, Livros didáticos)

STÁVALE, Jacomo. Quinto ano de Matemática. 2. ed. São Paulo: Companhia Editora Nacional, 1937. 69 v. (Biblioteca Pedagógica Brasileira, Livros didáticos)

TAUNAY, Alfredo D'E.; ACCIOLI, Roberto. História do Brasil: para o exame de admissão. São Paulo: Companhia Editora Nacional, 1961.

TAUNAY, Alfredo D'Escragnolle; MORAES, Dicamôr. História do Brasil: para o segundo ano colegial. 4. ed. São Paulo: Companhia Editora Nacional, 1955

TAUNAY, Alfredo D'Escragnolle; MORAES, Dicamôr. História Geral: para o primeiro ano colegial. 7. ed. São Paulo: Companhia Editora Nacional, 1956

TONISSI, João; PENTEADO, José de Arruda. Curso de Desenho: para segunda série ginasial. São Paulo: Companhia Editora Nacional, 1955.

TORRES, Artur de Almeida. Compêndio de Língua Portuguêsa: gramática. 4. ed. São Paulo: Companhia Editora Nacional, 1945. 116 v. (Biblioteca Pedagógica Brasileira, Livros didáticos)

TÔRRES, Artur de Almeida. Compêndio de Língua Portuguesa: antologia e gramática, primeira e segunda séries ginasiais. 28. ed. São Paulo: Companhia Editora Nacional, 1958

TÔRRES, Artur de Almeida. Compêndio de Língua Portuguesa: antologia: 1a e 2a séries. 6. ed. São Paulo: Companhia Editora Nacional, 1944. 117 v. (Biblioteca Pedagógica Brasileira, Livros didáticos).

TÔRRES, Artur de Almeida. Compêndio de Língua Portuguesa: antologia e gramática, primeira e segunda séries ginasiais. 22. ed. São Paulo: Companhia Editora Nacional, 1956. 117 v. (Biblioteca Pedagógica Brasileira, Livros didátiCOS).

TÔRRES, Artur de Almeida. Compêndio de Língua Portuguesa: gramática histórica para a $4^{a}$ série do ginasial. 3. ed. São Paulo: Companhia Editora Nacional, 1941. 75 v. (Biblioteca Pedagógica Brasileira, Livros didáticos). 
TÔRRES, Artur de Almeida. Compêndio de Língua Portuguesa: gramática e antologia, para a quarta série ginasial. 4. ed. São Paulo: Companhia Editora Nacional, 1957. 147 v. (Biblioteca Pedagógica Brasileira, Livros didáticos).

TÔRRES, Artur de Almeida. Compêndio de Língua Portuguesa: literatura, gramática, antologia, 5a série ginasial. 2. ed. São Paulo: Companhia Editora Nacional, 1937. 59 v. (Biblioteca Pedagógica Brasileira, Livros didáticos).

VASCONCELOS, Nuno Simth de. English Intuitive Method: para 2a série ginasial. São Paulo: Companhia Editora Nacional, 1936. 50 v. (Biblioteca Pedagógica Brasileira, Livros didáticos).

VIANNA, Hélio. História do Brasil Independente: para terceiro ano colegial. São Paulo: Companhia Editora Nacional, 1953.

\section{Fontes primárias: outros livros}

ALI, M. Said. Grammatica elementar da lingua portugueza. São Paulo: Melhoramentos, 1923.

ALMEIDA, Guilherme de. Simplicidade. São Paulo: Companhia Editora Nacional, 1929.

BARROSO, Gustavo. A Guerra do Rosas. São Paulo: Companhia Editora Nacional, 1929.

BASTIDE, Roger. Arte e Sociedade. 2. ed. São Paulo: Companhia Editora Nacional, 1971. 43 v. (Biblioteca Universitária: Ciências Sociais)

BRAGA, Erasmo. Leitura II. São Paulo: Melhoramentos, 1922.

BILAC, O; BONFIM, M. Através do Brasil: (Narrativa). Rio de Janeiro, Francisco Alves, 192?

BURROUGHS, Edgar Rice. Tarzan, o Terrível. 5. ed. São Paulo: Companhia Editora Nacional, 1958. 36 v. (Coleção Terramarear)

CAMARA, Jayme Adour da. Oropa, França, Bahia. São Paulo: Companhia Editora Nacional, 192?.

CARNEIRO, Dulce. Lições Rimadas. São Paulo: Monteiro Lobato \& $\mathrm{Cia}, 19$ ??

CARVALHO, Felisberto de. Quarto livro de leitura. Rio de Janeiro: Paulo de Azevedo, 192?

CORRÊA, Viriato. Bahú velho: roupas antigas da história brasileira 3. ed. São Paulo: Companhia Editora Nacional, 1927.

CORRÊA, Viriato. Cazuza. São Paulo: Companhia Editora Nacional, 1938

CORRÊA, Viriato. Cazuza. 16 ed. São Paulo: Companhia Editora Nacional, 1967.

CORRÊA, Viriato. No reino da bicharada. São Paulo: Companhia Editora Nacional, 1931.

CORRÊA, Viriato. Terra de Santa Cruz: contos e crônicas da história brasileira 3. ed. São Paulo: Companhia Editora Nacional, 1928.

DORIA, A de Sampaio. Como se Aprende a Lingua: curso complementar. 3. ed. São Paulo: Monteiro Lobato \& Cia, 1923.

DORIA, A de Sampaio. Como se Ensina. São Paulo: Monteiro Lobato \& Cia, 1923.
WAGNER, Luiz Amaral. Nosso Brasil: para quarto grau primário. São Paulo: Companhia Editora Nacional, 19??.

YAZIGI, Elias; NUNES, Maximo. Elementary English Grammar:2nd and 3nd grade. São Paulo: Companhia Editora Nacional, 1939. (Dom Bosco).

ZANELLO, Hipérides. Ciências físicas e naturais: primeira série, curso ginasial. 6. ed. São Paulo: Companhia Editora Nacional, 1940. 61 v. (Biblioteca Pedagógica Brasileira, Livros didáticos).

ZANELLO, Hipérides. Elementos de Geometria e Desenho Linear: curso primário. 4. ed. São Paulo: Companhia Editora Nacional, 1939. 39 v. (Biblioteca Pedagógica Brasileira, Livros didáticos).

DREYFUS, André. Vida e universo e outros ensaios. São Paulo: Companhia Editora Nacional, 1934. 5 v. (Bibliotheca Pedagógica Brasileira: Iniciação Scientífica)

DYVONNE. O Rapto de Jadette. São Paulo: Companhia Editora Nacional, 1956. 18 v. (Biblioteca das Moças)

GOMES Jr., João (Apr.). Cantigas da minha terra: para coro escolar. Monteiro Lobato \& Cia., 1924.

HAGGARD, H Rider. Benita. São Paulo: Companhia Editora Nacional, 1933.

HAGGARD, H Rider. Ella. 5. ed. São Paulo: Companhia Editora Nacional, 1957. 43 v. (Coleção Paratodos).

JURUÁ, Abel, A Veranista. São Paulo: Monteiro Lobato \& Cia., 192?.

KAEMPFFERT, Waldemar. Nos Domínios da Ciência. São Paulo: Companhia Editora Nacional, 1954. 20 v. (Biblioteca do Espirito Moderno: Ciência)

LEITÃO, C. de Mello. Visitantes do Primeiro Império. São Paulo: Companhia Editora Nacional, 1934. 22 v. (Bibliotheca Pedagógica Brasileira: Brasiliana)

LERY, Jean de. Historia de uma viagem á terra do Brasil. Tradução ordenada literariamente por Monteiro Lobato. São Paulo: Companhia Editora Nacional, 1926. (série Brasil Antigo)

LOBATO, J. B. Monteiro. História do Mundo para as Crianças. 9. ed. São Paulo: Companhia Editora Nacional, 1943. 10 v. (Biblioteca Pedagógica Brasileira: Literatura Infantil)

LOBATO, J. B. Monteiro. Narizinho Arrebitado. São Paulo: Monteiro Lobato \& Cia., 1921.

LOBATO, J. B. Monteiro. O Saci. 5. ed. São Paulo: Companhia Editora Nacional, 1934. 4 v. (Biblioteca Pedagógica Brasileira: Literatura Infantil)

MAUROIS, André. A Vida de Disraeli.7. ed. São Paulo: Companhia Editora Nacional, 1957. 3 v. (Biblioteca do Espirito Moderno: História e Biografia)

MORAES, Theodoro de. Cartilha do operário. São Paulo: Typographia Siqueira, 1924.

OLIVEIRA, Mariano de. Nova cartilha analytico-sintethica. BRAGA, Erasmo. Leitura II. São Paulo: Melhoramentos, 1923. 
PAVAN, Crodowaldo; CUNHA, Antônio Brito da (Org.). Elementos de Genética. 2. ed. São Paulo: Companhia Editora Nacional, 1966. 2 v. (Biblioteca Universitária: Ciências Puras).

PEIXOTO, Afranio. Missangas: poesia e folklore. São Paulo: Companhia Editora Nacional, 1931.

PEIXOTO, Afranio.Sinházinha. São Paulo: Companhia Editora Nacional, 1929.

PEREIRA, Eduardo Carlos. Grammatica Historica. São Paulo: Monteiro Lobato \& Cia, 1923. PICCHIA, Menotti del. Juca Mulato. 7. ed. São Paulo: Companhia Editora Nacional, 1928.

PETER, José Ladislau. Grammatica latina. 7. ed. São Paulo: Melhoramentos, 1923.

PFEIFFER, John. Uma visão nova da educação: "Systems analysis", ou a análise de sistemas em nossas escolas e faculdades. São Paulo: Companhia Editora Nacional/Editora da Univerisdade de São Paulo, 1971. 13 v. (coleção Cultura, Sociedade, Educação)

PIÉRON, Henri. Psicologia do Comportamento. São Paulo: Companhia Editora Nacional, 1935. 11 v. (Biblioteca Pedagógica Brasileira: Atualidades Pedagógicas)

POMBO, Rocha. Historia do Brasil: com muitos mappas historicos e gravuras explicativas. São Paulo: Melhoramentos, 1925.

RENGADE, J. A Viagem Submarina. São Paulo: Companhia Editora Nacional, 1934. 30 v. (Coleção Terramarear)

ROCA, Ramon; Oliveira, Mariano de. Novas leituras: Terceira série. 2. ed. São Paulo: Typographia Siqueira, 1915.

SANTOS, Theobaldo Miranda. Noções de Psicologia Experimental. São Paulo: Companhia Editora Nacional, 1949. (Biblioteca Pedagógica Brasileira, Iniciação Científica)

SANTOS, Theobaldo Miranda. Noções de Psicologia Educacional. São Paulo: Companhia Editora Nacional, 1954. 3 v. (Curso de Psicologia e Pedagogia)
SANTOS, Theobaldo Miranda. Noções de Psicologia da Personalidade. São Paulo: Companhia Editora Nacional, 1964. 19 v. (Curso de Psicologia e Pedagogia)

SETTE, Mário. Brasil, minha terra!: leitura cívicas. 4. ed. São Paulo: Melhoramentos, 1928?

SETUBAL, Paulo. Alma cabocla. São Paulo: Cia. Graphico-Editora Monteiro Lobato, 1925.

SETUBAL, Paulo. A Marqueza de Santos. São Paulo: Cia. Graphico-Editora Monteiro Lobato, 1925.

SETUBAL, Paulo. A Marqueza de Santos. 7. ed. São Paulo: Companhia Editora Nacional, 1930

SETUBAL, Paulo. Nos bastidores da história. São Paulo: Companhia Editora Nacional, 1928.

SILVA, J. Pinto e. Meus deveres: Educação Moral e Cívica. 9. ed. São Paulo: Typographia Siqueira, 1927.

SILVEIRA, Valdomiro. Os caboclos. São Paulo: Companhia Editora Nacional, 1928.

STADEN, Hans. Meu captiveiro entre os selvagens do Brasil. Texto ordenado literariamente por Monteiro Lobato. 2. ed. São Paulo: Companhia Editora Nacional, 1926. (série Brasil Antigo).

TAPAJÓS, Vicente. História da América. São Paulo: Companhia Editora Nacional, 1954. 57 v. (Biblioteca do Espirito Moderno: História e Biografia).

TAPAJÓS, Vicente. História do Brasil. 10. ed. São Paulo: Companhia Editora Nacional, 1960. 41 v. (Biblioteca do Espirito Moderno: História e Biografia)

YUTANG, Lin. Uma Folha na Tempestade. 7. ed. São Paulo: Companhia Editora Nacional, 1958. 13 v. (Biblioteca do Espirito Moderno: Literatura). Tradução de Ruth Lobato e Monteiro Lobato. 
